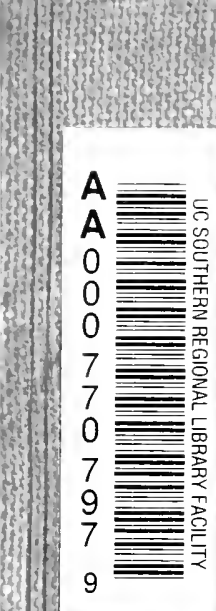




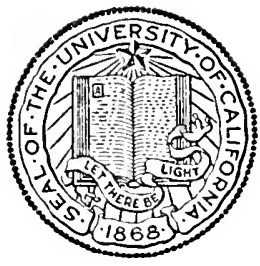

THE LIBRARY
OF

THE UNIVERSITY

OF CALIFORNIA

LOS ANGELES

SCHOOL OF LAW 


$$
\text { - }
$$

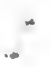
. - 


Digitized by the Internet Archive in 2008 with funding from Microsoft Corporation 


\title{
THE LAW
}

\author{
OF \\ NEGOTIABLE INSTRUMENTS
}

STATUTES, CASES AND AUTHORITIES

\author{
EDITED BY

\section{ERNEST W. HUFFCUT} \\ PROFESSOR OF LAW IN CORNELL UNIVERSITY
COLLEGE OF LAW
}

NEW YORK

BAKER, VOORHIS \& COMPANY 


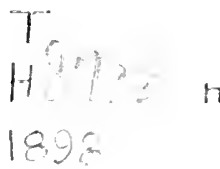

COPYRIGHT, ISQS

By ERnest W. HufFCuT

TVEED-PARSONS PRINTING COMPANY PRINTERS AND ELECTROTYPERS

ALEANY, $X, Y$. 


\section{PREFACE.}

THE enactment of the Negotiable Instruments Law in several American States and its probable enactment in others, renders necessary a familiarity with that Code on the part of all law students. Founded as it is upon the Digest of Judge Chalmers, afterward enacted into the English Bills of Exchange Act, it presents the best statement available of the results of English and American judicial decisions. Even before its adoption by the legislatures in Great Britain and the United States, Judge Chalmers' Digest had been edited for use in law schools, and had met with much favor for purposes of study and instruction.

A Digest or Code is, however, but a set of abstract rules. The student needs to see the rules in operation upon concrete facts in order to appreciate their force and effect. It is the purpose of this book to set over against each important rule a case or a selection of cases from which the rule might be deduced did no Code exist and in which the rule, as embodied in the Code, may be studied in its application to concrete facts. In this way it is hoped to give vitality and interest to what are otherwise mere abstract propositions of law. As to the relation of the cases to the Code, the reader is referred to Judge Chalmers' remarks, found on page IIg of this work, and to the opinion of Lord Herschell on page 127, and of Lord Russell of Killowen on page 442.

Under the sections of the statute will be found references to the "Cases and Authorities" which make up Part II of the work. Conversely there is set opposite the title to each case the section number of the statute which is applicable to it. Under this arrangement the student has constantly before him the enactment of the legislatures and the decisions of the courts. 
In Article I, dealing mainly with matters of historical interest, the editor has made free use of the Introduction to Chalmers' Digest and of the first two chapters of Mr. Scrutton's Elements of Mercantile Law. Elsewhere in the book, two or three chapters of Byles' Treatise on Bills of Exchange have been reprinted, where a selection of cases would have occupied space out of proportion to the importance of the subject. The topics of "Guaranty," "Non-negotiable Notes," and some others of minor interest, have been added to those included within the Negotiable Instruments Law.

In the preparation of the book the editor has derived the greatest assistance from the well-known works of Sir John Byles, Mr. Daniel, and Professor Ames, and from the article on Bills of Exchange in the second edition of the American and English Encyclopedia of Law.

The book is intended primarily for students. It constitutes, however, a somewhat complete annotation of the Negotiable Instruments Law, and as such may prove of value to practitioners. On many points, editorial notes have been added, in order to give greater completeness to the subject treated, and to indicate any conflict of authority that may have preceded the enactment of the statute.

E. W. H.

Cornell University,

February, 1898 . 


\title{
TABLE OF CONTENTS.
}

\section{PART I.}

\section{Statutes.}

PAGE.

American Negotiable Instruments Law ..................... 3

ENGlish Bills of ExchaNge ACt $\ldots \ldots \ldots \ldots \ldots \ldots \ldots \ldots \ldots \ldots \ldots \ldots \ldots \ldots \ldots$

\section{PART II.}

\section{Cases and Authorities.}

\author{
ARTICLE I. \\ General Provisions.
}

I. The English Bills of Exchange Act........................ II

2. The American Negotiable Instruments Law.............. I 22

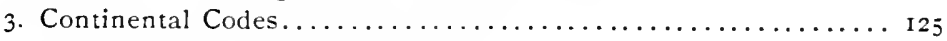

II. Construction of conffying stattes.................. 127

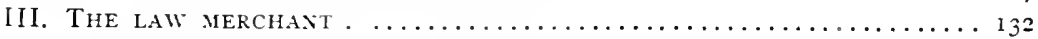

1. The Law Merchant and its history................. I32

2. History of negotiable instruments.................. I 42

(a) Bills, notes and checks ...................... It2

(b) Other negotiable paper...................... 149

\section{ARTICLE II. \\ FORM AND INTERPRETATION. \\ (i) Form Required.}

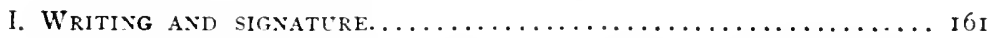

II. UXCONDITIONAL PROMISE OR ORDER TO PAY A SUM CERTAIN IN MONEY.. 164

I. A note must contain a promise $\ldots \ldots \ldots \ldots \ldots \ldots \ldots \ldots \ldots \ldots \ldots$

2. A bill must contain an order...................... 173

3. The promise or order must be unconditional........... 176

(a) Conditional promises or orders not negotiable........ I 76

(b) An order or promise to pay out of a particular fund is con-

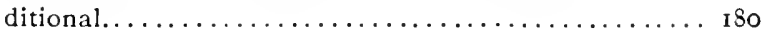


(c) An indication of a particular fund does not render order or promise conditional ... $\ldots \ldots \ldots \ldots \ldots \ldots \ldots \ldots, \mathbf{I} \delta_{3}$

(d) Nor a statement of transaction which gives rise to instrument.......................... I9o

4. The sum to be paid must be certain................ I 95

(a) What amounts to certainty generally $\ldots \ldots \ldots \ldots \ldots \ldots$ I95

(b) Engagement to pay interest: contingency.......... I99

(c) Engagement to pay by instalments: contingency...... 202

(d) Engagement that on default whole shall be due........ 208

(e) Engagement to pay exchange $\ldots \ldots \ldots \ldots \ldots \ldots \ldots \ldots \ldots \ldots \ldots \ldots \ldots$

( $f$ ) Engagement to pay costs of collection or attorney's fees.. 215

5. Must be payable in money....................... 2I 8

(a) Payment must be in money. . . ............... 218

(b) What constitutes current money ................ 219

6. Must not order or promise any act in addition to payment of

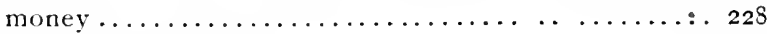

(a) Effect of additional stipulations................. $22 s$

(b) Exceptions: (I) Authorizing sale of collateral......... 229

(2) Authorizing confession of judgment.... 230

(3) Waiving exemptions ............. 23I

(4) Election to require something in lieu of

money.................. 233

III. Payable on demand or at a determixable future time $\ldots \ldots \ldots 234$

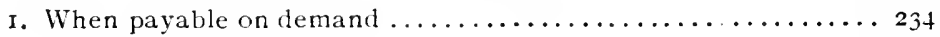

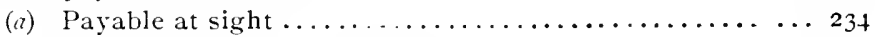

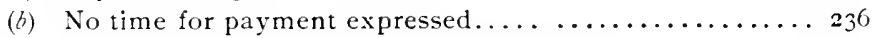

(c) Issued, accepted or indorsed when overdue................. 236

2. When payable at a fixed or determinable future time........ 235

-(a) A fixed ine after date or sight ............... 238

(b) On or Lefore a fixed determinate time specified ......... 238

(c) On or at a fixed period after the occurrence of a specified

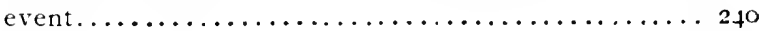

3. When payable on a contingency..................... 241

IV. Payable to order or bearer....................... 248

I. Payable to order of a specified person $\ldots \ldots \ldots \ldots \ldots \ldots \ldots \ldots 248$

(a) Payee must be certain....................... 248

(b) Payee may be: (I) One not maker, drawer or drawee... 254

(2) Drawer or maker............... 254

(3) Drawee ....................... 254

(4) Two or more payees jointly........ 255

(5) One or more of several payees ..... $25 \mathrm{~S}$

(6) The holder of an office for the time

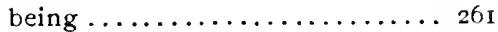

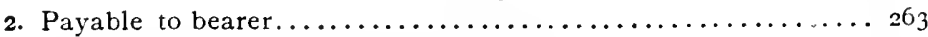

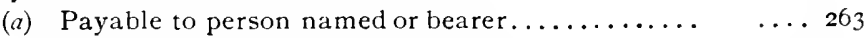

(b) Payable to order of fictitious person.... .......... $26_{3}$

(c) Payable to name not purporting to be name of any person. 268

(d) When only or last indorsement in blank............. 268

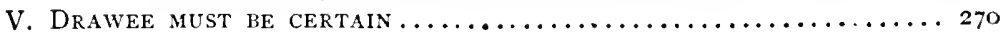




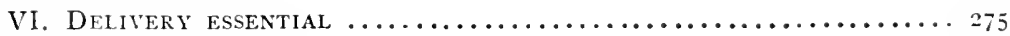

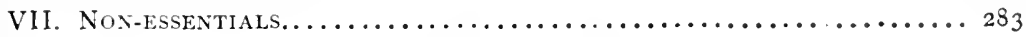

(ii) Interpretation.

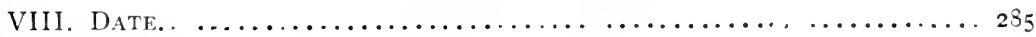

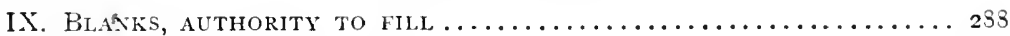

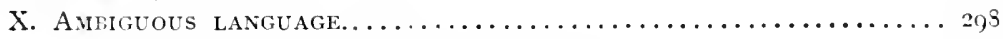

I. Discrepency between words and figures ................. $29^{9}$

2. Interest, how computed ......................... 301

3. Instrument not dated............................. $3^{01}$

4. Conflict between written and printed provisions........... 301

5. Doubt whether bill or note..................... 302

6. Irregular signatures.......................... 302

7. Joint and several liability....................... 302

XI. Ameiguous signatures .................................. $30_{4}$

I. Only those liable whose signatures appear.............. 304

2. Assumed or trade name......................... 306

3. Liability of person signing as agent................. 311

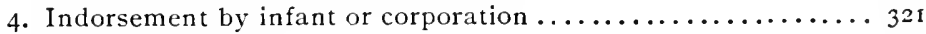

5. Forged signatures............................ 322

\section{ARTICLE III.}

\section{Consideration of Negotiable Instruments.}

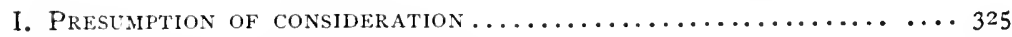

II. What constitutes consideration...................... 327

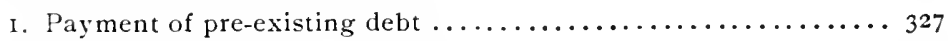

2. Collateral security for pre-existing debt $\ldots \ldots \ldots \ldots \ldots \ldots \ldots \ldots . \ldots \ldots \ldots$

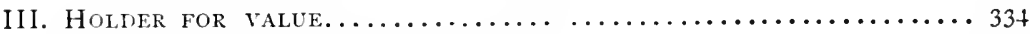

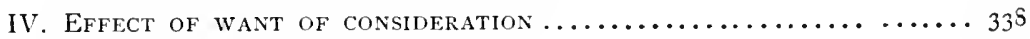



\section{ARTICLE IV.}

\section{Negotiation.}

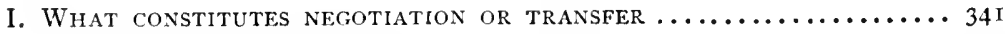

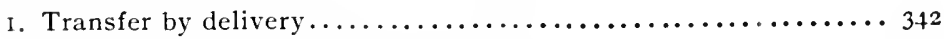

2. Transfer by indorsement and delivery ................. 343

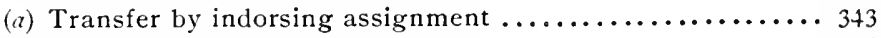

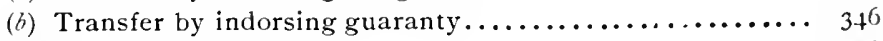

II. INDORSEMENT : FORM REQUIRED ....................... 348

I. Must be written on instrument or allonge................ $37^{8}$

2. Must be of entire instrument........................ 350

III. INDORSEMENT: KINDS OF................................. 35 I

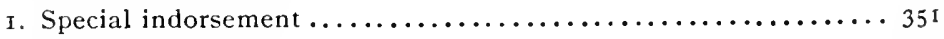

2. Blank irdorsement................................. 352

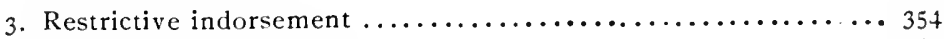

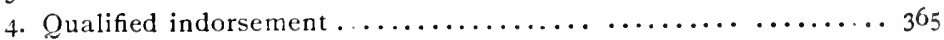

5. Conditional indorsement............................. $3^{67}$ 
IV INDORSEMENT : METHODS AND EFFECT $\ldots \ldots \ldots \ldots \ldots \ldots \ldots \ldots \ldots \ldots \ldots, 368$

I. Indorsement of instrument payable to bearer ............ 368

2. Indorsement where payable to two or more persons ......... 37 I

3. Indorsement where payable to cashier, etc.............. 373

4. Indorsement where name misspelled, etc $\ldots \ldots \ldots \ldots \ldots \ldots \ldots . \ldots \ldots 373$

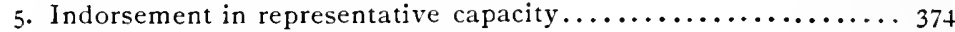

6. Presumption as to time of indorsement................... 374

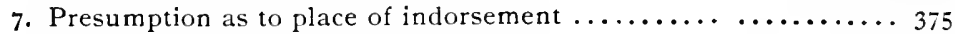

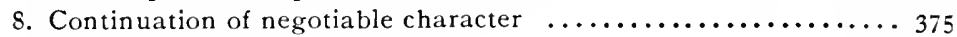

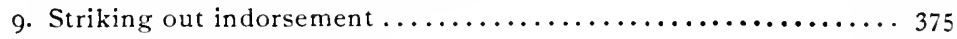

V. Transfer without indorsement.................... 375

VI. RE-TRANSFER TO PRIOR PARTY. ..................... 378

\section{ARTICLE V. \\ Righ'Ts OF HOLder.}

I. To sue and Receive payment.... . . . . . . . . . . . . . 379

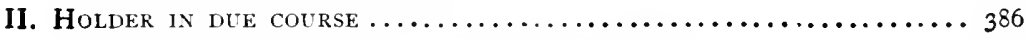

I. Requisites to constitute holder in due course............. 386

(a) Instrument must be complete and regular. ........... 386

(b) Instrument must not be overdue................. 387

(c) Must be taken in good faith and for value ........... 397

(d) Must be taken without notice of infirmity or defect....... 400

(c) Notice before full amount paid.................. 415

2. Holder deriving title from holder in due course $\ldots \ldots \ldots \ldots \ldots \ldots+17$

3. Right of holder in due course to recover full amount... ..... +

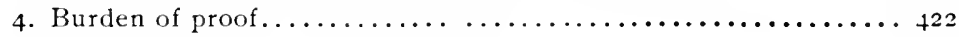

III. Defences to negotiable instruments................... 425

\section{ARTICLE VI.}

\section{Liability of Parties.}

1. Maker : absolute, primary liability ; admissions............. 446

1. Presentment for payment unnecessary $\ldots \ldots \ldots \ldots \ldots \ldots \ldots \ldots+46$

2. Liability on lost or destroyed instrument $\ldots \ldots \ldots \ldots \ldots \ldots \ldots+46$

3. Admission of existence and capacity of payee.............. $4+7$

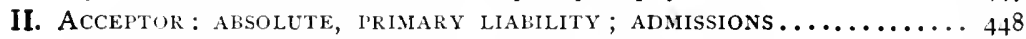

I. Presentment for payment unnecessary $\ldots \ldots \ldots \ldots \ldots \ldots \ldots \ldots+44^{8}$

2. Admissions as to drawer and payee $\ldots \ldots \ldots \ldots \ldots \ldots \ldots \ldots \ldots+48$

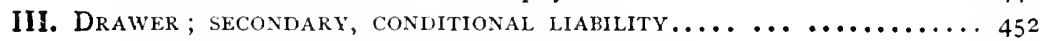

I. Conditions : presentment, notice, protest................ 452

2. Admissions as to payee............................ 452

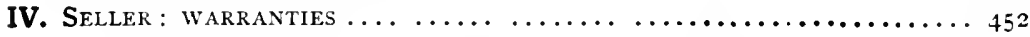

I. Instrument genuine and what it purports to be.... ... ... 452

2. Title of seller ............................ 468

3. Capacity of prior parties...................... 468

4. Knowledge of invalidity or valuelessness.............. 469

5. Indorser: instrument valid and subsisting $\ldots \ldots \ldots \ldots \ldots \ldots \ldots+72$

6. Liability of agent as seller....... $\ldots \ldots \ldots \ldots \ldots \ldots \ldots \ldots 473$ 
FAGE,

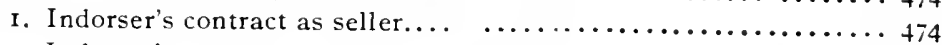

2. Indorser's contract as assurer of payment............... 474

3. Irregular indorser.......................... 4 ts

4. Order of indorsers' liability.................... tso

VI. ACCEPTOR FOR HONOR............................ + 6

VII. Guarantor.................................... +56

I. (a) Does guaranty-indorsement by holder transfer title?..... 456

(b) May a guaranty be written above a blank indorsement?... 456

2. Is a transferee by guaranty-indorsement a holder in due course? $4{ }^{5} 7$

3. What is the contract of the guarantor?...............

4. Is the guaranty transferable $\ldots \ldots \ldots \ldots \ldots \ldots \ldots \ldots \ldots \ldots \ldots+\ldots \ldots$ I

(a) Is it negotiable $\ldots \ldots \ldots \ldots \ldots \ldots \ldots \ldots \ldots \ldots \ldots \ldots \ldots \ldots \ldots \ldots$

(b) Is it assignable ?.......................... 492

5. Defences available to guarantor..................... 494

AR'TICLE VII.

Duties of Holder: Presentment for Payment.

I. Necessity of presentment . ......................... 49

I. Not to charge acceptor or maker.................... +98

Presentment necessary to charge drawer or indorser........ 50 I

II. What constitutes sufficient PRESENTMENT................ 50

I. By holder or authorized representative... $\ldots \ldots \ldots \ldots \ldots \ldots$ 50 I

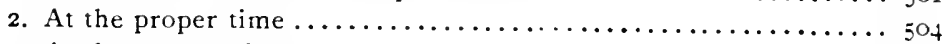

3. At the proper place............................ 512

4. To the proper person.......................... 517

5. By exhibiting the instrument ..................... 520

III. When delay in PRESENTMENT EXCUSED................ 52 I

IV. WheN pRESENTIENT dispensed with................... 523

I. When no right to require or expect it. ............. 523

2. When impossible.................................. 524

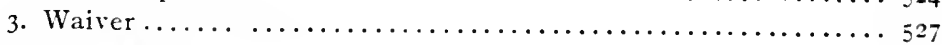

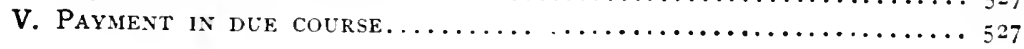

ARTICLE VIII.

\section{Duties of Holder: Notice of Dishonor.}

I. Notice Necessary to Charge DRAWER or indorser.......... 525

II. What constitutes sufficient notice...................... $52 s$

I. By whom notice must be given $\ldots \ldots \ldots \ldots \ldots \ldots \ldots \ldots \ldots \ldots$

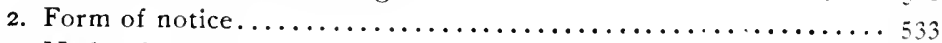

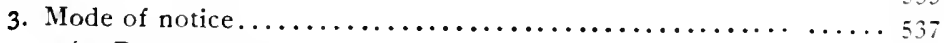

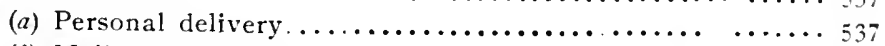

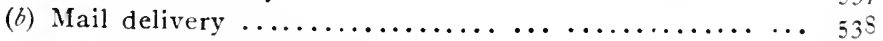

4. To whom notice may be given..................... 540

5. Time within which notice must be given.. ............. 542

(a) Where parties reside in the same place.............. 542

(b) Where parties reside in different places................. 544

(c) Successive notices... . . ................ 550

6. Place at which notice must be given $\ldots \ldots \ldots \ldots \ldots \ldots \ldots 52$ 


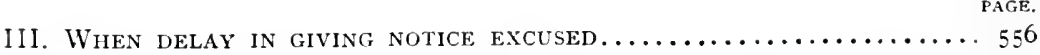

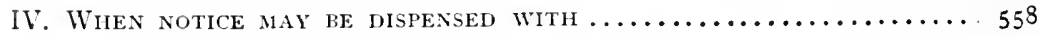

I. When notice need not be given to drawer................ $55^{8}$

2. When notice need not be given to indorser.............. $56 \mathbf{r}$

3. When notice to drawer or indorser dispensed with $\ldots \ldots \ldots \ldots . \ldots 5^{6} 3$

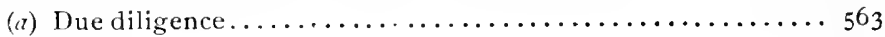

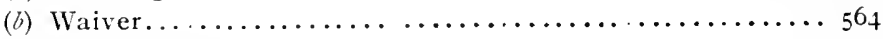

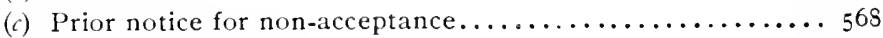

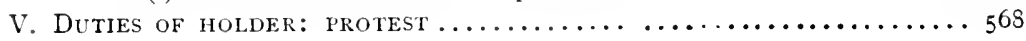

\section{ARTICLE IX. \\ Discharge of Negotiable Instruments.}

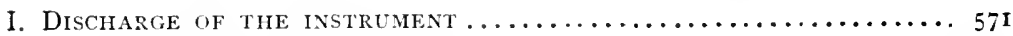

I. Payment and re-transfer.......................... 57 r

2. Cancellation or renunciation......................... 579

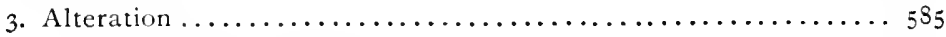

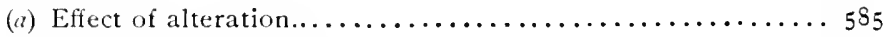

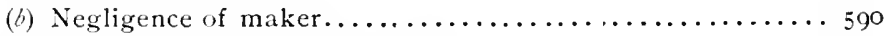

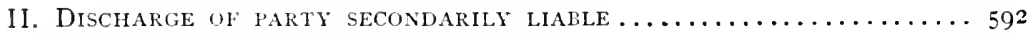

III. Payment by party Secondarily liable.................... 599

IV. PAYMENT FOR HONOR............................. 602

\section{ARTICLE X.}

\section{Bills of Exchange: Foril and Interpretation.}

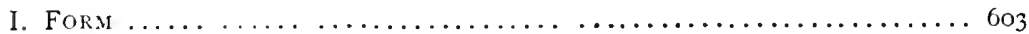

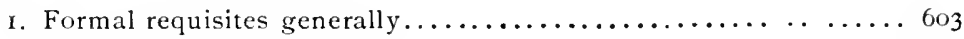

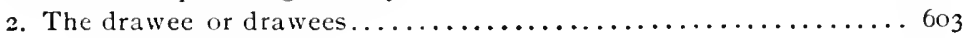

(a) Must be certain. ........................603

(b) May be joint, but not alternative or successive ........6603

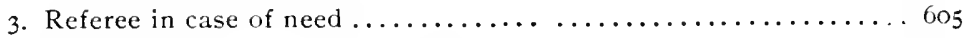

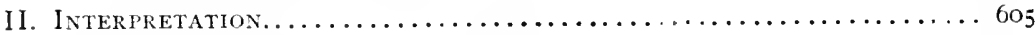

I. Bill not an assignment of funds... ................ 605

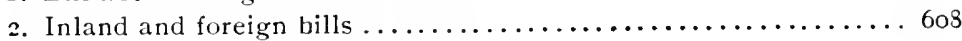

3. Bill treated as promissory note..................... 609

\section{AR'TICLE XI.}

\section{Acceptance of Bills of Exchange.}

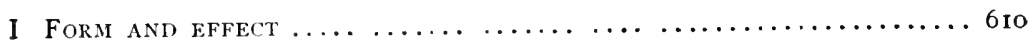

I. Acceptance must be in writing and signed by drawee......... fro

(a) Writing and signature....................... 6ro

(b) Only the drawee can accept.................. 6II

(c) Delivery necessary........................ 612

2. Promise to accept must be in writing.................. $61_{3}$

3. Acceptance by refusal to return the bill $\ldots \ldots \ldots \ldots \ldots 6 . \ldots \ldots 67$

4. Acceptance of incomplete or dishonored bill... .......... 6ra 
PAGE.

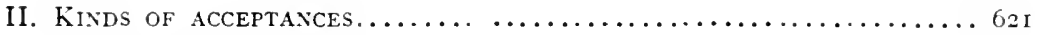

1. General acceptance.......................... 62 I

2. Qualified acceptance........................ 626

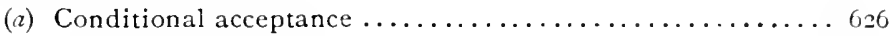

(b) Partial acceptance........................ 628

(c) Local acceptance .......................... 625

(d) Acceptance qualified as to time..................629

(c) Acceptance by one or more drawees, but not by all ......6630

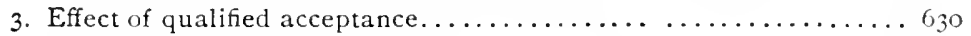

(a) Holder may refuse qualified acceptance.............. 630

(b) Qualified acceptance discharges non-assenting antecedent parties...........................6. $6 \ldots \ldots$

\section{ARTICLE XII.}

\section{Presentment of Bills of Exchange for Acceptance.}

I. IN What CASES PRESENTAENT FOR ACCEPTANCE NECESSARY ...... 632

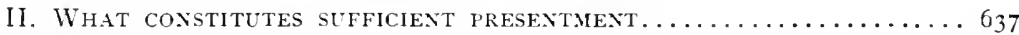

III. When PRESENTMENT FOR ACCEPTANCE EXCUSED..............6 6 I

IV. EFFECT OF DISHONOR OF BILL PRESENTED FOR ACCEPTANCE.......6 6 I

\section{ARTICLE XIII.}

\section{Protest of Bills of Exchajge.}

I. What instruments Must be protested .................6 443

II. What constitutes sufFicient pRotest ...... . . . . . . . 643

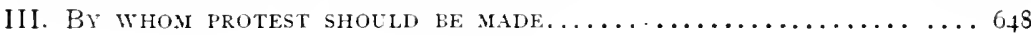

ARTICLE XIV.

ACCEPTANCE FOR HONOR................................... 65

ARTICLE XV.

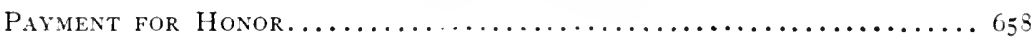

ARTICLE XVI.

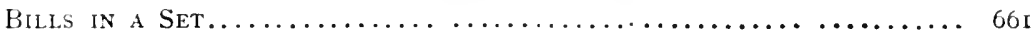

\section{ARTICLE XVII. \\ Promissory Notes and Checks.}

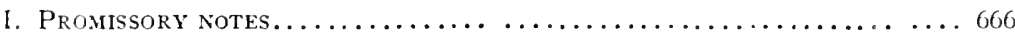

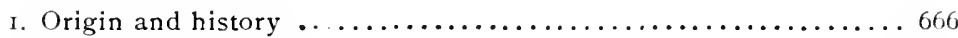

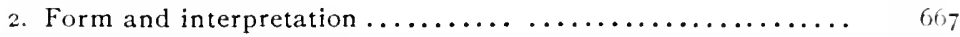

3. Non-negotiable notes ......................... 667

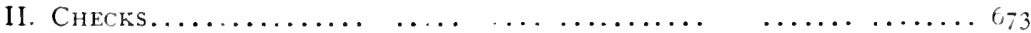

1. Check distinguished from bill of exchange......... . . . 673

2. Presentment : effect of delay upon drawer's liability......... 676 
3. Certification : effect upon drawer's liability . ..............6.682

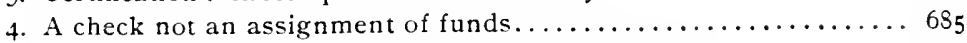

5. Liability of drawee to drawer for wrongful dishonor..........688

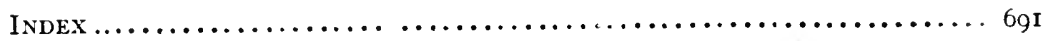




\section{TABLE OF CASES REPORTED.}

${ }^{*} *$ Where $d$ is prefixed to the page number, the case is digested or but briefly reported in the text; where $n$ is prefixed to the page number, the case is digested in a note.

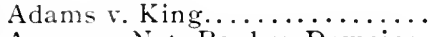
Agawam Nat. Bank v. Downing. Alabama Coal Mining Co, v.

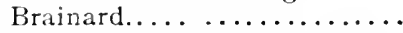
Almich v. Downey.............

American Express Co. v. Pinck-

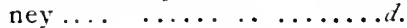
American Nat. Bank v. Junk Bros.................. American Nat. Bank v. Sprague. Anderton v. Shoup............ Anon (12 Mod. 447)........... Armstrong v. National Bank... Atlantic Nat. Bank v. Davis..... Aymar v. Beers..............

Bank of Commerce v. Chambers. Bank of England v. Vagliano Bros ............. 1 27 , Bank of Geneva v. Howlett ..... Bank of Michigan v. Ely ....... Bank of Orleans v. Whittemore. Bank of the Republic v. Millard. Bank of Rochester v. Gray ...... Barnes v. Vaughan.......... Bartlett v. Tucker ........... Bartlett v. Robinson ......d. Baxendale v. Bennett........ Belden v. Hann............. Berry v. Robinson ........... Bishop v. Curtis............. Bissell v. Dickerson.......... Bitzer v. Wagar............. Blake v. Coleman............ Blake v. McMillen............

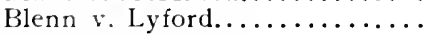
Boehm v. Garcias............ Bolles v. Stearns ...... .... Brick v. Freehold Nat. Bank... Bristol v. Warner .......... Brook \& Co. v. Vannest ........ Brooks v. Struthers........... Brooks v. Higby............ Brown v. Butchers, etc., Bank.. Brown v. Curtiss............
PAGE.

301

563

245

304

604
263

688

636

554 266
Brown v. Jordhal. PAGE.

Brown.. Jordhal.. .......... 283

Brown v. Montgomery. ...... 469

Brown v. Reed............. 59 I

Brush v. Administrators of Reeves ............... Bull v. Bank of Kasson.......... 475

Campbell Printing, etc., Co, v. Jones ............... 3 . $30 \mathbf{1}$ Cape Ann Nat. Bank v. Burns.. 590 Carlon v. Kenealy........... 203 Carnwrightv. Gray ........... 668 Carter v. Union Bank........ 6. 6 48 Casco Nat. Bk. v. Clark....... 317 Cathell v. Goodwin.......... $\quad 560$ Caulkins v. Whister... ...... 299 Cayuga, etc., Bank v. Hunt.... 646 Central R. v. First Nat. Bk. ... 357 Challiss v. McCrum......... $46 \mathrm{4}$ Chamberlain v. Young ....... 249 Chanoine v. Fowler......... 525 Chapman v. Keane.......... 53 I Chapman v. Rose.......... 435 Cheever v. Pittsburgh, etc., R... 407 Chester v. Dorr............ 393 Chicago Ry. Co. v. Merchants' Bank................ 209 Chipman v. Foster......... $3 \mathbf{1 7}$ Chrysler v. Renois .......... 223 Citizens' Nat. Bk. v. Piollet..... 246 Clark v. Pease............ $\quad 425$ Clarke v. Patrick ........... 354 Clutton v. Attenborough......d. $\$ 66$ Cock v. Fellows........... 342 Commonwealth v. Butterick ...d. I7t Continental N. B. v. Townsend . $\quad 357$ Continental Life Ins. Co. v. Barber............... 596 Cooke v. Horn... ......... 202 Cooperv. Dedrick......... 492 Cota v. Buck............. I $3 \mathbf{I}$ Coulter v. Richmond......... $47^{8}$ Crist v. Crist.............. 3 . . Cromwell v. Hewitt......... 672 
Cruchley v. Clarance.......d.

Currier v. Lockwood..........

Curtis v. Sprague ...........

Dabney v. Stidger............

Daniels v. Hammond........n.

Dart $v$. Sherwood ............

Davies v. Wilkinson..........

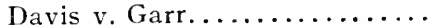

Davis v. Reilly .............

Davis Sewing Machine Co. v. Best....... ........

De la Torre v. Barclay.. ......

Dennistoun v. Stewart.........

De Witt v. Perkins............

Dodge v. Emerson...........

Dresser v. Missouri, etc., Co....

Duffield v. Johnston ...........

Dunavan. v. Flynn..........d.

Dwight v. Pease ............

Easterly v. Barber........... Eldred v. Malloy............. Elgin City Banking Co v. Zelch.

Erwin v. Downs............

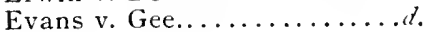

Everson v. Gere..............

Fall River Union Bank v. Willard.

Farnsworth v. Allen..........

First Nat. Bank v. Farneman...

First Nat. Bank v. Slaughter ...

First Nat. Bank v. Slette......

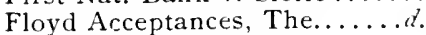

Folger v. Chase.............

Fox v. Citizens' Bank.........

Frazier v. Massey ............

Freeman v. Exchange Bank...

Freeman's Nat. Bk. v. Savery...n.

Funk v. Babbitt............

Gardner v. Maynard..........

Gay v. Rooke..............

Geary v. Physic............

Goodman v. Harvey...........

Goodwin v. Robarts .........

Gordon v. Anderson..........

Gove v. Vining .............

Gowan v. Jackson...........

Grange v. Reigh............

Gregg v. Beane.............

Grey v. Cooper.............

Grocers' Bank v. Penfield......

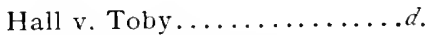

Hamilton v. Vought..........

Hammett v. Brown.........d.

Hannum v. Richardson.........

Harrisburg Trust Co.v. Shufeldt,

Harrison v. Nicollet Nat. Bank,

Harrison v. Ruscoe.........n.

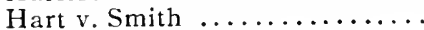

Harvey v. Cane..........
PAGE.
Hastings v. Thompson........

Hatcher v. Stalworth.........

Hays v. Hathorn............

Head v. Hornblower..........

Hegeman v. Moon.........d.

Herrick v. Bennett. .........

Herring v. Woodhull .........

Heuertematte v. Morris... 336,

Hillsdale College $v$. Thomas....

Hobbs v. Straine...........

Hodges v. Shuler............

Hoffman $v$. Bank ........

Hogue v. Williamson ........

Holbrook v. Payne...........

Hook v. Pratt..............

Hopps \& Co. v. Savage........

Horn v. Newton City bank.....

Hotchkiss v. National Banks..d.

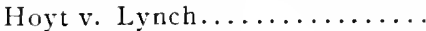

Hughes v. Kiddell,.........

Hull v. Myers..............

Hunter v. Wilson.............

Hussey v. Winslow..........

Ives v. Farmers' Bank.........

Jackson v. Hudson............

James v. Wade. ............. 556

Jarvis $v$. St. Croix Mfg. Co......

Jennings v. Roberts......... 531

Johnson v. Barrow .......... 367

Johnson v. Conklin.......... 44 447

Johnson v. Haight........... $50_{4}$

Johnson $v$. Mitchell........... 369

Jones v. Gordon............. $39 s$

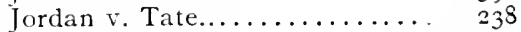

Joslyn v. Eastman............. 593

Josselyn v. Lacier.......... IS 3

Kelley v. Hemmingway...... 241

Kelley v. Whitney,........... 394

King v. Ellor................ I I

King v. Hurley............ 533

Kinyon v. Wohlford......... 279

Laird v. State............ 2 I9

Lancaster $v$. Baltzell.......... 322

Lancey v. Clark............. 578

Lane v. Stacey.............. $44_{5}$

Larkin v. Hardenbrook....... 579

Leavitt v. Putnam ........... 356

Leonard v. Mason........... $22 \mathrm{.}$

Lewis v. Clay ............. 440

Light v. Kingsbury........... . $\quad 337$

Lindenberger v. Beall........ 544 
Lysaght v. Bryant...........

McGregory v. McGregory.......

McIntosh v. Lytle...........

Madison Square Bank v. Pierce..

Market and Fulton N. B. v. Sargent.

Markey v. Corey ............

Matteson v. Moulton.........

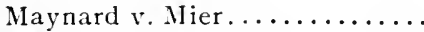

Mears v. Graham..............

Mehlberg v. Tisher...........

Merritt v. Benton .. ........

Meyer v. Richards ...........

Meyer \& Co. v. Decroix, Verley

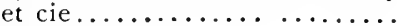

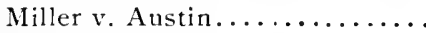

Miller v. Poage

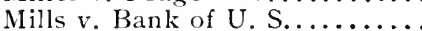

Minot v. Russ.............

Montgomery v. Elliott.........

Moore v. Coffield.............

Moore v. Cushing............

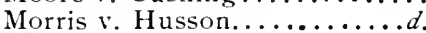

Musselman v. Oakes..........

National Bank of Commonwealth v. Law

National Bank of Michigan v.

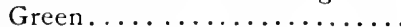

National Park Bank v. Ninth Nat. Bk..............

Newark, etc., MIg. Co.,v. Bishop. Nixon v. Palmer..............

Noll v. Smith

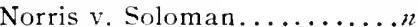

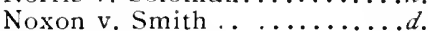

O'Callaghan v. Sawyer.

Ocean Nat. Bank v. Fant...........

Ohio Life Ins., etc., Co. v. McCague................

Oothout v. Ballard...........

Osborn v. Hawley...........

Osgood v. Artt .............

Page v. Cook............... Page v. Morrel..............

Pardee v. Fish.............

Parker v. Kellogg ...........

Parker v. Plymell ............

Parker v. Reddick............

Parsons v. Jackson...........

Pasmore v. North............

Pearce v. Langht.............

Petit v. Benson .............

Peto v. Reynolds..............

Pier v. Heinrichshoffen........

Plato v. Reynolds............ Post v. Kinzua Hemlock Ry. Co. Power v. Finnie............ Prescott N. B. v. Butler ...... Prouty v. Roberts........... Putnam v. Crymes..........
PAGE,
Putnam v. Schuyler.......... Railroad Co. v. National Bank. .

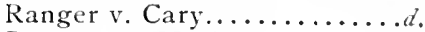

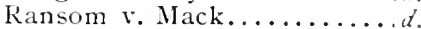

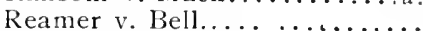

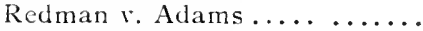

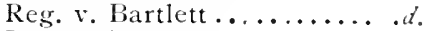
Reg. v. Harper.............. Rice v. Stearns. ............ Richardson v. Ellett ........d.

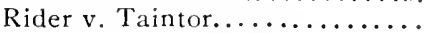
Riker v. Sprague Mfg. Co....... Robertson v. Kensington ........ Robinson v. Ames ............ Rockville Bank v. Holt.........

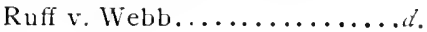

Sackett v. Palmer. ........... Saloman v. Pfeister \& Vogel Leather Co............... Saunders v. McCarthy.........

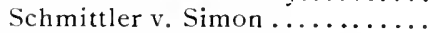
Schmitz v. Hawkeye, etc., Co.d. Schofield v. Bayard........... Scott v. Calkin............. Sharpe v. Drew ............ Shaw v. Camp..............

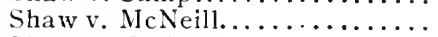

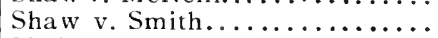
Sheldon v. Benham...........

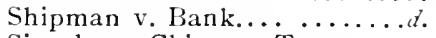
Siegel v. Chicago Trust, etc., Bank................

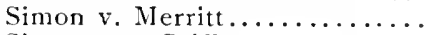
Simpson v. Griffin........... Simpson v. Turney........... Slade v. Mutrie..............

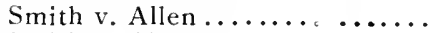

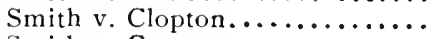
Smith v. Crane..............

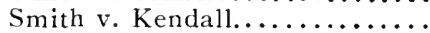

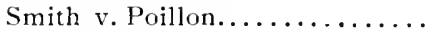

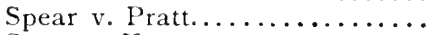

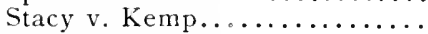

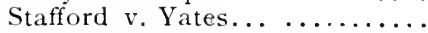

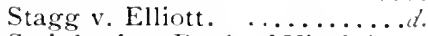
Stainback v. Bank of Virginia... Stapleton v. Louisville Banking Co................... Stevens v. Androscosgin Water Power Co................ Stewart v. Eden.............

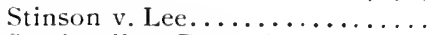
Stockwell v. Bramble.......... Stoddard v. Burton........... Stoddard v. Kimball............ Sullivan v. Rudisill........... Sussex lont

Tatam. Haslar........... 422 Taylor v. Dobhins........... ${ }_{16} 63$ Taylor v. Snyder............ 516
PAGE. 494 
Toby v. Maurian..............

Tombeckbee Bank v. Dumell...

Troy City Bank v. Lauman.....

True v. Fuller...............

Trust Co. v. National Bank.....

Turner v. Iron Chief Mining Co.

Union Nat. Bank v. Marr's Adm'r.

Valley Nat. Bk. v. Crowell......

Violett v. Patton...............

Wait $v$. Thayer..............

Walker $v$. Bank.................

Walker v. Ebert...............

Wallace v. Agry ............

Walsh v. Blatchley...........

Walton v. Williams.............

PAGE.

639 Wellington v. Jackson.......... 324

625 Wells v. Brigham............. 193

49I Wheeler v. Webster ........d. 272

346 White v. Cushing........... $\quad$ I 77

504 White $v$. Madison........... 3II

Waring v. Betts.............

White Sewing Machine Co. v.
557
Dakin...............

$229 \quad$ Inst....................... 468

296 Wilson v. Campbell............. 2

Wintermute $v$. Post.......... 630

406 Winthrop v. Pepoon.. ....... 641

631 Witte $v$. Williams.......... 254

431 Witty v. Michigan, etc., Ins. Co. 298

636 Worden v. Dodge............. Iso

663 Worth v. Case................ 277

6 I I Worthington v. Cowles........ 473

Watrous v. Halbrook..............

524

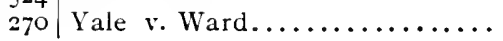


NEGOTIABLE INSTRUMENTS:

STATUTES, CASES AND AUTHORITIES.

\author{
PART I.
}

STATUTES. 



\section{NEGOTIABLE INSTRUMENTS LAW.}

Laws of New York, iS97, Chapter 6 i 2 ; is98, Chapter 336 (Text).

Laws OF Colorado, i897, Chapter 239.

Laws of Connecticut, i 897 , Chapter 74 .

Laws OF Florida, i 897 , No. io, Chapter 4524.

Laws of Maryland, i898, Chapter i i 9.

Laws of Virginia, i $897-98$, Chapter 866.

Laws of Massachusetts, I Rev. Laws (igo2), p. 628 (Act i 898 , Chapter 533).

Laws of Dist. of Columbia, i 899,30 U. S. St. at L., P. 785.

Laws of North Carolina, i 899, Chapter 733.

Laws of North Dakota, i 899 , Chapter II 3 .

Laws of Oregon, i 899 , Page is.

Laws of Rhode Island, i 899 , Chapter 674.

Laws of Tennessee, I 899 , Chapter 94.

Laws of Utah, 1899 , Chapter 83 .

Laws of Washington, i 899, Chapter 149.

LAWS OF Wisconsin, I 899, Chapter $35^{6}$.

Laws of Pennsylvania, igor, Chapter i62.

LAWS OF OHIO, I 902 .

Laws of New Jersey, 1902, Chapter i 84 . 


\section{EXPLANATORY NOTE,}

The text is that of the New York Negotiable Instruments Law. The Act as passed in other States is identical except as to section numberings and headings. The section numbers in brackets at the right of the headings and elsewhere are those of the other States and are uniform in those States from [ $\left[\S_{1}\right]$ to $\left[\S_{1} \$_{9}\right]$, inclusive. The notes in brackets are those of the draftsman (J. J. Crawford, Esq.), as they appeared in the draft printed by the Commissioners on Uniformity of Laws. The reference, "Cases, pp. $x-x$," is to the "Cases and Authorities" contained in this volume. The reference "Chalmers" is to Chalmers' Bills of Exchange Act (5th ed.), London, r896. The reference to Daniel on Negotiable Instruments is to

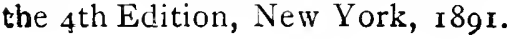




\title{
THE NEGOTIABLE INSTRUMENTS LAW.
}

\author{
Laws of New York, i897, Chapter 612.
}

An act in relation to negotiable instruments, constituting chapter fifty of the general laws. [Became a law May I9. I 897.$]$

The People of the State of New York, represented in Senate and Asscmbly, to cnact as follows:

\section{THE NEGOTIABLE INSTRUMENTS LAW.}

"ARTICLE 1. GENERAL PROVISIONS. (§S I-7.)

II. Form AND interpretation of Negotiable Instruments. (SS 20-12.) $[S S$ I-23.]

iII. Consideration. (SS 50-55.) [SS 24-29.]

[V. Negotiation. (SS 60-8o.) [S 30-50.]

?. Rights OF HOLDER. (\$\$ 90-9S) [S. 5I-59.]

VI. Liabilities of parties. (SS i IO-I i9.) [SS 60-69.]

VII. Presentuent for Payment. (\$S I $30-1+8$.) [S 70-S8.]

VIII. Notice of vishonor. (\$S I60-I89.) [SS OS-IIS.]

IX. Discharge of negotiable instruments. (SS 200-206.) [SS I I 9-I25.]

X. Bills of EXchaNge; FORM AND INTERPRETAtion. (?S 210-215.) [S. I26-I3I.]

XI. ACCeptaxce. (\$S 220-230.) [SS I32-I42.]

XiI. Presentilent for acceptaxce. (\$S 240-24S.) [SS I $43-I 5 I$.

XIII. Protest. (\$S 260-268.) [SS I 52-I60.]

XIV. ACCEPTANCE FOR HONOR. (SS 280-290.) [SS IGI-I7o.]

XV. PAVMeNT For hoNoR. (S 300-306.) [S: I I I-I77.]

XVI. Bills in a SET. (SS 310-3I5.) [\$S I $78-183$.

XVII. Promissory Yotes and checks. (\$ 320-325.) [SS IS4-I89.]

XVIII. Notes given for PATENT RIghts aND fOR a SPECulative CONSID ERATION. (\$\$330-332.)

XIX. LaWS REPEALED, WheN tO TAKE EFFect. (\$S 3+0-3+I.)

* In the other States the act is divided as follows: Title I. Negotiable Instruments in General (Arts. I to VIII); Title II. Bills of Exchange (Arts I to VI"). Title III. Promissory Notes and Checks. 


\section{ARTICLE I.}

*Section 1. Short title.

\section{GENERAL PROVISIONS.}

2. Definitions and meaning of terms.

3. Person primarily liable on instrument.

4. Reasonable time, what constitutes.

5. Time, how computed; when last day falls on holiday.

6. Application of chapter.

7. Rule of law merchant; when governs.

\section{Short title.}

This act shall be known as the negotiable instruments law. (a)

(a) It will be observed that the Act as they are anything more than comapplies only to negotiable instruments. mon-law contracts. See $\$ 320$ [I84], Non-negotiable bills and notes are still post.

governed by the law merchant, so far

\section{Definitions and meaning of terms.}

In this act, unless the context otherwise requires:

"Acceptance" means an acceptance completed by delivery or notification.

"Action" includes counter-claim and set-off.

“ Bank" includes any person or association of persone carrying on the business of banking, whether incorporated or not.

"Bearer" means the person in possession of a bill or note which is payable to bearer.

" Bill" means bill of exchange, and " note" means negotiable promissory note.

"Delivery" means transfer of possession, actual or constructive, from one person to another.

"Holder" means the payee or indorsee of a bill or note, who is in possession of it, or the bearer thereof.

" Indorsement" means an indorsement completed by delivery.

"Instrument" means negotiable instrument.

"Issue" "means the first delivery of the instrumert; complete in form to a person who takes it as a holder.

"Person" includes a body of persons, whether incorporated or not.

* $\S$ Igo to $\S$ Ig6 in Colorado; no section numbers in the other States. 
"Value" means valuable consideration.

"Written" includes printed, and "writing " includes print.

See Bills of Exchange Act, section 2.

\section{§3. Person primarily liable on instrument.}

The person "primarily" liable on an instrument is the person who by the terms of the instrument is absolutely required to pay the same. All other parties are "secondarily" liable.

\section{$\S 4$. Reasonable time, what constitutes.}

In determining what is a "reasonable time" or an " unreasonable time" regard is to be had to the nature of the instrument, the usage of trade or business (if any) with respect to such instruments, and the facts of the particular case.

See Bills of Exchange Act, sections 40, 45, 74, 86 .

\section{$\S 5$. Time, how computed; when last day falls on holiday.}

Where the day, or the last day, for doing any act herein required or permitted to be done falls on Sunday or on a holiday $(a)$, the act may be done on the next succeeding secular or business day. (b)

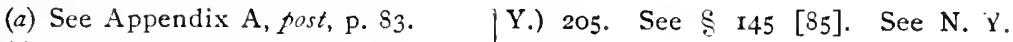

(b) See Salter v. Burt, 20 Wend. (N. Statutory Construction Law, $\$ \$ 26,27$.

\section{$\S 6$. Application of chapter.}

The provisions of this act do not apply to negotiable instruments made and delivered prior to the passage hereof.

\section{\$ 7. Law merchant; when governs.}

In any case not provided for in this act the rules of the law merchant (a) shall govern.

(a) Cases, pp. 132-160.

\section{ARTICLE II}

\section{FORM AND INTERPRETATION.}

*Section 20. Form of negotiable instrument.

$2 \mathrm{I}$. Certainty as to sum; what constitutes. 
Section 22. When promise is unconditional.

23. Determinable future time; what constitutes.

24. Additional provisions not affecting negotiability.

25. Omissions; seal; particular money.

26. When payable on demand.

27. When payable to order.

2S. When payable to bearer.

29. Terms when sufficient.

30. Date of; presumption as to.

3I. Ante-dated and post-dated.

32. When date may be inserted.

33. Blanks, when may be filled.

34. Incomplete instrument not delivered.

35. Delivery; when effectual; when presumed.

36. Construction where instrument is ambiguous.

37. Liability of persons signing in trade or assumed name.

38. Signature by agent; authority; how shown.

39. Liability of person signing as agent, et cetera.

40. Signature by procuration; effect of.

4I. Effect of indorsement by infant or corporation.

42. Forged signature; effect of.

\$20. Form of negotiable instrument.

An instrument to be negotiable must conform to the fol. lowing requirements:

I. It must be in writing $(a)$ and signed by the malser or drawer. (b)

2. Must contain an unconditional $(c)$ promise $(d)$ ct order $(c)$ to pay a sum certain $(f)$ in money $(g)$;

3. Must be payable on demand $(h)$, or at a fixed or determinable future time $(i)$;

4. Must be payable to order $(k)$ or to bearer $(l)$; and

5. Where the instrument is addressed to a drawee, he must be named or otherwise indicated therein with reasonable certainty. $(m)$

[Note, - See Bills of Exchange Act, sections 3, 4, 5, 6.] For definition of bill, note, check, see $\$ 2$ Io [126], 320 [I 84$], 32$ I [ 85 ], post.

(a) See $\$ 2$ [General Provisions]. Cases, pp. I6I-I62.

(b) Cases, pp. I62-I64.

(c) See $\$ 22$ [3]. Cases, pp. 176-195.

(d) Cases, pp. I64-172.

(c) Cases, Pp. I73-I 75 .

(f) See $\$ 2 \mathrm{I}[2]$. Cases, pp. I95-2I7.

(g) Cases, pp. 218-227. (h) See $\& 26[7]$. Cases, pp. 234-237

(i) See $\$ 23[4]$. Cases, pp. $23^{8-2}-27$

(k) See $\$ 27[8]$. Cases, pp. $248-262$

(l) See $\$ 28$ [9]. Cases, pp. 263-270.

(m) See $\$ 2$ Iо [126]. Cases, pp. 270275. [Peto v. Reynolds, 9 Exch. 410. Ball v. Allen, I5 Mass. 433.] 
$\S 2$ r. Certainty as to sum; what constitutes.

The sum payable is a sum certain (a) within the meaning of this act, although it is to be paid:

I. With interest; $(b)$ or

2. By stated installments; $(c)$ or

3. By stated installments, with a provision that upon default in payment of any installment or of interest, the whole shall become due; $(d)$ or

4. With exchange, whether at a fixed rate or at the current rate; $(c)$ or

5. With costs of collection or an attorney's fee, in case payment shall not be made at maturity. $(f)$

[Note. - See Bills of Exchange Act, section 9.]

(a) Cases, pp. 195-199.

(b) Cases, pp. I99-202.

(c) Cases, pp. 202-20s.

(d) Cases, pp. 2o5-2ir.

(e) Cases, Pp. 212-2I5.

(f) Cases, pp. 215-2I7. [Nat. Bank 331; 52 Fed. Rep. I9I; Montgomery v Crossthwait, 9o Ala. 553; Bank v Marsh (Iowa), 56 N. W. Rep. $45^{5}$ Dorsey v. Wolff, I 42 Ill, 589; Trade: v. Chidester, 4 I Ark. $2+2$; Stapleton $r$. v. Sutton Mfg. Co., 6 U. S. App. 312, Rep. 81.]

\section{$\S 22$. When promise is unconditional.}

An unqualified order or promise to pay is unconditional within the meaning of this act, though coupled with:

I. An indication of a particular fund out of which reimbursement is to be made, or a particular account to be debited with the amount; $(\alpha)$ or

2. A statement of the transaction which gives rise to the instrument. (b)

But an order or promise to pay out of a particular fund is not unconditional. $(c)$

[Note. - See Bills of Exchange Act, section 3, subdivision 3.] Cases, pp. $176-195$.

(a) Cases, pp. 153-159.

(b) Cases, pp. 190-195.

(c) Cases, pp. I8o- 183 .

\section{§23. Determinable future time; what constitutes.}

An instrument is payable at a determinable future time, within the meaning of this act, which is expressed to be payable:

I. A.t a fixed period after date or sight; $(a)$ or 
2. On or before a fixed or determinable future time specified therein; (b) or

3. On or at a fixed period after the occurrence of a specified event, which is certain to happen, though the time of happening be uncertain. (c)

An instrument payable upon a contingency is not negotiable, and the happening of the event does not cure the defect. $(d)$

[Note. - See Bills of Exchange Act, section II.]

(a) Cases, pp. 238 .

(b) Cases, pp. 238-240. [Mattison A. v. Marks, 3I Mich. 42I; Smith v. Ellis, 29 Me. 422; Riker v. Sprague Mfg. Co., If R. I. fo2; Kiskadden v. Allen, 7 Colo. 206; Jordan v. Tate, ig Ohio St. (d) Cases, pp. I76-183.

\section{\$ 24. Additional provisions not affecting negotiability. [ $\$ 5]$}

An instrument which contains an order or promise to do any act in addition to the payment of money is not negotiable. (a) But the negotiable character of an instrument otherwise negotiable is not affected by a provision which:

I. Authorizes the sale of collateral securities in case the instrument be not paid at maturity; $(b)$ or

2. Authorizes a confession of judgment if the instrument be not paid at maturity; $(c)$ or

3. Waives the benefit of any law intended for the advantage or protection of the obligor; $(d)$ or

4. Gives the holder an election to require something to be done in lieu of payment of money. $(e)$

But nothing in this section shall validate any provision or stipulation otherwise illegal.

(a) Cases, pp. 223-229.

(b) Cases, pp. 229-230. [Perry v. man v. Anderson, 67 Pa. St. 42 I.]

Bigelow, I28 Mass. I29.]

(c) Cases, pp. 230-23I [Osborn v. Hawley, I9 Ohio, izo. Contra, Sweeney v. Thickstun, $77 \mathrm{~Pa}$. St. I3I.]

$\S 25$. Omissions; seal; particular money.

The validity and negotiable character of an instrument are not affected by the fact that:

I. It is not dated; $(a)$ or 
2. Does not specify the value given, or that any value has been given therefor; $(a)$ or

3. Does not specify the place where it is drawn or the place where it is payable; $(a)$ or

4. Bears a seal; $(b)$ or

5. Designates a particular kind of current money in which payment is to be made. $(c)$

But nothing in this section shall alter or repeal any statute requiring in certain cases the nature of the consideration to be stated in the instrument. $(d)$

[NoTE. - See Bills of Exchange Act, section 3, subdivision (4).]

(a) Cases, p. 233. See $\$ 32$ [13], of exchange between the two." $I b$., post. "Under most of the conti- p. I5.

nental Codes it is essential that a bill (b) Cases, pp. 283-284. [This is the should be dated." Chalmers' Bills of rule in many states by statute. See Exchange Act (5th ed.), p. I3. And Daniel on Neg. Inst., section 33. See state a consideration. Ib., p. It. And also Weeks v. Es]er, I43 N. Y. 374.]

in some it is necessary that a bill should (c) Cases, pp. 218-227. [Daniel on Neg. be payable in a place different to that Inst., section 56 et seq., and cases cited.] in which it is made. "No distance is (d) See New York Neg. Inst. L., fixed by the codes, but it has been de- $\$ S 33^{0}-33$. . [To cover cases like those cided that the place of payment must provided for by Laws of N. Y. IS77. be so far distant from the place of ch. 65, section I (repealed); and Laws issue that there may be a possible rate of N. Y. I 894 , ch. 262, section I.]

\&26. When payable on demand.

An instrument is payable on demand:

I. Where it is expressed to be payable on demand, or at sight $(a)$, or on presentation; or

2. In which no time for payment is expressed. (b)

Where an instrument is issued, accepted or indorsed when overdue, it is, as regards the person so issuing, accepting or indorsing it, payable on demand. (c)

[Note. - See Bills of Exchange Act, section Io.]

(a) Cases, pp. 234-236.

(b) Cases, p. 236.

Wilby, 45 Ohio St. 333; Smith v. Cord,

(c) Cases, pp. 236-237. [Light v. sections 6II, 996.]

Kingsbury, $5^{\circ}$ Mo. 33I; Bassenhorst $v$.

$\S 27$. When payable to order.

The instrument is payable to order where it is drawn payable to the order of a specified person or to him or his order. (a) It may be drawn payable to the order of:

I. A payee who is not maker, drawer or drawee; or 
2. The drawer ${ }^{*}$ or maker; $(b)$ or

3 The drawee; $(c)$ or

4. Two or more payees jointly; $(d)$ or

5. One or some of several payees; $\left(c^{\prime}\right)$ or

6. The holder of an office for the time being. $(f)$

Where the instrument is payable to order the payee must be named or otherwise indicated therein with reasonable certainty. $(g)$

[Note. - See Bills of Exchange Act, sections 5, 7, 8.]

(a) [The Bills of Exchange Act provides that "a bill is payable to order which is expressed to be so payable or which is expressed to be payable to a particular person and does not contain words prohibiting transfer or indicating an intention that it should not be transferable." But this changes the law (Byles, $8_{3}$; Smith v. Kendall, 6 T. R. I23; Maule v. Crawford, I4 Hun, I93; Daniel on Neg. Inst., section I05), and the change is not deemed advantageous. Frederick v. Cotton, 2 Shower, 8; Smith v. McClure, 5 East, 476; Howard v. Palmer, 64 Me. 86; Daniel on Neg. Inst., section Io6.]

(b) Cases, p. 254. (c) Cases, pp. 254-255.

(d) Cases, pp. $255^{-258}$.

(c) Cases, pp. 255-26I. [The Bills of Exchange Act permits the instrument to be drawn to "one or two payees in the aiternative." But this changes the law. Blanckenhagen $v$ Blundell, 2 Barn. \& Ald. 4Is; Walrad v. Petrie, 4 Wend. 576; Watson v. Evans, r Hurl. \& Colt. 663.]

( $f$ ) Cases, pp. 26I-263. [Davis v. Garr, 6 N. Y. I24; Daniel on Neg. Inst., section IOI.]

(s) Cases, pp. 248-253. [Byles on Bills, so; Blackman v. Lehman, 63 Ala. 547; United States v. White, 2 Hill, 59.]

\section{$\S 28$. When payable to bearer.}

The instrument is payable to bearer:

I. When it is expressed to be so payable; $(a)$ or

2. When it is payable to a person named therein or bearer; $(a)$ or

3. When it is payable to the order of a fictitious or non-existing person, and such fact was known to the person making it so payable; $(b)$ or

4. When the name of the payee does not purport to be the name of any person; $(c)$ or

5. When the only or last indorsement is an indorsement in blank. $(d)$

[NoTE. - See Bills of Exchange Act, sections 7, 8.]

(a) Cases, p. 263. [Eddy v. Bond, (c) Cases, p. 265. [Byles on Bills, ig Me. 46r.]

(b) Cases, pp. 263-268. [Byles on $\left.s_{3 .}\right]$

Bills, 82.]

(d) Cases, pp. 268-27o. See $\$ 64$ [34], post.

* "Drawee" is used by mistake in N. Y. Act.-ED. 
§29. Terms when sufficient.

The instrument need not follow the language of this act, but any terms are sufficient which clearly indicate an intention to conform to the requirements hereof.

30. Date, presumption as to.

$[\S I \mathrm{I}]$

Where the instrument or an acceptance or any indorsement thereon is dated, such date is deemed prima facie to be the true date of the making, drawing, acceptance or indorsement as the case may be. (a)

[NoTE. - See Bilis of Exchange Act, section 13.]

(a) Cases, pp. $285-286$.

\$3. Ante-dated and post-dated.

LSI2]

The instrument is not invalid for the reason only that it is ante-dated or post-dated, provided this is not done for an illegal or fraudulent purpose. The person to whom an instrument so dated is delivered acquires the title thereto as of the date of delivery. $(a)$

[Note. - See Bills of Exchange Act, section 13. See Pasmore v. North, I3 East, 517; Brewster v. McCordle, 8 Wend. 478; Bayley v. Taber, 5 Mass. 286.]

(a) Cases, pp. 286-287.

$\S 32$. When date may be inserted.

$[\S$ I3]

Where an instrument expressed to be payable at a fixed period after date is issued undated, or where the acceptalice of an instrument payable at a fixed period after sight is undated, any holder may insert therein the true date of issue or acceptance, and the instrument shall be payable accordingly. (a) The insertion of a wrong date does not avoid the instrument in the hands of a subsequent holder in due course; but as to him, the date so inserted is to be regarded as the true date. $(b)$

[Note. - See Bills of Exchange Act, section I2. See note, section 7.]

(a) See $\$ 33[\mathbf{I} 4]$.

(b) Cases, pp. 288-289. [Mitchell v Culver, 7 Cowen, 336.]

\section{$\S 33$. Blanks; when may be filled.}

$[\S 14 \mathrm{I}$

Where the instrument is wanting in any material particu. lar, the person in possession thereof has a prima facie authority to complete it by filling up the blanks therein. (a) 
And a signature on a blank paper delivered by the person making the signature in order that the paper may be converted into a negotiable instrument operates as a prima facie authority to fill it up as such for any amount. (b) In order, however, that any such instrument, when completed, may be enforced against any person who became a party thereto prior to its completion, it must be filled up strictly in accordance with the authority given and within a reasonable time. But if any such instrument, after completion, is negotiated* to a holder in due course, it is valid and effectual for all purposes in his hands, and he may enforce it as if it had been filled up strictly in accordance with the authority given and within a reasonable time. $(c)$

[Nоте. - See Bills of Exchange Act, section 20.] See 206 [125], fost.

(a) Cases, pp. 2SS-2Sg. [Bank of] (c) Cases, pp. 29I-29S. [Schultz r. Pittsburg v. Neal, 22 How. 96; Mitchell Astley, 2 Bing. N. C. 54t: Van Duzer v. Culver, 7 Cowen, 336; Kitchen v. v. Howe, 21 N. Y. 53r; Garrard v. Place, 4I Barb. 465.]

(b) Cases, pp. 289-29I. [Russell v. feld, 33 Gratt. 384 ; Redlich r. Dall. 54 Langstaffe. 2 Doug. 5I4; Collis v. N. Y. 234.]

Emett, I H. Black, 3I3.]

\section{\$34. Incomplete instrument not delivered.}

Where an incomplete instrument has not been delivered it will not. if completed and negotiated, without authority, be a valid contract in the hands of any holder, as against any person whose signature was placed thereon before delivery. (a)

[Note. - See Davis Machine Co. v. Best, I05 N. Y. 59, 67; Sedgwick $v$. McKim, 53 N. Y. 307, 3I3; Baxendale v. Bennett, L. R. 3 Q. B. 525; Daniel on Neg. Inst., sections $84 \mathrm{I}, 842 \mathrm{a}$.

(a) Cases, pp. $2 \mathrm{So}_{\mathrm{O}} \mathrm{S}_{3}$.

\section{$\S 35$. Delivery; when effectual; when presumed.}

Every contract on a negotiable instrument is incomplete and revocable until delivery of the instrument for the purpose of giving effect thereto. As between immediate parties, and as regards a remote party other than a holder in due course, the delivery, in order to be effectual, must be made either by or under the authority of the party making, drawing, accepting or indorsing, as the case may be: and in

* "Negotiable" appears by mistake in the New York Act." - ED. 
such case the delivery may be shown to have been conditional, or for a special purpose only, and not for the purpose of transferring the property in the instrument. (a) But where the instrument is in the hands of a holder in due course, a valid delivery thereof by all parties prior to him so as to make them liable to him is conclusively presumed. (b) And where the instrument is no longer in the possession of a party whose signature appears thereon, a valid and intentional delivery by him is presumed until the contrary is proved. (c)

[NOTE. - See Bills of Exchange Act, section 2I.]
(a) Cases, pp. 275-279.
(c) Cases supra. [15], ante.

$\S 36$. Construction where instrument is ambiguous.

Where the language of the instrument is ambiguous, or there are omissions therein, the following rules of construction apply:

I. Where the sum payable is expressed in words and also in figures and there is a discrepancy between the two, the sum denoted by the words is the sum payable; but if the words are ambiguous or uncertain, references may be had to the figures to fix the amount; $(a)$

2. Where the instrument provides for the' payment of interest, without specifying the date from which interest is to run, the interest runs from the date of the instrument, and if the instrument is undated, from the issue thereof; $(b)$

3. Where the instrument is not dated, it will be considered to be dated as of the time it was issued; $(c)$

4. Where there is a conflict between the written and printed provisions of the instrument, the written provisions prevail; $(d)$

5. Where the instrument is so ambiguous that there is doubt whether it is a bill or note, the holder may treat it as either at his election; $(e)$

6. Where a signature is so placed upon the instrument that it is not clear in what capacity the person making the same intended to sign, he is to be deemed an indorser $;(f)$ 
7. Where an instrument containing the words " I promise to pay" is signed by two or more persons, they are deemed to be jointly and severally liable thereon. $(g)$

[Note. - See Bills of Exchange Act, section 9.]

(a) Cases, pp. 295-300.

(b) Cases, p. 301 .

(c) Cases, p. 30I. [Byles on Bills, 77; Daniel on Neg. Inst., sections 83, 84.]

(a) Cases, p. 30I.

(c) Cases, p. 302. [Heise v. Bum- ( $\mathrm{g}$ ) Cases, pp. 302-304. [See Bills of pass, to Ark. 547; Planters' Bank v. Exchange Act, section 85.]

\section{$\$ 37$. Liability of person signing in trade or assumed name.}

No person is liable on the instrument whose signature does not appear thereon, except as herein otherwise expressly provided. (a) But one who signs in a trade or assumed name will be liable to the same extent as if he had signed in his own name. (b)

[Note. - See Bills of Exchange Act, section 23.]

(a) Cases, pp. 304-306. See $\$ 72$ [42], (b) Cases, pp. 306-3II. post.

\section{$\$ 38$. Signature by agent; authority; how shown.}

The signature of any party may be made by a duly authorized agent. No particular form of appointment is necessary for this purpose; and the authority of the agent may be established as in other cases of agency. (a)

(a) See Huffcut on Agency, $9-59$.

\section{$\$ 39$. Liability of person signing as agent, etc.}

[\$20]

Where the instrument contains or a person adds to his signature words indicating that he signs for or on behalf of a principal, or in a representative capacity, he is not liable on the instrument if he was duly authorized; $(a)$ but the mere addition of words describing him as an agent, or as filling a representative character, without disclosing his principal, does not exempt him from personal liability. (b)

[Note. - See Bills of Exchange Act, section 26; Byles on Bills, 36; Daniel on Neg. Inst., sections 298-302.]

(a) Cases, pp. 3II-3I6. Mr. Craw- edition of the Neg. Inst. Law (p. 26), ford, the draftsman of the Act, in his says: "In the original draft submitted 
to the conference of commissioners on uniformity of laws this section read as follows: "Where a person adds to his signature words indicating that he signs for or on behalf of a principal, or in a representative capacity, he is not liable on the instrument; but the mere addition of words describing him as an agent, or as filling a representative character, does not exempt him from personal liability. In determining whether a signature is that of the principal or of the agent by whose hand it is written, that construction is to be adopted which is most favorable to the validity of the instrument.' This is the English rule, and was the rule in New York prior to the statute. Under that rule a person signing for or on behalf of a principal was not liable on the instrument, notwithstanding he had no authority to bind his principal. There was an implied warranty on his part that he possessed such authority, and if he did not, he became liable upon such warranty for the damages resulting from the breach. (Miller v. Reynolds, 92 Hun, 400.) But no action could be maintained against him on the instrument, when by its terms it did not purport to bind him. And his liability upon the implied warranty did not accompany the transfer of the instrument. unless the claim founded upon the warranty was also assigned to the person to whom the instrument was transferred. (Id.) The effect of the section, as it now stands, is to permit the holder to sue the agent on the instrument, if he was not duly authorized to sign the same on behalf of the principal."

(b) Cases, pp. 3I7-320.

\section{$\$ 40$. Signature by procuration; effect of.}

[§ 2r]

A signature by "procuration" operates as notice that the agent has but a limited authority to sign, and the principal is bound only in case the agent in so signing acted within the actual limits of his authority. (a)

[Note. - See Bills of Exchange Act, section 25; Byles on Bills, 33; Daniels on Neg. Inst., section 280 .]

(a) Cases, pp. 320-321.

\section{$\$ 4$ I. Effect of indorsement by infant or corporation.}

The indorsement or assignment of the instrument by a corporation or by an infant passes the property therein, notwithstanding that from want of capacity the corporation or infant may incur no liability thereon. $(a)$

[Note. - See Bills of Exchange Act, section 22.]

(a) Cases, pp. 32I-322. This section a contingent liability on the part of the " is probably declaratory, but the law was not very clear." Chalmers, Bills of Exchange Act (5th ed.), p. 60. ' Capacity to incur liability must be distinguished from capacity to transfer. * * An indorsement usually consists of two distinct contracts, one executed, the other executory. It transfers the property in the bill, and it also involves

\begin{abstract}
indorser." ( $I b$.$) By this section, when$ a bill is payable to the order of an infant, his indorsement transfers the property therein. *** In America it is not uncommon to get a bill made pay able to the order of an infant clerk. His indorsement then operates as an indorsement sans recours, though without discrediting the bill." (Ib., p. 63.)
\end{abstract}




\section{$\S 42$. Forged signature; effect of.}

Where a signature is forged or made without authority of the person whose signature it purports to be, it is wholly inoperative, and no right to retain the instrument, or to give a discharge therefor, or to enforce payment thereof against any party thereto, can be acquired through or under such signature $(a)$, unless the party, against whom it is sought to enforce such right, is precluded from setting up the forgery or want of authority. (b)

[NotE. - See Bills of Exchange Act, section 24.]

(a) Cases, pp. 322-323. |lish technical term, unknown to the

(b) Cases, p. 324. "The word "pre- Scotch law." Chalmers, Bills of Excluded ' was inserted in committee in change Act (5th ed.), p. 74. lieu of the word 'estopped,' an Eng-

\section{ARTICLE III.}

\section{CONSIDERATION OF NEGOTIABLE INSTRUMENTS.}

* Section 50. Presumption of consideration.

$5 \mathrm{I}$. What constitutes consideration.

52. What constitutes holder for value.

53. When lien on instrument constitutes holder for value.

54. Effect of want of consideration.

55. Liability of accommodation indorser.

\section{$\S 50$. Presumption of consideration.}

Every negotiable instrument is deemed prima facie to have been issued for a valuable consideration; and every person whose signature appears thereon to have become a party thereto for value. $(a)$

[Note. - See Bills of Exchange Act, section 30.]

(a) Cases, Pp. 325-327.

\section{$\S 5$ I. Consideration, what constitutes.}

Value $(a)$ is any consideration sufficient to support a simple contract. (b) An antecedent or pre-existing debt constitutes value; and is deemed such whether the instrument is payable on demand or at a future time. $(c)$

(a) See $\S 2$ [General Provisions], (b) “A cross acceptance (Rose v. ante. Sims, I B. \& Ad. p. 526), the forbear- 
ance of the debt of a third person (Bal- | Hughes, I K. \& J. 4+3), or a voluntary four v. Sea Assur. Co., 3 C. B. N. S. gift of money (Hill v. Wilson, L. R. 8 300 ; Crears v. Hunter, L. R. I9 Q. B. Ch., p. S94), do not constitute value." D. 34I), the compromise of a disputed Chalmers, Bills of Exchange Act (5th liability (Cook v. Wright, 3o L. J. Q. B. ed.), p. so.

32I), a promise to give up a bill thought (c) Cases, pp. 327-333. [This is the to be invalid (Smith v. Smith, I3 C. B. rule of the Supreme Court of the N. S. 4I8), a debt barred by the statute United States. (Railroad Company v. of limitations (Latouche v. Latouche, 3 National Bank, Io2 U. S. I4.) It is H. \& C., p. 576), or the obligation on also the English rule. See Bills of the part of a thief to restore stolen prop- Exchange Act, section 27. The State erty (London, etc., Bank v. River Plate decisions are very conflicting. (See Bank, L. R. 2I Q. B. D. 535), constitute numerous cases collected in Daniel on value.

"A mere moral obligation (Eastwood v. Kenyon, i I A. \& E. +38 ), a debt represented to be due though not really reconcile all the decisions of the New due (Southall v. Rigg, I I C. B. ${ }_{4} \mathrm{SI}$ ), York courts.] the giving up a void note (Coward $v$.

\section{What constitutes holder for value.}

Where value has at any time been given for the instrument, the holder is deemed a holder for value in respect to all parties who became such prior to that time. (a)

[Note. - See Bills of Exchange Act, section 27, subdivision (2).]

(a) Cases, pp. 334-337. A holder in due course. See $\$$ I [52], post. for value may or ma not be a holder

\section{$\S 53$. When lien on instrument constitutes holder for value.}

Where the holder has a lien on the instrument, arising either from contract or by implication of law, he is deemed a holder for value to the extent of his lien. $(a)$

[NoTE, - See Bills of Exchange Act, section 27.]

(a) Cases, pp. 337-33s. Discount may recover the whole amount, acmust be distinguished from pledge or counting to the pledgor for any surplus deposit for security. A discounter or above the amount of the lien; otherpurchaser of the bill is a holder for wise he can recover only the amount of full value. A pledgee is a trustee of the lien. Chalmers, Bills of Exchange the pledgor. If the pledgor could have Act (5th ed.), p. $\$ 6$. sued on the instrument the pledgee

\section{\$54. Effect of want of consideration.}

Absence or failure of consideration is matter of defense as against any person not a holder in due course; $(\alpha)$ and partial failure of consideration is a defense pro tanto whether the 
failure is an ascertained and liquidated amount or otherwise. (b)

(a) See $\$$ gr [52], post.

(b) Cases, pp. 338-339. An imme- course. See Chalmers, p. 95. diate party stands in the same relation

\section{§5. Liability of accommodation party.}

An accommodation party is one who has signed the instrument as maker, drawer, acceptor or indorser, without receiving value therefor, and for the purpose of lending his name to some other person. (a) Such a person is liable on the instrument to a holder for value, notwithstanding such holder at the time of taking the instrument knew him to be only an accommodation party. (b)

[Note. - See Bills of Exchange Act, section 25.]

(a) If the principal debtor (maker or come accommodation parties. Nor has acceptor) be an accommodation party, one partner implied power to lend the the instrument is an accommodation credit of the firm as accommodation note or bill. Chalmers, p. 87. party.

Corporations may not, usually, be- (b) Cases, pp. 339-340.

\section{ARTICLE IV.}

\section{NEGOTIATION.}

*Section 6o. What constitutes negotiation.

6I. Indorsement; how made.

62. Indorsement must be of entire instrument.

63. Kinds of indorsement.

64. Special indorsement; indorsement in blank.

65. Blank indorsement; how changed to special indorsement.

66. When indorsement restrictive.

67. Effect of restrictive indorsement; rights of indorsement.

68. Qualified indorsement.

69. Conditional indorsement.

7o. Indorsement of instrument payable to bearer.

71 . Indorsement where payable to two or more persons.

72. Effect of instrument drawn or indorsed to a person as cashier.

73. Indorsement where name is mispelled, et cetera.

74. Indorsement in representative capacity.

75. Time of indorsement; presumption.

76. Place of indorsement; presumption.

77. Continuation of negotiable character.

78. Striking out indorsement.

79. Transfer without indorsement; effect of.

8o. When prior party may negotiate instrument.

\footnotetext{
* $s[30]$ to $[50]$ in the other States.
} 
860. What constitutes negotiation.

An instrument is negotiated when it is transferred from one person to another in such manner as to constitute the transferee the holder thereof. $(a)$ If payable to bearer $(b)$ it is negotiated by delivery $(c)$; if payable to order $(d)$ it is negotiated by the indorsement of the holder completed by delivery. $(e)$

[Note. - See Bills of Exchange Act, sections 3I, subdivisions (I), (2) and (3).]

(a) Cases, p. 34I. See "holder" defined, ante, $\S 2$ [General Provisions]

(b) See $\$ 28$ [9], ante.

(c) Cases, pp. 342-3+3. (a) See \& 27 [8], ante.

(c) Cases, pp. 3千3-34S (including indorsement in form of assignment and of guaranty).

\section{$\S 6$ I. Indorsement; how made.}

The indorsement must be written on the instrument itself or upon a paper attached thereto. (a) The signature of the indorser, without additional words, is a sufficient indorsement. (b)

(a) Cases, pp. 348-350. [Crosby v. statement of the rule would give rise Roub, I6 Wis. 6I6; Folger v. Chase, to a question of fact which might be I8 Pick. 63; French v. Turner, I5 Ind. determined variously.] See Bills of 59. The rule as commonly stated is, Exchange Act, section 32. "Some of that where there is not room on the the foreign codes contain minute probill, the indorsement may be on an visions to prevent frauds. $e$. $g$, that allonge. But it is not necessary that the first indorsement on the allonge there should be a physical impossibil- must begin on the bill and end on the ity of writing the indorsement on the allonge; otherwise an allonge might instrument itself; it may be on an be taken from one bill and stuck on to allonge whenever the necessity or con- another." Chalmers, Bills of Ex. venience of the parties require it. (See change Act, (5th ed.), p. I07.

cases above cited.) Besides, any such (b) See $\$ S 63-64[33-34]$, post.

\section{\$62. Indorsement must be of entire instrument.}

The indorsement must be an indorsement of the entire instrument. An indorsement, which purports to transfer to the indorsee a part only of the amount payable, or which purports to transfer the instrument to two or more indorsees severally, does not operate as a negotiation of the instrument. (a) But where the instrument has been paid in part, it may be indorsed as to the residue. (b)

[Note. - See Bills of Exchange Act, section 32, subdivision (2); Lindsay v. Price, 33 Tex. 280; Hughes v. Kiddell, 2 Bay, 324; Daniel on Neg. Inst., section 668.] 
(a) Cases, pp. 350-35r.

(b) "C, the holder of a bill for Ioo l., Cardy, I Ld. Raym. 360.)" Chalmers, indorses it, 'Pay D, or order, 30 l.' Bills of Exchange Act (5th ed.), p. ro7. This is invalid, unless $C$ also acknowl-

§63. Kinds of indorsement.

An indorsement may be either special or in blank; and it may also be either restrictive or qualified, or conditional.

§64. Special indorsement; indorsement in blank.

[\&34]

A special indorsement specifies the person to whom, or to whose order the instrument is to be payable; and the indorsement of such indorsee is necessary to the further negotiation of the instrument. (a) An indorsement in blank specifies no indorsee, and an instrument so indorsed is payable to bearer, and may be negotiated by delivery. (b)

[Note. - See Bills of Exchange Act, section 34.]

(a) Cases, p. 35r. See $\$ 27$ [8], anti, | operates as if he had written: I. I and $\$ 70[40]$, post.

(b) Cases, pp. 352-354. See $\$ 2 S[0]$, 2. I hereby undertake that if this bill ant' "Bill payable to the order of be dishonored, I, on receiving due John Smith. He signs on the back notice thereof, will indemnify the 'John Smith.' This act is interpreted bearer." Chalmers, Bills of Exchange by the law merchant as an indorse- Act (5th ed.), p. Iro. See $\$$ ir6 [66], ment in blank by John Smith, and tost.

\section{$\S 65$. Blank indorsement; how changed to special indorse- ment. \\ $[\S 35]$}

The holder may convert a blank indorsement into a special indorsement by writing over the signature of the indorser in blank any contract consistent with the character of the indorsement. $(a)$

[Note. - See Bills of Exchange Act, section 34; Daniel on Neg. Inst., section 694, and cases cited.]

(a) Cases, pp. 352-354. "The an indorser, but the transaction operholder of a bill, indorsed by $\mathrm{C}$ in ates as a special indorsement from $\mathrm{C}$ blank, writes over C's signature the to D. (Vincent v. Horlock, I Camp. words, "Pay to the order of D.' The +42.)" Chalmers, Bills of Exchange holder who does this is not liable as Act (5th ed.), p. II2.

$\S 66$. When indorsement restrictive.

An indorsement is restrictive, which either:

I. Prohibits the further negotiation of the instrument; $(a)$ or 
2. Constitutes the indorsee the agent of the indorser; $(b)$ or

3. Vests the title in the indorsee in trust for or to the use of some other person. $(c)$

But the mere absence of words implying power to negotiate does not make an indorsement restrictive. $(d)$

[NoTe. - Illustrations:

(I) Pay Bank of A. only. For deposit in Bank of A. only.

(2) Pay A. Cashier, or order, for collection.

(3) Pay A. for account of C.

The language of the Bills of Exchange Act, $(\$ 35)$, is: "It is a mer authority to deal with the bill as thereby directed, and not a transfer of the ownership thereof." But this cannot apply to the indorsement mentioned in subdivision (3); for in such a case the indorser means that the title shall pass. Thus, if the indorsement is "Pay A for use of B" the title passes to A; but the indorsement is restrictive to the extent that it gives notice that the instrument cannot be negotiated by A for his own debt or for his own benefit. Hook v. Pratt, 78 N. Y. 371, 375.]

(a) Cases, pp. 35t-357.

(b) Cases, pp. 357-36r.

(c) Cases, pp. 36I-364.

(a) Cases, pp. 356-357.

\section{$\S 67$. Effect of restricting indorsement; rights of indorsee.}

A restrictive indorsement confers upon the indorsee the right:

I. To receive payment of the instrument;

2. To bring any action thereon that the indorser could bring; $(a)$

3. To transfer his rights as such indorsee, where the form of the indorsement authorizes him to do so.

But all subsequent indorsees acquire only the title of the first indorsee under the restrictive indorsement.

[NoTE. - See Bills of Exchange Act, section 35.]

Cases, pp. 304-365. See $\$ 77[47]$, post.

(a) [See Wilson v. Tolson, 79 Ga. 555. Contra, Roch Co. Nat. Bank v. I37; Cummings v. Kohn, I2 Mo. App. Hollister, 21 Minn. 385.]

585 ; Wintermute v. Torrent, 83 Mich.

68. Qualified indorsement.

Qualified indorsement constitutes the indorser a mere assignor of the title to the instrument. (a) It may be made by adding to the indorser's signature the words " without recourse" or any words of similar import. Such an indorse- 
ment does not impair the negotiable character of the instrument. (b)

[Nore. - See Daniel on Neg. Inst., section 700.] See Bills of Exchange Act, section $\mathrm{I} 6$.
(a) See $\S \mathrm{II}_{5}[65]$, post.
(b) Cases, pp. 365-367.

§69. Conditional indorsement.

[§39]

Where an indorsement is conditional, a party required to pay the instrument may disregard the condition, and make payment to the indorsee or his transferee, whether the condition has been fulfilled or not. But any person to whom an instrument so indorsed is negotiated, will hold the same, or the proceeds thereof, subject to the rights of the person indorsing conditionally.

[Note. - The first sentence is the same as section 33 of the Bills of Exchange Act with a slight modification. In his note to that section Judge Chalmers says: "This section alters the law. It was formerly held that if a bill was indorsed conditionally, the acceptor paid it at his peril if the condition was not fulfilled. This was hard on him. If he dishonored the bill he might be liable to damages, and yet it might be impossible for him to find out if the condition had been fulfilled." See Daniels on Neg. Inst., sections 697, 69Sa. There appear to be no American cases upon the subject; and the only English case is that of Robertson v. Kensington, 4 Taunt. 30.]

Cases, pp. 367-365.

$\S 70$. Indorsement of instrument payable to bearer.

[§ 40]

Where an instruinent, payable to bearer, is indorsed specially, it may nevertheless be further negotiated by delivery $(a)$; but the person indorsing specially is liable as indorser to only such holders as make title through his indorsement. (b)

[Note. - See Johnson v. Mitchell, 50 Tex. 212; Smith v. Clarke, Peake, 225; Daniel on Neg. Inst., sections 663a, 696.]

(a) Cases, pp. 365-3ir.

(i) See sis I6-II7 [66-67], post.

\section{$\S 7$ I. Indorsement where payable to two or more persons.}

Where an instrument is payable to the order of two or more payees or indorsees who are not partners, all must indorse, unless the one indorsing has authority to indorse for the others. (a)

[Note. - See Bills of Exchange Act, section 32, subdivision (3). Daniel on Neg. Inst., section 7ora.]

(a) Cases, pp. 37I-372. 


\section{$\S 72$. Effect of instrument drawn or indorsed to a person as cashier.}

Where an instrument is drawn or indorsed to a person as " cashier" or other fiscal officer of a bank or corporation, it is deemed prima facie to be payable to the bank or corporation of which he is such officer; and may be negotiated by either the indorsement of the bank or corporation, or the indorsement of the officer. (a)

[NOTE. - It is common practice for banks to indorse in this manner paper remitted for collection. The rule above stated is supported by the following cases: Bank of the State r. Muskingum Bank, 29 N. Y. 6r9: First Nat. Bank v. Hall, + N. Y. 395; Bank of Genesee v. Patchin Bank, I9 N. I. 312; Folger $v$. Chase, IS Pick. 63; Farmers', etc., Bank v. Troy City Bank, I Dough. (Mich.), 457, Watervliet Bank v. White, I Denio, 6os.]

(a) Cases, P. 373. See 37 [rj], ante.

$\S 73$. Indorsement where name is mispelled, et cetera. [ 43$]$

Where the name of a payee or indorsee is wrongly desig. nated or misspelled, he may indorse the instrument as therein described, adding, if he think fit, his proper signature. $(a)$

[Note. - See Bills of Exchange Act, section 32, subdivision (4).]

(a) Cases, pp. 373-374. 'A ques- John Jones.' The form sometimes tion sometimes arises as to how a bill adopted, riz., 'Mrs. John Jones,' is payable (say) to 'Mrs. John Jones' clearly irregular, though its invalidity should be indorsed. The proper form has never been decided." Chalmers, appears to be 'Ellen Jones, wife of Bills of Exchange Act (5th ed.), p. rog.

\section{$\S 74$. Indorsement in representative capacity.}

Where any person is under obligation to indorse in a representative capacity, he may indorse in such terms as to negative personal liability. (a)

[Note. - Same as Bills of Exchange Act, section 3I, subdivision (5).] $\leqslant 63$ [38], ante; also $39[20]$, ante.

(a) Cases, p. $37+$

\section{$\S 75$. Time of indorsement; presumption.}

Except where an indorsement bears date after the maturity of the instrument, every negotiation is deemed prima facie to have been effected before the instrument was overdue. $(a)$

[Note. - See Bills of Exchange Act, section 36, subdivision (t). New Orleans, etc. v. Montgomery, 95 U. S. I; Collins v. Gilbert, 9t U. S. 753. See also numerous cases cited in Daniel on Neg. Inst., section 728.]

(a) Cases, pp. 37+-375. See 51 [52], fost. 
$\S 76$. Place of indorsement; presumption.

Except where the contrary appears every indorsement is presumed prima facie to have been made at the place where the instrument is dated. (a)

[Note. - See Maxwell v. Vansant, 56 Ill. 58.] "The contract is made where delivery is effected, not where the signature is attached. (Chapman v. Cottrell, 34 L. J. Ex. IS6.) "' Chalmers, Bills of Exchange Act (5th ed.), p. 239. For summary of rules governing conflict of laws, see Bills of Exchange Act, $\S 72$.

(a) Cases, p. 375.

$\$ 77$. Continuation of negotiable character.

An instrument negotiable in its origin continues to be negotiable until it has been restrictively indorsed $(a)$ or discharged by payment $(b)$ or otherwise. (c)

[Note. - See Bills of Exchange Act, section 36.]

(a) See $\$ s 66-67$ [36-37], ante.

(b) See $\$ 200$ [1 I9], post.

(c) Cases, p. 375 .

\section{$\S 78$. Striking out indorsement.}

The holder may at any time strike out any indorsement which is not necessary to his title. (a) The indorser whose indorsement is struck out, and all indorsers subsequent to him, are thereby relieved from liability on the instrument. (b)

(a) Cases, p. 375 .

(b) See $\$$ II6 [66], post.

$\S 79$. Transfer without indorsement; effect of.

Where the holder of an instrument payable to his order transfers it for value without indorsing it, the transfer vests in the transferee such title as the transferer had therein, and the transferee acquires, in addition, the right to have the indorsement of the transferer. (a) But for the purpose of determining whether the transferee is a holder in due course, the negotiation takes effect as of the time when the indorsement is actually made. $(b)$

(a) Cases, pp. $375-378$. [This is the equitable rule as the rule at law. same as Bills of Exchange Act, section Daniel on Neg. Inst., section 74r.]

3I, subdivision (4). It establishes the

(b) Cases, pp. 375-378. [Goshen Nat. Bank v. Bingham, IIS N. Y. 349.]

$\S 80$. When prior party may negotiate instrument.

Where an instrument is negotiated back to a prior party $(a)$, such party may, subject to the provisions of this act $(b)$, 
reissue and further negotiate the same. $(c)$ But he is not entitled to enforce payment thereof against any intervening party to whom he was personally liable. $(d)$

[Note. - See Bills of Exchange Act, section 37.]

(a) See $\$ 202[\mathrm{I} 2 \mathrm{I}]$, post.

(b) See ș 200-206 [1 I9-125], post, as to discharges. (c) Cases, p. 378 .

(d) This is a rule against circuity of action.

\section{ARTICLE V.}

\section{RIGHTS OF HOLDER.}

*Section 9o. Right of holder to sue; payment.

9I. What constitutes a holder in due course.

92. When person not deemed holder in due course.

93. Notice before full amount paid.

94. When title defective.

95. What constitutes notice of defect.

96. Rights of holder in due course.

97. When subject to original defenses.

98. Who deemed holder in due course.

$\S 90$. Right of holder to sue; payment.

The holder $(a)$ of a negotiable instrument may sue thereon in his own name $(b)$; and payment to him in due course discharges the instrument. $(c)$

[Note. - See Bills of Exchange Act, section 38, subdivisions (I) and (3).]

(a) See $\S 2$ [General Provisions], as choses in action or chattels accordante. "The Act deals only with trans- ing to the general law," (e.g., by marfer by negotiation, that is, transfer riage, death, bankruptcy, sale on exeaccording to the law merchant. It cution, etc.). Chalmers, Bills of leaves untouched the rules of general Exchange Act (5th ed.), p. I25.

law which regulate the transmission of bills by act of law, and their transfer

(b) Cases, pp. 379-385

(c) See $\circlearrowleft \mathrm{I}_{4} \mathrm{[}[88], 200[\mathrm{II} 9]$, post.

\section{$\S 9$ I. What constitutes a holder in due course.}

A holder in due course is a holder who has taken the instrument under the following conditions:

I. That it is complete and regular upon its face; $(a)$

2. That he became the holder of it before it was overdue, and without notice that it had been previously dishonored, if such was the fact; $(b)$

3. That he took it in good faith and for value; $(c)$

* $\S[5 \mathrm{I}]$ to $\$[59]$ in the other States. 
4. That at the time it was negotiated to him he had no notice of any infirmity in the instrument or defect in the title of the person negotiating it. $(d)$

[Note. - See Bills of Exchange Act, section 29, subdivisions (a) and (b).] "The act has substituted the term 'holder in due course' for the cumbrous equivalent bona fide holder for value without notice." Chalmers, Bills of Exchange Act (5th ed.), p. 90.

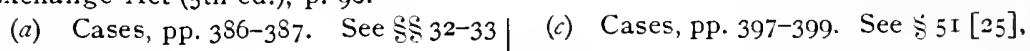
[I3-I4], ante.

(b) Cases, pp. 3S7-397. ante.

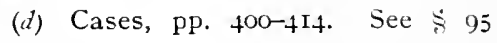
[56], post.

\section{$\$ 92$. When person not deemed holder in due course.}

Where an instrument payable on demand $(a)$ is negotiated an unreasonable length of time $(b)$ after its issue, the holder is not deemed a holder in due course. (c)

[Note. - See Bills of Exchange Act, section 36, subdivision (3). Crim v. Stockweather, 88 N. Y. 339; Herrick v. Woolverton, 4I N. Y. 58I.]

(a) See $\$ 26[7]$, ante.

(b) See $\$ 4$ [General Provisions],

(c) Cases, pp. 396-397. ante.

\section{\$ 93. Notice before full amount paid.}

[§54]

Where the transferee receives notice of any infirmity in the instrument or defect in the title of the person negotiating the same before he has paid the full amount agreed to be paid therefor, he will be deemed a holder in due course only to the extent of the amount theretofore paid by him. $(a)$

(a) Cases, pp. 415-417.

$\S 94$. When title defective.

The title of a person who negotiates an instrument is defective within the meaning of this act when he obtained the instrument, or any signature thereto, by fraud, duress, or force and fear, or other unlawful means, or for an illegal consideration, or when he negotiates it in breach of faith, or under such circumstances as amount to a fraud. (a)

[NoTE. - See Bills of Exchange Act, section 29, subdivision (2).] “ This list of defects in title may not be exhaustive. A person whose title is defective must be distinguished from a person who has no title at all, and who can give none; as for instance, a person making title through a forged indorsement. The words 'force and fear' were inserted in committee as the equivalent of the English technical term duress, which is unknown to Scotch law. (See Bell's Principles, 9th ed., S I2.)" Chalmers, Bills of Exchange Act (5th ed.), p. 92.

(a) Cases, pp. 425- 445 . 
$\S 95$. What constitutes notice of defect.

$[856]$

To constitute notice of an infirmity in the instrument or defect in the title of the person negotiating the same, the person to whom it is negotiated must have had actual knowledge of the infirmity or defect, or knowledge of such facts that his action in taking the instrument amounted to bad faith. (a)

[Note. - Murray v. Lardner, 2 Wall. I Io; Swift v. Smith, Io2 U. S. $4+2$; Belmont v. Hoge, 35 N. Y. 65; Welsh v. Sage, 47 N. Y. I43; Nat. Bank of Republic v. Young, fI N. J. Eq. 53r; Fifth Ward Sav. Bank v. First Nat. Bank, 48 N. J. L. 5I3; Credit Company v. Howe Machine Co., 54 Conn. 357; Morton v. N. A. \& Selma R'y Co., 79 Ala. 590.]

(a) Cases, pp. 400-4I 4 , See Bills of Two years later Lord Denman states it Exchange Act, $\$ 90$. "The test of bona as settled law that bad faith alone could fides as regards bill transactions has prevent a holder for value from recovvaried greatly. Previous to I 820 the ering. Gross negligence might be evilaw was much as it now is under the dence of bad faith, but was not concluAct. But under the influence of Lord sive of it. (Goodman v. Harvey, $4 \mathrm{~A}$. Tenterden due care and caution was \& E. at p. 876 , Uther v. Rich, Io A. \& made the test (Gill v. Cubitt, 5 D. $\&$ R. E. 784.$)$ This principle has never since 324 ), and this principle seems to be been shaken in England, and it seems adopted by section 9 of the Indian Act. now firmly established in the United In 1834 the Court of King's Bench held States. (Murray v. Lardner, 2 Wallace, that nothing short of gross negligence at p. I2I; Chapman v. Rose, 56 N. Y., could defeat the title of a holder for at p. I40.)" Chalmers, Bills of Exvalue. (Cook v. Jadis, 5 B. \& Ad. 909.) change Act (5th ed.), p. 272.

\section{$\$ 96$. Rights of holder in due course.}

$[\S 57]$

A holder in due course holds the instrument free from any defect of title of prior parties and free from defenses available to prior parties among themselves, and may enforce payment of the instrument for the full amount thereof against all parties liable thereon. (a)

[Note. - See Bills of Exchange Act, section 38, subdivision (2).]

(a) Cases, pp. 4I9-42I. [Cromwell v. County of Sac, 96 U. S. 5I, 60.]

\section{\$97. When subject to original defenses.}

In the hands of any holder other than a holder in due course, a negotiable instrument is subject to the same defenses as if it were non-negotiable. $(a)$ But a holder $(b)$ who derives his title through a holder in due course, and who is not himself a party to any fraud or illegality affecting the instrument, has all the rights of such former holder in respect of all parties prior to the latter. $(c)$ 
[NOTE. - (a) It is not deemed expedient to make provision as to what equities the transferee will be subject to; for the matter may be affected by the statutes of the various States relating to set-off and counterclaim. On the question whether only such equities may be asserted as attach to the bill, or whether equities arising out of collateral matters may also be asserted, the decisions are conflicting. In an act designed to be uniform in the various States, no more can be done than fix the rights of holders in due course.]

(b) "Whether for value or not." Bills of Exchange Act, $\S 29$, subsec. (3).

(c) Cases, Pp. 4I7-4I9.

\section{$\S 98$. Who deemed holder in due course.}

Every holder is deemed prima facie to be a holder in due course; but when it is shown that the title of any person who has negotiated the instrument was defective, the burden is on the holder to prove that he or some person under whom he claims acquired the title as a holder in due course. (a) But the last mentioned rule does not apply in favor of a party who became bound on the instrument prior to the acquisition of such defective title.

[Note. - This is similar to Bills of Exchange Act, section 3o, subdivision (2); but the phraseology has been changed so as to better harmonize with the language of section 55, (N. Y. $\$ 94$ ), which is the same as Bills of Exchange Act, section 29, subdivision (2). The language of the Bills of Exchange Act is " subsequent to the alleged fraud or illegality." But this is not quite correct; for the holder may be a holder in due course, though the fraud or illegality was in the transfer to him. The last sentence has no equivalent in the Bills of Exchange Act; but it is necessary to qualify the general statement. If $A$ issues his note to $B$, and $C$ gets possession of it and fraudulently negotiates it to $D$, the fraud of $C$ in nowise affects $A$, and is no defense to him when sued on the instrument by D.]

(a) Cases, Pp. 422-425. See Tatam/struing Bills of Exchange Act, $\S 30$, v. Haslar, L. R. 23 Q. B. D. 3+5: con- subsec. (2).

\section{ARTICLE VI. \\ LIABILITIES OF PARTIES.}

* Section Iro. Liability of maker.

III. Liability of drawer.

112. Liability of acceptor.

II3. When person deemed indorser.

II4. Liability of irregular indorser.

II 5. Warranty; where negotiation by delivery, et cetera.

II6. Liability of general indorsers.

II7. Liability of indorser where paper negotiable by delivery.

II8. Order in which indorsers are liable.

II9. Liability of agent or broker.

* $\$[60]$ to $\$[69]$ in the other States. 
\& II0. Liability of maker.

The maker of a negotiable instrument by making it engages that he will pay it according to its tenor $(a)$; and admits the existence of the payee and his then capacity to indorse. $(b)$

[Note. - See Bills of Exchange Act, section 88.]

(a) Cases, pp. 446. "The maker|bill of exchange. In general the maker of a promissory note is the principal of a note corresponds with the acceptor debtor on the instrument. The maker of a bill of exchange, and the same is sometimes called the drawer, but rules apply to both." Chalmers, Bills the primary and absolute liability of of Exchange Act (5th ed.), p. 27o. See the maker of a note must be distin- $\$$ I 30 [70], post.

guished from the secondary and con- (b) Cases, p. 447. ditional liability of the drawer of a

$\S$ III. Liability of drawer.

$[\$ 6 I]$

The drawer by drawing the instrument admits the existence of the payee and his then capacity to indorse; and engages that on due presentment the instrument will be accepted and paid, or both, according to its tenor, and that if it be dishonored, and the necessary proceedings on dishonor be duly taken, he will pay the amount thereof to the holder, or to any subsequent indorser who may be compelled to pay it. (a) But the drawer may insert in the instrument an express stipulation negativing or limiting his own liability to the holder. (b)

(a) Cases, p. 452. Bills of Exchange (b) [See Bills of Exchange Act, secAct, $\$ 55$, subsec. (I). The drawer's tion 16.] See $\$ 68$ [38], ante.

liability is similar to that of the indor-

ser's. See \& II6 [66], post.

\section{$\S$ II2. Liability of acceptor.}

[S 62]

The acceptor by accepting (a) the instrument engages that he will pay it according to the tenor of his acceptance $(b)$; and admits :

I. The existence of the drawer, the genuineness of his signature, and his capacity and authority to draw the instrument; $(c)$ and

2. The existence of the payee and his then capacity to indorse. $(d)$

[Note. - See Bills of Exchange Act, section 54. The Bills of Exchange Act contains the words, "but not the genuineness or validity of his indorsement."

But as the section purports to specify what the acceptance admits, all other 
matters are necessarily excluded by implication. To specify in some instances and not in others what is excluded destroys the symmetry of the Act, and, besides, might give rise to doubts as to its construction.]

(a) As to acceptances, see $\$ 820-230$ [I32-I42], post.

(b) The acceptor is a primary party and absolutely liable. See $\$ 3$ [General Provisions], ante. No demand on him is necessary to fix his liability. See s $130[70]$, post.

(c) Cases, pp. $448-45 \mathrm{I}$.

(d) Same as in $\$ 110[60]$, ante. "This of Exchange Act (5th ed.), p. I 85.

\section{\&I3. When person deemed indorser.}

A person placing his signature upon an instrument otherwise than as maker, drawer or acceptor is deemed to be an indorser, unless he clearly indicates by appropriate words his intention to be bound in some other capacity. $(a)$

[Note. - Section 56 of the Bills of Exchange Act provides: "Where a person signs a bill otherwise than as drawer or acceptor, he thereupon incurs the liabilities of an indorser to a holder in due course." But this language is too broad. There is no reason why one should not bind himself as guarantor or surety to a holder in due course if he clearly indicates such an intent. The language "otherwise than as maker," etc., would not meet the case of a signature so placed that there would be a question whether the person signing meant to bind himself as joint maker or otherwise. But the point is corrected in section $I 7$ (N. Y. $\$ 36)$, by the provision " that where a signature is so placed upon the instrument that it is not clear in what capacity the person making the same intended to sign, he will be deemed an indorser."']

(a) See Herring v. Woodhull, 25 Ill. 92. Cases, p. 345. And see the next section.

\section{§ II4. Liability of irreguíar indorser.}

Where a person, not otherwise a party to an instrument, places thereon his signature in blank before delivery, he is liable as indorser $(a)$ in accordance with the following rules:

I. If the instrument is payable to the order of a third person, he is liable to the payee and to all subsequent parties.

2. If the instrument is payable to the order of the niaker or drawer, or is payable to bearer, he is liable to all parties subsequent to the maker or drawer.

3. If he signs for the accomniodation of the payee, he is liable to all parties subsequent to the payee.

(a) Cases, pp. 478-450. 
[Note. - This section is intended to cover irregular indorsements. On this subject the decisions are very conflicting. In some jurisdictions a person plac. ing his signature on the back of a note before the payee has indorsed is deemcd a joint maker; in other jurisdictions he is regarded as a guarantor; and in still others as an indorser; and those courts which hold him to be an indorser differ as to whether he is a first or second indorser. The cases are too numerous to be cited here. Many of them will be found in Daniel on Negotiable Instru. ments, sections 707-719. The rule stated above is embodied in part in section 3117 of the Civil Code of California, which reads: "One who indorses a nego. tiable instrument before it is delivered to the payee is liable to the payee thereon, as an indorser." This is also the effect (probably) of section 56 of the Bills of Exchange Act. (See Chalmers on Bills, Notes and Cheques, section 56.) The California rule is adopted because it is conducive to certainty, and because it appears to accord more nearly with what must have been the intention of the parties. When a plain man puts his signature on the back of a negotiable instrument he ordinarily understands that he is becoming liable as an indorser; and if he puts it there before the instrument is delivered, he usually does so for the purpose of giving the maker or drawer credit with the payee or other person to whom it is negotiated. In many of the cases the reasoning is highly technical, and the decisions are based upon considerations which, in all probability, never entered the heads of the parties themselves. The California Code makes no provision for a case where the instrument is drawn to the order of the maker or drawer. This is covered by subdivision 2, above. Subdivision 3 is added to provide for a case where, the pavee being unabie to enforce payment, there might be a question whether the indorser would be liable to a person claiming under the payee

\section{ILLUSTRATIONS.}

Note made by $A$, payable to order of $B$, indorsed by $C$, and afterwards delivered to $\mathrm{B}$. $\mathrm{C}$ is liable as indorser to $\mathrm{B}$.

Note made by $A$, payable to order of himself, indorsed by $B$, and afterwards delivered to $\mathrm{C}$. $\mathrm{B}$ is liable as indorser to $\mathrm{C}$.

Note made by $A$, to order of $B$, indorsed by $C$ before $B$, but for accommodation of $\mathrm{B}$, and discounted by Bank of $\mathrm{X}$. C is liable as indorser to Bank of $\mathrm{X}$ and not to B.]

"Avals. - Such an indorsement as is referred to by this section would in continental countries be termed an 'aval,' which is said by Lord Blackburn to be an antiquated term signifying 'underwriting.' (5 App. Cas. at p. 772.) According to Pothier (as cited by Lord Blackburn, supra), an 'aval' might be either on the bill itself or on a separate paper, and if such an 'aval' was given by anyone, his obligation to all subsequent holders of the bill was precisely the same as that of the person to facilitate whose transfer the aval was given, and under whose signature it was written. English and Scotch law, as Lord Blackburn proceeds to point out, do not go so far as this. If a person, not the holder, indorse a bill, he is not a surety for the drawee or acceptor to the drawer; 'such an indorsement creates no obligation to those who previously were parties to the bill, it is solely for the benefit of those who take subsequently. It is not a collateral engagement, but one on the bill, and it is for that reason and because the original bill has incident to it the capacity of an indorsement in the nature of an 'aval,' that such an indorsement requires no new stamp. (Steele v. McKinlay, 5 App. 754; see also, at p.7S2, per Lord 
Watson, and his comments thereon, in Macdonald v. Whitfield, 8 App. Cas. 733, at p. 748.)" Chalmers, Bills of Exchange Act (5th ed.), pp. I89-Igo.

\section{§I5. Warranty where negotiation by delivery, et cetera.}

$[\S 65]$

Every person negotiating an instrument by delivery or by a qualified indorsement, warrants: $(a)$

I. That the instrument is genuine and in all respects what it purports to be;

2. That he has a good title to it;

3. That all prior parties had capacity to contract;

4. That he has no knowledge of any fact which would impair the validity of the instrument or render it valueless.

But when the negotiation is by delivery only, the warranty extends in favor of no holder other than the immediate transferee. The provisions of subdivision three of this section do not apply to persons negotiating public or corporate securities, other than bills and notes.

(a) Cases, pp. 452-47I.

[Note. - Where there is a latent defect, as for example, usury, it is not covered by the implied warranty of a person negotiating the instrument without indorsement. In such cases scienter is necessary in order to render the transferer liable. (Litthauer v. Goldman, 72 N. Y. 506.) Nor would he be liable if the maker of the note had become insolvent unless he knew such fact. (Bicknall v. Waterman, 5 R. I. 43; Fenn v. Harrison, 3 T. R. 757; Fydell v. Clark, I Esp. 447.) The application of the rule of commercial paper to persons selling corporate bonds, etc., would work great hardships and much public inconvenience. (See Otis v. Cullum, 92 U. S. 448.)]

See Bills of Exchange Act, section 58 , subsection (3). "There is some confusion in the cases owing to the distinction between the warranty of genuineness and the liability on the consideration having been lost sight of. The warranty of genuineness is an incident of the contract of sale, and it is immaterial whether the thing sold be a bill or any other personal chattel. The transferer is for this purpose an ordinary vendor." Chalmers, Bills of Exchange Act (5th ed.), p. 196.

\section{§ II6. Liability of general indorser.}

Every indorser who indorses without qualification, warrants to all subsequent holders in due course:

I. The matter and things mentioned in subdivisions one, two and three of the next preceding section; and,

2. That the instrument is at the time of his indorsement valid and subsisting. (a) 
And, in addition, he engages that on due presentment. it shall be accepted or paid, or both, as the case may be, according to its tenor, and that if it be dishonored, and the necessary proceedings on dishonor be duly taken, he will pay the amount thereof to the holder, or to any subsequent indorser who may be compelled to pay it. (b)

[Note. - See Bills of Exchange Act, section 55, subdivision (2). The language of the Bills of Exchange Act fixing the liabilities of the various parties is uniformly, "is precluded from denying, etc." But this is stating the effect of the principle and not the principle itself. Upon such a statement the question arises: Why is he precluded? The reason is that he has given implied warranties and admissions. The more scientific method is to state what these warranties and admissions are, and the other will follow by implication.] *
(a) Cases, p. 472 .
(b) Cases, pp. $474-47$.

\section{$\S$ II7. Liability of indorser where paper negotiable by de- livery.

Where a person places his indorsement on an instrument negotiable by delivery he incurs all the liabilities of an indorser. $(a)$

[Note. - See Daniel on Neg. Inst., section 663a, and cases there cited.]

(a) Cases, p. 475 .

\section{$\S$ r18. Order in which indorsers are liable.}

As respects one another, indorsers are liable prima facie in the order in which they indorse; but evidence is admissible to show that as between or among themselves they have agreed otherwise. (a) Joint payees or joint indorsees who indorse are deemed to indorse jointly and severally. (b)

[Note. - Evidence to show an agreement for a joint liability: See Easterly v. Barber, 66 N. Y. 433; Phillips r. Preston, 5 How. (U. S.) 278; Edelen v. White, 6 Bush, 4os. Contra, Johnson v. Ramsay, 43 N. J. L. 279; Daniel on Neg. Inst., section 703. Evidence to show contract that one was to be prior indorser: See Slack v. Kirk, 77 Pa. St. 380; Reinhart v. Schall, 69 Mld. 352; Slagel v. Rust, + Gratt. 274; Daniel on Neg. Inst., section 704. As to joint payees indorsing: See Lane v. Stacy, 8 Allen, $4 \mathrm{I}$; Daniel on Neg. Inst., section 704.]

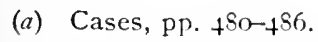

(b) Cases, pp. $485-486$.

* The following provision in the original draft was omitted in the final revision: [But the provisions of this section do not apply to an indorser to whom the instrument has been indorsed restrictively as agent only. National Park Bank v. Seaboard National Bank, 1 it N. Y. 25; United States v. American Exchange Nat. Bank, 7o Fed. Rep. 232.] 
$\S$ II9. Liability of an agent or broker.

Where a broker or other agent negotiates an instrument without indorsement, he incurs all the liabilities prescribed by section sixty-five* of this act, unless he discloses the name of his principal, and the fact that he is acting only as agent. $(a)$

[Note. - See Meridan Nat. Bank v. Gallaudet, I20 N. Y. 298; Cabot Bank v. Morton, 4 Gray, I56; Worthington v. Cowles, Ir2 Mass. 30.]

(a) Cases, Pp. 473-474.

\section{ARTICLE VII. \\ PRESENTMENT FOR PAYMENT.}

† Section 130. Effect of want of demand on principal debtor.

I3r. Presentment where instrument is not payable on demand.

132. What constitutes a sufficient presentment.

133. Place of presentment.

134. Instrument must be exhibited.

135. Presentment where instrument payable at bank.

136. Presentment where principal debtor is dead.

137. Presentment to persons liable as partners.

133. Presentment to joint debtors.

139. When presentment not required to charge the drawer.

Ifo. When presentment not required to charge the indorser.

$\mathrm{I}_{4} \mathrm{I}$. When delay in making presentment is excused.

142. When presentment may be dispensed with.

143. When instrument dishonored by non-payment.

I44. Liability of person secondarily liable, when instrument dishonored.

I45. Time of maturity.

I46. Time; how computed.

147. Rule where instrument payable at bank.

148. What constitutes payment in due course.

\section{\& 130. Effect of want of demand on principal debtor.}

Presentment for payment is not necessary in order to charge the person primarily [liable] $\ddagger$ on the instrument $(a)$; but if the instrument is, by its terms, payable at a special place, and he is able and willing to pay it there at maturity, such ability and willingness are equivalent to a tender of payment upon his part. But except as herein otherwise pro-

* Error. Should read $\$$ II 5 in New York Act. It is $\$ 65$ of the Act in the other States. - ED.

$\dagger \S[70]$ to $\$[88]$ in the other States.

$\ddagger$ Omitted by error in New York Act. - ED. 
vided, presentment for payment is necessary in order to charge the drawer and indorsers. (b)

[Note. - See Bills of Exchange Act, section 52; Hills v. Place, 48 N. Y. 520 , 523: Parker v. Stroud, 98 N. Y. 379. 384; Cox v. National Bank, Ioo U. S. 713; Wallace v. McConnell, I3 Peters, 136; Lozier v. Horan, 55 Iowa, 77; Insurance Company v. Wilson, 29 W. Va. 543.]

(a) Cases, pp. 498-501.

(b) Cases, p. 50I. See $\$$ II I $[6 \mathrm{I}]$,
\$ II6 [66], ante.

\section{§ I3I. Presentment where instrument is not payable on de- mand [and where payable on demand]. \\ [S7I]}

Where the instrument is not payable on demand, presentment must be made on the day it falls due. (a) Where it is payable on demand, presentment must be made within a reasonable time (b) after its issue (c), except that in the case of a bill of exchange, presentment for payment will be sufficient if made within a reasonable time after the last negotiation thereof. $(d)$

[Note. - See Bills of Exchange Act, section 45, subdivision (2). All the authorities agree that checks and bills of exchange payable on demand must be presented promptly; but as to promissory notes drawn so payable there is much conflict. In Merritt v. Todd (23 N. Y. 28) the rule was laid down by the Court of Appeals of New York that "a promissory note payable on demand, with interest, is a continuing security; that an indorser remains liable until an actual demand, and that the holder is not chargeable with neglect for omitting to make such demand within any particular time." The doctrine of this case has been much criticized. In some States the time within which promissory notes, payable on demand, must be presented, is fixed by statute. California Civil Code, section 3248; Connecticut Gen'l Statutes, p. 405, section I859; Minnesota Statutes (189I), section 2104.]

(a) Cases, p. 504 .

(b) See $\$ 4[$ General Provisions], (d) Cases, pp. 504-509. See $\$ 24 \mathrm{I}$ ante.

\section{$\S$ I32. What constitutes a sufficient presentment.}

Presentment for payment, to be sufficient, must be made:

1. By the holder, or by some person authorized to receive payment on his behalf; $(a)$

2. At a reasonable hour on a business day; $(b)$

3. At a proper place as herein defined: (c)

4. To the person primarily liable on the instrument, or if he is absent or inaccessible, to any person found at the place where the presentment is made. $(d)$ 
(a) Cases, pp. 501-503. [See Bills ${ }_{13} 38[76-78]$, post. [The language of of Exchange Act, section 45, subdivi- the Bills of Exchange Act is "or to sion (2). Daniel on Neg. Inst., sections some person authorized to pay or re$571-587$.

(b) Cases, pp. 509-510. [Salt Springs Nat. Bank v. Burton, 5 S N. Y. 430, 432; Farnsworth v. Allen, 4 Gray, 453; Barclay v. Bailey, 2 Camp. 527; Wilkins v. Jadis, 2 B. \& Ald. I88.]

(c) See $\$ \mathrm{I} 33[73]$.

(d) Cases, pp. 517-519. See ริ 136fuse payment on his behalf if with the exercise of reasonable diligence such person carnot be found." But this rule appears to be more stringent than that of the law merchant. See Cromwell v. Hynson, 2 Camp. 596; Daniel on Neg. Inst., section 590.]

\section{$\S$ 133. Place of presentment.}

Presentment for payment is made at the proper place:

1. Where a place of payment is specified in the instrument and it is there presented; $(a)$

2. Where no place of payment is specified, but the address of the person to make payment is given in the instrument and it is there presented; (b)

3. Where no place of payment is specified and no address is given and the instrument is presented at the usual place of business or residence of the person to make payment; $(c)$

4. In any [other] ${ }^{*}$ case if presented to the person to make payment wherever he can be found, or if presented at his last known place of business or residence. $(d)$

[NotE. - See Bills of Exchange Act, section 45, subdivision (4).]

(a) Cases, pp. 512-513. "The place of payment may be specified either by the drawer, or by the acceptor [or maker]." Chalmers, p. 145 . See $\$ 228$ [140], post. (b) Cases, pp. 5I2-5I3.

(c) Cases, pp. 5I4-5I7. [Gates v. Beecher, 60 N.Y. 5IS, 522; Daniel on Neg. Inst., sections 635, 636.]

(d) Cases, pp. 5I4-5I7.

\section{$\S$ I34. Instrument must be exhibited.}

The instrument must be exhibited to the person from whom payment is demanded, and when it is paid must be delivered up to the party paying it. (a)

[Note. - See Musson v. Lake, 4 How. 262; Freeman v. Boynton, 7 Mass. 483; Draper v. Clemens, 7 Mo. 52; Daniel on Neg. Inst., section 654.]

(a) Cases, pp. 520-52I. "In Eng- the person presenting, he must pay or land, it is conceived that possession is refuse payment at his own risk." prima facie evidence of identity, and Chalmers, Bills of Exchange Act (5th that if the payer doubts the identity of ed.), p. 203. 
\& 135. Presentment where instrument payable at bank. $[\$ 75]$

Where the instrument is payable at a bank, presentment for payment must be made during banking hours, unless the person to make payment has no funds there to meet it at any time during the day, in which case presentment at any hour before the bank is closed on that day is sufficient. (a)

[Note. - See Salt Springs Nat. Bank v. Burton, 58 N. Y. 430, and cases there cited; Reed v. Wilson, 4I N. J. Law, 29.]

(a) Cases, pp. $5^{\mathrm{IO}-512 .}$

§ I30. Presentment where principal debtor is dead.

[\$76]

Where the person primarily liable on the instrument is dead, and no place of payment is specified, presentment for payment must be made to his personal representative, if such there be, and if with the exercise of reasonable dili. gence, he can be found. $(a)$

[Note. - See Bills of Exchange Act, section 45, subdivision (7); Daniel on Neg. Inst., section 5or.] This is declaratory. (Williams on Executors, 7th ed., p. 2003.) See $\$ 242$ (2) [I45], and 245 (I) [ I48], post, for rule governing presentment for acceptance.

(a) Cases, pp. 518-5I9.

\section{$\S$ I37. Presentment to persons liable as partners.}

$\lceil\S 77\rceil$

Where the persons primarily liable $(a)$ on the instrument are liable as partners, and no place of payment is specified, presentment for payment may be made to any one of them, even though there has been a dissolution of the firm. (b)

「Note. - See Hubbard v. Matthews, 54 N. Y. 43, 50; Fourth Nat. Bank v. Heuschuk, 52 Mo. 207; Crowley v. Barry, 4 Gill. I94; Cayuga Co. Bank v. Hunt, 2 Hill, 635; Daniel on Neg. Inst., sections 592-593.]

(a) See $\$ 2$ [General Provisions], (b) Cases, p. 519. ante.

$\S$ I38. Presentment to joint debtors.

$[\$ 78]$

Where there are several persons not partners, primarily liable on the instrument, and no place of payment is specified, presentment must be made to them all. (a)

[Note. - See Bills of Exchange Act, section 45, subdivision (6). Gates v. Beecher, 60 N. Y. 518, 523; Union Bank v. Willis, 8 Metc. 504; Arnold v. Dresser, 8 Allen, 435; Wiilis v. Green, 5 Hill, 232. In some cases this might be impracticable, but such cases are covered by section 82 . (N.Y.. I I 2.)] "This is probably declaratory (Union Bank v. Willis, 49 Mass. 504), but the point was 
not clear. Of course, if one pays, or in refusing payment, acts as the agent of the others, that is enough." Chalmers, Bills of Exchange Act (5th ed.), p. 146.

(a) Cases, p. 5 I9.

\section{I39. When presentment not required to charge the drawer.}

[§ 79]

Presentment for payment is not required in order to charge the drawer where he has no right to expect or require that the drawee or acceptor will pay the instrument. $(a)$

[Note. - See Bills of Exchange Act, section 46, subdivision (2) (c). Life Insurance Company v. Pendleton, II2 U.S. 696; Daniel on Neg. Inst., sections 1074-I076.] See $\$ \$ 185-186$ [II4-I I5], post.

(a) Cases, pp. 523, 558-561.

\section{$\S$ I40. When presentment not required to charge the indor- ser.

Presentment for payment is not required in order to charge an indorser where the instrument was made or accepted for his accommodation, and he has no reason to expect that the instrument will be paid if presented. $(a)$

[Note. - See Bills of Exchange Act, section 46, subdivision (2) (d).] See $\S \mathrm{I} 86[$ I I 5$]$, post.

(a) Cases, pp. 56I-563.

\section{$\S \mathrm{I} 4 \mathrm{I}$. When delay in making presentment is excused. [\$ $8 \mathrm{I}]$}

Delay in making presentment for payment is excused when the delay is caused by circumstances beyond the control of the holder and not imputable to his default, misconduct or negligence. When the cause of delay ceases to operate, presentment must be made with reasonable diligence. (a)

[Note. - See Bills of Exchange Act, section 46, subdivision (I)] “ The cases do not clearly distinguish between excuses for non-presentment and excuses for delay in presentment, but when the question is one of reasonable diligence the distinction is an important one. (cf. Allen v. Edmundson, 2 Exch., at p. 724, notice of dishonor.) If presentment is delayed at the request of the drawer or indorser sought to be charged, the delay is presumably excused. (Lord Ward v. Oxford R'y Co., 2 DeG. M. \& G. 750.)" Chalmers, Bills of Exchange Act, ( 5 th ed.), p. 149. "Bill drawn in England, payable in Leghorn. At the lime the bill matures Leghorn is besieged. The holder is not in Leghorn. This excuses delay. (Patience v. Townley, 2 Smith, 223.)" Ib., p. I48.

(a) Cases, pp. 521-523. 


\section{\& I42. When presentment may be dispensed with.}

Presentment for payment is dispensed with:

I. Where after the exercise of reasonable diligence presentment as required by this act cannot be made; $(a)$

2. Where the drawee is a fictitious person; (b)

3. By waiver of presentment express or implied. (c)

[Note. - See Bills of Exchange Act, section 46, subdivision (2).]

(a) Cases, pp. 524-527. The Bills of (Foster v. Julien, 24 N. Y. 25.) This Exchange Act adds: "The fact that tendency is of doubtful expediency ant? the holder has reason to believe that finds no favor in England."

the bill will, on presentment, be dishonored, does not dispense with the necessity for presentment." Chalmers (p. 150), says: "In some American States there is a tendency to dispense with the attempt to make presentment when such attempt would be futile.

(b) Cases, p. 559, note. This is decliaratory. (Smith v. Bellamy, 2 Stark. 223.) Chalmers, p. I50. See $\$$ I $\$ 5$ ' [I I4], post.

(c) On waiver, see $\$ \$$ I $80-182[\mathrm{IOg}-$ III], post. Cases, p. $56+$.

$\S \mathrm{I} 43$. When instrument dishonored by non-payment. [\$ 83]

The instrument is dishonored by non-payment when:

I. It is duly presented for payment and payment is refused or cannot be obtained; or

2. Presentment is excused and the instrument is overdue and unpaid.

[Note. - See Bills of Exchange Act, section 47, subdivision (I).]

\section{$\S \mathrm{I} 44$. Liability of person secondarily liable, when instrument dishonored.

Subject to the provisions of this act $(a)$, when the instrument is dishonored by non-payment, an immediate right of recourse to all parties secondarily liable $(b)$ thereon, accrues to the holder. $(c)$

[Note. - See Bills of Exchange Act, section 47, subdivision (2).]

(a) See $\$ s 50-259$ [I6I-I7o], post. time when it is sent (Cartrique v. Ber-

(b) See $\$ 3$ [General Provisions], nabo, 6 Q. B. 498); and in any case ante.

(c) Cases, pp. 474-478. "As a genthere is no right of action till the day after dishonor. The right of recourse eral rule the holder's right of action must be distinguished from the right against a drawer or indorser dates from of action. (Kennedy v. Thomas, I894. the time when notice of dishonor is or 2 Q. B. 759.) " Chalmers, Bills of Exought to be received and not from the change Act (5th ed.), p. I52. 
I45. Time of maturity.

Every negotiable instrument is payable at the time fixed therein without grace. (a) When the day of maturity falls upon Sunday, or a holiday, the instrument is payable on the next succeeding business day. (b) Instruments falling due on Saturday are to be presented for payment on the next succeeding business day, except that instruments payable on demand may, at the option of the holder, be presented for payment before twelve o'clock noon on Saturday when that entire day is not a holiday. (c)

(a) [Note. - Days of grace have/the last day of grace." Cases, pp.234been abolished in the following States: California, Connecticut, Idaho, Illinois, Montana, New Jersey, New York, Oregon, Pennsylvania, Utah, Vermont, Wisconsin.] Days of grace are preserved by the Bills of Exchange Act, \&4: “Three days, called days of grace, are, in every case where the bill itself does not otherwise provide, added to the time of payment as fixed by the bill, and the bill is due and payable on 236,504 , note.

(b) Where days of grace are allowed and the last day of grace is a holiday, the instrument is due on the preceding day. Bills of Exchange Act, $\$$ I4.

(c) [Laws of Mass., March $30, \mathrm{I} 895$; May 28, I895. Laws of New York, I887, ch. 289, ch. 46r; Laws of Penn., May 31, I893; Laws of U. S., Feb. I8, I 893 ; Laws of N. J., ch. 43.]

\section{$\$$ I46. Time; how computed.}

Where the instrument is payable at a fixed period after date, after sight, or after the happening of a specified event, the time of payment is determined by excluding the day from which the time is to begin to run, and by including the date of payment.

[Note. - See Bills of Exchange Act, section I4.] See New York Statutory Construction Law, 898 26, 27. Cases, p. 504, note.

\section{$\S 147$. Rule where instrument payable at bank.}

Where the instrument is made payable at a bank it is equivalent to an order to the bank to pay the same for the account of the principal debtor thereon. $(a)$

[Note. - Ætna Nat. Bank v. Fourth Nat. Bank, 46 N. Y. 82; Commercial Bank v. Hughes, I7 Wend. 94; Commercial Nat. Bank v. Henninger, Io5 Pa. St. 496; Bedford Bank v. Acoarn, I25 Ind. 582; Home Nat. Bank v. Newton, 8 Bradwell, 563; Contra Grissom v. Commercial Bank, 87 Tenn. 35o.]

(a) Cases, p. 521, note.

$\S$ 148. What constitutes payment in due course.

Payment is made in due course when it is made at or after 
the maturity of the instrument to the holder therenf in good faith and without notice that his title is defective. (a)

[NotE. - See Bills of Exchange Act, section 59.] See $\$ 200$ [119], post.

(a) Cases, pp. 57I-579. See $\$ 2$ faith;" $\$$. $9+$ [55], ante, as to defective [General Provisions], ante, as to title.

"holder;" \$95 [56], ante as to "good

\section{ARTICLE VIII.}

\section{NOTICE OF DISHONOR.}

* Section I60. To whom notice of dishonor must be given.

I6r. By whom given.

I62. Notice given by agent.

163. Effect of notice given on behalf of holder.

I64. Effect where notice is given by party entitled thereto.

I65. When agent may give notice.

I66. When notice sufficient.

I67. Form of notice.

168. To whom notice may be given.

I69. Notice where party is dead.

I 70 . Notice to partners.

I7I. Notice to persons jointly liable.

I72. Notice to bankrupt.

173. Time within which notice must be given.

174. Where parties reside in same place.

I75. Where parties reside in different places.

176 . When sender deemed to have given due notice.

I77. Deposit in post office, what constitutes.

I78. Notice to subsequent parties, time of.

179. Where notice must be sent.

I8o. Waiver of notice.

I8I. Whom affected by waiver.

182. Waiver of protest.

I83. When notice dispensed with.

I84. Delay in giving notice; how excused.

185. When notice need not be given to drawer.

136. When notice need not be given to indorser.

I87. Notice of non-payment where acceptance refused.

I83. Effect of omission to give notice of non-acceptance.

I89. When protest need not be made; when must be made.

$\S$ I60. To whom notice of dishonor must be given.

Except as herein otherwise provided $(a)$, when a negotiable instrument has been dishonored by non-acceptance $(b)$ or nonpayment $(c)$, notice of dishonor must be given to the drawer 
and to each indorser, and any drawer or indorser to whom such notice is not given is discharged. $(d)$

[NotE. - See Bills of Exchange Act, section 48.]

(a) See $\$ \$$ I80-I86 [109-II5], post.

(b) See $\$ 246$ [149], post.

(c) See $\$ \mathrm{I}_{43}\left[\mathrm{\delta}_{3}\right]$, ante.

(d) Cases, P. 528. "Where the drawer or indorser of a bill is discharged from his liability thereon by the omission to give him due notice of dishonor, he is also discharged from

any liability on the consideration therefor. (Bridges v. Berry, 3 Taunt. I30; Peacock v. Pursell, I4 C. B. N. S. 728.) " Chalmers, Bills of Exchange Act (5th ed.), p. I53. For drawer's and indorser's contract, see $\$$ III [6I], and S II6 [66], ante.

Note. - A maker or acceptor is not entitled to presentment ( $\$$ 130 [70], ante) or notice. Want of notice of dishonor is no defense to a guarantor, unless he is actually injured for want of such notice. Brown v. Curtis, 2 N. Y. 225. Cases, p. 487 .

$\S$ I6I. By whom given.

[§ 90]

The notice may be given by or on behalf of the holder, or b.y or on behalf of any party to the instrument who might be compelled to pay it to the holder, and who, upon taking it up would have a right to reimbursement from the party to whom the notice is given. (a)

[Note. - See Bills of Exchange Act, section 49, subdivision (I); Daniel on Neg. Inst., sections 987-990. The Bills of Exchange Act uses only the words "holder" and "indorser." But the rigint extends to any person liable only as a surety, whether he is technically an indorser or not.]

(a) Cases, pp. 528-533.

$\S$ I62. Notice given by agent.

[§ 9I]

Notice of dishonor may be given by an agent either in his own name or in the name of any party entitled to give notice, whether that party be his principal or not. (a)

[Note. - See Bills of Exchange Act, section 49, subdivision (2); Daniel on Neg. Inst., sections 99I, 992, and cases cited.]

(a) Cases, pp. 53I-532 n. "A bill in-|W. 23I.)" Chalmers, Bills of Exdorsed by $\mathrm{C}$ is held by D. D's attorney change Act (5th ed.), p. I55. "A party gives notice of dishonor to the drawer, entitled to give notice may constitute but by mistake gives it in C's name the drawee or acceptor his agent for instead of D's. The notice is suf- the purpose of giving notice of discient, provided $\mathrm{C}$ is liable to $\mathrm{D}$, honor. (Rosher v. Kieran, 4 Camp. and has a right of recourse against the 87 , as modified by Harrison v. Ruscoe, drawer. (Harrison v. Ruscoe, I5 M. \& I5 M. \& W., at p. 235.)" Ib.

\section{\& I63. Effect of notice given on behalf of holder.}

Where notice is given by or on behalf of the holder, it 
enures for the benefit of all subsequent holders and all prior parties who have a right of recourse against the party to whom it is given. (a)

[Note. - See Bills of Exchange Act, section 49, subdivision (3); Daniel on Neg. Inst., section 990.]

(a) Cases, pp. 530-533.

\section{\&64. Effect where notice is given by party entitled thereto.}

Where notice is given by or on behalf of a party entitled to give notice, it enures for the benefit of the holder and all parties subsequent to the party to whom notice is given. $(a)$

[Note. - See Bills of Exchange Act, section 49, subdivision (4); Daniel on Neg. Inst., section 990.] “In a New York case it was held that a notice duly. sent by the holder did not enure for the benefit of a prior indorser when it did not reach the party to whom it was sent, but the circumstances of the case were somewhat special. (Beale v. Parish, 20 N. Y. 407.) The Act does not countenance this view." Chalmers, Bills of Exchange Act (5th ed.), pp. 156-7. Chalmers cites Chapman v. Keane, 3 A. \& E. I93; Lysaght v. Bryant, I9 L. J. C. P. I6o; Streeter v. Fort Bank, $3+$ N. Y. 413.

(a) Cases, pp. 530-533.

$\S$ I65. When agent may give notice.

Where the instrument has been dishonored in the hands of an agent, he may either himself give notice to the parties liable thereon, or he may give notice to his principal. If he give notice to his principal, he must do so within the same time as if he were the holder, and the principal upon the receipt of such notice has himself the same time for giving notice as if the agent had been an independent holder. $(a)$

[Note. - See Bills of Exchange Act, section 49, subdivision (13).] "A bill vayable in London is indorsed in blank by the holder, and deposited with a country banker for collection. The country banker's London agent presents it for payment and gives him due notice of its dishonor. The country banker on the day after the receipt of such notice gives notice to his customer, who in turn gives similar notice to his indorser. The indorser has received duc notice. (Bray v. Hadwen, 5 M. \& S. 68. See also Clode v. Bayley. I2 M. \& W. 5I; Prince v. Oriental Bank, L. R. 3 App. Cas., at p. 332.)" Chalmers, Bills of Exchange Act (5th ed.), p. 162.

(a) Cases, pp. 532-533.

$\S$ I66. When notice sufficient.

A written notice need not be signed $(a)$ and an insufficient written notice may be supplemented and validated by verbal 
communication.(b) A misdescription of the instrument does not vitiate the notice unless the party to whom the notice is given is in fact misled thereby. $(c)$

[Note. - See Bills of Exchange Act, section 49, subdivision (7). Byles on Bills, 276; Daniel on Neg. Inst., sections 979a-98o. Subdivision (6) of section 49 of the Bills of Exchange Act, which reads " Return of a dishonored bill to the drawer or an indorser is in point of law deemed a sufficient notice of dishonor" is omitted. In his note to that sub-section, Judge Chalmers says: "This subsection approves a common practice of collecting bankers which was previously of doubtful validity." No such practice prevails in this country.]

(a) But it must come from the right person. See $\$ \$$ I6I-162 [90-9I], ante. See Maxwell v. Brain, Io L. T. N. S. 301 .

(b) The sufficiency or insufficiency in such case is a question of fact. Houlditch v. Canty, + Bing. N. C. 4 II ; Metcalfe v. Richardson, II C. B. IOII.

(c) Cases, pp. 533-534. "A notice to the drawer which describes the bill as payable at the ' $\mathrm{S}$ Bank,' when in fact it was payable at the " $T$ Bank'

\section{$\S$ I67. Form of notice.}

The notice may be in writing or merely oral (a) and may be given in any terms which sufficiently identify the instrument, and indicate that it has been dishonored by non-acceptance or non-payment. (b) It may in all cases be giren by delivering it personally or through the mails. (c)

(a) [See Bills of Exchange Act, sec- the notice must inform the holder, tion 49, subdivision (5); Cuyler v. Ste- either in terms or by necessary implivens, 4 Wend. 566; Glasgow v. Pratte, S Mo. 336; Byles on Bills, 271; Daniel on Neg. Inst., section 972.]

(b) Cases, pp. 534-537. [Byles on Bills, 976; Daniel on Neg. Inst., sections 793-978. The statement that the holder looks for payment to the party to whom notice is sent is not necessary; for this is implied from the fact of giving notice. Bank of U.S. v. Carneal, 2 Peters, 543; Mills v. Bank, I I Wheat. 43I, 436; Nelson v. First Nat. Bank (U. S. Circuit Ct. App.), 69 Fed. Rep. 798, 8or.] "Notices of dishonor are now construed very liberally. In r834 the House of Lords, in Solarte v. Palmer I Bing. N. C. I94, decided that! [106], post, and $\$ 179$ [108], post. 
Notice of dishonor may be given either to the party him. self or to his agent in that behalf. (a)

[Note. - See Bills of Exchange Act, section 49, subdivision (8). Fassin v. Hubbard, 55 N. Y. 465, 47I; Lake Shore Nat. Bank v. Butler Colliery Co., 5 I Hun, 63, 68.]

(a) Cases, pp. 540-54r. "It is the some person there to receive notice on duty of the drawer or indorser of a bill, his behalf." Chalmers, p. I6o, citing if he be absent from his place of busi- Allen v. Edmundson, 2 Exch., at p. 723. ness or residence, to see that there is

\section{$\S$ I69. Notice where party is dead.}

[\$ 98]

When any party is dead, and his death is known to the party giving notice, the notice must be given to a personal representative, if there be one, and if with reasonable diligence, he can be found. (a) If there be no personal representative, notice may be sent to the last residence or last place of business of the deceased. (b)

(a) Cases, pp. 540-54I. [See Bills Mass. 82; Bealls v. Peck, 12 Barb. of Exchange Act, section 49, subdivi- 245; Cayuga Co. Bank v. Bennett, 5 sion (9). The 'statement is based upon Hill, 236; Maspero v. Pedesclaux, 22 the American decisions. Massachu- La. Ann. 227.]

setts Bank v. Oliver, to Cush. 557; (b) Cases, pp. 540-541. [Goodnow Merchants' Bank v. Birch, I7 Johns. 24. v. Warren, I22 Mass. 82; Merchants' See also Smalley v. Wright, 40 N. J. Bank v. Birch, I7 Johns. 25.]

Law, 47I; Goodnow v. Warren, I22

$\S$ I70. Notice to partners.

Where the parties to be notified are partners notice to any one partner is notice to the firm even though there has been a dissolution. $(a)$

(a) Cases, pp. 54I-542. [See Coster Matthews, 54 N. Y. 43, 50; Fourth Nat. v. Thomason, I9 Ala. 717; Slocomb v. Bank v. Henschuh, 52 Mo. 207.] Lizardi, 2 I La. Ann. 355; Hubbard v.

$\S$ I7I. Notice to persons jointly liable.

Notice to joint parties who are not partners must be given to each of them, unless one of them has authority to receive such notice for the others. (a)

[NotE. - See Bills of Exchange Act, section 49, subdivision (I I). The rule is based upon the American decisions. Willis v. Green, 5 Hill, 232. See also Daniel on Neg. Inst., section 999a, and cases cited.]

(a) Cases, p. $542 n$. 


\section{I72. Notice to bankrupt.}

Where a party has been adjudged a bankrupt or an insolvent, or has made an assignment for the benefit of creditors, notice may be given either to the party himself or to his trustee or assignee. (a)

[NoTE. - See Bills of Exchange Act, section 49, subdivision (to). Daniel on Neg. Inst., section 1002; Callahan v. Kentucky Bank, S2 Ky. 23I; Contra, House v. Vinton Bank, 43 Ohio St. 346.] "All that had been decided before the Act was that notice given to the bankrupt in ignorance that a trustee had been appointed was sufficient." Chalmers, p. I60.

(a) Cases, p. $5+2 n$.

\section{$\$$ I73. Time within which notice must be given.}

[§ I02]

Notice may be given as soon as the instrument is dishonored $(a)$; and unless delay is excused as hereinafter provided, must be given within the times fixed by this act. (b)

(a) Cases, pp. 542-552. [Bank of 49 , subdivision (I2). The phrase Alexandria v. Swan, 9 Peters, 33: "must be given within a reasonable Lenox $v$. Roberts, 2 Wheat. 373; Ex parte time thereafter," used in the Bills of Moline, I9 Ves. 2I6; Daniel on Neg- Exchange Act, is omitted; for the time Inst., section I036.] Bills of Exchange is definitely fixed and this language Act, section 49, subdivision (I2).

(b) [Bills of Exchange Act, section

\section{\$ I74. Where parties reside in same place.}

Where the person giving and the person to receive notice reside in the same place, notice must be given within the following times:

I. If given at the place of business of the person to receive notice, it must be given before the close of business hours on the day following; $(\alpha)$

2. If given at his residence, it must be given before the usual hours of rest on the day following; $(b)$

3. If sent by mail, it must be deposited in the postoffice in time to reach him in usual course on the day following. (c)

(a) Cases, pp. 542-543. [See Adams v. Wright, I4 Wis. 408; Cayuga County Bank v. Hunt, 2 Hill, 236; Daniel on Neg. Inst., section 1038.]

(b) Cases, p. $543 n$. [See Phelps v. Stocking, 2 I Neb. 44t; Darbishire v. Parker, 5 East, 8.] (c) Cases, p. 544 n. [This rule is that of the Bills of Exchange Act ( $\$ 49$, subsec. 12), and is in accordance with the practice in New York City. Some of the decisions deem service through the post-office insufficient, unless there is proof that the notice was actually re- 
ceived in due time. (See Daniel on tremely inconvenient in large places.] Neg. Inst., section roo5, and cases See next sectio cited.) But this rule would be ex-

\section{$\S \mathrm{I75}$. Where parties reside in different places.}

Where the person giving and the person to receive notice reside in different places, the notice must be given within the following times:

I. If sent by mail, it must be deposited in the postoffice in time to go by mail the day following the day of dishonor, or if there be no mail at a convenient hour on that day, by the next mail thereafter. $(a)$

2. If given otherwise than through the post-office, then within the time that notice would have been received in due course of mail, if it had been deposited in the post-office within the time specified in thelast subdivision. (b)

(a) Cases, pp. 544-548. [This is (b) Cases, pp. 549-550. [See Bank substantially the same as the Bills of of Columbia v. Lawrence, I Peters, 578; Exchange Act, section 49, subdivision Jarvis v. St. Croix Mfg. Co., $23 \mathrm{Me}$. (I2) (b). It is supported by numerous 287.]

American decisions. See Daniel on

Neg. Inst., sections I039-IO4I.]

\section{$\S$ I76. When sender deemed to have given due notice. [ $\$$ I05]}

Where notice of dishonor is duly addressed and deposited in the post-office, the sender is deemed to have given due notice, notwithstanding any miscarriage in the mails. (a)

[Note. - See Bills of Exchange Act, section 49, subdivision (I5); Byles on Bills, 277.]

(a) Cases, p. 544. "It lies on the tice is bound to use reasonable diligence sender to prove that the letter con- to discover such place of business or taining the notice was duly addressed residence. (Berridge v. Fitzgerald, L. and posted. (Hawkes v. Salter, 4 R. 4 Q. B. 639.) When, however, the bill Bing. 715; cf. Skilbeck v. Garbett, $7 \mathrm{Q}$. contains an address it seems that such B. ${ }_{4} 6$.) The sufficiency of the direction address is in any case sufficient to on the letter is a question of reasonable charge the party giving that address. diligence. If the drawer or indorser has (Burmester v. Barron, I7 Q. B. 828; cf. a place of business, the notice should Ex parte Baker, L. R. 4 Ch. D. at p. be addressed to him there; if he has not, 799.) Chalmers, Bills of Exchange Act then it should be addressed to him at (5th ed.), pp. I55-6.

his residence, and the party giving no-

$\S$ I77. Deposit in post-office; what constitutes.

Notice is deemed to have been deposited in the post-office NEGOT. INSTRUMENTS - 4 
when deposited in any branch post-office or in any letter box under the control of the post-office department. (a)

[Note. - See Casco Nat. Bank v. Shaw, 79 Me. 376; Pearce v. Langfit, Ior Pa. St. 507.]

(a) Cases, p. 539 .

\section{$\S$ I78. Notice to subsequent party; time of.}

[§ 107$]$

Where a party receives notice of dishonor, he has, after the receipt of such notice, the same time for giving notice to antecedent parties that the holder has after the dishonor. (a)

[Note. - See Bills of Exchange Act, section 49, subdivision (r4); Daniel on Neg. Inst., section I044; Byles on Bills, 283.]

(a) Cases, pp. 550-552. See \& 165 [94], ante, note.

\& I79. Where notice must be sent.

[§ 108]

Where a party has added an address to his signature, notice of dishonor must be sent to that address $(a)$; but if he has not given such address, then the notice must be sent as follows :

I. Either to the post-office nearest to his place of residence, or to the post-office where he is accustomed to receive his letters; $(b)$ or

2. If he live in one place, and have his place of business in another, notice may be sent to either place; $(c)$ or

3. If he is sojourning in another place, notice may be sent to the place where he is so sojourning. $(d)$

But where the notice is actually received by the party within the time specified in this act, it will be sufficient, though not sent in accordance with the requirements of this section.

(a) Cases, p. 552. Note to $\S 176 \mid$ (c) Cases, pp. 553-554. [Bank of [105], ante.

(b) Cases, pp. 553-554. [See Bank of Columbia v. Lawrence, I Peters, 578; National Bank v. Cade, 73 Mich. 449; Northwestern Coal Co. v. Bowman, 69 Iowa, I03.]

U. S. v. Carneal, 2 Peters, 549; Williams v. Bank of U. S., 2 Peters, 96; Montgomery Co. Bank v. Marsh, $7 \mathrm{~N}$. Y. 481.$]$

(d) Cases, pp. 554-556. [Chouteau v. Webster, 6 Met. I.]

$\S$ I80. Waiver of notice.

[\$ 109]

Notice of dishonor may be waived, either before the time of giving notice has arrived (a), or after the omission to give due notice (b), and the waiver may be express or implied. (c) 
[Nore. - See Bills of Exchange Act, section 50, subdivision (2); Daniel on Neg. Inst., sections II+7-1I6\&; Byles on Bills, 293.]

(a) Cases, pp. 564-565.

(b) Cases, pp. 565-567.

(c) For waiver of presentment see $\S I_{4}\left[\mathrm{~S}_{2}\right]$, ante. "Waiver of notice of dishonor in favor of the holder enures for the benefit of parties prior to such holder as well as subsequent holders. (Rabey v. Gilbert, 30 L. J. Ex. 17o.) Wairer of notice of dishonor by an indorser does not affect parties prior to such indorser. (Turner $r$. Leech, $+\mathrm{B}$. $\therefore$ Ald. 45I.) An acknowledgment of liability must be made with full knowledge of the facts in order to operate as d waiver of notice of dishonor. (Goodall v. Dolley, I T. R. 712; cf. Pickin v. Graham, I Cr. \& II., at p. 729.) Nany of the cases fail to distinguish between admissions of liability, which are evidence of due notice having been received, and admissions of liability when due notice has not been given, and which therefore are evidence of waiver. The distinction is important. (As to what is evidence of due notice, see Taylor $x$. Jones, 2 Camp. I05; Hicks $v$. Beaufort, + Bing. N. C. 229; Brownell $r$. Bonney, I Q. B. 39; Curlewis v. Corfield, I Q. B. SIf; Campbell r. Webster, I5 L. J. C. P. 4; Mills v. Gibson, I6 L. J. C. P. 249; Jackson r. Collins, 17 L. J. Q. B. I 42 ; Bartholomew v. Hill, 5 L. T. N. S. 756 . As to what is not, Borradaile $r$. Lowe, + Taunt. 93; Braithwaite $v$. Coleman, 4 N. \& M. 654; Bell v. Frankis, + M. \& G. 46 ; Holmes v. Staines, 3 C. \& K. Ig.) In America it has been held that a verbal waiver of notice may be revoked before the time for giving notice has expired. (Second Nat. Bank v. Mcguire, 3 I Am. R. 539; s. c., 33 Oh. St. 295). Chalmers, Bills of Exchange Act (5th ed.), pp. $166-7$.

\section{$\S$ I8I. Whom affected by waiver.}

Where the waiver is embodied in the instrument itself, it is binding upon all parties $(a)$; but where it is written above the signature of an indorser, it binds him only. (b)

(a) Cases, pp. $56+-565 \%$. [See Pool $v$. an indorsement in the above form Anderson, II6 Ind. 94; Bryant v. Mer- dispenses with the necessity of notice chants' Bank, $\$$ Bush. 43.]

to all subsequent indorsers (Daniel.

(b) [Woodman v. Thurston, S Cush. S Iogo; Parshley v. Heath, 69 Me. 90); I57; Farmers' Bank v. Ewing, $78 \mathrm{Ky}$, and in France a similar construction 264.] "Such an indorsement is some- has been put on the phrases 'Retou" times spoken of as a facultative indorse-| sans frats," Retour sans frotét,' and ment. It relates only to the inc. orser's 'sans compte de retour.' (Nouguier. liability, and does not otherwise affect $\$ 2$; Ger an Exchange Law, art. 42, the negutiation of the bill. Such stipu- seems ambiguous) It is doubtful lations are rosorted to when the pay- whether the English Act would bear ment of the bill is doubtful, and the such an interpretation." Chalmers, drawer or indorser wishes to save ex- Bills of Exchang Act (5th ed.), p. 40. pense in case of its return. In the The a'ove section fixes the law conUnited States it has been held that trary to Parshley v. Heath, supra.

\$82. Waiver of protest.

A waiver of protest, whether in the case of a foreign bill of exchange $(a)$ or other negotiable instrument (b), is deemed 
to be a waiver not only of a formal protest, but also of presentment and notice of dishonor. (c)

(a) [See Union Bank v. Hyde, 6/Welford v. Andrews, 29 Minn. 25r; Wheat, 572; Brown v. Hull, 33 Gratt. Coddington v. Davis, I N. Y. IS6; 31.]

(b) [Pool v. Anderson, it6 Ind. 94; (c) Cases, pp. 566-567.

$\S \mathrm{I} 83$. When notice is dispensed with.

[ $\S$ II2]

Notice of dishonor is dispensed with when, after the exercise of reasonable diligence, it cannot be given to or does not reach the parties sought to be charged. (a)

[Note. - See Bills of Exchange Act, section 50, subdivision (2).]

(a) Cases, pp. 563-564.

\& 184 . Delay in giving notice; how excused.

[§ II3]

Delay in giving notice of dishonor is excused when the delay is caused by circumstances beyond the control of the holder and not imputable to his default, misconduct or negligence. When the cause of delay ceases to operate, notice must be given with reasonable diligence. $(a)$

[Note. - See Bills of Exchange Act, section 5o; Daniel on Neg. Inst., sections ro59-II+6. A more specific statement of what will excuse delay is deemed impracticable. Any attemot to enumerate particular instances would lead to confusion.]

(a) Cases, pp. $556-55^{5}$.

$\S$ I85. When notice need not be given to drawer.

[\$ II4]

Notice of dishonor is not required to be given to the drawer in either of the following cases:

I. Where the drawer and drawee are the same person; $(\alpha)$

2. Where the drawee is a fictitious person or a person not having capacity to contract; (b)

3. Where the drawer is the person to whom the instrument is presented for payment; $(c)$

4. Where the drawer has no right to expect or require that the drawee or acceptor will honor the instrument; $(d)$

5. Where the drawer has countermanded payment. (c)

(a) Cases, pp. 555-559. [See Bills of Exchange Act, section 5o, subdivision (2) (c); Daniel on Neg. Inst., sections r28-r29, ro88a.] See 'person' defined, 2 [General Provisions], ante. 70s; Daniel on Neg. Inst., sections (b) $\mathrm{Ib} .,[\mathrm{Ib}$.

(c) $I h .,[\mathrm{Ib}$.

(d) Cases, pp. 560-56r. [Life Insurance Company v. Pendleton, ir2 U. S. 
1074, 1076. The language of the Bills / should be any obligation to accept. of Exchange Act is "where the drawee See Adams v. Darby, 28 Mo. I62; Dickor acceptor is as between himself and ens v. Beal, Io Peters, 572.]

the drawer under no obligation to accept ( $\left.{ }^{\prime}\right)$ [Sutcliffe v. McDowell, 2 Nott. or pay the bill." But this is too nar- \& M'C. 25I; Daniel on Neg. Inst., row. It is not required that there section IOSI.]

$\S$ I86. When notice need not be given to indorser.

Notice of dishonor is not required to be given to an indorser in either of the following cases:

I. Where the drawee is a fictitious person or a person not having capacity to contract, and the indorser was aware of the fact at the time he indorsed the instrument; $(a)$

2. Where the indorser is the person to whom the instrument is presented for payment; $(b)$

3. Where the instrument was made or accepted for his accommodation. $(c)$

[Note. - See Bills of Exchange Act, section 50, subdivision (2) $(d)$.]

(a) See preceding section, note (b).

(c) Cases, p. 563 .

(b) Cases, pp. 56I-563. See preced-

ing section, note $(c)$

\section{$\S 187$. Notice of non-payment where acceptance refused.}

Where due notice of dishonor by non-acceptance has been given, notice of a subsequent dishonor by non-payment is not necessary, unless in the meantime the instrument has been accepted. $(a)$

[Note. - See Bills of Exchange Act, section 48, subdivision (2); Daniel on Neg. Inst., section 932.]

(a) Cases, P. 568.

\section{$\S \mathrm{I} 88$. Effect of omission to give notice of non-acceptance.}

An omission to give notice of dishonor by non-acceptance does not prejudice the rights of a holder in due course subsequent to the omission. (a)

[Note. - See Bills of Exchange Act, section 4S, subdivision ( $\mathrm{T}$ ).]

(a) Cases, p. $528 n$. 


\section{\$ I89. When protest need not be made; when must be made.}

[S II8]

Where any negotiable instrument has been dishonored it may be protested for non-acceptance or non-payment, as the case may be; but protest is not required, except in the case of foreign bills of exchange. (a)

[Note. - See Bills of Exchange Act, section 51, subdivision (1); Daniel on Neg. Inst., sections 926, 928; Byles on Bills, 260. For the other provisions relative to protests see sections 152 and 160 . (N. Y., ss 260 and 268 .) ]

(a) Cases, pp. 565-570.

\section{ARTICLE IX.}

DISCHARGE OF NEGOTIABLE INSTRUMENTS.

* Section 200. Instrument; how discharged.

201. When persons secondarily liable on, discharged.

202. Right of party who discharged instrument.

203. Renunciation by holder.

204. Cancellation; unintentional; burden of proof.

205. Alteration of instrument; effect of.

206. What constitutes a material alteration.

\$200. Instrument; how discharged.

[§ II9]

A negotiable instrument is discharged:

I. By payment in due course by or on behalf of the principal debtor; $(a)$

2. By payment in due course by the party accommodated, where the instrument is made or accepted for accommodation; $(b)$

3. By the intentional cancellation thereof by the holder; $(c)$

4. By any other act which will discharge a simple contract for the payment of money; $(d)$

5. When the principal debtor becomes the holder of the instrument at or after maturity in his own right. (e)

[Note. - See Bills of Exchange Act, sections 59, 61, 63.]

(a) Cases, pp. 571-577. See sits) (c) Cases, pp. 579-585. See $\$ 204$ [ss], ante.

(b) Cases, pp. 575-579. See $s 5$ (d) Cases, p. 585 et seq. [29], ante.

(c) Cases, pp. 575-579. See $\subseteq 8$ [50], ante. 
$\S 20 I$. When persons secondarily liable on, discharged. $\{\$$ I20 $\rfloor$

A person secondarily liable on the instrument is discharged:

I. By any act which discharges the instrument; $(a)$

2. By the intentional cancellation of his signature by the holder; (b)

3. By the discharge of a prior party; $(c)$

4. By a valid tender of payment made by a prior party; $(d)$

5. By a release of the principal debtor, unless the holder's right of recourse against the party secondarily liable is expressly reserved; $(c)$

6. By any agreement binding upon the holder to extend the time of payment or to postpone the holder's right to enforce the instrument, unless the right of recourse against such party is expressly reserved. $(f)$

(a) See preceding section.

(b) See $\$ 7^{8}[4 \delta]$, anti. [See Bills of Exchange Act, section 63.] Ingham v. Primrose, 7 C. B. N. S. 82 ; Ralli v. Dennistoun, 6 Exch. 483; Bank of Scotland v. Dominion Bank, I8g I, A. C. 592 .

(c) Cases, pp. 592-593. [Daniel on Neg. Inst., section I307.] (d) Cases, pp. 593-594. [Spurgeon v. Smiths, IIt Ind. 453.]

(e) Cases, pp. 594-596. [Daniel on Neg. Inst., section I3Io.]

( $f$ ) Cases, pp. 596-59s. [Daniel on Neg. Inst., section $1326-1388 a$.

See also cases, pp. 598-599.

\section{$\S 202$. Right of party who discharges instrument.}

$[\S \mathrm{I} 2 \mathrm{I}]$

Where the instrument is paid by a party secondarily liable thereon, it is not discharged; but the party so paying it is remitted to his former rights as regards all prior parties, and he may strike out his own and all subsequent indorsements, and again negotiate the instrument, except:

I. Where it is payable to the order of a third person, and has been paid by the drawer; $(a)$ and

2. Where it was made or accepted for accommodation, and has been paid by the party accommodated. (b)

[Note. - See Bills of Exchange Act, section 59; Daniel on Neg. Inst., sections 1235a-124I.] This section is, perhaps, not altogether clear. Exception (I) qualifies the last clause beginning " and he may strike out," etc., while exception (2) qualifies the whole of the preceding statement. If the instrument is paid by the party accommodated, it is discharged under the provisions of $\$ 200$ (I) [II (I)] If paid by a drawer of a bill payable to the order of a third person, the drawer (not being an accommodated party), may enforce payment against tho acceptor but may not re-issue the bill. If paid by an indorser, or 
by a drawer of a bill payable to drawer's order, the party paying (not being an accommodated party), may enforce payment against prior parties or may strike out his own and subsequent indorsements, and re-issue the instrument.

(a) Cases, pp. 599-600.

(b) Cases, pp. 600-602. See $\$ 55$ [29].

\section{$\S 203$. Renunciation by holder.}

[\$ 122$]$

The holder may expressly renounce his rights against any party to the instrument, before, at or after its maturity. An absolute and unconditional renunciation of his rights against the principal debtor made at or after the maturity of the instrument, discharges the instrument. But a renunciation does not affect the rights of a holder in due course without notice. A renunciation must be in writing, unless the instrument is delivered up to the person primarily liable thereon. $(a)$

[Note. - See Bills of Exchange Act, section 62; Byles on Bilis, I9o, I9I; Daniel on Neg. Inst., sections 5+I-5+5. The Bills of Exchange Act requires the renunciation to be "in writing, unless the bill is delivered to the acceptor." But this effected a change in the law.] "The words requiring the renunciation to be in writing were added in committee. They alter the English law, but bring it into accordance with the Scotch law. At common law a contract cannot be discharged by accord without satisfaction. The special rule as to bills and notes partially reproduced in this section seems to have been consciously imported into the law merchant from French law. (See Parke, B., in Foster v. Dawber, 6 Exch., at p. 852.) This mode of discharge is known in France as ' remise voluntaire,' and is recognized in countries where the civil law is followed. (See Nouguier, 5 I043-1052.) " Chalmers, Bills of Exchange Act (5th ed.), p. 2 I2.

(a) Cases, pp. 579-581.

\section{§ 204. Cancellation; unintentional; burden of proof. [s I23]}

A cancellation made unintentionally, or under a mistake, or without the authority of the holder, is inoperative; but where an instrument or any signature thereon appears to have been canceled the burden of proof lies on the party who alleges that the cancellation was made unintentionally, or under a mistake or without authority. (a)

[Note. - See Bills of Exchange Act, section 63 subdivision (3).] Chalmer cites: Raper v. Birkbeck, I5 East, I7; Wilkinson v. Johnson, 3 B. \& C. 42S; Novelli v. Rossi, 2 B. \& Ad. 757; Castrique v. Imrie, L. R. 4 H. L. 435; Warwick v. Rogers, 5 M. \& Gr. 340 and 373; Prince v. Oriental Bank, L. R. 3 App. Cas. 325; Dominion Bank v. Anderson, I5 Sess. Cas 408.

(a) Cases, pp. 582-585. 


\section{$\S 205$. Alteration of instrument; effect of}

Where a negotiable instrument is materially altered without the assent of all parties liable thereon, it is avoided, except as against a party who has himself made, authorized or assented to the alteration and subsequent indorsers. (a) But when an instrument has been materially altered and is in the hands of a holder in due course, not a party to the alteration, he may enforce payment thereof according to its original tenor. (b)

[Note. - See Bills of Exchange Act, section 64, subdivision (I); Daniel on Neg. Inst., sections I393-I 42 Ia.

The Bills of Exchange Act contains a provision that " where a bill has been materially altered, but the alteration is not apparent, and the bill is in the hands of a holder in due course, such holder may avail himself of the bill as if it had not been altered, and may enforce payment of it according to its original tenor." But this effects a change in the law.] This change was subsequently adopted by the Commissioners on Uniformity of Laws, and is introduced in substance above.

(a) Cases, pp. $5^{s_{5}-592 .}$

(b) Cases, p. $587 n$. "The pro-viso was introduced in committee to mitigate the rigor of the common-law rule in favor of a holder in due course. * * At common law a material alteration, by whomsoever made (Davidson v. Cooper, II M. \& W. at p. 799; aff'd I3 M. \& W. 343), avoided and discharged the bill, except as against a party who made or assented to the alteration. (Hamelin $\mathrm{v}$, Bruck, $9 \mathrm{O}, \mathrm{B}$ 306.) Thus where a bill was altered Mason, 452; Dinsmore r. Duncan, 57 by adding a place of payment without N. Y. $\left.5^{8} \mathrm{I}.\right)$ " Chalmers, Bills of Exthe acceptor's consent, and was subse- $\mid$ change Act (5th ed.), p. 2 I4.

$\S 206$. What constitutes a material alteration.

[S I25]

Any alteration which changes:

I. The date; $(a)$

2. The sum payable, either for principal $(b)$ or inter. est; $(c)$

3. The time $(d)$ or place $(e)$ of payment;

4. The number or the relations of the parties; $(f)$

5. The medium or currency in which payment is to be made; $(g)$

Or which adds a place of payment where no place of payment is specified $(h)$, or any other change or addition 


\section{which alters the effect of the instrument in any respect, is a material alteration. (i)}

[Note. - See Bills of Exchange Act, section 64.] Cases, pp. 585-592.

(a) [See Wood v. Steele, 6 Wallace, / by Cotton. L. J., at pp. 574, 575.) The 80; Crawford v. West Side Bank, Ioo materiality of an alteration is a quesN. Y. 50, 56; Daniel on Neg. Inst., sec- tion of law. (Vance v. Lowther, I Ex. tion 1376 .] See $\$ 32$ [13], ante.

(b) [See Daniel on Neg. Inst., section 1384.$]$

(c) [Daniel on Neg. Inst., section I 385 , and cases there cited.]

(a) [Weyman v. Yeomans, 84 Ill. 403; Miller v. Gilleland, I9 Pa. St. I I9.]

(e) [Tidmarsh v. Grover, I Maule \& S. 735 ; Bank of Ohio Valley v. Lockwood, $1_{3}$ W. Va. 392.]

( $f$ ) [Daniel on Neg. Inst., sections 1387-1390.]

(g) [Angle v. Insurance Company, 92 U. S. 330; Church v. Howard, I 7 Hun, 5; Darwin v. Rippey, 63 N. C. 3Is; Bagarth $r$. Breedlove, 39 Tex. 56r.]

(h) [Whitesides v. Northern Bank, Io Bush, 50I.]

(i) Distinguish authorized filling of blanks: $33[\mathrm{I}+]$, ante.

"An alteration is material which in any way alters the operation of the bill and the liabilities of the parties, whether the change be prejudicial or beneficial (Gardner v. Walsh, 5 E. \& B. 83, at p. 89); and it may be that even this test is not wide enough. 'Any alteration,' says Brett, L. J.. ' seems to me material which would alter the business effect of the instrument, if used for any business purpose.' (Suffell v. Bank of England, 9 Q. B. D. 555 , at p. 568 ; see the test suggested

\section{176 .)}

Subject to two exceptions the holder of a bill, which has been avoided by a material alteration, cannot sue on the consideration in respect of which it was negotiated to him. (Alderson v. Langdale, 3 B. \& Ad. 660.) Exception I. If the bill was negotiated to him after the alteration was made, and he was not privy to the alteration, he may sue on the consideration. (Burchfield v. Moore, 23 L. J. Q. B. 261 ; cf. Cundy v. Marriott, I B. \& Ad. 696.) Exception 2. If the bill was altered while in his custody or under his control, he can still recover, provided (a) that he did not intend to commit a fraud by the alteration (Parsons, vol. II., p. 572 ; Hunt v. Gray, 35 N. J. L. 227), and (b), that the party sued would not have had any remedy over on the bill, if it had not been altered. (Atkinson v. Hawdon, $2 \mathrm{~A}$. \& E. 625 ; cf. Sutton v. Toomer, 7 B. \& C. 4I6; Alderson v. Langdale, 3 B. \& Ad. 66o.)

When a bill appears to have been altered, or there are marks of erasures on it, the party seeking to enforce the instrument is bound to give evidence to show that it is not avoided thereby. (Knight v. Clements, 8 A. \& E. 215; Clifford v. Parker, 2 M. \& Gr. 909.)" Chalmers, Bills of Exchange Act (5th ed.), pp. 2I7-2I8.

\section{ARTICLE X.}

BILLS OF EXCHANGE; FORM AND INTERPRETATION.

* Section 2 ro. Bill of exchange defined.

2II. Bill not an assignment of funds in hands of drawee. 
Section 212. Bill addressed to more than one drawee.

213. Inland and foreign bills of exchange.

214. When bill may be treated as promissory note.

215. Drawee in case of need.

§ 2ro. Bill of exchange defined.

[§ 126]

A bill of exchange is an unconditional order in writing addressed by one person to another, signed by the person giving it, requiring the person to whom it is addressed to pay on demand or at a fixed [or] * determinable future time a sum certain in money to order or to bearer.

[Note. - See section I (N. Y. 20); Bills of Exchange Act, section 3.]

"A bill is sometimes called a draft, and an accepted bill is often referred to as ' an acceptance.' The person who gives the order is called the drawer. The person thereby ordered to pay is called the drawee, and if he signifies his assent to the order in due form [see $\$ 220$ (132), post], he is then called the acceptor. The person to whom the money is payable is called the payee or bearer, as the case may be. [See $\$ 2$ (General Provisions), ante.] The foreign codes for the most part provide in terms that a bill may be drawn by one person for the account of another. The person for whose account the bill is drawn is spoken of in England as the 'third account.' For example, a merchant in America may direct his agent in England to draw on a correspondent in Paris for his (the principal's) account." Chalmers, Bilis of Exchange Act (5th ed.), p. 8.

\section{$\S 2$ Ir. Bill not an assignment of funds in hands of drawee.}

$[\S 127]$

A bill of itself does not operate as an assignment of the funds in the hands of the drawee available for the payment thereof, and the drawee is not liable on the bill unless and until he accepts the same. (a)

[Note. - See Bills of Exchange Act, section 53.]

(a) Cases, pp. 605-607

$\$ 2$ I2. Bill addressed to more than one drawee.

$[\S 128]$

A bill may be addressed to two or more drawees jointly, whether they are partners or not; but not to two or more drawees in the alternative or in succession. (a)

[NotE. - See Bills of Exchange Act, section 6. subdivision (2).] See $\$ 229$ (5), [14I], post, and 242 (I) [145], post.

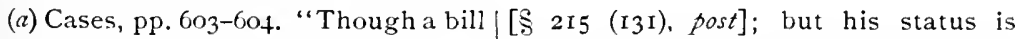
may not be addressed to two drawees wholly different from that of an ordiin succession, or in the alternative, it nary drawee. Alternative or successive may name a drawee in case of need drawees would give rise to difficulty as

\footnotetext{
* Omitted by mistake in N. Y. Act.-ED.
} 
to the recourse if the bill was dishonored. The difficulty does not arise in the case of a note, consequently the makers of a note may be liable jointly, or jointly and severally, according to its tenor, while the acceptors of a bill can only be liable jointly. A note payable in the alternative by one of two makers is invalid. (Ferris $r$. Bond, 4 B. \& Ald. 679.)" Chalmers, Bills of Exchange Act (5th ed.), p. I9.

\section{\& 2I3. Inland and foreign bills of exchange.}

An inland bill of exchange is a bill which is, or on its face purports to be, both drawn and payable within this state. Any other bill is a foreign bill. $(a)$ Unless the contrary appears on the face of the bill, the holder may treat it as an inland bill.

[Note. - See Bills of Exchange Act, section 4, subdivision (1); Buckner v. Finley, 2 Peters, 586; Strawbridge v. Robinson, 5 Gilman, 470.]

(a) Cases, p. 608.

\section{\$2I4. When bill may be treated as promissory note.}

Where in a bill drawer and drawee are the same person, or where the drawee is a fictitious person, or a person not having capacity to contract, the holder may treat the instrument, at his option, either as a bill of exchange or a promissory note.

[Note. - See Bills of Exchange Act, section 5, subdivision (2).] See $\$ 36$ (5) [I7], ante. "If both drawer and drawee are fictitious persons the bill might, perhaps, be treated as a note made by the first indorser." Chalmers, p. Is.

Cases, p. 609.

\section{$\S 215$. Referee in case of need.}

The drawer of a bill and any indorser may insert thereon the name of a person to whom the holder may resort in case of need, that is to say, in case the bill is dishonored by nonacceptance or nor-payment. Such person is called the referee in case of need. It is in the option of the holder to resort to the referee in case of need or not as he may see fit.

[NoTE. - See bills of Exchange Act, section 15; Daniel on Neg. Inst., sections III, 529.] Cases, p. 605.

"The referee in case of need is sometimes called the drawee in case of need, or simply the 'case of need.' A bill must be protested or noted for protest before it can be presented to the case of need. [See $\$ ? 280$ (I6I), 256 (I67), post.] The concluding words of the section settle the moot point, whether presentment to the case of need is obligatory or optional." - Chalmers, p. 38 . 


\section{ARTICLE XI. \\ ACCEPTANCE OF BILLS OF EXCHANGE.}

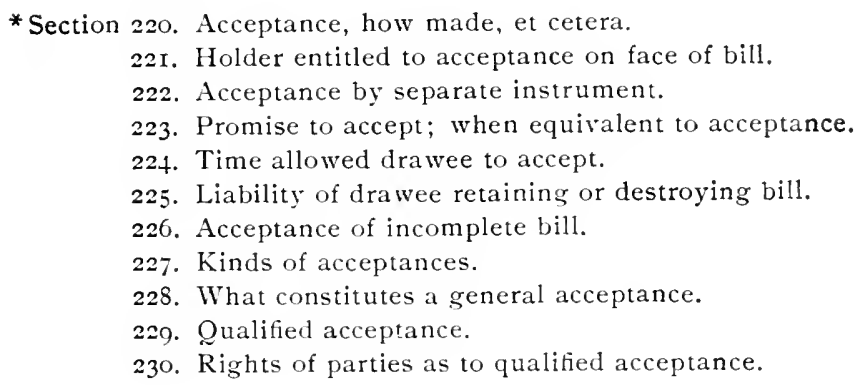

\$220. Acceptance; how made, et cetera.

The acceptance $(a)$ of a bill is the signification by the drawee of his assent to the order of the drawer. The acceptance must be in writing and signed by the drawee. $+(b)$ It must not express that the drawee will perform his promise by any other means than the payment of money. $(c)$

(a) See 2 [General Provisions], ante. ance be written on the bill. The Ameri(b) Cases, pp. 6ro-6r3. [See Bills of can statutes do not generally require Exchange Act, section 17 ; I N. Y. Rev. this.] See next two sections.

Stat., 768 , 5 . The Bills of Exchange (c) [See Bills of Exchange Act, secAct, following previous English stat- tion $I_{7}$, subdivision (2) (b).] See $\$ 20$ utes (I \& 2 George IV., c. 7 ; I9 \& 20 [I], ante.

Victoria. c. 7 ) requires that the accept-

\section{$\$ 22 \mathrm{I}$. Holder entitled to acceptance on face of bill.}

The holder of a bill presenting the same for acceptance may require that the acceptance be written on the bill, and if such request is refused, may treat the bill as dishonored.

[Note. - I N. Y. Rer. Stat., 768, section 9.] The English Act requires that the acceptance be written on the bill; the American Act leaves it optional with the holder to require it, or to waive it. This permits acceptances by telegraph. Garretson r. North Atchison Bank, 39 Fed. Rep. II3, 47 Fed. Rep. 867, 5 I Fed. Rep. 168 .

\section{$\$$ 222. Acceptance by separate instrument.}

Where an acceptance is written on a paper other than the bill itself, it does not bind the acceptor except in favor of a

$* \$[132]$ to $\$[1+2]$ in the other States.

$\nmid$ "Drawer" appears by mistake in N. Y. Act -ED. 
person to whom it is shown and who, on the faith thereof, receives the bill for value. $(a)$

[Note. - I N. Y. Rer. Stat. 768, section 7.]

(a) Cases, pp. 613-6i6.

\section{§ 223. Promise to accept; when equivalent to acceptance.}

1 I35]

An unconditional promise in writing to accept a bill before it is drawn is deemed an actual acceptance in favor of every person who, upon the faith thereof, receives the bill for value. (a)

[Note. - I N. Y. Rev. Stat. 768, section 8.]

(a) Cases, pp. 613-616.

\&224. Time allowed drawee to accept.

[§ 136]

The drawee is allowed twenty-four hours after presentment in which to decide whether or not he will accept the bill $(a)$; but the acceptance if given dates as of the day of presentation. (b)

(a) [See Byles on Bills, Is?: Daniel (b) [There does not appear to be any on Neg. Inst., section 492. By statute direct authority on this point; the rule in Massachusetts, the drawee has until stated conforms to what is the common two o'clock on the day following. practice. See also statute of MassaPublic Statutes, 1882 , ch. 77 , sec. I7.] chusetts above referred to.]

$\S 225$. Liability of drawee retaining or destroying bill. [ $\$$ I37]

Where a drawee to whom a bill is delivered for acceptance destroys the same, or refuses within twenty-four hours after such delivery, or within such other period as the holder may allow, to return the bill accepted or non-accepted to the holder, he will be deemed to have accepted the same. (a)

[Note. - I N. Y. Rev. Stat. 769, section II; see Daniel on Neg. Inst., section 500.]

(a) Cases, pp. 6I7-6I9.

\section{$\S 226$. Acceptance of incomplete bill.}

A bill may be accepted before it has been signed by the drawer, or while otherwise incomplete $(a)$, or when it is overdue, or after it has been dishonored by a previous refusal to accept, or by non-payment. (b) But when a bill 
payable after sight is dishonored by non-acceptance and the drawee subsequently accepts it, the holder, in the absence of any different agreement, is entitled to have the bill accepted as of the date of the first presentment. (c)

[NotE. - See Bills of Exchange Act, section 18; Daniel on Neg. Inst., sections $490-495$.

(a) Cases, pp. 6I9-620. See $\S 33$ ble, in the same position as if the bill [I4], ante.

(b) Cases, pp. 620-62I. Chalmers cites Mutford v. Walcot, I Ld. Raym. 5i4; Wynne v. Raikes, 5 East. 5 I4.

(c) "This subsection was added in committee. It accords with mercantile practice, and was intended to secure that, apart from special agreement, the holder should be put, as far as possi- of Exchange Act (5th ed.). p. 45.

\section{§227. Kinds of acceptances.}

An acceptance is either general or qualified. A general acceptance assents without qualification to the order of the drawer. (a) A qualified acceptance in express terms varies the effect of the bill as drawn. (b)

[Note. - See Bills of Exchange Act, sect:on 19; Byles on Bills, 193; Daniel on Neg. Inst., section 509 et seq.]

(a) Cases, pp. 621-625. "An accept- of the acceptance. (Fanshawe v. Peet, ance is, whenever possible, to be con- 26 L. J. Ex. 314; cf. Stone v. Metcalfe, strued as general, not qualified; and a ${ }_{4}$ Camp. 217 ; Fitch v. Jones, 5 E. \& B., at mere memorandum, such as a wrong due p. 246; Decroix v. Meyer, 25 Q. B. D. date, inconsistent with such construc- 343.)" Chalmers, p. 46.

tion, has been rejected as being no part $($ b) See $\$ 229$ [I4I], fost.

\section{$\S 228$. What constitutes a general acceptance.}

An acceptance to pay at a particular place is a general acceptance unless it expressly states that the bill is to be paid there only and not elsewhere. (a)

[Note. - See Bills of Exchange Act, section I9, subdivision (2); Wallace v. McConnell, I3 Peters, I36; Daniel on Neg. Inst., sections 5I9-520, 64I-643.]

(a) Cases, pp. 625-626. "This sub- Bligh. H. L. 39I, where it was held section reproduces the effect of the re- that an ordinary acceptance payable at pealed I \& 2 Geo. 4, c. 78 , which was a banker's was a qualified acceptance." passed to override the case of Rowe v. Chalmers. Bills of Exchange Act (5th Young, 2 Brod. \& Bing. I65; s. c. 2 ed.), p. 48. 


\section{§ 229. Qualified acceptance.}

An acceptance is qualified, which is :

I. Conditional, that is to say, which makes payment by the acceptor dependent on the fulfillment of a condition therein stated; $(a)$

2. Partial, that is to say, an acceptance to pay part only of the amount for which the bill is drawn; $(b)$

3. Local, that is to say, an acceptance to pay only at a particular place; $(c)$

4. Qualified as to time; $(d)$

5. The acceptance of some one or more of the drawees, but not of all. $(e)$

[Note. - See Bills of Exchange Act, section I9, subdivision (2); Byles on Bills, I93-194; Daniel on Neg. Inst., sections 508-520.]

(a) Cases, pp. 626-628.

(b) Cases, p. 628 .

(c) Cases, pp. 62\$-629. See $\$ 228$ [140], ante.

(d) Cases, p. 629

(e) Cases, p. 630. "Bill drawn on

$B, X$ and $Y$. B accepts, $\mathrm{X}$ and $\mathrm{Y}$ refuse to accept. This is a qualified acceptance." Chalmers (p. 48), citing Marius, No. 16; New York Draft Code, § 1784 ; Nouguier, $\$+5 \mathrm{I}$.

\section{$\$ 230$. Rights of parties as to qualified acceptance.}

[ร I42]

The holder may refuse to take a qualified acceptance, and if he does not obtain an unqualified acceptance, he may treat the bill as dishonored by non-acceptance. (a) Where a qualified acceptance is taken, the drawer and indorsers are discharged from liability on the bill, unless they have expressly or impliedly authorized the holder to take a qualified acceptance, or subsequently assent thereto. $(b)$ When the drawer or an indorser receives notice of a qualified acceptance, he must within a reasonable time express his dissent to the holder, or he will be deemed to have assented thereto. (c)

[Note. - See Bills of Exchange Act, section 44; Byles on Bills, I92-193; Daniel on Neg. Inst., sections 508, 5 IO.

The Bills of Exchange Act provides that the provisions relative to the assent of the drawer and indorser do not apply " to partial acceptance whereof due notice has been given," and that " where a foreign bill has been accepted as to part, it must be protested as to the balance." But there appears to be some doubt whether this correctly states the rule of the law merchant. See Daniel on Neg. Inst., section 511 ; Story on Bills, section 272.]

(a) Cases, p. 630. "According to the holder cannot refuse a partial acthe continental codes, it seems that ceptance. He can only protest as to 
the balance. (French Code, arts. IIgI2O; German Exchange Law, arts. 2528.) " Chalmers, p. I40.

(b) Cases, p. 631. (c) "This sub-section settles a doubtful point in favor of the holder. See subject discussed in Rowe v. Young, 2 Bligh. 39ı." Chalmers, p. I4I.

\section{ARTICLE XII.}

\section{PRESENTMENT OF BILLS OF EXCHANGE FOR ACCEPTANCE.}

* Section 240. When presentment for acceptance must be made.

241. When failure to present releases drawer and indorser.

242. Presentment; how made.

243. On what days presentment may be made.

244. Presentment; where time is insufficient.

245. When presentment is excused.

246. When dishonored by non-acceptance.

247. Duty of holder where bill not accepted.

248. Rights of holder where bill not accepted.

\section{$\S 240$. When presentment for acceptance must be made.}

Presentment for acceptance must be made:

I. Where the bill is payable after sight, or in any other case where presentment for acceptance is necessary in order to fix the maturity of the instrument; $(a)$ or

2. Where the bill expressly stipulates that it shall be presented for acceptance; $(b)$ or

3. Where the bill is drawn payable elsewhere than at the residence or place of business of the drawee. $(c)$

In no other case is presentment for acceptance necessary in order to render any party to the bill liable. $(d)$

(a) [See Bills of Exchange Act, sec- $j$ bill is dishonored by non-acceptance. tion 39, subdivision (I); Daniel on Neg. An agent is bound to use due diligence Inst., section 454 .]

(b) [See Bills of Exchange Act, section 39 , subdivision (2).]

(c) [Yd.] See $\$ 244[147]$, post.

(d) Cases, pp. 632-636. "Where presentment is optional, the object of presenting is ( $\mathrm{I}$ ), to obtain the acceptance of the drawee, and thereby secure his liability as a party to the bill; (2), to obtain an immediate right of recourse against antecedent parties in case the in presenting for acceptance, even when presentment is optional for the purposes of the Act, and he is liable to his principal for damages resulting from his negligence. (Pothier, No. 128; Nouguier, $\$ 462$; Allen v. Suydam, 20 Wend. 321 ; Bank of Van Diemen's Land v. Victoria Bank, L. R. 3 P. C. at p. 542.) " Chalmers, Bills of Exchange Act (5th ed.), p. 132.

$$
\text { * } \$[I+3] \text { to } \$\left[I_{5} I\right] \text { in the other States. }
$$

NEGOT. INSTRUMENTS -5 
$\S 24 \mathrm{I}$. When failure to present releases drawer and indorser.

[§ 144$]$

Except as herein otherwise provided, the holder of a bill which is required by the next preceding section to be presented for acceptance must either present it for acceptance or negotiate it within a reasonable time. (a) If he fails to do so, the drawer and all indorsers are discharged. $(b)$

[Note. - See Bills of Exchange Act, section 40, subdivision (I); Wallace $\mathbf{v}$. Agry, 4 Mason, 333; Daniel on Neg. Inst., sections 469-472.]
(a) See $\S+[$ General Provisions],
(b) Cases, pp. 633-636. ante.

§ 242. Presentment; how made.

[\$ I45]

Presentment for acceptance must be made by or on behalf of the holder at a reasonable hour $(a)$, on a business day, and before the bill is overdue $(b)$, to the drawee* or some person authorized to accept or refuse acceptance on his behalf $(c)$; and

I. Where a bill is addressed to two or more drawees who are not partners, presentment must be made to them all, unless one has authority to accept or refuse accept. ance for all, in which case presentment may be made to him only; $(d)$

2. Where the drawee is dead, presentment may be made to his personal representative; $(\varepsilon)$

3. Where the drawee has been adjudged a bankrupt or an insolvent, or has made an assignment for the benefit of creditors, presentment may be made to him or to his trustee or assignee. $(f)$

[NotE. - See Bills of Exchange Act, section 4I, subdivision (I).]

(a) See S I 32 (2) [72], ante. [See Smith v. New South Wales Bank, S Daniel on Neg. Inst., section 464 a.]

(b) See Plato v. Reynolds, 27 N. Y. 586. Cases, p. 632.

(c) Cases, pp. 637-640. [Byles on Bills, I82; Daniel on Neg. Inst., section 487 .]

(d) [Daniel on Neg. Inst., section 485]. Ante, 229 (5) [I4I]. Moore, P. C. N. S., at pp. $461,462$. Now the holder has an option." (See $\$ 245$ (I) [Its], post.) Chalmers, p. I36n. ( $f$ ) [The Bills of Exchange Act provides that, "Where authorized by agreement or usage a presentment through the post office is sufficient." But probably no such practice prevails

(e) [Daniel on Neg. Inst., section in this country, nor does it appear to 59I.] "Before this enactment the law be a practice that should be encouron this point was very doubtful. aged.] 
§243. On what days presentment may be made.

[ร I 46$]$

A bill may be presented for acceptance on any day on which negotiable instruments may be presented for payment under the provisions of sections seventy-two* and eighty-five* of this act. When Saturday is not otherwise a holiday, presentment for acceptance may be made before twelve o'clock noon on that day.

$\S 244$. Presentment where time is insufficient.

$[\$$ I47]

Where the holder of a bill drawn payable elsewhere than at the place of business or the residence of the drawee has not time with the exercise of reasonable diligence to present the bill for acceptance before presenting it for payment on the day that it falls due, the delay caused by presenting the bill for acceptance before presenting it for payment is excused and does not discharge the drawers and indorsers.

[Note. - See Bills of Exchange Act, section 39, subdivision (4).]

This section is rendered necessary by 240 [I 47 , subsec. 3. ante. "It settles a moot point, and perhaps alters the law. Suppose a bill, payable one month after date, is drawn in New York on a Liverpool firm, but payable at a London bank. It only reaches the English holder, or his agent, on the day that it matures. He must, nevertheless, present it for acceptance to the drawees in Liverpool. The Act provides that he shall not be prejudiced by so doing. Before the Act the usual practice was to protest the bill in London without any presentment to the drawees - an obviously inconvenient mode of proceeding, for the holder's object is to get the bill paid, and not to run up expenses against the drawer and indorsers." Chalmers. p. 133.

\section{$\S 245$. Where presentment is excused.}

Presentment for acceptance is excused and a bill may be treated as dishonored by non-acceptance in either of the following cases:

I. Where the drawee is dead (a), or has absconded (b), or is a fictitious person or a person not having capacity to contract by bill; $(c)$

2. Where after the exercise of reasonable diligence, presentment cannot be made; $(d)$

3. Where although presentment has been irregular, acceptance has been refused on some other ground. $(e)$

\footnotetext{
*In the New York Act these sections should read, "Sections I32 and 145," - ED.
} 
(a) [See Bills of Exchange Act, sec-|ante; also $\$ 18_{3}$ [112], ante.

tion $4 \mathrm{I}$, subdivision (2); Daniel on Neg. Inst., section 1178.] Compare $\S 242$ [I 45$]$, subsec. 2, ante.

(b) [Daniel on Neg. Inst., section I144. By the Bills of Exchange Act the bankruptcy of the drawee will excuse presentment for acceptance. But this is not the rule of the Commercial Law. Daniel on Neg. Inst., sections I I 7 I - I I 7 7 2.]

(c) [See Daniel on Neg. Inst., section IIII.]

(d) [Daniel on Neg. Inst., section I059, et seq.] See \$ I 42 [82], subsec. I, (e) "This is, perhaps, new law, and is important, having regard to the next subsection." Chalmers, p. I37n. The subsection referred to reads: "The fact that the holder has reason to believe that the bill, on presentment, will be dishonored, does not excuse presentment." This provision does not appear in the American Act. But if the drawer has no right to expect acceptance, presentment for payment is excused. \& I39 [79], ante.

Cases, p. 64 I.

\section{$\S 246$. When dishonored by non-acceptance.}

A bill is dishonored by non-acceptance:

I. When it is duly presented for acceptance, and such an acceptance as is prescribed by this act is refused or cannot be obtained; or

2. When presentment for acceptance is excused and the bill is not accepted.

[NotE. - See Bills of Exchange Act, section 43, subdivision (1).]

\section{$\$ 247$. Duty of holder where bill not accepted.}

Where a bill is duly presented for acceptance and is not accepted within the prescribed time, the person presenting it must treat the bill as dishonored by non-acceptance or he loses the right of recourse against the drawer and indorsers. (a)

[NotE. - See Bills of Exchange Act, section 42. The language of the Bills of Exchange Act is, " within the customary time," but the time herein is fixed by section 136 . (N. Y., S224.)]

(a) That is, due notice must be given to parties secondarily liable. See, however, $\$$ I88 [II7], ante.

\section{$\S 248$. Rights of holder where bill not accepted.}

When a bill is dishonored by non-acceptance, an immediate right of recourse against the drawers and indorsers accrues to the holder, and no presentment for payment is necessary.(a)

[Note. - See Bills of Exchange Act, section 43, subdivision (2).] 
(a) Cases, pp. 64I-642. "The imme- I nental codes the holder can only protest diate right of recourse arising on non- the bill for non-acceptance, and demand acceptance is an exceptional right, and security from the drawer and indorsers. seems peculiar to English and American (French Code, arts. II9, 120; German law. (Whitehead v. Walker, 9.I. K W., Exchange Law, arts. 25-28.) The at p. 516; Watson v. Tarpley, 2o How. effect of this conflict of laws does not (U. S.), at p. 5I9; cf. Dunn v. O'Keefe, appear to have been judicially consid5 M. \& S., at p. $2 S_{9}$.) Under the conti- ered." Chalmers, p. I 40.

\section{ARTICLE XIII.}

\section{PROTEST OF BILLS OF EXCHANGE.}

* Section 260. In what cases protest necessary.

26I. Protest; how made.

262. Protest; by whom made.

263. Protest; when to be made.

264. Protest; where made.

265. Protest both for non-acceptance and non-payment.

266. Protest before maturity where acceptor insolvent.

267. When protest dispensed with.

268. Protest; where bill is lost, et cetera.

$\S 260$. In what cases protest necessary.

[\$ $\$$ I 52$]$

Where a foreign bill (a), appearing on its face to be such is dishonored by non-acceptance, it must be duly protested for non-acceptance, and where such a bill which has not previously been dishonored by non-acceptance is dishonored by non-payment, it must be duly protested for non-payment. If it is not so protested, the drawer and indorsers are discharged. (b) Where a bill does not appear on its face to be a foreign bill, protest thereof in case of dishonor is unnecessary. (c)

[Note. - See Bills of Exchange Act, section 5I, subdivision (2).]

(a) See $\S 2$ I3 [129], ante.

(b) Cases, p. 643. "The notice of dishonor is not bad because it omits to state that the bill has been pro-

tested. (Ex parte Lowenthal, L. R. 9 Ch. 59I.) " Chalmers, p. 172.

(c) Cases, p. $6+3$.

$\S 261$. Protest; how made.

The protest must be annexed to the bill, or must contain a copy thereof $(a)$, and must be under the hand and seal $(b)$ of the notary making it, and must specify:

I. The time and place of presentment; 


\section{The fact that presentment was made and the manner} thereof;

3. The cause or reason for protesting the bill;

4. The demand made and the answer given, if any, or the fact that the drawee or acceptor could not be found. (c)

(a) [See Bills of Exchange Act, sec- / certificate is to be used in other juris tion 5I, subdivision (7); Daniel on dictions.]

Neg. Inst., section 944.]

(c) Cases, pp. 643-647. [See Daniel

(b) [Cases, pp. 503, 569. In some of on Neg. Inst., sections 950-958. The the States, as in New York, the use of Bills of Exchange Act provides that a seal is not necessary where the certificate is to be used in the State; but a seal is probably desirable where the protest must specify the person at whose request the bill is protested, but this makes a change in the law. Daniel on Neg. Inst., section 956.]

$\S 262$. Protest; by whom made.

[\$ 154$]$

Protest may be made by:

I. A notary public; $(a)$ or

2. By any respectable resident of the place where the bill is dishonored, in the presence of two or more credible witnesses. (b)

[Note. - See Todd v. Neal's Administrator, 49 Ala. 273; Daniel on Neg. Inst., sections 934-93+a; Civil Code of California, 3226.]

(a) Cases, pp. 648-650. "In Eng- protest founded on such presentment land the notarial presentment of the has been doubted. (See Parsons on bill to the drawee or acceptor is almost Bills, p. 64I.) " Chalmers, p. I75.

always made by the notary's clerk. (b) See Bills of Exchange Act, sec(Brooks' Notary, $4^{\text {th }}$ ed., pp. $7^{8}$ and tion 94.

I35.) In America the validity of a

$\S 263$. Protest; when to be made.

[\$ I55]

When a bill is protested, such protest must be made on the day of its dishonor $(a)$, unless delay is excused as herein provided. (b) When a bill has been duly noted $(c)$, the protest may be subsequently extended as of the date of the noting. $(d)$

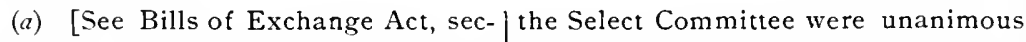
tion $5 \mathrm{I}$, subdivision (4); Dennistoun v. Stewart, I9 How. 6o6; Byles on Bills, 257.] "Before the act it was not clear that a bill could not be lawfully noted for protest on the day after its dishonor: but the business members of ute made by a notary public on a disin thinking that noting on the day of dishoror should be made obligatory." Chalmers, p. 173 .

(b) See $\$ 267$ [159], post.

(c) " $\mathrm{By}$ ' noting' is meant the min- 
honored bill at the time of its dishonor. jen on the bill itself." Chalmers, p. The formal notarial certificate, or pro- I7I. test, attesting the dishonor of the bill, is based upon the noting. The 'noting.' consists of the notary's initials, the date, the noting charges, and a mark referring to the notary's register writ-

(d) Cases, p. 647. [Bailey v. Dozier, 6 How. 23; Cayuga Co. Bank v. Hunt, 2 Hill, 635; Daniel on Neg. Inst., section 940 ; Byles on Bills, 257.]

\section{§ 264. Protest; where made.}

[\$ 156$]$

A bill must be protested at the place where it is dishonored (a), except that when a bill drawn payable at the place of business or residence of some person other than the drawee, has been dishonored by non-acceptance, it must be protested for non-payment at the place where it is expressed to be payable, and no further presentment for payment to, or demand on, the drawee is necessary. (b)

(a) [See Daniel on Neg. Inst., sec- It is dishonored by non-acceptance. tion 935; Byles on Bills, 217.$]$

(b) [Bills of Exchange Act, section ment in London without any fur5I, subdivision (6); 2 and 3 William ther demand on B. Ordinarily the IV., ch. 98 : Daniel on Neg. Inst., sec- protest recites the demand on the action 935; Byles on Bills, 258.] "Sup- ceptor or other payer." Chalmers, pose a bill is drawn on $\mathrm{B}$ in Liverpool, p. I74.

'payable at the $\mathrm{X}$ Bank in London.'

\section{$\S 265$. Protest both for non-acceptance and non-payment.}

[§ I57]

A bill which has been protested for non-acceptance may be subsequently protested for non-payment.

[Note. - See Bills of Exchange Act, section 5I, subdivision (3).] " Protest in such case might be necessary for the purpose of charging a foreign drawer or indorser in his own country. An English Act can only lay down the law for the United Kingdom, though by the comity of nations the duties of the holder would generally be regarded as regulated by the law of the place where they are to be performed. $* * *$ Under some continental codes no right of action arises on non-acceptance; the holder can denand security from antecedent parties, but he is bound to re-present the bill at maturity." Chalmers, p. I72.

\section{$\S 266$. Protest before maturity where acceptor insolvent.}

[\$ 158$]$

Where the acceptor has been adjudged a bankrupt or an insolvent or has made an assignment for the benefit of creditors, before the bill matures. the holder may cause the bill to be protested for better security against the drawer and indorsers. 
[Note. - See Bills of Exchange Act, section 51, subdivision (5); Daniel on Neg. Inst., section 530.] "Under some continental codes, when the acceptor fails during the currency of a bill, security can be demanded from the drawer and indorsers. (German Exchange Law, art. 29; Netherlands Code, arts. I7\%, 178.) English law provides no such remedy, and the only effect of such a protest in England is that the bill may be accepted for honor. In France, if the acceptor fails, the bill may at once be treated as dishonored and protested for non-payment. (French Code, art. I63; Nouguier, $\$ 1277$.$) " Chalmers, p. I73.$

\section{$\S 267$. When protest dispensed with.}

[S I59]

Protest is dispensed with by any circumstances which would dispense with notice of dishonor. (a) Delay in noting or protesting is excused when delay is caused by circumstances beyond the control of the holder and not imputable to his default, misconduct, or negligence. $(b)$ When the cause of delay ceases to operate, the bill must be noted or protested with reasonable diligence.

[NoTE. - See Bills of Exchange Act, section 5I, subdivision (9).]

(a) Cases, p. 562. See $\$ \S$ I $80-186 \mid$ I2 East, I7I; Campbell v. Webster, I5 [109-II5], ante. Does this incorporate L. J. C. P. 4; Rothschild v. Currie, I \$ I88 [II7], ante? See Chalmers, p. I76. Q. B., at p. 47.

(b) Chalmers cites: Legge v. Thorpe,

\section{$\S 268$. Protest where bill is lost, et cetera.}

[§ I60]

Where a bill is lost or destroyed or is wrongly detained from the person entitled to hold it, protest may be made on a copy or written particulars thereof.

[Note. - See Bills of Exchange Act, section 5I, subdivision (8); Daniel on Neg. Inst., section 1464.] ' Pothier, No. I45; Brooks' Notary, 4th ed., pp. I37 and 217 . See further as to lost bills, sections 69 and 70 (Bills of Exchange Act). The particulars can usually be obtained from the bill book." Chalmers, p. $175 n$.

\section{ARTICLE XIV.}

\section{ACCEPTANCE OF BILLS OF EXCHANGE FOR HONOR.}

* Section 280. When bill may be accepted for honor.

28. Acceptance for honor; how made.

282. When deemed to be an acceptance for honor of the drawer.

283. Liability of acceptor for honor.

284. Agreement of acceptor for honor.

285. Naturity of bill payable after sight: accepted for honor.

286. Protest of bill accepted for honor, et cetra. 
Section 287. Presentment for payment to acceptor for honor; how made. 285. When delay in making presentment is excused.

2S9. Dishonor of bill by acceptor for honor.

Note. - See Cases, pp. $65 \mathrm{I}-657$.

$\S 280$. When bill may be accepted for honor.

[§ I6I $]$

Where a bill of exchange has been protested for dishonor by non-acceptance or protested for better security and is not overdue, any person not being a party already liable thereon, may, with the consent of the holder, intervene and accept the bill supra protest for the honor of any party liable thereon or for the honor of the person [for] ${ }^{*}$ whose account the bill is drawn. The acceptance for honor may be for part only of the sum for which the bill is drawn; and where there has been an acceptance for honor for one party, there may be a further acceptance by a different person for the honor of another party.

[Note. - See Bills of Exchange Act, section 65, subdivisions ( 1 ) and (2); Byles on Bills, 262-266. The Bills of Exchange Act makes no provision for different acceptances supra protest; but this is authorized by the commercial law. Byles on Bills, 263.] "In the United States, as in England, the holder may refuse to allow acceptance for honor (See Story, \$ I22), for he may wish to exercise his immediate right of recourse which arises on non-acceptance." Chalmers, p. 226.

$\S 28 \mathrm{I}$. Acceptance for honor; how made.

$[\S I 62\rfloor$

An acceptance for honor supra protest must be in writing and indicate that it is an acceptance for honor, and must be signed by the acceptor for honor.

[NotE. - See Bills of Exchange Act, section 65, subdivision (3). The Bills of Exchange Act requires the acceptance for honor to be written on the bill, but see note to section 132 (N. Y., \&220).]

\section{$\S 282$. When deemed to be an acceptance for honor of the drawer. \\ [s I63]}

Where an acceptance for honor does not expressly state for whose honor it is made, it is deemed to be an acceptance for the honor of the drawer.

[Note. - See Bills of Exchange Act, section 65, subdivision (4).

* Omitted by error in N. Y. Act. - ED. 
$\S 283$. Liability of the acceptor for honor.

[§ 164$]$

The acceptor for honor is liable to the holder and to all parties to the bill subsequent to the party for whose honor he has accepted.

[NotE. - See Bills of Exchange Act, section 66, subdivision (2).]

$\$ 284$. Agreement of acceptor for honor.

[\$ I65]

The acceptor for honor by such acceptance engages that he will on due presentment pay the bill according to the terms of his acceptance, provided it shall not have been paid by the drawee, and provided also, that it shall have been duly presented for payment and protested for non-payment and notice of dishonor given to him.

[Note. - See Bills of Exchange Act, section 66, subdivision (I).]

$\S 285$. Maturity of bill payable after sight; accepted for honor.

[\$ 166$]$

Where a bill payable after sight is accepted for honor, its maturity is calculated from the date of the noting for nonacceptance and not from the date of the acceptance for honor.

[NotE-See Bills of Exchange Act, section 65, subdivision (5).] “This section brings the law into accordance with mercantile understanding, and gets rid of an inconvenient ruling to the effect that maturity was to be calculated from the date of acceptance for honor. (William v. Germaine, 7 B. \& C. 468.) " Chalmers, p. 228.

$\S 286$. Protest of bill accepted for honor, et cetera.

[§ I67]

Where a dishonored bill has been accepted for honor supra protest or contains a reference in case of need, it must be protested for non-payment before it is presented for payment to the acceptor for honor or referee in case of need.

[Note. - See Bills of Exchange Act, section 67, subdivision (I).]

$\$ 287$. Presentment for payment to acceptor for honor; how made.

[\$ 168$]$

Presentment for payment to the acceptor for honor must be made as follows:

I. If it is to be presented in the place where the protest for non-payment was made, it must be presented not later than the day following its maturity;

2. If it is to be presented in some other place than the place where it was protested, then it must be for- 
warded within the time specified in section one hundred and four.*

[NoTE, - See Bills of Exchange Act, section 67, subsec. (2). " Doubts having arisen as to the day when the bill should be again presented to the acceptor for honor, or referee in case of need, for payment, the 6 and 7 Will. 4, c. 58 , enacts, that it shall not be necessary to present, or in case the acceptor for honor or referee live at a distance, to forward for presentment, till the day following that on which the bill becomes due." Byles on Bills, 263.]

$\S 288$. When delay in making presentment is excused. [ $\$$ I69]

The provisions of section eighty-one tapply where there is delay in making presentment to the acceptor for honor or referee in case of need.

$\$ 289$. Dishonor of bill by acceptor for honor.

[\$ 170$]$

When the bill is dishonored by the acceptor for honor it must be protested for non-payment by him.

[NoTE. - Bills of Exchange Act, section 67, subdivision (4.)]

\section{ARTICLE XV. \\ PAYMENT OF BILLS OF EXCHANGE FOR HONOR.}

$\ddagger$ Section 300 . Who may make payment for honor.

301. Payment for honor; how made.

302. Declaration before payment for honor.

303. Preference of parties offering to pay for honor.

30.4. Effect on subsequent parties where bill is paid for honor.

305. Where holder refuses to receive payment supra protest.

306. Rights of payer for honor.

Note. - See Cases, pp. 658-660.

$\$ 300$. Who may make payment for honor.

$[\S I 7 I]$

Where a bill has been protested for norn-payment, any person may intervene and pay it supra protest for the honor of any person liable thereon or for the honor of the person for whose account it was drawn.

[NotE. - See Bills of Exchange Act, section 68, subdivision (r); Byles on Bills, 267-269; Daniel on Neg. Inst., section r254.]

* N. Y. Act should read " section I 75." - ED.

$+N$. Y. Act should read " section r4r." - ED.

$\ddagger \$[171]$ to $\$[177]$ in the other States. 
$\S 30$. Payment for honor; how made.

[S 172$]$

The payment for honor supra protest in order to operate as such and not as a mere voluntary payment must be attested by a notarial act of honor which may be appended to the protest or form an extension to it.

[Note. - See Bills of Exchange Act, section 68. subdivision (3); Byles on Bills, 267; Daniel on Neg. Inst., section 1258.]

$\$$ 302. Declaration before payment for honor.

[\$ I73]

The notarial act of honor must be founded on a declaration made by the payer for honor or by his agent in that behalf declaring his intention to pay the bill for honor and for whose honor he pays.

[NotE. - See Bills of Exchange Act, section 68, subdivision (4).]

\section{$\S 303$. Preference of parties offering to pay for honor.}

[§ I74]

Where two or more persons offer to pay a bill for the honor of different parties, the person whose payment will discharge most parties to the bill is to be given the preference

[NotE. - See Bills of Exchange Act, section 68, subdivision (2).]

$\S 304$. Effect on subsequent parties where bill is paid for honor.

[ $\$$ I75]

Where a bill has been paid for honor all parties subsequent to the party for whose honor it is paid are discharged, but the payer for honor is subrogated for, and suceeds to, both the rights and duties of the holder as regards the party for whose honor he pays and all parties liable to the latter.

[Note. - See Bills of Exchange Act, section 68, subdivision (5); Daniel on Neg. Inst., section I255.]

$\S 305$. Where holder refuses to receive payment supra protest

[\$ I76]

Where the holder of a bill refuses to receive payment supra protest, he loses his right of recourse against any party who would have been discharged by such payment.

[Nore. - See Bills of Exchange Act, section 68, subdivision (7).]

$\S 306$. Rights of payer for honor.

[\$ 177$]$

The payer for honor on paying to the holder the amount of the bill and the notarial expenses incidental to its dis- 
honor, is entitled to receive both the bill itself and the protest.

[NotE. - See Bills of Exchange Act, section 63, subdivision (6).]

\section{ARTICLE XVI.}

\section{BILLS IN A SET.}

* Section 3 10. Bills in sets constitute one bill.

3II. Rights of holders where different parts are negotiated.

3I2. Liability of holder who indorses two or more parts of a set to different persons.

313. Acceptance of bills drawn in sets.

314. Payment by acceptor of bills drawn in sets.

315. Effect of discharging one of a set

Note. - See Cases, pp. 66I-665.

\section{$\S$ 3I0. Bills in sets constitute one bill.}

Where a bill is drawn in a set, each part of the set being numbered and containing a reference to the other parts, the whole of the parts constitute one bill.

[NotE. - See Bills of Exchange Act, section 7I, subdivision (I); Byles on Bills, 3S7; Daniel on Neg. Inst., seccion II3.] "If one part omit reference to the rest, it becomes a separate bill in the hands of a bona fide holder. It has been held that an agreement to deliver up an unaccepted bill drawn in a set is an agreement to deliver up all the parts in existence (Kearney v. West Granada Co., 26 L. J. Ex. I5): and also that a person who negotiates a bill of exchange drawn in a set, is bound to deliver up all the parts in his possession, but by negotiating one part he does not warrant that he has the rest. (Pinard $v$. Klockman, 32 L. J. Q. B. 82.) In England the obligation to give a set is presumably a matter of bargain." Chalmers, p. 235.

\section{II. Rights of holders where different parts are negotiated.}

[\$ I79]

Where two or more parts of a set are negotiated to different holders in due course, the holder whose title first accrues is as between such holders the true owner of the bill. But nothing in this section affects the rights of a person who in due course accepts or pays the part first presented to him.

[Note. - See Bills of Exchange Act, section 7I, subdivision (3); Byles on Bills, 389.]

* $\S[178]$ to $\left[18_{3}\right]$ in the other States. 


\section{$\S$ 312. Liability of holder who indorses two or more parts of a set to different persons. \\ [\$ I80]}

Where the holder of a set indorses two or more parts to different persons he is liable on every such part, and every indorser subsequent to him is liable on the part he has himself indorsed, as if such parts were separate bills.

[Note. - See Bills of Exchange Act, section 7I, subdivision (2); Holdsworth v. Hunter, Io B. \& C. 449; Byles on Bills, 359.]

\section{\$13. Acceptance of bills drawn in sets.}

The acceptance may be written on any part, and it must be written on one part only. If the drawee accepts more than one part, and such accepted parts are negotiated to different holders in due course, he is liable on every such part as if it were a separate bill.

[Note. - See Bills of Exchange Act, section 7I, subdivision (4); Holdsworth v. Hunter, to B. \& C. 449; Byles on Bills, 389.$]$

$\$ 3$ I4. Payment by acceptor of bills drawn in sets.

When the acceptor of a bill drawn in a set pays it without requiring the part bearing his acceptance to be delivered up to him, and that part at maturity is outstanding in the hands of a holder in due course, he is liable to the holder thereon.

[NotE. - See Bills of Exchange Act, section 7I, subdivision (5); Byles on Bills, 359.]

\section{$\S 3$ I5. Effect of discharging one of a set.}

Except as herein otherwise provided, where any one part of a bill drawn in a set is discharged by payment or otherwise the whole bill is discharged.

[Note. - See Bills of Exchange Act, section 7I, subdivision (6); Byles on Bills, 388.$]$

\section{ARTICLE XVII.}

\section{PROMISSORY NOTES AND CHECKS.}

* Section 320. Promissory note defined.

321. Check defined.

322. Within what time a check must be presented.

323. Certification of check; effect of.

324. Effect where holder of check procures it to be certified.

325. When check operates as an assignment.

$* \subseteq\left[\mathrm{IS}_{4}\right]$ to $\$\left[\mathrm{I} \mathrm{S}_{9}\right]$ in the other States. 
$\S 320$. Promissory note defined.

[\$ 184$]$

A negotiable promissory note within the meaning of this act is an unconditional promise in writing made by one person to another signed by the maker engaging to pay on demand or at a fixed or determinable future time, a sum certain in money to order or to bearer. $(a)$ Where a note is drawn to the maker's own order, it is not complete until indorsed by him. (b)

[Note. - See Bills of Exchange Act, section 83.] "A bank note may be defined as a promissory note issued by a banker payable to bearer on demand. But a bank note differs from an ordinary note in various important respects. Among others it may be reissued after payment. See further distinctions pointed out by Bramwell, B. (Lichfield Union v. Greene, 26 L. J. Ex., at p. 142.)" Chalmers, p. 263.

(a) Cases, pp. 666-673. See $\S 20$ former New York Statute. (Carn[I], ante, and cases under that section. wright v. Gray, 127 N. Y. 92.) This See generally on form and interpreta- section changes the New York law and tion, $\$ 520-42[\mathrm{I}-23]$, ante.

The English Act includes notes payable " To, or to the order of, a specified person or to bearer," that is, it includes non-negotiable notes. So also was the

$\S 321$. Check defined.

[\$ 185$]$

A check is a bill of exchange drawn on a bank $(a)$, payable on demand. (b) Except as herein otherwise provided, the provisions of this act applicable to a bill of exchange payable on demand apply to a check. (c)

(a) Cases, pp. 673-676. [See Bills $38 \mathrm{I}$, as modified by L. R. I9 Eq., at p. of Exchange Act, section 73: Bull v. 76, Jessel, M. R.), Palles, C. B. (Io Ir. Kasson, 123 U. S. 105; Hopkinson v. Foster, L. R. Is Eq. 74.] See 5 [General Provisions], ante, defining "bank."

(b) [Daniel on Neg. Inst., \& I574.]

(c) "The Act is declaratory in so far as it defines a check as a bill of exchange. (M'Lean v. Clydesdale Bank, L. R. 9 App. Cas. 95.) It is no part of the definition that a check should be an inland bill, or that it should be drawn by a customer upon his banker. * * * See checks compared with and distinguished from ordinary bills by Parke, B. (9 Moore P. C., at p. 69), Erle, J., and Byles, J. (8 C. B. N. S., at pp. 380 , confines the operation of the Act to negotiable notes.

(b) See $\$ 27[8]$, subsec. 2 . and $\$ 28$ [9], subsec. 5 , ante.

R. C. L., at p. 49o), and the Supreme Court of the United States. (Io Wallace, at p. 647.) All checks are bills of exchange, but all bills of exchange are not checks; therefore, an authority to draw checks does not necessarily include an authority to draw bills. Forster v. Mackreth, L. R. 2 Ex. 163.) Apart from statute, the distinctions between checks and ordinary bills of exchange arise from the relationship of banker and customer subsisting between the drawer and drawee of a check. A check is intended for prompt presentment, while a note payable on demand is deemed to be a continuing 
security. (Brooks v. Mitchell, 9 M. \& son, L. R. 3 C. P., at p. 579.)" ChalmW., at p. I8; Chartered Bank v. Dick- ers, pp. 245-246.

\section{$\$ 322$. Within what time a check must be presented.}

A check must be presented for payment within a reasonable time after its issue or the drawer will be discharged from liability thereon to the extent of the loss caused by the delay. $(a)$

[Note. - See Smith v. Jones, 2 Bush. I03; Cork v. Bacon, 45 Wis. I92; Bull v. Kasson, I23 U. S. I05; Daniel on Neg. Inst., sections 1586-I600.] See Bills of Exchange Act, section 74 .

(a) Cases, pp. 676-68I. See "rea- of the bank to pay a check, if the check sonable time," defined in $\$ 4$ [General is presented for payment within ten Provisions], ante. Independent of stat- days from the date thereof; "but this ute a check must be presented or for- was struck out of the final draft. warded for presentment on the day [This was taken from the statutes of after it is received. Chalmers, p. Massachusetts (Pub. St. Supp. ISS8, 243. The draft of the American Act ch. 2Io.) There seems to be some originally contained the following: doubt as to the common-law rule. See "The death of the drawer does not Daniel on Neg. Inst., section I6ISb.] operate as a revocation of the authority

\section{\$323. Certification of check; effect of.}

Where a check is certified by the bank on which it is drawn the certification * is equivalent to an acceptance. $(a)$

[Note. - See Merchants' Bank v. State Bank, to Wall. 645; Cooke v. State Nat. Bank, 52 N. Y. 96 ; Farmers and Mechanics' Bank v. Butchers and Drovers' Bank, I6 N. Y. I25.]

(a) Cases, pp. 682-685.

\section{\$24. Effect where the holder of check procures it to be certi- fied. \\ [§ I88]}

Where the holder of a check procures it to be accepted or certified the drawer and all indorsers are discharged from liability thereon. (a)

[Note. - See Minot v. Russ, I56 Mass. 458; Metropolitan Bank v. Jones, I37 Ill. 634; Meridan Nat. Bank v. First Nat. Bank (Ind.), 33 N. E. Rep. 247; First Nat. Bank v. Leach, 52 N. Y. 350.]

(a) Cases, pp. 6\$2-685. 


\section{$\S 325$. When check operates as an assignment.}

A check of itself does not operate as an assignment of any part of the funds to the credit of the drawer with the bank, and the bank is not liable to the holder, unless and until it accepts or certifies the check. (a)

[Note. - See Bank v. Millard, Io Wall. I52; Bank v. Schuler, I20 U. S. 5 II; Bank v. Whitman, 94 U. S. 343 , 344; St. L. \& S. F. R'y Co v. Juhnston, I33 U. S. 566; Attorney-General v. Cuntinental Lif $\curvearrowright$ Insurance Co., 7 I N. Y. 325, 330; First Nat. Bank of Union Mills v. Clark, I34 N. Y. 368 ; O'Connor v. Mechanics' Bank, I24 N. Y. 324; Covert v. Rhodes, 48 Ohio St. 66; Pickle v. Peoples' Nat. Bank, 88 Tenn. 3 3 ; Boctcher v. Colorado Nat. Bank, 15 Colo. 16: Hopkinson v. Foster, L. R. I8 Eq. 74; Contra, Fonner v. Smith, 3I Neb. 107: Munn v. Burch, 25 Ill. 35; Bank v. Patton, I09 I11. 470, 485.] See $\S 211$ [127], ante.

(a) Cases, pp. 685-688.

\section{ARTICLE XVIII.*}

\section{NOTES GIVEN FOR A PATENT RIGHT AND FOR A SPECULATIVE CONSIDERATION.}

Section 330. Negotiable instruments given for patent rights.

33I. Negotiable instruments given for a speculative consideration.

332. How negotiable bonds are made non-negotiable.

\section{$\S 330$. Negotiable instruments given for patent rights.}

A promissory note or other negotiable instrument, the consideration of which consists wholly or partly of the right to make, use or sell any invention claimed or represented by the vendor at the time of sale to be patented, must contain the words "given for a patent right" prominently and legibly written or printed on the face of such note or instrument above the signature thereto; and such note or instrument in the hands of any purchaser or holder is subject to the same defenses as in the hands of the original holder $(a)$; but this section does not apply to a negotiable instrument given solely for the purchase price or the use of a patented article.

(a) It is a misdemeanor, to take, "given for a patent right" appear on sell, or transfer such an instrument, the instrument above the signature. knowing the consideration to be as N. Y. Penal Code, $\$ 384 \mathrm{~m}$ (Laws of N. above described, unless the words Y. I897, c. 613).

* Not a part of the Negotiable Instruments Law in other states. - ED. NEGOT. INSTRUMENTS -6 


\section{$\S 33$. Negotiable instrument for a speculative consideration.}

If the consideration of a promissory note or other negotiable instrument consists in whole or in part of the purchase price of any farm product, at a price greater by at least four times than the fair market value of the same product at the time, in the locality, or of the membership and rights in an association, company or combination to produce or sell any farm product at a fictitious rate, or of a contract or bond to purchase or sell any farm product at a price greater by four times than the market value of the same product at the time in the locality, the words, "given for a speculative consideration," or other words clearly showing the nature of the consideration, must be prominently and legibly written or printed on the face of such note or instrument, above the signature thereof $(a)$; and such note or instrument, in the hands of any purchaser or holder, is subject to the same defenses as in the hands of the original owner or holder.

(a) See N. Y. Penal Code, $\S 384$ n. (Laws of N. Y. I 897, c. 613.)

\section{$\S 332$. How negotiable bonds are made non-negotiable.}

The owner or holder of any corporate or municipal bond or obligation (except such as are designated to circulate as money, payable to bearer), heretofore or hereafter issued in and payable in this state, but not registered in pursuance of any state law, may make such bond or obligation, or the interest coupon accompanying the same, non-negotiable, by subscribing his name to a statement indorsed thereon, that such bond, obligation or coupon is his property; and thereon the principal sum therein mentioned is payable only to such owner or holder, or his legal representatives or assigns, unless such bond, obligation or coupon be transferred by indorsement in blank, or payable to bearer, or to order, with the addition of the assignor's place of residence.

\section{ARTICLE XIX.*}

LAWS REPEALED; WHEN TO TAKE EFFECT.

Section 340. Laws repealed.

$34 \mathrm{I}$. When to take effect.

\section{$\S 340$. Laws repealed.}

The laws or parts thereof specified in the schedule hereto annexed, are hereby repealed.

\footnotetext{
* Applies only in New York.-ED.
} 


\section{$\S 34 I$. When to take effect.}

This chapter shall take effect on the first day of October, eighteen hundred and ninety-seven.

\section{Schedule of Laws Repealed.}
Revised Statutes.
Sections.
Subject matter.

R. S., pt. II, ch. 4, tit. II..... Al1.... Bills and notes.

Laws of Chapter. Sections. Subject matter.

I $835 \ldots$ I $41 \ldots$ A ..... Notice of protest; how given.

I $857 \ldots . .4$ I $6 \ldots . .$. A11.... Commercial paper.

I $865 \ldots . .309 \ldots$ A11.... . Protest of foreign bills, etc.

I870... $438 \ldots$. All.... Negotiability of corporate bonds; how limited.

I871.... $84 \ldots .$. All.... Negotiable bonds; how made non-negotiable.

I873... 595.... All.... Negotiable bonds; how made negotiable.

I $877 \ldots \quad 65 \ldots \ldots \quad$ I, $3 \ldots \ldots$ Negotiable instruments given for patent rights.

I887... 46r.... A11.... E Effect of holidays upon payment of commercial paper.

I888. . . 229.... All.... . One hundredth anniversary of the inauguration of George Washington.

I891 ... 262.... I..... Negotiable instruments given for a speculative purpose.

I894.... 607 .... All.... Days of grace abolished.

APPENDIX A.

Laws of New York, I897, chapter 6i4.

An act to amend the statutory construction law, in relation to public holidays.

Became a law May I9, I897, with the approval of the Governor. Passed, a majority being present.

The People of the State of New York, represented in Senate and Assembly, do enact as follows:

Section I. Section twenty-four of chapter six hundred and seventy-seven of the laws of eighteen hundred and ninetytwo, entitled "An act relating to the construction of statutes, 
constituting chapter one of the general laws," is hereby amended to read as follows:

\$24. Public Holidays; half holidays. - The term holiday includes the following days in each year: The first day of January, known as New Year's day; the twelfth day of February, known as Lincoln's birthday; the twenty-second day of February, known as Washington's birthday; the thirtieth day of May, known as Memorial day; the fourth day of July, known as Independence day; the first Monday of September, known as Labor day, and the twenty-fifth day of December, known as Christmas day, and if either of such days is Sunday, the next day thereafter; each general election day and each day appointed by the president of the United States or by the governor of this State as a day of general thanksgiving, general fasting and prayer, or other general religious observances. The term, half-holiday, includes the period from noon to midnight of each Saturday which is not a holiday. The days and half days aforesaid shall be considered as the first day of the week, commonly called Sunday, and as public holidays or half-holidays, for all purposes whatsoever as regards the transaction of business in the public offices of this State, or counties of this State. On all other days and half days, excepting Sundays, such offices shall be kept open for the transaction of business.

$\$ 2$. Chapter twenty-seven of the laws of eighteen handred and seventy five, chapter thirty of the laws of eighteen hundred and eighty-one, chapter two hundred and eighty-nine of the laws of eighteen hundred and eighty-seven and chapter six hundred and three of the laws of eighteen hundred and ninety-five, are hereby repealed.

$\$$ 3. This act shall take effect October first, eighteen hundred and ninety-seven. 


\section{ENGLISH}

\section{BILLS OF EXCHANGE ACT, I882.}

45 AND 46 VICT. Ch. 61. 



\title{
BILLS OF EXCHANGE ACT, 1882.
}

\author{
45 AND 46 Vict., $\mathrm{CH}_{\mathrm{H}} 6 \mathrm{I}$.
}

An act to codify the law relating to bills of exchange, cheques, and promissory notes.

[18th August, 1882.]

Be it enacted by the Queen's Most Excellent Majesty, by and with the advice and consent of the Lords Spiritual and Temporal, and Commons, in this present Parliament assembled, and by the authority of the same, as follows:

\section{PART I.}

\section{Preliminary.}

\section{Short title.}

This act may be cited as the Bills of Exchange Act, 1882.

\section{Interpretation of terms.}

In this act, unless the context otherwise requires -

"Acceptance" means an acceptance completed by delivery or notification.

"Action" includes counter-claim and set-off.

"Banker" includes a body of persons, whether incorporated or not, who carry on the business of banking.

"Bankrupt" includes any person whose estate is vested in a trustee or assignee, under the law for the time being in force relating to bankruptcy.

"Bearer" means the person in possession of a bill or note which is payable to bearer.

" Bill" means bill of exchange, and " note" means promissory note.

"Delivery" means transfer of possession, actual or constructive, from one person to another.

"Holder" means the payee or endorsee of a bill or note who is in possession of it, or the bearer thereof.

"Indorsement" means an indorsement completed by delivery.

"Issue" means the first delivery of a bill or note, completed in form, to a person who takes it as a holder.

"Person" includes a body of persons, whether incorporated or not.

"Value" means valuable consideration.

"Written" includes printerl, and "writing" includes print. 
PART II.

Bills of Exchange.

Form and Interpretation.

\section{Bill of exchange defined.}

(1) A bill of exchange is an unconditional order in writing, addressed by one person to another, signed by the person giving it, requiring the person to whom it is addressed to pay on demand or at a fixed or determinable future time, a sum certain in money to or to the order of a specified person, or to bearer.

(2) An instrument which does not comply with these onditions, or which orders any act to be done in addition to the payment of money, is not a bill of exchange.

(3) An order to pay ont of a particular fund is not unconditional within the meaning of this section ; but an unqualified order to pay, coupled with $(a)$ an indication of a particular fund out of which the drawee is to re-imburse himself or a particnlar account to be debited with the amount, or (b) a statement of the transaction which gives rise to the bill, is unconditional.

(4) A bill is not invalid by reason-

(a) That it is not dated;

(b) That it does not specify the value given, or that any value has been given therefor;

(c) That it does not specify the place where it is drawn or the place where it is payable.

\section{Inland and foreign bills.}

(1) An inland bill is a bill which is, or on the face of it purports to be $-(a)$ both drawn and payable within the British Islands, or (b) drawn within the British Islands upon some person resident therein. Any other bill is a foreign bill.

For the purposes of this act " British Islands" mean any part of the United Kingdom of Great Britain and Ireland, the Islands of Man, Guernsey, Jersey, Alderney, and Sark, and the islands adjacent to any of them being part of the dominions of Her Majesty.

(2) Unless the contrary appear on the face of the bill the holder may treat it as an inland bill.

\section{Effect where different parties to bill are the same person.}

(1) A bill may be drawn payable to, or to the order of, the drawer; or it may be drawn payable to, or to the order of, the drawee.

(2) Where in a bill drawer and drawee are the same person, or where the drawee is a fictitious person or a person not having capacity to contract, the holder may treat the instrument, at his option, either as a bill of exchange or as a promissory note.

\section{Address to drawee.}

(1) The drawee must be named or otherwise indicated in a bill with reasonable certainty.

(2) A bill may be addressed to two or more drawees whether they are partners or not, but an order addressed to two drawees in the alternative, or two or more drawees in succession, is not a bill of exchange. 


\section{Certainty required as to payee.}

(1) Where a bill is not payable to bearer, the pasee must be named or otherwise indicated therein with reasonable certainty.

(2) A bill may be made payable to two or more payees jointly, or it may be made payable in the alternative to one of two, or one or some of sereral payees. A bill may also be made payable to the holder of an office for the time being.

(3) Where the payee is a fictitious or non-existing person, the bill may be treated as payable to bearer.

\section{What bills are negotiable.}

(1) When a bill contains words prohibiting transfer, or indicating an intention that it should not be transferable, it is valid as between the parties thereto, but is not negotiable.

(2) A negotiable bill may be payable either to order or to bearer.

(3) A bill is payable to bearer which is expressed to be so payable, or on which the only or last indorsement is an indorsement in blank.

(4) A bill is payable to orler which is expressed to be so payable, or which is expressed to be payable to a particular person, and does not contain words prohibiting transfer or indicating an intention that it should not be transferable.

(5) Where a bill, either originally or by indorsement, is expressed to be payable to the order of a specified person, and not to him or his order, it is nevertheless payable to him or his order at his option.

\section{Sum payable.}

(1) The sum payable by a bill is a sum certain within the meaning of this act, although it is required to be paid -

(a) With interest.

(b) By stated installments.

(c) By stated installments, with a provision that upon default in pay. ment of any installment the whole shall become due.

(d) According to an indicated rate of exchange, or according to a rate of exchange to be ascertained as directed by the bill.

(2) Where the sum payable is expressed in words and also in figures, and there is a discrepancy between the two, the sum denoted by the words is the amount payable.

(3) Where a bill is expressed to be payable with interest, unless the instrument otherwise prorides, interest runs from the date of the bill, and if the bill is undated from the issue thereof.

10. Bill payable on demand.

(1) A bill is payable on demand -

(a) Which is expressed to be payable on demand, or at sight, or on presentation ; or

(b) In which no time for payment is expressed.

(2) Where a bill is accepted or indorsed when it is overdue, it shall, as regards the acceptor who so accepts, or any indorser who so indorses it, be deemed a bill payable on demand.

\section{Bill payable at a future time.}

A bill is parable at a determinable future time within the meaning of this act which is expressed to be payable- 
(1) At a fixed period after date or sight.

(2) On or at a fixed period after the occurrence of a specified event which is certain to happen, though the time of happening may be uncertain.

An instrument expressed to be payable on a contingency is not a bill, and the happening of the event does not cure the defect.

\section{Omission of date in bill payable after date.}

Where a bill expressed to be payable at a fixed period after date is issued undated, or where the acceptance of a bill payable at a fixed period after sight is undated, any holder may insert therein the true date of issue or acceptance, and tbe bill shall be payable accordingly.

Provided that (1) where the holder in good faith and by mistake inserts a wrong date, and ( $\mathcal{~})$ in every case where a wrong date is inserted, if the bill subsequently comes into the hands of a holder in due course, the bill shall not be aroided thereby, but shall operate and be payable as if the date so inserted had been the true date.

\section{Ante-dating and post-dating.}

(1) Where a bill or an acceptance or any indorsement on a bill is dated, the diate shall, unless the contrary be proved, be deemed to be the true date of the drawing, acceptance or indorsement, as the case may be.

(2) A bill is not invalid by reason only that it is ante-dated or post-dated, or that it bears date on a Sunday.

\section{Computation of time of payment.}

Where a bill is not payable on demand, the das on which it falls due is determined as follows:

(1) Three days, called days of grace, are, in every case where the bill itself does not otherwise provide, added to the time of payment as fixed by the bill, and the bill is due and pasable on the last das of grace :

Provided that -

(a) When the last day of grace falls on Sunday, Christmas Day, Good Friday, or a day appointed by Royal proclamation as a public fast or thanksgiving day, the bill is, except in the case hereinafter provided for, due and payable on the preceding business day:

(b) When the last day of grace is a bank holiday (other than Christmas day or Good Friday) under the Bank Holidays Act, 1871,* and acts amending or extending it, or when the last day of grace is a Sunday and the second day of grace is a bank holiday, the bill is due and payable on the succeeding business day.

(2) Where a bill is payable at a fixed period after date, after sight, or after the happening of a specified event, the time of payment is determined by excluding the day from which the time is to begin to run and by including the day of payment.

(3) Where a bill is payable at a fixed period after sight, the time begins to run from the date of the acceptance if the bill be accepted, and from the date of noting or protest if the bill be noted or protested for non-acceptance or for non-delivery.

(4) The tern " month" in a bill means calendar month. 


\section{Case of need.}

The drawer of a bill and any indorser may insert therein the name of a person to whom the holder mas resort in case of need, that is to say, in case the bill is dishonored by non-acceptance or non-payment. Such person is called the referee in case of need. It is in the option of the holder to resort to the referee in case of need or not as he may think fit.

\section{Optional stipulations by drawer or indorser.}

The drawer of a bill, and any indorser, may insert therein an express stipulation-

(1) Negativing or limiting his own liability to the holder ;

(2) Waiving as regards himself some or all of the holder's duties.

\section{Definition and requisites of acceptance.}

(1) The acceptance of a bill is the signification by the drawee of his assent to the order of the drawer.

(?) An acceptance is invalid unless it complies with the following conditions, namely :

(a) It must be written on the bill and be signed by the drawee. The mere signature of the drawee without additional words is sufficient.

(b) It must not express that the drawee will perform his promise by any other means than the payment of money.

\section{Time for acceptance.}

A bill may be accepted -

(1) Before it has, been signed by the drawer, or while otherwise incomplete :

$(?)$ When it is orerdue, or after it has been dishonored by a previous refusal to accept, or by non-payment :

(3) When a bill payable after sight is dishonored by non-acceptance, and the drawee subsequently accepts it, the holder, in the absence of any different agreement, is entitled to have the bill accepted as of the date of first presentmont to the drawee for acceptance.

\section{General and qualified acceptances.}

(1) An acceptance is either (a) general or (b) qualified.

(2) A general acceptance assents without qualification to the order of the drawer. A qualified acceptance in express terms varies the effect of the bill as drawn.

In particular an acceptance is qualified which is -

(a) Conditional, that is to say, which makes payment by the acceptor dependent on the fulfillment of a condition therein stated :

(b) Partial, that is to say, an acceptance to pay part only of the amount for which the bill is drawn:

(c) Local, that is to sas, an acceptance to pay only at a particular specified place:

An acceptance to pay at a particular place is a general acceptance, unless it expressly states that the bill is to be paid there only and not elsewhere :

(d) Qualified as to time :

(e) The acceptance of some one or more of the drawees, but not of all 


\section{Inchoate instruments.}

(1) Where a simple signature on a blank stamped paper is delivered by the signer in order that it may be converted into a bill, it operates as a prima facie authority to fill it up as a complete bill for any amount the stamp will cover, using the signature for that of the drawer, or the acceptor, or an indorser ; and, in like manner, when a bill is wanting in any material particular, the person in possession of it has a prima facie authority to fill up the omission in any way he thinks fit.

(2) In order that any such instrument when completed may be enforceable against any person who became a party thereto prior to its completion, it must be filled up within a reasonable time, and strictly in accordance with the authority given.

Reasonable time for this purpose is a question of fact.

Provided that if any such instrument after completion is negotiated to a holder in due course, it shall be valid and effectual for all purposes in his hands, and he may enforce it as if it had been filled up within a reasonable time and strictly in accordance with the authority given.

\section{Delivery.}

(1) Evers contract on a bill, whether it be the drawer's, the acceptor's, or an indorser's, is incomplete and revocable, until delivery of the instrument in order to give effect thereto.

Provided that where an acceptance is written on a bill, and the drawee gives notice to or according to the directions of the person entitled to the bill that he has accepted it, the acceptance then becomes complete and irrerocable.

(2) As between immediate parties, and as regards a remote party other than a holder in due course, the delivery -

(a) In order to be effectual must be made either by or under the authority of the party drawing, accepting, or indorsing, as the case mas be:

(b) May be shown to have been conditional or for a special purpose only, and not for the purpose of transferring the property in the bill.

But if the bill be in the hands of a holder in due course a valid delivery of the bill by all parties prior to him so as to make them liable to him is conclusivels presumed.

(3) Where a bill is no longer in the possession of a party who has signed it as drawer, acceptor, or indorser, a valid and unconditional delivery by him is presumed until the contrary is proved.

\section{Capacity and Authority of Parties.}

\section{Capacity of parties.}

(1) Capacity to incur liability as a party to a bill is co-extensive with capacity to contract.

Provided that nothing in this section shall enable a corporation to make itself liable as drawer, acceptor, or inclorser of a bill unless it is competent to it so to do under the law for the time being in force relating to corporations.

$(\stackrel{2}{)}$ Where a bill is drawn or indorsel by an infant. minor, or corporation having no capacity or power to incur liability m a bill, the drawing or indorse- 
ment entitles the holder to receive payment of the bill, and to enforce it against any other party thereto.

\section{Signature essential to liability.}

No person is liable as drawer, indorser, or acceptor of a bill who has not signed it as such :

Provided that-

(1) Where a person signs a bill in a trade or assumed name, he is liable thereon as if he had signed it in bis own name:

(2) The signature of the name of a firm is equivalent to the signature by the person so signing of the names of all persons liable as partners in that firm.

\section{Forged or unauthorized signature.}

Subject to the provisions of this Act, where a signature on a bill is forged or placed thereon without the authority of the person whose signature it purports to be, the forged or unauthorized signature is wholly inoperative, and no right to retain the bill, or to give a discharge therefor, or to enforce payment thereof against any party thereto, can be acquired through or under that signature, unless the party against whom it is sought to retain or enforce payment of the bill is precluded from setting up the forgery or want of authority.

Provided that nothing in this section shall effect the ratification of an unauthorized signature not amounting to a forgery.

\section{Procuration signatures.}

A signature by procuration operates as notice that the agent has but a limited authority to sign, and the principal is only bound by such signature if the agent in so signing was acting within the actual limits of his authority.

\section{Person signing as agent or in representative eapacity.}

(1) Where a person signs a bill as drawer, indorser, or acceptor, and adds words to his signature indicating that he signs for or on behalf of a principal, or in a representative character, he is not personally liable thereon; but the mere addition to his signature of words describing him as an agent, or as filling a representative character, does not exempt him from personal liability.

( 2 ) In determining whether a signature on a bill is that of the principal or that of the agent by whose hand it is written, the construction most favorable to the validity of the instrument shall be adopted.

\section{The Consideration for a Bill.}

\section{Value and holder for value.}

(1) Valuable consideration for a bill may be constituted by, -

(a) Any consideration sufficient to support a simple contract;

(b) An antecedent debt or liability. Such a debt or liability is deemed valuable consideration whether the bill is payable on demand or at a future time.

(2) Where value has at any time been given for a bill the holder is deemed to be a holder for value as regards the acceptor and all parties to the bill who became parties prior to such time.

(3) Where the holder of a bill has a lien on it arising either from contract or by implication of law, he is deemed to be a holder for value to the extent of the sum for which he has a lien. 


\section{Accommodation bill or party.}

(1) An accommodation party to a bill is a person who has signed a bill as drawer, acceptor, or indorser, without receiving value therefor, and for the purpose of lending his name to some other person.

(2) An accommodation party is liable on the bill to a holder for value; and it is immaterial whether, when such holder took the bill, he knew such party to be an accommodation party or not.

\section{Holder in due course.}

(1) A holder in due course is a holder who has taken a bill, complete and regular on the face of it, under the following conditions; namely,

(a) That he became the holder of it before it was orerdue, and without notice that it had been previously dishonored, if such was the fact:

(b) That he took the bill in good faith and for value, and that at the time the bill was negotiated to him he had no notice of any defect in the title of the person who negotiated it.

(2) In particular the title of a person who negotiates a bill is defective within the meaning of this Act when he obtained the bill, or the acceptance thereof, by fraud, duress, or force and fear, or other unlawful means, or for an illegal consideration, or when he negotiates it in breach of faith, or under such circumstances as amount to a fraud.

(3) A holder (whether for value or not), who derives his title to a bill through a holder in due course, and who is not himself a party to any fraud or illegality affecting it, has all the rights of that holder in due course as regards the acceptor and all parties to the bill prior to that holder.

\section{Presumption of value and good faith.}

(1) Every party whose signature appears on a bill is prima facie deemed to hare become a party thereto for value.

(2) Every holder of a bill is prima facie deemed to be a holder in due course ; but if in an action on a bill it is admitted or proved that the acceptance, issue, or subsequent negotiation of the bill, is affected with fraul, duress, or force and fear, or illegality, the burden of proof is shifted, unless and until the holder proves that, subsequent to the alleged fraud or illegality, value has in good faith been given for the bill.

\section{Negotiation of Bills.}

\section{Negotiation of bill.}

(1) A bill is negotiated when it is transferred from one person to another in such a manner as to constitute the transferee the holder of the bill.

(2) A bill payable to bearer is negotiated by delivery.

(3) A bill payable to order is negotiated by the indorsement of the holder completed by delivery.

(4) Where the holder of a bill payable to his order transfers it for value without indorsing it, the transfer gives the transferee such title as the trans. feror had in the bill, and the transferee in addition acquires the right to have the indorsement of the transferor.

(5) Where any person is under obligation to indorse a bill in a representative capacity, he may indorse the bill in such terms as to negative personal liability. 


\section{Requisites of a valid indorsement.}

An indorsement in order to operate as a negotiation must comply with the following conditions, namely, -

(1) It must be written on the bill itself and be signed by the indorser. The simple signature of the indorser on the bill, without additional words, is sufficient.

An indorsement written on an allonge, or on a "copy" of a bill issued or negotiated in a country where "copies" are recognized, is deemed to be written on the bill itself.

(2) It must be an indorsement of the entire bill. A partial indorsement. that is to say, an indorsement which purports to transfer to the indorsee it part only of the amount payable, or which purports to transfer the bill to two or more indorsees severally, does not operate as a negotiation of the bill.

(3) Where a bill is payable to the order of two or more payees or indorsees who are not partners all must indorse, unless the one indorsing has authority to indorse for the others.

(4) Where, in a bill payable to order, the payee or indorsee is wrongly designated, or his name is misspelt, he may indorse the bill as therein described adding, if he thinks fit, his proper signature.

(5) Where there are two or more indorsements on a bill, each indorsement is deemed to have been made in the order in which it appears on the bill, until the contrary is proved.

(6) An indorsement may be made in blank or special. It may also contain terms making it restrictive.

\section{Conditional indorsement.}

Where a bill purports to be indorsed conditionally, the condition may be disregarded by the payer, and payment to the indorsee is valid whether the condition has been fulfilled or not.

\section{Indorsement in blank and speeial indorsement.}

(1) An indorsement in blank specifies no indorsee, and a bill so indorsed becomes payable to bearer.

(2) A special indorsement specifies the person to whom, or to whose orter, the bill is to be payable.

(3) The prorisions of this Act relating to a payee apply with the necessary modifications to an indorsee under a special indorsement.

(4) When a bill has been indorsed in blank, ans holder may convert the blank indorsement into a special indorsement by writing abore the indorser's signature a direction to pay the bill to or to the order of himself or some other person.

\section{Restrictive indorsement.}

(1) An indorsement is restrictive which prohibits the further negotiation of the bill, or which expresses that it is a mere authority to deal with the bill as thereby directed, and not a transfer of the ownership thereof, as, for example, if a bill be indorsed "Pay D. only," or "Pay D. for the account of X.," or "Pay D. or order for collection."

(2) A restrictice indorsement gives the indorsee the right to receive payment of the bill and to sue any party thereto that his indorser could have 
sued, but gives him no power to transfer his rights as indorsee unless it expressly authorize him to do so.

(3) Where a restrictive indorsement authorizes further transfer, all subsequent indorsees take the bill with the same rights and subject to the same liabilities as the first indorsee under the restrictive indorsement.

\section{Negotiation of overdue or dishonoured bill.}

(1) Where a bill is negotiable in its origin it continues to be negotiable until it lias been $(a)$ restrictively indorsed or $(b)$ discharged by payment or otherwise.

(2) Where an orerdue bill is negotiated, it can only be negotiated subject to any defect of title affecting it at its maturity, and thenceforward no person who takes it can acquire or give a better title than that which the person from whom he took it had.

(3) A bill payable on demand is deemed to be overdue within the meaning and for the purposes of this section, when it appears on the fice of it to hare been in circulation for an unreasonable length of time. What is an unreasonable length of time for this purpose is a question of fact.

(4) Except where an indorsement bears date after the maturity of the bill, every negutiation is prima facie deemed to have been effected before the bill was overdue.

(5) Where a bill which is not overdue has been dishonoured any person who takes it with notice of the dishonour takes it subject to any defect of title attaching thereto at the time of dishonour, but nothing in this sub-section shall affect the rights of a holder in due course.

\section{Negotiation of bill to party already liable thereon.}

Where a bill is negotiated back to the drawer, or to a prior indorser, or to the acceptor, such party may, subject to the provisions of this Act, re-issue and further negotiate the bill, but he is not entitled to enforce payment of the bill against any intervening party to whom he was previously liable.

\section{Rights of the holder.}

The rights and powers of the holder of a bill are as follows:

(1) He may sue on the bill in his own name:

(2) Where he is a holder in due course, he holds the bill free from any defect of title of prior parties, as well as from mere personal defences available to prior parties among themselses, and may enforce payment against all parties liable on the bill:

(3) Where his title is defective $(a)$ if he negotiates the bill to a holder in due course, that holder obtains a good and complete title to the bill, and $(b)$ if he obtains payment of the bill the person who pays him in due course gets a valid discharge for the bill.

\section{General Duties of the Holder.}

\section{When presentment for acceptance is necessary.}

(1) Where a bill is payable after sight, presentment for acceptance is necessary in order to fix the maturity of the instrument.

(2) Where a bill expressly stipulates that it shall be presented for acceptance, or where a bill is drawn payable elsewhere than at the residence or place of business of the drawee, it must be presented for acceptance before it can be presented for payment. 
(3) In no other case is presentment for acceptance necessary in order to render liable any party to the bill.

(4) Where the holder of a bill, drawn payable elsewhere than at the place of business or residence of the drawee, has not time, with the exercise of reasonable diligence, to present the bill for acceptance before presenting it for pasment on the day that it falls due, the delay caused by presenting the bill for acceptance before presenting it for payment is excused, and does not discharge the drawer and indorsers.

\section{Time for presenting bill payable after sight.}

(1) Subject to the provisions of this Act, when a bill payable after sight is negotiated, the holder must either present it for acceptance or negotiate it within a reasonable time.

(2) If he do not do so, the drawer and all indorsers prior to that holder are discharged.

(3) In determining what is a reasonable time within the meaning of this section, regard shall be had to the nature of the bill, the usage of trade with respect to similar bills, and the facts of the particular case.

\section{Rules as to presentment for acceptance, and excuses for non-pre- sentment.}

(1) A bill is duly presented for acceptance which is presented in accordance with the following rules:

(a) The presentment must be made by or on behalf of the holder to the drawee, or to some person authorized to accept or refuse acceptance on his behalf, at a reasonable hour on a business day and before the bill is overdue :

(b) Where a bill is addressed to two or more drawees, who are not partners, presentment must be made to them all, unless one has authority to accept for all, then presentment may be made to him only :

(c) Where the drawee is dead, presentment may be made to his personal representative :

(d) Where the drawee is bankrupt, presentment may be made to him or his trustee:

(e) Where authorized by agreement or usage, a presentment through the post office is sufficient.

(2) Presentment in accordance with these rules is excused, and a bill may be treated as dishonoured bs non-acceptance-

(a) Where the drawee is dead or baukrupt, or is a fictitious person or a person not haring capacity to contract by bill :

(b) Where, after the exercise of reasonable diligence, such presentment cannot be effected :

(c) Where, although the presentment has been irregular, acceptance has been refused on some other ground.

(3) The fact that the holder has reason to believe that the bill, on presentment, will be dishonoured does not excuse presentment.

\section{Non-acceptance.}

(1) When a bill is duly presented for acceptance and is not accepted within NEGOT. INSTRUMENTS - 7 
the customary time, the person presenting it must treat it as dishonoured by non-acceptance. If he do not, the hoider shall lose his right of recourse against the drawer and indorsers.

\section{Dishonour by non-aceeptance and its consequences.}

(1) A bill is dishonoured by non-acceptance-

(a) When it is duly presented for acceptance, and such an acceptance as is prescribed by this act is refused or cannot be obtained; or

(b) When presentment for acceptance is excused and the bill is not accepted.

(2) Subject to the provisions of this Act, when a bill is dishonoured by non acceptance, an immediate right of recourse against the drawer and indorsers accrues to the holder, and no presentment for payment is necessary.

\section{Duties as to qualified acceptances.}

(1) The holder of a bill may refuse to take a qualified acceptance, and if he does not obtain an unqualified acceptance may treat the bill as dishonoured by non-acceptance.

(2) Where a qualified acceptance is taken, and the drawer or an indorser has not expressly or impliedly authorized the holder to take a qualified acceptance, or does not subsequently assent thereto, such drawer or indorser is discharged from his liability on the bill.

The provisions of this sub-section do not apply to a partial acceptance, whereof due notice has been given. Where a foreign bill has been accepted as to part, it must be protested as to the balance.

(3) When the drawer or indorser of a bill receives notice of a qualified acceptance, and does not within a reasonable time express his dissent to the holder, he shall be deemed to have assented thereto.

\section{Rules as to presentment for payment.}

Subject to the provisions of this Act, a bill must be duly presented for payment. If it be not so presented the drawer and endorsers shall be discharged.

A bill is duly presented for payment which is presented in accordance with the following rules:-

(1) Where the bill is not payable on demand, presentment must be made on the day it falls due.

(2) Where the bill is payable on demand, then, subject to the provisions of this Act, presentment must be male within a reasonable time after its issue in order to render the drawer liable, and within a reasonable time after its indorsement, in order to render the indorser liable.

In determining what is a reasonable time, regard shall be had to the nature of the bill. the usage of trade with regard to similar bills, and the facts of the particular case.

(3) Presentment nust be made by the holder or by some person authorized to receive payment on his behalf at a reasonable hour on a business day, at the proper place as hereinafter defined, either to the person designated by the bill as payer, or to some person authorized to pay or refuse payment on his behalf if with the exercise of reasonable diligence such person can there be found. 
(4) A bill is presented at the proper place :-

(a) Where a place of payment is specified in the bill and the bill is there presented.

(b) Where no place of payment is specified, but the address of the drawee or acceptor is given in the bill, and the bill is there presented.

(c) Where no place of payment is specified and no address given, and the bill is presented at the drawee's or acceptor's place of business if known, and if not, at his ordinary residence if known.

(d) In any other case if presented to the drawee or acceptor wherever he can be found, or if presented at his last known place of business or residence.

(5) Where a bill is presented at the proper place, and after the exercise of reasonable diligence no person authorized to pay or refuse payment cau be found there, no further presentment to the drawee or acceptor is required.

(6) Where a bill is drawn upon, or accepted by, two or more persons who are not partners, and no place of payment is specified, presentment must be made to them all.

(T) Where the drawee or acceptor of a bill is dead, and no place of payment is specified, presentment must be made to a personal representative, if such there be, and with the exercise of reasonable diligence he can be found.

(8) Where authorized by agreement or usage a presentment through the post-office is sufficient.

\section{Excuses for delay or non-presentment for payment.}

(1) Delay in making presentment for payment is excused when the delay is caused by circumstances beyond the control of the holder, and not imputable to his default, misconduct, or negligence. When the cause of delay ceases to operate presentment must be made $w$ ith reasonable diligence.

(2) Presentment for pasment is dispensed with, -

(a) Where, after the exercise of reasonable diligence, presentments as required by this Act, cannot be effected.

The fact that the holder has reason to believe that the bill will, on presentment, be dishonoured, does not dispense with the necessity for presentment.

(b) Where the drawee is a fictitious person.

(c) As regards the drawer where the drawee or acceptor is not hound, as between himself and the drawer, to accept or pay the bill, and the drawer has no reason to believe that the bill would be paid if presented.

(d) As regards an indorser, where the bill was accepted or made for the accommodation of that indorser, and he has no reason to expect that the bill would be paid if presented.

(e) By waiver of presentment, express or implied.

\section{Dishonour by non-payment.}

(1) A bill is dishonoured by non-payment $(a)$ when it is duly presented for payment and payment is refused or cannot be obtained, or $(b)$ when presentment is excused and the bill is orerdue and unpaid.

(2) Subject to the provisions of this Act, when a bill is dishonoured by non- 
payment, an immediate right of recourse against the drawer and indorsers accrues to the holder.

\section{Notice of dishonour and effect of non-notice.}

Subject to the provisions of this Act, when a bill has been dishonoured by non-acceptance or by non-payment notice of dishonour must be given to the drawer ant each indorser, and any drawer or indorser to whom such notice is not given is discbarged;

Prorided that -

(1) Where a bill is dishonoured by non-acceptance, and notice of dishonour is not given, the rights of a holder in due course subsequent to the omission, shall not be prejudiced by the omission.

(2) Where a bill is dishonoured by non-acceptance, and due notice of dishonor is giren, it shall not be necessary to gire notice of a subsequent dis. honour by non-payment unless the bill shall in the meantime have been accepted.

\section{Rules as to notice of dishonour.}

Notice of dishonour in order to be valid and effectual must be giren in accordance with the following rules :-

(1) The notice must be given by or on behalf of the holder, or by or on behalf of an indorser who, at the time of giving it, is himself liable on the bill.

(2) Notice of dishonour may be given by an agent either in his own name, or in the name of any party entitled to give notice whether that party be his principal or not.

(3) Where the notice is given by or on behalf of the holder, it enures for the benefit of all subsequent holders and all prior indorsers who have a right of recourse against the party to whom it is given.

(4) Where notice is given by or on behalf of an indorser entitled to give notice as hereinbefore provided, it enures for the benefit of the holder and all indorsers subsequent to the party to whom notice is giren.

(5) The notice may be given in writing or by personal communication, and may be giren in any terms which sufficiently identify the bill, and intimate that the bill has been dishonoured by non-acceptance or non-payment.

(6) The return of a dishonoured bill to the drawer or an indorser is, in point of form, deemed a sufficient notice of dishonour.

(7) A written notice need not be signed, and an insufficient written notice may be supplemented and validated by verbal communication. A misdescription of the bill shall not vitiate the notice unless the party to whom the notice is given is in fact misled thereby.

(8) Where notice of dishonour is required to be given to any person, it may be given either to the party himself, or to his agent in that behalf.

(9) Where the drawer or indorser is dead, and the party giving notice knows it, the notice must be given to a personal representative, if such there be, and with the exercise of reasonable diligence he can be found.

(10) Where the drawer or indorser is bankrupt, notice may be given either to the party himself or to the trustee.

(11) Where there are two or more drawers or indorsers who are not partners notice must be given to each of them, unless one of them has authority to receive such notice for the others. 
(12) The notice may be giren as soon as the bill is dishonoured, and must be given within a reasonable time thereafter.

In the absence of special circumstances notice is not deemed to have heen given within a reasonable time, unless -

(a) Where the person giving and the person to receise notice resicle in the same place, the notice is giren or sent off in time to reach the latter on the day after the dishonom of the bill.

(b) Where the person giving and the person to receive notice reside in different places, the notice is sent off on the day after the dishonour of the bill, if there be a post at a convenient hour on that day, and if there be no such post on that day then by the next post thereafter.

(13) Where a bill when dishonoured is in the hands of an agent, he may either himself give notice to the parties liable on the bill, or he may give notice to his principal. If he give notice to his principal, he must do so within the same time as if he were the holder, and the principal upon receipt of such notice has himself the same time for giving notice as if the agent had been an independent holder.

(14) Where a party to a bill receives due notice of dishonour, he has after the receipt of such notice the same period of time for giving notice to antecedent parties that the holder has after the dishonour.

(15) Where a notice of dishonour is duly addressed and posted, the sender is deemed to have given due notice of dishonour, notwithstanding any miscarriage by the post-office.

\section{Excuses for non-notice and delay.}

(1) Delay in giving notice of dishonour is excused where the delay is caused by circumstances beyond the control of the party giving notice, and not imputable to his default, misconduct, or negligence. When the cause of delay ceases to operate the notice must be given with reasonable diligence.

(2) Notice of dishonour is dispensed with -

(a) When, after the exercise of reasonable diligence, notice as required by this act cannot be given to or does not reach the drawer or indorser sought to be charged :

(b) By waiver, express or implied. Notice of dishonour may be waired before the time of giving notice has arrived, or after the omission to give due notice :

(c) As regards the drawer in the following cases, namely, (1) where drawer and drawee are the same person, (2) where the drawee is a fictitious person or a person not having capacity to contract, (3) where the drawer is the person to whom the bill is presented for payment, (4) where the drawee or acceptor is as leetwen himself and the drawer under no obligation to accept or pay the bill, (5) where the drawer has countermanded parment:

(d) As regards the indorser in the following cases, namely. (1) where the drawee is a fictitious person or a person not having capacity to contract and the indorser was aware of the fact at the time he indorsed the bill, (2) where the indorser is the person to whom the bill is presented for payment, (3) where the bill was accepted or made for his accommodation. 


\section{Noting or protest of bill.}

(1) Where an inland bill has been dishonoured it may, if the holder think fit, be noted for non-acceptance or non-payment, as the case may be ; but it shall not be necessary to note or protest any such bill in order to preserve the recourse against the drawer or indorser.

(2) Where a foreign bill, appearing on the face of it to be such, has been dishonoured by non-acceptance it must be duly protested for non-acceptance, and where such a bill, which has not been previously dishonoured by nonacceptance, is dishonoured by non-payment it must be duly protested for nonpayment. If it be not so protested the drawer and indorsers are discharged. Where a bill does not appear on the face of it to be a foreign bill, protest thereof in case of dishonour is unnecessary.

(3) A bill which has been protested for non-acceptance may be subsequently protested for non-payment.

(4) Subject to the provisions of this Act. when a bill is noted or protested, it must be noted on the day of its dishonour. When a bill has been duly noted, the protest may be subsequently extended as of the date of the noting.

(5) Where the acceptor of a bill becomes bankrupt or insolvent or suspends payment before it matures, the holder may cause the bill to be protested for better security against the drawer and indorsers.

(6) A bill must be protested at the place where it is dishonoured :

Provided that -

(a) When a bill is presented through the post-office, and returned by post dishonoured. it may be protested at the place to which it is returned and on the day of its return if received during business hours, and if not received during business hours, then not later than the next business day:

(b) When a bill drawn payable at the place of business or residence of some person other than the drawee, has been dishonoured by nonacceptance, it must be protested for non-payment at the place where it is expressed to be payable, and no further presentment for payment to, or demand on, the drawee is necessary.

(7) A protest must contain a copy of the bill, and must be signed by the notary making it, and must specif $s-$

(a) The person at whose request the bill is protested:

(b) The place and date of protest, the cause or reason for protesting the bill, the demand made, and the answer given, if any, or the fact that the drawee or acceptor could not be found.

(8) Where a bill is lost or destroyed, or is wrongly detained from the person entitled to hold it, protest may be made on a copy or written particulars thereof.

(9) Protest is dispensed with by any circumstance which would dispense with notice of dishonour. Delay in noting or protesting is excused when the delay is caused by circumstances besond the control of the holder, and not imputable to his default, misconduct, or negligence. When the cause of delay ceases to operate the bill must be noted or protested with reasonable diligence.

\section{Duties of holder as regards drawee or acceptor.}

(1) When a bill is accepted generally presentment for payment is not neces. sary in order to render the acceptor liable. 
(2) When by the terms of a qualified acceptance presentment for payment is required, the acceptor, in the absence of an express stipulation to that effect, is not discharged by the omission to present the bill for payment on the day that it matures.

(3) In order to render the acceptor of a bill liable it is not necessary to protest it, or that notice of dishonour should be given to him.

(4) Where the holder of a bill presents it for payment, he shall exhibit the bill to the person from whom he demands payment, and when a bill is paid the holder shall forthwith deliver it up to the party paying it.

\section{Liabilities of Parties.}

\section{Funds in hands of drawee.}

(1) A bill, of itself, does not operate as an assignment of funds in the hands of the drawee available for the payment thereof, and the drawee of a bill who does not accept as required by this Act is not liable on the instrument. This sub-section shall not extend to Scotland.

(2) In Scotland, where the drawee of a bill has in his hands funds available for the payment thereof. the bill operates as an assignment of the sum for which it is drawn in favor of the holder, from the time when the bill is presented to the drawee.

\section{Liability of acceptor.}

The acceptor of a bill, by accepting it -

(1) Engages that he will pay it according to the tenor of his acceptance :

(2) Is precluded from denying to a holder in due course :

(a) The existence of the drawer, the genuineness of his signature, and his capacity and authority to draw the bill ;

(b) In the case of a bill payable to drawer's order, the then capacity of the drawer to indorse, but not the genuineness or validity of his indorsement ;

(c) In the case of a bill payable to the order of a third person, the existence of the payee and his then capacity to indorse, but not the genuiness or validity of his indorsement.

\section{Liability of drawer or indorser.}

(1) The drawer of a bill by drawing it-

(a) Engages that on due presentment it shall be accepted and paid according to its tenor, and that if it be dishonoured he will compensate the holder or any indorser who is compelled to pay it, provided that the requisite proceedings on dishonour be duly taken;

(b) Is precluded from denying to a holder in due course the existence of the payee and his then capacity to indorse.

(2) The indorser of a bill by indorsing it -

(a) Engages that on due presentment it shall be accepted and paid according to its tenor, and that if it be dishonoured he will compensate the holder or a subsequent indorser who is compelled to pay it, provided that the requisite proceedings on dishonour be duly taken ;

(b) Is precluded from denying to a holder in due course the genuine. 
ness and regularity in all respects of the drawer's signature and all previous indorsements ;

(c) Is precluded from denying to his immediate or a subsequent indorsee that the bill was at the time of his indorsenment a valid and subsisting bill, and that he had then a good title thereto.

\section{Stranger signing bill liable as indorser.}

Where a person signs a bill otherwise than as drawer or acceptor, he thereby incurs the liabilities of an indorser to a holder in due course.

\section{Measure of damages against parties to dishonoured bill.}

Where a bill is dishonoured, the measure of damages, which shall be deemed to be liquidated damages, shall be as follows:

(1) The holder may recover from any party liable on the bill, and the drawer who has been compelled to pay the bill may recover from the acceptor, and an indorser who has been compelled to pay the bill may recover from the acceptor or from the drawer, or from a prior indorser -

(a) The amount of the bill:

(b) Interest thereon from the time of presentment for payment if the bill is payable on demand, and from the maturity of the bill in any other case :

(c) The expenses of noting, or, when protest is necessary, and the protest has been extended, the expenses of protest.

(2) In the case of a bill which has been dishonoured abroad, in lieu of the above damages, the holder may recover from the drawer or an indorser, and the drawer or an indorser who has been compelled to pay the bill may recover from any party liable to him, the amount of the re-exchange with interest thereon until the time of payment.

(3) Where by this Act interest may be recovered as damages, such interest may, if justice require it, be withheld wholly or in part, and where a bill is expressed to be payable with interest at a given rate, interest as damages may or may not be given at the same rate as interest proper.

\section{Transferor by delivery and transferee.}

(1) Where the holder of a bill payable to bearer negotiates it by delivery without indorsing it, he is called a " transferor by delivery."

(2) A transferor by delicery is not liable on the instrument.

(3) A transferor by delivery who negotiates a bill thereby warrants to his immediate transferee being a holder for value that the bill is what it purports to be, that he has a right to transfer it, and that at the time of transfer he is not aware of any fact which renders it valueless.

\section{Discharge of Bill.}

\section{Payment in due course.}

(1) A bill is discharged by payment in due course by or on behalf of the drawee or acceptor.

"Payment in due course" means payment made at or after the maturity of the bill to the holder thereof in good faith and without notice that his title to the bill is refective.

(2) Subject to the provisions hereinafter contained, when a bill is paid by the drawer or an indorser it is not discharged : but 
(a) Where a bill payable to, or to the order of, a third party is paid by drawer, the drawer may enforce pasment thereof against the acceptor, but may not re-issue the bill :

(b) Where a bill is paid by an indorser, or where a bill payable to drawer's order is paid by the drawer, the party paying it is remitted to his former rights as regards the acceptor or antece. dent parties, and he mas, if he thinks fit, strike out his own and subsequent indorsements, and again negotiate the bill.

(3) Where an accommodation bill is paid in due course by the party accommodated the bill is discharged.

\section{Banker paying demand draft whereon indorsement is forged.}

Where a bill payable to order on demand is drawn on a banker, and the banker on whom it is drawn pass the bill in good faith and in the ordinary course of business, it is not incumbent on the banker to show that the indorsement of the payee or any subsequent indorsement was made by or under the authority of the person whose indorsement it purports to be, and the banker is deemed to have paid the bill in due course, although such indorsement has been forged or made without authority.

\section{Acceptor the holder at maturity.}

When the acceptor of a bill is or becomes the holder of it at or after its maturity, in his own right, the bill is discharged.

\section{Express waiver.}

(1) When the holder of a bill at or after its maturity absolutely and unconditionally renounces his rights against the acceptor the bill is discharged.

The renunciation must be in writing, unless the bill is delirered up to the acceptor.

(2) The liabilities of any party to a bill may in like manner be renounced by the holder before, at, or after its maturity; but nothing in this section shall affect the rights of a holder in due course without notice of the renunciation.

\section{Cancellation.}

(1) Where a bill is intentionally cancelled by the holder or his agent, and the cancellation is apparent thereon, the bill is discharged.

(2) In like manner any party liable on a bill may be discharged by the intentional cancellation of his signature by the holder or his agent. In such case any indorser who would have had a right of recourse against the party whose signature is caucelled, is also discharged.

(3) A cancellation made unintentionally, or under a mistake, or without the authority of the holder, is inoperative; but where a bill or any siguature thereon appears to have been cancelled the burden of proof lies on the party who alleges that the cancellation was made unintentionally, or under a mistake, or without authority.

\section{Alteration of bill.}

(1) Where a bill or acceptance is materially altered without the assent of all parties liable on the bill, the bill is avoided except as against a party who 
has himself made, authorised, or assented to the alteration, and subsequent indorsers.

Provided that,

Where a bill has been materially altered, but the alteration is not apparent, and the bill is in the hand of a holder in due course, such holder may avail himself of the bill as if it had not been altered, and may enforce payment of it according to its original tenor.

(2) In particular the following alterations are material, namely, any alteration of the date, the sum payable, the time of payment, the place of payment, and, where a bill has been accepted generally, the addition of a place of payment without the acceptor's assent.

\section{Acceptance and Payment for Honour.}

\section{Acceptance for honour supra protest.}

(1) Where a bill of exchange has been protested for dishonour by nonacceptance, or protested for better security, and is not orerdue, any person, not being a party already liable thereon, may, with the consent of the holder, intervene and accept the bill supra protest for the honour of any party liable thereon. or for the honour of the person for whose account the bill is drawn.

(2) A bill may be accepted for honour for part only of the sum for which it is drawn.

(3) An acceptance for honour supra protest in order to be valid must -

(a) Be written on the bill, and indicate that it is an acceptance for honour:

(b) Be signed by the acceptor for honour.

(4) Where an acceptance for honour does not expressly state for whose honour it is made, it is deemed to be an acceptance for the honour of the drawer.

(5) Where a bill payable after sight is accepted for honour, its maturity is calculated from the date of the noting for non-acceptance, and not from the date of the acceptance for honour.

\section{Liability of acceptor for honour.}

(1) The acceptor for honour of a bill by accepting it engages that he will, on due presentment, pay the bill according to the tenor of his acceptance, if it is not paid by the drawee, provided it has been duly presented for payment, and protested for non-payment, and that he receives notice of these facts.

(2) The acceptor for honour is liable to the holder and to all parties to the bill subsequent to the party for whose honour he has accepted.

\section{Presentment to acceptor for honour.}

(1) Where a dishonoured bill has been accepted for honour supra protest, or contains a reference in case of need, it must be protested for non-payment before it is presented for parment to the acceptor for honour, or referee in case of need.

(2) Where the address of the acceptor for honour is in the same place where the bill is protested for non-payment, the bill must be presented to him not later than the day following its maturity: and where the address of the acceptor for honour is in some place other than the place where it was protested for non-payment, the bill must be forwarded not later than the day following its maturity for presentment to him.

(3) Delay in presentment or non-presentment is excused by any circum- 
stance which would excuse delay in presentment for payment or non-presentment for payment.

(4) When a bill of exchange is dishonoured by the acceptor for honour it must be protested for non-payment by him.

\section{Payment for honour supra protest.}

(1) Where a bill has been protested for non-payment, any person may interrene and pay it supra protest for the honour of any party liable thereon, or for the honour of the person for whose account the bill is drawn.

(2) Where two or more persons offer to pas a bill for the honour of different parties, the person whose payment will discharge most parties to the bill shall have the preference.

(3) Payment for honour supra protest, in order to operate as such and not as a inere voluntary payment, must be attested by a notarial act of honour which may be appended to the protest or form an extension of it.

(4) The notarial act of honour must be founded on a declaration made by the payer for honour, or his agent in that behalf, declaring his intention to pay the bill for honour, and for whose honour he pars.

(5) Where a bill has been paid for honour, all parties subsequent to the party for whose honour it is paid are discharged, but the payer for honour is subrogated for, and succeeds to both the rights and duties of, the holder as regards the party for whose honour he pays, and all parties liable to that party.

(b) The payer for honour, on paying to the holder the amount of the bill and the notarial expenses incidental to its dishonour, is entitled to receive both the bill itseif and the protest. If the holder do not on demand deliver them up, he shall be liable to the payer for honour in damages.

(7) Where the holder of a bill refuses to receive payment supra protest he shall lose his right of recourse against any party who would have been discharged by such payment.

\section{Lost Instruments.}

\section{Holder's right to duplicate of lost bill.}

Where a bill has been lost before it is overdue, the person who was the holder of it may apply to the drawer to give him another bill of the same tenor, giving security to the drawer if required to indemnify him against all persons whatever in case the bill alleged to have been lost shall be found again.

If the drawer on request as aforesaid refuses to give such duplicate bill, he may be compelled to do so.

\section{Action on lost bill.}

In any action or proceeding upon a bill, the court or a judge may order that the loss of the instrument shall not be set up, provided an indemnity be given to the satisfaction of the court or judge against the claims of any other person upon the instrument in question.

\section{Bill in a Set.}

\section{Rules as to sets.}

(1) Where a bill is drawn in a set, each part of the set being numbered, and containing a reference to the other parts, the whole of the parts constitute one bill. 
(2) Where the holder of a set indorses two or more parts to different persons, he is liable on every such part, and every indorser subsequent to him is liable on the part he has himself indorsed as if the said parts were separate bills.

(3) Where two or more parts of a set are negotiated to different holders in due course, the hoider whose title first accrues is as between such holders deemed the true owner of the bill ; but nothing in this sub-section shall affect the rights of a person who in due course accepts or pays the part first presented to him.

(4) The acceptance may be written on any part, and it must be written on one part only.

If the drawee accepts more than one part, and such accepted parts gets into the hands of different holders in due course, he is liable on every such part as if it were a separate bill.

(5) When the acceptor of a bill drawn in a set pays it without requiring the part bearing his acceptance to be delivered up to him, and that part at maturity is outstanding in the hands of a holder in due course, he is liable to the holder thereof.

(6) Subject to the preceding rules, where any one part of a bill drawn in a set is discharged by payment or otherwise, the whole bill is discharged.

\section{Conflict of Laws.}

\section{Rules where laws conflict.}

Where a bill drawn in one country is negotiated, accepted, or payable in another, the rights, duties, and liabilities of the parties thereto are determined as follows:-

(1) The ralidity of a bill as regards requisites in form is determined by the law of the place of issue, and the validity as regards requisites in form of the supervening contracts, such as acceptance, or indorsement, or acceptarce supra protest, is determined by the law of the place where such contract was made.

Provided that -

(a) Where a bill is issued out of the United Kingdom it is not invalid by reason only that it is not stamped in accordance with the law of the place of issue :

(b) Where a bill, issued out of the United Kingdom, conforms, as regards requisites in form, to the law of the United Kingdom, it mas, for the purpose of enforcing payment thereof, be treated as ralid as between all persons who negotiate, hold, or become parties to it in the United Kingdom.

(2) Subject to the provisions of this Act, the interpretation of the drawing, indorsement, acceptance, or acceptance supra protest of a bill, is determined by the law of the place where such contract is made.

Provided that where an inland bill is indorsed in a foreign country the indorsement shall as regards the payer be interpreted according to the law of the United Kingdom.

(3) The duties of the holder with respect to presentment for acceptance or payment and the necessity for or sufficiency of a protest or notice of dishonour, or otherwise, are determined by the law of the place where the act is done or the bill is dishonoured.

(4) Where a bill is drawn ont of but pasable in the United Kingdom and the 
sum payable is not expressed in the currencs of the United Kinglom, the amount shall, in the absence of some express stipulation, be calculaterl according to the rate of exchange for sight drafts at the place of payment on the day the bill is payable.

(5) Where a bill is drawn in one country and is parable in another, the due date thereof is determined according to the law of the place where it is parable.

\section{PART III.}

\section{Cheque defined.}

\section{Cheques oN a BANKer.}

A cheque is a bill of exchange drawn on a banker payable on demand.

Except as otherwise provided in this Part, the provisions of this Act appli. caule to a bill of exchange payable on demand apply to a cheque.

\section{Presentment of cheque for payment.}

Subject to the provisions of this Act -

(1) Where a cheque is not presented for payment within a reasonable time of its issue, and the drawer or the person on whose account it is drawn had the right at the time of such presentment as between him and the banker to hare the cheque paid and suffers actual damage through the delay, he is discharged to the extent of such damage, that is to say, to the extent to which such drawer or person is a creditor of such hanker to a larger amount than he would have been had such cheque been paid.

(2) In determining what is a reasonable time regard shall be had to the nature of the instrument, the usage of trade and of bankers, and the facts of the particular case.

(3) The holder of such cheque as to which such drawer or person is discharged shall be a creditor, in lieu of such drawer or person, of such banker to the extent of such discharge, and entitled to recorer the amount from him.

\section{Revocation of banker's authority,}

The duty and authority of a banker to pay a cheque drawn on him by his customer are determined by -

(1) Countermand of payment :

(2) Notice of customer's death.

\section{Crossed Cheques.}

\section{General and special crossings defined.}

(1) Where a cheque bears across its face an addition of $-(a)$ the words " and company" or any abbreviation thereof between two parallel transverse lines, either with or without the words " not negotiable;" or $(b)$ two parallel transrerse lines simply, either with or without the words " not negotiable,-- " that addition constitutes a crossing, and the cheque is crossed generally.

(2) Where a cheque bears across its face an ardition of the name of a banker, either with or without the words " not negotiable," that addition constitutes a crossing, and the cheque is crossed specially and to that banker.

\section{Crossing by drawer or after issue.}

(1) A cheque may be crossed generally or specially by the drawer. 
(2) Where a cheque is uncrossed, the holder may cross it generally or specially.

(3) Where a cheque is crossed generally the holder may cross it specially.

(4) Where a cheque is crossed generally or specially, the holder may add the words " not negotiable."

(5) Where a cheque is crossed specially, the banker to whom it is crossed may again cross it specially to another banker for collection.

(6) Where an uncrossed cheque, or a cheque crossed generally, is sent to a banker for collection, he may cross it specially to himself.

\section{Crossing a material part of eheck.}

A crossing authorized by this Act is a material part of the cneque; it shall not be lawful for any person to obliterate or, except as authorized by this Act, to add to or alter the crossing.

\section{Duties of banker as to erossed cheques.}

(1) Where a cheque is crossed specially to more than one banker except when crossed to an agent for collection being a banker, the banker on whom it is drawn shall refuse payment thereof.

(2) Where the banker on whom a cheque is drawn which is so crossed nerertheless pays the same, or pays a cheque crossed generally otherwise than to a banker, or if crossed specially otherwise than to the banker to whom it is crossed, or his agent for collection being a banker, he is liable to the true owner of the cheque for any loss he may sustain owing to the cheque having been so paid.

Provided that where a cheque is presented for parment which does not at the time of presentment appear to be crossed, or to have had a crossing which has been obliterated, or to hare been added to or altered otherwise than as authorised by this Act, the banker paying the cheque in good faith and without negligence shall not be responsible or incur any liability, nor shall the payment be questioned by reason of the cheque having been crossed. or of the crossing having been obliterated or having been added to or altered otherwise than as authorised by this Act, and of parment haring been made otherwise than to a banker or to the banker to whom the cheque is or was crossed, or to his agent for collection being a banker, as the case may be.

\section{Protection to banker and drawer where eheque is erossed.}

Where the banker, on whom a crossed cheque is drawn, in good faith and without negligence pays it, if crossed generally, to a banker, and if crossed specially, to the banker to whom it is crossed, or his agent for collection being a banker, the banker paying the cheque, and, if the cheque has come into the hands of the payee, the drawer, shall respectively be entitled to the same rights and be placed in the same position as if payment of the cheque had been made to the true owner thereof.

\section{Effect of erossing on holder.}

Where a person takes a crossed cheque which bears on it the words " not negotiable," he shall not hare and shall not be capable of giring a better title to the cheque than that which the person from whom he took it had.

\section{Protection to collecting banker.}

Where a banker in good faith and without negligence receires payment for a customer of a cheque crossed generally or specially to himself, and the 
customer has no title or a defective title thereto, the banker shall not incur any liability to the true owner of the cheque by reason only of having received such payment.

\section{PART IV.}

\section{Promissory Notes.}

\section{Promissory note defined.}

(1) A promissory note is an unconditional promise in writing made by one person to another signed by the maker, engaging to pay, on demand or at a fixed or determinable future time, a sum certain in money, to, or to the order of, a specified person or to bearer.

(2) An instrument in the form of a note payable to maker's order is not a note within the meaning of this section unless and until it is indorsed by the maker.

(3) A note is not invalid by reason only that it contains also a pledge of collateral security with authority to sell or dispose thereof.

(4) A note which is, or on the face of it purports to be, both made and parable within the British Islands is an inland note. Any other note is a foreign note.

\section{Delivery necessary.}

A promissory note is inchoate and incomplete until delivery thereof to the payee or bearer.

\section{Joint and several notes.}

(1) A promissory note may be made by two or more makers, an. they mily be liable thereon jointly, or jointly and severally according to its tenor.

(2) Where a note runs "I promise to pay" and is signed by two or more persons it is deemed to be their joint and several note.

\section{Note payable on demand.}

(1) Where a note payable on clemand has been indorsed, it must be presented for payment within a reasonable time of the indorsement. If it be not so presented the inclorser is discharged.

(2) In determining what is a reasonable time, regard shall be had to the nature of the instrument, the usage of trade and the facts of the particular case.

(3) Where a note payable on demand is negotiated, it is not deemed to be overdue, for the purpose of affecting the holder with lefects of title of which he had no notice, by reason that it appears that a reasonable time for presenting it for payment has elapsed since its issue.

\section{Presentment of note for payment.}

(1) Where a promissory note is in the body of it marle payable at a particular place, it must be presented for payment at that place in order to render the maker liable. In any other case, presentment for payment is not necessin? in order to render the maker liable.

(2) Presentment for payment is necessary in order to render the indorwer if a note liable.

(3) Where a note is in the body of it made payable at a particular plice, 
presentment at that place is necessary in order to render an indorser liable; but when a place of payment is indicated by way of memorandum only, presentment at that place is sufficient to render the indorser liable, but a presentment to the maker elsewhere, if sufficient in other respects, shall also suffice.

\section{Liability of maker.}

The maker of a promissory note by making it -

(1) Engages that he will pay it according to its tenor ;

(2) Is precluded from denying to a holder in due course the existence of the payee and his then capacity to indorse.

\section{Application of Part II to notes.}

(1) Subject to the provisions in this Part, and except as by this section provided, the provisions of this Act relating to bills of exchange apply, with the necessary modifications, to promissory notes.

(2) In applying those provisions the maker of a note shall be deemed to correspond with the acceptor of a bill, and the first indorser of a note shall be deemed to correspond with the drawer of an accepted bill payable to drawer"s order.

(3) The following prorisions as to bills do not apply to notes; namely, prorisions relating to -

(a) Presentment for acceptance;

(b) Acceptance;

(c) Acceptance supra protest;

(d) Bills in a set.

(4) Where a foreign note is dishonoured, protest thereof is unnecessary.

\section{PART V.}

\section{SUPPLEMENTARY.}

\section{Good faith.}

A thing is deemed to be done in good faith, within the meaning of this Act, where it is in fact done honestly, whether it is done negligently or not.

\section{Signature.}

(1) Where, by this Act, any instrument or writing is required to be signed by any person, it is not necessary that he should sign it with his own hand, but it is sufficient if his signature is written thereon by some other person by or unler his authority.

(2) In the case of a corporation, where by this Act any instrument or writing is required to be signed, it is sufficient if the instrument or writing be sealed with the corporate seal.

But nothing in this section shall be construed as requiring the bill or note of a corporation to be under seal.

\section{Computation of time.}

Where. by this Act, the time limited for doing any act or thing is less than three dars, in reckoning time, non-business days are excluded.

"Non-business dạ̦s" for the purposes of this Act mean -

(1) Sunday, Good Friday, Christmas Day : 
(b) A bank holiday under the Bank Holidays Act, 1871, or acts amending it :

(c) A day appointed by Royal proclamation as a public fast or thanksgiving day.

Any other day is a business day.

\section{When noting equivalent to protest.}

For the purposes of this Act, where a bill or note is required to be protested within a specified time or before some further proceeding is taken, it is sufficient that the bill has been noted for protest before the expiration of the specified time or the taking of the proceeding ; and the formal protest may be extended at any time thereafter as of the date of the noting.

\section{Protest when notary not accessible.}

Where a dishonoured bill or note is authorized or required to be protested, and the services of a notary cannot be obtained at the place where the bill is dishonoured, any householder or substantial resident of the place may, in the presence of two witnesses, give a certificate, signed by them, attesting the dishonour of the bill, and the certificate shall in all respects operate as if it were a formal protest of the bill.

The form given in Schedule 1 to this Act may be used with necessary modifications, and if used shall be sufficient.

\section{Dividend warrants may be crossed.}

The provisions of this Act as to crossed cheques shall apply to a warrant for pasment of dividend.

\section{Repeal.}

The enactments mentioned in the second schedule to this Act are hereby repealed as from the commencement of this Act to the extent in that schedule mentioned.

Provided that such repeal shall not affect anything done or suffered, or any right, title, or interest acquired or accrued before the commencement of this Act, or any legal proceeding or remedy in respect of any such thing, right, title, or interest.

\section{Savings.}

(1) The rules in bankruptcy relating to bills of exchange, promissory notes, and cheques, shall continue to apply thereto notwithstanding anything in this Act contained.

(2) The rules of common law including the law merchant, save in so far as they are inconsistent with the express provisions of this Act, shall continue to apply to bills of exchange, promissory notes, and cheques.

(3) Nothing in this Act or in any repeal effected thereby shall affect -

(a) The provisions of the Stamp Act, $1870,{ }^{*}$ or acts amending it, or any law or enactment for the time being in force relating to the revenue :

(b) The provisions of the Companies Act, 1862. $f$ or acts amending it, or any act relating to joint stock banks or companies :

* 33 and 34 Vict. c. 97 .

+25 anil sict e 89

NEGOT. INSTRUMENTS - 8 
(c) The provisions of any act relating to or confirming the privileges of the Bank of England or the Bank of Ireland respectively :

(d) The validity of any usage relating to dividend warrants, or the indorsements thereof.

\section{Saving of summary diligence in Scotland.}

Nothing in this Act or in any repeal effected thereby shall extend or restrict, or in any way alter or affect the law and practice in Scotland in regard to summary diligence.

\section{Construction with other acts, ete.}

Where any act or document refers to any enactment repealed by this Act, the act or document shall be construed, and shall operate, as if it referred to the corresponding provisions of this Act.

\section{Parol evidence in judicial proceedings in Scotland.}

In any judicial proceeding in Scotland, any fact relating to a bill of exchange, bank cheque, or promissory note, which is relerant to any question of liability thereon, may be proved by parol exidence: Prorided that this enactment shall not in any way affect the existing law and practice whereby the party who is, according to the tenor of any bill of exchange, bank cheque, or promissory note, debtor to the holder in the amount thereof, may be required, as a condition of obtaining a sist of diligence, or suspension of a charge, or threatened charge, to make such consignation, or to find such caution as the court or juage before whom the cause is depending may require.

This section shall not apply to any case where the bill of exchange, bank cheque, or promissory note has undergone the sesennial prescription.

\section{First Schedule.* (Sec. 94.)}

Form of protest which may be used when the services of a notary cannot be obtained.

Know all men that I, A. B. (householder), of in the county of , in the United Kingdom, at the request of C. D., there being no notary public arailable, did on the day of 188 at demand payment (or acceptance) of the bill of exchange hereunder written, from E. F., to which demand he made answer (state answer, if any). Wherefore, $I$ now in the presence of $G$. H. and J. K. do protest the said bill of exchange.

$$
\text { (Signed) }
$$

A. B.

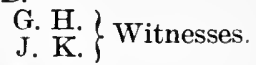

N. B. - The bill itself should be annexed, or a copy of the bill and all that is written thereon should be underwritten.

* The other schedules are purely local in interest, and are therefore omitted.-ED. 


\section{PART II.}

CASES AND AUTHORITIES.

[II5] 


\section{EXPLANATORY NOTE.}

The section numbers opposite the titles of cases and elsewhere refer to the sections of the Negotiable Instruments Law. The unbracketed numbers refer to the sections of the New York Act; the bracketed numbers refer to the sections of the Act as passed in the other States. 


\section{CASES AND AUTHORITIES}

ON

\section{NEGOTIABLE INSTRUMENTS.}

\section{ARTICLE I. \\ General Provisions.}

\section{Codes governing bills, notes and checks.}

I. The English Bills of Exchange Act.

A Digest of the law of Bills of Exchange, Promissory Notes and Cheques. By M. D. Chalmers, ${ }^{1}$ M. A., of the Inner Temple, BarrisTER AT LAw. LONDON, I878.

[From the Introduction to the First Edition.]

As far as form goes, the present Digest is modeled on the Indian Codes. * * * It is almost needless to point out, that the similarity between the Indian Codes and a Digest like the present is merely resemblance in form. There all analogy ends. In a code the subject in hand is treated completely and finally. A code states methodically the law as the legislature is of opinion that it ought to be. This Digest is an attempt to state methodically the law as it is. In a code, propositions and illustrations are alike authoritative. In this Digest, the illustrations taken from decided cases are alone authoritative. The general propositions are only entitled to weight in so far as they are complete and legitimate inductions from decided cases which are unquestioned law. A general proposition, supported by reference to cases, merely amounts to a verifiable hypothesis as to what the law is. In the theory of English law, there exists in nubibus a complete set of principles applicable to every conceivable state of facts that can arise. Theoretically the judges

1 Now his Honor Judge Chalmers.

[II 7] 
do not makelaw. They only interpret it. They are merely the conductors by which the principle is brought down from the clouds and made available to men. Practically, however, their functions are frequently and of necessity legislative. If a wide subject be investigated systematically, four states of the law will be found to exist. First, the law on a given point may be reasonably certain. All authority, or the great weight of authority, may be in favor of a given proposition. Secondly, a proposition on a given point can only be stated as probably holding good. For instance, it may rest merely on unchallenged obiter dicta, or there may be a decision in favor of it, and weighty obiter dicta opposed to it. Thirdly, the law on a given point may be uncertain. Decisions may be in direct conflict, or again there may be a decision in point which has never been directly questioned, but the ratio decidendi of which seems entirely opposed to the principle of later cases. Fourthly, there may be an entire absence of authority on a given question. Such being the state of the materials available for forming a Digest, it is clear that if the subject is to be treated methodically, many propositions can only be stated tentatively. Many of the articles, therefore, are qualified with a (probably) or a (perhaps), and the reason of the qualification is then stated in a note.

On doubtful points frequent reference is made to American cases and Continental Codes and writers. In mercantile matters, when the law is uncertain or authority wanting, there is an increasing tendency to refer to foreign codes and laws in order to see how other nations have solved the difficulty. This is especially the case as regards negotiable instruments, the most cosmopolitan of all contracts. Mr. Justice Story, in his judgment in Swift v. Tyson (I6 Peters, I), gives forcible expression to the principle. He says, "The law respecting negotiable instruments may be truly declared, in the language of Cicero, adopted by Lord Mansfield in Luke v. Lyde (2 Burr. 887), to be in a great measure, not the law of a single country only, but of the commercial world. Non erit lex alia Romee, alia Athenis, alia nunc, alia post hac, sed et apud omnes gentes et omni tempore una eademque lex obtinebit."

An American decision, it is needless to say, is not a binding authority in this country, but, if well reasoned, it is always considered with respect by our courts. Many of the American judgments are very valuable as expounding and testing the principles of English decisions. An English case there, like an American case here, is only an authority in so far as it appears to be a correct deduction from the general principles of the common law and the law merchant which prevail in both countries alike. 
When the subject matter of an article of this Digest is dealt with by the French "Code de Commerce," or the "German General Exchange Law, I849," their respective provisions are compared.

\section{[From the Introduction to the Third Edition.]}

Soon after the publication of the Second Edition of this Digest the law relating to bills, notes, and cheques was codified by the Bills of Exchange Act, $\mathbf{8} 88_{2}$. For the most part the propositions of the Act were taken word for word from the propositions of the Digest. In the introduction to the Second Edition it was pointed out that the general propositions of the Digest could only be considered as law, in so far as they were correct and logical inductions from the decided cases which were cited as illustrations. Now the position is reversed. The cases decided before the Act are only law in so far as they can be shown to be correct and logical deductions from the general propositions of the Act. The illustrations, therefore, must always be tested by the language of the Act itself.

In the notes to the Act I have carefully pointed out the few provisions which were deliberately intended to alter the law. When a proposition in the Act appears to be of wide scope, I have added illustrations taken from decided cases. When a proposition appears to be of narrow scope, I have merely given a reference to the cases which were before me when drafting it. It may be said that the Act should be left to speak for itself. I am well aware that there is no necesssary connection between the intention of the draftsman and the intention of the Legislature as deduced by the Courts from the terms of a statute. Still, in the present case, there will be a strong disposition on the part of the Courts to construe the Act as declaratory; and it may be useful to the profession to be referred from the abstract propositions of the Act, to the concrete facts which gave rise to them. As Mr. Justice Holmes, in his admirable work on the Common Law, observes (p. 27), "However much we may codify the law into a series of seemingly self-sufficient propositions, those propositions will be but a phase in a continuous growth. To understand their scope fully, to know how they will be dealt with by judges trained in the past which the law embodies, we must ourselves know sometning of that past. The history of what the law has been is necessary to the knowledge of what the law is."

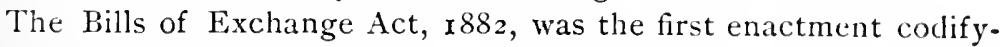
ing any branch of the Common Law which found its way into the Statute Book. It has now been followed by the Partnership Act, 
I890, which was originally drafted by Sir Frederick Pollock.' But as a Code is still somewhat of a novelty in the English law, it may be of interest to refer to the conditions under which the experiment was successfully carried out, and to consider how far it can or ought to be repeated as regards other portions of the law. Of late years several attempts at codification have been made, but from various causes they have mostly proved unsuccessful. The success of the Bills of Exchange Bill depended on the wise lines laid down by Lord Herschell. He insisted that the Bill should be introduced in a form which did nothing more than codify the existing law, and that all amendments should be left to Parliament. A Bill which merely improves the form, without altering the substance, of the law creates no opposition, and gives very little room for controversy. Of course codification pure and simple is an impossibility. The draftsman comes across doubtful points of law which he must decide one way or the other. Again, voluminous though our case law is, there are occasional gaps which a codifying bill must bridge over if it aims at anything like completeness. Still in drafting the Bills of Exchange Bill my aim was to reproduce as exactly as possible the existing law, whether it seemed good, bad, or indifferent in its effects. The idea of codifying the law of negotiable instruments was first suggested to me by Sir Fitz-James Stephen's Digest of the Law of Evidence, and Sir F. Pollock's Digest of the Law of Partnership. Bills, notes, and cheques seemed to form a well isolated subject, and I therefore set to work to prepare a digest of the law relating to them. I found that the law was contained in some 2,500 cases, and I 7 statutory enactments. I read through the whole of the decisions, beginning with the first reported case in 1603 . But the cases on the subject were comparatively few and unimportant until the time of Lord Mansfield. The general principles of the law were then settled, and subsequent decisions, though very numerous, have been for the most part illustrations of, or deductions from, the general propositions then laid down. On some points there was a curious dearth of authority. As regards such points I had recourse to American decisions, and to inquiry as to the usages among bankers and merchants. As the result, a good many propositions in the Digest, even on points of frequent occurrence, had to be stated with a (probably) or a (perhaps). Some two years after the publication of my Digest, I read a paper on the question of codifying the law of negotiable instruments before the Institute of Bankers. Mr. John

\footnotetext{
1 For an account of this Act, see the Introduction to the 5 th edition of Pollock on Partnership.
} 
Hollams, the well known commercial lawyer, who was present, pointed out the advantages of a Code to the mercantile community; and, mainly I think on his advice, I received instructions frum the Institute of Bankers and the Associated Chambers of Commerce to prepare a bill on the subject. The draft of the bill was first submitted to a sub-committee of the Council of the Institute of Bankers, who carefully tested such portions of it as dealt with matters of usage uncovered by authority. ${ }^{1}$ The bill was then introduced by S:r John Lubbock, the President of the Institute. After it had been read a second time in the Commons, it was referred to a strong Select Committee of merchants, bankers, and lawyers, with Sir Farrer Herschell as chairman. ${ }^{2}$ As the Scotch law of negotiable instruments differed in certain particulars from English law, the bill was originally drafted to apply to England and Ireland only. The first work of the Select Committee was to take the evidence of Sheriff Dove-Wilson of Aberdeen, a well-known authority on Scotch $\mathrm{C}$ (mmercial Law. He pointed out the particulars in which the bill, if applied to Scotland, would alter the law there. With three exceptions the points of difference were insignificant. The Committee thereupon resolved to apply the bill to Scotland, and Sheriff DoveWilson undertook the drafting of the necessary amendments. Eventually the Scotch rules were in three cases preserved as to Scotland, while on the other points the Scotch rule was either adopted for England, or the English rule applied to Scotland. A few amendments in the law were made when the Committee was unanimous in their favor, but very wisely no amendments were pressed on which there was a difference of opinion. Sir Farrer Herschell reported the bill to the House, and it was read a third time and sent up to the Lords without alteration. In the House of Lords it was again referred to a Select Committee with Lord Bramwell for Chairman.' A few amendments were there inserted, mainly at Lord Bramwell's suggestion. These were agreed to by the Commons, and the bill passed without opposition.

The Act has now ( $189 \mathbf{r}$ ) been in operation for more than eight years, so that some estimate can be formed as to its results. Merchants and Bankers say that it is a great convenience to them to

'Mr. Billinghurst, of the London and Westminster Bank, and Mr. Slater, of the London and County Bank, undertook the brunt of the work.

2 The committee included Sir Farrer Herschell, Q. C.: Sir John Lubbock, Mr. Asher, Q. C.; Mr. Cohen, Q. C.; Mr. Reid, Q. C.: Mr. Whilley, Mr. T. C Maring, Mr. R. B. Martin, Mr. Orr-Ewing, Mr. Jackson, and Sir Charles Mills

${ }^{3}$ The committee included the Lord Chancellor (Selborne), Lord Bramweli, Lord Fitzgerald, Lord Balfour of Burleigh, and Lord Wolverton. 
have the whole of the general principles of the law of bills, notes, and cheques contained in a single Act of roo sections. As regards par. ticular cases which arise, it is seldom necessary to go beyond the Act itself. It must also be an advantage to foreigners who have English bill transactions to have an authoritative statement of the English law on the subject in an accessible form. If I could do the work over again, I certainly could do it better and should profit by past experience. But is it is, the Act, as yet, has given rise to very little litigation. I am sure that furcher codifying measures can be got through Parliarent, if those in charge of them will not attempt too much, but will be content to follow the lines laid down by Lord Herschell Let a codifying bill in the first instance simply reproduce the existing law, however defective. If the defects are patent and glaring, it will be easy to get them amended. If an amendment be opposed, it can be dropped without sacrificing the bill. The form of the law at any rate is improved, and its substance can always be amended by subsequent legislation. If a bill when introduced proposes to effect changes in the law, every clause is lroked at askance, and it is sure to encounter opposition.

Assuming then the possibility of further codification, the question arises whether its extension is expedient. All the continental nations have codified their laws, and none of them show any signs of repenting it. On the contrary, most of them are now engaged in remodeling and amplifying their existing codes. In India a good deal of codification has been carried out, and public and professional opinion seems almost unanimous in its favor. The Bills of Exchange Act, I882, has been adopted by New Zealand, Victoria, New South Wales, South Australia, Queensland, Tasmania, and with slight modifications by Canada. ${ }^{1}$

\section{The American Negotiabe Instruments Law.}

LAWS OF NEW YORK, IS9O, Chapter 205.

$\S \mathrm{I}$. Within thirty days after the passage of this act, the governor shall appoint, by and with the consent of the senate, three commissioners, who are hereby constituted a board of commissioners by the name and style of "Commissioners for the Promotion of Uniformity of Legislation in the United States." It shall be the duty of said board to examine the subjects of marriage and divorce, insolvency, the form of notarial certificates and other subjects; to

${ }^{1}$ It has now been adopted by forty of the English colonies and dependencies. See Art. by E. Dove-Wilson, on Codification of Commercial Law, in 8 Jurid. Rev. (1896), 329.-ED. 
ascertain the best means to effect an assimilation and uniformity in the laws of the States, and especially to consider whether it would be wise and practicable for thc State of New York to invite the other States of the Union to send representatives to a convention to draft uniform laws to be submitted for the approval and adoption of the several States, and to devise and recommend such other course of action as shall best accomplish the purpose of this act.

Report of Commissioners on Uniformity of Laws to the Senate of New JERSEy, SEssion OF I 896 .

The undersigned, ${ }^{2}$ who were appointed commissioners for the promotion of uniformity of legislation in the United States, in pursuance of Chapter CCXXV of the Laws of 1895 , beg leave to report

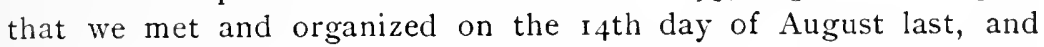
attended a conferencs of commissioners from different States, appointed under similar laws, at Detroit, Michigan, on the 26 th of said month. Commissioners from nineteen States attended the conference, and we learned that commissioners have been appointed in eimt other States.

Several conferences have been held in former years, but as few States were represented it had not been thought wise to attempt to formulate a uniform statute on any important subject.

In view of the fact that nineteen States were represented by commissioners at Detroit, and that commissioners had been appointed in other States, we thought the time had arrived when some important subject of general interest should be taken up. Accordingly Mr. Bergen offered the following resolution, which was adopted:

" That the committee on commercial law be requested to procure, as soon as practicable, a draft of a bill relating to commercial paper, based on the English statute on that subject, and on such other sources of information as said committee may deem proper to consult, and cause said draft and statute to be printed and sent by mail, with a copy of these resolutions, to every commissioner on uniform laws in office, and invite comments on said draft.

"That comments on said draft be sent by commissioners to the chairman of said committee without delay, and the said committee meet at a place to be appointed by its chairman to revise said clraft and report on the same to the next meeting of this conference."

Subsequently the committee on commercial law, referred to in the

1 Similar acts have been passed in many of the American States, and commis. sioners appointed. $-\mathrm{E}_{\mathrm{\nu}}$.

2 J. Franklin Fort, Frank B:rgan and J. D. Bedle. 
resolution, met and appointed a sub-committee of three, of which one of the subscribers is a member, to carry out the instructions contained in the resolution. About the $15^{\text {th }}$ of September last, the sub-committee employed Mr. John J. Crawford, of New York City, who has made a special study of the law relating to commercial paper, to make a draft of a bill as required by the resolution. Mr. Crawford completed the draft in December, and it was thereupon carefully revised by the sub-committee. It has been annotated for convenience of study. We submit herewith a copy, together with a copy of the English statute relating to negotiable instruments. Copies have been sent to the commissioners of other States and comments invited.

As the resolution requires the draft of bill to be submitted to the conference of commissioners to be held at Saratoga next summer, it should not be passed by the present Legislature, even if its provisions are satisfactory; but in order that suggestions and criticism may be made conveniently, we suggest that the bill be introduced, and printed and distributed among the members of the Legislature, or otherwise published.

We believe that commercial paper is a subject on which it will be generally agreed the law should be uniform among the States, and as the subject is important in itself, it seems to us to be especially adapted for treatment in the manner contemplated by the statutes under which the commissioners have been appointed. We brought this matter to the attention of the commissioners at the conference, not merely on account of its importance, but for the reason that we thought it would afford a practical and probably a decisive test of the question whether any desirable and important reform in the law can be effected by the voluntary co-operation of the States.

The Negotiable Instruments Law, with Copious Axwotations. By John J. Crawford, of the New York Bar. New York, i897.

\section{[From the Preface.]}

In 1895 the Conference of Commissioners on Uniformity of Laws, which met that year in Detroit, instructed the Conmittee on Commercial Law to have prepared a codification of the law relating to bills and notes. The matter was referred to a sub-committee consisting of Lyman D. Brewster, of Connecticut, Henry C. Willcox, of New York, and Frank Bergen, of New Jersey; and I was employed by the sub-committee to draw the proposed law. When completed, the draft, with my notes, was submitted to the sub-committee, who 
printed it and sent copies to each member of the conference, and also to many prominent lawyers and law professors, and to several English judges and lawyers, with an invitation for suggestions and criticisms. The draft was submitted to the conference which met at Saratoga in August, $\mathbf{I} \delta_{96} 6$; and the commissioners who were in attendance, being twenty-seven in all, and representing fourteen different States, went over it section by section, and made some amendments therein, most of which were such changes in the existing law as I had not felt at liberty to incorporate into the original draft. The draft as thus amended was adopted by the conference; and in such form it has been submitted to the legislatures of many of the States. It has been passed, and has become a law in New York, Connecticut, Colorado, and Florida. I am informed that the Commissioners on Uniformity of Laws will make special effort to have it adopted in many other States at the next session of their legislatures.

\section{Continental Codes.}

Chalmers' Digest of the Law of Bills of Exchange, etc.

[From the Introduction to the Third Edition.]

The French Code ${ }^{2}$ is of particular interest. Although enacted more than eighty years ago, no substantial alteration has been made in it by subsequent legislation. For many years it was the model of nearly all the Continental Codes. For instance, the Belgian Code de Commerce of 1872 enacted for Belgium the provisions of the French Code regarding bills and notes, with a few slight modifications borrowed from Germany, and the addition of three or four articles which embodied the result of French judicial decisions on the construction of the Code. Of late years, however, there has been a tendency to adopt the somewhat wider provisions of the German Exchange Law. Until ${ }_{1} 88_{3}$ the Italian Commercial Code was closely modeled on the French, but the new Italian Code which came into force in 1883 has departed from the French model as regards bills and notes, and has substantially adopted the provisions of the German Exchange Law. Again, the Portuguese Code of ${ }_{1} \Omega_{33}$ was mainly founded on the French Code. But the Code of I 888 in many respects departs from the French model, and has in the main followed the German Exchange Law, though a few provisions seemed

${ }^{1}$ Code de Commerce. I807. This is available in translation in a work by L. Goiraud on the French Code of Commerce, London, I830. Articles Iro-IS9 deal with bills and notes. Checks are dealt with in separate Acts (IS65 \& IS74). - ED. 
to be borrowed from the English Act. I believe the Hungarian Code of 1875 , the Scandinavian laws of 1880 , the Swiss law of 1881 , and the Spanish Code of 1885 have also departed from the French idea and followed the German lead. French law is worthy of attention in another respect. In the absence of English authority, our Courts have, in some instances, consciously taken it as their guide. (See per Parke, B., in Foster v. Dawher, 6 Exch. 852.) The "Code de Commerce," to a great extent, embodies and enacts the opinions of Pothier, whose authority, says Best, C. J. (in Cox v. Troy, 5 B. \& Ald. 481), " is as high as can be had next to the decision of a Court of Justice in this country." On doubtful points not dealt with by the Code, reference is occasionally made to Pothier, and also to the exhaustive treatise of M. Nouguier (Des Lettres de Change et des Effets de Commerce, $4^{\text {th }}$ ed. 1875 ), which gives the latest results of French law.

The German General Exchange Law of 1849 (slightly modified, 1869), is important in two respects. First, it is the most elaborate and carefully worked out of the foreign codes, and it appears to be the model to which the other continental states (with the exception of France) are now assimilating their laws. Secondly, it is an international and not merely a national Code. All the German States, including Austria, have adopted it, and the terms of its adoption are these: Each State is at liberty to supplement it by additional laws of its own, but such laws are not in any way to contradict or override it. M. Nouguier, in the work above referred to, gives in French the text of the Exchange Law, and also the various supplementary laws passed by the different States. ${ }^{1}$

It would probably be very advantageous to the commercial world if this principle of an International Code could be further extended. The difficulties of carrying it out do not seem insuperable, though, doubtless, they would be great. The provisions of such a Code would have to be settled by agreement, and then each State would enact it for its own territory. In the case of England it would probably be necessary to confine its operation to foreign bills, that is to say; to bills drawn or payable abroad. Our law, as regards foreign bills, does not widely diverge from the law of other commercial countries, and it diverges chiefly by allowing greater latitude than is adopted in practice.

Occasional reference is also made to the Indian Code (Act XXVI, of $\mathrm{I} 88 \mathrm{I}$, as amended by Act II of 1885 ) which in substance reproduces

' See Art. by E. Schuster on the German Civil Code, I2 Law Q. R. (I896). 17. - ED. 
the English law as it stood in I88I. In a work like the present, it is thought it would be waste of space to carry references to foreign laws or authorities any further, but it may be worth while to mention where they can be found.

Borchardt (Vollständige Sammlung der geltenden Wechsel-und Handels Gesetze aller Länder, I87I), collects the statutory enactments of all countries relating to Bills of Exchange. Part I gives a German translation, Part II the original text. More than forty countries have codified their law on this subject; in fact, some English colonies and the United States seem to be the only civilized nations which have not done so. Since Borchardt's work was published, however, several continental states have re-cast their laws relating to negotiable instruments. A new Commercial Code has been enacted for the Netherlands, and an official translation of the part relating to negotiable instruments has been published in England. [See Commercial, No. 30, of 1880, c. 2609.] M. Nouguier, in a supplementary chapter to his work on Bills (Des Lettres de Change, 1875), compares the laws of the chief commercial nations with the French Code. The Comité de Législation Étrangère, under the direction of the French Ministry of Justice, are preparing cheap French translations of the various foreign laws relating to commercial matters. Several volumes have already been published with excellent introductions and notes. Having regard to our own insular isolation, I fear it will be long before any English government department undertakes similar useful work. M. Massé's "Droit Commercial et des Gens " is a valuable work on the conflict of laws, especially as regards bills. ${ }^{2}$

\section{Construetion of eodifying statutes.}

\section{LORD HERSCHELl IN BANK OF ENGLAND $v$. VAGLIANO BROTHERS.}

L. R. I8gi, Appeal Cases, p. I44.

[The question arises on the construction of section 7 , subsec. 3 , of the Bills of Exchange Act, which reads: "Where the payee is a fictitious or non-existing person the bill may be treated as payable to bearer." "2]

My Lords, I propose to deal at the outset with the question of the

1 Some of the Spanish-American commercial codes have been printed in translation in the United States. See Handbook of Mexico, Chicago, I S92. - Ed.

${ }^{2}$ Observe the different reading of the Negotiable Instruments Law, $\$ 28$ [9], subsec. 3. - ED. 
construction of the Bills of Exchange Act, which gave rise to a difference of opinion in the court below. ***

The conclusion at which the majority of the Court of Appeal arrived with reference to the construction of the sub-section of the Bills of Exchange Act with which your Lordships have to deal is thus stated: "The word 'fictitious' must in each case be interpreted with due regard to the person against whom the bill is sought to be enforced. If the drawer is the person against whom the bill is to be treated as a bill payable to bearer, the term ' fictitious ' may be satisfied if it is fictitious as regards himself, or in other words, fictitious to his knowledge. If the obligations of the acceptor are in question, and the acceptor is the person against whom the bill is to be so treated, 'fictitious' must mean fictitious as regards the acceptor, and to his knowledge. Such an interpretation is based on good sense and sound commercial principle."

The conclusion thus expressed was founded upon an examination of the state of the law at the time the Bills of Exchange Act was passed. The prior authorities were subjected by the learned judges who concurred in this conclusion to an elaborate review, with the result that it was established to their satisfaction that a bill made payable to a fictitious person or his order was, as against the acceptor, in effect a bill payable to bearer, only when the acceptor was aware of the circumstance that the payee was a fictitious person, and further, that his liability in that case depended upon an application of the law of estoppel. It appeared to those learned judges that if the exception was to be further extended, it would rest upon no principie, and that they might well pause before holding that sect. 7, sub-sect. 3 , of the statute was "intended not merely to codify the existing law, but to alter it and to introduce so remarkable and unintelligible a change."

My Lords, with sincere respect for the learned judges who have taken this view, I cannot bring myself to think that this is the proper way to deal with such a statute as the Bills of Exchange Act, which was intended to be a code of the law relating to negotiable instruments. I think the proper course is in the first instance to examine the language of the statute and to ask what is its natural meaning, uninfluenced by any considerations derived from the previous state of the law, and not to start with inquiring how the law previously stood, and then, assuming that it was probably intended to leave it unaltered, to see if the words of the enactment will bear an interpretation in conformity with this view.

If a statute, intended to embody in a code a particular branch of the law, is to be treated in this fashion, it appears to me that its 
utility will be almost entirely destroyed, and that the very object with which it was enacted will be frustrated. The purpose of such a statute surely was that on any point specifically dealt with by it, the law should be ascertained by interpreting the language used instead of, as before, by roaming over a vast number of authorities in order to discover what the law was, extracting it by a minute critical examination of the prior decisions, dependent upon a knowledge of the exact effect even of an obsolete proceeding such as a demurrer to evidence. I am, of course, far from asserting that resort may never be had to the previous state of the law for the purpose of aiding in the construction of the provisions of the code. If, for example, a provision be of doubtful import, such resort would be perfectly legitimate. Or, again, if in a code of the law of negotiable instruments words be found which have previously acquired a technical meaning, or been used in a sense other than their ordinary one, in relation to such instruments, the same interpretation might well be put upon them in the code. I give these as examples merely; they, of course, do not cxhaust the category. What, however, I am venturing to insist upon is, that the first step taken should be to interpret the language of the statute, and that an appeal to earlier decisions can only be justified on some special ground.

One further remark I have to make before I proceed to consider the language of the statute. The Bills of Exchange Act was certainly not intended to be merely a code of the existing law. It is not open to question that it was intended to alter, and did alter it in certain respects. And I do not think that it is to be presumed that any particular provision was intended to be a statement of the existing law, rather than a substituted enactment.

Turning now to the words of the sub-section, I confess they appear to me to be free from ambiguity. "Where the payee is a fictitious or non-existent person " means, surely, according to ordinary canons of construction, in every case where this can, as a matter of fact, be predicated of the payee.

I can find no warrant in the staute itself for inserting any limitation or condition. I am putting aside for the present the question by whom a bill answering the description of the sub-section may be treated as payable to bearer, and I am accepting, too, for the moment, the meaning attributed by the majority of the Court of Appeal to the word " fictitious," viz., a creation of the imagination, confining myself to the question in what cases a bill purporting on the face of it to be payable to order may be treated as payable to bearer. I find it impossible, without doing violence to the language of the statute, to give any other answer than this: - In all cases in which

NEGOT. INSTRUMENTS - 9 
the payee is a fictitious or non-existent person. The majority of the Court of Appeal read the section thus: Where the payee is a fictitious or non-existent person, the bill may, as against any party who had knowledge of the fact, be treated as a bill payable to bearer. It seems to me that this is to add to the words of the statute and to insert a limitation which is not to be found in it or indicated by it. It is said that when the acceptor is the person against whom the bill is to be treated as payable to bearer, " 'fictitious' must mean fictitious as regards the acceptor, and to his knowledge." With all respect, I am cnable to see why it must mean this. I confess I cannot altogether follow the meaning of the words fictitious " as regards" the acceptor. I have a difficulty in seeing how a payee, who is in fact a "fictitious" person in the sense in which that word is being used, can be otherwise than fictitious as regards all the world - how such a payee can be "fictitious" as regards one person and not another. The truth is the words, "as regards" the acceptor, are treated as equivalent to the words, "to the knowledge of "the acceptor. But I do not think these expressions are synonymous. It seems to me that to import into the statute after the words "fictitious person" the words " as regards" the acceptor or drawer, as the case may be, and then to interpret those words as meaning " to the knowledge of," only tends to obscure the fact that the condition that the payee must be fictitious to the knowledge of the person sought to be charged as upon a bill payable to bearer is being introduced into the enactment.

For the reasons I have given I find myself compelled to the conclusion, notwithstanding my respect for those who have expressed a contrary view, that in order to establish the right to treat a bill as payable to bearer it is enough to prove that the payee is in fact a fictitious person, and that it is not necessary if it be sought to charge the acceptor to prove in addition that he was cognizant of the fictitious character of the payee.

My Lords, if the conclusion which I have indicated as being, in my opinion, the sound one, involved some absurdity or led to some manifestly unjust result, I might perhaps, even at the risk of straining the language used, strive to put some other interpretation upon it. But I cannot see that this is so, or that the interpretation I have adopted does any violence to good sense, or is otherwise than in accordance with sound commercial principle. I will assume that as the law stood at the time the Bills of Exchange Act was passed, a bill drawn to the order of a fictitious payee could have been treated as a bill payable to bearer only as against a party who knew that the payee was fictitious. This decision even was arrived at little more 
than a century ago, and was dissented from by distinguished judges, and it is obvious from the observations of Lord Ellenborough in Bennett v. Farnell (I Camp. I3०, 180, c.) that by some eminent lawyers at least it was regarded rather as a departure from strict principle, which ought not to be further extended than as an embodiment of sound commercial principle.

But is it impossible to take any step beyond this without violating sound principle and working injustice? [His Lordship then points out that the holder would suffer, with no corresponding benefit to the acceptor, unless a bill payable to a fictitious payee be treated as one payable to bearer.]

It may be that the right of the holder to treat such a bill, as against an acceptor ignorant of the fictitious character of the payee, as a bill payable to bearer, could not be established merely by an appeal to the law of estoppel, and that such estoppel would exist only against the drawer who knew that the payee was a fictitious person. I will assume that this was the law prior to the recent statute. But why should not the Legislature have intervened with a positive enactment imposing this liability upon the acceptor - an enactment which, it seems to me, would wrong no one, and would prevent a holder for value from suffering wrong? Estoppel is not the only sound principle upon which a law can be based. The law of estoppel was not thought to afford sufficient protection to those dealing with the apparent owner of goods. The Legislature deemed it necessary to intervene, and the Facturs Acts were passed, each of which added something to the protection of persons so dealing. Why, then, should it be thought improbable that the Legislature should have created in the holder of a bill drawn payable to a fictitious person a new right against the acceptor? If I am correct in thinking that this added right would obviate and not entail injustice, that it would make the law more reasonable and bring it more into conformity with the course of commercial transactions, I can see no reason for doubting that the Legislature so intended, if this be the plain, natural meaning of the words they have used, or for endeavoring so to construe the language as to find in it no more than a statement of the previous law. 


\section{The law merchant.}

\section{The Law Merchant and its History.}

The Elements of Mercantile Law. By Thomas Edward Scrutton. LONDON, I89I.

[From Chapter I.]

[Books recommended. - The best, and almost the only satisfactory sketch of the history of the Law Merchant with which I am acquainted, is the Introduction prefixed by Master Macdonell to the tenth edition of Smith's Mercantile Law. See also the Prefaces to Chalmers on Bills of Exchange, and Lowndes on Marine Insurance; and Scrutton on the Influence of the Roman Law on the Law of England, chapters xiii, xiv.]

I.

The fact that so wide a meaning is given . . . to the term "Common Law," may properly call your attention to the different meanings that the term " Common Law," itself has. In the first place " Common Law" is used in distinction to " Equity." The Common Law alone was administered by the King's Courts in this country, and suitors who complained of the rules of the law addressed petitions to the King, as the fountain of justice, asking for " Equity." The King, if he had time or inclination, dealt with these petitions himself; but when, as generally happened, he had not time or inclination, he referred them to his Chancellor, and the Chancellor dealt out "Equity" to petitioners injured by the stringent rules of the Common Law. The Equity administered at first was variable; as Selden said, it " varied with the length of the Chancellor's foot," but by degrees Equity itself came to settle down to rigid rules, until with the same case you might know beforehand that you would be successful on the Common Law side of Westminster Hall and unsuccessful on the Equity sidc. At last under the Judicature Act' the rules of Equity prevailed over the rules of Common Law, and the distinction became abolished except in as far as certain subjects were assigned to the Court of Chancery, and that certain subjects were assigned to the Queen's Bench Division.

A second meaning of the term "Common Law" is when it is used in opposition to " Statute Law." In that sense Common Law is the unwritten law of the kingdom which exists in gremio legis, in the bosom of the judges, which they bring forth from that mysterious recess when new points have to be dealt with; while the Statute 
Law is the written law of the kingdom as it has been laid down by the Legislature in Acts of Parliament.

Another sense in which the term "Common Law" is used is when it is distinguished from the "Civil Law," and in that sense the Common Law is the law of England; the Civil Law is the law of those countries who have founded their system upon the Roman Law. For instance, if you go north of the Border to Scotland, you find a system administered differing from the Law of England, and founded upon the Civil Law. If you cross the Atlantic to the United States you find the States in the North, such as Massachusetts, administering a system founded on Common Law; and if you go to Louisiana, in the South, you find a system founded on the old Roman Law, and known as a Civil Law system.

II.

There was yet another distinction which leads me to the subject of this course of lectures. If you read the law reports of the seventeenth century you will be struck with one very remarkable fact; either Englishmen of that day did not engage in commerce, or they appear not to have been litigious people in commercial matters, each of which alternatives appears improbable. But it is a curious fact that one finds in the reports of that century, two hundred years ago, hardly any commercial cases. If one looks up the Law of Bills of Exchange, "the cases on the subject are comparatively few and unimportant till the time of Lord Mansfield." ' If you turn to Policies of Insurance, and to the work of Mr. Justice Park on the subject published at the beginning of this century, you find him saying: "I am sure I rather go beyond bounds if I assert that in all our reports from the reign of Queen Elizabeth to the year $175^{6}$, when Lord Mansfield became Chief Justice of the King's Bench, there are sixty cases upon matters of insurance." 2 If you come to Charter Parties and Bills of Lading, which have always been productive of litigation, you find Sir John Davies in the seventeenth century saying that "until he understood the difference between the Law of Merchants and the Common Law of England, he did not a little marvel what should be the cause that in the books of the Common Law of England there should be found so few cases concerning merchants and ships, but now the reason was apparent, for that the Common Law did leave these cases to be ruled by another law, the Law Merchant, which is a branch of the Law of Nations." 3

${ }^{1}$ Chalmers, Bills, Pref. p. 36.

2 Park, I. Pref. 43.

${ }^{2}$ Zouch, Jurisdiction of the Admiralty (1686), p. 89. 
The reason why there were hardly any cases dealing with commercial matters in the Reports of the Common Law Courts is that such cases were dealt with by special Courts and under a special law. That law was an old established law and largely based on mercantile customs. Gerard Malynes, who wrote the first work on the Mer. chant Law in England, called his book, published in 1622 , "Consuetudo a'd Lex Mercatoria," or the Ancient Law Merchant; and he said in his preface: "I have entituled the book according to the ancient name of Lex Mercatoria and not $\mathcal{F} u s$ Mercatorum, because it is a customary law approved by the authority of all kingdoms and commonweales, and not a law established by the sovereignty of any prince." And Blackstone, in the middle of the last century, says: "The affairs of commerce are regulated by a law of their own called the Law Merchant or Lex Mercatoria, which all nations agree in and take notice of, and it is particularly held to be a part of the law of England which decides the causes of merchants by the general rules which obtain in all commercial countries, and that of ten even in matters relating to domestic trade, as for instance, in the drawing, the acceptance, and the transfer of Bills of Exchange." Later than Blackstone, Lord Mansfield lays down that "Mercantile Law is not the law of a particular country, but the law of all nations;" " while so recently as $\mathrm{I}_{3} 8_{3}$ you find Lord Blackburn saying in the House of Lords that " the general Law Merchant for many years has in all countries caused Bills of Exchange to be negotiable; there are in some cases differences and peculiarities which by the municipal law of each country are grafted on it, but the general rules of the Law Merchant are the same in all countries." ${ }_{3}$

\section{III.}

Now if we foliow the growth of this Law Merchant or Mercantile Law, which was two hundred years ago so distinct from the Common Law, we find it in England going through three stages of development. ${ }^{4}$ The first stage may be fixed as ending at the appointment of Coke as Lord Chief Justice in the year 1606, and before that time you will find the Law Merchant as a special law administered by special Courts for a special class of people.

In the first place as to the special Courts. The greater part of the foreign trade of England, and indeed of the whole of Europe at that time, was conducted in the great fairs, held at fixed places and fixed

1 Blackstone, Commentaries. I. 273; IV. 67.

${ }^{2}$ Luke v. Lyde, 2 Burr. at p. 887.

${ }^{3}$. W'Lean v. Clydesdale Bank, 9 App. C., at p. ro5.

- Macdonell, Preface to Smith's Mercantile Law, p. 82 
times in each year, to which merchants of all countries came; fairs very similar to those which meet every year at the present time at Novgorod in Russia, and at other places in the East. In England, also, there were then the great fairs of Winchester and Stourbridge, and the fairs of Besançon and Lyons in France, and in each of those fairs a Court sat to administer speedy justice by the Law Merchant to the merchants who congregated in the fairs, and in case of doubt and difficulty to have that law declared on the basis of mercantile customs by the merchants who were present. You will find this Court mentioned in the old English law books as the Court Pepoudrous, so called because justice was administered "while the dust fell from the feet," so quick were the Courts supposed to be. "This Court is incident to every fair and market because that for contracts and injuries done concerning the fair or market there shall be as speedy justice done for advancement of trade and traffic as the dust can fall from the feet, the proceeding there being de hora in horam." I Indeed, so far back as Bracton in the thirteenth century, it had been recognised that there were certain classes of people "who ought to have swift justice, such as merchants, to whom justice is given in the Court Pepoudrous." 2 The records of these Courts are few, for obviously in Courts for rapid business law reporters were rather at a discount. As a consequence, "there is no part of the history of English law more obscure than that connected with the maxim that the Law Merchant is part of the law of the land." ${ }_{3}$ We are, however, fortunate enough to have one or two records of the Courts of the Fairs. The Selden Society has succeeded in unearthing the Abbott's roll of the fair of St. Ives held in 1275 and $1291,{ }^{4}$ containing a series of cases which show how the merchants administered the Law Merchant in the Courts of the fair, and why such cases did not come into the King's Court. For instance:- "Thomas, of Wells, complains of Adam Garsop that he unjustly detains and deforces from him a coffer which the said Adam sold to him on Wednesday next after Mid Lent last past for sixpence, whereof he paid to the said Adam twopence and a drink in advance" - (it appears to have been a very good mercantile custom, still existing, to "wet a bargain," and the drink was a matter to which great importance was attached by the merchants present); " and on the Octave of Easter came and would have paid the rest, but the said Adam would not receive it nor answer for the said coffer,

\footnotetext{
"Coke, Inst. IV. 272. ["Pypowder" courts appurtenant to fairs were authorized in New York in I692.- I Col. Laws (ed. I894), p. 298. - ED.

2 Bracton, f. 334 .

${ }^{3}$ Blackburn on Sale, rst ed. p. 207.

4 Selden Society, Vol. Ii. pp. I30 et seq.
} 
but detained it unconditionally to his damage and dishonour, $2 s$, and he produces suit. The said Adam is present and does not defend. Therefore let him make satisfaction to the said Thomas and be in mercy for the unjust detainer; fine $6 d$.; pledge his overcoat." The next defendant was not so fortunate as to have an overcoat. "Reginald Picard of Stamford came and confessed by his own mouth that he sold to Peter Redhood of London a ring of brass for $5 \frac{1}{2} d$., saying that the said ring was of the purest gold, and that he and a one-eyed man found it on the last Sunday in the churchyard of St. Ives, near the cross." (One fancies one has heard that tale about the brass ring before.) "Therefore it is considered that the said Reginald do make satisfaction to the said Peter for the $5 \frac{1}{2} d$. and be in mercy for the trespass; he is poor; pledge his body." The next case introduces the Law Merchant. " Nicolas Legge com. plains of Nicolas of Mildenhall for that unjustly he impedes him from having, according to the usage of merchants, part in a certain ox which Nicolas of Mildenhall bought in his presence in the village of St. Ives on Monday last past to his damage $2 s$., whereas he was ready to pay half the price, which price was $2 s .6 d$. And Nicolas of Mildenhall defends, and says that the Law Merchant does well allow that every merchant may participate in a bargain in the butcher's trade if he claim a part thereof at the time of the sale; but to prove that the said Nicolas Legge was not present at the time of the purchase nor claimed a part thereof he is ready to make law." Then they went to the proof. The custom of the Law Merchant relied on admitted any merchant standing by to claim a share in any bargain on paying a share of the price. The defence is, "You were not there, so you cannot claim." The next and last case is one which puzzled the Court, and therefore I omit the details, but it is recited in the Abbott's roll: "And the case is respited till it shall be more thoroughly discussed by the merchants. And the merchants of the various commonalties and others being convoked in full Court it is considered " - and then they go on to discuss it. There you see the Merchants' Court at work, giving quick justice in all mercantile disputes, and in cases of doubt calling upon the merchants present to declare what the Law Merchant is. So much for the fairs.

In most seaport towns also you will find a similar Court dealing with cases arising out of ships. In the Domesday Book of Ipswich" it is stated, "The pleas between strange folk that men call "pypoudrous' should be pleaded from day to day. The pleas in time of fair between stranger and passer should be pleaded from hour to

1 Black Book of Admiralty, Rolls Series, II. 23. 
hour, as well in the forenoon as in the afternoon, and that is to wit of plaints begun in the same time of fair, and the pleas given to the law marine for strange mariners passing, and for them that abide not but their tide, should be pleaded from tide to tide." Any ship coming into the port of Ipswich with a dispute about its Charter Party or Bill of Lading may get summary justice at once from this Court at Ipswich between tide and tide. Stress may be laid on the fact that the Courts sat in the afternoon, because at that time the King's Courts only sat from eight in the morning till eleven and then adjourned for the rest of the day. "For in the afternoons these Courts are not holden. But the suitors then resort to the perusing of their writings, and elsewhere consulting with the serjeantsat-law and other their counsellors," ' so that the time taken up in consultation by the Courts in London was taken up by the Courts at Ipswich in dealing summarily with cases, and letting the strange mariners go who were only waiting for their tide.

There were special Courts by statute, of which a number of "grave and discreet merchants " were necessary members, in order that the Mercantile Law founded on the custom of merchants might be duly applied to the case before them. ${ }^{2}$ The law which these Courts administered was what was called by merchants the Law Merchant and Law of the Sea, and it was common to nearly every European country. Much of it was to be found in a series of codes of Sea Laws, such as the Laws of Oleron and Wisbury, and the Consolato del Mare, embodying the customs and practices of merchants of different countries, and it was not the Common Law of England. Further, it was only for a particular class. You had to show yourself to be a merchant before you got into the Mercantile Court; and until about two hundred years ago it was still necessary to show yourself to be a merchant in the Common Law Courts before you could get the benefit of the Law Merchant. ${ }^{3}$

IV.

Now the second stage of development of the Law Merchant may be dated from Lord Coke's taking office in $\mathrm{x} 606$, and lasts until the time when Lord Mansfield became Chief Justice in $175^{6}$, and during that time the peculiarity of its development is this: That the special

\footnotetext{
'Sir J. Fortescue.

'E. $g$. the Court established by 43 Eliz. c. I2, of which eight "grave and discreet merchants" were to be members, who were to determine all insurance cases in a brief and summary course, without formalities of pleadings or proceedings.
}

Vide post, pp. 29, 30. [Herein at p. 144. - ED. 
Courts die out, and the Law Merchant is administered by the King's Courts of Common Law, but it is administered as a custom and not as law, and at first the custom only applies if the plaintiff or defendant is proved to be a merchant. In every action on a Bill of Exchange it was necessary formally to plead "secundum usum et consuetudinem Mercatorum " - according to the use and custom of merchants; ${ }^{1}$ and it was sometimes pleaded that the plaintiff was not a merchant but a gentleman. ${ }^{2}$ And as the Law Merchant was considered as custom, it was the habit to leave the custom and the facts to the jury without any directions in point of law, with a result that cases were rarely reported as laying down any particular rule, because it was almost impossible to separate the custom from the facts; as a result little was done towards building up any system of Mercantile Law in England.

$$
\text { V. }
$$

The construction of that system began with the accession of Lord Mansfield to the Chief Justiceship of the King's Bench in 1756 , and the result of his administration of the law in the Court for thirty years was to build up a system of law as part of the Common Law, embodying and giving form to the existing customs of merchants. When he retired, after his thirty years of office, Mr. Justice Buller paid a great tribute to the service that he had done. In giving judgment in Lickbarrow v. Mason, ${ }^{3}$ he said: "Thus the matter stood till within these thirty years. Since that time the Commercial Law of this country has taken a very different turn from what it did before. Lord Hardwicke himself was proceeding with great caution, not establishing any general principle, but decreeing on all the circumstances put together. Before that period we find in Courts of Law all the evidence in mercantile cases was thrown together; they were left generally to the jury, and they produced no established principle. From that time we all know the great study has been to find some certain general principle, not only to rule the particular case under consideration, but to serve as a guide for the future. Nost of us have heard those principles stated, reasoned upon, enlarged, and explained till we have been lost in admiration at the strength and stretch of the human understanding, and I should be sorry to find myself under the necessity of differing from Lord Mansfield, who may truly be said to be the founder of the Commercial Law of this country." Lord Mansfield, with a Scotch training, was not too favourable to the

\footnotetext{
${ }^{1}$ Chalmers, Bills, Pref. 44.

'Cf. Sarsfield v. Witherby' (1692), Carthew, 82.

${ }^{3} 2$ T. R. 73 ,
} 
Common Law of England, and he derived many of the principles of Nercantile Law, that he laid down, from the writings of foreign jurists, as embodying the custom of merchants ali over Europe. For instance, in his great judgment in Luke v. Lyde, ${ }^{1}$ which raised a question of the freight due for goods lost at sea, he cited the Roman Pandects, the Consolato del Mare, laws of Wisbury and Oleron, two English and two foreign mercantile writers, and the French Ordonnances, and deduced from them the principle which has since been part of the Law of England. ${ }^{2}$ While he obtained his legal principles from those sources, he took his customs of trade and his facts from Mercantile Special Juries, whom he very carefully directed on the law; and Lord Campbell, in his life of Lord Mansfield, has left an account of Lord Mansfield's procedure. He says: ${ }^{3}$ "Lord Mansfield reared a body of special jurymen at Guildhall, who were generally returned on all commercial cases to be triec there. $\mathrm{He}$ was on terms of the most familiar intercourse with them, not only conversing freely with them in Court, but inviting them to dine with him. From them he learned the usages of trade, and in return he took great pains in explaining to them the principles of jurisprudence by which they were to be guided. Sereral of these gentlemen survived when I began to attend Guildhall as a student, and were designated and honoured as 'Lord Mansfield's jurymen.' One in particular I remember, Mr. Edward Vaux, who always wore a cocked hat, and had almost as much authority as the Lord Chief Justice himself.'

Since the time of Lord Mansfield other judges have carried on the work that he began, notably Abbott, Lord Chief Justice, afterwards Lord Tenterden, the author of " Abbott on Shipping," Mr. Justice Lawrence, and the late Mr. Justice Willes; and as the result (f) their labours the English Law is now provided with a fairly complete code of mercantile rules, and is consequently inclined to disregard the practice of other countries. In Lord Mansfield's time it would have been a strong argument to urge that all other countries had adopted a particular rule; at the present time English Courts are not alarmed by the fact that the law they administer differs from the law of other countries. In a recent case before the Court of Appeal, Lord Esher says:" "It was urged that even if the

\footnotetext{
${ }^{1} 2$ Burr. 883 .

${ }^{2}$ Cf. the judgment of Willes, J., in Dakin v. Oxl'y, r5 C. B. N. S. 64o, for similar authorities.

${ }^{3}$ Campbell's Lives of the Lord Chief Justices, II. 407, note.

4 Suendsen v. Wallace, I3 Q. B. D. 73, cf. per Willes, J. in Lloyd v. Guibert, L. R. I Q. B. I 19,123 .
} 
proposition is stated in terms larger thain have hitherto been recognised in English Law, yet it ought now to be adopted in order to bring the principle of English Law on the subject into consonance with the laws of all other countries. But to this I cannot agree. It is useless to inquire whether the law is, as stated, the same in all European countries. For if it is, yet no English Court has any mission to adapt the Law of England to the laws of other countries; it has authority only to declare what the Law of England is." Lord Mansfield would have found out what the Law of England in mercantile matters was by considering what was the law of other countries, if there was no English decision laying down any clear rule. The Courts of the present day in the wealth of English commercial law, feel entitled to disregard the law of other countries.

VI.

Further than this, the Law Merchant, which was originally based upon the usage of merchants, can now be extended by new usages which have sprung up, may be constantly added to by proof of fresh usages of the mercantile world. That is very clearly and strongly laid down in the case of Goodwin v. Robarts. ${ }^{1}$ It was a case involving the question whether a particular form of debenture scrip was negotiable, and it was alleged that by the custom of merchants it had been so for the last twenty years. It was answered to that, relying upon a judgment of Mr. Justice Blackburn, ${ }^{2}$ that no addition could be made to the Law Merchant by so recent a usage as twenty years, but that it must be shown to be part of the ancient Law Merchant; but Chief Justice Cockburn, in delivering the judgment of the Court of Exchequer Chamber in Goodzin v. Robarts, said: " Having given the fullest consideration to this argument, we are of opinion that it cannot prevail. It is founded on the view that the Law Merchant is fixed and stereotyped, and incapable of being enlarged so as to meet the wants and requirements of trade in the varying circumstances of commerce. It is true that Law Merchant is sometimes spoken of as a fixed body of law forming part of the law, and, as it were, coeval with it, but as a matter of legal history this view is altogether incorrect.

The Law Merchant is of comparatively recent origin; it is neither more or less than the usages of merchants and traders in the different departments of trade ratified by the decisions of the Courts of Law, which, upon such usages being proved before them, have adopted them as settled law with

1 L. R. : U Ex. 346, 352.

2 Crouch v. Crédit Foncier, L. R. 8 Q. B. 386. 
a view to the interests of trade and public convenience, the Court proceeding herein on the well-known princıple of law that, with respect to transactions in the different departments of trade, Courts of Law, in giving effect to the contracts and dealings of the parties, wiil assume that the latter have dealt with one another on the footing of any custom or usage prevailing in that particular department." Thus it is that Courts of Law continually take notice of customs of trade, only to the word " customs" they give a mucin wider meaning than it bears in the Common Law. A weil-known lawyer said rather cynically once that he had heard a good many customs found by juries, but he had never heard one proved yet; and it is so that the evidence on which a mercantile jury, who know a great deal more about the matter than the lawyers or witnesses, very often will find that a custom exists, is such as would not suffice to establish any custom under the strict rules of the Common Law.

For according to the Common Law a custom must have six attributes. In the first place it must date from time immemorial, which has been conveniently fixed by the Common Law as when our Lord Richard returned from Palestine, in 18 89. Now, obviously, when our Lord Richard returned from Palestine, the amount of mercantile custom existing in England was of the very slightest description, and if one is to trace all one's mercantile customs back to his return from Palestine, or if a custom is liable to be defeated by proof of a later origin, very few mercantile customs can possibly be proved. The custom must be continuous from that date in the second place. In the third place it must be universally acquiesced in. In the fourth place it must be reasonable. In the fifth place it must be certain; and in the last place it must be binding. Now in proving a mercantile custom you can dispense with our Lord Richard at once; it is sufficient for you to prove that the custom is certain, so that people know what it is; that it is reasonable; that is is fairly universal (of course it is not quite universal, because somebody is disputing it in the action in question); that it has existed for some time (five years may suffice); and that merchants in the trade consider it binding; and on those lines the law is continually being added to by the find. ing of customs by special juries. 


\section{History oF Negotiable INSTRUMENTS.}

\section{(a) Bills, Notes and Checks.}

Sckutron. Elements of Mercantile Law. I8g1.

[From Chapter II.]

[For authorities, see the Preface to Mr. Chalmers' work on Bills of Exchange; the notes to Miller v. Race in I Smith's Leading Cases, 9th ed. p. 49I; and the judgment of Cockburn, C. J., in Goodwin r. Robarts, L. R. Io Ex. 346.]

Many of the rules of Mercantile Law, the Law Merchant, are directed to evade inconvenient rules of the Common Law.

* * * * * * * * * * * * *

Another rule of the Common Law which is found inconvenient by merchants is the old rule that a "chose in action" is not transferable. A "chose in action" is a right to recover a thing, as distinguished from the thing itself. A bill of lading, as distinguished from the goods it represents, is such a "chose in action." If you [X.] had a right to recover property from A., and wanted to assign that right to B., so that B. could recover such property from A., you could not do it by the old common law. Equity would have recognised that you had transferred the right to B., but even then B. must bring his action in the name of $\mathbf{X}$., who had given him the right; he could not sue in his own name. And further, when the "chose in action" was transferred, such a transfer passed no better title than the transferor had. Now the Law Merchant dealt with many " choses in action," and it would have been very inconvenient, for instance, that the man who took a bill of exchange should not be able to sue on it in his own name, but should have to sue in the name of the man whose name was mentioned as payee in the bill of exchange. It would have been highly inconvenient that the indorsee of a bill of exchange should have to inquire into the title of all previous indorsers, to see that there was no defect in any of their titles. As a result the Law Merchant establishes certain instruments or "choses in action," which were transferable by delivery or indorsement, so that the holder could sue in his own name, and which passed a good title to a transferee who took them in good faith, notwithstanding that the transferor or his predecessors had no title. These documents had thus two distinguishing features: They could be sued on by the holder in his own name; and they were not affected by previous lack of title; and instruments of this class are called Negrotiable Instruments. ${ }^{1}$ To illustrate the general

${ }^{1}$ See the leading case of Hiller v. Kace, I Sinith L. C. gth ed. 49 I, and per Bowen, L. J., in Picker v. London and County Bank, IS Q. B. D. 5 Ig. 
doctrine I have been explaining to you, a bill of exchange is by the custom of merchants transferable either by delivery, if it is to bearer, or by indorsement, if it is to order, and the indorsee or person who takes it can sue in his own name, and is not affected by the fact of previous want of title in an indorser if he was not a party to that defect.

The indorsement of a bill of lading by the custom of merchants passes such property in the goods represented by it as it was intended to pass $;^{1}$ but it needed a statute, the Bills of Lading Act, ${ }^{2}$ to get a further effect and allow a holder of a bill of lading to sue in his own name on the contract contained in the bill of lading. Thus the bill of lading obtained a similar position to that of a negotiable instrument by the double effect of the custom of merchants and of the statute. A policy of insurance does not by assignment pass goods insured under it, although the assignee may by statute sue in his own name, and therefore it is not a complete negotiable instrument. For to make a negotiable instrument you must have two marks; that the holder gets a title, though his transferor had no title, and that the holder can sue in his own name - each of these marks meeting one of the rules of the Common Law already referred to.

The law of negotiable instruments is, with some few exceptions depending on statutes, entirely built upon the custom of merchants, and the history of that law as applied to particular classes of instruments you will find best stated in the judgment of Lord Chief Justice Cockburn in Goodwin v. Robarts, ${ }^{3}$ which I recommend to your careful reading. The earliest form of negotiable instrument was the bill of exchange. ${ }^{4}$ Originally bills of exchange were used solely for the purpose of foreign trade. It was an instrument by which an English merchant contrived to avoid sending money out of the country or bringing money into the country by giving an order on his foreign debtor to pay a third person, or by accepting an order to pay a third person from his foreign creditor. ${ }^{5}$ It was purely a trade transaction for the purpose of avoiding sending money out of the country, and the French Law has adhered to that idea of a bill of exchange to this day, and treats it merely as a trade transaction. The English Law has treated it as an instrument of credit. Bills of exchange seem to have been introduced into England by the Vene-

1 Vide post, p. 153.

${ }^{2}$ I8 \& I9 Vic. c. III.

${ }^{3}$ L. R. Io Ex. 346.

- Defined in Bills of Exchange Act, 1882, $\$ 3$, and post, pp. 40, $4 \mathrm{I}$.

- See Chalmers, Bills, Pref. p. 46. 
tians or Florentines, and there were bills of exchange for foreign trade known to England as early as the reign of Richard II. The first reported case in the English Courts is in the year $1603,{ }^{1}$ and the Courts, in developing what was originally simply a bill in a transaction of foreign trade, have followed the custom of merchants. Chief Justice Treby, in the case of Bromwich v. Lloyd,$^{2}$ explained the stages by which a bill of exchange was developed. "Bills of Exchange," he said, " at first extended only to merchant strangers trafficking with English merchants; and afterwards to inland bills between merchants trafficking the one with the other in England; and afterwards to all traders, and then to all persons whether traiers or not; and there was then no need to allege any custom of merchants." So beginning with the necessity to allege an English merchant and a foreign merchant, you dispense with the foreign merchant and allege two English merchants trading; then you dispense with the particular transaction of trade; then you drop the trader, or the allegation that there is any merchant at all, and simply produce the bill. But in a case in $1613^{3}$ there was a plea that an acceptor of a bill of exchange was not a merchant, and it was held a good answer. A bill of exchange could not be made at that time by people who were not merchants. In I692, however, the Courts had got a little further." There was a plea then that the acceptor of a bill of exchange was a gentleman and not a merchant, and the Court of Queen's Bench, following the earlier case, held that a good defence; but the Court of Appeal, the Exchequer Chamber, reversed the decision, "having consideration to the inconvenience that might ensue and the suspicion which might increase among foreign merchants," and they laid down very sensibly that if "gentlemen " took upon themselves to accept bills they ought to pay them. The custom of merchants has gone on developing bills of exchange until the law with regard to them is now all but settled; they pass by indorsement or delivery the right to the indorsee to sue in his own name; they pass title to a bona fide holder for value though the indorser's title is bad; and it is not necessary to allege any consideration for the bill, for consideration is presumed until the contrary is proved. The only trace of the former history of bills of exchange is the difference between inland and foreign bills of exchange, which is, in the words of Lord Holt, " All the difference between foreign and inland bills is that foreign bills must be

1 .Martin v. Boure, Cro. Jac. 6.

2 (I698) 2 Lutwyche's Reports, p. 1585.

${ }^{8}$ Oaste v. Taylor, I Cro. Jac. 306.

4 Sarsfield v. Witherby, Carthew, 82. 
protested before a notary before the drawer can be charged; but inland bills need no protest," ${ }^{2}$ notice of dishonour being sufficient.

The next document which obtained the features of negotiability was a promissory note. In a bill of exchange there are, after acceptance, two people who offer security to the holder, the drawer and the acceptor; in a promissory note there is at first only the single security, that of the person who promises in the note to pay. The first case in which promissory notes were recognised by the Courts as negotiable instruments was the case of Shelden v. Hentley, ${ }^{2}$ in 1680 , where the Court held a promissory note to be a negotiable instrument, expressly saying that "it was the custom of merchants that made that good." That decision for some years afterwards was followed in other cases till Holt became Chief Justice. Lord Holt set his face against the custom of merchants and against promissory notes as negotiable instruments. In the case of Clarke v. Martin $^{3}$ the reporter says: "But Holt, C. J., was with all his strength against this action, (on a promissory note), and said that this note could not be a bill of exchange; that the maintaining of these actions upon such notes were innovations upon the rules of Common Law, and that it amounted to setting up a new sort of specialty unknown to the Common Law, and inrented in Lombard Street, which attempted in these matters of bills of exchange to give laws to Westminster Hall; that the continuing to declare upon these notes upon the custom of merchants proceeded from obstinacy and opinionativeness, since he had always expressed his opinion against them." It appears that Lombard Street and the merchants therein thought that the "obstinacy and opinionativeness" was upon the side of Lord Holt, for they continued to use these documents and to sue upon them; and in the next year, in another case of Buller v. Crispe, ${ }^{4}$ Lord Holt again expressed his opinion in strong terms, and said that these notes were not in the nature of bills of exchange, but were only an invention of the goldsmiths in Lombard Street, who had a mind to make a law to lind all that did deal with them. "At another day Holt, C. I., declared that he had desired to speak with two of the most famous merchants in London, to be informed of the mighty ill-consequences that it was pretended would ensue by obstructing this form, and they had told him that it was very frequent with them to make such notes, and that they looked upon them as bills of exchange, and that they had been used for a matter

1 Buller v. Cripps, 6 Mod. 29.

${ }^{2} 2$ Showers, p. I60.

3 ( 702 ) 2 Lord Raymond, $75^{8}$.

-6 Modern Reports, p. 29. 
of thirty years; that not only notes but bonds for money were transferred frequently, and endorsed as bills of exchange," and the reporter winds up significantly, " the Court at last took the vacation to consider of it." Parliament stepped in and saved them from considering it any further, for by an act of the year $1704^{2}$ it was expressly provided that promissory notes should be deemed as negotiable as bills of exchange. The preamble of the Act began: "Whereas it hath been held that promissory notes are not indorsable over, within the custom of merchaits, therefore to encourage trade and commerce be it enacted." So in this case also the custom of merchants introduced an innovation into the law of Westminster Hall, although it needed th. sanstion of Parliament to induce Westminster Hall to recognise it.

The next step in the history was that bankers and goldsmiths who held money on deposit began to issue promissory notes payable on demand, that is to say they began to issue Bank Notes. To these again the custom of merchants very speedily gave negotiability, and in the leading cese of Miller $\mathrm{v}$. Race, ${ }^{2}$ Lord Mansfield decided that bank notes also were negotiable instruments, holding that it was necessary for the purposes of commerce that their currency should be established and secured. And by the custom of merchants, bank notes have acquired a superior position to promissory notes. They are payable to any holder who may present them without the necessity of his indorsing them. There is a legend that the Bank of England always required persons presenting their bank notes to indorse them, and that on one occasion when the clerk of the bank behind the counter spoke in rather a cavalier manner to a gentleman who came in, telling him that he could not be paid unless he wrote his name on the back, the gentleman with the note walked out and promptly sued the Bank of England for dishonouring their promissory note, and of course sued them successfully, with the result of altering the custom at the Bank. Bank of England notes are now legal currency and tender, and in the case of country banks their notes may be, under certain circumstances, treated as currency and payment.

The next step was when the banks, besides issuing their promissory notes payable on demand, or bank notes, accepted and honoured bills of exchange drawn on them by their customers, payable on demand; that is to say when the system of Chcques came into existence, for a cheque is a bill of exchange drawn on a bank by its cus-

$13 \&+$ Anne, c. 9 .

'I Smith's Leading Cases, 9th ed. p. 490. 
tomer, payable on demand.' To cheques, also, the practice of merchants has affixed certain incidents, as for instance the practice of crossing cheques, which originated partly in the usages of commerce and partly in the Clearing House; and has now been definitely recognised by Act of Parliament. Banks, by the custom of merchants, are also bound to honour cheques if they have funds of the customer in their hands; though a drawee, even though he had funds in his hand, would not be bound to accept a bill of exchange.

So far, the law of negatiable instruments, (bills of exchange, promissory notes, cheques, bank notes), has been codified by Parliament in the Bills of Exchange Act, ISSz; " an Act to codify the law relating to bills of exchange, cheques, and promissory notes," 2 and on all matter treated on by that . Ict the Law Merchant is now to be found in its clauses, and not in the cases and customs on which those clauses were founded.

\section{Chalmers' Digest of Bills of Exchaige, etc,}

\section{[From the Introduction to the Third Edition.]}

The results of this formation of the law by custom are instructive. A reference to Marius' treatise on Bills of Exchange, written about

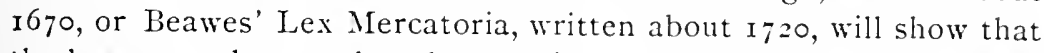
the law, or perhaps rather the practice, as to bills of exchange, was even then pretty well defined. Comparing the usage of that time with the law as it now stands, it wi.l be seen that it has been modified in some important respects. Comparing English law with French, it will be seen that, for the most part, where they differ, French law is in strict accordance with the rules laid down by Beawes. 'The fact is, that when Beawes wrote, the law or practice of both nations on this subject was uniform. The French law, however, was embodied in a Code by the "Ordonnance de 1673 ," which is amplified but substantially adopted by the Code de Commerce of $\mathrm{r} 8 \mathrm{I} S$. Its development was thus arrested, and it remains in substance what it was 200 years ago. English law has been developed piecemeal by judicial decision founded on custom. The result has been to work out a theory of bills widely different from the original. The English theory may be called the Banking or Currency theory, as opposed to the French or Mercantile theory. A bill of exchange in it origin was an instrument by which a trade debt, due in one place, was transferred in another. It merely avoided the necessity of transmitting cash from place to place. This

\footnotetext{
1 Bills of Exchange Act (1852), ธิ 73.
}

${ }^{2} 45 \&{ }^{6} 6$ Vic. c. 6 I. 
theory the French law steadily keeps in view. In Engiand bills have developed into a perfectly flexible paper currency. In France a bill represents a trade transaction; in England it is merely an instrument of credit. ${ }^{1}$ English law gives full play to the system of accommodation paper; French law endeavors to stamp it out.

A comparison of some of the main points of divergence between English and French law will show how the two theories are worked out. In England it is no longer necessary to express on a bill that value has been given, for the law raises a presumption to that effect. In France the nature of the value nust be expressed, and a false statement of ralue aroids the bill in the hands of all parties with notice. In England a bill may now be drawn and payable in the same place (formerly it was otherwise, see the definition of bill in Comyns' Digest). ${ }^{2}$ In France the place where a bill is drawn must be so far distant from the place where it is payable, that there may be a possible rate of exchange between the two. A false statement of places, so as to evade this rule, aroids the bill in the hands of a holder with notice. As French lawyers put it, a bill of exchange necessarily presupposes a contract of exchange. ${ }^{3}$ In England, since ${ }_{7} 65$, a bill may be drawn payable to bearer, though formerly it was otherwise. ${ }^{*}$ In France it must be payable to order; if it were not so, it is clear that the rule requiring the consideration to be expressed would be an absurdity. In England a bill originally payable to order becomes payable to bearer when indorsed in blank. In France an indorsement in blank merely operates as a procuration. An indorsement, to operate as a negotiation, must be an indorsement to order, and must state the consideration; in short, it must conform to the conditions of an original draft. In England, if a bill be refused acceptance, a right of action at once accrues to the holder. This is a logical consequence of the currency theory. In France no cause of action arises unless the bill is again dishonored at maturity; the holder, in the meantime, is only entitled to demand security from the drawer and indorsers. In England a sharp distinction is drawn between current and overdue bills. In France no such distinction

1 This passage was written in $15-3$. when the first edition was published. The theory it advances is independently confirmed by the excellent introduction to the Portuguese Commercial Code in the French edition, published by the Comité dé Législation Étransère. See p. xxix.

: A bill of exchange is when a man takes money in one country or city upon exchange, and draws a bill whereby he directs another person in another country or city to pay so much to $A$. or order for value received of B., and subscribes it."

${ }^{3}$ This rule is said to be now obsolete; but the Code remains unaltered.

- See Steiidrt v. Hodres (I692), I 2 Mod. 36 . 
is drawn. In England no protest is required in the case of an inland bill, notice of dishonor alone being sufficient. In France every dishonoured bill must be protested. Grave doubts may exist as to whether the English or the French system is the soundest and most beneficial to the mercantile community, but this is a problem which it is beyond the province of a lawyer to attempt to solve.

\section{(b) Other Tisotiable Paper.}

\section{Scrlttox, Elenexts of Merchitile Law. ISgi.}

\section{[From Chapt:r II.]}

There are, however, other negotiable instruments besides those which have been dealt with by the Act of I $S S_{2}$, and to such instruments the rules of the Common Law and the customs of the Law Merchant are still applicable. Fresh usages may be introduced, or new documents may be proved by the usage of merchants to have the two marks of negotiability already stated.' The usage that is proved must, however, be a usage of Eiglish merchants. In the case of Picker v. The London and Conntr Bunk," an attempt was made to treat certain Prussian bonds as negotiable instruments in England; but the only evidence that was offered was that those bonds were negotiable by the custom of Prussian merchants, and the Court unanimously rejected the evidence as insufficient. As it was pointedly put, the fact that in Africa cowries are negotiable instruments does not therefore bind the English Courts to accept cowries as negotiable instruments in England, and the same principle has always been applied in any attempt to prove the negotiability of instruments in England; the usage proved must be a usage of English merchants. It is not necessary that that usage should be from time immemorial. Mr. Iustice Blackburn did, indeed, in one case ${ }^{3}$ lay down that such a usage, existing as part of the ancient Law Merchant was necessary; but in the later case, Gondain r. Roburts, ${ }^{*}$ both the Court of Appeal and the House of Lords held that to be too narrow a limitation, deciding that the Law Merchant might be added to by proof of recent usage, and thus that new negotiable instruments might be from time to time created. We find in the Reports a series of illustrations of these principles of law in the varıous documents that have

1.Ate. p. 26. [Herein pp. It2-3. - ED.

Is Q. B. D. P. 515.

3 Crouch r. Crint Fincior, L. R. S Q. B. 37t, followed on this by Manisty, J. in 20 Q. B. D. at p. 239

${ }^{4}$ L. R. Io Ex, at D. 355 ; I App. C. at p. 494. 
been from time to time proved or not proved to be negotiable instruments. For instance, in the case of Glymn v, Baker, 'East India bonds were held not to be negotiable in the absence of any evidence that they customarily passed by delivery; but the decision in the Courts was immediately remedied by Parliament, who passed an Act giving to East India bonds the character of negotiability. " In Dixon v. Booill, ${ }^{3}$ a document called an " iron warrant," running, "I will deliver one hundred tons of iron when required after Sept. I8th to the party lodging this document with me," was held by the House of Lords not to be a negotiable instrument, and not therefore to pass by delivery, there being no evidence before the Court of any mercantile usage affecting such documents; it is, however, very probable that if the question of iron warrants came before the Court at the present day, they could be abundantly proved to be negotiable.

To come to more recent cases, in The Fine Arts Society v. The Union Bank, ${ }^{4}$ it was held that Post Office orders crossed for collection by a bank were not negotiable instruments; and in Crouch v. The Crédit Foncier, ${ }^{5}$ debenture bonds of an English company were held not negotiable because the only proof of usage tendered was one originating in the last twenty years. On the other hand, in Gorgice v. Mieville, ${ }^{6}$ certain foreign bonds were held to be negotiable instruments on proof that bonds of that description were sold in the English market, and passed from hand to hand daily like Exchequer bills. And that case was followed in Goodwinv. Robarts, in which certain scrip, which on the payment of all instalments due was to be exchanged for bonds, was held a negotiable instrument on proof of usage of the English Stock Exchange. ${ }^{*}$ There is one other case I wish to mention to you as an illustration of the Common Law maxim I have already reminded you of, that a man cannot give what he has not got, and therefore if he has not got a title cannot give it. The recent case of Bartonv. The London and North Westrm Raihioly " is at the present time exciting very great apprehen-

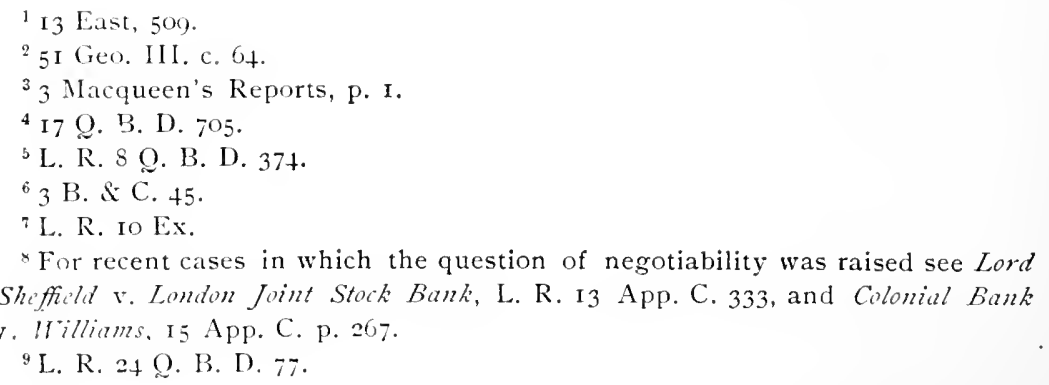


sion in commercial circles. Mr. Barton held certain shares in the L. $\&$ N. W. Railway which passed to his executors, and one of the executors by forging the signature of the other executor sold those shares some twelve or thirteen years ago. The purchaser took the transfer with the forged signature to the L. S N. IV. Raliway Company, who registered it, and for the twelve or thirteen years the purchaser has been registered for those shares and has received the dividends. The executrix whose signature was forged — for a lady was concerned - did not find out the absence of these shares for the thirteen years, but on finding it out and on proof of the forgery, the L. \& N. W. Company were ordered to replace her name on the register, and the unfortunate purchasers have had to give up their shares, and to pay back the dividends which they have received during the thirteen years. A man cannot give what he has not got.

The people who purported to pass these shares had not got them to give. At present agitation, if one may use such a word, is taking place on every English Stock Exchange for an Act which will protect the people whose transfers have been registered by Railway Companies against the rules of the Common Law.

\section{GOODMII'. ROBARTS.}

L. R. IO Exchequer, 337- - I875.

Cockburs, C. J. - The question for our decision in this case is whether certan scrip issued by the authority of the Russian Government, and certain other scrip issued by the authority of the AustroHungarian Government, is a negotiable security for money, so that the transfer of it by a person not being the true owner to a bona fide holder, for value, can confer a good title on the latter.

The scrip in question was bought by the plaintiff through one Clayton, a stock broker, and was allowed to remain in Clayton's hands, who unlawfully pledged it with the defendants, who are bankers, as security for a loan of money. Clayton having become bankrupt, and having absconded, the defendants sold the scri, at the market price of the day, and the plaintiff brings his action to recover the amount realized on such sale.

[The scrip was issued by Messrs. de Rothschild as agents of the Russian and the Austro-Hungarian governments, and the essential part of it was as follows:]

Received the sum of twenty pounds, being the first instalment of 20 per cent. upon one hundred pounds stock, and on payment of the remaining instalments 
at the period specified, the bearer will be entitled to receive a definitive bond or bonds for one hundred pounds after receipt thereof from the Imperial Government.

[Then follow other receipts for $20 l$. each, making up the Iool., for which the bond is afterwards to be given.]

The contention on the part of the plaintiff was that scrip of this description not coming under the category of any of the securities for money which, by the law merchant, are capable of being transferred by indorsement or delivery - indeed, not being a security for money at all, but only for the future delivery of a bond - the right of the true owner could not be divested by the fraudulent transfer of the chattel by a person who had no title as against the owner.

On the part of the defendants it was contended that the finding as to general usage brought the case within the decisions in Gorgier v. Wieville, (3 B. \& C. 45 ) and Attorney-General v. Bouwens (4 M. \& W. I7I). * * *

Strenuous efforts were made by Mr. Benjamin, in his able argument on behalf of the plaintiff, to distinguish the present case from Gorgier v. Miczille. *** The substance of Mr. Benjamin's argument is, that, because the scrip does not correspond with any of the forms of the securities for money which have been hitherto held to be negotiable by the law merchant, and does not contain a direct promise to pay money, but only a promise to give security for money, it is not a security to which, by the law merchant, the character of negotiability can attach.

Having given the fullest consideration to this argument, we are of opinion that it cannot prevail. It is founded on the view that the law merchant thus referred to is fixed and stereotyped, and incapable of being expanded and enlarged so as to meet the wants and requirements of trade in the varying circumstances of commerce. It is true that the law merchant is sometimes spoken of as a fixed body of law, forming part of the common law, and as it were coeval with it. But as a matter of legal history, this view is altogether incorrect. The law merchant thus spoken of with reference to bills of exchange and other negotiable securities, though forming part of the general body of the lex mercatoria, is of comparatively recent origin. It is neither more nor less than the usages of merchants and traders in the different departments of trade, ratified by the decisions of courts of law, which, upon such usages being proved before them, have adopted them as settled law with a view to the interests of trade and the public convenience, the court proceeding herein on the well-known principle of law that, with reference to transactions in the different departments of trade, 
courts of law, in giving effect to the contracts and dealings of the parties, will assume that the latter have dealt with one another on the footing of any custom or usage prevailing generally in the particular department. By this process, what before was usage only, unsanctioned by legal decision, has become engrafted upon, or incorporated into, the common law, and may thus be said to form a part of it. "When a general usage has been judicially ascertained and established," says Lord Campbell, in Brandao v. Barnett (1 $2 \mathrm{Cl}$. \& F. at p. 805) " it becomes a part of the law merchant, which courts of justice are bound to know and recognize."

Bills of exchange are known to be of comparatively modern origin, having first been brought into use, so far as is at present known, by the Florentines in the twelfth, and by the Venetians about the thirteenth century. The use of them gradually found its way into France, and, still later and but slowly, into England. We find it stated in a law tract, by Mr. MacLeod, entitled "Specimen of a Digest of the Law of Bills of Exchange," printed, we believe, as a report to the government, but which, from its research and ability, deserves to be produced in a form calculated to insure a wider circulation, that Richard Malynes, a London Merchant, who published a work called the Lex Mercatoria, in 1622, and who gives a full account of these bills as used by the merchants of Amsterdam, Hamburg, and other places, expressly states that such bills were not used in England. There is reason to think, however, that this is a mistake. Mr. MacLeod shows that promissory notes, payable to bearer, or to a man and his assigns, were known in the time of Edward IV. Indeed, as early as the statute of 3 Rich. 2, c. 3 , bills of exchange are referred to as a means of conveying money out of the realm, though not as a process in use among English merchants. But the fact that a London merchant writing expressly on the law merchant was unaware of the use of bills of exchange in this country, shows that that use at the time he wrote must have been limited. According to Professor Story, who herein is, no doubt, perfectly right, "the introduction and use of bills of exchange in England," as indeed it was everywhere else, " seems to have been founded on the mere practice of merchants, and gradually to have acquired the force of custorn." With the development of English commerce the use of these most convenient instruments of commercial traffic would of course increase, yet, according to Mr. Chitty, the earliest case on the subject to be found in the English books is that of Martin v. Boure (Cro. Jac. 6), in the first James I. Up to this time the practice of making these bills negotiable by indorsement had been unknown, and the earler bills are found to be made 
payable to a man and his assigns, though in some instances to bearer. But about this period, that is to say, at the close of the sixteenth or the commencement of the seventeenth century, the practice of making bills payable to order, and transferring them by indorsement, took its rise. Hartmann, in a very learned work on Bills of Exchange, recently published in Germany, states that the first known mention of the indorsement of these instruments occurs in the Neapolitan Pragmatica of 1607 . Savary, cited by Mons. Nouguier, in his work, "Des Lettres de Change," had assigned to it a later date, namely r6zo. From its obvious convenience this practice speedily came into general use, and, as part of the general custom of merchants, received the sanction of our courts. At first the use of bills of exchange seems to have been confined to foreign bills between English and foreign merchants. It was afterwards extended to domestic bills between traders, and finally to bills of all persons, whether traders or not. (See Chitty on Bills, Sth ed., p. I3.)

In the meantime, promissory notes had also come into use, differing herein from bills of exchange that they were not drawn upon a third party, but contained a simple promise to pay by the maker, resting; therefore, upon the security of the maker alone. They were at first made payable to bearer, but when the practice of making bills of exchange payable to order, and making them transferable by indorscment, had once become established, the practice of making promissory notes payable to order, and of transferring them by indorsement, as had been done with bills of exchange, speedily prevailed. And for some time the courts of law acted upon the usage with reference to promissory notes, as well as with reference to bills of exchange.

In 1680 , in the case of Shelden v. Hentley (2 Show. r60), an action was brought on a note under seal by which the defendant promised to pay to bearer $100 l$., and it was objected that the note was void because not made payable to a specific person. But it was said by the Court "Traditio facit chartam loqui, and by the delivery he (the maker) expoundis the person before meant; as when a merchant promises to pay to ine bearer of the note, anyone that brings the note shall be paid." Jones, J., said that "it was the custom of merchants that made that good." In Bromaich v. Lloyd (2 Lutw. 1582), the plaintiff deciared upon the custom of merchants in London, on a note for money payabic on demand, and recovered; and Treby, C. I., said that "bilis of exchange were originally between foreigners and merchants tracaing with the English; afterwards, when such bills came to be more frequent, then they were allowed between merchants tasding in England, and afterwards between any traders 
whatsoever, and now between any persons, whether trading or not; and, therefore, the plantifi need not allege any custom, for now those bilis were of that general use that upon an indebitutus assumpsit they may be given in evidence upon the trial." To which Powell, J., added, "On indebitatus assumpsit for money received to the use of the plaintiff the bill may be left to the jury to determine whether it was given for value received."

In Villiams v. Williums (Carth. 269), where the plaintiff brought his action as indorsee against the payee and indorser of a promissory note, declaring on the custom of merchants, it was objected on error, that the note laving been made in London, the custom, if any, should have been laid as the custom of London. It was answered "that this custom of merchants was part of the common law, and the court would take notice of it ex officio; and, therefore, it was needless to set forth the custom specially in the declaration, but it was sufficient to say that such a person secundum usum ct consuetudinum mercatorum, drew the bill." And the plaintiff had judgment.

Thus far the practice of merchants, traders, and others, of treating promissory notes, whether payable to order or bearer, on the same footing as bills of exchange had received the sanction of the courts, but Holt having become Chief Justice, a somewhat unseemly conflict arose between him and the merchants as to the negotiability of promissory notes, whether payable to order or to bearer, the Chief Justice taking what must now be admitted to liave been a narrow-minded view of the matter, setting his face strongly against the negotiability of these instruments, contrary, as we are told by authority, to the opinion of Westminster Hall, and in a series of successive cases, persisting in holding them not to be negotiable by indorsement or delivery. The inconvenience to trade arising therefrom led to the passing of the statute of 3 and 4 Anne, c. 9, whereby promissory notes were made capable of being assigned by indorsement, or made payable to bearer, and such assignment was thus rendered valid beyond dispute or difficulty.

It is obvious from the preamble of the statute, which merely recites that "it had ben held that such notes were not within the custom of merchants," that these decisions were not acceptable to the profession or the country. Nor can there be much doubt that by the usage prevalent amongst merchants, these notes had been treated as securities negotiable by the customary method of assignment as much as bills of exchange properly so-called. The Statute of Anne may. indeed, practically speaking, be looked upon as a declaratory statute, confirming the decisions prior to the time of I, ord Holt.

We now arrive at an epoch when a new form of security for money, 
namely, goldsmiths' or bankers' notes, came into general use. Holding them to be a part of the currency of the country, as cash, Jord Mansfield and the Court of King's Bench had no difficulty in holding, in Miller v. Race (I Burr. 452), that the property in such a note passes, like that in cash, by delivery, and that a party taking it bona fice, and for value, is consequently entitled to hold it against a former owner from whom it has been stolen.

In like manner it was held, in Collins v. Martin (1 B. \& P. 648), that where bills indorsed in blank had been deposited with a banker, to be received when due, and the latter had pledged them with another banker as security for a loan, the owner could not bring trover to recover them from the holder.

Both these decisions of course proceeded on the ground that the property in the bank-note payable to bearer passed by delivery, that in the bill of exchange by indorsement in blank, provided the acqui. sition had been made bona fide.

A similar question arose in Trookey v. Pole (4 B. \& Ald. I), in respect of an exchequer bill, notoriously a security of modern growth. These securities being made in favor of blank or order, contained this clause, "If the blank is not filled up the bill will be paid to bearer." Such an exchequer bill, having been placed, without the blank being filled up, in the hands of the plaintiff's agent, had been deposited by him with the defendants, on a bona fide advance of money. It was held by three judges of the Queen's Bench, Bayley, J., dissentiente, that an exchequer bill was a negotiable security, and judgment was therefore given for the defendants. The judgment of Holroyd, J., goes fully into the subject, pointing out the distinction between money and instruments which are the representatives of money, and other forms of property. "The courts," he says, "have considered these instruments, either promises or orders for the payment of money, or instruments entitling the holder to a sum of money, as being appendages to money, and following the nature of their principal." After referring to the authorities, he proceeds: "These authorities shew, that not only money itself may pass, and the right to it may arise, by currency alone, but further, that these mercantile instruments, which entitle the bearer of them to money, may also pass, and the right to them may arise, in like manner, by currency or delivery. These decisions proceed upon the nature of the property (i.e. money), to which such instruments give the right, and which is in itself current, and the effect of the instruments, which either give to their holders, merely as such, a right to receive the money, or specify them as the persons entitled to receive it." 
Another very remarkable instance of the efficacy of usage is to be found in much more recent times. It is notorious that, with the exception of the Bank of England, the system of banking has recently undergone an entire change. Instead of the banker issuing his own notes in return for the money of the customer deposited with him, he gives credit in account to the depositor, and leares it to the latter to draw upon him, to bearer or order, by what is now called a cheque. Upon this state of things the general course of dealing between bankers and their customers has attached incidents previously unknown, and these by the decisions of the courts have become fixed law. Thus, while an ordinary drawee, although in possession of funds of the drawer, is not bound to accept, unless by his own agreement or consent, the banker, if he has funds, is bound to pay on presentation of a cheque on demand. Even admission of funds is not sufficient to bind an ordinary drawee, while it is sufficient with a banker; and money deposited with a banker is not only money lent, but the banker is bound to repay it when called for by the draft of the customers. (See Pott v. Clegg, I6 M. \& W. 32 I.) Besides this, a custom has grown up among bankers themselves of marking checks as good for the purposes of clearance, by which they become bound to one another.

Though not immediately to the present purpose, bills of lading may also be referred to as an instance of how general mercantile usage may give effect to a writing which without it would not have had that effect at common law. It is from mercantile usage, as proved in evidence, and ratified by judicial decision in the great case of Lickbarrow v. Mason ( 2 T. R. 63), that the efficacy of bills of lading to pass the property in goods is derived. ${ }^{1}$

It thus appears that all these instruments which are said to have derived their negotiability from the law merchant had their origin, and that at no very remote period, in mercantile usage, and were adopted into the law by our courts as being in conformity with the usages of trade; of which, if it were needed, a further confirmation might be found in the fact that, according to the old form of declaring on bills of exchange, the declaration always was founded on the custom of merchants.

Usage, adopted by the courts, having been thus the origin of the whole of the so-called law merchant as to negotiable securities, what is there to prevent our acting upon the principle acted upon by our predecessors, and followed in the precedents they have left to us?

'See Shazi' v. Railroad, ror U. S. 557 , as to statutory " negotiability" of bills of lading. - ED. 
Why is it to be said that a new usage which has sprung up under altered circumstances is to be less admissible than the usages of past times? Why is the door to be now shut to the admission and adoption of usage in a matter altogether of cognate character, as though the law had been fully stereotyped and settled by some positive and peremptory enactment? It is true that this scrip purports on the face of it to be a security not for money, but for the delivery of a bond; nevertheless we think that substantially and in efiect it is a security for money, which, till the bond shall be delivered, stands in the place of that document, which, when delivered, will be beyond doubt the representative of the sum it is intended to secure. Suppose the possible case that the borrowing government, after receiving one or two instalments, were to determine to proceed no further with its loan, and to pay back to the lenders the amount they had already advanced; the scrip with its receipts would be the security to the holders for the amount. The usage of the money market has solved the question whether scrip should be considered security for, and the representative of, money, by treating it as such.

The universality of a usage voluntarily adopted between buyers and sellers is conclusive proof of its being in accordance with public convenience; and there can be no doubt that by holding this species of security to be incapable of being transferred by delivery, and as requiring some more cumbrous method of assignment, we should materially hamper the transactions of the money market with respect to it, and cause great public inconvenience. No doubt there is an evil arising from the facility of transfer by delivery, namely, that it occasionally gives rise to the theft or misappropriation of the security, to the loss of the true owner. But this is an evil common to the whole body of negotiable securities. It is one which may be in a great degree prevented by prudence and care. It is one which is counterbalanced by the general convenience arising from facility of transfer, or the usage would never have become general to make scrip available to bearer, and to treat it as transferable by delivery. It is obvious that no injustice is done to one who has been fraudulently dispossessed of scrip through his own misplaced confidence, in holding that the property in it has passed to a bona fide holder for value, seeing that he himself must have know that it purported on the face of it to be available to bearer, and must be presumed to have been aware of the usage prevalent with respect to it in the market in which he purchased it.

Lastly, it is to be observed that the tendency of the courts, except only in the time of Lord Holt, has been to give effect to mercan. tile usage in respect to securities for money, and that where legal 
difficulties have arisen, the legislature has been prompt to give the necessary remedy, as in the case of promissory notes and of East India bonds.

The authorities relied on on the part of the plaintiff do not appear to us materially to conflict with this view. [The Court then discusses: Glyn v. Baker (13 East, 509); Partridger. Gorernor and Company of the Bank of England (9 Q. B. 396); Dixon r. Borill (3 Macq. I); Crouch v. The Crédit Foncier of England (L. R. S Q. B. 374); Lang v. Smith (7 Bing. 284).]

We must by no means be understood as saying that mercantile usage, however extensive, should be allowed to prevail if contrary to positive law, including in the latter such usages as, having been made the subject of legal decision, and having been sanctioned and adopted by the courts, have become, by such adoption, part of the common law. To gire effect to a usage which incolves a defiance or disregard of the law would be obviously contrary to a fundamental principle. And we quite agree that this would apply quite as strongly to an attempt to set up a new usage against one which has become settled and adopted by the common law as to one in conflict with the more ancient rules of the common law itself. Thus it has been decided in the two cases of More v. Manning (I Comyns' Rep. $3 \mathrm{Ir}$ ), and Acheson v. Fountain (r Str. 557), that when a bill of exchange was endorsed to A. B., without the words " or order," the bill was nevertheless assignable by A. B., by further indorsement; Lord Mansfield and the Court of King's Bench in the case of Edie v. The East India Company (2 Burr. 1216), held that eridence of a contrary usage was inadmissible. In like manner in Grant r. Vaughan (3 Burr. 556), where a cash note, payable to bearer, had been lost by the owner but had been taken by the plaintiff bond fide for value, on an action on the note by the latter against the maker, Lord Mansfield having left it to the jury to say "whether such drafts as this, when actually paid away in the course of trade dealing and business, were negotiable or in fact and practice negotiable," and the jury, influenced no doubt by the natural desire to protect the owner of the note, having found for the defendant. Lord Mansfield and the court here again set the verdict aside, on the ground that, the law having been settled by former decisions that notes payalle to bearer passed by delivery to a bona fude holder, the judge ought to have directed a verdict for plaintiff.

If we could see our way to the conclusion that, in holding the scrip in question to pass by delivery, and to be arailable to bearer, we were giving effect to a usage incompatible either with the common law or with the merchant as incorporated into and embodied 
in it, our decision would be a very different one from that which we are about to pronounce. But so far from this being the case, we are, on the contrary, in our opinion, only acting on an established principle of that law in giving legal effect to a usage, now become universal, to treat this form of security, being on the face of it expressly made transferable to bearer, as the representative of money, and as such, being made to bearer, as assignable by delivery. This being the conclusion at which we have arrived, the judgment of the Court of Exchequer will be affirmed.

Judgment affirmed. ${ }^{1}$

'See also on the subject of negotiable instruments, other than bills, notes and checks, Chalmers' Bills of Exchange Act (5th ed.), pp. 312-327; 2 Ames' Cases on Bills and Notes, pp. $744_{-7}-S_{4} ; 2$ Daniel on Neg. Inst., pp. 496-595, 730. 785. - ED. 


\section{ARTICLE II.}

\section{Form ANd Interpretation.}

\section{(i) Form Required.}

\section{Writing and signature.}

5 Barnewall \& Creswell (K. B.), 234.- - I826.

Assumpsit by the plaintiff as indorsee against the defendant as maker of a promissory note for the sum of $30 l$. payable two months after date to the order of one Folder, and indorsed by him, Folder, to one Kemp, who subsequently indorsed the note to the plaintiff. At the trial before Abbott, C. J., at the London sittings after Hilary term, I 825 , it appeared that the indorsement by Kemp to the plaintiff was in pencil, and it was thereupon objected that the plaintiff could not recover; an indorsement in fencil not being such an indorsement as the law and custom of merchants recognizes to be sufficient to pass the interest in a till of exchange, and promissory notes being by the statute 3 and 4 Ann, C. 9 , $\$$, assignable or indorsable in the same manner as unpaid bills of exchange are according to the custom of merchants. The Lord Chief Justice thought it sufficient, and directed the jury to find a verdict for the plaintiff, reserving liberty to the defendant's counsel to move to enter a nonsuit, if the court should be of opinion that the indorsement of the promissory note in pencil was not a good and valid indorsement.

Аввотт, C. J. - There is no authority for saying that where the law requires a contract to be in writing, that writing must be in ink. The passage cited from lord Coke shows that a deed must be written on paper or parchment, but it does not show that it must be written in ink. That being so, I am of opinion that an inclorsement on a bill of exchange may be by writing in pencil. There is not any great danger that our decision will induce individuals to adopt such a mode of writing in preference to that in general use. The imperfection of this mode of writing, its being so subject to obliteration, and the impossibility of proving it when it is obliterated, will pre- 
vent it being generally adopted. There being no authority to show that a contract which the law requires to be in writing should be written in any particular mode, or with any specific material, and the law of merchants requiring only that an indorsement of bills of exchange should be in writing, ${ }^{*}$ without specifying the manner with which the writing is to be made, I am of opinion that the indorsement in this case was a sufficient indorsement in writing within the meaning of the law of merchants, and that the property in the bill passed by it to the plaintiff.

BArLer, J. - I think that a writing in pencil is a writing within the meaning of that term at common law, and that it is a writing within the custom of merchants. I cannot see any reason why, when the law requires a contract to be in writing, that contract shall be roid if it be written in pencil. If the character of the handwriting were thereby wholly destroyed, so as to be incapable of proof, there might be something in the objection; but it is not thereby destroyed, for, when the writing is in pencil, proof of the character of the handwriting may still be given. I think, therefore, that this is a valid writing at common law, and also that it is an indorsement according to the usage and custom of merchants; for that usage only requires that the indorsement should be in writing, and not that that writing should be made with any specific materials.

Holroyd, J., concurred.

Rule discharged. ${ }^{1}$

$\S 20$

REG. $\imath$. HARPER.

$[\S \mathbf{I}]$

L. R. 7 Quees's Bench Division, 78, - I88I.

[Court for Crown Cases Reserved.]

INDICTMENT for forging an indorsement to a bill of exchange. John Watson \& Son drew a bill on Harper, but did not sign it. Harper accepted it, forged the indorsement of John Hunt, and returned it. Watson and Son indorsed it and placed it in bank for collection.

* See custom stated in Lutwyche, 878.

1 Accord: Broten v. Butchers, eti, Bank, 6 Hill (N. Y.) 4+3, fost, p. I64; Closson v. Stiarns, + Vt. II; Recdr. Rourk, it Tex. 329. Where an acceptance of a bill is required by statute to be in writing (Neg. Inst. L.. \$ 220 [132]), a telegraphic acceptance satisfies the statute. Garrttson v. North Atchison Bank, 39 Fed. Rep. I63; 47 Fed. Rep. 567; 5I Fed. Rep. I68.

A negotiable instrument may be drawn in any language. Ri. Marseilles Co., L. R. $30 \mathrm{Ch}$. D. 59 \&. - ED. 
They did not at any time sign it as drawers. The following is a copy of the bill:

£22 10s. 4 d.

KILMARNOCK, 2 H'r', ISSO.

One month after date pay to me or order the sum of $£ 22$, Ios. 4 d., that being for value received in machinery.

To Mr. J. HARPER, Etc.

[Across the face]: Accr d payable at the Union Bank of London. JoHs HARPER.

[Indorsed]: John Hust. JohN Watsox \& Sox.

Harper was convicted and sentenced, but execution of the sentence was suspended till the decision of the case by the Court for Crown Cases Reserved.

Lord Coleridge, C. I. - The conviction cannot be sustained. The instrument was not a bill of exchange; it was an inchoate bill of exchange. The point requires no authority, though it has the authority of the cases of McCall v. Taylor (34 L. I. C. P. 365); Stoessiger v. South Eastern Ry. Co. (3 E. \& B. 549); Pcto v. Reynolds (23 I. J. Ex. 98; 9 Ex. 4Io; I I Ex. 4 I8); and Rex v. Pateman (Russ \& Ry. 455).

STEPHEx, J.- Though I entirely agree with the opinion expressed by my Lord, I cannot help observing that the act of the prisoner has all the effect of a forgery punishable under the statute as a felony; the prisoner could, however, have been indicted, and ought to have been indicted, for forgery at common law.

Grove, Hawkins and Lopes, JJ., concurred.

Conviction quashed. ${ }^{1}$

I Strange (K. B.), 399.- I720.

IN CASE upon a promissory note the declaration ran, that the defendant made a note, et mame sua propria scripsit. Exception was taken, that since the statute he should have said that the defenclant signed the note, but the Court held it well enough, because laid to be wrote with his own hand, and there needs no subscription in that case, for it is sufficient his name is in any part of it. I. J.S. promise to pay, is as good as I promise to pay, subscribed $\int . S^{*} * 2$

1 Accord: Tizis v. Youns, I Metc. (Ky.) I97: Heman v. Francisco, 12 Mo. App. 560 . - ED.

* Iide Eliot v. Couper, I Strange, 6og.

${ }^{2}$ Accord: Quinv. Sterne, 26 Ga. 223. The courts make a elear distinction between the statutory requirement that an instrument shall be "signed" and the requirement that it shall be "subseribed."-James 5. Pattin, 6 N. Y. 9. - ED. 


$$
6 \text { Hill (N. Y.), 443. }-\mathrm{IS}_{4}
$$

On ERror from the Superior Court of the city of New York, where the Butchers and Drovers' Bank sued Brown as the indorser of a bill of exchange, and recovered judgment. The indorsement was made with a lead pencil, and in figures, thus, "I. 2. 8." no name being written. Evidence was given strongly tending to show that the figures were in Brown's handwriting, and that he meant they should bind him as indorser; though it also appeared he could write. The court below charged the jury that, if they believed the figures upon the bill were made by Brown, as a substitute for his proper name, intending thereby to bind himself as indorser, he was liable. Exception. The jury found a verdict for the plaintiffs below, on which judgment was rendered, and Brown thereupon brought error.

By the Court, Neuson, Ch. J. - It has been expressly decided that an indorsement written in pencil is sufficient; (Geary v. Physic, 5 Barn. \& Cress. 234); and also that it may be made by a mark. (George v. Surrev, I Mood. \& Malk. 516). In a r_cent case in the K. B. it was held that a mark was a good signing within the statute of frauds; and the court refused to allow an inquiry into the fact whether the party could write, saying that would make no difference. (B zker v. Dening, 8 Adol. \& Ellis, 94; and see Harrison v. Harrison, 8 Ves. r86; Adldy v. Grix, id. 504.)

These cases fully sustain the ruling of the court below. They show, I think, that a person may become bound by any mark or designation he thinks proper to adopt, provided it be used as a substitute for his name, and he intend to bind himself.*

Judgment affirmed.

\section{Unconditional promise or order to pay a sum certain in money.}

\section{i. A Note Must Contain a Promise.}

$$
\text { GAY i'. ROOKE. }
$$

$$
\text { I5I MASSACHUSETTS, II 5. - I8go. }
$$

Contract on the following instrument, declared on as a promissory note:

Marlboro', Sept. 23, issi. dolls. 5-100 for value received.

I. O. U., E. A. Gay, the sum of seventeen JoH: R. RoOKE.

Writ dated September I 9, $x S_{7}$. At the trial in the Superior Court, without a jury, before Dewey, J., the only issue was whether the 
plaintiff was entitled to interest from the date of the instrument, or from that of the writ, the service of which was the only demand made by the plaintiff.

The plaintiff asked the judge to rule, as a matter of law, that he was entitled to interest from the date of the instrument. The judge declined so to rule, and ruled that interest could be recorered from the date of the writ only, and found for the plainteff for $s_{1} .05$ only; and the plaintiff alleged exceptions.

Devens, J. - In order to constitute a good promissory note there should be an express promise on the face of the instrument to pay the money. A mere promise implied by law, founded on an acknowledged indebtedness, will not be sufficient. (Storr, Prom. Notes, \$ 14; Brouin v. Gilman, I3 Mass. I5s.) While such promise need not be expressed in any particular form of words, the language used must be such that the written undertaking to pay may fairly be deduced therefrom. (Commonatealth Ins. Co. v. Whitney. I Met. 2r.) In this view the instrument sued on cannot be considered a promissory note. It is an acknowledgment of a lebt only, and, although from such an acknowledgment a promise to pay may be legally implied, it is an implication from the existence of the debt, and not from any promissory language. Something more than this is necessary to establish a written promise to pay money. It was therefore held in Gray v. Bowden (23 Pick. 282 ), that a memorandum on the back of a promissory note, in these words, "I acknowledge the within note to be just and due," signed by the maker and attested by a witness, was not a promissory note signed in the presence of an attesting witness within the meaning of the statute of limitations. In England an I. O. U., there being no promise to pay embraced therein, is treated as a due bill only. The cases, which arose principally under the Stamp Act, are very numerous, and they have held that such a paper did not require a stamp, as it was only evidence of a debt. (1 Danl. Neg. Inst. $3 \mathrm{~d}$ ed. $\$ 3^{6 ;}$ i Randolph, Com. Paper, $\$ 88 ;$ Fesenmayer v. Adcoli, , 6 .I. \& W. 449; Melanotte v. Teasdale, I3 M. \& W. 216; Smith r. Smith, I F. \& F. 539; Gould v. Coombs, I C. B. 543; Fisher v. Lestic, I Esp. 425 ; Israd v. Isracl, 1 Camp. 499; Childers v. Boulnois, Iowl. \& Ry. N. P. 8; Beeching v. Westhroke, S M. \& W. +1,.)

While in a few States it has been held otherwise, the law as grenerally understood in this country is, that, in the absence of any statute, a mere acknowledgment of a debt is not a promissory note, and such is, we think, the law of this Commonwealth. (Gray' v. Bonden, 23 Pick. 282; Commontealth Ins. Co. v. Whitnel, 1 Met. 21; Daggett v. Daggett, 124 Mass. 1 49 ; Almy v. Minslun', г26 Mass. 
342 ; Carson v. Lucas, I3 B. Mon. (Ky.) 213; Garland v. Scott, I5 La. Ann. I43; Currier v. Lockwood, 40 Conn. 349; Brenzer v. Wightman, 7 Watts \& Serg. 264; Biskup v. Oberlc, 6 Mo. App. 5.3.) Some States have by statute extended the law of bills and promissory notes to all instruments in writing whereby any person acknowledges any sum of money to be due to any other person. ( I Randolph, Com. Paper, s8; Rez'. Sts. Ill. I 884 , c. 98, $\$ 3 ;$ Gin. Sts. Col. I $88_{3}$, c. 9,

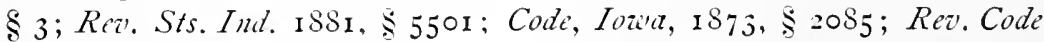
Miss. I $880, S S$ I 123 , I 124 .)

We have no occasion to comment upon those instruments in which words have been used or superadded from which an intention to accompany the acknowledgment with a promise to pay has been gathered, or where the form of the instrument fairlyled to that conclusion. (Daggett v. Daggett, I24 Mass. 149; Almy v. ITinslow', I 26 Mass. 342.) No such words exist in the instrument sued, nor is it in form anything but an acknowledgment. The words "for value received " recite indeed the consideration, but they add nothing which can be interpreted as a promise to pay. It is therefore unnecessary to consider whether, if the paper were a promissory note, interest should be calculated from its date. Upon this point we express no opinion. ${ }^{1}$ If it is to be treated as an acknowledgment of debt only, as we think it must be, the plaintiff is not entitled to interest except from the date of the writ. Even if it was the duty of the defendant to have paid the debt on demand, yet if no demand was made, if no time was stipulated for its payment, if there was no contract or usage requiring the payment of interest, and if the defendant was not a wrongdoer in acquiring or detaining the money, interest should be computed only from the demand made by the service of the writ. (Dodge v. Perkins, 9 Pick. 368; Hunt v. Nevers, I5 Pick. 500.) " In general," says Chief Justice Shaw, "when there is a loan without any stipulation to pay interest, and where one has the money of another, having been guilty of no wrong in obtaining it, and no default in retaining it, interest is not chargeable." (Hubbard v. Charlestow'n Rabload, I I Met. I24; Caltonv. Bragg, 15 East., 222; Shaz'v. Picton, 4 B. \& C. 7 I5; Moses v. Ma:ferlan, 2 Burr. I005; Whalker v. Constable, I Bos. \& P. 306.)

Exceptions overruled.

1 It seems that in the case of a negotiable instrument payable on demand, no interest being reserved, interest will run only from the date of demand. Scozil

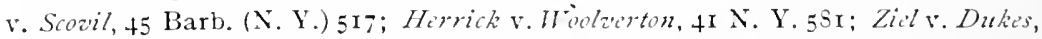
I Calif. 479. But bringing an action constitutes demand. Pierev. Fotheryill, 2 Bing. N. C. 167; Bank v. Dazidson, 70 N. Car. I18. Sees r 30 [70], post, and cases. - ED. 
5 DAY, (CONY) $337 .-1812$.

THIs was an action of assumpsit, originally brought by the defendant in error, against the plaintiffs in error.

The declaration was of the following tenor, aiz. "For that the defendants, in and by a certain writing or note, under their hands, by them well executed, dated the 3 oth day of August, A. D. I $\$ \circ 8$, promised the plaintiff to pay to him, for value received, the sum of ninety-four dollars, ninety-one cents, on demand; which is in the words following:

Due John Allen ninety-four dollars, 9r cents, on demand. LitchField, August 3oth, Isoos.

Joseph L. Silth, Seth P. Beers.

" Now the plaintiff further says, that the defendants, their promise aforesaid not regarding, have never performed the same," etc., "which is to the damage of the plaintiff the sum of Ioo dollars," etc.

To this there was a demurrer; and the Supreme Court adjudged the declaration sufficient, and rendered judgment for the plaintiff, for II dollars, 99 cents, and costs; and to reverse this judgenent, the present writ of error was brought.

Sulth, J. - This was a writ of error, brought by the defendants in the court below, to reverse a judgment rendered against them in that court.

The declaration was in common form, in assumpsit, counting upon a promissory note, and demanding $\$ 100$ damages. To this, there was a demurrer and joinder in demurrer. The writing counted upon, and recited in the declaration, was of the following tenor, viz.

Due John Allen ninety-iour dollars, gr cents, on demand.

Jostiril 1. Sintil. SETII P. BEERS.

Litchifield, $A$ uszust 30 , isos.

The court below adjudged the declaration to be sufficient and rendered judgment for the plaintiff, to recover i i dollars, 92 cents, damages.

On inspection of the record, it appears that judgment was rendered for a larger sum than is warranted by law, and therefore, on that ground, is clearly erroneous, and must be reversed.

But still, the question arises, whether this cause shall be remanded to the Superior Court? The decision of this question depends upon the sufficiency or insufficiency of the plaintiff's declaration: Because, if the instrument on which the action is brought, and which is recited in the declaration, will not sustain it, it will be useless to send the cause back for farther trial. 
On this subject, in my view, it is very clear, that where a writing contains nothing more than a bare acknowledgment of a debt, it does not, in legal construction, import an express promise to pay. It would not appear, from such a writing, that the parties intended the debt should be paid. Their meanng might be, in such case, merely to settle their accounts, in writing, with a view to further dealings.

But where a writing imports not only the acknowledgment of a debt, but an agreement to pay it, this amounts to an express contract.

From the writing in question, it is perfectly manifest that the debt acknowledged to be due was to be paid on demand, as fully, as if the words "to be paid" or "which we promise to pay," had been inserted next before the words " on demand."

I think, therefore, that the declaration is sufficient; and that the cause ought to be remanded for further proceedings.

The other judges severally concurred in this opinion.

Judigment reversed, and the cause remanded. ${ }^{3}$

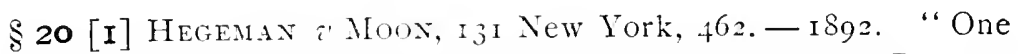
year after my death I hereby direct my executors to pay to A. B., etc., being the balance due him for cash adranced, etc." PEckHAM, I. "The acknowledgment of the indebtedness, and that it is due, implies a promise to pay it on demand. It is a promissory note within the statute. $* * *$ The direction is, however, in the nature of a promise and expresses a time of payment, and, therefore, excludes the presumption that it is payable immediately, which would otherwise arise from the use of the word dut."

\$ 20 [I] Schmitza. Hawkeye Goln Mining Co. (So. Dak.), 67 N. W. R. 618- I896. "Time Check, No. IS9. \$98.65. General Managers' Office, Hawkeye Gold Mining Company. Pluma, So. Dak., June roth, I 893 . Due W. C. Robinson the sum of ninety-eight dollars and sixty-five cents $(\$ 98.65)$, payable at this office, on the zoth day of June, $\mathbf{1} 893$, to him or order. Darid Hunter, General

1 "Due A. B. \$325 payable on demand," Kimball v. Huntington, ro Wend. (N. Y.) 675 ; "I. O. U. £20 to be paid on the $22 \mathrm{~d}$ instant," Brooks v. Elkins, 2 Meeson $\&$ Welsby, 74, accord. "Borrowed this day of A. B. £loo for one or two

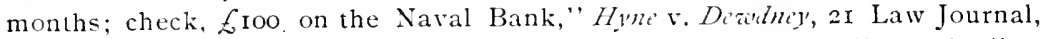
Q. B. 278 , contra. If the due bili have words of negotiation as "or order" or " or bearer," it is generally held to be a promissory note. Russell v. Whipple, 2 Cow. (N. Y.) 536; Sackett v. Spencer, 29 Barb. (N. Y.) I So. - Ed. 
Manager, by L. A. Fell. W. C. Robinson." [Indorsed] “W. C. Robinson." Fuller, J. - " As the writing before us is negotiable in form, and the signer, in legal effect, promises to pay a specified sum of money, we conclude that the instrument is a promissory note, and that appellant's [Robinson's] liability was only that of an indorser. The words "payable to IV. C. Robinson or order, unconditionally, at a specified time and place, a certain amount of money, import a promise; and the instrument contains every essential element of a promissory note. $* * *$ There was no allegation in the complaint nor proof at the trial by which to charge appellant, as an indorser or otherwise."

\$20 [I] Hussey a. Winslow, 59 Maine, 170.- is7o. "Nobleboro, Oct. 4, I 869 . Nathaniel O. Winslow, $C r$. By labor $16 \frac{3}{4}$ days (c) $\$ 4$ per day, \$67.00. Good to bearer. William Vannah." DANFORTH, J. - " It would seem that the only possible construction which can be given to this instrument is, substantially, this: In consideration of $16 \frac{3}{4}$ days' labor, performed by Nathaniel $O$. Winslow. at $\$+$ per day, amounting to $\$ 67.00$, I promise to pay him, or bearer, that sum on demand. Signed, William Vannah. Here we have every element of a negotiable promissory note; a maker, a payee, a promise or engagement to pay a certain sum of money at a specified time, absolutely and unconditionally, and the word bearer to make it negotiable."

\$20 [I] Hamett $i$. Brown, 4t So. Car. 397. - IS95. (I) " $\$ 3,53$. This is to show that I have received from my father, as so much interest in his estate, a tract of land containing 353 acres, known as the Gore's Meeting House tract, for which I account to the estate for $\$ 3,53 \circ$, for which I promise to pay C. B. Hammett, during his lifetime, seven per cent. per annum interest, to begin the ist day of next December, then the interest to be paid the ist day of each December thereafter, which is value received, this May 2Sth, I885. (Signed) Agnes Brown. Test. J. F. Sloan." (2) "This is to show that my father has advanced me $\$ 500$ in cash as so much advanced on his estate, for which I have to pay interest

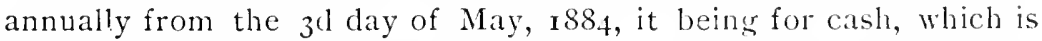
value received this 28 th day of May, $188_{5}$. (Signed) $\Lambda$ gnes Brown. Test. J. F. Sloan." Mr. Justice Gary. - "Appellant's first exception complains of error on the part of the presiding judge in holding and charging that the causes of action sued on were notes. This was substantially the decision rendered by this court in the 
case of Hammettr. Hammett ( $3^{8}$ S. C. $\left.5^{\circ}\right)$. This exception is, therefore, overruied. The second exception complains of error on the part of the presiding judge in holding and charging that the causes of action matured at the death of testator. The instruments of writing show that the presiding judge was correct in so charging, and this exception is also overruled. The third exception complains of error on the part of the presiding judge in holding and charging that the causes of action were payable to the estate of the testator. We do not see how it can even admit of question that the money was due to the estate of the testator in the absence of a contrary showing. This exception is also overruled. The fourth exception complains of error on the part of the presiding judge in holding and charging that the defendant was due the estate the principal amount sued for, with interest from the death of the testator. We agree with the Circuit Judge in his construction of the instruments of writing. This exception is also overruled."

40 Connecticut, $3+9 .-$ I $8 ; 3$,

Assumpsit upon a written instrument, which the plaintiffs claimed was a promissory note, non-negotiable, and was not barred until seventeen years from its date. The trial court held it not a promissory note and that it was barred by the statute of limitations.

SEYMOUR, C. J.- The first question in this case is whether the writing sued upon is a promissory note within the meaning of those words in the statute of limitations. The statute is as follows: "No action shall be brought on any bond or writing obligatory, contract under seal, or promissory note not negotiable, but within seventeen years next after an action shall accrue." The instrument sued upon is as follows:

Bridgeport, Jan. 22nd, IS63, \$r7.i4. Due Currier and Barker seventeen dollars and fourteen cents, value received.

FREDERICK LOCKWOOD.

Promissory notes not negotiable are by the statute above recited put upon the footing of specialties in regard to the period of limitation, and for most other purposes such notes have been regarded as specialties in Connecticut. 'The instrtment, however, to which this distinction has been attached is the simple express promise to pay money in the stereotyped form familiar to all. The writing given in evidence in this case is a due bill and nothing more. Such acknowledgments of debt are common and pass under the name of 
due bills. They are informal memoranda, sometimes here as in England in the form "I. O. U." 'They are not the promissory notes which are classed with specialties in the statute of limitations. The law implies indeed a promise to pay from such acknowledgments, but the promise is simply implied and not express. It is well said by Smith, J., in Smith v. Allen (5 Day, 337), "Where a writing contains nothing more than a bare acknowledgment of a debt, it does not in legal construction import an express promise to pay; but where a writing imports not only the acknowledgment of a deht but an agreement to pay it, this amounts to an express contract."

In that case the words " on demand" were held to import and to be an express promise to pay. That case adopts the correct principle, namely, that to constitute a promissory note there must be an express as contra-distinguished from an implied promise. The words " on demand" are here wanting. The words "value received," which are in the writing signed by the defendant, cannot be regarded as equivalent to the words " on demand." The case of Smith v. Allen went to the extreme limit in holding the writing there given to be a promissory note, and we do not feel at liberty to go further in that direction than the court then went.

The writing then not being a promissory note, the plaintiff's action is barred by the six years' clause of the statute, unless revived by a new promise to pay.

A new trial is not advised.'

Park and Carpenter, JJ., concur. Foster and Phelps, JJ., dissent.

I 3 HOWAKD (U. S.) 218 . - I85I.

Action by indorsee against indorser, alleging due presentment, demand, notice and protest. Judgment for plaintiff. Defendant brings writ of error.

Upon the trial, the plaintiff offered the note in evidence, together with the protest, etc. Objection was taken, but the court overruled it and admitted the evillence. This was the subject of the first bill of exception.

The second exception was to the refusal of the court to grant certain prayers asked for by the defendant, of which it is only necessary to notice the following:

${ }^{1}$ Contra: Jacquin v. Wraren, 4o Ill. 459; Brady v. Chandler, 3 I Mo. 23. For criticism of Currie'r v. Lockwood, see I4 Am. L. Reg. N. S. 20. - Ev. 
Ist. That the paper offered in evidence is not a negotiable instrument under the laws of Ohio, and cannot be sued on by the plaintiff in the cause.

6th. That said paper offered in evidence is not a promissory note, nor is it a bill of exchange, but it is a mere certificate, acknowledging the receipt and deposit of paper or obligations of some kind, which are payable twelve months after ist May, s $8_{39}$, bearing interest at the rate of five per cent. till due.

Mr. Justice Catron delivered the opinion of the court.

The only question this case presents that we deem worthy of notice is, whether the paper sued on is a negotiable instrument; it is as follows:

No. 959. Mississipt Uxion Baxk,

Jackson, (Miss.) Feb. S, Is fo. I hereby certify, that Hugh Short has deposited in this bank, payable twelve months from Ist May, I\$39, with 5 per cent. interest till due, fifteen hundred dollars, for the use of Henry Miller, and payable only to his order upon the return of this certificate, \$I,500.

Whlliali P. Graysox, Cashier.

The suit was by the last indorsee against his immediate indorser, and brought in Ohio. The statute of that State declares all promissory notes, drawn for a sum certain, payable to any person or order, or to any person or his assigns, negotiable by indorsement.

The established doctrine is, that a promise to deliver, or to be accountable for, so much money, is a good bill or note. Here the sum is certain, and the promise direct. Every reason exists why the inclorser of this paper should be held responsible to his indorsee, that can prevail in cases where the paper indorsed is in the ordinary form of a promissory note; and as such note, the State courts generally, have treated certificates of deposit payable to order; and the principles adopted by the State courts in coming to this conclusion, are fully sustained by the writers of treatises on bills and notes. Being of opinion that the Circuit Court properly held the paper indorsed, negotiable, it is ordered that the judgment be affirmed. ${ }^{1}$

Accord: Pardie v. Fish, 60 N. Y. 265; Frank r. Wissels, $6+$ N. Y. 155; Batdsliy v. Weibir, Iot Mich. Ss; Kirkwood r. First Kat. Bk., to Neb. $+s_{+}$; Alauber v. Bigserstaff, +7 Wis. $55 \mathrm{I}$. The certificate of deposit is to be dislinguished from the " deposit slip," which is merely a receipt or memorandum, containing no promise, and requiring no return. First Nat. Bk. v. Clark, I34 N. Y. 368,372 .

For orders on savings banks, see White v. Cushing, 88 Me. 339, fost, p. 177. ED. 


\section{A Bill Must Contain an Order.}

2 SANDFORd's Sulerior CoURT ReP. (N. Y.) $328 .-18+9$.

Assumpsit on an order drawn upon the defendant, with the common courts. At the trial, it appeared that Smith and Woglom, builders, erected certain buildings for the defendant, in Williamsburgh, in 1847 . The plaintiff claimed to have tinned the roofs and put up the gutters for those buildings, and his bill for the work, rendered to $\mathrm{S}$. $\&$ W., amounted to $\$ 300.8 S$. They gave an order ou the defendant, written at the foot of the bill, as hereafter set forth. The order was presented by one Harris to the defendant, who said he could not pay it until lie went and saw how the buildings progressed. The plaintiff then proved by Harris, that two or three days afterwards the defendant met the latter at the buildings, and there promised to pay the order as soon as the sashes were put in, and those were put in early in January, is 48 .

The bill and order were read in evidence in these words, viz: -

Messrs. SMith AND Woglon, NEw YORK, I6th Dec., I $\$_{47}$

To C. H. Hoyt, Dr.

To tin roof, $86 \mathrm{ft} . \times 37 \mathrm{I}-2 \mathrm{ft} .3225 \mathrm{ft}$. (4) $7 \mathrm{I}-2 \mathrm{c} \ldots \ldots \ldots \ldots \ldots \$ \$ 24 \mathrm{I} . \mathrm{S}_{7}$

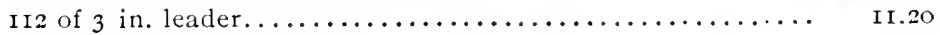

$s_{5} \mathrm{ft}$. of copper gutter, $4 \mathrm{~s} 6 \mathrm{~d} \ldots \ldots \ldots \ldots \ldots \ldots \ldots \ldots \ldots \ldots \ldots \ldots \ldots \ldots \ldots+4.8 \mathrm{I}$

$\$ 300.85$

Mr. J. Lynch

Williamsetirgh, Dec. i6, is 47 .

Please pay the above bill, being the amount for tinning your houses on South Sixth street, and charge the same to our account,

And much oblige yours,

SiIth \& Woglon.

By the Court. OAKLEr, Cr. J.- [After disposing of another matter.] There was another question argued, which must arise on a new trial, and it is right that we should express our views npon it at this time. It is said that the order upon which the suit is founded, is a bill of exchange, and that there is no written acceptance of the same.

On consideration, we have come to the conclusion that this is a bill of exchange. It is an order in writing, drawn ly one party on another, requesting the latter to pay a certain sum of money to a third party, at all events; depending upon no contingency, and payable out of no particular fund. It comes within the reason of the 
statute requiring a written acceptance to charge the drawee. It is true this order is not negotiable, but that is not necessary to make it a bill of exchange. ${ }^{2}$

New trial granted. ${ }^{2}$

$\$ 20$ [I] The King i. Ellor, I Leach, Crown Law, 323. - i 784. "Messrs. Songer, - Please to send $\mathcal{E}_{10}$ by the bearer, as I am so ill I cannot wait on you. Elizabeth Wery." Ellor was indicted for forging a bill of exchange. THE CouRT.- "This appears to be a mere letter, rather requesting the loan of money than ordering the payment of it. The terms of it do not import anything compulsory on the part of the drawee to pay it."

\$20 [I] Regina $\because$. Bartlett, 2 Moody \& Robinson, 362. - I34I. "To Mr. G. Peckford: Please to pay to your order the sum of forty-seven pounds for value recenvel. J. Bishop." Indorsed: "J. Bishop." Bartlett was indicted for forging a bill of exchange. It was objected for the prisoner that this could not be called a bill of exchange; it was nothing more than a request to a man to pay himself, and the acceptance of such a document laid the acceptor under no obligation to a third party. "ERskine, J., said he should reserve the point for the consideration of the judges, and left the case to the jury, who convicted the prisoner; and he was sentenced to transportation. His Lordship, however, afterwards thought the objection so clearly valid, that he did not submit the case to the judges, but recommended a pardon for the offence."

Commonifalth v. Butterick, ioo Mass. 12. - i868. “Three months after date pay to the order of myself eight hundred and fifty dollars, value received, and charge the same to the account of your obedient servant, J. S. Butterick. To J. S. Butterick, Sterling Mass." [On the face]: "Payable at the Lancaster N. Bank, J. S. Butterick." [Indorsed]: “J. S. Butterick." “J. M. Stevenson." Indictment for forging the name of J. M. Stevenson to a bill of exchange.

${ }^{1}$ See Mehlhers v. Tisher, 24 Wis. 607. post. - ED.

2 Norris v. Soloman, 2 Moody \& Robinson, 266. - r\$40. “Mr. Samuel Soloman: Dr. to R. Norris [here follows a statement of the account]. Mr. Solomon, - Please 10 pay the above account to Messrs. Oliver \& Son, 7 Lawrence Lane, and oblige, yours respectfully, R. Norris." Maule, J. -- "I am of opinion that this is not a bill of exchange, nor anything like one." - ED. 
Foster, J. - "Upon principle, as well as by the authorities cited by the attorney-general, we entertain no doubt that an order for the payment of money, drawn by one in his own favor on himself, and by himself accepted and indorsed, may be treated as a bill of exchange, and so described in an indictment. Such instruments are well known in commerce; especially in the case of mercantile firms which have branches in different cities, all composed of the same partners. Perhaps such a bill may also be declared upon as a promissory note. But we agree with the court of Queen's Bench in the latest Engrlish case on the question, decided in $\mathbf{r} \delta_{\mathbf{5} 2}$, that 'it is not unjust to presume that it was drawn in this form for the purpose of suing upon it either as a promissory note or a bill of exchange.' (Lloy'd v. Olizer, is Q. B. 47.) It is sufficient that the instrument was in the form of, and purported to be, a bill of exchange; and the defendant might be convicted of forging this indorsement, if all the other names were also forged or were those of fictitious personages."

\$ 20 [I] RufF i'. Webe, I Espinasse, I 29. - I 794. " Mr. Nelson will much oblige Mr. Webb by paying I. Ruff, or order, twenty guineas on his account." "LoRD Kexros said, that he was of opinion, that the paper offered in evidence was a bill of exchange; that it was an order by one person to another, to pay money to the plaintiff or his order, which was in point of form a bill of exchange."

\$ 20 [I] Little í. Slackford, Moody \& Malkin, i7 I. - I 828. “Mr. Little: - Please to let the bearer have seven pounds, and place to my account, and you will oblige, your humble servant, $R$. Slackford." - Lokd Texterden, C. I. - “'The paper does not purport to be a demand made by a party having a right to call on the other to pay. The fair meaning is, "you will oblige me by doing it.' "'

1"Thomas Williams, Esq. - Please let the bearer have $\$ 50 . \quad$ I will arrange it with you this noon. Yours, most obedient, S. R. Biesenthall," was held to be a bill of exchange. Bie'senthall v. Williams, I Duvall (Ky.) 329, IS64. Words of civility do not prevent the instrument from being an order. "Thatliy v. Strobe, I2 Cal. 92.

By the law merchant a bill of exchange need not be payable to order or bearer, or have the words value received, or be payable at a day certain or at any particular place. Thus: "To Hoxie \& Rich: Please pay w Chas. Mehlberg the sum of $\$ 69.20$, and charge to me. Chas. Tisher," is a bill of exchangre by the law merchant. Hehlbers v. Tisher, $2+$ Wis. 607. See $\$ 25[0]$, fost. - E1). 


\title{
3. The Promise or Order Must Be Unconditional.
}

(a) Conditional promises or orders are not negotiable.

\section{$\S 20$}

\author{
BLAKE $\approx$. COLEMAN.
}

22 Wiscossin, $396 .-1868$.

Complaint on a promissory note; answer, a general denial. On the trial, the instrument was put in evidence, and was on its face a promissory note in the usual form, signed by defendant and running to plaintiff, but endorsed thereon were the following words, without date or signature: “The conditions of the within note are as follows: L. S. Blake or bearer is not to ask or expect payment of said note until his, Coleman's, old mill is sold for a fair price." This was admitted in evidence against defendant's objection. Defendant testified that the indorsement was made before the note was signed; that the note was given for a fanning mill purchased of plaintiff; and that he (defendant) had a fanning mill on hand at the time he gave it. Defendant offered to show by parol that the agreement was that plaintiff should dispose of the old mill, and that it had not been disposed of, but was still in defendant's possession, and plaintiff had never demanded it nor offered to dispose of it; but this evidence was rejected as tending to vary the terms of the written instrument. Judgment for the plaintiff; from which the defendant appealed.

Paine, J. - The court below erred in holding that the instrument on which the action was brought was not affected by the indorsement on the back, but was admissible as a mere promissory note. It may be shown by parol that the indorsement was on the note at the time it was signed. And that being so, it became a part of it, and turned it into a mere agreement. (Chitty on Bills [Sth ed.] pp. I60-6I ; Lecls v. Lancashire, z Campb. 205 ; Hurtley v. Milkinson, 4 Id. I 27 ; Cookv. Kelse'r, i 9 N. Y. 4I5.) As this condition qualified the note, the action could not be sustained without showing that it had been fulfilled. We are inclined to think the legal effect of the indorsement is, that the owner of the old fanning mill was to sell it; and that parol evickence would be incompetent to show that it was agreed that plaintiff should sell it. But for the reason above stated, the judgment must be reversed, and the cause remanded for a new trial.

By the Court. - Ordered accordingly. 
WHITE $\tau^{\prime}$. CUSHING.

S8 MAINE, 339. - I896.

Assumpsit on an order. The trial court ruled that the order was negotiable and the action could be maintanied in the name of White by a simple indorsement by Lawler. Defendant excepted.

Foster, J. - The plaintiff sues as indorsee of an order signed by the defendant of the following tenor:

\$1 20.

DOVer, Oct. 27, I893.

Piscataguis Savings Bank.

Pay James Lawler, or order, one hundred and twenty dollars, and charge to my account on book No. -

J. N. Cushisig.

Witness .

The bank book of the depositor must accompany this order.

The order was indorsed in blank on the back by James Lawler and Samuel Lewis, and the plaintiff claimed to recover against the defendant as upon a negotiable instrument. The real question presented is whether the instrument declared on is negotiable, so that an action may be maintained upon it in the name of the indorsee.

To constitute a negotiable draft or order, it must be a written order from one party to another for the payment of a certain sum of money, and that absolutely, and without any contingency that would embarrass its circulation, to a third party or his order or bearer.

It has often been held that a bill or note is not negotiable if made payable out of a particular fund. But there is a distinction between such instruments made payable out of a particular fund, and those that are simply chargeable to a particular account. In the latter case, the payment is not made to depend upon the adequacy of that fund, the only purpose being to inform the drawee as to his means of rembursement, and the negotiability of the instrument is not affected by it.

The objection that is raised to the negotiability of this instrument is, not that it is made payable out of a particular fund, but that it is subject to such a contingency as necessarily embarrasses its circulation and imposes a restraint upon its negotiability, by means of these words contained upon the face of the order: "The bank book of the depositor must accompany this order." Although these words are upon the face of the order below the signature of the drawer, they were there at the time of its inception, became a substantive part of it and qualified its terms as if they had been inserted in the body of the instrument. (Littlefield $v$. Coombs, i M Maine, r 10 ; Cushing v. Field, 70 Maine, 50, 54; Johnson v. Heagan, 23 Maine, 329; Barnard v. Cushing, 4 Metcalf, 230 ; Helwood v. Perrin, Io Pick. 228; 
Benedict v. Cowden, 49 N. Y. 396; Costelo v. Crowell, 127 Mass. 293, and cases there cited.)

Was the order negotiable? The answer to that depends upon the effect of the words "The bank book of the depositor must accompany this order." If not negotiable, the plaintiff as indorsee cannot maintain an action upon it. (Noyes v. Gilman, 65 Maine, 589.) If their effect is such as constitutes a contingency in relation to the payment of the order, dependent upon the production of the drawer's bank book by the holder or indorsee of the order, then they must be regarded as such an embarrassment to the negotiation of the order, and such a restriction upon its circulation for commercial purposes as to render it non-negotiable.

Without these words the order is payable absolutely, and there is no apparent uncertainty affecting its negotiability. With them, the order is payable only upon contingency, or condition, and that is upon the production of the drawer's bank book. This is rendered imperative from the language employed, and the bank upon which the order is drawn, would have the right to insist upon such production of the book in compliance with the terms of the order; and the case shows that it has refused payment upon presentation of the order for the reason that it was not accompanied by the bank book. It cannot, therefore, be regarded as payable absolutely and without any contingency that would embarrass its circulation. The drawer has it in his power to defeat its payment by withholding the bank book. Certainly the bank book of the depositor is within his own control rather than that of the indorsee of this order.

It was the necessity of certainty and precision in mercantile affairs and the inconveniences which would result if commercial paper was incumbered with conditions and contingencies, that led to the establishment of an inflexible rule that to be negotiable they must be payable absolutely and without any conditions or contingencies to embarrass their circulation. (American Ex. Bank v. Blanchard, 7 Allen, 333.) In that case the words, " subject to the policy," being included in a promissory note, were held to render the promise conditional and not absolute, and so the note was held not to be negotiable. (Noyes v. Gilman, 65 Maine, 589, 59I; Hubbard v. Mosely, I I Gray, 170.)

A case in every essential like the one we are considering was before the Supreme Court of Pennsylvania in r89r. A fac simile of the order is given in the opinion. No two cases could be nearer alike. There, as here, the order was drawn on a savings bank. The suit was by the indorsee against the drawer as in this case. There, as here, the order contained a statement upon its face, but below the 
signature of the drawer, that the " Deposit book must be at bank before money can be paid." In discussing the question of its negotiability cases are cited from the courts of Maine, Vermont, Massachusetts and New lork, as well as from Pennsylvanis. In the course of the opinion the court says:

"It sufficiently appears from the memoranda on its face that it was drawn on a specially leposited fund held by the bank subject to certain rules and regulations, in force between it and the depositor, requiring certain things to be done before payment could be required, viz.: previous notice of depositor's intention to draw upon the fund, return of the notice ticket with the order to pay, and the presentation of the deposit book at the bank, so that payment might be entered therein. **** It is, in substance, merely an order on the dollar savings bank to pay J. W. Quinn, or order, nine hundred dollars in nine weeks from date, or February i, I 888 , provided he or his transferee present to the bank, with the order, the notice ticket, and also produce at and before the time of payment the drawer's deposit book. As already remarked, these are undoubtedly prerequisites which restrain or qualify the generality of the order to pay as contained in the body of the instrument. They are also prerequisites with which it may be difficult, if not sometimes impossible, for the payee, transferee, or holder of such an order to comply." (Iron City Wat. Bank v. McCord, I39 Pa. St. 52, 23 Am. State Rep. I66.)

The order in question was drawn upon a savings bank, and it is common knowledge that all such banks in this State have a by-law which all depositors are required to subscribe to, that " no money shall be paid to any person without the production of the original book that such payment may be entered therein."

This court in the case of Sulliz'an v. Leziston Inst. for Sazings (56 Maine, 507), has considered the purpose and necessity of these salutary regulations. We should be slow to countenance any departure from this rule needed for the protection of depositors in our savings banks now numbering more than 160,000 , and where deposits aggregate nearly $\$ 60,000,000$.

Inasmuch as this order is not negotiable and no suit can be maintained upon it by the plaintiff as indorsee, it becomes unnecessary to consider the other exceptions.

Exceptions sustained. ${ }^{1}$

\footnotetext{
${ }^{1}$ See also the cases and authorities, post, pp. 228 et seq.- ED.
} 
(b) An order or promise to pay out of a particular fund is conditional.

4 Denio (N. Y.) $159 .-18+7$.

Assumpsit. On the trial the plaintitt gave in evidence an agreement, signed by the defendants, bearing date October $12,18_{39}$, by which, for value received, they jointly and severally promised to pay to the plaintiff, by his name or order, $\$ 25^{\circ}$, with interest, payable one-half in two years and the other half in three years from the day of said agreement, " out of the net proceeds, after paying the cost and expenses of ore to be raised and sold from the bed on the lot this day conveyed by Edward Madden to Edwin Dodge, which bed is to be opened and the ore disposed of as soon as conveniently may be."

On reading the agreement the plaintiff rested, and the defendants moved for a nonsuit, as the plaintiff had not shown that the defendants had received enough from the ore to pay the note, nor had they shown any default or negligence on their part. The judge held that the plaintiff could not recover without proving that the defendants had received funds from the ore to enable them to pay, or had neglected to work the ore bed, and directed a nonsuit.

The plaintiff excepted.

By the Court, Beardsley, J. - The nonsuit was proper. A promissory note must be payable absolutely, and not upon any contingency as to time or event. (3 Kent, 5 th ed. p. 74; Smith on Merc. Law, I1 3,116 ; Story on Prom. Notes, s. I, 22 to 26 ; Id. on Bills of Exch. $\$ \$ 46,47$; Chit. on Bills, roth Amer. ed., p. 132 to I39.)

This was not such an engagement, for although the promise was to make payments at certain specified times, the payments were to be made "out of the net proceeds" "of ore to be raised and sold" from a certain ore bed. Here was a contingency; the fund might turn out to be inadequate, in which case there would be no obligation to pay at any time. It is not a promise to pay " absolutely and at all events," as a promissory note always is.

New trial denied. ${ }^{1}$

1 "Please pay A. B., or order, $\$ 500$, for value received, . . . out of the proceeds of the claim against the Peabody Estate, now in your hands to collect, when the same shall have been collected by you," is not a negotiable instrument, as the money is payable out of a particular fund. Richardson $v$. Carpenter, $46 \mathrm{~N} . \mathrm{Y} .66 \mathrm{o}$.

"You will please pay to A. B. the amount of a note for $\$ 2,000$, dated December 3Ist, I868, and deduct the same from my share of the profits of our partnership business in malting," is not a bill of exchange, for it is payable out of an uncertain fund, from profits. Munger v. Shannon, 6r N. Y. 251. - ED. 
7 Metcalf (Mass.), $588 .-18+4$.

Ixdebitatus assumpsit on the common money counts. Plea, the general issue. Trial in the court of common pleas.

The plaintiff, to maintain the issue on his part, offered in evidence the following instrument:

New Ashford, March i3th, is to.

For value received, I promise to pay John Pero, or bearer, five hundred and seventy dollars, it being for property I purchased of him in value at this date, as being payable as soon as can be realized of the above amount for the said property I have this day purchased of said Pero, which is to be paid in the course of the season now coming.

Bushrod Buck.

The defendant objected, that this instrument was not a negotiable note, and therefore could not be given in evidence by the plaintiff in this action brought in his own name. The court decided that said instrument was a negotiable note transferable by delivery, and the same was given in evidence to the jury, who returned a verdict thereon for the plaintiff. The defendant alleged exceptions to said decision.

Shaw, C, J. - The true test of the negotiability of a note seems to be, whether the undertaking of the promisor is to pay the amount at all events, at some time which must certainly come, and not out of a particular fund, or upon a contingent event. If it were payable on a contingency, or out of a particular fund, it would not be negotiable. This note, we think, was payable by the promisor at all events, and within a certain limited time. The note is obscurely written and ungrammatical. But we think the meaning was this: that the signer, for value received in the purchase of property, promised to pay Pero or bearer the sum named, as soon as the termination of the coming season, and sooner, if the amount could be sooner realized out of the fund. Such reference to the sale of the property was not to fix the fund from which it was to be paid, but the time of payment. The undertaking to pay was absolute, and did not depend on the fund. So as to the time, whatever time may be understood as the "coming season," whether harvest time or the end of the year, it must come by the mere lapse of time, and that must be the ultimate limit of the time of payment.

Exceptions overruled. 


$$
56 \text { Iowa, 96. - I } 88 \mathrm{I} \text {. }
$$

Action on the following instrument in writing:

$\$ 100$

Audubon Tr., Audubon Co., Iowa, April 26, is78.

One year after date I promise to pay to the treasurer of the National Iron Fence Co., of Cedar Rapids, Iowa, or order, one hundred dollars, at Cedar Rapids, Iowa, value received, with interest at ten per cent. from date. Reasonable attorney fee if suit be instituted on this note. If this agent does not sell enough in one year, one more is granted.

[Signed.]

There was judgment for the defendant and the plaintiff appeals.

Seevers, J. - The only question to be determined is whether the instrument sued is negotiable. The appellee insists it is not, because of the italicized words. The appellant insists the instrument is not payable out of a certain fund, and is payable at the expiration of two years from date, if not sooner, and is, therefore, negotiable.

We think the true construction is that the maker was the agent of the payee for the sale of something, and if he realized sufficient funds from such sales the amount specified was to be paid within one year. Payment during such time was to be made only on condition that the necessary funds were realized. This clearly implies the instrument was to be paid out of a particular fund, and for this reason, and because payable only on the happening of a condition, it was not negotiable during the period aforesaid. It is true it is payable absolutely at the expiration of two years. But we think it must have been negotiable when executed, and continuously from that time, or not at all.

No adjudicated case to which our attention has been called is precisely like this. The nearest approach to it is Cota v. Buck (7 Met: 588). It is difficult to draw a sharp distinction between the two cases. We shall not, therefore, make the attempt, but determine the case at bar upon principle, as we deem right.

Affirmed.

DAY, J., dissenting. - I cannot concur in the foregoing opinion. It cites no authority and is in conflict with Cota $v$. Buck (7 Met. 588 ), to which it refers. In my opinion the instrument in question possesses all the elements of negotiability. The italicized portion does not render the note payable out of a particular fund, but simply provides a condition upon which the payment shall be extended one year. The note may be payable in one year. It is payable abso- 
lutely in two years. In my opinion the plaintiff should have recovered.

ADams Ch. J., concurs in this dissent. ${ }^{1}$

\section{(c) An indication of a particular fund does not render promise} conditional.

IOI NEW York, $554-1856$.

RUGER, Ch. J. - The plaintiff claimed to recover as the holder of a draft drawn upon and accepted by the defendant, reading as follows:

\section{New York, February, 26 187\%.}

Mr. ADAM Simox, executor, will please pay to Johannes Schmittler or his otder, on the first day of July, which will be in the year $15 \% 9$, the sum of \$9oo, with seven per cent. interest, to be paid besides this amount yearly, July month, and charge the amount against me and of my mother's estate.

Willimi J. Schares.

[Written upon the face]: Accept, ADm Simox, exicutor; [and indorsed]: Pay to the order of Mary Schmittler, the amount of note. JohANises Schamt ter.

Upon the trial, after proving the execution of the draft, its acceptance and transfer, and offering to prove the payment of a consideration by the plaintiff to the payee, which was objected to by defendant, and excluded by the court, the plaintiff rested. The defendant thereupon mored to nonsuit upon the ground that the obligation was not binding upon the defendant personally, but he was liable thereon, if at all, in his representative character alone, and that it was payable out of a specific fund, and a recovery thereon could not be had without proving the existence and extent of such fund. The court thereupon nonsuited the plaintiff, to which decision she excepted. The General Term having affirmed the determination of the trial court, the plaintiff took this appeal.

We think the court below erred as to both of the grounds upon

${ }^{1}$ Josselyx i'. LAcier, io Mod. R. 294, 3I6, - I715. Evans drew a bill upon Josselyn, requiring him to pay Lacier seven pounds every month out of the growing subsistence of Evans, and place it to his account. Josselyn accepted it, and afterward refused to pay. PARKER, C. I. - "We are all of opinion that it is not a bill within the custom of merchants; it concerns neither trade nor crelit: it is to be paid out of the growing subsistence of the drawer: if the party die, or his subsistence be taken away, it is not to be paid." Accord: Jinney v. Iterle, 2 Ld. Raym. I36I; We Ge v. Larramore, 50 Mo. 425; Jackmanv. Bowker, + Met. (Mass.) 235 - E1). 
which their judgment proceeded. That the defendant was liable upon the draft, if liable at all, in his individual capacity alone, seems under the authorities to admit of no doubt. ${ }^{1}$

$\S 74$ [44] Neither executors nor administrators have power to bind the estate represented by them through an executory contract, having for its object the creation of a new liability, not founded upon the contract or obligation of the testator or intestate. They take the personal property as owners and have no principal behind them for whom they can contract. The title vests in them for the purposes of administration, and they must account as owners to the persons ultimately entitled to distribution. In actions upon contracts made by them, however they may describe themselves therein, they are personally liable, and in actions thereon the judgment must be de bonis propriis. Not so, however, upon contracts made by their testator or intestate; in such cases the judgment is always de bonis testatoris. (Gillet v. Hutchinson's Adm., 24 Wend. I8 4 ; Ferrin v. Myrick, $4 \mathrm{I} \mathrm{N}$. Y. 315; Austin v. Honroe, 47 id. $360,366$.

The action here is exclusively upon the undertaking of the defendant, importing a promise to pay the sum of $\$ 900$ on the ist day of July, $\mathbf{I} 879$, to the payee of the draft or his order for a consideration received by the promisor. No facts are alleged or proved, showing any liability on the part of the defendant's testator to the drawee of the draft, or any legal demand existing in his favor, against the estate represented by the defendant.

It follows that the obligation must be held to be the individual contract of the defendant, and enforceable as such by a judgment against him, and execution to be levied de bonis propriis, or it is nudum pactum creating no liability whatever.

The cases are very numerous to the effect that the addition of an official character, to the signatures of executors and administrators, in executing written contracts and obligations has no significance, and operates merely to identify the person and not to limit or qualify the liability. Thus it was held in Pinney v. Adm'rs of Johnson (8 Wend. 500), that a bond given by administrators in their representative capacity to a creditor for a debt of their intestate, was the individual obligation of the administrators and enforceable against them de bonis propriis only; that the description of the obligors in the bond as administrators, and their promise in that character was surplusage, and they were chargeable upon such a bond only in their personal capacity. (See, also, Gould v. Ray, iz Wend. 633.) Parsons

${ }^{1}$ On a subsequent appeal, after a new trial, the court thought this result might be qualified by parol evidence. S. C. IIt N. Y. I77. See Neg. Inst. L. $\S 74[4+] .-$ Ev. 
on Bills and Notes (vol. I, I6r), lays down the rule that " an administrator or executor can only bind himself by his contracts; he cannot bind the assets of the deceased. Therefore, if he make, indorse, or accept negotiable paper, he will be held personally liable, even if he adds to his own name the name of his office; signing a note for example, 'A. as executor of B.,' for this will be deemed only a part of his description or will be rejected as surplusage." similar effect are Pumpelly v. Phelps, 40 N. Y. 59; Taft v. Brezister, 9 Johns. 334; Forster v. Fuller, 6 Mass. 58; Hills v. Banister, 8 Cow. 3I; Thatcher v. Dismore, 5 Mass. 299; Cornthuate v. First Nat. Bank, 57 Ind. 268.)

$\$ 22$ [3] Being of the opinion, therefore, that the defendant is liable upon the draft in question in his individual capacity alone, the question still remains as to the extent of such liability. He was undoubtedly competent to enter into a personal contract in reference to the funds in his possession, and in such case would be bound to perform according to the tenor and legal effect of the obligation assumed by him, and entitled to be allowed the amount paid upon an accounting, as executor. Such instruments are subject to the rules of construction applicable to other contracts, and must be interpreted upon consideration of the language used by the parties, with a view of arriving at their intention in executing them. The court below held that the draft in question was payable only from a particular fund, and was, therefore, non-negotiable, and enforceable only to the extent of the fund referred to.

Considering the question as we are compelled to do from the language of the instrument alone, we are unable to agree to the intrepretation thus put upon it. It is not claimed that there is any distinstion between the instrument in question and an ordinary bill of exchange except that made by the clause referring to the mother's estate. Unless that clause deprives the paper of its commercial character, the rights and liabilities of the parties thereto must be governed by the rules pertaining to negotiable securities, which would render the defendant liable for the amount named in the draft, upon the theory that his acceptance was an admission by him of assets applicable to its payment.

The distinction between a fund from which a draft or order is directed to be paid, and one referred to as the means of reimbursement to its drawee, is a material one and cannot be disregarded in the construction of such instruments. Thus it is said: "When a reference is made to a special fund merely as a direction to the drawee how to reimburse himself, and the payment is not made to depend upon the adequacy of the fund, it will not vitiate the bill." 
(Edw. on Bills and Notes, $\S 158$; see also Parsons on Merc. Law, 87; Chitty on Bills, 158.) Dwight, Com., in Munger v. Shannon (6 1 N. Y. 255), says: "A bill is an order drawn by one person on another to pay a third a certain sum of money absolutely and at all events. Under this definition the order cannot be paid out of a particular fund, but must be drawn on the general credit of the drawer, though it is no objection, when so drawn, that a particular fund is specified from which the drawee may reimburse himself." Judge Rapallo, in Brill v. Tuttle (8r N. Y. 457), says: "If a draft be drawn generally upon the drawee, to be paid by him in the first instance, on the credit of the drawer and without regard to the source from which the money used for its payment is obtained, the designation by the drawer of a particular fund, out of which the drawee is to subsequently reimburse himself for such payment, or a particular account to which it is to be charged, will not convert the draft into an assignment of the fund, and the payee of the draft can have no action thereon against the drawee unless he duly accepts." In that case the drawee refused to accept and the action was sought to be maintained upon the theory of an equitable assignment. It was held under the peculiar circumstances of the case, and the form of the instrument, that it did transfer the fund.

It is thus seen that the mere mention of a fund in a draft, does not necessarily deprive it of the character of commercial paper, but it must further appear, in order to have that effect, that it contains either an express or implied direction to pay it therefrom, and not otherwise.

The question, therefore, to be determined here is, whether the fund in question is referred to as the measure of liability or the means of reimbursement. While the point is not free from doubt, we think a reasonable construction of the draft favors the conclusion that it is mentioned only as the source of reimbursement. No express language in it can be pointed out as requiring its payment from the fund mentioned, and none from which that requirement can be implied, except such as exists in all drafts where a fund is referred to. Its language is to "charge the amount against me and of my mother's estate" and contains no provision for delay until the amount is realized from the estate, or for payment pro tanto in case the estate should prove insufficient to pay the whole amount. There is no language importing a transfer of the fund to the payee, and nothing from which such an intention can be inferred. The draft contains an absolute direction to pay a fixed sum, at a specified date, with interest. It imports a present indebtedness of a sum named, from the drawee to the payee, and an absolute direction to 
pay that sum at a fixed date, subject to no contingency either as to time or amount. In express language he directs the amount when paid to be charged against him individually, and adds the words, plainly implying, as we think, that the fund for the acceptor's reimbursement would be found in an amount eventually, or immediately payable to the drawer from his mother's estate.

We think, also, that the insertion of words expressly making the paper negotiable, was quite significant and indicated an intention on the part all of parties, that it should be transferable, and partake of the character of commercial paper. Any contingency inferable from the language of the draft, making the amount payable thereon indefinite and uncertain, would tend largely to depreciate its value for such purpose, and defeat the intention with which it was apparently made.

If the language of the paper could be considered at all ambiguous, it was the duty of the defendant to limit his liability by apt words of acceptance when it was presented to him, but as it is, he has unqualifiedly promised to pay a fixed and definite sum at a specified time, and we think, should be held to the contract which other parties were authorized by his acceptance to infer he intended to make.

The case of Tassey v. Church (4 Watts \& Sergeant, 346), seems quite in point. The instrument there read:

\section{$\$ 555.4$.}

Alleghasy, ist July, is 40 .

Please pay Church, McVay $\&$ Gordon $\$ 555.48$ and charge the estate of Thomas C. Patterson.

AdaM Fleming, Trustee.

To Johx TASsEY, Administrator.

[Indorsed]: Accepled, Johx TAssey, Administrator.

Fleming was the trustee of Mrs. Patterson, who was the heir at law of Thomas C. Patterson; Tassey was the administrator of Patterson's estate. It was held that the promise of the acceptor was unconditional and bound him absolutely. In Childs v. Monins (6 Eng. C. L. 228), the defendants, as executors of the estate of

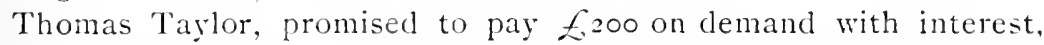
signing as executors. It was held that they became personally liable. and that the plea of plene administratit was no defense. It was further held that the promise to pay interest made the debt that of the administrators personally. In Kelly v. Brookly ( + Hill, 263), the action was upon an order drawn by the mayor upon the treasurer of the defendant in the following words: "Pay Alexander Lyon or order \$r,500 for award No. 7, and charge to Bedford Road Assessment." It was held that it was a bill of exchange and not payable from a particular fund. For further illustration of the point under discussion we would refer to Hollister r. Mopkins (13 Hun, 210); 
Redman v. Adams (5 I Me. 429); Luff v. Pope (5 Hill, 4I3). The case of Tooker v. Arnoux ( $76 \mathrm{~N}$. Y. 397), is referred to by the respondent as sustaining the views of the court below; but we are of the opinion that it cannot be so regarded. The order there directed the drawee to pay a certain sum out " of the money to be realized from the sale" of certain houses. This order was accepted, and it was held that a sale of the houses was a condition precedent to any liability on the part of the acceptor. This was the plain language of the contract.

In all the cases examined by us where an order has been held to operate as an equitable assignment of a fund, there were either special phrases contained in the instrument, indicating an intent to have it so operate, or ambiguous language used, which, construed in the light of surrounding circumstances, justified the inference of a limitation of liability. (Parker v. Syracuse, 3 I N. Y. 376; Alger v. Scott, 54 id. I4; Munger v. Shannon, 6r id. 25 r; Ehrichs v. De Mill, 75 id. 370 ; Brill v. Tuttle, supra.) Here, however, there is no such language, and this contract is to pay a fixed amount at a specified date, absolutely and unconditionally.

We are, therefore, of the opinion that the instrument in question is a bill of exchange and rendered the parties executing it liable absolutely for the amount stated therein.

The judgment of the courts below should be reversed and a new trial ordered, with costs to abide the event.

All concur.

Judgment reversed.

$\S 22$

$$
\text { REDMAN } \because \text { ADAMS. }
$$

$$
5 \text { I MAINE, 429. - I863. }
$$

CAse stated by the parties.

Assumpsit on an order of which the following is a copy:

$$
\text { Castine, Jan. 5, is6o. }
$$

For value received, please pay to order of G. F. and C. W. Tilden forty dollars, and charge same against whatever amount may be due me for my share of fish caught on board schooner "Morning Star," for the fishing season of I 860 .

Yours, etc.,

To Messrs. Adams \& Co.

FraNk R. Blake.

Accepted to pay. - Adans \& Co.

If the plaintiff, as indorsee of the order, cannot maintain this action, he is to become nonsuit; otherwise the action is to stand for trial. 
The opinion of the court was drawn up by

Barkows, J. - Is the instrument declared on negotiable, so that an action may be maintained upon it in the name of an indorsee against either of the prior parties? What constitutes a negotiable draft? It must be a written order from one party to another for the payment of a sum certain of money only, and that absolutely and without contingency, to a third party or his order or bearer.

It has often been held that a bill or note payable out of a particular limited fund is not negotiable, but there is a difference between making the money payable out of a particular fund and a mere reference to the fund in the draft to call the attention of the drawee to his means of reimbursement.

In this case, the order requires the drawees to pay to the order of G. F. and C. W. Tilden the sum of forty dollars, absolutely and without contingency. A means of reimbursement is indicated to the drawees in the words appended, " and charge the same against. whatever amount may be due me for my share of fish, etc.," but the payment of the order is not made to depend upon his having any share of fish, nor is the call limited to the proceeds thereof.

In Reeside v. Knox (2 Wheaton, 253), cited by defendant's counsel, the order was drawn on the Postmaster General of the United States, and in his official capacity. The Court expressly say, "no objection would lie to the form of the bill in the present instance, were the drawee an individual. It is matter of public notoriety that government accepts for no more, and is bound for no more, whatever be the form of the acceptance, than it has in its hands, and that it treats a bill drawn on it as no more than an assignment or order of transfer." In that case, the language of the draft was, " pay to my order five thousand dollars, for value received, and charge the same to my account, for transporting the U.S. mail." No substantial difference in form between that order and the one under consideration is observed. Such an order, the Court in that case say, would be negotiable, but for the fact of its being drawn on a government officer.

According to the agreement of the parties,

The case is to stand for trial. 
(d) Statement of transaction which gives rise to instrument does not render promise conditional.

\section{$\$ 22$ SIEGEL $\vartheta$. CHICAGO TRUST \& SAVINGS BANK.}

$$
\text { I3r Illinois, 569. - I89o. }
$$

Mr. Chief Justice Shope delivered the opinion of the Court.

This was an action of assumpsit, by appellee, against appellants, upon the following instrument:

$\$ 300$.

Chicago, March 5, I887.

On July I, Iss7, we promise to pay D. Dalziel, or order, the sum of three hundred dollars, for the privilege of one framed advertising sign, size $-\mathrm{x}-$ inches, one end of each of one hundred and fifty-nine street cars of the North Chicago City Railway Co., for a term of three months, from May I5, ISs7.

Siegel, CoOfer ANd Co.

- which was indorsed by Dalziel, the payee, to appellee, for value on the day of its execution.

The first question presented is, is this instrument negotiable? and this question has been answered affirmatively by the Circuit and Appellate Courts. The Appellate Court having affirmed the judgment in favor of the plaintiff, the case is brought here by appeal, upon certificate of importance granted by that court.

It appears, that before the time when the privilege of advertising was to commence Dalziel forfeited any right he may have acquired to use the cars in the manner indicated, and the privilege specified never was furnished appellants; and it is insisted that the instrument is a simple contract, only, and that therefore the same defense, - failure of consideration, - is available against the indorsee of the paper for value, and before due, as might be interposed against such paper in the hands of the payee. It is also insisted, that the instrument shows, on its face, that payment depended upon a condition precedent to be performed by the payee, and therefore the indorsee took it with notice, and by the failure of the payee to perform the condition, no right of recovery exists in the indorsee. It is not contended that the indorsee had any other notice than that contained in the instrument itself, and it is apparent that at the time of its indorsement, which was the day of its execution, no right to the consideration had accrued to the makers. It is a promise to pay a certain sum of money at a day certain, for a consideration thereafter to be rendered, and depends for its ralidity upon the implied promise of the payee to furnish the consideration at the time and in the manner stipulated, - that is, it is a promise to pay a sum certain on a particular day, in consideration of the 
promise of the payee to do and perform on his part. A promise is a valuable consideration for a promise.

But the question remains, whether the statement or the recital of the consideration on the face of the instrument impairs its negotiability, and, in this instance, amounts to a condition precedent. The mere fact that the consideration for which a note is given is recited in it, although it may appear thereby that it was given for or in consideration of an executory contract or promise on the part of the payee, will not destroy its negotiability, unless it appears, through the recital, that it qualifies the promise to pay, and renders it conditional or uncertain, either as to the time of payment or the sum to be paid. (Danicl on Neg. Inst. secs. 790-797; Daris v. McCreadl', I 7 N. Y. 320; State Nat. Bank v. Casson, 39 La. Ann. 865; Goodloe v. Taylor, I 3 X. C. $45^{S}$; Sterens v. Blunt, 7 Mass. 240.)

In State Nat. Bank v. Casson (supra), it is said: "Plaintiff received the note before maturity, and before the failure of the consideration. Even if it were known to him that the consideration was future and contingent, and that there might be offsets against it, this would not make him liable to the equities between the defendant and the payee. It cannot affect the negotiability of a note that its consideration is to be hereafter realized, or that, from contingency, it may never be enjoyed."

The most that can be said of a recital in the instrument itself, of the consideration upon which it rests, is, that the indorsee, taking it before maturity, is chargeable with notice of the recital. Such recital, however, is not sufficient, of itself, to advise him that there was, or would necessarily be, a failure of consideration, but if, at the time of the indorsement, the consideration has in fact failed, the recital might be sufficient to put him upon inquiry, and, in connection with other facts, amount to notice. (Henneberry v. Morse, 56 Ill. 394.) The case at bar does not, however, fall within the rule just stated, for the assignment was made the same day the note was made, and by the terms of the recital it was apparent the payee was required to do no act till the 15 th of May following, - an interval of seventy days.

There is a distinction, clearly recognized in the authorities, between an instrument payable at a particular day, and one payable upon the happening of some event; and the rule is, that where the parties insert a specific date of payment, the instrument is then payable at all events, - and this, although, in the same instrument, an uncertain and different time of payment may be mentioned, as, that it shall be payable upon a particular day, or upon the completion of a house, or the performance of other con- 
tracts, and the like. (McCarty v. Howell, 24 Ill. $34 \mathrm{I}$, and authorities supra.) But the doctrine of this and kindred cases, where there are both a certain day of payment and one more or less contingent, need not be here invoked, for the time of payment in the instrument under consideration is not made to depend upon the happening or not happening of any event, but is specific and certain, and must occur by the efflux of time, alone.

If, therefore, it be conceded, as it must, that a condition inserted in a promissory note, postponing the day of payment until the happening of some uncertain or contingent event, will destroy its negotiability and render the instrument a mere agreement, yet under the authorities, if by the instrument the maker promises to pay a sum certain at a day certain to a certain person or his order, such instrument must be regarded as negotiable, although it also contains a recital of the consideration upon which it is based, and although it further appear that such consideration, if executory, may not have been performed. Here, the money was payable, absolutely, on the first day of July, I $\$ 87$, - a time when the contract for the advertising could not have been completed. If the instrument had remained the property of the payee, and upon its maturity and performance to that time, suit had been brought, it is clear that no plea of partial failure of consideration could have been sustained, for the reason that the entire term had not then expired. No analysis of the instrument itself is necessary. The most careful examination of it will fail to disclose a condition precedent to the payment of the money at the time stipulated. Nor is there anything in the recital of the consideration to put the indorsee upon inquiry at the time the indorsement was made. Indeed, it is clear that at that time no inquiry would have led to notice that Dalziel would fail to comply with his contract on the I5th of May thereafter, when the term was to commence. All that the recitals would give notice of was, that the note was given in consideration of an agreement on the part of the payee that the privilege of advertisement named should be enjoyed by the makers for three months, from May 15, I 887 . Giving to the language employed its bioadest possible meaning, it cannot be construed as notice to the indorsee of the future breach of the contract by Dalziel. The presumption of law would be, that the contract would be carried out in good faith, and the consideration performed as stipulated. The makers had put their promissory note in the hands of Dalziel upon an express consideration which they were thereafter to receive, and for the performance of which they had seen fit to rely upon the undertaking of Dalziel, and we are aware of no rule by which they can hold this indorsee for value, 
before due and before the time of performance was to begin, chargeable with notice that the promise upon which the makers relied would not be kept and performed. (Wade on Notice, \$94a; Loomis v. Maury, 15 N. Y. 312 ; Dai'is v. McCready, supra.)

It is also contended that the court erred in giving the eighth instruction in behalf of appellee, as to the meaning of the words "good faith." Without pausing to discuss the instruction, we think it clear that appellants were not prejudiced thereby, and that no inference unfavorable or prejudicial to them could have been drawn therefrom by the jury. While, therefore, the instruction may be regarded as inaccurate, it worked no injury, and the appellants cannot complain. (Comstock et al. v. Hannah, 76 Ili. 530.)

Other minor objections are urged, which, it is sufficient to say, we have examined with care, but find no prejudicial error.

The judgment of the Appellate Court will be affirmed.

Judgment affirmed. ${ }^{2}$

$\$ 22$ [3] Wells $z^{\prime}$. BrighaM, 6 Cushing (Mass.) 6. - I 850 . “ Mr. Brigham, Dear Sir: You will please pay Elisha Wells $\$ 3^{\circ}$, which is due me for the two-horse wagon bought last spring, and this may be your receipt." SHAw, C. J. - "The fact that the draft indicates a debt due to the drawer as the consideration, between llawer and drawee, does not make it the less a cash order or draft. **** The statement of the origin of the debt, the purchase of the wagon, did not make it the less payable absolutely, and at all events, and not conditionally or out of a particular fund."

izi Pexisyluania State, 6i5. - is95.

Assumpsit by the indorsee of an instrument in writing against the maker. The trial court ruled the instrument non-negotiable, and that the indorsee could not maintain this action upon it in his own name so as to exclude any defenses the maker may have. Plaintiff appealed.

${ }^{1}$ See Neg. Inst. L.. 95 [50]. - Er.

"Accord: Chase v. Pihrmu, Io Daly (N. Y.) 3t4. Contra: Jurisv. Milkins, $7 \mathrm{M} . \& \mathrm{~W} .+10$, where the instrument read: "I undertake to pay A. I. the sum of $\mathcal{L}_{6} 4 \mathrm{~s} .$, for a suit of, ordered by Daniel Page." Flithir v. Thompsom, $55 \mathrm{~N}$. H. 308. Sie Post v. Kinzut, etc, Co., post. - Ev. 
The instrument is as follows:

250.00.

Kane, Pa., March 5 th, I89r.

On the first day of July, IS9I, without grace, there will be due to the American Car \& Equipment Company or order two hundred and fifty dollars for rental of rolling stock, under contract of lease and conditional sale of even date herewith, payable at the office of the American Car and Equipment Company in the city of New York, with interest at 6 per cent. per annum added.

Kinzea Hemlock R. R. Co., By Thos. L. Kane, President.

Series B. 87.

No. I due June Ist, I 89 I.

[Endorsed on the back]:

The Anerican Car and Equipment Compant.

S. L. Mitchell, Treas.

Opinion by Mr. Justice McCollum, Norember 4, is95:- The single question in this case is whether the instrument declared upon is a negotiable promissory note. If it is the plaintiffs are entitled to maintain their suit as it was brought, and the learned court below erred in the ruling complained of in the first specification. If it is not, both specifications must be overruled. In passing upon the question of the negotiability of the paper it will be observed that the sum referred to in it represents rent to accrue under a contract of lease and conditional sale of rolling stock, and that the plaintiffs' contention, if successful, will enable them to avoid a defense available against the payee. In other words, if the plaintiffs are bona fide purchasers of the paper before maturity, and it is negotiable, they may recover the sum named in it, although the maker may have a good defense against the payee, arising from the latter's non-compliance with the terms of the contract. But for the protection the negotiability of the instrument would afford them against such a defense they might as well have brought suit upon it, or on the contract, in the name of the payee to their use. We allude to this, not as a matter affecting the question before us, but as explanatory of what might otherwise seem to be a merely technical and unnecessary contest.

The instrument in suit and the contract to which it refers were executed and delivered on the same day, and the former is more in the nature of a statement of a stipulation in the latter than of an independent undertaking for a past or present consideration to pay a sum certain at the time stated in it. It says, in substance, that under a contract of lease and conditional sale "of even date herewitin" there will be due to the payee or order on the first of July, I89I, for the rental of rolling stock, two hundred and fifty dollars "with interest at six per cent. per annum added," payable at the office of the payee, in New York. The payee in the instrument on which the action is based was the lessor 
in the contract, and the sum to become due on the first of July was rental for the rolling stock that was leased. If the lessor refused to deliver the stock to the lessee in accordance with the terms of the contract the rent reserved for the use of it did not become due on the first of July or at any time. What the lessee said in the paper in question regarding the sum to become due on the first of July for rental of rolling stock was based on compliance with the lease, and is not applicable to a repudiation of it. We cannot, therefore, regard the paper in suit as creating a liability independent of and unaffected by the contract to which it refers. We think it embraces a contingency which renders it non-negotiable, and if the maker is liable upon it to the plaintiffs, or to the payee, the liability is qualified and measured by " the contract of lease and conditional sale." Nothing is better settled than the rule which requires that an instrument to be negotiable shall be free from contingencies and conditions. (Oierton v. Tajlor, $3 \mathrm{~Pa}$. 346; Saceny v. Thickstun, $77 \mathrm{~Pa} . \mathrm{I}^{\mathrm{I}}$; Woods v. North, $8_{4}$ Pa. 407 ; and Iron City Bank v. McCord, 139 Pa. 52.)

The specifications of error are overruled and the judgment is affirmed.

\section{The Sum to be Paid Must be Certain.}

(a) What amounts to certainty generally.

$\S 20$

DODGE $\tau$. EMERSON.

34 MAINE, $96 .-I 8_{52}$.

Assumpsit, by the indorsee against the makers of a note payable to the Protection Insurance Company or order, for “ \$271.25, with such additional premium as may arise on policy No. 50, issued at the Calais agency."

Appleton, J. - No principle of law is more fully established by authority and the universal concurrence of the commercial world, than that to make a written promise a valid promissory note, it must be for a fixed and certain, and not for a variable amount. In France it is so determined by the provisions of the Code Napoleon. It is the recognized mercantile law of continental Europe. In England and in this country, it has received the sanction of repeated and well-considered adjudications. (Story on Promissory Notes, $\$ 20$.) Without this essential requisite, a written promise, though in terms payable to order, is to be regarded as a simple contract and not negotiable. 
The defendants in this case have promised to pay two several sums; one certain and definite, the other uncertain and contingent. 'The defendants' liability being for both these sums, is obviously for an unascertained and indefinite amount.

It is insisted in argument, that the plaintiff may abandon all claim for the additional premium, which is uncertain, and proceed only for the certain sum expressed in the contract. Undoubtedly he may take judgment for any sum less than the amount due, and in that mode abandon a portion of his legal claims, but that still leaves the contract in its original state, and can in no way affect its legal construction. He could not erase the clause relating to the additional premium, without thereby making such an alteration in the instrument declared on, as would discharge the defendants.

In Smith v. Nightingale ( 2 Stark. R. 375 ), the promise was to pay the payee sixty-five pounds and all other sums that may be due him, and it was claimed for the plaintiff, to whom the interest in the contact had passed by indorsement, that he might disregard the latter clause and recover on the certain sum set forth in his contract as indorsee, but the Court decided otherwise. (Dazis v. Milkinson, ro Adol. \& El. 9s.)

The inquiry is made by the counsel for the plaintiff, whether the clause providing for the payment of an additional sum, introduced after the promise to pay the sum fixed and certain, controls that sum so as to make it in any event uncertain. The amount due to the plaintiff is uncertain. Whether the contract is to be regarded as a promise to pay one sum, which shall be the aggregate composed of a certain and of an uncertain sum, the amount of which is to be ascertained at some subsequent time, or as a promise to pay two sums, one fixed and the other uncertain, is perfectly immaterial. In either case there is no precise and ascertained amount due by the contract, and it cannot be regarded as a promissory note. If it was not in its origin, it cannot be made one by any abandonment, which the plaintiff may deem it advisable to make, of any portion of the sum due him. The contract declared on not being in its character negotiable, the action cannot be maintained by the present plaintiff.

Plaintiff nonsuit. ${ }^{1}$

1 “\$350, and also such additional premium as may become due on said policy," is uncertain. Palmer v. Mard, 6 Gray (Mass.) 340; Marett v. Equitable Ins. Co., $5+\mathrm{Me} .537$.

“\$I,ooo, or what might be due after deducting all advances and expenses," is uncertain. Cushmanv. Haynes, 20 Pick. (Mass.) I.32.

"\$300, subject to the provisions contained in an agreement this day made 
4 TEXAS, 109. - I849.

Appeal from Bastrop. Clopton, as bearer of the following instrument in writing, sued Smith in a Justice's Court:

On or before the first day of January next, I promise to pay W. B. Waldrop, or bearer, one doilar and fifty cents for each and every acre of land which lies north (that is to say) above Walnut Creek, which said Waldrop has this day sold to me, being part of the land, which was sold unto the said Waldrop by $L$. C. Cunningham, the said land being the consideration of this note; and if this note is not paid promptly at maturity it shall draw interest at the rate of ten per cent. per annum until paid.

Bastrop, April 15, ISt8.

Thomas M. SmTh.

Witness: L. C. Cunningham.

Since the within was written, the land has been surveyed and found to be sixty-five acres, which will make the within call for $\$ 97.50$.

Bastrop, Nov. Ioth, i848.

Thomas M. Sinth.

Clopton recovered judgment in the Justice's Court, and Smith appealed to the District Court, where Clopton again recovered judgment.

Hemphill, Ch. J. - The first position contended for by appellant is that the instrument sued on is not a promissory note, and if a promissory note, it is not, according to the laws of this State, negotiable, nor does it vest such rights in Clopton as are acquired by the holders of instruments made negotiable by the law merchant or by statute.

The objection to its being regarded as a promissory note, from the circumstance that no precise sum was, in its original formation, designated as the amount to be paid, we consider as obviated by the fact that this was ascertained and acknowledged on the same instrument, under the signature of the maker, before the note arrived at maturity. This acknowledgment conferred upon it certainty as to the amount, the only requisite wanting to constitute it a commercial negotiable instrument; and from the date of the admission, it became the promissory note recognized by our laws as having the

between $\mathrm{C}$ and myself," is uncertain where the agreement referred to provides for a contingent deduction. Dilley v. Van Wie, $6 \mathrm{~W}$ is. 206.

$\$ 60$, but $\$ 50$ if paid by Jan. Ist, is uncertain. Fralick v. Worton, 2 Mich. I3o.

\$200, award of assessor of damages to be subtracted, and on payment of award note delivered up, is uncertain, and in the nature of a penal bond. Ellett v. Eberts. $7+$ lowa, 597 .

"Pay A B for 68 bu. wheat in store at three cents below first quality wheat," is uncertain. Lent v. Itodgman, ${ }_{5}$ Barb. (N. Y.) 274. - ED. 
quality of negotiability, and other incidents pertaining to mercantile paper by the usages of the law merchant.

[Omitting matter not relating to this question.]

The instrument sued on, having been decided to be a negotiable promissory note, must be presumed to have been transferred before maturity, there being no evidence to the contrary, and is, therefore, in the hands of the plaintiff, not subject to defenses which might well be pleaded in an action brought by the payee, or assignee after the note became due.

The trial below was on an appeal from a magistrate. There were no pleadings in the case, nor was any of the evidence taken admissible, except the instrument sued upon; which proved itself. There was no foundation laid for the introduction of the proof, by showing such circumstances as would have subjected the plaintiff to the equities which were raised or supposed to exist against the vendor.

Judgment affirmed.

§o Mr. Justice Bradley in PaRSONS $\%$ JACKSON.

99 United States, 434, 438, 440. - I873.

$\mathrm{EACH}_{\mathrm{A}}$ bond, on its face, certifies " that the Vicksburg, Shreveport, and Texas Railroad Company is indebted to John Ray, or bearer, for value received, in the sum of either $£ 225$ sterling or $\$ 1,000$ lawful money of the United States of America, to wit, $£ 225$ sterling if the principal and interest are payable in London, and $\$ 1,000$ lawful money of the United States of America, if the principal and interest are payable in New York or New Orleans," etc. This is the obligatory part of the instrument, and is necessarily indeterminate in its character without some further designation of the place at which it is to be paid. Each bond, further, on its face declares that " the president of said company is authorized to fix, by his indorsement, the place of payment of the principal and interest in conformity with the terms of this obligation." And on the back of the bonds is indorsed a printed blank in the following words, to wit, "I hereby agree that the within bond and the interest coupons thereto attached shall be payable in

The uncertainty of the amount payable, in the absence of the required indorsement, is of itself a defect which deprives these instruments of the character of negotiability. As they stand, they amount to a promise to pay so many pounds, or so many dollars, - without saying which. One of the first rules in regard to negotiable paper is that the amount to be paid must be certain, and not be made to 
depend on a contingency. (I Daniel, Neg. Inst., \$ 53.) And although it is held that id certum est quod certum reddi potest, - a maxim which would have given the bonds negotiability in this instance, had the requisite indorsement been made, - yet, without such indorsement, the uncertainty remains, and operates as an intrinsic defect in the security itself.

\section{(b) Engagement to pay interest: contingency.}

23 Kansas, 402. - ISSO.

Action by Parker, against Plymell and wife, upon two promissory notes, and a mortgage given as security for their payment. The facts are stated in the opinion. Trial at the April Term, I879, of the District Court, and judgment for the defendants. The plaintiff brings the case here.

The opinion of the court was delivered by

Brewer, J.: This was an action on two notes, and for a foreclosure of the mortgage given as security for them. The plaintiff was a bona fide holder for value, before maturity. No actual notice of any defenses was shown. The notes were negotiable, unless and save as affected by the following matters. The promise was to pay interest at twelve per' cent., after maturity; and after this promise were these words: "If this note is not paid at maturity, the same shall bear twelve per cent. interest from date." As a fact, there was usury in the inception of the notes. As a conclusion of law, the court held, that by reason of the words above quoted, the purchaser took the notes, charged with notice of the usury; and this presents the sole question for our consideration.

Clearly, these words do not destroy the negotiability of the paper.

They do not leave uncertain either the fact, the time, or the amount of payment. Indeed, up to and including the maturity of the notes, they are entirely without force. They became operative only after the notes are dishonored and have ceased to be negotiable, and then there is no uncertainty in the manner or extent of their operation. They create, as it were, a penalty for non-payment at maturity, and a penalty the amount of which is definite, certain and fixed. In this respect, they are even less objectionable than the stipulation concerning attorney-fees, which was considered in the case of Seaton v. Scovill (I 8 Kans. 433), for there the amount was not 
fixed and named, but the stipulation was for reasonable attorneyfees. (See also I Danicl on Neg. Insts., $\$ 53,54,6$ I, 62; Tholen v. Duffy, 7 Kans. tro; Gould v. Bishop Hill Co., 35 Ill. 325.)

Now if these words do not affect the negotiability of the paper, can they restrict the amount of recovery as against a bona fide holder for value before maturity? Is not the very essence of negotiability, that such a holder may rely upon the face of the contract, and recover according to its terms, any transaction between the maker and payee to the contrary notwithstanding? The court held that these words imparted notice of usury. But how? The penalty is not recoverable as interest, and if it were in this case, it is not usurious. Grant that the courts will not tolerate a penalty which is a mere cover for usury, and still this penalty would have to be sustained, for it only calls for twelve per cent. interest. This stipulation provides for twelve per cent. interest before maturity, as another stipulation does for twelve per cent. interest after maturity. Nowhere in the note is more than twelve per cent. named. The effect of these stipulations is no more than that of a promise to pay twelve per cent. from date until paid, with a proviso that if promptly paid at maturity, no interest will be required. It may be said that where a note calls for no interest till after maturity, the presumption is that the interest was taken out in advance. Whatever may be true of bank paper, we think no such presumption of law exists as to ordinary notes. Generally it may be true that such is the case, but it is not always so. The loan may be a friendly one, and only the certainty of prompt payment a matter desired by the lender, or there may be no loan at all, but a sale of property on time with security, and the only purpose of the penalty to secure promptness in payment. The note does not say the interest has been taken out in advance, nor is such fact necessarily to be presumed from its terms. The utmost that can be said is that the language suggests the probability of such a fact, but this is far from imparting notice to a bona fule purchaser, or operative to restrict his right of recovery.

The judgment will be reversed, and the case remanded with instructions to render judgment for the full amount of principal and interest due upon the face of the papers.

All the justices concurring. ${ }^{1}$

${ }^{1}$ Accord: Crump v. Berdan, 97 Mich. 297; Hope v. Barker, II2 Mo. 338. An option on the part of the debtor to pay interest in paper money at 73 -1o per cent. or in gold at 6 per cent. does not destroy negotiability. Dinsmore v. Duncan, 57 N. Y. 573. - ED. 
33 Mixesota, I+4.-1885.

Actior by indorsee against maker. Court charged that "the instrument offered in eridence is not a promissory note, but is subject to all equities existing between the defendant and D. M. Osborne \& Co., whether it was assigned before or after maturity." Defendant has a verdict, and plaintiff appeals from an order refusing a new trial.

\section{BERRY, I.:-} $\$ 100$.

GOOD ThUNDER, July 2.4, ISS2.

For valu, received on or before the first day of January, IEst, I, or we, or cither of us, promise to pay to the order of D. M. Osborne and Co. the sum of one hundred dollars, at the office of Gebhard and Moore, in Mankato, with interest at ten percent. per annum from date until paid; seren. if paid when due.

W. J. B. CRANE.

A negotiable promissory note must be certain as to amount. (Jones v. Radatz, 27 Minn. 240.) It is so certain when the sum to become absolutely payable upon it at any given time is ascertainable upon its face. (I Daniel, Neg. Inst., \$ 53; Tonine v. Rice, r2z Mass. 67; Jones v. Radatz, supra.)

The defendants' position is that the foregoing instrument is rendered uncertain as to amount by the interest clause, and therefore is not a negotiable promissory note. As to the legal effect of such a clause the authorities disagree. Some hold that the contract reserics the higher rate of interest, with a provision for its abatement, upon a condition to be performed, and that, therefore, the difference between the two rates is not a penalty, but the contract is to be enforced according to its literal terms. The cases holding this view rest upon Nicholls v. Malnard (3 Atk. 519). (See Walmesley v. Booth, Barn. Ch. $478,48 \mathrm{I}$; Bonafous v. Rybot, 3 Burr. I370; Waller v. Long, 6 Munf. (Va.) 71.) Other authorities hold that the clause is the same in effect as if it had resered the lower rate of interest, with a provision that if the indebtedness is not paid at maturity, interest shall run at a higher rate. (Seton v. Slade, 7 Ves. 265, and see Stanhope v. Manners, 2 Eden, 197 ; Brockway v. Clark, 6 Ohio, 45; Longworth v. Askren, ${ }_{5}$ Ohio St., 370 ; Brown v. Barkham, I P. Wms. 652.) If this be the true construction of the clause, it is generally agreed that the difference between the two rates is to be treated as a penalty. (Talcott v. Marston, 3 Minn. 238, (339); Newell v. Houlton, 22 Minn. I9; and cases last cited.)

In our opinion the view taken by the authorities last mentioned as to the legal effect of the interest clause under consideration, is the 
more sensible, and most in accordance with what would seem to be the real object of the parties to the contract. What the payee really wants is his money at the due date of the contract, and to secure this he holds an increase of the rate of interest over the debtor's head. In other words the increase is a penalty for the debtor's delinquency. Treating the increase as a penalty, it follows, under the decisions of the court before cited, that the note in suit will in law draw the same rate of interest before as after maturity, - that is to say, 7 per cent., - and that, therefore (whatever might be the case if the interest clause were upheld according to its literal terms), the sum absolutely payable upon the instrument at any given time is thus made certain, as the principal, and 7 per cent. interest. ***

Order reversed and new trial directed."

(c) Engagement to pay by statcd instalments; contingent instalments.

$\S 2$ I

COOKE $\approx$. HORN.

29 Law Trmes, N. S. (Q. B.) 369. - Is73.

ThIs was an action upon a promissory note, tried before Honyman, J., at the York Summer Assizes. A verdict of $175 l .5 \mathrm{~s}$. rod. was found for the plaintiff, leave being reserved to the defendant to move to enter a verdict for him, on the ground that the note was not good.

The form of the note was as follows:¿I 7 .

25th April, is 72 .

We promise to pay to Messrs. M. H. Cooke and Co. I7ol., with interest thereon al the rate of $5 l$. per cent. per annum, as follows: the first payment, to wit, $4 \%$.. or more. to be made on the Ist Feb. 1873 , and $5 \%$ on the first day of each month following until this note and interest shall be fully salisfied. And in case default shall be made in payment of any of the said instalments, the full amount then remaining due in respect of the said note and interest shall be forthwith payable.

The note was signed by the defendant and one John Horn, since deceased.

BLACKBURN, J. - I do not thing there should be any rule in this case. The objection to the note is, that if the first payment were more than $40 \mathrm{l}$., which the note provides it might be, the subsequent instalments and the final time of payment would be indefinite. The amount of the note, however, is certain, and any variation in the

${ }^{1}$ For view as to treating such stipulations as a penalty, see post, p. 217 , note 2. - ED. 
time will depend only upon the defendant. No case has been cited which is an authority against this note; and by analogy with other objections, this one, as it seems to me, ought not to prevail. I do not see why a stipulation which enables the maker of a note to reduce his liability for interest, should prevent the instrument containing it from being a promissory note.

Quain and Archibald, JJ., concurred.

Rule refused.

\section{§ 2 RIKER $v$. SPRAGUE MANUFACTURING CO.}

If RHODE ISLAND, 402 . - ISS4.

TillinghAST, J. - This case and the following one' are actions, this case against the maker and indorsers, and the following one against the indorsers only, of a large number of promissory notes, set out and declared on by the plaintiffs as negotiable, and are tried together, by agreement of parties, upon the defendant's petition for a new trial, in each case on the ground of certain alleged misrulings by the court at the jury trials, and also that the verdict was against the evidence in each case. The questions raised by the exceptions to the rulings of the court in this case, in so far as they were relied on at the trial, are first, whether the notes declared on are negotiable; and second, whether there was a waiver by the indorsers of demand and notice, which excused the plaintiffs from proof thereof at the trial to the jury.

The notes are all in the following form, which is a copy of one of the notes in suit:

$$
\text { E. No. }
$$

$\$ I, 000$

Providence, November Ist, IS73.

Three years from January Ist, IS74, for value received, the $A$. \& W. Sprague Manufacturing Company promise to pay to the order of A. \& W. Sprague One Thousand Dollars, with interest from January I, I874, payable semi-annually, at the rate of seven and three-tenths percent. per annum, till said principal sum is paid, whether at or after maturity: and all instalments of interest in arrear shall bear interest at the rate aforesaid till paid, but reserving the right to pay this note before maturity in instalments of not less than five (5) per cent. of the principal thereof, at any time the semi-annual interest becomes payable. Principal and interest payable at their place of business in said Providence.

Countersigned,

Amasa Sprague,

Z. CiIAFEe, Trustee.

Treasurer.

[Indorsed]

A. \& W. Sprague. 
The defendants contend that said notes are not negotiable for two reasons, namely: first, because the time of payment is uncertain; and second, because the amount to be paid is also uncertain.

If either of these grounds is estab'ished, the notes must be held not negotiable, and this action, as against the indorsers at least, cannot be maintained; for it is elementary law that amongst the essential requisites of a negotiable promissory note are certainty as to the amount to be paid, and certainty as to the time when the payment is to be made.

First, then, are the notes certain as to amount? They are each for a definite, fixed, and certain sum, and the payment of this sum is not subject to any uncertainty or contingency. But the defendants urge that by reason of the reserved right on the part of the maker expressed in the body of the note, to pay the same before maturity, in instalments of not less than five per cent. of the principal thereof, at any time the semi-annual interest becomes payable, the amount of the note is rendered uncertain. We fail to see how the amount to be paid becomes any less certain by reason of this reservation. Suppose part payment to be made at one of the stated periods provided therefor: that is a payment on the principal of the note, and simply reduces said principal by so much as is paid, leaving the note as definite as to amount as it was before; so that although the amount actually due upon the principal of one of these notes at a given time in its existence might be different from the amount due at some other time, yet it would always be a fixed and certain amount, and the total sum payable would not be changed. The object of the law, therefore, in requiring certainty as to amount as well as to time of payment, which is to give to negotiable paper as far as possible the quality of a circulating medium, like money, and practically to make it represent money, is fully met in a note in this form.

The cases in which it has been held that there was not that certainty as to amount to be paid which the law requires in negotiable paper are those, in the main, where the principal of the note could not be determined by anything which appeared therein: as where a promise was made to pay a certain sum, " and all fines according to rule" (Ayrey v. Fearnsides, 4 M. \& W. I68); or a certain sum, and also "all other sums which may be due" (Smith v. Nightingale, 2 Stark. 375); or a certain sum with interest, and also to pay "the demands of the sick club at, etc., in part of interest" (Bolton v. Dugdale, 4 B. \& Ad. 619; Daries v. Wilkinson, ro A. \& E. 98$)$; or a certain sum deducting what interest or money A. may owe the maker (Barlow v. Broadhurst, 4 Moore, $47 \mathrm{I}$ ); or a certain sum 
together with all cost of collection including attorney's fees (Jones v. Radatz, 27 Minn. 240; Maryland Fertilising and Manufac. Co. v. Newman, $60 \mathrm{MId}$. 584; Johnston r. Speer, $92 \mathrm{~Pa}$. St. 227.) These, and many others of like character, illustrate and make plain what is meant by the term "uncertain as to amount," as applied to promissory notes, and what degree of certainty is essential to render a note negotiable.

That no such uncertainty exists, however, in the notes declared on in the case at bar, is clearly manifest upon the most casual inspection thereof; and we conclude that, so far as certainty in amount is concerned, they unquestionably come within the rule which the adjudged cases make.

Second, then, are they certain as to time of payment?' ${ }^{\text {And upon }}$ this point let us first ascertain what degree of certainty is meant by this expression. We think the rule of law is clearly this, namely: "that if the time of falment named in the note must certainly" come, althoug in the precise day may not be specified therein, it is sufficiently' eertain as to time." In other words, it must not depend upon any contingency: as "when A. shall marry," (Pearson v. Garrett, 4 Mod. 242); or when a certain ship shall arrive (Coolidge v. Ruggles, 15 Mass. ${ }_{3} S_{7}$; Grant v. Wood, I2 Gray, 220; Palmer v. Pratt, 2 Bing. I85); or when a certain suit is determined (Shclton v. Bruce, 9 Yerg. 24; see, also, Woodbury, Williams and English v. Roberts, 59 Iowa, 348.) And here the maxim, Id certum est quod certum reddi potest, is applicable, although perhaps it is not as to the amount.

So in Cota r. Buck (7 Met. 588), it was held, Shaw, C. J., delivering the opinion of the court, that a note in the following form, namely: "For value received I promise to pay J. P., or bearer, $\$ 57^{\circ} .5^{\circ}$, it being for property I purchased of him in value at this date, as being payable as soon as can be realized of the above amount for the said property I have this day purchased of said P., which is to be paid in the course of the season now coming," was a negotiable promissory note, on the ground that it was payable at all erents within a limited time, namely, "the coming season," and that whether that meant "harvest time or the end of the year, it must come by the mere lapse of time, and that must be the ultimate limit of the time of payment."

So, also, in Curtis v. Horn ( 58 N. H. $\left.5^{\circ} 4\right)$, a note payable " on or before the first day of May next," was held to be negotiable. In delivering the opinion of the court in that case, Justice IBingham said: "It is now the common law, that where the payment is made 
to depend upon an event that is certain to come, and uncertain only in regard to the time when it will take place, the note or bill is negotiable." In Mattison v. Marks (31 Mich. 421), it was held that a promise to pay "on or before" a day named stated the time for payment with sufficient certainty. In that case Cooley, J., said: "The legal rights of the holder are clear and certain; the note is due at a time fixed, and is not due before. True, the maker may pay sooner if he shall choose, but this option, if exercised, would be a payment in advance of the legal liability to pay, and nothing more. Notes like this are common in commercial transactions, and we are not aware that their negotiable quality is ever questioned in business dealings." (See, also, Edwards on Bills and Notes, r42; Story on Promissory Notes, $\$ 27$; Wheatley v. Williams, M. \& W. 533; Ernst v. Steckman, 74 Pa. St. 13; Danicl on Neg. Inst., $5 \$ 43,48$.)

Indeed, the cases have gone so far in this direction as to hold that a note payable within a limited time after the death of a person named is sufficiently certain as to time. (Cooke v. Colehan, 2 Strange, ra 17 ; Colchanv. Cooke, Willes, 393.) So, also, it has been repeatedly held that notes payable in instalments at fixed dates are negotiable. (I'an Buskirk v. Day, 32 Ill. 260; Carlon v. Kenealy, I 2 M. \& W. 139.)

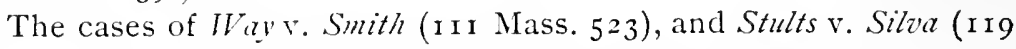
Mass. ${ }^{137}$ ), cited by the defendants, seem to support their position in the case at bar; but we prefer the reasoning of the court in Cota v. Buck, ante, to that given in the subsequent case of Hubbard v. Mosely (x I Gray, r70), upon which these cases seem to rest.

The case of Carlos v. Fancourt (5 Term. Rep. 482 ), cited by the defendants, was one in which the note was made payable out of a fund that should arise from the sale of certain property, and was therefore held not negotiable because not payable at all events. It is in harmony with nearly all of the more modern decisions upon that point, and doubtless states the law correctly. (Story on Prom. Notes, $\$ 25$.) But we do not understand it to be seriously claimed in the case at bar, nor do we think it could be successfully claimed, that the notes are necessarily payable out of any particular fund or property; or, in other words, that the payment thereof is based upon any contingency whatever.

The notes in suit are made payable three years from January I, IS 74 , with the reserved right on the part of the maker to pay the same before maturity, in part or in whole, at any time when the semi-annual interest becomes payable. They are payable at all events within a limited time, and payment cannot be enforced until the expiration of that time; but the maker reserves an option within 
that limit of which he may avail himself if he sees fit. But even this option cannot be exercised except at certain periods which are definitely expressed in the notes.

We think that a note is negotiable if one certain time of payment is fixed, although the option of another time of payment be given.

As the notes in suit come clearly within both the letter and spirit of the rule which we have stated, we decide that they are negotiable promissory notes.

[Omitting portion on waiver of demand and notice.]

It therefore follows that the notes were properly admitted in evidence against the indorsers; and, there being no other defense than that concerning the negotiability of the notes, which we have already disposed of, that it was the plain duty of the court to direct a verdict for the plaintıffs. The petition for a new trial must, therefore, be denied, and judgment entered on the verdict.

Petition dismissed. ${ }^{1}$

\section{AlleN (MASS.), 42. - I 864.}

Contract on a promissory note for $\$ 825$, dated Oct. 7, I857, payable as follows: "One hundred dollars on the first day of March, A. D., I 858 , and the balance in two years from this date, with interest from the first day of November next on the said sum." The writ was dated Nov. $\mathbf{I}_{3}, \mathbf{I}_{5} 8$, and was brought to recover the first instalment. The note bore this indorsement: “ Nov. I9, 1859 . Received on within, $\$ 488$, amount received on sale of personal property mortgaged to secure this note, and applied to payment of last instalment."

The defendant contended that the money received from the sale of the wood should be applied first to the payment of the first instalment of the note; but the judge ruled that " there was no evidence of the amount for which the wood was sold, except what might be inferred from the indorsement on the note, and that the amount so indorsed should be applied to both instalments in proportion as the instalments bore to each other; " and he ordered a verdict for the plaintiff for the sum of $\$ \mathbf{r} 8 \mathbf{r . 9 4}$. The defendant alleged exceptions.

\footnotetext{
$1 \$ 50$, to be paid in such instalments and at such times as the directors of said company may, from lime to time assess or require, is a promissory note. White v. Smith, 77 11l. 351; Goshen Turnpike Co. v. Hurtin, 9 Johns. (N. Y.) 217. But see I/cClillandv. Forfolk Southern R. Co., i ro N. Y. 469, 475-6. - Ev.
} 
Chapman, J. - The first question to be determined is, the amount which, independently of payments, should be recovered in this suit. When the action was commenced, the sum of \$roo had become due, but the balance of the principal was not due. As to the interest, by the terms of the note it was payable on the whole note, including the $\$ 100$, from November I, I857. But it was not to be paid annually, and therefore no interest became due on the balance of the principal until the principal itself became due; so that the amount to be recovered in this action, disregarding payments, is the sum of $\$ 100$, with interest thereon from November I, I857.***

The remaining question relates to the payments, and the proper application of them. As the whole note was due at the date of the indorsement, the plaintiff had a right to appropriate the amount he received to either instalment, at his option. (Allcn v. Kimball, 23 Pick. 473.) It cannot be considered as a payment by process of law or in invitum, like payment by levy of an execution, as was the case in Blackstone Bank v. Hill (10 Pick. I29). But it was paid by the sale of property under an agreement with the defendant, in which the defendant reserved no right to make the appropriation. And the rights of sureties are not concerned in the present case, if that be a material fact. $* * *$

Exceptions sustained.

(a) Engagement that on default the whole sum shall become due.

I2 Meeson \& Welsby (ExCH.), I39. - I $8+3$.

Assumpsit by the indoresee against the maker of a promissory note. The declaration stated, that the defendant on, etc., made his promissory note in writing, and delivered the same to T. C., and thereby promised to pay the said T. C., or order, $5^{2 l}$. Ios., by two equal instalments, on the ist of May, I 843 , and the ist of November, i 843 , and that the whole amount, $52 l$. Ios., should become immediately payable on default being made in payment of the first instalment. The declaration then averred, that $T$. C. endorsed the note to the plaintiff; that the defendant made default in payment of the first instalment, and that he had not paid the amount of the note.

Special demurrer, on the ground that, the second instalment on the said promissory note being made payable by way of condition and penalty immediately on default in payment of the first instalment, the note was not made according to the custom of merchants 
with regard to inland bills of exchange, and consequently the title thereto, and the right of action thereon, could not pass by endorsement. Joinder in demurrer.

Lord Abixger, C. B. - Suppose the case of a note payable ten days after sight - there the subsequent parties do not know when they are to be called upon. I think there is no ground for saying the defendant is not liable.

PARkE, B. - Now, to hold that actions could not be maintained upon such notes as this, would be to impugn all the established practice. Almost every note payable by instalments has such a condition. It is not a contingency - it depends on the act of the maker himself; and on his default, it becomes a promissory note for the whole amount. The point was in effect determined in Oridge v. Sherborne (I I M. \& IV. 374).

Gurney, B., and Rolfe, B., concurred.

Judgment for the plaintiff.

UPON like grounds it has been held that the negotiability of the note is not affected by its being made payable on or before a named date, or in instalments of a particular amount. In Ackley School Dist. v. Hall ( I 13 U. S. I35, I 40), it was held that municipal bonds, issued under a statute providing that they should be payable at the pleasure of the district at any time before due, were negotiable; for, the court said: "By their terms, they were payable at a time which must certainly arrive; the holder could not exact payment before the day fixed in the bonds; the debtor incurred no legal liability for non-payment until that day passed." In Mattison v. Marks (3I Mich. 42I), which was the case of a note payable " on or before " a day named, it was said: "True, the maker may pay sooner if he shall choose, but this option, if exercised, would be a payment in advance of the legal liability to pay, and nothing more. Notes like this are common in conmercial transactions, and we are not aware that their negotiable quality is ever questioned in business dealings." (Carlon v. Kenealy, I 2 M. \& IV. I 39; Colehan v. Willes, Willes, 393; Jordan v. Tate, in Ohio St. 5S6; Curtis v. Home, $5^{8} \mathrm{~N}$. H. 504 ; Howard v. Simtkins, 6o Georgia, 340; Protection Ins. Co. r. Bill, $3^{\mathrm{I}}$ Conn. 534, 538; Goolloe v. Tavlor, 3 Hawks, 458; Rikerv. Sprague 
$M f g . C o .$, I 4 R. I. 402.) In the last-named case it was said that if the time of payment named in the note must certainly come, although the precise date may not be specified, it is sufficiently certain as to time. It was, consequently, held that a reservation in a note of the right to pay it before maturity in instalments of not less than five per cent. of the principal at any time the semi-annual interest becomes payable, did not impair its negotiability; the court observing that a note is negotiable if one certain time of payment is fixed, although the option of another time of payment be given. In view of these authorities, as well as upon principle, we adjudge that the negotiability of the notes in suit was not affected by the provision that upon the failure of the maker to pay any one of the notes of the series to which those in suit belonged, the rest should become due and payable to the holder.

§2I [2] Wilson $\%$. Campbell (Mich.), 68 Northwestern Reporter, 278. - i 896 . Montgomeri, J.- **** But it is contencled that the note is not negotiable, the ground being that the note gives an option to declare the whole amount due in case of default in payment of an instalment of interest, and, while the point is not made, the question suggests itself whether the similar provision contained in the mortgage, giving a like option in case of default in payment of taxes, renders the security non-negotiable, and, as this question is discussed in Brooke v. Struthers ${ }^{1}$ (now pending before us), $68 \mathrm{~N}$. W. 272, we consider both questions.

In Littlefield v. Hodge (6 Mich. 327 ), it was held that a note in form negotiable is none the less negotiable when secured by a mortgage

${ }^{1}$ A gives $\mathrm{B}$ a note containing the clause: "This note is of even date with a certain real estate mortgage made by the maker hereof to said payee and collateral hereto." The mortgage contains a clause to the effect that A will pay all taxes levied "upon this mortgage." Hcld, "A mortgage, executed simultaneously with a note, is a part of the contract, and they are to be construed together. . . In view of the fact that under the law as it then existed the mortgagee was liable to pay the tax upon the mortgage . . . this provision indicates a purpose by the mortgagor to undertake to relieve the mortgagee of the obligation, and to that extent renders the amount payable to or on behalf of the mortgagee uncertain, and the note non-negotiable. If the stipula. tion were to pay and discharge the taxes which the mortgagor was in law bound to pay, it would add nothing to the amount payable to or for the use of the mortgagee. Nor would it render that amount uncertain, or impair the negotiability of the note." - Brooke v. Struthers (Mich.), 68 N. W. Rep. 272 (two judges holding the note non-negotiable because the time of payment is uncertain).-Ev. 
containing provisions not repugnant to it. We apprehend the test in such cases is, are the provisions of the mortgage such as to introduce uncertainty as to time or amount? What elements of uncertainty inconsistent with negotiability here exist, if any? Is there such uncertainty as to time as renders the note non-negotiable? It seems to me very clear that the answer must be in the negative. [Citing and discussing authorities.]

There is no uncertainty as to the amount stipulated to be paid. The engagement to pay all taxes and assessments adds nothing to the obligation of the mortgagor. The obligation rests upon him independently of any stipulation on the subject, and his failure to meet the obligation gives the mortgagee the right to discharge the lien for the purpose of preserving his security, and add the amount to the mortgage debt. (2 Jones, Mortg. \$S I1 37 , I68 3 ; Insurance Co. v. Bulte, 45 Mich. 122,7 N. W. 707.) It is a radical mistake, therefore, to consider this an obligation to pay the mortgagee so much in addition as the taxes and assessments amount to. The obligation is, in the first instance, to pay to the public authorities authorized to receive the amount, and it is only by implication, if at all, that the indebtedness is ever to be added to the mortgage.

At the time this mortgage in question was executed there was, under the law, no duty resting upon the mortgagee to pay the tax on any portion of the mortgaged premises, and we think it cannot be said that subsequent legislation which for a time relieved the mortgagor of a portion of the burden, and imposed it upon the mortgagee, should be so construed as to render an instrument non-negotiable which was, when made, negotiable. As the parties then viewed it, there was no uncertainty as to the amount. The case differs from Carmody v. Crane $(68 \mathrm{~N}$. W. 268$)$, as in that case the contract itself contemplated that taxes might be imposed on the mortgagee's interest, and provided for their payment by the mortgagor, and this engagement was embodied in the note, bringing the case directly within the rule of Bank v. Purdy $\left(5^{6}\right.$ Mich. $7,22 \mathrm{~N}$. IV. 93), and the cases which have followed it, holding that it is incompetent to interpolate into negotiable notes provisions superadding duties to be performed by the maker, or additional obligations other than the payment of a sum certain at maturity. As has been stated above, we do not think this limitation precludes the parties from making provision for the security of the note by a collateral mortgage. The clause in the mortgage is clearly not open to a construction which entitles the mortgagee to foreclose for the amount without himself paying the taxes, although he may, for the mortgagor's default in that regard, declare the whole amount due. 


\section{(e) Engagement to pay exchange.}

5+ MINNESOTA, I84.-IS93.

ACTion by indorsee against maker to recover on promissory notes. Defendant answered setting up a good defense, unless they were negotiable and in the hands of a bona fide indorsee for value. Plaintiff demurred, and the sole question presented was, whether the insertion in the notes of the words, "with current exchange on New York City," rendered the notes non-negotiable and open to the defense. It was admitted that the plaintiff was a bona fide holder for value before maturity. The trial court overruled the demurrer and plaintiff appeals.

Mitchell, J. - The only point raised on this appeal is whether the instruments sued on are promissory notes, for, if they are, they are unquestionably negotiable under the law merchant. They are promises to pay specified sums of money in St. Paul, " with current exchange on New York City;" and the only question is whether this provision as to exchange renders the sums required to discharge them uncertain, within the meaning of the familiar rule that one of the essential qualities of a promissory note is that the amount to be paicl must be fixed and certain and not contingent. In the definitions of a promissory note or bill of exchange it is generally, if not always, stated that the amount necessary to discharge it must be ascertainable from the face of the paper itself, without having to refer to any extrinsic evidence. Construing this definition literally, it must be admitted that the instruments in question do not strictly fall within it, for, of course, extrinsic evidence must be resorted to in order to ascertain the rate of exchange at a given time between two places.

Upon examination of the reports and text-books it is surprising how little direct authority of any value is to be found as to the effect of the addition of such a provision to an instrument for the payment of money. Daniel, Randolph, and Tiedeman state in general that such a provision does not affect the commercial or negotiable character of the paper, but none of them discuss it at any length, and all of them treat of the question as if it only went to the negotiability of the instruments, whereas the real question lies back of that, and is whether they are promissory notes or bills of exchange at all. (Tied. Com. Paper, $\$$ 2Sa: Rand. Com. Paper, $\$$ 200; Daniel, Neg. Inst., $\$$ 54.) We have found no English case directly in point, 
and none bearing on the question, except Pollard v. Harries (3 Bos. \& P. 335), where such an instrument was declared on as a promissory note.

If the question was authoritatively settled in the leading commercial states of the Union or in the federal courts, we would be inclined, for the sake of uniformity, to follow their decisions; but we have been unable to find that the supreme Court of the United States, or of either Massachusetts, New York, or Pennsylvania, has ever passed upon the question. The only cases, state, federal, or colonial, which we have found which may be considered as having passed on the question, are the following, which may be classified thus: That such instruments are not promissory notes: (Lowe v. Bliss, 24 Ill. I68: Read v. MeNulty, I2 Rich. Law, 445; Carroll Co. Saź. Bank v. Strother, 28 S. C. 504, 6 S. E. Rep. 3I3; Palmer v. Falnestock, 9 Up. Can. C. P. r72; Saxton v. Stowenson, 23 Up. Can. C. P. 503; Philadelphia Bank v. Newkirk, 2 Miles, 442; New IVindsor Bank v. Bymum, S4 N. C. 24; Russell v. Russell, I MacAr. 263; Fitsharris v. Leggatt, Iо Mo. App. 527; Mushitt v. Johnson, sS Fed. Rep. S65; Mindsor Saź. Bank v. Mial Mahon, 38 Fed. Rep. $2 S_{3}$ ). ${ }^{1}$ That such instruments are promissory notes: (Smith v. Kendall, 9 Mich. 242; Johnson v. Frishie, I5 Mich. 286; Leggett v. Jones, Io Wis. 35; Morgan v. Edaards, 53 Wis. 599, (I I N. W. Rep. 2 I ); Bradly v. Lill, 4 Bliss, 473). ${ }^{2}$ In very few of these cases is the question discussed at any length, or considered on principle. Some of them were decided by courts of inferior jurisdiction, and in others the remarks of the court were obiter. Many of those which hold that such instruments are not promissory notes rest, without discussion, upon a strict literal construction of the rule that the sum to be paid must appear from the face of the paper without resort to extrinsic evidence. About the only cases where the question is discussed at any length upon principle or authority are Smith v. Kendall, Bradley v. Lill, Morganv. Edwards, and Mindsor Sar. Bank v. MeMahon, supra.

In view of this state of the decisions, while in mere numbers the decided weight of authority may be in favor of the contention of the defendant, we feel at liberty to decide the question in the way we deem most in accordance with principle and business usages, and in accordance with the rule which, in view of such usages, the leat-

${ }^{1}$ To the same effect: Sicond Nat. Bink v. Basmier, $6_{5}$ Fed. Rep. 58 (under Dakota slatute); Flaggr v. School Dist., + N. Dak. 30; Culbertson v. Nolson, 93 Iowa, 187 ; s. C. 61 N. W. 954 ; Nicely v. Commercial Bank, 5 Ind. App. 563. - Ev. ${ }^{2}$ To lhe same effect: Whittli v. Fond du Lac Nat. Pk. (Tex.), 26 S. W. Rep. IIOG. - EI. 
ing courts of the country are most likely to finally settle down upon. The following are, in brief the considerations which have led us to the conchusion that such instruments ought to be held to be promissory notes under the law merchant:

I. The reason and purpose of the rule that the sum to be paid must be certain is that the parties to the instrument may know the amount necessary to discharge it, without investigating facts not within the general knowledge of everyone, and which may be subject to more or less uncertainty, or more or less under the influence or control of one or other of the parties to the instrument. The provision for the payment of the current rate of exchange between the place of payment and some other place is not within the reason of this rule, or subject to the evils or inconveniences which it was designed to prevent. While the rate of exchange is not always the same, and while it is technically true that resort must be had to extrinsic evidence to ascertain what it is, yet the current rate of exchange between two places at a particular late is a matter of common commercial knowledge, or at least easily ascertainable by any one, so that the parties can always, without difficulty, ascertain the exact amount necessary to discharge the paper. It seems to us that within the spirit of the rule requiring precision in the amount to be paid a provision for the payment of the current rate of exchange in addition to the principle amount named does not introduce such an element of uncertainty as deprives the instrument of the essential qualities of a promissory note. A provision for the payment of exchange is very different from one for the payment of reasonable attorneys' fees in calse of suit, as in Jones $x$. Radatz (27 Minn, 240, $6 \mathrm{~N}$. W. Rep. 80o). The latter introduces an element of uncertainty very different both in kind and degree from that introduced by the former. Not only is the amount of the attorney's' fees incapable of either easy or definite ascertainment, but the amount of it is more or less under the control of the holder of the instrument. Moreover, such a provision has never been considered in business circles as properly ancillary or incidental to commercial paper, or any part of its legitimate " luggage."

2. The law merchant, including the law of negotiable paper, is founded upon, and is the creature of, commercial usage and custom. Custom and usage have really made the law, and courts, in their decisions, merely declare it. The law of negotiable paper is not only founded on commercial usage, but is designed to be in aid of trade and commerce. Its rules should, therefore, be construed with reference to and in harmony with general business usages, and, as far as possible, with the common understanding in commercial circles. This was the 
very purpose of the statute of Anne placing promissory notes on the same footing as bills of exchange, and thus setting at rest a question upon which there had been some difference of opinion in the courts. Now, we think we are safe in saying, and justified in taking notice of the fact, that if bankers or other business men accustomed to dealing in commercial paper were asked whether such an instrument is a promissory note, and whether they would deal with it as negotiable paper, the answers would, in almost every instance, be unhesitatingly in the affirmative. We have no doubt but that this is the way in which such paper is generally looked upon and treated in commercial and other business circles; and, if so, the courts should, as far as possible, make their decisions to conform to this general custom and understanding. We recognize the importance of simplicity and certainty in the terms and conditions of commercial paper; and appreciate the objections to permitting it to be loaded down with unnecessary "luggage," but we cannot see, under all the circumstances, and especially in view of what we believe to be the commercia? usage, that any practical evil will result from permitting the addition of such a provision for the payment of current exchange on the principal amount. Nor are we disposed, as a rule, to extend the quality of negotiable paper to contracts for the payment of money beyond the strict limits of the already established rules of law; but to exclude from that category paper like that under consideration would be to exclude the very class of paper which ought to be held negotiable, if any promissory notes ought to be so held, - paper given and taken in commercial transactions, properly so called; for rarely, if ever, would a provision for exchange be incorporated in any other.

Order reversed.

Application for re-argument denied July 20, I $\$ 93$.

(f) Engagement to pay costs of collection or attorney's fees.

$\S 2$ STAPLETON $i$. LOUISVILLE BANKING CO.

$$
95 \text { GEORGIA, SO2.- I895. }
$$

Simmoxs, C. I. - The contrulling question in this case is, whether a promissory note is rendered non-negotiable by a stipulation to pay "all costs and ten per cent. on amount for counsel fees, if placed in the hands of an attorney for suit." There is no prior decision of the court upon the question, and the decisions of other courts as 
to the effect of such stipulations are conflicting. We think the better view, and the one supported by the weight of authority, is that such a stipulation does not impair the negotiable character of the paper. Our code defines a promissory note to be "a written promise made by one or more to pay to another, or order, or bearer, at a specified time, a specific amount of money, or other articles of value." (\$ 2774.) It is defined by Story to be " a written promise by one person to pay to another person therein named, or order, a fixed sum of money, at all events and at a specified time, or at a time which must certainly arrive." (Story, Prom. Notes, p. z). The note in question conforms to all these requirements. It is certain as to the payee, as to the time of payment, and as to the amount. The stipulation as to costs and attorney's fees is not a part of the main engagement, but relates to the remedy in case of failure to comply with the contract, and is intended to compensate for the expense resulting from its breach. It does not become effective unless there is a failure to pay at the time specified; and it cannot then affect its negotiability, for negotiability in the full commercial sense ceases at maturity. As has been well said by Mr. Daniel in his work on Neg. Instruments (rol. I, $62 a$, 4th ed.), “it seems paradoxical to hold that instruments evidently framed as bills and notes are not negotiable during their currency, because when they cease to be current they contain a stipulation to defray the expenses of collection." So far from tending to check the circulation of the paper, such a provision adds to its value and thus renders it more available for commercial purposes. In support of these views, see the following authorities: (I Danicl, Neg. Inst., $4^{\text {th }}$ ed. \$ 62 ct seq.; I Randolph, Com. Paper, $\$ \$ 205$, 206; Parsons, Bills and Notes, 146,147 ; Tiedeman, Com. Pap., \& 28b; $2 \mathrm{Am}$. S Eng. Enc. of Law', 324; Wontgomery v. Crossthiuit, 90 Ala. 553, 24 Am. State Rep. 832, and cases cited; Farmers' Nat. Bank v. Sutton Mfr. Co., 6 U. S. Appeals, 3г2, 33I; Shonandoah Nat. Bank v. Marsh (Iowa), $5^{6}$ N. W. Rep. 458; Sccond Nat. Bank v. Anglin, 33 Pac. Rep. 1056, 6 Wash. 403 ; Dorsey v. Wolff, 32 N. E. Rep. 495, affirming 38 Ill. App. 305 ; Stoneman v. Pylc, 35 Ind. 103, 9 Am. Rep. 637; Proctor v. Baldwin, S2 Ind. 370; Gaar v. Louisaille Bkg. Co., I 1 Bush (Ky.), I8o; Scaton v. Scorill, I 8 Kans. 433; Nickersonv. Shcldon, 33 Ill. 373, 85 Am. Dec. 2So; Dietrich v. Bayhil, 23 La. Ann. 767; Trader v. Chidester, 4 I Ark. 242, 48 Am. Rep. 38 ; Farmers' Nat. Bank v. Rasmussen, i Dak. 6o; Heard v. Dubuque Bank, 8 Neb. Iо; $30 \mathrm{Am}$. Rep. $\mathrm{S}_{\mathrm{I}}$; Howenstcin v. Barnes, 5 Dillon, $4 \mathrm{~S}_{2}$; Bank of Commerce v. Fluqua. I I Montana, 285. See also Touine v Rice, i 22 Mass. 67; Arnold v. Rock River Valley R. Co., 5 Duer, 207; Adams 
v. Adaington, I6 Fed. Rep. 39; Hughitt v. Johnson, 28 Fed. Rep. 865; I6 Am. Law Rev. 853 ). ${ }^{1}$

It was complained that the court erred in directing the jury to find in faror of the plaintiff the amount of attorney's fees stipulated in the note, in addition to the principal and interest, the objection being that there was no evidence to show that the note had ever been placed in an attorney's hands for collection. We think the fact that the plaintiff was represented in this action by an attorney was sufficient, without further evidence, to authorize the court to so instruct the jury. (See No. Atchison Bank v. Gay, 21 S. W. Rep. 479.) Judgment affirmed.

S5 INIDANA, 3I7.-ISS2.

Woods, C. J. - Appeal from a judgment on a promissory note, a copy of which was filed with the complaint. It contains a promise in the ordinary form, to pay a sum named, "with interest at the rate of ten per cent. after maturity, and ten per cent. attorney's fees."

It is claimed that the court erred in overruling the defendants' demurrer to the complaint. The entire argument on the point is in these words: "The complaint is not sufficient in this, it is not definite and certain, and the copy of the note shows that the agreement (is) to pay ten per cent. attorney's fees, which we insist is void, and that, therefore, the note is usurious as to that amount, and should be held roid, and the judgment reversed."

If the stipulation for attorney's fees were conceded to be roid the validity of the note would not be otherwise affected, and consequently the demurrer was properly overruled.

Judgment affirmed, with costs. ${ }^{2}$

${ }^{1}$ Contra. First Wat. Bk. v. Babcock, 94 Cal. 96; Maryland Firtilizing Co. v. Newman, 60 Md. $5 s_{4}$; Altman v. Rittershofer, 68 Mich. $2 \S_{7}$; Jones v. Radatz, 27 Minn. 240; McCoy v. Green, 83 Mo. 626; Decorah First Niat. Bk. v. Laughlin, 4 N. Dak. 39I; Hoods v. North, 84 Pa. St. 407 ; Stillwuter First Wat. Bk. v. Larsen, 60 Wis. 206. - ED.

2There are three views as to the validity of the stipulation as to attorney's fees: (1) The stipulation is valid. Bowie v. Hall, $69 \mathrm{Md}, 433$; Dorsey v. Holff, It2 Ill. 589 . (2) The stipulation is void. Bullock v. Taylor, 39 Mich. I37; Rixey v. Pearre, S9 Va. I13; Security Co. v. Eyer. 36 Neb. 507; Withersfoon v. Masselman, It Bush (Ky.), 214. (3) The stipulation to pay such fees as the court adjudges reasonable, is valid, but a stipulation for a specific sum is void. Levens v. Briggs, 21 Ore. 333. Most courts hold that the amount stipulated is 


\section{Must be Payable in Money; But Particular Kind May be Designated.}

(a) Payment must be in money.

$\$ 20$ FIRST NATIONAL BANK OF BROOKLYN $v$.

$[\S \mathbf{I}]$ SLETTE.

69 Northwestern Reporter (Mich.), i i48.- i 897.

Acrion on an instrument set out in the opinion. Verdict for plaintiff. From an order denying a new trial, defendants appeal.

StaRT, C. J. - This action is based upon an obligation, which is substantially in these words:

$\$ 1,673$.

Halstad, Minx., July' 26, I894.

For value received, we promise to pay to the order of the John Good Cordage and Machine Company the sum of sixteen hundred and seventy-three dollars, as follows: Payable by New York or Chicago exchange, $\$ 560$, Nov. I5th, I $\$ 94$; $\$ 560$, Dec. Ist, I $\$ 94 ; \$ 560$, Dec. I5th, I $\$ 94$. Without interest, if paid as due; if not, then legal rate from date until paid.

The only question on this appeal is whether this is a negotiable instrument under the law merchant. It is absolutely essential, in order to constitute a promissory note under the law merchant, that the promise be to pay in money. If this instrument can be construed as an absolute promise to pay in money $\$ \mathrm{I}, 673$, with exchange, it is negotiable; otherwise, not. (Hastings v. Thompson, $54 \mathrm{Minn}$. I84, 55 N. W. 968.) The case of Bradley v. Lill (4 Biss. 473, Fed. Cas. No. $\left.1,78_{3}\right)$, is the only one to which our attention has been called, where the language of the instrument was similar to the one under consideration. In the case referred to the note was made in Chicago, and was payable at New York, "in" exchange; and it

not conclusive, but that there must be proof (if the actual value of the services. First Nat. Bank v. Larsen, 6o Wis. 206; Goss v. Bowen, Iot Ind. 207.

There are four distinct holdings as to the result upon the negotiability of a bill or note of the insertion of a stipulation as to payment of attorney's fees: (I) The stipulation is valid and enforceable, and does not affect the negotiability of the instrument. Dorscy v. Wolff, I42 Ill. $5 s_{9}$. (2) The stipulation is valid and enforceable, but it destroys the negotiability of the instrument. Jones v. Radatz, 27 Minn. 240; Johnston Harvester Co. v. Clark, 3o Minn. 30s; First Mat. Bk. v. Larsen, 60 Wis. 206. (3) The stipulation is void, and as it may therefore be disregarded, it does not affect the negotiability of the instrument. Gilmore v. Hirst. 56 Kans. 626; Chandler v. Kennedy' (S. D.). 65 N. W. R. 439. (4) The stipulation is void, but nevertheless it destroys the negotiability of the instrument. Bullock v. Taylor, 39 Mich. 137; Altman v. Rittershofer, 68 Mich. 287; Tinsliy v. Hoskins, II I N. C. 340 ; New IVindsor First liat. Bk. v. Bynum, 84 N. C. 24 . It is difficult to support this view upon principle. - ED. 
was held that the note was negotiable, upon the ground that the promise was to pay the sum named in the note, "with" exchange, which was a mere incident to the debt. In the case at bar the note is not payable at any particular place, and the promise is, not to pay a given number of dollars in money "with" — that is, plus - the current rate of exchange, but it is to pay the sum named in the note by New York or Chicago exchange. The holder of this instrument cannot demand in payment thereof $\$ 1,673$ in money, plus the cost of exchange; for the maker is not bound to discharge his obligation except by means of inland bills on New York or Chicago. Nor can the maker tender in payment $\$ 1,673$ in money, with the cost of exchange; for his promise is to make payment by inland bills, which he must purchase in the market. The instrument, then, is not payable in money, and is, therefore, not a promissory note, within the law merchant. (Easton v. Hyde, I $_{3}$ Minn. 9o (Gil. 83); Jones v. Fales, 4 Mass. 245; Irine v. Loiery, I 4 Pet. 293; i Daniel, Neg. Inst., $\$$ \$5 56; Tied. Com. Paper, \$ 29 ; I Rand. Com. Paper, $\$$ 90). In reaching this conclusion we have not been unmindful of the fact that, in commercial usage, bills of exchange are regarded as substitutes for money; but this usage cannot make them such. Order reversed, and a new trial granted. ${ }^{2}$

\section{(b) What constitutes current money. ${ }^{2}$}

\section{$\S 25$}

$$
\text { LAIRD } 2 \text {. STATE. }
$$

$$
\text { 6i Marilani, 309.- IS83. }
$$

Robinson, J., delivered the opinion of the Court.

The plaintiff in error was indicted for forging and uttering a bill of exchange, which is set out in the indictment as follows:

\section{Staunton, Va., Sete'mber 4, is8z.}

Augusta National Bank, pay to J. Edwin Laird or bearer, the sum of seventyfive dollars $(\$ 75)$ current funds.

Correct, W. P. Taris, Cashier.

G. G. Gooch.

[And endorsed] J. EnWIx LAIRI.

I"A $B$ has deposited in this bank $\$ 2,180$ in cks., payable to the order of himself, on the return of this certificate properly indorsed," is not negotiable because it does not appear that the bank promises to pay in money.-First National Bank of Farmersvilte v. Grinville National Bank, st Tex. fo. An order "to pay rents as they become due" is not a bill of exchange because (I) it is payable out of a particular fund, and (2) it is not payable in money on its face. "It is to pay rents, which may be due in wheat, fowls, or services, as well as money." - Worton v. Varlor, I Hill (N. Y.), 5s3 (Is+r). - ED.

"See Neg. Inst. L., $25[6]$, subsect. 5. - Ev. 
A dimurer was filed to the indictment, which was overuled, and the prisuner was tried before the court and found guilty.

Motions for new trial, and to quash the indictment were made, and both overruled, and the prisoner was sentenced to the penitentiary for five years. The record comes before us on petition setting forth the points and questions, by the decision of which the plaintiff in error feels aggrieved.

In regard to the first assignment of error, that there is a variance between the presentment and indictment, it is only necessary to say, that when one is tried upon an indictment, we must look to it and not to the presentment to ascertain the nature and character of the offense charged. By the finding of the indictment, the grand jury has the right to correct, change, or modify the presentment.

In the next place it is argued, that the paper writing set forth in the indictment, is not a bill of exchange because it is payable "in curront funds." Bills of exchange pass by delivery or endorsement, and it is essential that the instrument purporting to be one, should be payable in money. A direction to pay out of certain funds, or notes of a particular bank, or the currancy of a particular place or state, have been held to destroy its negotiability, because the medium of payment is fluctuating and uncertain. The many and conflicting decisions on this subject, will be found collected in I Danicl on Neg. Inst., scos. 6I-3, and note. All the cases, however, agree, if the instrument be payable in current money, it is sufficient, because legal tender money will be presumed to be intended. The words " current funds," as used in the paper before us, mean nothing more or less than "current money," and so construed the instrument was negotiable.

Again it is said the paper ought to have been described as a check or an order for the parment of monel. Since the decision in Hazthorn v. State ( 56 Md. 530 ), this is no longer an open question in this state. The subject was fully considered in that case and it was held that a check drawn on a bank is a bill of exchange, and the forgery of the indorsement thereon was a felony punishable under the Colle. The check set out in the indictment was drawn, it is true, in the state of Virginia, but there is no proof in the record to show the law is different in that state.

[Omitting a question as to stamping.]

Judgment affirmed. 
$\S 25$ Mr. Justice Field in BULL $v$. BANK OF KASSON.

I23 United States, 105, II2.- ISS7.

THE certificate of division of opinion presents to us only one question, and yet, to answer that correctly, we must consider whether the negotiability of the instruments in suit was affected by the fact that they were payable "in current funds." Undoubtedly it is the law that, to be negotiable, a bill, promissory note or check, must be payable in money, or whatever is current as such by the law of the country where the instrument is drawn or payable. There are numerous cases where a designation of the payment of such instruments in notes of particular banks or associations, or in paper not current as money, has been held to destroy their negotiability. (Irine v. Lowry, r+ Pet. 293; Miller v. Austen, I3 How. 2r8, 22S). But within a few years, commencing with the first issue in this country of notes declared to have the quality of legal tender, it has been a common practice of drawers of bills of exchange or checks, or makers of promissory notes, to indicate whether the same are to be paid in gold or silver, or in such notes; and the term " current funds" has been used to designate any of these, all being current and declared, by positive enactment, to be legal tender. It was intended to cover whatever was receivable and current by law as money, whether in the form of notes or coin. Thus construed, we do not think the negotiability of the paper in question was impaired by the insertion of these words.

${ }^{1}$ CURRENT Fuxds. - In the following cases "current funds" was held the equivalent of "money:" Lacy r. Holbrook, 4 Ala. 8s; Phanix Ins. Co. v. Allon, II Mich. 50I; s. C., I3 Mich. I9I; Ithite v. Richmond, I6 Oh. 6; Citizens' Nut. Bk.v. Brown, 45 Oh. St. 39; Telford r. Patton, It4 Ill.6ri. In the following cases " current funds " was held not the equivalent of " money: " Lafayette Bank v. Ringel, 51 Ind. 393; Johnson v. Ituderson, 76 N. Car. 227; IVright v. Ilart, $t_{4}$ Pa. St. 45t; Texas Land, etc., Co. v. Carroll, 63 Tex. 4 S; Platt v. Sank Co. Sank, I7 Wis. 230.

Currency. In the following cases "currency" was held the equivalent of money: Sivift r. Whitney, so I11. Ift; Pholts v. Town, It Mich. 374; Mitchill r. Ileavitt, I3 Niss. 361 ; Dugan v. Camphell, I Oh, II5; Howe v.llartness, $11 \mathrm{Oh}$. St. 449; Butler v. Paine, S Minn. 32.4; Frank v. Wissels, 64 N. Y. I55 " paper currency," when there is a legal tender paper currency); Alauber v. Rigse'rstaff, 47 Wis. 55I; Wright v. Morgan (Tex.), 37 S. W. 627. In the following cases "currency" was held not the equivalent of "money:" Mobile Bank v. Brown, 42 Ala. Io8; Dillard v. Evans, 4 Ark. 175; Rindskoff v. Barrett, I Iowa, I72; Iluse v. Ilamblin, 29 Iowa, 5or; Chambers v. Grorge, 5 Litt. (Ky.) 335; (otherwise of "Kentucky currency," Lamplon v. IJasura, 3 Monr. (Ky.), I49); Fartell v. Kénnett. 7 Mo. 595; IIicklin v. Tucker, 2 Yerg. (Tenn.) 448; Ford v. Mitchell, 15 Wis. $334 .-\mathrm{ED}$. 
6 NEW YORK, 265. - I 875.

IT Is further urged that the instrument in question is not commercial paper for the reason that it is made payable in current bank notes instead of money. The authorities in this state, I think, are adverse to this position. In Keith v. Jones (9 Johns. r 20), the note upon which the action was brought was declared to be payable in "York State bills or specie," and it was said that it "is the same thing as being made payable in lawful current money of the state, for the bills mentioned mean bank paper, which is here in conformity with common usage and common understanding regarded as cash." In Judah v. Harris (I9 Johns. I44), a promissory note payable "in bank notes current in the city of New York," was held to be a negotiable note within the statute. It is said that these decisions were placed upon the ground that the court could take judicial notice that such bills are equivalent to specie. The same rule may well apply here, as "current bank notes" are rotes or bills used in general circulation as money, and constituted the general currency of the country recognized by law at the time and place where payment was to be made and demanded. These notes which were in circulation when the certificate was given and payment demanded, were almost entirely of one kind authorized by the government as currency. They thus being lawful money of the United States, the courts were bound to take judicial notice of that fact. The cases of Licber v. Goodrich (5 Cow. I 86), and Thompson v. Sloan (23 Wend. 77), are not in conflict with Heath v. Jones and Judah v. Harris (supra). Although the doctrine of the latter was doubted in 3 Kent's Commentaries, pp. $75^{-7} 6$, and in some of the state courts it is held that a note payable in current funds is not negotiable, it is safe to follow the adjudications in this state as settling the law upon the subject. Even although a demand was necessary upon the bank before an action could be brought against it on the instrument, thus distinguishing the case from that of a promissory note, where the maker may be sued without any demand, I do not think that this fact takes away the negotiable character of the instrument under the decisions cited, and it must, therefore, be considered as possessing all the features of a negotiable promissory note.'

"BANk Notes. The following were held quivalent to "money:" "The bank notes current in the city of New York." Judah v. Ilarris, t9 Johns. (N. Y.) I44. "Current bank notes." Pardee v. Fish, supra; Fleming v. Nall, I Tex. 246. 
43 NEW YORK, 209.-I87o.

ACtion by indorsee on a draft for I, 205 gold dollars. Judgment for plaintiff.

Alles, J. - [After disposing of another matter]. The bill in suit was drawn in Montreal on a business firm at Whitehall in this state, payable in New York in dollars, the money of account of the state, and in gold dollars, a coin authorized by Congress, and made a legal tender in the payment of debt. It was, therefore, negotiable as a bill of exchange. (r R. S., 6ri, \$ r ; 9 U. S. Stat. at Large, 397.)

It is enough that it is for the payment of money and money only, in cash and not something that may differ in value from cash. (Leiber v. Goodrich, 5 Cow. I86.) It is agreed that bills payable in merchandise or anything but money are not good bills of exchange, but the cases are not agreed in all respects as to what shall be deemed money. In this state it is held that a promissory note, payable " in bank notes current in the city of New York" or "in New York state bills or specie," are negotiable notes within the statutes (Kcith v. Jones, 9 Johns. I 20 ; Judah v. Harris, 19 Johns. I44), while a note payable "in Canada money" is not a negotiable note. (Thompson v. Sloan, 23 Wend. 7r.) The first cases were decilled upon the ground that the court might take judicial notice that bank notes, current in the city of New York, were customarily considered and treated as equivalent to money, which could not be predicated of a note payable in Canada money. Coin current in Canada night not be current in this state, and foreign bills are not regarded as money. (Jones v. Fales, 4 Mass. 245.) In other states a different rule prevails; and bills payable in bank bills, even of the state where payable, are held not negotiable. (McCormick r. Trotter, ıo Serg. \& R. 94.) In this action the bill is for $\mathrm{I}, 205$ gold dollars, that is $\$ \mathrm{I}, 205$ in gold coin, and, as is claimed, in coin of a particular denomination; but it is nevertheless payable in a coin known and recognized as a part of the currency of the country, coined by authority of Congress

"Current bank notes of Cincinnati." Morris v. Edwards, I Oh. IS9; Swetland v. Creigh, is Oh. IIs.

The following were held not equivalent to "money:" "Current bank paper." Camplell v. Weister, I Litt. (Ky.), 3o. " Notes receivable in bank." Breckinridge v. Ralls, 4 Monr. (Ky.), 533. " Current notes of North Carolina." Warren v. Brown, 64 N. Car. 38 I. "Current bank notes." Gray v. Donahoe, 4 Watts. (Pa.) 4oo; Gamble v. Hatton, Peck (Tenn.) I3o; Kirkatrick v. McCullough, 3 Humph. (Tenn.) I7I; McDowell v. Keller, 4 Coldw. (Tenn.) 258. "Current bills." Collins v. Lincoln, II Vt. 268. - ED. 
and made receivable in all payments (9 Stat. at Large, 397). If the bill had called for $\$ 1,205$ without specifying the coin or currency it would have been payable in any lawful currency, and the acceptors might have discharged their obligations by tendering payment in "gold dollars." The tender would have been in money; but if "gold dollars" are but an article of merchandise, a commercial commodity, as claimed, a tender of these in satisfaction of an obligation for the payment of money would not be good, and a debtor could not by such tender relieve himself from his obligation. The laws have not been repealed which declare the money value of the gold and silver coin of the United States and make them a legal tender in the payment of debts. The bill has all the qualities of a negotiable bill of exchange; it is payable absolutely, and in money, and not out of a particular fund.

There are two descriptions of lawful money in use under acts of Congress (assuming the validity of the "legal tender" acts, so called, as applicable to any contract calling for money), and it does not destroy the negotiability of commercial paper or change its character, that it is in terms made payable in any description of money that is recognized and known as money current in business, and which is made a legal tender in payment of debts. (Butler 1 . Horitit, 7 Wall. 258; Bronson v. Rodes, 7 Wall. 229.) Bills of exchange are favored as valuable instruments in commerce, and merchants must be permitted to make them payable in any money lawful and current in the place where payable; and if more than one description of money is recognized by the law of the place, to select that which is most convenient to the parties, without changing the character and legal incidents of the instruments and destroying their negotiability.

But the referee has found, as a question of fact, that the contents of the said bill of exchange or draft were expressed in the money of account and currency of the province of Canada, and has awarded damages for non-payment upon that theory, that is, has given judgment for the value of the amount called for in Canada coin in Montreal on the day the bill matured. In this the referee erred. The contract, interpreted by the law of the place where payable, called for payment in money there current and the construction of the contract was one of law and not of fact.

The error of the referee was carried into the judgment in the assessment of the damages.

Upon this construction of the contract, and an allegation in the complaint, that the value in New York of a draft on Montreal for $\$ 1,205$ was at the time of the default in payment, $\$ \mathbf{I}, S_{3} \mathbf{I} .60$, not denied by the answer, the referee reported in favor of the plaintiff 
for that amount, with interest to the date of the report, and the plaintiff had judgment accordingly. The plaintiff was entitled to a judgment following the contract, and payable in coin for the amount to which the law entitled him upon the dishonor of the bill. That was the sum specified in the bill, with interest thereon, at the rate allowed by law.

There is no warrant for an allowance of damages for the non-payment of money beyond the interest given by statute, neither can the courts compel a party, who has stipulated for the receipt of money in coin, to accept of an equivalent in depreciated currency. So long as the inferior currency, which is excluded from the operation of the contract, and cannot be paid, or tendered in satisfaction, fluctuates in value, absolute justice cannot be done to the parties by adjudging payment in the depreciated currency of a debt due in coin, with an addition for the difference in value.

The only way in which effect can be given to the contract, is by a judgment in terms payable in the better currency to which the creditor is entitled, and an execution following the judgment, and so long as the law recognizes the two currencies of different values, judgments upon contracts for the payment in the better currency, must of necessity, be given in this form, or the distinction between the two kinds of money as affecting the rights of parties, vanishes when the contract is merged in the judgment, and the rights of a creditor under a contract for payment in coin are of no value. This form of judgment is sanctioned by precedent, and has the warrant of the Supreme Court of the United States. (Bronson v. Rodes, 7 Wall. 229; Cheanyker v. United States, 3 Idl. 320 .)

The judgment must be modified, and reduced to the amount to whic h the plaintiff was entitled, payable in coin, with costs of the court below, payable in currency, without costs to either party upon the appeal.

All the judges concurring, judgment modified in accordance with the opinion of Allen, I.

\section{HOGUE $\because$ WILLIAMSON.}

$$
85 \text { TExas, 553.- I } \$ 93 .
$$

Gaines, Associate Justice. - This is a question certified to us for determination by the Court of Civil Appeals for the Third Supreme Juchicial District. 'The certificate is as follows:

“The plaintiff, Hogue, brought suit against defendant, Williamson, upon a written obligation, which reads as follows: 
SAltillo, January 25, ISSS.

On or before May I, ISSS, I promise to pay C. C. Hogue, or order, one thousand Mexican silver dollars.

\$r,ooo, Mex.

Geo. S. Williamson.

The petition alleges that on Nay I, I 888 , Mexican dollars were each worth $8_{5}$ cents in 'American' coin, and plaintiff asks judgment for $\$ 8_{5}$. He states in his petition that the note is payable in Mexican silver dollars.

The defendant filed a general denial, and also averred in his answer, under oath, that the note sued on was given for money which the plaintiff had won from defendant in a game with cards, and was therefore illegal and roid.

Upon the trial in the court below, the plaintiff put in evidence the written obligation sued on, and proved that on May I, Is88, Mexican silver dollars were worth 80 cents each. The plaintiff then rested and the defendant introduced no testimony.

The court instructed the jury to return a verdict for defendant, which was done, and judgment entered accordingly.

If the instrument sued on was a promissory note, this is in error. (Wewton v. Newton, 77 Texas, 5 I r.)

With this explanation, the Court of Civil Appeals for the Third Supreme Judicial District certifies and submits to the Supreme Court, for decision as a part of the law of this case, as a new or novel question, the following proposition:

Was the burden of proof on the plaintiff, after the introduction of the instrument sued on, to show non-performance of its obligations by defendant? In other words, is the written obligation sued on a promissory note, obligating its maker to pay a certain sum of money; or is it an ordinary contract for the delivery of a certain commodity; and must the plaintiff, by affirmative testimony, show a breach of the contract?"

We are of the opinion that the instrument in question is a promissory note. It is such in form and substance, unless the fact that the sum payable is expressed in Mexican silver dollars should make a difference. Speaking of the sum for which a bill of exchange must be drawn, Mr. Chitty says: "It may be the money of any country." (Chitty on Bills, 160). Judge Story says: "But provided the note be for the payment of money only, it is wholly immaterial in the currency or money of what country it may be payabie. It may be payable in the money or currency of England, or France, or Spain, or Holland, or Italy, or any other country. It may be payable in coins, such as in pounds sterling, livres, tomnosis, francs, florins, etc., for in all these and the like cases the sum of money to be paid is fixed by the par of exchange, or the known denomination of the currency with reference to the par." (Story on Prom. Notes, s i 7.) The same rule is distinctly laid down in I Danicl on Neg. Inst., $s 58$, and in Tiedeman on Com. Paper, $\$ 29 b$. In view of the opinion of 
these eminent text-writers, it is remarkable that we have found but two cases in which the question is discussed or decided.

In Black v. IVard (27 Mich. I9I), it is held, that a note made in Michigan, payable in Canada in "Canada currency." is payable in money, and is therefore negotiable. But in Thompsonv. Sloun (23 Wendell, 7 I ), a note made in New York and payable there in "Canada currency" was held not negotiable. The court, however, say: "This view of the case is not incompatible with a bill or note payable in money of a foreign denomination, or any other denomination, being negotiable, for it can be paid in our own coin of equivalent value, to which it is always reduced by a recovery. A note payable in pounds, shillings, and pence, made in any country, is but another mode of expressing the amount in dollars and cents, and is so understood judicially. The course therefore in an action on such instrument is to aver and prove the value of the sum expressed in our own tenderable coin."

This decision was made in $I S_{4}$, and it is to be inferred that at that time the dollar was not a denomination of the lawful money of Canada. We also infer, that when the Michigan case arose, this had been changed and the denomination of Canada money corresponded with that of the United States. Upon this theory, it would seem that the cases may be reconciled. The language quoted from the opinion in Thompson v. Sloan, supra, indicates clearly, that if the money named in the note had been a denomination of Canada money, the ruling would have been different, unless, perchance, the word "currency" would have affected the question. The note we have under consideration is for Mexican silver dollars - coins recognized by the laws of the United States as money of the Republic of Mexico. (U. S. Rev. Stats., $\$ 35^{6} 7$.)

We conclude that the note sued upon in this case was a negotiable promissory note, and that when the plaintiff offered it in evidence, and proved the value of the Mexican dollar at the time of its maturity, he had made a prima facie case, and our opinion will be certified accordingly. ${ }^{1}$

'A nole payable in New Brunswick in "U.S. currency" is negotiable. "It is not necessary that the money payable by a note should be current in the place of payment or where the bill is drawn; it may be in the money of any country whatever. *** And may it not be assumed that 'United States currency' means the money of the United Slates, and that the note is for the payment of three hundred and seventy-one dollars of the United States. [Citing slatute recognizing United States coinage.] This is a legislative recognition that the eagle of the United States and the divisions thereof are coins; or, in other words, the currency of that country." - St. Stephen Branch Ry. Co. v. Black, 2 Hannay (N. H.), 139 (1870). - Ev. 
6. Must not Contain an Order or Promise to do Any Act in Adition to Payment of Money.

\section{(a) Effect of additional stipulations.}

io Adolpuus \& Ellis (Q. B.) 95.- 1839.

ON the trial the plaintiff gave in evidence the following document:

"I agree to pay to Mr. Charles Davies, or his order, the sum of 695\%, at four instalments, viz., the first instalment to be paid on Monday next, June Ioth, 1833, being 20ol: the second on the settling day at Doncaster after the St. Leger, being $150 /$; the third on the settling day at Doncaster, after Epsom, 1834, being 150l.; and the fourth on the settling day at Doncaster, after the St. Leger, I834, being rool.; the remainder, $95 \%$, to go as a set-off for an order of Mr. Reynolds to Mr. Thompson, and the remainder of his debt owing from C. Davies to him. (Signed) Janes Wilkixsox."

The defendant's counsel objected that the instrument was a promissory note, and should have been stamped accordingly.

Lorb Denase, C. I. - The first objection is, that this instrument was improperly received in evidence, being a promissory note not duly stamped. It is a note, ttp to a certain point, but it ends, " $95 l$. to go as a set-off for an order of Mr. Reynolds to Mr. Thompson, and the remainder of his debt owing from C. Daries to him." I think that takes from it the character of a promissory note, and make it an agreement, and that it was properly received.'

I Wexdell (N. Y.) 522.- IS2S.

Error from the Onondaga Common Pleas. A. Leonard sued Mason in a Justice's Court, on an order for the payment of money accepted by Mason. The plaintiff held a promissory note against one $\mathrm{N}$. Leonard for $\$ 3.48$, underneath which was written an order or bill of exchange. in these words: "Levi Mason, Esq.. please

${ }^{1}$ An order directing the drawee to pay $\$ 400$, and take up the drawer's note given to A B, is not a bill. "The essential qualities of a bill or note are (I) that it be payable at all events; not dependent on any contingency, nor payable out of any particular fund; and (2) that it be for the payment of money only, and not for the performance of some other act, or in the alternative." Cook v. Satterlec, 6 Cow. (N. Y.), ros. Accord: Killam v. Sihochs, 26 Kans. 3 ro; Bunker v. Athearn, 35 Me. 364 - ED. 
pay the above note, and hold it against me in our settlement. $\mathrm{N}$ Leonard." The justice gave judgment for the defendant, and the plaintiff appealed to the Onondaga Common Pleas. On the trial in that court, the note, with the order written thereunder, were produced, and a presentment to, and a parol acceptance and promise to pay by, the drawee proved. The Common Pleas nonsuited the plaintiff, holding the promise of the defendant to be within the statute of frauds.

By the Court, SAvage, CH. J. - The only question is, whether the order which the defendant accepted is a good bill of exchange: if so, a parol acceptance is good. ${ }^{1}$ It is supposed that this case depends on the same principles as the case of Cooke v. Sattrile $b$ Satterlee (6 Cowen, Io\$). The rule there recognized is, that a bill of exchange must be for the payment of money, and nothing else. In that case, the drawees were required to pay a certain sum of money, and take up a note given by the drawer to a third person. Here it is to pay a note, which is referred to merely to ascertain the amount; and the retaining the note as a voucher is no more the performance of another act beside the payment of the money than the retaining the order itself for the same purpose.

The court erred. The judgment must be reversed, and a venire de novo is awarded to Onondaga Common Pleas. ${ }^{2}$

(b) Exceptions: (1) Authorizing sale of collateral.

\section{$\S 24$ VALLEY NATIONAL BANK ${ }^{\prime}$. CROWELL.}

I 4 S Pennsyluania State, 254.- 1892.

Actrons on promissory notes.

The defense set up by the affidavit was that there was no technical liability as indorsers on the part of clefendants, because of the nonnegotiability of the notes sued on. These notes contained, in addition to the ordinary form of note, the clause which is quoted in the opinion of the Supreme Court.

The court below, Sadler, P. J., of the Ninth judicial district, specially presiding, made the rules absolute in both cases, and defendants appealed.

Errors assigned were making the rule absolute and entering judgment.

${ }^{1}$ But see Negotiable Instruments Law, $\$ 220$ [132]. - ED.

${ }^{2}$ See also White v. Cushing, 88 Me. 339, antc, p. 177.-ED. 
Per Curiam, Mar. 28, i892:

The only question in this case was whether the note in controversy was negotiable. It is in the usual form of negotiable paper, but it is contended that its negotiability is destroyed by reason of the following provision contained therein:

"Having deposited herewith a like amount of Crowell Company mortgage bonds as collateral security, which we authorize the holder of this note, upon the non-performance of this promise at malurity, to sell either at the broker's board, or at public or private sale, without demnnding payment of this note or the debt due thereon, and withou? further notice, and apply proceeds, or as much thereof as may be necessary, to the payment of this note and all necessary charges, holding us, as makers and indorsers, responsible for any deficiency."

We find nothing in this to destroy the negotiability of the note. While it has been truly said that a promissory note is a courier without luggage, we find nothing in the language quoted beyond the statement that the note is accompanied with certain collateral. The mere giving of collateral security with a promissory note does not destroy its negotiability. (Arnold v. Rock River Valley Union R. R., 5 Duer, $38_{2}$; Towne v. Rice, 122 Mass. 67.) In IVoods v. North $(84 \mathrm{~Pa} .407)$; Johnston v. Speer $(92 \mathrm{~Pa} .227)$, the amount of the note was held to be uncertain. In Bank v. Poillet (126 Pa. I95), the court refused to hold the indorser liable, because the time of payment was not fixed, and in Bank v. McCord (139 Pa. 52), the payment was made dependent upon certain conditions. In the case in hand, the amount of the note is not uncertain, nor is there any question about the time of payment. And the payment is not made dependent upon any condition whatever.

The agreemnt, that if the collateral proves insufficient for the payment of the note, and all necessary expenses and charges, the makers will be responsible for any deficiency, neither increases nor decreases the responsibility of the makers. It merely requires them to do what the law would compel them to do without such an agreement.

We are of the opinion that the affidavit of defense was insufficient, and the judgment properly entered.

Judgment affirmed.

(b) Exceptions: (2) Authorizing confession of iudgment.

OSBORN $\approx$. HAWLEY.

I9 OH1о, I30.- I85o.

Caldwell, J. - The action in the court below was assumpsit. The plaintiff declared as indorsee of a promissory note made by

${ }^{1}$ See especially, Arnold v. R. R., 5 Duer (N. Y.), 207. - ED. 
defendant for $\$ \$_{5.00}$. The declaration also contained the common counts. The case being at issue, the plaintiff offered the note in evidence, which was ruled out by the court, and the plaintiff nonsuited. The refusal by the court to permit the note to go in evidence, is assigned for error. No argument is presented on either side, and the bill of exceptions only shows that the court decided that the note was not proper evidence in the cause.

On examination of the record, we do not see any objection to the note being given in evidence, and we think the court erred in ruling it out. The note has attached to it, and forming a part of the instrument, a power of attorney to confess a judgment, and we presume the court may have held that that fact would prevent its negotiability. And on that presumption, we would merely remark that the power of attorney, being added to the note, does not in any way change the legal character of the note, except that it gives a more summary proceeding for its collection. It is still a promissory note, and being payable to order, is negotiable by indorsement. The power of attorney is not negotiable, and when the legal title to the note is transferred, the power of attorney becomes invalid, and no power whatever can be exercised under it, for the benefit of the indorsee; and he holds the note as if no such power had ever been attached to it.

The judgment of the Court of Common Pleas will be reversed, and the cause remanded for further proceedings. ${ }^{1}$

(b) Exceptions: (3) Waizing exemptions.

\$24 FIRST NATIONAL BANK $i$. SLAUGHTER.

9S AlabaMA, 602.- ISg2.

ACTION by indorsee against makers on an instrument as follows:

Patsbug, Ala., July 15, 1859 .

For value received, the undersigned, of the county of Crenshaw, state of Alabama, jointly and severally promise to pay to the order of Montgomery Iron Works, two hundred and forty-five dollars, payable at First National Bank of Montgomery, with interest until paid, and reasonable attorney's fees, if collected by law, and we hereby waive presentation for payment, and notice of protest for non-payment of the sum, and also waive all homestead and exemption laws as to this debt. It is also further understood and agreed that the title to the Loach wheel and Pratt gin, for which the note is given in payment, shall remain in said Montgomery Iron Works until this note, and interest, is paid in full.

${ }^{1}$ Contra: Ozerton v. Tyler, 3 Barr. (Pa.) 3+6. - ED. 
After the plaintiff had offered the contract in evidence and rested, the defendants offered to prove a failure of the consideration for which said agreement had been executed, whereupon the plaintiff objected, on the ground that the contract sued on was commercial paper. The court overruled the objection, and the plaintiff excepted. The court further ruled that the clauses in saik agreement, providing for the retention of legal title of the property for which it was given, and the payment of reasonable attorney's fees, rendered the instrument non-negotiable, and subject to all set-offs, etc. that it would be subject to in the hands of the original payee. To this ruling the plaintiff also duly excepted. There was much evidence offered by the defendants under their pleas, and there was judgment for the defendants. The rulings of the court, as shown above, are here assigned as error.

Coleman, I. - The instrument sued on possesses all the requisites of commercial paper. It is made payable absolutely at a designated bank, for a sum certain, and at a definite time. The fact that it contains a provision for the payment of attorney's fees, a waiver of exemptions, or the retention of the legal title to the property for which it was given as security for the payment of the debt, does not impede its circulation, or impair its validity as negotiable paper. (Wontgomery v. Crosstharate, 90 Ala. 553; MeGhee v. Imp. S Tra. Bank, 93 Ala. 192.) The Circuit Court was in error in holding that the paper, the foundation of the suit, was not commercial paper. ${ }^{1}$

There are other exceptions reserved, a consideration of which would lead to a reversal of the case on other grounds; but we are of the opinion, that all such questions will be eliminated from the case on another trial. The holder of such paper, received in due course of trade before maturity, for a valuable consideration, without notice, is not affected by any defense or equities which might be arailable to the maker against the payee; and by the express provison of the statute of this state, " paper governed by the commercial law, negotiated before maturity, is not subject to set-off or recoupment." (Code of I $\$ 86, \$ 268_{4}$.)

The evidence shows that plaintiff became the owner, in due course of trade for value, before maturity. There is no proof of notice to the plaintiff, nor of facts calculated to put him upon notice, of any defense to the note. Under such circumstances the plaintiff was entitled to a verdict. (Ross v. Drinkard, 35 Ala. 44I; Johnsonv. Hanozer Bank, S8 Ala. 274-5; Barton v. Barton. 75 Ala. 400.)

Reversed and remanded.

Accord: Zimmerman v. Anderson, $67 \mathrm{~Pa}$. St. 42I, distinguishing Ozerton v: Tyler, 3 Barr. 346. - ED. 
(b) Exceptions: (4) Election to require something in lieu of mone'y.

HODGES $\because$ SHLTLER.

22 NEW YORK, IIH.- IEGO.

THE action was against the defendants as indorsers of the following instrument or note:

Rethand and Burlington RaIlroad CoMpany.

No. 253 .

Si, OOO.

Bostox, Atril r. IBso.

In four years from date, for value received, the Rutland and Burlington Railroad Company promises to pay in Boston, to Messrs. W.S. \& D. W. Shuler, or order, \$I,ooo, with interest thereon, payable semi-annually, as per interest warrants hereto attached, as the same shall become due; or upon the surrender of this note, together with the interest warrants, not due, to the treasurer, at any time until six months of its maturity, he shall issue to the holder thereof ten shares in the capital stock in said company in exchange therefor, in which case interest shall be paid to the date to which a dividend of profits shall have been previously declared, the holder not being entitled to both interest and accruing profits during the same period.

T. Follett, President.

Sam. Hexshaw, Treaszer.

The court decided that the plaintiff was entitled to recover against the defendants, and gave judgment accordingly.

WRIGHT, J. - The single question is, whether the defendants can be held as indorsers. It is insisted that they cannot, for the reasons: Ist. That the instrument set out in the complaint, is neither in terms nor legal effect a negotiable promissory note, but a mere agreement; the indorsement in blank of the defendants, operating, if at all, only as a mere transfer, and not as an engagement to fulfill the contract of the railroad company in case of its default; and 2 nd. That if it be a note, the notice of its dishonor was insufficient to charge the defendants as indorsers. ***

The instrument on which the action was brought has all the essential qualities of a negotiable promissory note. It is for the unconditional payment of a certain sum of money, at a specified time, to the payee's order. It is not an agreement in the alternative, to pay in money or railroad stock. It was not optional with the makers to pay in money or stock, and thus fulfill their promise in either of two specified ways; in stuch case, the promise would have been in the alternative. The possibility seems to have been contemplated that the owner of the note might, before its maturity, surrender it in exchange for stock, thus canceling it and its money promise; but that promise was nevertheless absolute and unconditional, and was as lasting as the note itself. In no event could the 
holder require money and stock. It was only upon a surrender of the note that he was to receive stock; and the money payment did not mature until six months after the holder's right to exchange the note for stock had expired. We are of the opinion that the instrument wants none of the essential requisites of a negotiable promissory note. It was an absolute and unconditional engagement to pay money on a day fixed; and although an election was given to the promisees, upon a surrender of the instrument six months before its maturity, to exchange it for stock, this did not alter its character, or make the promise in the alternative, in the sense in which that word is used respecting promises to pay. The engagement of the railroad company was to pay the sum of $\$ 1,000$ in four years from date, and its promise could only be fulfilled by the payment of the money, at the day named.

[Omitting the question of notice.]

I am of the opinion that the action was well brought against the defendants as indorsers of a negotiable promissory note, and that the notice of its dishonor was sufficient.

The judgment of the Supreme Court should be affirmed.

All the judges agreed that the instrument in suit was a promissory note; Desio and Welles, JJ., dissented on the ground that the notice of non-payment was insufficient in omitting the number upon the margin of the note. ${ }^{1}$

Judgment affirmed. ${ }^{2}$

\section{Payable on demand or at a determinable future time.}

I. When Payable on Demand.

(a) Payable at sight.

$\S 26$

H.ART $\imath^{\prime}$. SMITH.

I5 Alabaia, So7.- 1849 .

DARGAN, J. This was an action of assumpsit, on a bill of exchange, drawn by the defendant in favor of the plaintiff, on Desha \& Smith, dated the 26 th February, i 846 , payable at sight. The only evidence introduced to charge the drawer was the bill,

1 See $S S$ i $66-167[95-96]$, fost. - Ev.

2 "I promise to pay to the order of $W, \$ 55$ at $\mathrm{my}$ store (or in goods on demand)," is a promissory note. Hosstatter v. Wilson, 36 Barb. (N. Y.), 307. Contra, Dinnitt v. Goodwin, 32 Me. 44.-ED. 
and protest, showing a demand of payment made of the drawees, on the $4^{\text {th }}$ of March, $18+6$, and notice to the drawer. The court charged the jury, that the plaintiff could not recover.

A bill, payable on demand, or at any fixed time, need not be presented for acceptance, but a demand of payment, at the time the holder has the legal right to demand payment, is all that is necessary. And if the bill be not paid, the holder may protest it for nonpayment, and on his giving due notice to the drawer and indorsers, their liability is fixed. (Ẽ̃'ans v. Bridge's, + Porter, 345; I Peters, 25; 2 Ib. r7o; Chitty on Bills [roth ed.], 272.) But when the time of payment is uncertain, and a presentation of the bill is necessary, in order to ascertain and fix the time of payment, as if the bill be payable at a number of days after sight, then the bill must be presented for acceptance before payment is demanded. (Story on Bills, § Ir 2, 227; Chitty on Bills [Ioth ed.], 272; Bayley on Bills $\left[5^{\text {th }}\right.$ ed. $\left.], 217,2 \mathrm{r} S.\right)^{1}$

It is contended that a bill payable at sight is entitled to days of grace, and therefore it must be presented for acceptance before payment can be demanded.

I am free to confess, that my opinion, untrammeled by authority, would incline me to hold, that a bill of exchange, payable at sisht, is not entitled to days of grace, and that payment may be demanded on presenting the bill; which, if refused, would authorize the holder forthwith to have it protested for non-payment, and, on giving notice to the drawer, to hold him liable. But the law seems to be settled otherwise. Judge Story, in his treatise on Bills, says, " that days of grace are allowed on all bills, whether payable at a certain time after date, after sight, or even at sight. And although there has been some diversity of opinion, whether bills payable at sight are entitled to days of grace, it is now settled by the decisions, both in England and America, that days of grace are allowable on such bills." (\$342, p. 429. To the same effect, see Chitty on Bills [roth ed.], 376 ; Bayley on Bills, [5th ed.], 244, 245; Selwyn's N. P. [9th ed.], 35I; Coleman v. Sarre, I Barnard, 303; Dehers v. Harriot, I Show. I65; Stephen's N. P., 876.) Under the influence of these authorities, I feel constrained to hold that a bill payable at sight is entitled to days of grace; consequently a demand of payment made of the drawer, upon the first presentation of the bill to him, is insufficient to charge the drawer, for the bill is not then due. As there was no evidence of any previous presentation of the bill for acceptance, nor notice given of non-acceptance, the demand of payment was prematurely made and was, therefore, a nullity. 
As the evidence fails to show a demand of payment on the day the bill was payable, the court correctly instructed the jury that the plaintiff could not recover.

Let the judgment be affirmed. ${ }^{1}$

\section{(b) No time for payment expressed.}

S JoHNSON (N. Y.) 37t.-TSII.

Assumpsit on a promissory note. The first count of the plaintiff's declaration stated, that the defendant, on May 25, iSo9, at, etc., made his certain promissory note in writing, subscribed, etc., and then and there delivered the same to the plaintiff, by which said note the defendant promised to pay to the plaintiff, or order, \$II 2.53 ; by reason whereof, etc. There was a demurrer to this count of the declaration, which was submitted to the court without argument.

Per CURiaM. It is to be presumed that the plaintiff has stated the note in his declaration, according to the terms of it, and that is sufficient. The conclusion of the law is, that where no time of payment is specified in a note, it is payable immediately. The first count, then, shows a cause of action, and the plaintiff is entitled to judgment.

Judgment for the plaintiff. ${ }^{2}$

(c) Issued, accepted or indorsed when oierdue.

$\S 26$

BERRY $i$. ROBINSON.

[S7]

9 Johnson (N. Y.) тгі.- ISI2.

Assumpsit against defendant as indorser of a promissory note, negotiated when overdue. No proof of demand or notice. Plaintiff nonsuited.

${ }_{1}$ Accord: Knott v. Tenable, 42 Ala. IS6; Cribbs r. Adams, 13 Gray (Mass.) 597; Halsh r. Dart, 12 Wis. 635; Luals v. Ladeai, 28 Mo. 342.

Contra: Trask r. Martin, I E. D. Smith (N. Y. C. P.) 505, where a rery full and learned discussion of the subject will be found. - ED.

${ }^{2}$ Accord: Bacon v. Page, I Conn. 404; Jones v. Brow'n, il Oh. St.60I; Messmore v. Mrrison, r;2 Pa. St. $300 ;$ Bank r. Price, 52 Iowa, 570; Libby r. Mikelborg, 28 Minn. 35: Rebertsv. Snow, 27 Neb. 425. - ED. 
Per Curias. The plaintiff was properly nonsuited for not proving demand of payment on the maker, and notice of his default to the indorser. 'Though the note was indorsed long after it was due, yet the indorsee took it subject to this condition. The books make no distinction, on this point, whether a note be indorsed before or after it is due. The indorsement, in every case, where a drawer really exists, is a conditional contract to pay in the event of a demand, or due diligence to make a demand on the maker, and his default. It was equivalent in this case to an order on the drawer to pay the amount. The motion to set aside the nonsuit is denied.

Motion denied.

\section{LEAVITT ¿. PUTNAM.}

3 NEW YORK, 494.- IS5O.

[Reported herein at p. - . . ]

50 Missotri, 331. - is72.

ADAMS, JUDGE. *** But it is unnecessary to review any of the positions assumed by counsel in this case, as the petition on its face does not state facts sufficient to constitute a cause of action against the defendants as indorsers of this note. It is a negotiable note, indorsed after due. Such indorsement is equivalent to drawing a new bill at sight, and the same diligence in making demand and giving notice is required to charge the indorsers. (See Daris v. Francisco, I I Mo. 572, opinion of Scott, J.: also Moodl et al. v. Mack, +3 Mo. 2 1о; Be\%y v. Robinson, 9 Johns. I2 ; Mikinnelv. Crawford, S Serg. \& R. 35I; Rugby r. Dazidson, 2 Mills Const. 33.)

The petition alleges that the indorsement was made about the I th $^{\text {th }}$ April, and alleges a demand and refusal on the 3 d of July following, and gives no excuse whatever for the delay. Even if this petition could be held good after verdict, there was nothing in the evidence to justify che delay in presenting the note for payment, and the indorsers were discharged by such delay. ${ }^{1}$

Judgment affirmed. The other judges concur.

1Accord: Bassenhorst v. Wilhy, +5 Ohio St. 333 (delay from July 30 to Nov. 2I). See Neg. Inst. L., $\stackrel{5}{I} I[Z I] .-E D$. 
2. When Payable at a Fixed or Determinable future Time. (a) A fixed time after date or sight.

I3I IlliNois, 569.

[Reported herein at p. Igo.]

(b) On or before a fixed or determinable time specified.

$$
\text { JORDAN } \approx \text { TATE. }
$$

19 OHio STate, $586 .-1869$.

Motios for leave to file a petition in error to reverse a judgment of the District Court of Montgomery county, affirming the judgment of the Court of Common Pleas.

BY THE CouRT: The negotiable character of a promissory note is not affected by the fact that it is made payable by its terms on or before a future day therein named. Though the maker has a right to pay such note at any time after its date, yet for all purposes of negotiation it is to be regarded as a note payable solely on the day therein named.

Wotion overruled. ${ }^{2}$

If RhODE ISLAND, 402.-I884.

[Reported hirein at p. 203.]

$\$ 23$

COTA $\because$ BUCK.

$$
\begin{gathered}
7 \text { Metcalf (Mass.) } 588 .- \text { I } 844 . \\
\text { [Reportid herein at f.I } \left.8_{\mathrm{I}}\right]
\end{gathered}
$$

Accord: Mattisonv. Marks, 3 I Mich. 421. Contra: Stults v. Sili'a, II9 Mass. I37.-ED. 


$$
\text { I64 Massachitsetts, im6.- IS95. }
$$

Contract upon the following promissory note:

\$50o. Boston, May' I, isgr. On demand, after daie, I promise to pay to the order of Hollis Buwman Pagre five hundred dollars, payable when payor and payee mutually agree. Value received. Grace V. Cook.

Trial in the Superior Court, before Sheldon, I., who directed the jury to return a verdict for the defendant, and reported the case for the determination of this colurt, in substance as follows:

It appeared that the note was given by the defendant to the plaintiff in consideration of the sum of five hundred dollars, delivered by him to her. There was no evidence that the parties had ever agreed upon a time when the note should become payable; but it appeared that the plaintiff had, before the date of the writ, demanded payment of the defendant, and the defentlant had refused payment; and it was agreed that thirty dollars had been paid upon the note.

If the ruling was wrong, the verdict was to be set aside, and judgment was to be entered for the plaintiff for the amount of the note, with interest from the date of the writ, to wit, June 27,1893 ; otherwise, judgment was to be entered on the verdict.

Morton, J. According to the literal construction of this note, although the defendant promises to pay the plaintiff the sum named when he demands it, she may escape the performance of this promise by refusing to agree with the plaintiff when it shall be paid. We think that it hardly could have been the intention of the parties to put it into the power of the defendant thus to aroid payment, and that it is more reasonable to construe it as meaning that it is payable when and after the payor ought reasonably to have agrced. (White v. Sucll, 5 Pick. 425; Sloanv. Hayden, I Io Mass. 141; Black v. Bachelder, I 20 Mass. I $7 \mathrm{I}$; Hawtkins v. Grakam, I 49 Mass. $28_{4}$; Crooker v. Holmes, 65 Maine, I95; Works v. Horsher, 35 Iowa, 340; Lewis v. Tipton, io Ohio St. 88.) The promise to pay is absolute. It is only the time of payment which is left to future agreement. Evidently it is expected from the tenor of the note that the parties will agree, and that a time will be fixed, and that the note will be paid. But no time is fixed within which that agreement is to be made. The law will, therefore, imply a reasonable time. Besides it is the payment, not the non-payment, of the note for which the parties are providing. If the payor does not within a reasonable time agree when the note shall be paid, there is nothing unjust nor 
at variance with the real meaning of the contract in holding that the payee may thereupon demand payment, and, if the note is not paid, proceed to collect it. The case of Barnard v. Cushing, (4 Met. $23^{\circ}$ ), is distinguishable. The question chiefly discussed in that case was whether the indorsement on the note constituted a part of it, and the court held that it did. The indorsement expressly provided, not only that the payees would receive the amount of the note when convenient for the promisors to pay, but that they would not compel its payment. In bringing suit the payees proceeded therefore in direct violation of their agreement. Possibly, if the question arose now, a different result might be reached from that arrived at in that case.

According to the terms of the report the entry must be,

Verdict set aside, and judgment for the plaintiff for the amount of the note, with interest from the date of the writ.

(c) On or at a fixed period after the occurrence of a specified event.

$$
\begin{aligned}
& \text { SHAW } \tau \text {. CAMIP. } \\
& \text { I60 IlLINOIS, 425.-IS96. }
\end{aligned}
$$

Mr. Justice Cartwright delivered the opinion of the court:

Appellee filed a claim in the County Court of Piatt county, against the estate of Edward Swaney, deceased, and the claim was rejected. In the Circuit Court, on appeal, there was a trial by a jury and a verdict for the claimant for $\$ 852.5^{\circ}$, upon which judgment was entered. The judgment was affirmed by the Appellate Court and a certificate of importance granted, under which the case is brought to this court. On the trial the claimant offered in evidence the instrument upon which his claim was founded, together with proof of the signature of the deceased. The instrument was as follows:

$\$ 750.00$

Benest, Ill., Dec. 27, ISgo.

After my death date I promise to pay E. Hanson Camp, or order, the sum of $\$ 75^{\circ}$, without interest at percent. per annum from date, value received."

Following the above there was a power of attorney, in the usual form, to confess judgment, and the signature of Edward Swaney. To the introduction of this instrument objection was made and overruled, and it is insisted that the ruling was wrong, for the reason that the instrument was not a promissory note. It is conceded that a promissory note may be made payable on the death of a certain person, or at a fixed time thereafter, or on demand after such 
death; but it is claimed that this instrument was not payable at a time fixed, and that the words " after my death date" should be construed to mean some uncertain time after that event. We do not regard the instrument as subject to the objection made. It did not become due until the death of the maker, which was an event certain to occur, but by its terms it became due at once after the occurrence of that event. There is nothing in the language to indicate that the money was to be paid at some uncertain time after the maker's death. The objection was properly overruled.'

3. When Payable in a Contingency.

$$
\text { I3 Illinois, 604.- - IS52. }
$$

TREAT, C. J. This was an action brought by Hemmingway against Kelley before a justice of the peace, and taken by appeal to the Circuit Court. On the trial in the latter court, the plaintiff offered in evidence an instrument in these words:

\section{Castleton, April 27, 1844.}

Due Henry D. Kelley fifty-three dollars, when he is twenty-one years old, with interest.

[On the back of which was this indorsement]

David Kelley.

$$
\text { RockToN, May' I, I849. }
$$

Signed the within, payable to Moses Hemmingway. HENRY Kelley.

The plaintiff proved that the payee became of age in August, I849. The defendant objected to the introduction of the instrument because it was not negotiable, but the court admitted it in evidence and rendered judgment for the plaintiff.

Our statute makes promissory notes assignable by indorsement in writing, so as absolutely to vest the legal interest in the assignee. Was the instrument in question a promissory note? To constitute a promissory note, the money must be certainly payable, not dependent on any contingency, either as to event, or the fund out of which payment is to be made, or the parties by or to whom payment is to

${ }^{1}$ A bill or note payable so many days after the death of a party is certain as to time, because the time is sure to arrive. Colehan v. Cooke. Willes, 393; affirmed 2 Str. I217; Bristol v. Warner, in Conn. 7, post. p. ; Conn v. Thornton, 46 Ala. 587; Price v. Jones, 105 Ind. 543; Carnwrisht v. Gray, 127 N. Y. 92; Hegeman v. Moon, 131 N. Y. 462; ante, p. 168; Martin v. Stone, (N. H.), 29 Atl. 845. -E.D. 
be made. If the terms of an instrument leave it uncertain whether the money will ever become payable, it cannot be considered as a promissory note. (Chitty on Bills, I34.) Thus, a promise in writing to pay a sum of money when a particular person shall be married is not a promissory note, because it is not certain that he will ever be married. (Pearson v. Ganct, 4 Mod. 242; Beardesley v. Baldain, 2 Strange, II5I.) So of a promise to pay when a particular ship shall return from sea, for it is not certain that she will ever return. (Palmer v. Pratt, 2 Bing. I $8_{5}$; Coolidge v. Ruggles, ${ }_{5}$ Mass. $38_{7}$.) In all such cases, the promise is to pay on a contingency that may never happen. But if the event on which the money is to become payable must inevitably take place, it is a matter of no importance how long the payment may be suspended. A promise to pay a sum of money on the death of a particular individual is a good promissory note, for the event on which the payment is made to depend will certainly transpire. (Colehan v. Cooke, Willes, 393; s. C. 2 Strange, I 217 .)

In this case, the payment was to be made when the payee should attain his majority - an event that might or might not take place. The contingency might never happen, and therefore the money was not certainly and at all events payable. The instrument lacked one of the essential ingredients of a promissory note, and consequently was not negotiable under the statute. The fact that the payee lived till he was twenty-one years of age makes no difference. It was not a promissory note when made, and it could not become such by matter $e x$ post facto. The plaintiff has not the legal title to the instrument. If it presents a cause of action against the maker, the suit must be brought in the name of the payee. The case of Goss v. Nelson, (1 Burr. 226), is clearly distinguishable from the present. There, the note was made payable to an infant when he should arrive at age, and the day when that was to be was specified. The court held the instrument to be a good promissory note, but expressly on the ground that the money was at all events payable on the day named, whether the payee should live till that time, or die in the interim; and it was distinctly intimated, that the case would be very different had the day not been stated in the note. It was regarded as an absolute promise to pay on the day specified, and no effect was given to the words that the payee would then become of age.

'The judgment must be reversed.

Judgment reversed. 
2 Colorado, 320.- IS74.

Assumpsit upon a written instrument in this form:

Gulden City, Col. Ter., May 20, 1870.

Nine months after date, for value received, I promise to pay J. A. Remington, or order, five hundred dollars, without defalcation or discount, at Golden City, Colorado. The consideration of the above is that if the railroad is completed and cars running to a point inside the Table Mountains, at Golden City, Colorado Perritory, on or before the 20 h of February, A. D. I87I, the above sum will be duly paid to the before mentioned J. C. Remington; otherwise the obligation will be null and void.

STEPHEN EldRED.

Remington assigned to Gorman, and the latter assigned to defendant in error, who was plaintiff below.

The plaintiff had judgment.

Belford, J. - [Omitting the question as to wagers.] - There is another objection equally fatal. The instrument sued on is not negotiable. To constitute a promissory note the money must be certainly payable, not dependent on any contingency, either as to time or the fund out of which payment is to be made, or the parties by or to whom payment is to be made. If the terms of an instrument leave it uncertain whether the money will ever become payable, it cannot be considered as a promissory note. In this case payment was to be made if the railroad reached a given point at a given time. If the point was not reached within the time, then the instrument was to be null and void. The contingency might never happen, and therefore the money was not certainly, and at all events, payable. The instrument then lacked an essential ingredient of a promissory note, and consequently was not negotiable under the statute. The fact that the railroad clid get there in time makes no difference. It was not a promissory note when made, and it could not become so by matter $e x$ post facto. 'The plaintiff has not the iegal title to the instrument, and could not bring the suit, and the defendant's objection to its introduction in evidence should have been sustained.

We will reverse the judgment without remanding the cause, and the plaintiff in error will recover his costs, both here and in the court below.

Reversed.

$\S 23$ [4] Duffield 7 . Jollnston, 96 New York, 369. - i 884. EARL, J. This action was brought to recover the last two payments 
mentioned in the following instrument dated at New Yo-k, December $2 \mathrm{I}, \mathrm{I} \& 78$.

\section{Timomas Johnston, Esq. :}

Diar Sir. - (1) Please pay to J. J. Duffield, or order, the sum of six hundred and sixty-six dollars when the brown stone work of your eight houses situate on the south side of East One Hundred and Fifth street, between Second and Third avenues, city, is topped out.

(2) The sum of four hundred dollars when the stoops of said eight houses are set.

(3) The sum of three hundred and seventy-five dollars when the brown stone work of the said eight houses is completed; and charge the same to me, and oblige yours, etc.,

Wh. CIIAVE.

Across the face of this instrument was written by the defendant these words: "Accepted, Thomas Johnston."

The order was not a bill of exchange, because it was not absolutely payable. (Cook v. Satterlec, 6 Cow. Ios; Seacord v. Burling, 5 Denio, 44t; Ian II asmerv. Terrtt, 27 Barb. 18 i Prindle v. Caruthcrs, I5 N. Y. 426.) It was payable only upon condition that the works should be done as specified, and might never become payable. It cannot, therefore, have the force or effect of a bill of exchange. It does not purport upon its face to be founded upon any considera. tion, and none can be presumed. Hence it was necessary for the plaintiff to prove the consideration upon which it was given, and that brought into the case all the circumstances under which it was given.

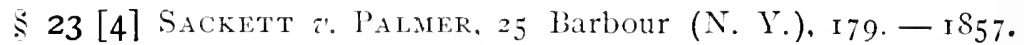
Action on a note payable "ninety days after the dissolution of the partnership between A. B. and C. D., and the settling of the books of said firm." JoHnses, J. 'The instrument on which the action is brought is not a promissory note. It is payable ninety days after the happening of two events, one of which may never happen. The general rule is, that an instrument payable only in money, is not a promissory note, unless it is payable at all events, not depending on any contingency. Though if the event on which the instrument is to become payable must inevitably happen, it is no objection that it is uncertain when it will happen; nor is it of any importance how long the payment may be in suspense; it will still be regarded as a promissory note. (Chit. on Bills [8th Am. ed.]. $\left.{ }_{155}{ }^{1} 5^{6}\right)$ It is not shown by the evidence how long the partnership was to continue by the agreement of the partners. It was certain, however, that there would at some time be a dissolution, by the death of one of the partners, if not otherwise. That event was suff. 
ciently certain. But the settling of the books of the firm was an event which might never happen. It would not inevitably happen. It might, and probably would, after a dissolution, in due course of law. But that is not enough; if it might not happen the instrument is not a promissory note.

\section{$\$ 23$}

AMERICAN NATIONAL BANK $v$ SPRAGUE.

I4 RHODE ISLAND, fIO.- ISS $_{4}$.

Action against indorsers on an instrument similar to the one in Riker v. Sprague $M f_{s}$. Co., (ante, p. 203), except that it was indorsed as follows:

"Issued as collateral to A. \& W. Sprague MIfg. Co.'s draft accepted by Hoyt, Spragues \& Co., No. 6806."

Tillinghast, J. *** It will at once be seen that these notes differ very materially from those cleclared on in the former case, and also that under the rule therein adopted they are clearly not negotiable. They were issued as collateral to certain drafts therein specifically designated, and obviously are not payable at all events; it being evident that the payment of the drafts would at once discharge both the makers and indorsers of the notes, and render said notes null and void. So also a partial payment on the drafts would at once reduce the amount collectible on the notes pro tanto.

The undertaking of the defendants, therefore, was at most a contingent one, and the sum which might become due at the expiration of the notes was uncertain.

We have patiently examined all of the cases cited by the counsel for the plaintiff in support of the negotiability of notes like these, together with numerous others bearing upon the same question, but we are unable to find any support in fact resulting therefrom. On the other hand, the current of authorities, both English and American, is strongly against the position taken. The cases of Costcllo $\mathrm{v}$. Crozicll, I 27 Mass. 293, and Haskell v. Lambert, I6 Gray, 592, cited by the defendant's counsel state the law correctly. The theory, therefore, upon which the plaintiff has thus far proceeded is erroneous and cannot be sustained.

Whether the defendants are liable as guarantors, joint makers, or otherwise, we are not now called upon to decicle. We only decide that, the notes being not negotiable, the defendants are not liable as indorsers.

Without considering the other points raised by the petition, we must, therefore, grant a new trial.

Petition granted. 


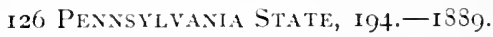

Action by holder against indorser upon the following instrument:

$\$ 500$.

Towanid, Pa., Feb. 20, iss7.

Three months after date the Eureka Mower Co. promise to pay to the order of V. E. Piollet five hundred dollars at the Citizens' National Bank of Towanda without defalcation for value received with interest and without grace.

No. 2717.

Attest: E. T. Fox, president.
EUREKA MOWER CO. by G. W. Buck, Treas.

This note is given for advancements and it is the understanding it will be renewed it maturity.

The defendant objected that the words written upon the face of the note made the time of payment uncertain and destroyed the negotiability of the paper; therefore, the defendant was not liable thereon.

By'the Court: 'The objection is sustained; offer refused; exception.

Oplnion, Mr. Justice Green: This is an action against the indorser of a promissory note. He is sued upon his contract of indorsement and not upon any other or independent special contract in relation to that indorsement. His liability therefore in the present action must be the technical liabilty of an indorser or the suit must fail. The note itself, without the written memorandum which appears upon its face, is a complete and perfect obligation of a negotiable character; and if the written memorandum were not there, we know of no reason why there should not be a recovery against the defendant as a mere indorser. But the memorandum is there; it is not alleged nor offered to be proved that it is there without authority, and if it has a controlling effect upon the note, it must be treated as a part of it. Its meaning is entirely plain.

The words, written across the end of the note, and on the face of it, in immediate proximity to the words of the note, are, "This note is given for advancements, and it is understood it will be renewed at maturity." 'The statement that it is given for advancements does not affect the certainty of the note, and it could easily be regarded as a mere memorandum not changing the contract and therefore not material. But the remainder of the writing is an agreement that the note will be renewed at maturity. As the bank is the holder and discounted the note when it was given, it is undoubtedly affected by the terms of the memorandum, and must be considered as having agreed to renew the note at its maturity. This being so, the obligation of the note is not an absolute, unconditional 
contract to pay the money at maturity. It is a qualified obligation to pay, with a condition that, instead of paying, the holder may give another note in its place which the bank would be bound to accept instead of money. This being so, the case comes within the rule that commercial paper, to be negotiable, must be certain, unconditional, and not contingent.

In Ozerton v. Tyler, (3 Pa. 346), Gibson, C. J. said: “But a negotiable bill or note is a carrier without luggage. It is requisite that it be framed in the fewest possible words, and those importing the most certain and precise contract; and, though this requisite be a minor one, it is entitled to weight in determining a question of intention. To be within the statute, it must be free from contingencies or conditions that would embarrass it in its course; for a memorandum, to control it, though indorsed on it, would be incorporated with it and destroy it. But a memorandum which is merely directory will not affect it." In IToods v. North, ( $S_{+}$Pa. 407), Sharswood, I. said: "It is a necessary quality of negotiable paper that it should be simple, certain, unconditional, not subject to any contingency. It would be a mere affectation of learning to cite the elementary treatises and the decided cases which have established this principle. It is very important to the commercial community that it should be maintained in all its rigor."

It is manifest from the foregoing that the only inquiry necessary to determine the question of negotiability is, the effect of the memorandum upon the terms of the note. As we have seen, it makes an important change in the note, in that, instead of the note being a distinct contract to pay a fixed sum of money at a day certain, the holder has agreed to accept, instead of payment in money, another note payable at another time which is not fixed. The obligation of the note, therefore, is uncertain, depending on whether the maker chooses to pay it or give a new note in place of it. This uncertainty destroys its negotiability, and for that reason relieves the indorser. As this is not an action against the indorser to recover damages for breach of an agreement by him to continue his indorsement, that aspect of the case cannot be considered.

Judgment affirmed. ${ }^{1}$

${ }^{1}$ It is not clear what liability attaches to the indorsement of a non-negotiable note. If the instrument is not a note at all, because lacking an essential element other than words of negotiability, the indorser would seem to be a mere assignor of a common law contract. Story v. Lamb, 52 Mich. 525. If the instrument is a note, but non-negotiable, it has been held that an indorser is a guarantor. Seymour v. Van Slyck, 8 Wend. (N. Y.) to3; Crom woll v. Itewitt, to N. Y. 491. See 4 Am. \& Eng. Encyc. L., p. 479 . See post, Art. XVII, Dir. I, 3. - ED. 


\section{Payable to order or to bearer.}

\section{Payade to the Order of a Specified Person.'}

\section{(a) Payce must be certain.}

26 MINN. 336. -I880.

Appeal by plaintiff from a judgment of the District Court for Ramsey county, the action having been tried before Wilkin, J., and dismissed on the defendant's motion.

Gilfillan, C. J. Action on a writing as follows: $\$ 200$.

DAwson \& Co., Bankers: Pay to the order of, on sight, two hundred dollars, in current funds.

\section{E. Lythe.}

When presented to Dawson \& Co., they refused payment, having been instructed so to do by the defendant.

A check must name or indicate a payee. Checks drawn payable to an impersonal payee, as to "bills payable" or order, or to a number or order, are held to be payable to bearer, on the ground that the use of the words "or order" indicates an intention that the paper shall be negotiable; and the mention of an impersonal payee, rendering an indorsement by the payee impossible, indicates an intention that it shall be negotiable without indorsement - that is, that it shall be payable to bearer. ${ }^{2}$ So when a bill, note, or check is made payable to a blank, or order, and actually delivered to take effect as commercial paper, the person to whom delivered may insert his name in the blank space as payee, and a bona file holder may then recover on it. ${ }^{3}$

\footnotetext{
${ }^{1}$ It is to be observed that the Neg. Inst. Law applies only to instruments containing words of negotiability. An instrument not containing words of negotiability may be a bill or note, but it is not covered by this Act. The English Bills of Exchange Act makes negotiable any bill or note which does not contain words prohibiting transfer; but this changes the law. Chalmers, Bills of Exchange Act (5th ed.), p. 25. - ED.

${ }^{2}$ Accord: Mechanics' Bank v. Straiton, 3 heyes (N. Y.), 365 ; Millets v. Phanix Bank, 2 Duer (N. Y.), I21. - Ev.

${ }^{3}$ That any bon fude holder may fill the blank under an implied authority, see Cruchley v. Clarance, 2 Maule \& Selwyn, 9o; Rich v. Starbuck, 5I Ind. 87; Dunham v. Clogs, 30 Md. 284. Sie Neg. Inst. L., S3 33 [ 4$]$. A note made payable " to the order of the indorser's name," is negotiable by indorsement; "it is like making a note payable in blank, which may be filled up by a bona fide holder with his own name." Unitid States v. Whiti, a Hill (N. Y.), 59. - ED.
} 
These cases differ essentially from the one at bar. In the latter case the person to whom delivered is presumed, in favor of a bona fide holder, to have had authority to insert a name as payee. In the former cases the instrument is, when it passes from the hands of the maker, complete, in just the form the parties intend. But in this case there is neither a blank space for the name of the payee, indicating authority to insert the payee's name, nor is the instrument made payable to an impersonal payee, indicating a fully completed instrument. It is claimed that the words "on sight" are such impersonal payee. They were inserted, however, for another purpose - to fix the time of payment, and not to indicate the payee. It is clearly the case of an inadvertent failure to complete the instrument intended by the parties. The drawer undoubtedly meant to draw a check, but having left out the payee's name, without inserting in lieu thereof words indicating the bearer as payee, it is as fatally defective as it would be if the drawee's name were omitted.

Judgment affirmed.

$$
\text { IS93, a QueEN's Bexcu (C. A.) } 206 .
$$

Application by the plaintiff for a new trial of the action, or that judgment might be entered for him.

The action was brought by the plaintiff as the indorsee for value, against the defendant Tower as the drawer and indorser, of a bill of exchange. The defendant loung, who was the acceptor, had become bankrupt.

At the trial, before Lawrance, J., and a jury, it appeared that the bill bore date May I $\delta, I \delta_{92}$, and the material part of it was as follows:

Five months after date pay to - - order the sum of one hundred and fifty pounds for value received.

To Mr. A. J. Young.

(Signed) E. MaLcolm Tower.

The bill was accepted by loung, and was indorsed by Tower, and by him handed to the plaintiff for value. It was duly stamper as a bill of exchange. The blank had never been filled in.

For the defense it was objected that the document was, neither at common law nor under the Bills of Exchange Act, I $88_{2}$, a bill of exchange, and that, consecpuently, an action could not be maintained upon it as such. The learned judge decided the point of law in favor of the defendant.

The plaintiff applied for a new trial or judgment. 
$\mathrm{KAY}, \mathrm{L} . \mathrm{J}$. Upon the question whether the defendant is estopped by sec. 55 of the Act, or otherwise, from denying that the document is a valid bill of exchange, I express no opinion, because $I$ think it does not really arise in this case. Upon looking at the document it appears that a blank is left just before the word "order." The word "or" does not precede the word "order," and therefore the document runs, " pay to order." It is signed by the drawer, and he is the first indorser, and it is plain that every one who had anything to do with the document treated it as a bill of exchange payable to the order of the drawer. That such a document is a good bill of exchange has not been denied. We asked in the course of the argum:nt for some authority that a bill payable to the order of the drawer is not a good bill of exchange, and no such authority was r roduced. And I find that as long ago as I 79r, Eyre, C. B., in Gibson v. Minct, ( $\mathrm{H}$. Bl. at p. 605), said: " Bills of exchange being of several kinds, the title to sue upon any one bill of exchange in particular will depend upon what kind of bill it is, and whether the holder claims title to it as the original payee, or as deriving from the original payee, or from the drawer in the case of a bill drawn payable to the drawer's own order, who is in the nature of an original payee." I think that this was a good bill of exchange, the meaning of it being, " Pay to the order of the drawer," and that every one always regarded it in that light. The objection that it was not a bill of exchange therefore fails entirely, and that is the only point we have now to decide, except that, there not having been a satisfactory trial of the question of fraud, that question must go back for a new trial.

Bowen, L. J. With regard to the question whether this document is a bill of exchange, if we could have seen our way to hold that it is not 'bill, there would have been an end of the plaintiff's case, and there need not have been a new trial. But, on looking carefully at the document, it is clear that it is a good bill. The case was argued for some time on the assumption that the direction was to "Pay to __ or order," and as if no name of a payee had been inserted. But in fact the document is not drawn in that form. It directs payment to be made " $t$._— order," and it is signed by Tower, so that the name of the payee is not omitted. The bill in its present form in effect directs payment " to my order," and this is a form of bill which is perfectly well known to the law, and perfectly consistent with its being a negotiable instrument from the moment when it was issued.

LORD Esher, M. R. also delivered a concurring opinion.

Application for new trial granted. 
ACtion on a promissory note payable to " the administrators of Abner Chase, deceased." Demurrer to declaration. Demurrer overruled. Defendants appeal.

Scates, J. The error assigned is for overruling a demurrer to the declaration. It was an assumpsit, and contained two counts; each upon a promissory note made by plaintiffs in error to "the administrators of Abner Chase, deceased," for four hundred dollars, with six per cent. interest from date, for value received, dated $;$ th March, I $8_{53}$, one payable in six and the other in twelve months.

The declaration further avers, that defendants were the administrators of Abner Chase on the $;$ th March, I $8_{53}$, with profert of the letters of administration, dated 19 th December, ${ }_{1} 8_{5} \mathrm{I}$; and that the notes were executed, delivered and made payable to the defendants, $b_{y}$ the name and style of the "administrators of Abner Chase, deceased."

The objections taken are, that this is not a promissory note; that there is no payee, or that the payee is uncertain; or if there be a payec, it is a promise to defendants in the representative character, and they should sue as administrator.

We do not assent to either objection. The general rule in relation to bills of exchange and promissory notes requires that the person to whom they are made payable, shall be specified. (Chit. on Bills, ${ }^{56}$ ). But this may be done without inserting the name; for that is certain, which may be rendered certain; and if the payee be so certainly described or referred to, as to be easily ascertained by allegations and proofs, the promise will be valid. The declaration avers that plaintiffs were "administrators of Abner Chase, deceased," at the time these promises were made; and that they were made to them personally, by that designation and description. These are traversable allegations, and must be denied under oath, by our statute as settled in Frye v. Menkins, ( $\mathrm{I}_{5}$ Ill. 339). The same rule was applied in ascertaining the promisors in Divight v. Neziell, (15 Ill. 333). They have not sued as administrators, and it was therefore unnecessary to aver that they were administrators at the time this action was commenced. The demurrer admits the promise to be to defendants personally, by a descziptive phraseology.

The case referred to in Breese, 2, was ruled upon the ground that there was no payee, and that in Breese, 155 was upon the same ground. 'The case of Berry v. Haw'by', (r Scam. 468), was put upon the ground of a want of power in a county treasurer to take under such a promise. 
The cases in 15 Ill. are decisive of this, in principle. The judgment must therefore be affirmed.

Judgment affirmed. ${ }^{1}$

$$
\text { I } 50 \text { Massachusetts, I66.-ISS9. }
$$

Contract by the administrator de bonis non of the estate of Frederick B. Bridgman, against the administrator of the estate of Eugene Bridgman, upon the following instrument:

\$126.00.

Belchertowx, July ig, 1573 .

For value received, I promise to pay F. B. Bridgman's estate, or order, one hundred and twenty-six dollars on demand, with interest annually.

Witness, A. Bridgutiav.

Eugene Bridguan.

Writ dated Narch I3, Is86. The answer set up, among other defenses, the statute of limitations.

The judge ruled that the instrument was not a witnessed promissory note, within the meaning of the statute, and was therefore barred by the statute of limitations, and found for the defendant; and the plaintiff alleged exceptions.

C. Allen, I. After providing that the ordinary limitation of actions of contract shall be six years, it is enacted in the Pub. Sts. (c. 197, sec. 6), that " none of the foregoing provisions shall apply to an action brought upon a promissory note signed in the presence of an attesting witness, if the action is brought by the original payee, or by his executor or administrator;" and by sec. 7 , such an action may be brought within twenty years. The defendant contends that the instrument sued on is not a promissory note, for want of a sufficiently definite payee, and he cites two decisions which sustain him in this contention. (Lyon v. Marshall, I I Barb. 24I; Tittle $r$ Thomas, 30 Miss. 1 22.)

But this would be too strict an application of the cloctrine that the person to whom a note is payable must be clearly expressed. It is an equally general rule, that it is sufficient if there is in fact a payee, who is so designated that he can be ascertained. (Story on Notes, $\$ 36$.) The illustrations of the manner in which this rule has been applied are numerous. Thus, written promises have been held to be valid notes or bills of exchange, though made payable to bearer, (Grant v. Vaughan, 3 Burr. $\left.{ }^{5} \mathrm{I}^{16}\right)$; or to persons designated

${ }^{1}$ A check drawn payable 10 a deceased person is void. U. S. v. First $N . B$, sz Fe(l. R. +10 . - En. 
simply by their office, without naming them, $c . g$. the treasurer of the First Parish in H. or his successor in said office, (Buck r. Mer. rick, 8 Allen, I23); the trustees of a particular church, (Foxon v. Smith, r27 Mass. $4 S_{5}$; Holmes v. Faques, L. R. I Q. B. 376$)$; the manager of the Provincial Bank of England, (Robertson r. Sheward, I Man. \& G. 5II); the treasurer-general of the Royal treasury of Portugal, (Soares v. Gly, S Q. B. 24); the executors of the late W. B., (Hamilton v. Aston, I C. \& K. 679); the administrators of a particular estate, (Moody v. Threlkeld, I3 Ga. 55; Adums v. King, r6 Ill. I69); the trustees acting under the will of the late Mr. W. B., (Megginson v. Harper, 2 Cr. \& M. 322). Also to the heirs of a particular person, even though that person was living at the time, (Baconv. Fitch, I Root. IS I Lockwoodv. Fesup, 9 Conn. 272; Cox ․ Beltihoorer, I I Miss. I42); to a business name adopted by the person in interest, (Bryant v. Eastman, 7 Cush. I I ; Brozinl. Parker, 7 Allen, 337); and to the steamboat Juda and owners, (Moore r. Anderson, S Ind. IS). So, a bill which was indorsed to a person who was already deceased was held valid in the hands of his legal representatives. (Muray v. East India Co., 5 B. \& Ald. 204.) More literally in point in the present case, and directly opposed to the two decisions relied on by the defendant, are Pelticr v. Babillion, (45 Mich. $38_{4}$ ), where a written promise payable to the order of J. V. Mehling estate was held to be a good note, and McKinmey. Harter, (7 Blackf. $38_{5}$ ), which was substantially similar. See also Storm v. Stirling, (3 El. \& B1. S32; S. C. sub nom. Coavie v. Stirling, $6 \mathrm{El} . \&$ Bl. 333); Jates V. Nash, $8 \mathrm{C} . \mathrm{B} . \mathrm{N} . \mathrm{S} .5 \mathrm{SI})$; where a promise to the officer for the time being of a society was held too indefinite, though the general rule as applied in other cases was recognized.

In the case before us, the promise was to pay to F. B. Bridgman's estate, or order. He was dead, and administrators had been appointed. There could be no doubt that the promise was intended to be one of which the administrators could avail themselves. They were in existence, and were ascertainable. If the administrators of his estate had been made the payees, without naming them, there can be no shadow of question that it would have been sufficient. It savors of too much refinement to hold that the instrument was not a valid promissory note for want of a sufficiently definite payee.

This is the only question presented by the bill of exceptions.

Exceptions sustained. ${ }^{1}$

${ }^{1}$ A promissory note payable " to the order of the estate of $\mathrm{A}$.," is payable to a fictitious payee where there is no such legal entity as the "Estate of A.," and if negotiated by the maker is to be treated as a note payable to bearer. Litisohn v. Kent \& Stanley Co., 87 Hun (N. Y.), 257. See Neg. Inst. L., 今28 [9], subsec. 3. - ED. 
(b) Payee may be (1) one not maker, drawer or drawee.

[This is the normal case and calls for no special illustration.]

(b) Payee may be (2) the drawer or the maker.

$\$ 27$

CHAMBERLAIN $\tau^{\prime}$. YOUNG.

I 893,2 Q. B. 206 (C. A.)

[Reportid herein at p. 249. $]^{1}$

(i) Pay'ec may' be (3) the dratee .

$\S 27$

WITTE $\%$ WILLIAMS.

$[\S 8]$

S Solth CAROLINA, 290.-I8;6.

ACTIOs by indorsee against drawer of a bill, drawn upon J. \& J. D. Kirkpatrick payable to the order of the said J. \& J. D. Kirkpatrick and by them indorsed to plaintiff. The trial court held that the instrument was not a bill of exchange and hence was open to a defense of fraud. ${ }^{2}$

Moses, C. J., (after disposing of another matter). The presiding judge, without any exception to the report of the referee to the character of the instrument sued upon, holds that one of them is not a bill of exchange because drawn on J. \&. J. D. Kirkpatrick, requesting the drawees to pay to their own order a certain sum of money, while a bill of exchange presupposes a duty on them to pay to some other than themselves. The only authority relied on in support of the position is found in Story on Bills, $\$ 35$. With the accustomed deference that is due to so distinguished a jurist as the late Mr. Justice Story, we are obliged to say that the proposition is not sustainable on either principle or authority. We are the more emboldened to say so because, in the same section, the learned writer thus expresses himself: "Nay, the drawer may at once become drawer, payee and drawee; as, for example, if he should draw a bill on hinself, payable to his own order at a particular place, naming no drawee, and then should indorse it over, the indorsee might sue him as acceptor of the bill or as maker of a promissory note, at his election." And in section 36 , he says, "the drawee and the payee may be also one and the same person." But in Willes v. Sarare. (I Story, 29), he lays down the rule in direct contradiction to his affirmation cited by the presiding judge

${ }^{1}$ See also Moses v. Lawinci Co. BR., I49 U. S. 29 S, post.-ED.

${ }^{2}$ Only so much of the case is given as relates to this point. - Ev. 
to sustain his own conclusion. We quote the very words of Justice Story: "The argument is that the bill is not a regular bill of exchange because it is drawn by Russell \& Co., payable to Wildes \& Co., who are the drawees of the bill. . . . An instrument is not the less a bill of exchange because all the parties to it in the character of drawers, payees and drawees, are not different persons. A bill drawn by a person payable to his own order has always been deemed to be a bill of exchange in the commercial sense of the phrase, and it would not cease to be such a bill if it should be indorsed by the drawer payable to the drawee. Now, such a bill so indorsed differs in nothing substantially from the present bill. In truth, where the bill is negotiable, and contains a drawer, a payee and a drawee, it is, in a commercial sense, a bill of exchange, although one or more of the parties shall fill a double character."

Mr. Chitty, in his work on Bills (page 25), says: "It is not, however, necessary that there should be three parties to a bill; there are sometimes only two; as where a person draws on another payable to his own order; and, indeed, a bill will be valid where there is only one party to it, for a man may draw on himself payable to his own order. In such cases, however, the instrument may be treated as, in legal operation, a promissory note, and declared on accordingly, but in practice it is usual to declare upon the instrument as if it were a bill not admitting the identity of drawer and drawee." The objection thus taken by the presiding judge to one of the bills cannot prevail, and, in conformity with our views herein expressed, the judgment must be set aside and the case remanded to the Circuit Court for a new trial. It is so accordingly ordered.

IOO MASSACHLSETTS, I2.-IS68.

[Reported herein at $f .17$. .]

(b) Payee may be (4) two or more payees jointly.

83 IOWA, 224.-IS9I.

THE plaintiff, as assignee for value and before maturity of two promissory notes, executed by defendants, payable " to Charles $R$. Whitesell et al. or order," askis judgment thereon, and the foreclos 
ure of a mortgage given by the aefendants to secure the same. The defendants answered that the notes and mortgage were executed for part of the purchase price of certain real estate sold to them by Charles R., Emily, J. L., and Phebe J., Whitesell, and for which Charles R., J. L., and Phebe J. executed to the defendants a warranty deed warranting the title to said property. The answer alleges a breach of the covenants of warranty, and damages in the sum of five hundred dollars, which the defendants ask as an offset against the notes. The plaintift demurred to the answer on the ground that the damages set up were claims against the payee of the notes, and no defense against the notes, in his hands, he being a purchaser before maturity, and without notice; and that the answer sets up no defense to said notes, as against the plaintiff, he being an innocent holder for value before maturity. The demurrer was sustained, and the defendants electing to stand upon their answer, and refusing to plead over, a decree was entered for the plaintiff, from which the defendants appeal.

Givex, J. The discussion is addressed entirely to the question whether the promissory notes sued upon are negotiable. It will be observed that they are promises "to pay to Charles R. Whitesell $\mathrm{ct}$ al. or order." The discussion is as to the construction to be given to the words "et al.," and the effect thereof. The words as here used evidently mean " and others." Therefore, the notes are payable to Charles R. Whitesell and others or order, without designating who the others are. To learn what qualities are essential to a negotiable promissory note, says Mr. Parsons, in his work on Notes and Bills, (page $3 \circ$ ), "we must bear in mind the purpose of the note, and of the law in relation to it. This is simply that the note may represent money, and do all the work of money in business transactions. For this purpose the first requisite - that thing which includes all the rest - is certainty." Certainty, says the author, as to the person who shall receive the money, the person or persons who are to make the payment; the amount to be paid, and the time when payment is to be made. In Story on Promissory Notes ( $\$ 35)$, it is said: "In instruments designed for circulation, it is of the highest importance to know to whom its obligations apply, and from whom a title can securely be derived." In Smith v. Marland, (59 Iowa, 645,649 ), it is said: "The qualities essential to a negotiable promissory note are that it shall possess certainty as to the payor, the payee, the amount, the time of payment, and the place of payment." Such is the rule uniformly laid down in all the authorities, and it does not require further citations. This case must not be confounded with notes payable in the alternative, as "to A. or B.;" 
it is a promise to pay to Charles R. Whitesell and others jointly. Neither must it be confounded with notes payable to bearer, without naming any payee, nor with the cases in which it has been held that whoever legally owns such a note may recover thereon. These notes being promises to pay Charles R. Whitesell and others jointly, Whitesell could not alone transfer them so as to convey the interest of the other payees any more than if they had been named in the notes. A note made to several persons not partners can only be transferred by the joint action of all of them. (Ryziner v. Fickert, 92 Ill. 305); " and neither payee can, of course, indorse the names of the others without special authority.' (Randolph on Commercial Paper, \$ I55.)

The appellee contends that these notes are in accord with the provision of section $208_{5}$ of the Code. Turning to section 2082 , we see that notes in writing, signed by the person promising "to pay to another person or his order or bearer, or to bearer only, any sum of money, are negotiable $b y$ indorsement or delivery. It will be observed that the promise must be to another person or his order or bearer, and does not dispense with the certainty of which we have been speaking as to who that other person is. Section $208_{5}$ is as follows: "Instruments by which the maker promises to pay a sum of money in property or labor, or to pay or deliver property or labor, or acknowledges property or labor or money to be due to another, are negotiable instruments, with all the incidents of negotiability, whenever it is manifest from their terms that such was the intent of the maker; but the use of the technical words 'order' or 'bearer' alone will not manifest such intent." Here, again, the promise must be to another, and there is nothing in the section to modify the rule requiring certainty as to who that other is. It is true, as contended, that negotiable instruments may be transferred by indorsement or delivery; but that does not aid us in determining whether these particular instruments are negotiable. It is said that Charles $R$. Whitesell is the only payee named. That is true, but the notes show that he is not the only person to whom parment is to be made. If it be true, as alleged in the answer, that the other persons named, together with Charles R., are in fact payees of the notes, then, surely, Charles $R$. is not the only payee, and could not alone transfer them. Authorities are cited in support of the claim that, if any words are used which indicate that the maker intended that the notes should be negotiable, the law will give effect to that intention, as against him. It is a sufficient answer to say that, in view of the law which requires certainty in negotiable instruments as to who the payee is, the fact that it is 
left uncertain rather indicates an intention that the instrument should not be negotiable.

The appellee relies upon Moore v. Anderson, S Ind. r8. That note was payable to steamboat Juda and owners, and the court held that the word "owners," as it occurred in the note, sufficiently indicated a person, within the intent of the law. It is a familiar rule that, when a person is designated as payee, and a question arises as to who of several persons bearing the same designation was meant, evidence is admissible to show which is the payee. (Parsons on Mercantile Law, 88.) Under this rule it was admissible to show who was the owner of the steamboat, and hence the designation was sufficient. In Grant v. Vaughan (3 Burrows, I5I6), it is held that a note payable "to ship Fortune or bearer is negotiable, under the rule that, if the name of payee be not the name of a person, as if it be the name of a ship, the instrument is payable to bearer." (See, also, Parsons on Mercantile Law, S9.) In each of these cases a person was designated as payee, - in the one as the owner of the steamboat Juda; and in the other as bearer. These notes are payable to Charles R. Whitesell and others or order. The others are not designated by name or otherwise, and, therefore, it is uncertain "as to the persons who shall receive the money," uncertain " to whom its obligations apply, and from whom a title can securely be derived."

We think the District Court erred in sustaining the demurrer to the answer.

Reversed.

(b) Payee may be (5) one or some of several payees.

MUSSELMAN $\because$. OAKES.

I9 Illinois, 81.-IS57.

DenurRer to declaration overruled, and judgment for plaintiff.

Caton, C. J. The declaration in this case was upon an instrument purporting to be a promissory note, payable to "Olive Fletcher or R. H. Oakes," in an action brought by Oakes. The declaration was demurred to, the demurrer overruled, and judgment rendered in favor of the plaintiff below. This was erroneous. The instrument sued on was payable in the alternative to one of two persons, and for that reason is not a promissory note, and could not be sued on as such. It is indispensable to a promissory note that it not only must be for a sum certain, and payable at a certain time, and without condition, but it must also be payable to a certain per- 
son, either specified on the face of the note, or who may be certainly identified by extrinsic proof, not inconsistent with the face of the note, as the assignee or bearer. Here the promise was to pay Fletcher or Oakes, but which, is uncertain; which of them had the right to receive the pay is not specified, and the legal right to the money is not vested in either. But this is a question of law too well settled by the books to require discussion, and I will only refer to Story on Prom. Notes (p. 40). The peculiarity of the note sued on was no doubt overlooked by the Circuit Court.

The judgment must be reversed.

Judgment reversed.'

\section{\$27 WATSON, SOUTHERN AND MAYER $*$ EVANS. [\$ 8] I HuRLSTONE \& COLTMAN (ExCh.) 662.-I863.}

Declaration. That the defendant and William Patrick Evans and George Thomas Evans, on, etc., made their joint and several promissory note in the words, letters, and figures, following, and as follows, that is to say:-

$£$ IоO.

Leamington, Dec. 2d, 1858 .

On demand, we jointly and severally promise to pay Messrs. Joseph Watson, Thomas Southern, and Daniel Mayer, or to their order, or the major part of them, the sum of one hundred pounds, with lawful interest, for value received.

GEORGE Evans.

William Patrick Evans.

George Thomas Evans.

That the said makers, by the said names following in the said note contained, that is to say, Joseph Watson, Thomas Southern, and Daniel Mayer, meant the plaintiffs; but the defendant and the said other makers did not, nor did either of them, pay the said note.

Demurrer, and joinder therein.

Hayes Serjt. (C. E. Coleridge with him), in support of the demurrer. The document is void for uncertainty. Is the money to be paid to the three payees, or any two of them? Again, do the words " or the major part of them" refer to the payment or the indorsement, or to both? [Pollock, C. B. - Is it not a promise to

${ }^{1}$ Accord: Osgood v. Pearsons, 4 Grav (Mass.), 455: Walrad v. Petrie, 4 Wend. (N. Y.), 575; Blanckenhagen v. Blundell 2 B. \& Ald. 417. Query: does the Neg. Inst. L., \$27, subsec. 5, change the law on this point? See the doubt as to its correctness in Walrad v. Petrie, + Wend. 575,576 ; and in Davis v. Garr, 6 N. Y. I24, 132, post, p. $261 .-$ ED. 
pay to the three persons or their order, or the order of the major part of them?] Suppose two of them said "pay to us;" and the other said "pay all three." If two alone sued, could the maker plead in abatement the non-joinder of the third? Assuming that the promise is to pay all three provided they agree, if not to pay any two of them, suppose they all disagree, and each says, " Do not pay to the other." [MARTin, B. - Payment to one of several joint creditors is a payment to all. | The general rule of law is qualified by the express words of the contract. In Bayley on Bills, (p. 34, 5 th ed.), $i$ is is laid down that "uncertainty as to the person to whom the payment shall be made will prevent the document from being a bill or note; as making it payable to A. or B." The authority there cited is Blanckenhagen v. Blundell, (2 B. \& Ald. 4I7), where Abbott, C. J., and Holroyd, J., agreed that such a document cannot be a promissory note within the statute 3 and 4 Anne, c. 9, the promise being conditional, to pay A. only if the maker had not paid B. [MARTIN, B. - Here the three payers are suing, which distinguishes the case from Blanckenlugen v. Blunlell. I Who is to indorse the notes, the three or any two of them? IMARTiN, B. - The words " or to their order, or the major part of them," mean the order of all three or of any two of them. The words "or the major part of them," must refer to the last antecedent order. WILDE, B. - It is "I promise to pay to all three or their order, but I allow any two to sign for them all.'] If the indorsement may be made by the three, or any two of them, Blanckenhagen $r$. Blundedl is an authority that the document is not a promissory note within the statute 3 and 4 Anne, c. 9. [MARTIN, B. - There cannot be any doubt in this case, as the three payees are suing. In the Author's Life, prefixed to the 9th edition of Noy's Maxims by Bythewood, p. viii., the following anecdote is related: "Three glaziers at a fair left their money with their hostess while they went to market; one of them returned, received the money and absconded; the other two sued the woman for delivering what she received from the three before they all came to demand.it together. The calise was clearly against the woman, and judgment was ready to be pronounced, when Mr. Noy, not being employed in the cause, desired the woman to give him a fee, as he could not plead in her twe lf unless he was employed"; and, having received it, he moved in arrest of julgment that he was retained by the defendant, and that the case was this: the defendant had received the money from the three together, and was not to deliyer it until the same three demanded it; that the money was ready to be paid whenever the three should demand it together. "This motion altered the whole proceedings."] 
Mellish appeared for the plaintiffs, but was not called upon to argue.

PER Curiay. There must be judgment for the plaintiffs. Judgment for the p!aintiffs.

$\$ 27$ [8]. Noxon 7 . Sirth, I27 Mass. $485-$ i 879 . Soule, J The instrument sued on is properly described as a promissory note. Though it purports to be payable to " the trustees of the Methodist Episcopal Church or their collector," the payee is not therefore uncertain, and the instrument does not come within the class of cases in which instruments otherwise in the form of promissory notes are held not to be promissory notes because made payable in the alternative to either of two persons named. (Osgood v. Pearsons, + Gray, 455.) That rule applies to cases in which, so far as the instrument shows, the two persons named as alternative payees are strangers to each other. It does not apply when the instrument discloses the fact that one of the two persons named is named as agent for the other to receive the money. (Holmes v. Faques, L. R. I Q. B. 376.) In the case at bar, it is evident that "their collector", is merely a person authorized by the payee to receive the money in its behalf. ${ }^{1}$

(b) Payee may be (6) the holder of an office for the time being.

6 NEW YORK, I24.-I85I.

Action on promissory notes payable to 'Joseph M. White, Charles A. Davis, and Louis McLane, trustees of the Apalachicola Land Company, or their successors in office, or order." Judgment for plaintiffs.

Gardixer, J. The first objection presented by the pleadings on the part of the defendants is, that the written instruments set forth in the declaration are payable to the trustes therein named or thit successors in office, and that the uncertainty as to which of the two

'A note payable "to M. K. or heirs," is sufficiently definite as to the payee. Knightv. Fones, 2 I Mich. I6I. But not one payable "to C. W. et al." Gordon v. Anderson, 83 Ia. 224; ante, p. 255. - ED. 
the payment is to be made invalidates them as promissory notes, though not as agreements.

I am unable to perceive any such contingency in the contracts. If the plaintiffs are to be considered as the representatives of a corporation, and the suit instituted for the benefit of their principal, the payment must be made to them, as trustees. If their term of office expired before the commencement of the suit, then, and in that event only, would a right of action enure to their successors. There never was a time, consequently, when the maker of the notes could discharge himself by a payment made at his election, to these plaintiffs, or their successors.

The term successors, implies one who takes a place that another has left.

It might be as reasonably contended, that the payee was contingent, where a note was made payable to $\mathrm{A}$. or his executors, or administrators, etc.

It has been determined that an undertaking to pay C. or D., or his or their order, is not a promissory note, because payable to either of the payees, and that only on the contingency of its not being paid to the other. (Story on Prom. Notes, $\$ 37 ; 4$ Wend. $575 ; 2$ B. \& Ald. 4I7.) The distinction between those cases (even if the doctrine thereby established is sound) and the present, is, that the contingency in them was apparent on the face of the instrument. Here there was no uncertainty in the contract, when the notes were made, or became payable; the ambiguity, if any, would arise from a change of trustees after the note took effect as a perfected contract.

Secondly. If the plaintiffs were not the representatives of a corporation, as the defendant insists, they could sustain the action in their own name; the word "trustees," would be merely a designation of the persons, and the phrase "their successors," may be rejected as surplusage. It has been decided that a note payable to a trustee, or agent, or executor, will maintain a suit in the name of the person mentioned. (3 Harrington, $385 ; 3$ Mass. R. 103; 2 Eng. [Ark.] R. 382. And see 9 John. 334; 8 Cowen, 3 r, and cases there cited.) I think, therefore, that these contracts are promissory notes, and consequently negotiable.

A majority of the court concurred in the foregoing opinion.

Foot, J., dissented, on the ground that the instruments declared upon were not promissory notes, there being a contingency as to the persons to whom payment was to be made.

Judgment affirmed. 
2. PaYable to Bearer.

(a) Payable to person named or bearer.

$\$ 28$

PUTNAM $\tau^{\prime}$. CRYMES.

I MC.IULlax's LAW (S. C.) 9.-ISło.

THE plaintiff in this case was not the original payee, but heid the note by transfer to himself by delivery. The note was made payable to Mancil Owens or holder; the plaintiff declared as holder, and defendants demurred on the ground that the holder could not sue without a written assignment. I regarded holder as synonymous with bearer and overruled the demurrer. Appeal by defendants on the ground that the demurrer should have been sustained.

Curia, per Butler, J. The word bearer is usually inserted in a negotiable note, transferable by delivery. But without it, the maker of a note may make it transferable by delivery, either by circumlocution, or using a word of precisely the same import. As if a note were made payable to A. B. or to any one to whom he may deliver it; or to any one who might hold the same by delivery. In both cases the bearer would be sufficiently meant and designated, although the word was not used. If it was the intention of the maker to make it payable to any one who acquires possession by delivery, he has no right to complain when it is presented to him without a written transfer. Holder is a word of the same import as bearer, and both may acquire a title by lawful delivery, according to the terms of the contract. All the law requires is, that the paper must have negotiable words on its face, showing it to be the intention to give it a transferable quality by delivery; otherwise the instrument must be transferred by written indorsement, if payable to order; or sued on by the original payee, if there are no negotiabie words at all.

The decision below is affirmed; the whole court concurring. ${ }^{1}$

(b) Payable to order of fititious person.

46 OHio State, 512.-I8S9.

ACtion by plaintiff to recover $\$ 450$ due her on a deposit. She had drawn a check on defendant bank payable to "William Brown,"

"A bill or note payable " to bearer," or "to A. or bearer," is negoliable by delivery without indorsement. Pierce v. Crafts, r2 Johns. (N. Y.), go; Truesdell v Thompson, 12 Met. (Mass.), 565. See Neg. Inst. L., \$60 [30], post. - ED. 
who was represented to her by one Grimes to be an actual person, and had delivered it to Grimes who procured it by fraud. Grimes indorsed on it the name "William Brown" and defendant, after prudent inquiry as to Grimes' identity, paid it. "Willam Brown" was a fictitious person. Judgment at Common Pleas for plaintiff; reversed at circuit. Plaintiff appeals from judgment of reversal.

Minshall, C. $\boldsymbol{y}$. This case is in its general features analogous to that of Dodge v. The National Exchange Bank, (20 Ohio St. 234), and should, as we think, be ruled by it. ***

The fact that the check was made payable to a person that had no existence does not alter the rights of the plaintiff as against the bank, for she supposed that Brown was a real person, and intended that payment should be made to such person. The doctrine that treats a check or bill made payable to a fictitious person as one made payable to bearer, and so negotiable without indorsement, applies only where it is so drawn with the knowledge of the parties. (Tatlock v. Harris, 3 T. R. I74, ISo; Vere v. Lewis, Id. I8z; Winct v. Gibson, Id. $48 \mathrm{r}$; s. C., in the House of Lords on error, Gibson v. Minet, I H. B1. 569; Collis v. Emett, I H. Bl. $3 \mathrm{I}_{3}$; Gibson v. Hunter, 2 H. Bl. i 87.) The doctrine that a bill payable to a fictitious person or order, is equivalent to one payable to bearer, had its origin in these cases, which all grew out of bills drawn by Levisay $\&$ Co., bankrupts, payable to a fictitious person or order, and were accepted by Gibson $\mathbb{E}$ Co.; but it will be noticed that the holding in each case was upon the express ground, that the acceptor knew at the time of his acceptance that the bill was payable to a fictitious person; and but for this fact the fictitious indorsement would have been held to be a forgery - some of the judges expressing a doubt whether it was not so, although its character was known to the acceptor. (3 T. R. I8I.) These cases will be found reviewed in a note to Bennett v. Farrell (i Campb. I 30 ). It was held in this case that a bill made payable to a fictitious person or order, is neither payable to the order of the drawer or bearer, but is completely void. But in an addendum to the case (at page I $80 \mathrm{c}$ of the report), Lord Ellenborough observes that this holding must be taken with this qualification: "unless it can be shown that the circumstance of the payee being a fictitious person was known to the acceptor." The rule with this qualification is stated as the law in Byles on Bills, 73. (See also, to the same effect, Forbes $\mathrm{r}$. Espy, 21 Ohio St. $48_{3}$; I Rand. Com. Paper, ss 162, I6 3, I6 2 Parsons N. \& B. 59I, and note a.) Mr. Daniel, in his work on Neg. Inst. (sec. I39), states the rule to be general, but, as shown by Mr. Randolph, the cases do not bear out the text. (I Rand. 
Com. Paper, \& I 64 , note 4.) And upon principle we do not see how the law could be held to be otherwise. For if the fictitious character of the payee is unknown to the drawer, whoever indorses the paper in that name with intent to defraud, perpetrates a forgery and the indorsement is roid, a general intent to defraud being suff. cient to constitute the offense.

[The court here discusses and distinguishes Lane v. Krekle, 22 Iowa, 399; Phillips v. Im Thurn, I8 C. B. N. S. 694; Rogers v. Ware, 2 Neb. 29; Ort v. Fonter, 3 I Kans. 478.]

If the drawer of a check, acting in good faith, makes it payable to a certain person or order, supposing there is such person, when in fact there is none, no good reason can be perceived why the banker should be excused if he pay the check to a fraudulent holder upon any less precautions, than if it had been made payable to a real person; in other words, why he should not be required to use the same precautions in the one case as in the other; that is, determine whether the indorsement is a genuine one or not. The fact that the payee is a non-existing person does not increase the liability of the bank to be deceived by the indorsement. The fact is that an ordinarily prudent banker would be less liable to be deceived into a mistaken payment by a fictitious indorsement such as this was, than by a simple forgery. The determination of the character of any indorsement invoives the ascertainment of two things: (I) the identity of the indorser; and (2) the genuineness of his signature; and no careful banker would pay upon the faith of the genuineness of any name, until he had fully satisfied himself both as to the identity of the person and the genuineness of his signature. Now, a careful banker may be deceived as to the signature of a person with whose identity he may be familiar; but he is less liable to be deceived where both the signature and the person whose signature it purports to be, are unknown to him. In making the inquiry required in such case to warrant him in acting, he will either learn that there is no such person, or that no credible information can be obtained as to his existence, which, with an ordinarily prudent banker, would be the same as actual knowledge that there is no such person, and he would withhold payment, as he would have the right to do in such case. But still, if he should be deceived as to the existence of the person, he would, nevertheless, recuire to be satisfied as to the genuineness of the signature. Of this, however, he could not be through his skill in such matters and on which bankers ordinarily rely, for he would be without any standard of comparison, and he could have no knowledge of the handwriting of the supposed person, for there is no such person. So that, if he 
acts at all, it must be upon the confidence he may place in the knowledge of some other person, and if he choose to act upon this, and make, instead of withholding, payment, he acts at his peril and must sustain whatever loss may ensue. It is a saying frequently repeated in "The Doctor and Student," that " he who loveth peril shall perish in it." In other words, where a person has a safe way and abandons it for one of uncertainty, he can blame no one but himself if he meets with misfortune.

The case of I agliano Brothers v. The Bank of England, recently decided in England by the Court of Appeal, (23 Q. B. D. 243), ${ }^{1}$ and called to my attention since the above opinion was written, fully supports the conclusion we have reached.

Judgment of the Circuit Court reversed, and that of the Common Pleas affirmed. ${ }^{2}$

$\S 28$ [9] Clutron \%. Atrenborough, (i 895,2 Queen's Bench [C. A.] 707). A clerk laid before plaintiff checks drawn to the order of "George Brett," a fictitious person. Plaintiff signed them. The clerk indorsed the name "George Brett" on them and defendant took them for value. Plaintiff's bank having paid the checks to defendant, plaintiff seeks to recover the amount of the checks as money paid under a mistake of fact. Judgment for defendant. Lopes, L. J. "The case of Bank of England v. Vagliano Brothers (I89I [A. C.] I07), appears to me to be conclusive of the present case. This case comes, in my opinion, within subsec. 3

1 Reversed on appeal, IS9I, A. C. ro7. See next note. - ED.

${ }^{2}$ Bank of England $\%$. Vagilano Bros., i $80 \mathrm{r}$, Appeal Cases, io7, (Rezersing S. C. 22 Q. B. D. I03, 23 Q. B. D. [C. A.] 243). V.'s clerk forged bills with A.'s name as drawer, B.'s as payee, and V.'s as drawee. A. and B. were real persons. V. accepted the drafts; the clerk forged B.'s indorsement and procured their payment at the bank. The bank charged the bills to V.'s account. V., on discovering the fraud, sought to compel the bank to pay over to him the sum of $£ 7$ I,500 charged against his account on these forged bills. The trial court and the Court of Appeal held that the plaintiff could recover. The House of Lords reversed the holding though the law lords did not agree as to the reasons. Lord Halsbury, L. C., and Lords Watson, Herschell, Macnaghten, and Morris, held that the payee was fictitious, or non-existent, within the meaning of sec. 7 , subsec. 3, of the Bills of Exchange Act, and the bills were therefore payable to bearer; and that the acceptor need not know that the payee is fictitious. Lord Halsbury, L. C., the Earl of Selborne, and Lords Watson and Macnaghten, held the defendant to be protected by the conduct of the plaintiff in accepting the bills. Lords Bramwell and Field dissented on the ground that the payee was not fictitious but real, and the bills were not payable to bearer within the clause of the Bills of Exchange Act. See a part of Lord Herschell's opinion, ante, p. $127 .-\mathrm{ED}$ 
of sec. 7, of the Bills of Exchange Act, I $\$ 82 .{ }^{1}$ The counsel for the p'aintiff, in their ingenious argument, endeavored to import into that enactment a qualification, namely, that the payee of the bill or check must be a fictitious or non-existing person to the knowledge of the drawer. This contention appears to me to be entirely contrary to the effect of the decision in Bank of Englandv. Vagliano Brothers." (Appeal dismissed.)

$\S 28$ [9] Shipmax $a$. Bank, (r26 New York, 3 r $S$ [rS9i]). Action by plaintiff against the bank to recover $\$ 198,045.50$ charged to his account. Plaintiff's clerk made out at various times sixteen checks payable to fictitious persons, and eleven checks payable to rea] persons; plaintiff signed the checks; the clerk indorsed the name of the payee upon the sixteen checks and forged the indorsement of the payee upon the eleven checks; the checks were paid by defendant and charged to plaintiff's account. O'BRIEs, J., (after holding that the payments upon the forged indorsements were at the peril of the bank). It is claimed by the defendant that the sixteen checks made payable to the order of persons having no existence were, in legal effect, payable to bearer. It is provided by statute that paper made payable to the order of a fictitious person and negotiated by the maker has the same validity "as against the maker, and all persons having knowledge of the facts, as if payable to bearer." (i R. S. 768, sec. 5.)

We are of the opinion, upon examination of the authorities cited by counsel on both sides, that this rule applies oniy to paper put in circulation by the maker with knowledge that the name of the payee does not represent a real person. The maker's intention is the controlling consideration which determines the character of such paper. It cannot be treated as payable to bearer unless the maker knows the payee to be fictitious and actually intends to make the paper payable to a fictitious person. (Iring National Bank v. Alley, 79 N. Y. 536; Turmbull v. Bowyer, to Id. 456; I'agliano v. Bank of England, L. R. 22 Q. B. I). Iо3; S. C., on appeal, 23 Id. 243 ; Armstrong v. Pomeroy National Bank, $4^{6}$ Ohio St. 5I2; 7 Railway \& Corporation Law Journal, is 4 Gibson v. Ninct, I H. Black. $569)$.

The findings of the referee that the plaintiffs in good faith believed that the names of the payees represented real persons, entitled to

1"Where the payee is a fictitious or non-existing person the bill may be treated as payable to bearer." Compare the Neg. Inst. L., 28 [9], subsec. 3. $-\mathrm{ED}$. 
receive from them the amount of the check in each case, having been led to believe this by the fraudulent contrivances of Bedell, and that they intended that Bedell should deliver the check to a real payee therein named, and that they did not intend that they should go into circulation or be paid by defendant otherwise than through a delivery to and indorsement by the payee named; and that plaintiffs gave no authority to Bedell to indorse the name of the payee, or to put the checks into circulation, and that no one in fact relied on any appearance of authority, derived from the plaintiffs, in Bedell to indorse the payee's name upon the checks or to put them in circulation, disposes of this question. The indorsement of the names of the fictitious payees upon the checks, with intent to deceive and to put the checks into circulation, constituted the crime of forgery, by means of which, and without any fault of the plaintiffs, payment was obtained thereon. The defendant does not occupy any different position with reference to the checks payable to fictitious payees than it does with reference to those payable to real parties whose indorsements were forged.

Bedell of course knew that the payees were fictitious, but he was not acting within the scope of his employment, but in carrying out a scheme of fraud upon the plaintiffs, and under such circumstances his knowledge cannot be imputed to his principals. (Frank v Chemical Nat. Bank, supra; IVisser v. Denison, supra; Welsh v. German Amerian Bank, supra; Care' v. Cate, L. R. I5 Ch. Div. 643, 644.) $)^{3}$

(c) When the name of the payee diss not purport to be the name of any person.

$\S 28$

MCINTOSH $\because$. LYTLE.

26 Minnesota, 336.-I8so.

[Reported herein at $p$. 245.]

(d) When the only or last indorsement is an indorsement in blank.

CURTIS $v$ SPRAGUE.

$$
5 \text { I CALifornia, 239.-I876. }
$$

JanUary 19, I865, the defendant, Thomas Sprague, made, executed, and delivered his promissory note to the plaintiff, Dennis, in the words and figures following, to wit:

${ }^{1}$ See also Phillips v. Mercantile N. B., Ito N. Y. 556. - ED. 
On the first of November, proximo, I promise to pay to Thomas Dennis, or order, two thousand four hundred dollars, for value received, in United States gold coin, with interest at the rate of one and one-half per cent. per month.

Thomas Sprague.

At the time of the making and delivery of the note, the defendant Huse guaranteed its payment by indorsing the same. When the note fell due, Dennis failed to make demand of payment and give notice of non-payment. Afterwards, and about the month of September, I866, Huse made a payment on the note, and said to the payee: "Mr. Dennis, I am responsible for that note." Dennis after this indorsed the note in blank, and delivered it to $\mathrm{F}$. Maguire. Subsequently, Maguire assigned the note to Dennis by indorsement, without recourse, and redelivered the same to him. Afterwards, Dennis delivered the note to the plaintiff Curtis, without receiving any value, but with an agreement that Curtis should bring suit and divide with him what he recovered. The plaintiff recovered judgment and the defendants appealed.

By the Court: I. The statement made by Huse, the guarantor, to Dennis, the payee, after the maturity of the note, that "I am responsible for that note," is, in substance, a promise to pay it. It is clear from the evidence that he then had full knowledge of the laches of the holder, in failing to demand payment of the maker, on the day the note matured; and it is well settled that a promise by an indorser or guarantor, after maturity, to pay the note, with notice of the laches, dispenses with the necessity of proving demand and notice. (Keyes v. Fenstermaker, 24 Cal. 333; Sigerson v. Matthez's, 20 How. 496.) The court below, therefore, properly held that Huse was not released by a failure of the plaintiff to prove demand and notice. ${ }^{1}$

2. There was no error in the refusal of the court below to nonsuit the plaintiff on the motion of the defendants. When the note was delivered to Curtis, it had on the back the blank indorsement of Dennis, the payee; and "the first effect of an indorsement in blank, is to make the paper payable, not to the transferee as indorsee, but as bearer." (2 Parsons on Notes and lills, ig.)

Curtis, therefore, acquired the legal title to the note, with a corresponding right of action, when it was delivered to him by the payee, indorsed in blank. We attribute no importance to the fact that the note had before been delivered by Dennis with the biank indorsement to Maguire, and that the latter had redelivered it to Dennis, with a special assignment. The title would have been as

${ }^{1}$ See Neg. Inst. L., $\$$ I $42[52]$, I8o [100], fost. - En). 
effectually reinvested in Dennis by mere delivery, without the assignment, as with it; and when Dennis afterwards delivered the note to Curtis, there was no need that he should again indorse it in blank, in order to convey the legal title, as the blank indorsement already on it was effectual for that purpose.

3. The legal title and right of action being wholly in Curtis, the court erred in permitting Dennis to be joined as a co-plaintiff. But it was an error which has wrought no substantial injury to the defendants. Nevertheless, in order to preserve a proper consistency in the record, we deem it better to remand the cause for furtlier proceedings.

It is therefore ordered that the judgment be reversed, and the cause remanded, with an order to the court below to vacate the order allowing Dennis to be joined as a co-plaintiff, and to enter a judgment in the findings in favor of the plaintiff Curtis. ${ }^{1}$

\section{Drawee must be certain.}

39 TExas, $573 .-1873$.

Ogden, P. J. This suit was brought by the heirs of John S. Storrs against the estate of D. E. Watrous, on the following instrument of writing, viz.:

\section{$\$ 2771.62$}

Moxtevallo, June I, is 58.

Ten months after date pay to the order of John S. Storrs, two thousand seven hundred and seventy-one and $\frac{\varepsilon \cdot}{100}$ dollars. value received, and charge to account of

To _- Mobile, Ala.

D. E. Watrols.

The petition charged that for a valuable consideration from John S. Storrs to him thereunto moving, said Daniel E. Watrous executed and delivered to said Storrs the instrument of writing above set out, and that thereby said Watrous undertook, and bound himself, and became liable to pay said sum therein specified.

To this petition the defendants filed a general and special demurrer, which were both overruled by the court, and judgment was rendered for the plaintiffs, and the defendants took their bills of exception to the ruling of the court, and brought the case here by appeal.

The only question now presented for decision is, does this instru-

'Accord: Middleton v. Griffith, 57 N. J. L. 442. - ED. 
ment, independent of any allegations of ownership for a valuable consideration, or promise to pay, give the holder any cause of action.

This instrument is not a promissory note in its ordinary form, nor can it be treated as such, since there is no promise to pay in any event. The instrument is directed to no one, and therefore cannot be considered a draft or bill of exchange. Had it been accepted by ary one, that acceptance would have constituted a promise to pay in the acceptor, and then the maker might have become liable as surety or guarantor; but as there is no drawee or acceptor, the maker cannot, without allegations and proof of other facts setting forth and establishing his liability, be held responsible. The instrument, with the exception of the want of a drawee, is in the ordinary form of an accommodation bill or draft, on which the maker cannot be held liable until after an acceptance or non-acceptance. We think the instrument, as it is, is an imperfect bill or draft, for the payment of which no one is liable. With proper averments, showing the objects and purpose of the parties, and that the maker intended to bind himself in the first instance to pay the same, he might possibly be held responsible without a drawee or acceptor, but not otherwise.

We can see no material difference between the writing here sued on and the one in Ball r. Allen (15 Mass. 433), in which the court says: "But the mere possession of a paper drawn in the form of an order, there being no drawee in existence, we think cannot entitle the possessor to an action in any form."

The same doctrine may be drawn from Peto v. Reynolds (9 Exch. R. 4I4) and in Daiis v. Clark (4 Eng. Com. Law R. I77). From these authorities, and the reason of law governing instruments of this or the like character, we are clearly of the opinion that the petition in this case did not set out a good cause of action, and that the court erred in overruling defendant's special demurrer to the same. We think the demurrer should have been sustained and the plaintiffs permitted to amend their pleadings, that, if desired, they might, by proper averments and proof, establish the liability of the maker or drawer in the first instance, without an acceptance or nonacceptance.

The judgment of the District Court is reversed and the cause remanded.

Reversed and remanded."

\footnotetext{
${ }^{1}$ In Peto v. Reynolds, (9 Exch. 410), ciled above, the bill was not addressed to any drawee, but across the face was written: "Accepted, Samuel Reynolds, Esq., Shorn Lane, Bedminster, Bristol." One Righton (the drawer of the bill) wrote this acceptance. Defendant denied Righton's authority. There was eri-
} 
$\S 20$ [I] FUnK v. BabBitT, 156 Ill. 408 - I895. “B. Apr. 23 , I891. Thirty days after date pay to the order of E. D. Babbitt $\$ 35^{\circ}$, for value received. Funk \& Lackey." Mr. Justice Baker: "Said instruments were declared on as promissory notes. It is urged that they are not notes, or even promises to pay, and, not being directed to any one, do not constitute drafts or orders, and in fact amount to no more than blank pieces of paper. They are, undoubtedly, very irregular and informal instruments, but they are not void as written evidences of indebtedness. A person may draw a bill upon himself, payable to a third person, in which case he is both drawer and drawee. Here the firm drew bills, but did not address them to any third person or persons, and it is therefore to be regarded that they were, in legal effect, addressed to themselves, as drawees, and the signatures of the firm to the several bills bound the firm both as drawers and acceptors. The instruments are inland bills of exchange, to which the firm sustains the triple relation of drawers, drawees, and acceptors, and as the declaration contains the consolidated common counts, the bills were admissible in evidence under them. Moreover, the drawers and drawees being the same, the bills are, in legal effect, promissory notes, and may be treated as such, or as bills, at the holder's option. (I Daniel on Neg. Inst., $\$$ I 28 , I 29)."

$\$ 20$ [I] Wheeler $v$. Webster, I E. D. Smith (N. Y. C. P.) I (I850). By the Court, Ingrahan, First J. "I am of the opinion that the omission of the name of the drawee at the foot of the bill will not vitiate it. The acceptance may be considered as supplying the defect, and as being an admission by the acceptor, that he is the person intended. At any rate, it does not lie with him to make such defense, after having admitted, by the acceptance, that he was the person intended, and after having promised to pay the draft at maturity. He is estopped, by his own act, from such a defense."

dence that defendant had orally promised to pay the bill, but whether absolutely or conditionally was not clear. Plaintiff had a verdict. The court held there must be a new trial because of the unsatisfactory state of the evidence. Three of the four judges expressed the opinion, however, that the instrument was not a bill of exchange for the want of a drawee, but might be treated as a promissory note if Reynolds, in fact, ratified the signature. - ED. 


$$
35 \text { Alabaia, 476. - I860. }
$$

THIs action was brought by James M. Brainard, against the Alabama Coal Mining Company, a domestic corporation; and the complaint was in the following words:

"The plaintiff claims of the defendant $\$ 2,200$, due on a bill of exchange, which was drawn by one R. Swan, on the i6th November, I $\$ 57$, for $\$ 2,200$, upon the defendant, by the name and style of 'Steamer C. $W$. Dorrance and owners,' (the said defendant being then and there the owner of said steamer), and accepted by said defendant, by the name and style of 'St'r Dorrance, per G. M. McConico, agent,' (the said McConico being then and there the agent of said defendant, duly authorized to accept said bill as aforesaid), payable to W. B. Seawell \& Co., on demand; which bill, after maturity, was endorsed to the plaintiff, and, with interest, is still due and unpaid."

A demurrer was interposed to the first count of the complaint, but was overruled by the court. On the trial, as the bill of excep. tions shows, the plaintiff offered in evidence a bill of exchange, of which the following is a copy:

Mobile, Nov. I6, I857.

Steamer C. $W$. Dorrance and owners will please pay W. B. Seawell \& Co. twenty-two hundred dollars, and charge the same to the account of yours, etc.

[Across the face] ST'R Dorrance, per G. M. McConico, agent.

R. SWAN.

[Indorsed] Pay R. Swan, or order, without recourse on us.

$\begin{array}{ll}\text { Pay James M. Brainard, or order. } & \text { W. B. SEAWELL. } \\ & \text { R. SWA. }\end{array}$

The defendant objected to the reading of said bill of exchange, with the acceptance thereof, because it was variant from the bill of exchange declared on, in that the complaint was upon a bill accepted by the defendant, while the bill offered was accepted by 'St' $r$ Dorrance, per G. M. McConico, agent;' also, because it was not evidence to sustain a complaint against the defendant as acceptor; also, because there was no proof of the handwriting of $\mathrm{R}$. Swan, the drawer; also, because there was no proof of the authority of G. M. McConico to make such acceptance; also, because said bill was payable to the order of W. B. Seawell \& Co., and had never been endorsed by them. Each of these objections, separately and severally as made, was overruled by the court, and the defendant excepted.

This being all the evidence, the court charged the jury, that if NEGOT. INSTRUMENTS - I 8 
they believed the evidence, they must find for the plaintiff to which charge the defendant also excepted.

The overruling of the demurrer to the first count in the complaint, the admission of the bill of exchange in evidence, and the charge of the court to the jury, are now assigned as error.

A. J. WaLkER, C. I. A bill of exchange may be drawn upon a person, natural or artificial, by a name different from the proper name of such person, and may be accepted by a name variant from the proper name of the acceptor. (Edwards on Bills, 25I, 9r.) The bill of exchange in this case is alleged to have been drawn upon the defendant, by the name and style of "Steamer $C$. $I V$. Dorrance and owners," and to have been accepted by the defendant, in and by the name and style of "St'r Dorrance, per G. M. McConico." The bill of exchange given in eridence corresponds, in the name and style of its address and acceptance, with the description alleged; and, if drawn upon the defendant, and by it accepted as alleged, was admissible in evidence.

$\$ 7 \mathrm{I}[4 \mathrm{I}]$ The bill of exchange in this case was drawn in favor of, and payable to W. B. Seawell \& Co. The phrase "\& Co.," affixed to the name " $W$. B. Seawell," is prima facie evidence that the bill of exchange was drawn in favor of and payable to a partnership of which W. B. Seawell was a member. It was competent for one of the partners, if the partnership was subsisting, to endorse the bill; but the legal title of the partnership could only be transferred by an endorsement in the name of the partnership. (Story on Bills, $\$ 97$, Story on Part., $\$ 602$; Chitty on Bills, $56,57,225$; Collyer on Part., SS 401, 402, 474; Knapp r. McBride $\$$ Norman, 7 Ala. 19; Lang's Heirs v. Wuring, I7 Ala. 145.) It is certain, therefore, that the endorsement of Seawell alone would not have the effect of transferring to the plaintiff's immediate endorser a legal title to the bill of exchange; and if it were necessary for the plaintiff to rely upon a legal title in this action, there could be no recovery. But, notwithstanding the endorsement by one of the partners, in his name alone, would not carry to the endorsee the legal title of the partnership, yet each partner has the complete jus disponendi of its choses in action and other personalty, and the transfer by one partner of the bill of the partnership must convey the entire equitable right of the partnership, unless it is assailed upon some adequate ground. (3 Kent's Comm., pp. 44, 45; P. \& M. Bank of Mobile v. Willis 今 Co., 5 Ala. $77^{\circ}$.)

By virtue of such an equitable title, the plaintiff might maintain 
an action in his own name, under section 2129 of the Code. The clause of that section which does not apply to bills of exchange, or instruments payable in bank, or at a private banking house, is that which subjects the party suing upon a contract, to any defense which the payor, obligor, or debtor, may have had against the payee, obligee, or creditor, previous to notice of the assignment or transfer.

But in this case, the first count of the complaint is upon an endorsement; and to allow a recovery upon an equitable title, would be violative of the principle that the allegata and probata must correspon.1. The charge of the court was, therefore, erroneous. The first count of the complaint does not contain an allegation appropriate to a recovery upon the equitable title. (Nesbitt v. Pearson, 33 Ala. 668.) If the bill could have been admitted in evidence under the common counts at all, it could only have been after proof of its execution. (May $\mathrm{s}$ Bell v. Willer $心$ Co., 27 Ala. 5I5.)

Judgment reversed, and cause remanded.

\section{Delivery essential.}

$$
\text { to Wiscossix, 66r. - Is;6. }
$$

Action on a promissory note signed by defendant's testator and payable to plaintiff.

The answer is to the effect that one Parmalee, an agent of the plaintiff, called upon the defendant's testator, and solicited him to purchase a scholarsinip in the plaintiff college, which he at first refused to do; that finally, at the request of Parmalee, he signed the note in suit, and left it with Parmalee, under an agreement that the latter should hold it for the testator until a certain time, to be returned to the testator in case he should not decicle to purchase such scholarship, and in the meantime the note should not he considered as delivered to the plaintiff; and that at the specified time, the testator informed Parmalee that he had decided not to purchase the scholarship, and demanded a return to him of the note, but Parmalee, professing to have sent the note by mistake to the plaintiff, did not comply with such demand.

On the trial, by proof and the defendant's admissions, plaintift made a prima facie case. Defendant offered testimony tending to prove the averments of the answer, but an objection to its admission was sustained; and the jurv, by direction of the court, returned a verdict for the plaintiff for the amount due on the note by its terms. From a judgment entered on such verdict the defendant appealed. 
Lyon, $J$. The ruling of the court rejecting all testimony under the answer is equivalent to an order sustaining a general demurrer thereto. It is an adjudication that the answer does not contain facts sufficient to constitute a defeuse to the action. If it states a defense, the ruling is erroneous and fatal to the judgment. We have no doubt whatever that the answer states a complete defense to the action, and that the testimony offered to prove the allegations thereof should have been receivel.

The note was not left with Parmalee, the agent of the plaintiff, as an escrow. On the contrary, the defendant's testator retained the absolute control of the note, and the right to recall it if he chose to do so. Such a deposit has none of the essential features of a delivery in escrow, and hence we are not called upon to determine the legal effect of the delivery of a note in escrow to the agent of the payee. ${ }^{1}$

There was no delivery of the instrument, and hence it never had an inception or legal existence as the note or obligation of the testator. It remained mere waste paper, just as it would have been had the testator kept it in his pocket instead of learing it with Parmalee. The fact that Parmalee was the agent of the plaintiff is of no importance. Were the plaintiff a natural person, and had the testator left the note with such person under the same circumstances, it would not be a delivery, and would confer no right of action. Had the paper been put in circulation, and were the plaintiff a bona fide holder thereof, for value, before due, we would or might have to determine whether or not the testator had been guilty of negligence in the premises. But we have no such question in this action. These views are abundantly sustained by the following cases: Walker v. Ebcrt, 29 Wis. 194; Kellogrs v. Stciner, Id. 626; Butler v. Carns, 37 Id. 6I; Thomas v. Watkins, I6 Id. 549; Chipman v. Tucker, 38 Id. 43 ; Rolverts v. McGrath, Id. 52; Roberts v. Wood, Id. 60.

Judgment reversed and a new trial awarded. ${ }^{2}$

${ }^{1}$ While it is now generally conceded that a negotiable instrument may be delivered in escrow to a third person for the payee, the same as a sealed instrument, it is a disputed question whether it may be so delivered in escrow directly to the payee or his agent. The following cases hold that it may not: Stewart v. Anderson, 59 Ind. 375; Jone's v. Shaze, 67 Mo. 667; Garner v. Fite, 93 Ala. 405: Carter v. Moulton, $5 \mathrm{I}$ Kans. 9. The following cases hold that it may: Burke v. Dulaney, 153 U. S. 225; Benton v. Martin, 52 N. Y. 570 ; Watkins v. Bowers, II Mass. 383; Brown v. St. Charles, 66 Mich. 7r; Swiet v. Stevens, 7 R. I. $375 .-E_{D}$.

${ }^{2} \mathrm{~A}$ note signed by a person, and found after his death among his papers, has no validity for want of delivery. Purviance v. Fones, r20 Ind. I62. - ED. 
ACtion upon a promissory note for \$10,000. Judgment for defendants; reversed at General Term. Defendants appeal and stipulate for judgment absolute for plaintiff if the judgment of the General Term is affirmed.

The defendant's testator handed to plaintiff, his sister, a sealed envelope on which was indorsed the following: "Mary C. Worth, this is not to be unsealed while I live, and returned to me at any time I may wish it; T. B. Worth." After the testator's death, plaintiff unsealed the envelope and found within it a promissory note in these words: "Addison, January 3 oth, I 864 . I promise to pay my sister, Mary C. Worth, on demand, ten thousand dollars, in consideration of services rendered to me. T. B. Worth."

Foster, J. . . I think there are but two questions in the case.

The first is, whether the delivery, in the manner and with the conditions specified, and under all the circumstances of the case, was such, that if the note was founded upon a sufficient valuable consideration, it would on his death constitute a valid and legal claim against his estate; and if so, then, scond, was there such a consideration expressed, and proved by parol, as would make the note a valid demand, if the delivery had been absolute and unconditional.

I think the circumstances show that the maker of the note delivered it to her with the intention that it should be hers absolutely, unless he should thereafter apply to her for its re-delivery, or unless she should open the envelope during his life. Or, in other words, that he intended to pass the title in it to her, subject to being divested (as she had the possession), by either of these acts; and that, if neither of them were performed, the title to the note should remain in her. It was not delivered to her as an cscrow, for such a delivery must be made to some third person; and, as a general rule, an escrow is made to await some affirmative action on the part of the other party, before he is entitled to the absolute delivery of the instrument, and not the affirmative action of the party who delivers it as an escrow. The delivery, therefore, was complete, provided there was an acceptance by her.

There is no doubt, that a delivery of a deed or note, or other obligation, to one person in favor of, and for the benefit of another, constitutes a valid and binding delivery as against the party who delivers it, whether the party in whose favor it is delivered is owner 
of it or not; and for the purpose of protecting his interests, the law holds the party receiving the delivery as his trustee, and makes his acceptance of it the acceptance of the beneficiary. And this, too, whether the person receiving the delivery knows the contents of the instrument or not, and whether he does anything more than merely receive it or not. And yet, when the person, in whose favor the instrument is executed will be injured by the acceptance of it, the delivery to such third person does not bind him, unless he authorized such acceptance or adopts it by some subsequent act.

The same is the case with an instrument executed and delivered personally to an idiot or lunatic. If beneficial to him, the party executing it is bound by it, and the idiot or lunatic is entitled to its beneîts; but if against his interests, he is not bound, although he has received the delivery. In these cases, the delivery is held good, though the grantee or obligee really had nothing to do with the transaction, in order to carry out the intent of the party who executed the instrument, and for the benent of the party for whose benefit it was delivered, and constitutes an acceptance on his part, when for his interest to do so, and not when otherwise.

Upon what principle is it, then, that a direct delivery of an obligation to the obligee himself, and a reception thereof by him, does not constitute an acceptance, if the contents of the instrument delivered are not at the time known to him?

And why may not a party deliver an instrument, the contents of which are not known to the party receiving it, with the like effect as if it were, without his knowledge, delivered for his benefit to some third person for him?

Or, suppose that on the 3 oth day of January, 1864, Theron B. Worth had been indebted to the plaintiff in the exact sum of $\$ 10,000$; and had on that day delivered the note in question precisely as he did; and it had remained in the possession of the plaintiff as it did, till his death; is it possible that the plaintiff could not maintain an action on the note, and that she would have been compelled to count on the original indebtedness? To my mind, the delivery and acceptance were more complete than in any of the other cases to which I have alluded. The delivery was to the party to be benefited; and from what appears it is manifest, that when she received it, she considered it to be something which was of value to her. He had told her that he would pay her well for the services performed for him, and had offered to buy her a house and lot in compensation; and when she received it, on the day when he left her to return to his home, she could not doubt that it contained the compensation, or the evidence of it, which he had promised to make to 
her; and no doubt she gladly accepted it as such, in the full belief that it contained a generous compensation.

As nothing happened subsequently to the delivery which would invalidate the note, the next question is, were the conditions such as to render it void perse.

By the terms of the delivery, it was intended to be valid, if neither of two affirmative acts were afterwards done. It is clear that neither of these acts were performed, and in my judgment the delivery and acceptance were sufficient, and the note, as such, remained valid in the hands of the plaintiff, provided it was executed for a good consideration.

I think the note was executed for a valuable consideration, and that it is valid against his executors.

The order of the General Term should be affirmed, and final judgment should be ordered for the plaintiff for the full amount specified in the note, with interest thereon, from the ${ }_{1} 5_{\text {th }}$ day of October, I867 (when the claim of the plaintiff was made upon the defendant), together with her costs of the action to be paid out of the estate of the deceased.

[Lотт, J. also read for affirmance, holding the note invalid for want of delivery, but available as evidence of the value of plaintiff's services.]

Earle, Ch. J., Hunt, Smith, and Ingalls, JJ., were for affirmance and judgment absolute for the plaintiff, concurring with Foster, J.

Grover and Sutherland, JJ., were for reversal.

Judgment affirmed, and judgment absolute ordered for the plaintiff.

17 Minnesota, 239. - I87I.

Action on a promissory note, brought in the District Court for Steele county, resulting in a verdict for the defendant. Plaintiff moved for a new trial, which was denied, and he appeals to this court from the order denying such new trial. A single point only is discussed in the appeal, which is fully stated in the opinion.

By the Court - Berry, J. This is an action upon a promissory note payable by its terms to C. W. Stevens, or bearer, and signed by the defendant.

There was plenary evidence showing that the plaintiff is a bona fide holder of the note, having purchased the same before maturity in good faith, without notice, and for value. 
The only defense urged here is that there was no delivery of the note to any person by or on behalf of the defendant; that for want of delivery it is not the note of defendant, and he is not liable thereon even to a bona fide holder. "A bona fide holder for value, without notice, is entitled to recover upon any negotiable instrument, which he has received before it has become due, notwithstanding any defect or infirmity in the title of the person from whom he derived it; as, for example, even though such person may have acquired it by fraud, or even by theft, or by robbery." (Story on Prom. Notes, \$ I9I; 2 Gr. Ev., \$ I7I; Sivift v. Tyson, I6 Pet. I; Goodman v. Symonds, 20 Howard, 365; Raphael v. Bank of England, ${ }_{17}$ C. B. 162; Whecler v. Guild, 20 Pick. 545 ; Magee v. Badger, 34 N. Y. 249 ; Powers v. Ball, 27 Vt. 662; Catlin v. Hamon, I Duer, 325; Gould v. Seger, 5 Duer, 268; Marston v. Allen, S Mees. \& W. 494; Sm. Lea. Cas. 597 et seq.; I Ross, Lead. Cases, 205 et seq.)

The fact that there has been no delivery of the instrument by or for the maker, or by or for an indorser through whom the holder must claim, is a defect or infirmity of title within the meaning of the rule above cited, a rule which is said to be laid up among the fundamentals of the law. (Worcester Co. Bank v. Dorch. $\&$ Melton Bk., ro Cush. 488 ; Edwards on Bills and Notes, I88; Gould v. Seger, supra; Ingham v. Primrose, 7 C. B. (N. S.) 82; Shippey v. Carroll, 45 Ill. 285 ; Clark v. Folinson, 52 Ill.)

The order denying a new trial must be reversed.'

L. R. 3 Queen's Bench Division (C. A.), 525.-1878.

Acrion on a bill of exchange accepted by defendant.

At the trial, before Lopes, J., without a jury, at the Hilary Sittings in Middlesex, the following facts were proved: The bill, dated the IIth of March, I 872 , on which the action was brought, purported to be drawn by one W. Cartwright on the defendant,

${ }^{1}$ Accord: Shipley v. Carroll, 45 Ill. 285 (stolen note); Clarke v. Johnson, 54 Ill. 296 (note forcibly taken); Gould v. Seger, 5 Duer (N, Y.), 265 (note wrongfully taken); Cooki v. U. S., 9I U. S. $3 S_{9}$; Worcester Bank v. Dorchester Bank, Io Cush. (Mass.) 4 SS (bank notes).

Contra: Burson v. Huntington, 2 I Mich. 415; Palmer v. Poor, I2I Ind. 135; Hall v. Wilson, 16 Barb. (N. Y.) 548 .

Where negotiable securities have been paid and canceled, and are stolen, the cancellation marks erased, and the instruments negotiated to a bona fide holder, the maker is not liable. District of Columbia v. Cornell, 130 U.S. 655. And see Branch v. Commissioners, So Va. 427. - ED. 
payabie to order at three months' date. It was indorsed in blank by Cartwright, and also by one $\mathrm{H}$. T. Cameron. The plaintiff received the bill from Cameron on the $3 \mathrm{~d}$ of $J$ une, $\mathrm{I}_{72}$, and was the bona fide holder of it, without notice of fraud, and for a valuable consideration.

One J. F. Holmes had asked the defendant for his acceptance to an accommodation bill, and the defendant had written his name across a paper which had an impressed bill stamp on it, and had given it to Holmes to fill in his name, and then to use it for the purpose of raising money on it. Afterwards Holmes, not requiring accommodation, returned the paper to the defendant in the same state in which he had received it from him. The defendant then put it into a drawer, which was not locked, of his writing table at his chambers, to which his clerk, laundress, and other persons coming there had access. He had never authorized Cartwright or any person to fill up the paper with a drawer's name, and he believed that it must have been stolen from his chambers.

On these facts the learned judge found that the bill was stolen from the defendant's chambers, and the name of the drawer afterwards added without the defendant's authority; but that the defendant had so negligently dealt with the acceptance as to have facilitated the theft; he therefore ruled, upon the authority of Ioung $r$. Grote, 4 Bing. 253 , and Ingham v. Primrose, 7 C. B. (N. S.) 82, that the defendant was liable, and directed judgment to be entered for the plaintifí for $50 l$ and costs.

BraMwELL, L. I. I am of opinion that this judgment cannot be supported. The defendant is sued on a bill alleged to have been drawn by $W$. Cartwright on and accepted by him. In very truth, he never accepted such a bill; and if he is to be held liable, it can only be on the ground that he is estopped to deny that he did so accept such a bill. Estoppels are odious, and the doctrine should never be applied without a necessity for it. It never can be applied except in cases where the person against whom it is used has so conducted himself, either in what he has said or done, or failed to say or do, that he would, unless estopped, be saying something contrary to his former conduct in what he had said or done, or failed to say or do. Is that the case here? Let us examine the facts. The defendant drew a bill (or what would be a bill had it had a drawer's name), without a drawer's name, addressed to himself, and then wrote what was in terms an acceptance across it. In this condition, it, not heing a bill, was stolen from him, filled up with a drawer's name, and transferred to the plaintiff, a bona fide holder for value. It may be that no crime was committed in the filling in of the 
drawer's name, for the thief may have taken it to a person telling him it was given by the defendant to the thief with the authority to get it filled in with a drawer's name by any person he, the thief, pleased. This may have been believed and the drawer's name bona fide put by such person. I do not say such person could have recovered on the bill; I am of opinion he could not; but what I wish to point out is that the bill might be rade a complete instrument without the commission of any crime in the completion. But a crime was committed in this case by the stealing of the document, and without that crime the bill could not have been complete, and no one could have been defrauded. Why is not the defendant at liberty to show this? Why is he stopped? What has he said or done contrary to the truth, or which should cause anyone to believe the truth to be other than it is? Is it not a rule that everyone has a right to suppose that a crime will not be committed, and to act on that belief? Where is the limit if the defendant is estopped here? Suppose he had signed a blank cheque, with no payee, or date, or amount, and it was stolen, would he be liable or accountable, not merely to his banker, the drawee, but to a holder? If so, suppose there was no stamp law, and a man simply wrote his name, and the paper was stolen from hin, and somebody put a form of a cheque or bill to the signature, would the signer be liable? I cannot think so. But what about the authorities? It must be admitted that the cases of Young v. Grote (4 Bing. 253), and Ingham v. Primrose (7 C. B. N. S. 82), go a long way to justify this judgment; but in all those cases, and in all others where the alleged maker or acceptor has been held liable, he has voluntarily parted with the instrument; it has not been got from him by the commission of a crime. This, undoubtedly, is a distinction, and a real distinction. The defendant here has not voluntarily put into any one's hands the means, or part of the means, for comnitting a crime.

But it is said that he has done so through negligence. I confess I think he has been negligent; that is to say, I think if he had had this paper from a third person, as a bailee bound to keep it with ordinary care, he would not have done so. But then this negligence is not the proximate or effective cause of the fraud. A crime was necessary for its completion. Then the Bank of Ireland r. Ein $^{\prime}$ ans' Trustees (5 H. L. C. 389 ) shows under such circumstances there is no estoppel. It is true that was not the case of a negotiable instrument; but those who complained of the negligence were the parties immediately affected by the forged instrument.

[BRETT, L. J., agreed with the conclusions of BRAMweLl, L. J., but not with his reasons, holding that after the return of the blank 
acceptance the defendant never authorized anyone to fill in a drawer's name, or issued the acceptance intending it to be used.]

BagGallar, L. J., concurred that the judgment ought to be entered for the defendant.

Judgment for the defendant.

\section{Non-essentials.}

$\$ 25$

MEHLBERG $\%$. TISHER.

24 Wiscosis, 607. - Is6g.

ACtion on the following instrument:

To Hoxie and Rich: Please pay to Chas. Mehlberg the sum of $\$ 69.20$, and charge to me.

Chas. Tisher.

Drxon, C. J. The written instrument. . was a bill of exchange. It is not essential to the validity of a bill of exchange that it should be made payable to order, or bearer, ${ }^{1}$ or have the words "value received," or be payable at a day certain, or at any particular place.

$\$ 25$

BROWN $\bullet$ JORDHAL.

32 Minnesota. I35. - ISS4.

Plaintiff brought this action in the District Court for Freeborn county, as holder of the following instrument:

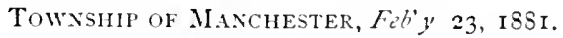

Si2o. Six months after date, (or before. if made out of the sale of Drake's horse hay fork and hay carrier), I promise to pay James B. Drake, or bearer, one hundred and twenty dollars.

Negotiable and payable at the Freeborn County Bank. Albert Lea, Minn., with ten per cent. interest after maturity until paid.

Witness: J. WiLliamson.

Ole J. JoRdahl [Seal]. [Seal].

At the trial, before Farmer, $J$, the plaintiff, having introduced evidence that he bought the note from Williamson for value, before maturity, in good faith and without notice of any defense to it,

${ }^{1}$ Nor to the validity of a promissory note that it should be payable to order or bearer. Smith v. Kendall, 6 T. R. I2t; Carnartight. Grat, r27 N. Y. 92; Wills v. Brigham, 6 Cush. (Mass.) 6. Contra: Bristolv. Warnir, ig Conn. 7. The matter as to promissory notes is one of construction of statute, as such notes are the creature of statute. See Neg. Inst. L., $\$ 320\left[1 S_{4}\right]$. It must be remembered, however, that the Negotiable Instruments Law applies only to negotiable paper. - ED. 
admitted that the note was obtained from defendant by Williamson by fraud, and that as between those parties the note was without consideration and fraudulent. The court thereupun directed a verdict for defendant, a new trial was denied, and the plaintiff appealed.

Gilfillan, C. J. The defendant executed an instrument in the form of a negotiable promissory note, except that after and opposite the signature were brackets, and between them the word "seal" thus, "[seal]." The question in the case is, is this a negotiable promissory note, so as to be entitled to the peculiar privileges and immunities accorded to commercial paper? The rule that an instrument under seal, though otherwise in the form of a promissory note, is not (certainly when executed by a natural person, however it may be when executed by a corporation) a negotiable note, entitled to such privileges and immunities, is universally recognized, and is not disputed in this state. But the appellant contends that merely placing upon an instrument a scroll or device, such as the statute allows as a substitute for a common-law seal, without any recognition of it as a seal in the body of the instrument, does not make it a sealed instrument. Undoubtedly, where there is a scroll or device upon an instrument, there must be something upon the instrument to show that the scroll or device was intended for and used as a seal. The scroll or device does not necessarily, as does a commonlaw seal, establish its own character. Such words in the testimonium clause as "witness my hand and seal," or "sealed with my seal," would establish that the scroll or device was used as a seal. No such reference in the body of the instrument was necessary in the case of a common-law seal. (Goddard's Case, 2 Coke Rep. 5a; 7 Bac. Abr. [Bouvier's ed.] 244.) Nor is there any reason to require it in the case of the statutory substitute, if the instrument anywhere shows clearly that the device was used as and intended for a seal. It would be difficult to conceive how the party could express that the device was intended for a seal more clearly than by the word "seal," placed within and made a part of it. This was an instrument under seal.

Order affirmed. ${ }^{1}$

\footnotetext{
${ }^{1}$ Accord: Warrin v. Lynch, 5 Johns. (N. Y.) 239; Ostorn v. Kistler, 35 Oh. St. 99; Osborne v. Hubbard, 20 Ore. 315: Wuse v. Dantsler, 85 Ala. 359. The statute (Neg. Irst. L., 55 [6], subsec. 4), changes the law upon this point. Without the aid of statutes the courts had decided that the bill or ncte of a corporation did not lose its negotiable character because of the presence of the corporate seal. Chase N. B. v. Faurot, I49 N. Y. 532 ; Mason v. Frick, 105 Pa. St. I62; Mackay v. Saint Mary's Church, I5 R. I. I2I; Central N. B. v. Charlotte, etc., $R ., 5 \mathrm{~S}$. Car. I56. In order to become a common-law specialty the instrument must recite the seal or otherwise indicate the intention of the maker to create a specialty. Wieks v. Esler, 143 N. Y. 374; cases supra.
} 
43 New YORK, 209. - I87o.

[Reported herein at p. 223.]

85 Texas, 553. - I893.

[Reported hirein at p. 225.]

\section{Date}

\section{(ii) Intcrpretation.}

45 Minfesota, $460 .-$ I89i.

ACtion on a promissory note for $\$ 500$, brought in the district court for Le Sueur county. Trial before Edson, J., and verdict for defendants, who appeal from an order granting a new trial.

Vanderburgh, J. Plaintiff is the indorsee of the note in suit. The note was dated June 25 , I $\$ 86$, and was by its terms payable six months after date. It is alleged in the complaint to have been executed and delivered on the day of its date. It appears from the evidence, however, that the note was actually executed and delivered on the $25^{\text {th }}$ day of June, $\mathbf{I} 88_{7}$, and that the date was written $\mathbf{I} 886$, by mistake. There was evidence to go to the jury tending to show that it was indorsed to the plaintiff for value within six months from the actual date of it: delivery, but not within six months or before its maturity, according to the face of the note. The court charged the jury, under plaintiff's exception, that if the note, when transferred to plaintiff, was due according to the date as actually expressed therein, and was given without consideration, their verdict must be for the defendants. If a note is antedated or posi-dated by the maker, it is a valid contract from the time of its delivery; and, since it is competent to express the agreement of the parties in that way, the courts will construe the instrument according to its terms; and if, when delivered, it is by its date overdue, it will then be treated as a demand note. (r Pars., Notes and B., p. 49; 3 Rand., Com. Paper, $\$$ ro34.) But where the note is intended to bear date as of the time of its delivery, that is the true date; and if by mistake 
another date is written on the face of the note, the mistake may be corrected, except as to an innocent indorsee or purchaser who would be prejudiced by the correction, and the mistake may be shown by parol. (2 Pars., Notes and B., 514.) As it clearly appeared that the note was given in 1887 , and the wrong year inserted in the date by mistake, the note, by intendment of law, was payable in six months from June 25,1887 ; and if negotiated and indorsed to the plaintiff before due, in good faith and for value, the defense of want of consideration is not available; and the mistake may in such case be shown as well by the indorsee as the payee of the note. (Drake v. Rogers, 32 Me. 524; Germania Bank r. Distler, 4 Hun, 633 ; affirmed in $6+\mathrm{N}$. Y. $66_{4} ;$; I Daniel, Neg. Inst., $\S 8_{3} ;$ I Edw., Bills and N., \$ г 7 г.)

The mistake should strictly have been alleged in the complaint, but as the evidence was received without objection, and the fact was before the court as if properly pleaded, and considered by the court in its charge, the objection to the pleading cannot be raised now. The pleading might have been amended formally to conform to the proofs after the evidence was in.

For the reasons stated, it is apparent that the court erred in its charge on this branch of the case, and the order granting a new trial was proper, though based on other grounds. The defense of want of consideration was clearly shown. The note was intended to offset or reduce the amount of a mortgage held by the defendant on the land of the deceased husband of the payee in the note. It was in reality intended as a gift or concession, and, being without consideration and incomplete or unexecuted, the defendant was entitled to defend against the note for want of consideration. It did not involve a settlement or compromise of a doubtful or disputed claim; and, if this defense was not shut out by the transfer of the note to plaintiff before due, she was entitled to interpose it.

Order affirmed.

Defendant, on May 4th, drew a bill, dated May irth, and delivered it to one Totty, the payee, who, on May $5^{\text {th indorsed it }}$ for a valuable consideration to the plaintiff, and died on the same day. Verdict for plaintiff on the bill, subject to the opinion of the court.

Lord Ellenborough, C. J. The period at which the bill is pay- 
able appears in this case by reference to the actual date; and so far only it is material to advert to it. All that we have of statutable recognition upon this subject is against the general materiality of the date: For the stat. I7 Geo. 3, c. 30, requires (amongst other things) that bills of exchange and promissory notes, etc., for sums of 20 s. and less than 51 ., "shall bear date before or at the time of drawing or issuing the same, and not on any date subsequent thereto; "which implies that the same regulation in not necessary to be observed in other bills for larger sums. Let us hear what objection the defendant's counsel makes to this bill: Does he mean to say that it was in abeyance in the immediate time between the issuing of it and the date.

Littledale for the defendant. The bill never had any operation by the custom of merchants, which does not apply to an instrument carrying a false appearance and deception upon the face of it. It was only meant to be taken as issued at the time of the date, and till that day was not a negotiable instrument, however it might bind the drawer to answer for the amount to the payee or his executors. The indorsement then was with reference to the same time, and could not have had any legal operation till then; but, before that time arrived the death of the payee destroyed the possibility of its ever becoming a negotiable instrument.

Lord Ellenborough, C. J. What deception does the post-dating hold out? Whoever takes the bill before the day when it bears date must see that it is only payable at 65 days after that date. A bill without any date would still be a good bill: Then why is not this as good? The act to which I have referred directs that bills drawn for less than 51. shall be made payable within three weeks after the date; which would have been futile, without prohibiting them to be post-dated. The post-dating of drafts upon bankers, unless drawn upon bill of exchange stamps, is by another act prohibited under a penalty, and the draft made void; and this perhaps may have led to the idea that this bill was void, to which the same objection does not apply. The time of payment in this case is certain with reference to the actual date.

The rest of the Court (Grose, J., absent) agreed; Le Blanc, J., adding, that the very party who now set up the defense, that this was not a negotiable instrument, was the person who issued it into the world as such. And they held that the plaintiff was entitled to recover for the whole amount of the bill; for which he took his judgment accordingly. ${ }^{1}$

${ }^{1}$ Accord: Brewster v. McCardell, 8 Wend. (N. Y.) 478. As to blank date see the next case. - Ev. 


\section{Blanks : Authority to fill.}

\section{Aвbott's Appeal Decisions (N. Y.) 433. - i866.}

Ira and Orlando Page sued David and Daniel H. Morrel, composing the firm of Morrel \& Son, and Benjamin N. Nellis, in the Supreme Court, on a promissory note, of which D. Morrel \& Son were makers, and Nellis the indorser.

The note was made on June $10,18_{59}$, for the sum of fifty dollars, payable thirty days after date. It was dated June, but with a blank where the day of the month is usually stated, thus: "June —, I 859 ."

In this condition the note was indorsed by the defendant Nellis for the accommodation of the makers, and on the same day, the tenth, the makers transferred it for value to one Wiles. On the fifteenth of the month, Wiles transferred the note to the plaintiffs for value, and they, without the knowledge of any of the other parties thereto, and of course without their express consent, filled the blank in the date with the figure " 1 ," so as to make the date " June I, I 859. ."

The indorser having been charged, on non-payment thirty days after June I, this action was brought; and the only question was, whether the note was valid against the defendants, notwithstanding the insertion of the figure in the date. The judge found the foregoing facts, and held that the note was valid, and gave judgment for the plaintiffs.

By the Court - Janes C. Surth, J. - The only question in this case is, whether, as between these parties, the note is rendered invalid, in consequence of its having been antedated by the plaintiffs after the transfer to them, so that it had ten days less to run than it would have had if it had been dated as of the day when it was indorsed and negotiated to Wiles.

There can be no doubt that, if the same day of the month had been inserted by the makers when they negotiated the note to Wiles, without the knowledge of the indorser, the note would not thereby have been rendered invalid, as against the indorser; and so if the day had been inserted by Wiles, with the express direction or consent of the maker. In such case, the note, when indorsed, being perfect in every respect but the date, and that having been left blank, the makers would have had an implied authority from the indorser, to insert any day of the month they might think proper. (Mitchell v. Culter, 7 Cow. 336; M. \& F. Bank v. Schuyler, Id. 337, 
note.) Such authority results from the general rule, that an indorsement on a blank note, without sum, or date, or time of payment, will bind the indorser, for any sum, payable at any time, which the person, to whom the indorser trusts it, chooses to insert. The date of a note is no exception to this rule, although it is not essential to the validity of a note that the date be expressed; for, where a note has no date, the time, if necessary, may be inquired into, and will be computed from the day it was issued. But it is essential to the free and uninterrupted negotiability of a note that it should be dated, and, therefore, all the parties to a note intended for circulation, are presumed to consent that a person, to whom such a note is intrusted for the purpose of raising money, may fill up the blank with a date. (Ib.) And a blank, left for the day of the month, may be filled with any day in that month, there being no fraud, or express direction to the contrary.

Upon the same principle, Wiles, to whom the note was delivered by the makers, had an implied authority, from both makers and indorsers, to fill the blank with any day in the month.

But it is claimed by the defendant's counsel, that the implied authority, above stated, is restricted to the first holder of a note, and that it was unlawfully exercised by the plaintiff, to whom the note was transferred in blank by Wiles.

That position cannot be maintained. It is immaterial, to the parties to the note, whether the blank in the date was filled by the first holder or his transferee. The latter acquired all the rights of the former in regard to the paper. Until the blank was filled, each successive holder took the note with authority to fill the blank, according to the implied intent of the parties. The reasoning of Justice Bockes upon this point, in the court below, is satisfactory and convincing. The case of Inglish v. Bruneman (5 Ark. 377), so far as it holds to the contrary, is not supported by authority.

The judgment should be affirmed.

All the judges concurred, except Morgan, J., who dissented. Judgment affirmed, with costs.

29 IOWA, 495. - IS70.

Action upon a promissory note; defense that the instrument is a forgery. The cause was submitted to the court without a jury. The court found the following facts: Defendant entered into a contract

NEGOT. INSTRUMENTS - I 9 . 
with one Smith to sell for him, as his agent, grain seeders. At Smith's request, defendant signed his name upon a blank piece of paper, which Smith was to send to the manufacturers of the seeders, that they might know defendant's signature upon orders which he should make upon them for the machines. The signature was made for no other purpose.

The instrument in suit was printed over the signature of defendant, so obtained, without his knowledge and consent, and the stamp in the same manner attached and canceled. The plaintiff purchased the note before maturity, for a valid consideration, and without knowledge of any matter connected with its execution. Upon these findings, the court held, that the note is a forgery and void, and that plaintiff is not entitled to recover thereon. Plaintiff appeals.

BECK, J. - A holder of negotiable paper, acquired before dishonor, is not protected against defenses that make void the instrument. He can have no claim upon forged paper against the person whose name is falsely affixed thereto as the maker, and who is without fault as to the forgery and the taking of the paper by the holder. (I Parsons, Bills and Notes, 75, and authorities cited.)

Is the note sued upon a forged instrument? "The making or alteration of any writing with fraudulent intent, whereby another may be prejudiced, is forgery." (State v. Wooderd, 20 Iowa, 542: Rev., $\$ 4253$.) In order to constitute the offense of forgery it is not necessary that the signature of the instrument be false. The instrument may be altered so that it is not the instrument signed by the maker, and, if this be fraudulently and falsely done, it is forgery. So if words be added to change its effect, with like intent, it is a forgery. In the case before us the instrument was falsely and fraudulently made over the genuine signature of defendant, which was not obtained for the purpose of binding defendant by any contract. It is evident that this differs, in no respect, from the cases mentioned, and that the note is a forgery and void. (See 2 Parsons, Bills and Notes, 584.)

The case differs materially in its facts from the cases cited in support of plaintiff's right to recover. In those cases blanks were filled up contrary to the direction of the maker, or without his authority. But in all of such cases the makers intended to execute an instrument that should be binding upon them. Blanks were filled up contrary to the authority given by the makers, or in some other way the instruments were made so that they did not correspond with the intention of the makers; but in all such cases there were makers and instruments, and through the frauds of those to whom the instru- 
ments were intrusted they were thus made to be of different effect than was designed by the makers. In these cases it is correctly held, that while the parties perpetrating the fraud in some cases may have been guilty of forgery, yet the makers were bound upon the instruments, as against holders in good faitn and for value. The reason is obvious. The maker ought rather to suffer, on account of the fraudulent act of one to whom he intrusts his paper, or who is made his agent in respect of it, than an innocent party. The law esteems him in fault in thus putting it in the power of another to perpetrate the fraud, and requires him to bear the loss consequent upon his negligence. In the case under consideration no fault can be imputed to the defendant. He did not intrust his signature to the possession of the forger for the purpose of binding himself by a contract. He conferred no power upon the party who committed the crime to use it for any such purpose. He was not guilty of negligence in thus giving it, for it is not unusual, in order to identify signatures, and for other purposes, for men thus to make their autographs. The defendant cannot be regarded as being so far in fault in the transaction that he ought to be required to bear the loss resulting from the crime.

In our opinion the decision of the circuit court is in accord with the law, and is therefore

Affirmed. ${ }^{\prime}$

85 MAINE, 349. - IS93.

Whitehouse, J. - This was an action on a promissory note for seven hundred and eighty-five dollars, brought by the plaintiff bank as indorsee of Earl B. Chace \& Company against the defendant as maker of the note.

The defendant seasonably filed his affidavit that the paper declared on had been materially altered since it was executed.

The facts were not controverted. The defendant had signed a prior note for the accommodation of Chace $\&$ Company which was outstanding and overdue at the time of the signing of the note in question. At Chace's request he agreed to sign three other accommodation notes to take up the overdue note, each to be for one-third

${ }^{1}$ See Walker v. Ebert, 29 Wis. I94, post; Chapman v. Rose, 56 N. Y. 137, post. - Ev. 
of the amount. But when the parties met for the purpose of executing this agreement, the amount of the overdue note was not definitely known to either of them, but was understood to be between six bundred dollars and six hundred and fifty dollars. Thereupon, at Chace's suggestion, the defendant signed three printed blank notes and delivered them to Chace, who agreed to fill them out with the requisite amount specified in each, when ascertained, and use them for the purpose of taking up the overdue note. The note in suit is one of the three notes thus signed. But instead of making it for one-third of the overdue note according to his agreement, Chace fraudulently wrote in "Seven hundred and eightyfive dollars" and indorsed the note to the plaintiff bank before maturity in the ordinary course of business, receiving therefor the full amount of the note less fifteen dollars and ninety-six cents discount thereon. It is not claimed, however, that Chace made any alteration in the printed terms of the blank thus delivered to him. He simply inserted in the blank spaces such words and figures as were necessary to constitute the instrument a complete promissory note. There is also positive testimony from the plaintiff $s$ discount clerk that, at the time the note was discounted, the bank had no knowledge of any equities existing between the defendant and Chace, but took the note in the usual course of business. Upon this evidence the presiding justice directed the jury to return a verdict for the plaintiff for the amount of the note in suit.

This instruction was correct. The court may properly instruct the jury to return a verdict for either party when it is apparent that a contrary verdict could not be sustained. (Heath v. Jaquith, 68 Maine, 433; Fetell v. Gagne, 82 Maine, 431; Moore v. McKenney, 83 Maine, 8o.)

It is well settled and familiar law that, if one affixes his signature to a printed blank for a promissory note and intrusts it to the custody of another for the purpose of having the blanks filled up and thus becoming a party to a negotiable instrument, he thereby confers the right, and such instrument carries on its face an implied authority, to fill up the blanks and complete the contract at pleasure, as to names, terms and amount, so far as consistent with its printed words. As to all purchasers for value without notice. the person to whom a blank note is thus intrusted must be deemerl the agent of the signer, and the act of perfecting the instrument is deemed the act of the principal. An oral agreement between such principal and agent limiting the amount for which the note shall be perfected, cannot affect the rights of an indorsee who takes the note before maturity $f(r$ value, in ignorance of such agreement, with a different amount 
written in it. (Bank of Pittsburgh v. Neal, 22 Howard, 97 ; Angic v. Ins. Co., 92 U. S. 330; Bamk v. Stowell, 1 23 Mass. 196; Kelloggv. Curtis, ${ }_{5}$ Maine, 59; Abbottv. Rose, 62 Maine, r94; Breckenridgev. Lea'is, 84 Maine, 349; Bigelow's Bills and Notes, 57 I.) ${ }^{1}$

$\S 98$ [59] But the defendant contends that it is not satisfactorily shown by affirmative eviderıce that the bank was an inrocent purchaser.

Proof of fraud in the inception of the note undoubtedly casts upon the indorsee the burden of showing that he took the ncte for value, before maturity without notice of the fraud. (Farrell v. Lorett, 68 Maine, 326; Killogg v. Curtis, 69 Maine, 213.) But proof that he paid full value for the note before maturity raises a presumption that he purchased it in good faith without notice of the fraud; and until overcome by rebutting evidence this presumption stands in lieu of direct proof. (Kellogg v. Curtis, supra.)

The plaintiff's testimony that the note was discounted in the usual course of business before maturity, for its face value less the disconnt stated, is not controverted. A prima facie case is thus made out for the plaintiff, without the aid of the affirmative statement of the discount clerk that the bank did not know of any equities between the defendant and Chace. There is no opposing evidence to overcome the presumption arising from the purchase of the note before maturity for full value, and no evidence in the case upon which a verdict for the defendant could be allowed to stand.

\section{Exceptions oierruled.}

$$
2 \text { Allex (Mass.) } 236 .-1861 .
$$

WRIT of review of a judgment in favor of the Farmers' Bank, of Bridgeport, Connecticut, against Geo. R. Ives, of Brooklyn, New York, upon the following note:

\footnotetext{
If a blank note is entrusted to A. by B., and $A$. fills the blanks but also adds " with interest, etc.," at the end, there being no blank space indicated for such purpose, B. is not liable, since this amounts to a material alteration. Farme'rs', etc., N. B. v. Nozich, 89 Tex. 381; Weyerhauser v. Dun, 100 N. Y. I50. See Neg. Inst. L., $5200[125]$ post. So, also, the distinction must be clearly drawn between issuing an instrument with blanks and sssuing one in which the blanks have been so imperfectly filled as to leave unoccupied spaces. In the latter case to fill the spaces would be an alteration and would destroy the instrument unless the maker were held to be estopped by the negligent manner in which he sent the instrument into the world. See post, Art. IX, Div. I. 3, p. 590 . - Ers.
} 
\$1 585.90 .

Brooklyx, Siptindir, 2oth, 1858.

Three months after date $I$ promise to pay to the order of Edwin $R$. Fale, Dec. 23, fiften hundred and eighty-five $\frac{90}{100}$ dollars at Atlantic Bank, Niw York, value received.

[Indorsed]: Edwin K. Yale.

Geo. R. Ive's.

At the trial in the superior court before Rockwell, J., the note was produced, and those portions of it which are printed above in Roman letters were engraved, and the rest, including the figures, filled in with a pen.

The note was discounted by the Farmers' Bank for Yale on the I 2 th of October, 1858 , and the sum of $\$ 400$ of its avails was applied in payment of an instaiment then due to them upon another note of Yale; and Ives contended that, as to this sum, the bank could not be considered as a bona fide holder of the note for value, but the judge declined so to rule.

The jury returned a verdict for the bank, for the amount of the note, deducting $\$ 2 \mathrm{I} 7$, which was claimed to have been paid under circumstances stated in the opinion; and both parties alleged exceptions.

HoAR, J., [after disposing of another matter]. - The plaintiff in review offered evidence tending to prove that, at the time when he signed the alleged note, he received a note of the said Yale for the same amount, as an accommodation note, engaging to pay the same at maturity; and that he did pay the same accordingly. He further offered to prove that, as a memorandum of the transaction, he took the printed blank form of a note. and wrote the figures, " $\$ r, 589.90$, , the date, "Dec. 23," in the body of the note, and signed his name at the bottom, the said Yale having written the date " September $20 t h, r 8_{5} 8$; " that he gave it to Yale in that condition as a memorandum only, and upon the express agreement that it should not be used as a note; and that subsequently, without his knowledge or consent, it was filled up by said Yale, and procured to be discounted. The presiding judge ruled that, if the bank discounted the note in good faith, these facts would constitute no defense.

It becomes important, then, to see what the paper, as it was at first delivered, imported upon its face; and whether it constituted a contract between the parties. If it were a complete and valid contract as it was delivered, it certainly would not be competent for either party to show by parol that it was not to have the effect of a contract, for this would be to vary by parol the meaning of a written instrument. If it were delivered as a perfect contract, without any authority express or implied to alter it in any manner, any material 
alteration made without the consent of the promisor would avoid it. (Wade v. Wirthington, I Allen, 56r.)

Taking the written and printed parts together, the note, as it was delivered by Ives to Yale, reads as follows:

\$1 585.90 .

Brooklyn, September 2oth, I85s

Dec. 23 ,

after date promise to pay to the order of dollars at

Value received.

Geo. R. Ives.

After much consideration we are of opinion that this was a promissory note, and that testimony was not admissible to show that it was intended only as a memorandum. It has the signature of a promisor; a date; the words "promise to pay;" a statement of the amount payable; ${ }^{1}$ a time of payment; and thus has all the parts of a complete note, except the name of a payee. But in Cruchley v. Clarance (2 M. $\&$ S., 90), it was held that issuing a bill with a blank for the name of the payee would authorize a bona fide holder to insert a name. Lord Ellenborough said: "As the defendant has chosen to send the bill into the world in this form, the world ought not to be deceived by his acts. The defendant by leaving the blank undertook to be answerable for it when filled up in the shape of a bill." And in Crutchly v. Maine (5 Taunt. 529), a bill was made payable to the order of — and the court held that any bearer who came regularly by it might fill the blank with his own name. (See also Attwood v. Griffin, I Ry. \& Mood. 425.) If it had been passed to the bank by Yale in the condition in which he received it, it would therefore have been a complete note, except the name of a payee, and the bank would have been authorized to fill the blank with any name that they had chosen; and as they took it in good faith, it can make no difference in the rights of any party that the blank was filled by Yale, in order to add his own liability as an indorser.

But delivering the note to Yale in that condition would not of itself give him authority to alter it in any particular in which it was already filled up and completed. ${ }^{2}$ The date at which it was payable was already inserted, namely, "Dec. 23." And although if Ives had authorized the insertion of the words "three months," so as to make it read " three months after date," the dates might very likely have been held not to be repugnant, by considering the date of "Dec. 23 " as merely indicating the time when the note payable in three months from date would actually be payable, including the

${ }^{1}$ See Witty v. Michigan Mutual Ins. Co., I23 Ind. 4II, post, p. 298, ED.

'See Neg. Inst. L., $§ 206$ [125], subsec. I. - ED. 
days of grace, yet without such authority the insertion of those words would make a material alteration of the note. A note payable on " Dec. 23," being payable on a day certain, would be entitled to grace, and so would not be due until December 26 th. If the case is tried again, it will therefore be proper to submit to the jury the question whether Yale was actually clothed by Ires with express or implied authority to fill up the blank preceding the words "after date" with the words "three months." It may also be proper to call their attention to the further consideration, whether in any event, as for example if Ires had neglected to pay the note which he borrowed from Yale, it was understood by the parties that Yale was at liberty to fill up the blanks so as to make it a note of similar tenor with the other; as, in such a case, the rule adopted in Putnam v. Sullizan (4 Mass. 45), and in Young v. Grote ( 4 Bing. 253), would be applicable, and the premature or fraudulent exercise of the authority would not affect the validity of the instrument in the hands of a bona fide holder.

$\S 5$ I [25] By the settled law of Massachusetts, a party who takes a negotiable instrument in payment of a pre-existing debt is regarded as entitled to the same protection as any other taker for a valuable consideration; and this law must govern in a trial in this commonwealth. (Blanchard v. Sterens, 3 Cush. 16z; Chicopee Bank v. Chapin, 8 Met. 40; Stoddard v. Kimball, 6 Cush. +69.) The same rule prevails in Connecticut, where the note was negotiated. (Mc Caskey v. Sherman, 2.t Conn. 605.) It seems also to be the latest rule adopted in New York, though the decisions in that state have been somewhat conflicting. (Youngs v. Lee, 2 Kernan, 55r.)

The request to the court to allow the jury to take into consideration the appearance of the note, in respect to the alleged alteration, does not appear to have been based upon any fact which required it to be granted.

Exceptions sustained.

$\$ 33$ [I4] Violett $a^{\prime}$. Patton, 5 Cranch (U. S.) i42. - ison. Narshall, Ch. J. - The second objection is, that the indorsement preceded the making of the note. This objection certainly comes with a very bad grace from the mouth of Violett. He indorsed the paper with the intent that the promissory note should be written on the other side; and that he should be considered as the indorser of that note. It was the shape he intended to give the transaction; 
and he is now concluded from saying or proving that it was not filled up when he indorsed it.

It would be to protect himself from the effect of his promise, by alleging a fraudulent combination between himself and another to obtain money for that other from a third person. The case of Russel v. Langstaffe, reported in Douglass [vol. 2, p 514], is conclusive on this point. ${ }^{1}$

$\$ 33$ [14] Cruchley $\because$ Clarance, z Maule \& Selwyn (K B.), 90. - I8I3. Defendant drew a bill on A., " to the order of _-.", [blank.] B. indorsed it to plaintiff, who inserted his name as payee. BAYLFY, J. - The issuing the bill in blank without the name of the payee was an authority to a bona fidc holder to insert the name. Per Curiam. Rule for new trial denied.

\$33 [I4] Harvey '́. Cane, 34 Law Times Rep. (C. P.), 64. I876. C. sent a bill to defendant with the drawer's name blank. Defendant accepted it and returned it to C. C. negotiated it to the plaintiff, who inserted his own name as drawer, and sued defendant on the bill. Grove, J. - The case depends, first, on the question whether, if the drawer's name is not inserted, anybody who gets the bill fairly is prima facie entitled to insert his own name as drawer and put the bill in force, and secondly, whether, under the circum. stances of the present case, the plaintiff had such authority. I am of opinion that he had. The reasonable inference to draw is that there was power to negotiate the bill; there were no conditions or circumstances tending to show the contrary, or to show that C. only had authority to insert his own name. Not only had C. power prima facic to deal with the bill, but it was intrusted to him withotit conditions, and the correspondence shows that the defendant contemplated that $\mathrm{C}$. should use the bill as valid. The plaintiff received the bill from C., and it seems therefore that the plaintiff had authority to insert his own name and put the bill in force.

A question might arise whether, supposing without the authority of the acceptor, but by accident or in consequence of some fraud, the bill were to come into the hands of a bona fule holder for value, he would

${ }^{1}$ An indorsement of a blank form of a bill or note is " a letter of credit for an indefinite sum." The holder for value and without notice may cuforce the instrument against the indorser, although the one to whom the indorser delivered it filled it in with larger sums than he was authorized to do. R'ussiv. Langstuffe, 2 Doug. (K. B.) 514. And the one to whom it is delivered may alter what he has written up to the time the instrument is actually issued on negotiated. Doushlass v. Scott, 8 Leigh (Va.) 43. - En). 
be entitled to insert his own name as drawer and sue upon the bill, but it is unnecessary to decide this, as it does not arise here.

It is not necessary to decide whether, if the instrument were filled up without authority, and afterwards came into the hands of a bona fide holder for value, the acceptor could be sued on it, or rather whether, as Mr. Channell contends, he would prima facie, be liable. Here the facts were that the bill was given in order that it might be put into circulation, and C. gave what authority he himself had to the plaintiff, who thereby acquired a right to sue. ${ }^{\mathrm{B}}$

L. R. 3 Queen's Bench Division (C. A.), 525. - I878.

[Reported herein at p.250.] ${ }^{2}$

\section{$\mathrm{X}$. Ambiguous language.}

I. Discrepancy Between Words and Figures.

$\S 36$ WITTy $v$. MICHIGAN MUTUAL LIFE INS. CO. [§ I7] I23 INDIANA, 4II. - I 889 .

Berkshire, J. - This was an action brought by the appellee against the appellant on the following writing:

$\$ 147.70$.

Indianapolis, Ind., Nov. 28, I883.

Four months after date I promise to pay to the order of the Michigan Mutual Life Ins. Co. - dollars —-, and five per cent. attorney's fees thereon per annum from date until paid, value received, without relief from valuation or appraisement laws of the State of Indiana. The indorsers jointly and severally waive presentment for payment, protest, and notice of protest, and non-payment of this note, and expressly agree, jointly and severally, that the holder may renew or extend the time of payment hereof from time to time, and receive interest in advance or otherwise from either of the makers or indorsers for any extension so made, without releasing them hereon.

Negotiable and payable at $\longrightarrow$.

Mar. 28, 31, '84, Indiana.

J. B. WitTY.

The appellee, in its complaint, did not ask for a reformation of the instrument, but relied on it as a promissory note complete in itself.

1 Accord: Scard v. Jackson, 34 L. T. Rep. (C. P.) 65a; Woiese v. Knapp, 30 Ga. 942. - ED.

${ }^{2}$ See also Cape $A n n N$. B. v. Burns, I29 Mass. 596, post; Noll v. Smith, 64 Ind. $5 \mathrm{II}$, post; Brown v. Reed, 79 Pa. St. 370, post. - ED. 
The appellant answered by the general denial only.

The cause was submitted to the court at special term, and a finding made for the appellee. The appellant filed a motion for a new trial, which the court overruled, and he excepted.

An appeal was taken to general term, and upon the errors assigned the judgment at special term was affirmed, and from the judgment in general term this appeal is prosecuted.

There is but one question presented for our consideration. Is the written instrument, as it appears in the record, an enforceable obligation? We are of the opinion that it is, if not so otherwise, by virtue of $\$ 55^{\circ}$ r, R. S. I88r, and is negotiable by indorsement.

It is signed by the appellant, and when taken as an entirety we think it contains a promise to pay $\$ \mathbf{I} 47.70$, together with five per cent. attorney's fees. By the very terms of the instrument the appellant obligates himself to pay to the appellee "dollars," and it is expressly recited that this promise rests upon a valuable consideration. No one can read the writing without at once coming to the conclusion that the appellant intended to obligate himself to the appellee for the payment of some definite amount of money, and that the appellee understood that it was receiving such an obligation.

Though there may be some formal imperfections in a written obli. gation or contract which parties have entered into, if it contains matter sufficient to enable the court to ascertain the terms and conditions of the obligation or contract to which the parties intended to bind themselves, it is sufficient. In the language of Lord Campbell, in Wrarrington v. Early ( 2 Ellis \& Bl., 763), "the effect of a written contract is to be collected from all within the four corners of the document," and no part of what appears there is to be excluded. We can imagine no good reason why the marginal figures upon the writing in question should be disregarded.

We know as a part of the commercial history of the country that the universal practice has been for a period so long that the memory of man runneth not to the contrary, to represent by superscription in figures upon all obligations for the payment of money the amount or sum which is written in the body of the instrument. The superscription is always intended to represent the amount found in the body of the instrument, and not a different amount; if, therefore, an obligation is found where there is a promise to pay " dollars," but the number of dollars in the body of the instrument is blank, and the margin of the instrument is found to contain a superscription which states the number of dollars, why, in view of the usage or custom which has so long prevailed, should the body of the instrument not 
be aided by the superscription? We think, in such a case, the figures found in the margin should be taken as the amount which the obligor intended to obligate himself to pay, and the obligation enforced accordingly. We do not think, in such a case, that the courts would be justified in disregarding the evident intention of the parties as indicated by the superscription upon the paper, and in holding the instrument void for uncertainty, or on the ground that it is not a perfect writing. And especially are we of the opinion stated, in view of the liberal statute which we have on the subject of promissory notes and other written obligations and their negotiation. (Section $550 \mathrm{I}$, supra.)

In the case under consideration the action is between the original parties to the instrument, and upon it in the form and condition in which it was executed, and, therefore, we do not think it would be profitable to consider questions which might arise where the obligation is made payable at a bank, the blank number of dollars after. wards filled in by the payee and indorsed by him to an innocent holder for value before maturity. As to whether the writing would be a negotiable instrument in its present condition but for our statute, we find some conflict of authority. We cite the following authorities for and against the proposition:

(For - In'e's v. Farme'rs' Bank, = Allen, 236; Sawetser v. French, I 3 Met. 262; Pitty v. Fleishel, 3 I Texas, i69; Corgan v. Frea', 39 Ill. 3 г; Hilliamson v. Smith, I Cold. [Tenn.], r.)

(Against - Voraich Bank v. Hyde, I3 Com. 279; Edwards, Bills, p. I68; Hollen v. Daris, 59 Iowa, $444 ; 44$ Am. Rep. 688 and note.) We find no error in the record.

Judgment is affirmed, with costs. ${ }^{1}$

$\$ 36$ [I7] Mears $\%$ Graham, 8 Blackf. (Ind.) I44. - is.46. BLACKFORD, J. - The circumstance that the figures in the margin of the note are "\$33r.15" and the words in the body are " three hundred and thirty-three dollars and fifteen cents," does not affect the validity of the note. The words in the body must govern, and the note is therefore for $\$ 3.33 .15$.

1 See also Ta'is v. Farme'rs' Bank, 2 Allen (Mass.) 236, anti, p. 293.

A note for the hundred dollars, the figures being $\$ 300$, is good for three hundred dollars, if the maker intended it to be for three hundred. Bumham v. Allen, I Gray (Mass.) 496. A bill payable in the United States for "3,000," "three thousand _-., omitting the dollar-mark and the word " dollars," is a valid bill for three thousand dollars. Williamson v. Smith, I Cold. (Tenn.) I. - ED. 


\section{Interest, How Computed.}

\$ 36 [I7] Campeell Printing Press, etc., Co. $i$. Jones, 79 Alabama, $475,-x 88_{5}$. Clopton, J. - The principle seems to be settled, that a promissory note payable at a future day, with intercst, hears interest from date, it heing considered as a part of the debt. (Dornan v. Dibden, R. \& M. 2So; Richards v. Richards, 2 B. \& Ad. $4+7$; Lersenbers v. Cleatland, i9 La. An. 473.) . . Otherwise, the words, bearing legal rate of interest, would be without meaning and operation. Such is the legal effect after maturity, without express stipulation. In Kennedy v. Nash (I Starkie, 452), Lord Ellenborough held, "that under the words, biaring interest, the plaintiff was entitled to recover interest from the date of the bill, since, without any such words, he would be entitled to interest from the time when the bill became due.' The obligation of the note is to pay the principal, with interest. To limit the time when the interest begins to run, to maturity, is to presume that the parties contemplated the notes would not be paid when payable, and therefore provided they should bear interest thereafter. In order to give some effect to all the terms of the notes, our conclusion is, that the interest runs from date. ${ }^{1}$

\section{Instrument Not Dated.}

s 36 [I7] Richardson ${ }^{2}$. Ellett, 10 Texas, 190. - I 853 . Hemphill, Ch. J. - Nor is the judgment excessive, as charged by the plaintiff in error. It is true that the note, as copied in the petition, does not bear any date; but the petition avers it to have been executed on the Sth day of January, is 850 , a fact not controverted by the defendant. By its terms the instrument bears interest from its date, and it appears to have been accurately estimated. ${ }^{2}$

4. Conflict Between Written and Printed Provisions.

\& 36 [I7] American Express Co. 2 . Pinckner, 29 Ill. 392.1862. Action for negligence in collecting a draft. The question arises on the construction of a partly printed and partly written receipt by defendant. Bresse, J. - The principle applicable in all such cases is, that a writing must be construed according to the clear intent of the parties, if that can be collected from the face of the instrument. . . But there is another principle of law

1 Interest on notes payable on demand runs only from the time of demand. Hunter v. Wood, $5+$ Ala. 7r; Dodge v. Perkins, 9 Pick. (Mass.) 360. - En.

${ }^{2}$ See Byles on Bills (izth ed.), p. 79. See, as to date, $25[6]$, 30 [II], anti. - En. 
applicable. In a case where the agreement is partly written and in part printed, the preference is always given to the written part. What is printed is intended to apply to large classes of contracts, and not to anyone exclusively; tine blanks are left purposely, that the special statements or provisions should be inserted which belong to the particular contract, and not to others, and thus to discriminate this from others. So Lord Ellenborough held, in the case of Robertson and Thomasson v. French (+ East, 360), when he said, that words superadded in writing are entitled, if there should be any reasonable doubt upon the sense and meaning of the whole, to have a greater effect attributed to them, than to the printed words, inasmuch as the written words are the immediate language and terms selected by the parties themselves for the expression of their meaning, and the printed words are a general formula adapted equally to their case, and that of all other contracting parties, upon similar occasions and subjects.

5. Doubt Whether Bill or Note.

$\$ 36$

FUNK $\approx$. BABBITT.

I56 Illinois, 408. - I895.

[Reported herein at $p .272.]^{1}$

6. Irregular Signature.

$\S 36$ HERRING $\because$. WOODHULL.

29 Illinols, 92. - IS62.

[Reported he'rein at p. $3+$ S.] $]^{2}$

7. Joint and Several Liability

$\S 36$

DART ${ }^{\prime}$. SHERIWOOD.

7 Wisconsin, 523. - I85s.

THIs is an action of assumpsit brought by the appellee against the appellants, as joint makers of a promissory note, which read as follows:

1 See also Peto v. Reynolds, 9 Exch. 410, ante, p. 27In; and compare Watrous v. Holbrook, 39 Tex. 573, ante, p. 270. - ED.

${ }^{2}$ See $\operatorname{II}_{3}[63]$, II $_{4}[64]$ post, and cases. - ED. 
$\$ 400$.

Ripon, Wis., Nov. 4 th, is56.

Thirty days after date, for value received, I promise to pay Putnam C. Dart, or order, four hundred dollars, with interest, at the rate of twelve per cent. per annum.

J. C. SHERWOOD.

WM. C. SHERWOOD,

Surety.

Both the appellants put in a plea of the general issue, with the usual notice of set off by the defendant, John C. Sherwood.

On the trial the plaintiff offered the note in evidence, and the defendants made two objections to the reading of the same: I. That the note could not be read under the common counts and notice. 2. That the note did not show a joint liability. The court allowed the note to be read, and the plaintiff rested his case. The defendants moved for a nonsuit on the ground that there was a mis-joinder of parties defendant. This motion was denied.

The defendant, John C. Sherwood, then offered to prove a set-off, consisting of the payment of moneys by him, the said John C., for the plaintiff, which was objected to by the counsel for the plaintiff, and the objection sustained by the court; to which the defendant excepted.

Judgment was then rendered by the court against the defendants for the sum of damages, four hundred and fifty-two dollars and eighty cents, and thirty-three dollars and eighty-two cents costs.

From which judgment this appeal is taken.

By the Court - Whiton, C. I. - The judgment of the court below is correct and must be affirmed. The note declared upon is the joint and several note of the defendants; joint because it is signed by both; and several, because each defendant promised sererally. (Story on Promissory Notes, $\$ 57$; Hunt v. Adams, 5 Mass. R. 358; Same v. Same, 6 do. 5 I9.)

The objection taken to its introduction in evidence under the common counts has no existence in fact, because it was specially declared upon according to its legal effect.

We have no doubt that as to the payee of the note the defendants were both principals, though we do not see as that question arises in the case.

The offer to prove the set-off was, under the circumstances of this case, properly rejected. The action was against two makers of a promissory note, and the defendant, John C. Sherwood, offered to prove a set-off consisting of moneys paid by hım for the henefit of Dart. It is well settled that one of several defendants cannot set off a debt due him alone from the plaintiff against a joint debt. 
(Sub. 6, $\$$ i, chap. 94, of R. S.; Warner v. Backer, 3 Wend. R. 400; Wolfe v. Washburne, 6 Cowen R. 26r. \$ 2 , chap. 93, of R. S., we do not think has any application to this case.)

The judgment of the circuit court must, therefore, be affirmed. ${ }^{1}$

\section{Ambiguous signatures.}

I. Only 'Those Liable Whose Signatures Appear.

I7 Oillo State, I25. - I866.

ACTION against George W. Shoup on the following instrument:

Dayton, Auszust II, I86I.

Dayton Branch, State Bank of Ohio, pay to J. B., or bearer, two hundred thirty dollars.

\$230.

Samuel Shoup, Agent.

Allegation that Samuel Shoup was defendant's agent and acted as such in drawing the check; that plaintiff is holder in due course; that the check was duly presented and was dishonored, etc.

Demurrer sustained and judgment for defendant. Plaintiff appeals.

DAY, C. J. - The averments in the petition will not warrant the claim in argument, that this is a case where a party himself uses a name other than his own in the transaction of his business. The most that can be claimed is, that the principal allowed the agent to sign his own name as agent in the transaction of some of the business of the principal.

It is undoubtedly well settled that, where an ordinary simple contract is signed by an agent in his own name, with the addition of the word "agent" thereto, the principal may be made liable thereon, whether his name appears on the paper or not. (Story on Agency, $\$$ r6oa., and authorities there cited.) But, for commercial reasons, a distinction is taken, in the authorities, between contracts of this class and negotiable paper. As to bills of exchange, it is said that the agent "must either sign the name of the principal to the bill, or it must appear on the face of the bill itself, in some way, that it was drawn for him, or the principal will not be bound." (Edw. on Bills, 8o; Chitty on Bills, 27.)

${ }^{1}$ Accord: Monson v. Drakeliy, 40 Conn. 552; Ely'v. Cluti', I9 Hun (N. Y.) 35; Wallace v. Fervell, 21 Oh. St. I63. - ED. 
The question as to the liability of the principal, on paper executed by an agent in his own name, was well considered by the Supreme Court of Massachusetts, in the cuses of the Eastern Railioad Company $\checkmark$ Benedict (5 Gray, 56r), and the Bank of America r. Hooper (Ib. 567$.

In the latter case, it is said that " there will be found to be a leading distinction taken between cases of commercial paper in the form of bills of exchange and negotiable promissory notes, and other simple contracts, holding that no one but a party to such negotiable paper can be sued for the non-payment thereof." In support of this distinction the following authorities are there cited: (Byles on Bills [ 5 th $^{\mathrm{t}}$ ed.], 26; Emly' Lye, I5 East, 7; Bechamv. Drake, 9 M. \& W. 92; Pint v. Stanton, ro Wend. 276; Stackpole v. Arnold, i I Mass. 27; Bedford Com. Ins. Co. v. Coì'll, \& Met. 442; Taber v. Cannon, Id. 456.)

The case of De Witt v. Walton (5 Seld. 571), decided by the New York court of appeals, is a strong case to the same point. It was a suit brought on a negotiable promissory note, signed "David Hubbell Hoyt, agent for "The Churchman." " Hoyt was an agent for a paper called "The Churchman." and was authorized to contract for the proprietor in that name, and the suit was against the proprietor, Hoyt's principal. It is said in the opinion, that " the good sense of many authorities upon this subject would seem to be, that, where a party is sought to be charged upon an express contract, it must at least appear upon the face of the instrument that the agent undertook to bind him as principal. Here the promise is not by the defendant or 'The Churchman,' nor by Hoyt for them or either of them, or in their behalf, but for himself. The formula used by him in the signature to the note in controversy has been determined, in this and other states, to create an obligation on the part of the agent personally, and not in behalf of the principal. There is no great hardship in requiring that if a man undertakes to oblige another, by note, bill of exchange, or other commercial instrument, he should manifest his purpose clearly and intelligibly, or that his principal will not be bound, whatever may be the result in reference to himself."

It was further held in this case, that the words added to the name of the person signing the paper was merely descriptio persona.

The principle maintained in these cases, it is said by the author of the notes in Smith's Leading Cases (vol. 2, p. 433), "would seem to be well settled on both sides of the Atlantic."

These principles applied to the case before us are decisive of it. The name of the defendant is in no way indicated upon the face of the instrument upon which alone the action is based.

NEGOT. INSTRUMENTS- 20 
It follows, therefore, that the ruling of the court below was correct, and that the judgment rendered by it must be affirmed. ${ }^{1}$

2. Assumed or Trade Name.

$\S 37$ BROWN v. BUTCHERS AND DROVERS' BANK. [ I8]

6 Hill (N. Y.), 443. - I844.

[Reported herein at p. I64.]

$\S 37$

BARTLETT $v$. TUCKER.

$[\S I 8]$

Io4 Massachusetts, 336 . - Is7o.

ConTRACT upon eleven promissory notes, each bearing another name than that of the defendant as maker, but alleged to have been signed by him, payable to the order of the firm of Coe \& Company, and by them indorsed.

The first count was as follows: "And the plaintiff says the

${ }^{1}$ Only those who appear as parties upon the face of a negotiable instrument can sue or be sued upon it. Huffcut on Agency, SS I28, I35, IS9-195; Grist $\mathrm{s}$. Backhouse, 4 Dev. \& Battle (N. C.) 362; Sparks v. Dispatch Transfir Co., 104 Mo. 531; Bradlee v. Boston Glass If' $f^{\prime} y$, 16 Pick. (Mass.) 3+7; Manufacturers and Traders' Bank v. Love, I3 App. Div. (N. Y.) 561. Where the name of the principal and the name of the agent both appear upon the instrument, it is a matter of construction which is bound, and, in cases of ambiguity, parol evidence is admissible to fix the liability. Huffcut on Agency, $8 S$ I89-I95. There is great diversity among the decisions in consţruing these signatures. Ibid. Some courts have shown a greater liberality in holding the signatures of bank cashiers (e.g. "A. B., Cashier)," and corporation officers (e.g. "A. B. President") to be the signatures of the bank or corporation than in the case of signatures of agents of individuals (e.g."A. B. Agent;") especially where the name of the principal appears in the heading or on the margin of the instrument. Ibid, \& I92; Hitchcock v. Buchanun, I05 U. S. 416; Chipman v. Fostc\% I I9 Mass. I89, post. Contra, Casco Nat. Bank v. Clark, I39 N. Y.: 307 , post. - ED.

A partnership bill or note in order to bind the firm must be signed in the partnership name. Siffkin v. Walker, 2 Camp. 308; Kirk v. Blurton, 9 M. \& IV. 284; National Bank v. Meader, to Minn. 325. But if the bill be drawn on the firm and accepted by one partner in his own name, it has been held that the firm is bound. Mason v. Rumsey, I Camp. $3 s_{4}$; Tolman v. Hanrahan, 44 Wis. 133. But see contra, Hecnan v. Wash, 8 Minn. 407. Where the firm does business in the name of one partner, a bill or note executed in that name, while frima facie the obligation of the individual, may be shown to be that of the partnership. I Daniel on Neg. Inst., \& 363; Rumsey v. Briggs, I39 N. Y. 323. - ED. 
defendant made a promissory note, a copy whereof is hereto annexed, payable to the order of Coe i Company, and Coe \& Company indorsed the same to the plaintiff; that the defendant signed said note in the name of James H. Stearns; that said James H. Stearns was a fictitious party or name, there being no such person, or no such person whose name the defendant was authorized to sign; wherefore the plaintiff says said note is the note of tire defendant, made and signed by him, and that he owes the plaintiff the amount thereof, with interest and costs of protest." Fach count was in like form, annexing a copy of the note, and the name signed to nearly every note being different from that signed to the others.

Trial before Gray, J., who reserved the case upon the following report: "The plaintiff offered to prove that these notes were made and signed by the defendiant, and that the signatures so affixed by him were either of fictitious persons, or persons whose names he had no authority to sign or use; that the defendant made the notes for and at the request of Coe $\&$ Company, with the knowledge that they intended to negotiate and use them as their business paper, for the purpose of raising money to be used in their business; and that the plaintiff bought the notes from Coe \& Company before maturity, for full consideration, as their business paper. The plaintiff did not offer to prove that the defendant had ever used either of the names signed to these notes for the purpose of transacting any other business, or had held himself out to the world as doing business under either of these names; or that the plaintiff had any knowledge, when he took the notes, that they were signed by the defendant, or gave him any credit thereon. The plaintiff contended, that, if he satisfied the jury that the defendant signed either fictitious names to the notes, or the names of real persons without any authority from them, he would be liable in this action. If, in the opinion of the full court, this position, or either alternative thereof, can be maintained, the case is to stand for trial; otherwise judgment is to be rendered for the defendant."

GRAY, J. -- Although the question presented by this case is novel in one of its aspects, the law of this Commonwealth, as established by previous decisions of this Court, will go far to assist us in determining it.

It is well settled that any person taking a negotiable promissory note contracts with those only whose names are signed to it as parties, and cannot therefore maintain an action upon the note against any other preson. (Bank of British North America v. Hooper, 5 Gray, 567; Williams v. Robbins, i6 Gray, 77; Brozen v. Parker, 7 Allen, 337; Tucker Manufacturing Co. v. Fairbanks, $9^{8}$ Mass. 1or, 
104, and other cases there cited.) That rule, of course, does not preclude charging a party who, instead of the name by which he is usually known, signs, with intent to bind himself thereby, his initials, or a mark, or any name under which he is proved to have held himself out to the world and carried on business. (Merchants' Bank v. Spicer, 6 Wend. 4+3; George v. Surrel, Mood. \& Malk. 516 ; Williamson r. Fohnson, 2 D. \& R. $28 \mathrm{I}$, s. C. I B. \& C. 146 ; Fuller r. Hooper, 3 Gray, 334.)

But if a person signs the name of another, as maker of a promissory note, who has not authorized him to do so, and who therefore is not bound by the signature, the signer is not personally liable in an action of contract upon the note itself, even if he signs his own name also as that of the agent affixing the other signature, and the party whose name he assumes to put to the note is incapable of making such a contract; but only in an action of tort for falsely representing himself to be authorized to sign the name of the other person. This rule has been asserted and steadfastly maintained by this court for half a century. [Citing and discussing Long r. Colburn, i I Mass. 97; Ballou v. Tillhot, I6 Mass. 46I; Jefts v. Iork, + Cush. 37 I, s. C. 10 Cush. 392 ; Abbey v. Chase, 6 Cush. $5+$; Draper v. Mass., cte., Co., 5 Allen, $\left.33^{\text {S. }}\right]^{1}$

Ia the present case, the plaintiff counts upon the notes themselves, seeking to charge the defendant as the maker of them, upon the alternative ground that the name signed by him to each of the notes was either the name of a person whose name he had no authority to sign or use, or the name of a fictitious person.

If either of those names was that of a real person, then, although no agency was expressed on the face of the note, and whether the signature was affixed uncler a mistaken belief of authority, or fraudulently, or even if it was a forgery, it was, so far as regards the liability to a civil action upon the notes, a mere case of signing without authority, and the signature might be adopted or ratified by that person, and such adoption or ratification would rencler him liable to be sued as maker thereof. (Ballou $7^{\prime}$. Tallot, i6 Mass. 46r, 463; Merrifield v. Parritt, i I Cush. 590, 597; Brigham v. Peters, I Gray,

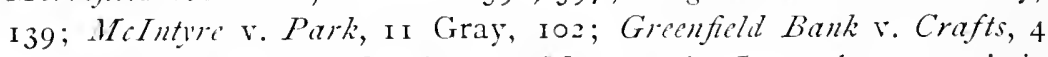
Allen, 447; Hunter v. Giddings, 97 Mass. 4I.) In such a case, it is clear that by the law of this Commonwealth, as shown by the cases already cited, the defendant could not be sued in contract upon the note, but only in tort. (See also Met. Con. ros, rog.)

The same rule must apply if the names signed to any of the notes were those of fictitious persons. In either alternative, the

'See Neg. Inst. L., $\leqslant 39$ [20]. - ED. 
notes were not signed in the defendant's own name, nor by any name under which he was shown tu have transacted, or held himself out as transacting, other business. The defendant has not, by word or act, asserted tiat they were his own promissory notes. The plaintiff did not take them immediately from him, or on his credit. The defendant therefore is not estopped to deny them to be his. The defendant's representation was, that they were signed by parties bearing, or doing business under, the names signed. He made no contract, and intended to make no contract, and was not understood by any other party to make any contract, himself. His relation to the plaintiff was not one of contract, but of tort. The case is not dis tinguishable in principle from that of Jefts v. York (ro Cush. 392), already stated. There is no essential difference in this respect between a note purporting to be made by a person or corporation that has no capacity to make it, and a note purporting to be made by one that in fact has no existence; or between a note on which the name of the person by whose hand it is written appears, and a note on which it does not; and no more reason for holding him liable to an action upon it as his own contract in the one case tian in the other.

The cases cited by the learned counsel for the plaintiff, when closely examined and weighed, afford no sufficient ground for a different conclusion.

The strongest case in his favor is tnat of Grafton Bank v. Flanders (4 N. H. 239). It was there held that a person who signed the name of another to a promissory note as maker without any authority from him, and delivered it to the payee for a valuable consideration, was himself liable upon the note as maker in an action by the payee, charging him as having made it in the name of the other person. It is to be observed that in that case the defendant himself delivered the note to the plaintiff. And a careful consideration of the elaborate opinion of the court has failed to satisfy us that it is in accordance with the law of this Commonwealth. The courts of New Hampshire have always gone beyond our own in holding a person signing the name of another without authority to be himself liable to an action upon the contract. (Underhillv. Gibson, 2 N. H. 352 , 356; Woodes v. Dinnett, 9 N. H. 55; Pettingill v. McGregor, I 2 N. H. I 79, I9I; Moor v. IVilson, 6 Foster, 332, 336; IV care v. Gor'e, 44 N. H. I 96.$)$

In Palmer v. Stephens ( I Denio, 47 I), the defendant had signed the promissory note sued on with his own initials; the court expressly waived the consideration of the question whether, if neither his name nor the initial letters thereof harl appeared on the paper, he could have been holden as a party to it; and the general statement in the 
opinion, that, "if one, assuming to be agent of another person, executes a note in his name, having in truth no authority for the purpose, the assumed agent is himself bound by the signature," though supported by the earlier cases in New York, is inconsistent with the later cases in that state, as it is with our own decisions. (Walker v. Bank of New York, 5 Selden, $5^{82}$; White v. Madison, 26 N. I. I I 7 .)

In Browen v. Butchers and Drowers Bank (6 Hill, 443), the signature which was held to bind the defendant as indorser of a bill of exchange was not of another name than his own, but of figures; and the report states that evidence was given strongly tending to show, not only that they were in his handwriting, but that he meant they should bind him as indorser.

The case of Melledge v. Boston Iron Co. (5 Cush. ${ }_{5} 8$ ), went no farther than to hold that a corporation was liable on a note given by its general agents, a mercantile firm, in their own name, for a debt of the corporation, if the note was in fact the note of the corporation, executed under a name which it had adopted and sanctioned as indicative of its contracts, or if the payee took the note under a misapprehension, caused by the acts of the corporation and its agents, as to the identity of the corporation with the firm whose name was signed to the notes. The doctrine of that case does not warrant charging either a corporation or a natural person upon a note signed in the name of another, without clear proof that such name has been adopted by the first for the purpose of transacting business. (IVilliams v. Robbins, I6 Gray, 77; Brown v. Parker, 7 Allen, 337.)

The remark of Mr. Justice Hoar, in Draper v. Massachusetts Stcam Heating Co. (5 Allen, 338 ), that " there may be cases in which the signature is in such a form that it might be held to be either the signature of the principal or of the agent, and in such case a want of authority to bind the principal might well be regarded as fixing the personal liability of the agent," related to cases in which the names of both agent and principal appeared upon the face of the contract, and in a form making it doubtful which was intended to be bound.

The plaintiff much relied on the English cases in which an acceptor of a bill of exchange, in which a fictitious person was named as payee, has been held to stand as if it had been payable to bearer, and to be liable for the amount of the bill to one who has discounted it on the faith of his acceptance, even when the signature of the drawer for whose honor he accepted it was forged. (Gibson i'. Minct, I H. B1. 569 ; s. C. 2 Bro. P. C. $48 ; 3$ T. R. ${ }_{4} 8$ r ; Phillips v. Im Thurn, 
Law Rep. I C. P. $46_{3}$; s. C. IS C. B. [N. S.], 694.) But those cases go upon the ground that the defendant's own acceptance bound him, so that he could not, even if he acted in good faith, dispute the genuineness of the prior signatures. They do not hold him liable upon those signatures as his own, but upon his own signature as acceptor.

The plaintiff also cited Lobdell v. Baker (3 Met. 469), in which it was held that if the holder of a promissory note, indorsed in blank by the payee, caused it to be indorsed by a minor, and then sold it, without erasing this indorsement or otherwise making it appear on the note to be without binding force, he was liable to all subsequent holders upon his implied representation that the indorsement constituted a valid contract. But the action in that case was in tort for the false representation. (See s. c. I Met. I93.)

The plaintiff further contended that he might waive the tort and sue in assumpsit; for which he cited Hill v. Perrott (8 Taunt. 274); Bidale v. Lezy (I Stark. 20); and Jones v. Hoar (5 Pick. 285). But as there was no offer to show that the defendant had received any money upon the notes, that rule does not apply. (Ladd v. Rogers, i Allen, 209.)

If the facts which the plaintiff offered to prove were true, he would seem to have been defrauded by the act of the defendant. But he must seek his remedy for such fraud in an appropriate form of action. He cannot compel the defendant to try the question of false representation in an action of contract upon the notes.

We regret that after much consideration our judgment is not unanimous. It is the opinion of a majority of the court, that, for the reasons above stated, this action cannot be maintained upon either alternative of the facts which the plaintiff offered to prove. The result is, that, according to the terms of the report upon which the case was reserved, there must be

Judgment for the defendant.

3. Liability of Person Signing as Agent.

$26 \mathrm{NEW}$ YORK, II7. - I862.

Action to recover the amount of a promissory note executed by the defendant in this style: "N. D. Snow, Sh'ff Chau. Co., by A. Z. Madison, Dep. Sh'ff;" also to recover the costs of a prior action against Snow upon the same note, in which plaintiff was nonsuited on the ground that Madison had no authority from the sheriff to 
make the note. The note was given to insure goods seized by the deputy sheriff under a writ of attachment. Judgment for plaintiff. Defendant appeals.

Selden, J. - It was proved on the trial in this case that the defendant, on the trial of the former action against the sheriff, testified that he had no authority from the sheriff to execute in his name the note mentioned in the complaint, unless that authority was within his general powers as a deputy of the sheriff; and the counsel on both sides have assumed that he had, as deputy, no such authority. It seems also to have been assumed that the sheriff had no power to insure, in his official capacity, the goods attached, and that consequently the deputy could not insure them in his name. The question of power on the part of the deputy to execute the note in the name of the sheriff does not depend upon that position. If the deputy had power to insure in the name of the sheriff, he could not, in effecting such insurance, subject the sheriff to the hazards of that most unsafe of partnerships - a mutual insurance company. $\mathrm{He}$ may have had power to insure the sheriff's goods without having power to make him the insurer of other people's goods. The latter power was attempted to be exercised when he made the note in question, and this was undoubtedly beyond his general authority.

The defendant, having executed the note in the name of Snow, without authority, would be held liable, according to several decisions in this State, as the maker of the note. (Dusenbury v. Ellis, 3 John. Cases, 70; White v. Skinner, I 3 John. 307 ; Feiter v. Heath, I I Wend. 487 ; Rossiter v. Rossiter, 8 Id. 494; Mecth v. Smith, 7 Id. 3 r5; Palmer v. Stephens, r Denio, 480 ; Plumb v. Milk, i9 Barb. 74.) The authority of these cases has been somewhat shaken by the remarks of the judges who delivered opinions in the case of $l$ ialker v. The Bank of the State of New York (5 Seld. $5^{82}$ ); and in England, as well as in several of the United States, the principle upon which they rest, if they are supposed to present the only ground of liability of the agent, has been substantially repudiated. (Collenv. Mrirht, 40 Eng. L. and Eq. I82; Randell v. Trimen, 37 Id. 275 ; Leais $\mathrm{r}$. Nicholson, r2 Id. 430; Smout v. Ilbery, го M. \& W. I; Pollite v. Walter, 3 B. \& Ad. I 4 ; Jenkins v. Hutchinson, I3 Ad. \& Ellis $[\mathrm{N}$. S.], 744; Long v. Colburn, i r Mass. 96; Ballou v. Talhot, r6 I.1. 46r; Jefts v. York, 4 Cush. 37 r; s. C. ro Id. 392; Abbey v. Chase, 6 Id. 54; Stetson v. Patten, 2 Greenl. 359; Bank v. Flanders, 4 N. H. 239; Woodes v. Dennett, 9 Id. 55; Johnson v. Smith, 2 I Co.nn. 627; Ogden v. Raymond, 22 Id. 379; Taylor v. Shelton, 30 Id. 122; Hopkins v. Mellaffy, I I S. \& R. I 26; 2 Smith's Leading Cases, 222; Story on Agency, $\$ 264, a$, and note r.) 
If it were necessary, in disposing of the present case, to decide the question, whether, as a general principle, one entering into a contract in the name of another, without authority, is to be himself holden as a party to the contract, I should hesitate to affirm such a principle By that rule courts would of ten make contracts for parties which they neither intended nor would have consented to make. The contract, if binding upon one party, must be binding upon both; and where burdensome conditions precedent were to be performed by the party contracting with the assumed agent, before performance could be demanded of the other party, or where the agent should undertake to sell, lease or mortgage the property of the assumed principal, or where credit should be given, which the responsibility of the agent would not justify, great injustice might result from such a rule. In those cases, and I think in all cases, where one, pretending to be an agent, has contracted as such without authority from the principal, the party contracted with, on learning the facts, must have the right to repudiate the contract, and to hold the assumed agent immediately responsible for damages, without waiting for the time when an action might be maintained on the contract itself; and the damages must be measured, not by the contract, but by the injury resulting from the agent's want of power. Whenever a person enters into a contract as agent for another, he warrants his own authority, unless very special circumstances, or express agreement, relieve him from that responsibility. (Snout $v$. Ilhery, 10 M. \& W. 9, 10; Pollill v. Walter, $3 \mathrm{~B}$ \& Ad. I1 4 ; Jenkins v. Mutchinson, 13 Ad. \& Ellis $\Gamma \mathrm{N}$. S. 1, 744; Jefts v. York, ro Cush. $395 ; 5$ Seld. 585 ; Story on Agency, $\$ 164$.$) An action upon such warranty must always be appropriate$ where personal liability attaches to an agent, in consquence of his contracting without authority. In such action the plaintiff would he relieved from the necessity of showing performance of conclitions precedent, and from the delay which the terms of the contract might require, if the remedy were limited to an action on the contract; and if special damage should he incurred in consequence of the agent's failure to bind his principal, such as the costs of an unsuccessful action against the principal to enforce the contract, they might be recovered. If the act of the agent were fraudulent, an action for the deceit would lie, but it would be a concurrent remedy with an action on the warranty, and so $I$ apprehend must be the action on the contract itself, if the cases which sustain such action are to be regarded as correctly decided. In Dusenbury v. Ellis (3 John. Cases, 70), the leading case in this State sustaining such an action, it does not appear what time the note executed by the assumed agent had to run at the time when it was given. Supposing it to have been given 
payable at a very distant day, was the holder, after discovering that Dusenbury had no authority from Sharpe (the assumed principal), to give it, bound to wait until the note became due, and then sue Dusenbury on the note as his contract; or could he repudiate the contract and immediately sue Dusenbury on the note as his contract; or could he repudiate the contract and immediately sue Dusenbury on the warranty of authority, implied, or rather, as I think, expressed, in the execution of the note? There can be but o'e answer to this question, and that is in favor of the right to repudiate the principal contract, and to prosecute on the subordinate contract of warranty, whether the right to elect between that course, and an action on the principal contract, existed or not. Whether Ellis, as indorsee of the note, could have maintained an action on the warranty, which was made originally to Fish, the payee, may be doubtful, unless it appeared that the agent knew he was acting without authority, in which case, according to English decisions, he would be liable on the warranty to anyone receiving the paper; the representation of his authority being in effect made to all to whom it might be offered in the course of circulation. (Polhill $r$. Wilter, 3 B. \& Ad. Ir 4.)

If the party receiving the note in the present case must be charged, as climed by the defendant's counsel, with knowledge of the extent of defendant's ordinary powers as a deputy of the sheriff (which is very questionable), the want of special authority for this particular act was not communicated, and could not be known. The defendant, therefore, is not within the cases in which agents have been held excused from liability for acts beyond their authority, when they have acted in good faith and the facts affecting their authority were equally well known to both parties. (Smout v. Ilbery, ro M. \& IV. II ; Story on Agency, $\$ \$ 265,265$ a.)

The recovery seems to have proceeded, in the court below, upon the ground that this was an action upon the note. It is rather, I think, to be regarded as an action on the warranty. The complaint states all the facts in respect to the making of the note by the defendant in the name of Snow; that he executed it without authority, and that the company issued the policy upon no other consideration than the note and the advance premium, relying on the authority of the defenclant to execute the note. It also set forth the proceedings in an unsuccessful suit against Snow on the note, and demands judgment for the costs of that suit, together with the full amount of the note; the assessments for losses being equal to that amount. On the facts stated, the law implies a warranty of authority to the defendant to execute the note for Snow, and it was unnecessary, under our present system of pleading, to allege that 
legal inference. (Eno v. Woodworth, + Comst. 249, 253.) In an action on the note as the contract of the defendant, a claim for the costs of a suit to enforce the note against Snow would be absurd. The amount of the note, less the assessment paid, was made the measure of damages, as if the action had been upon the note; but the allegations and proof showed that the share of the losses of the company, chargeable upon the note, during the time covered by the policy prior to its surrender, was equal to the amount of the note. That possibly might be regarded as a proper measure of damages upon the breach of warranty; but whether that be so or not, no question having been made before the jury as to the amount of the recovery, if the defendant was liable at all, none can be made now.

[The court then holds that the sheriff had an insurable interest in the goods.] The position of the defendant's counsel is doubtless correct, that if the sheriff was authorized to insure the goods, the deputy who seized them might insure them in his name, but this power, for the reasons given above, did not authorize the deputy to give the note in question.

[Omitting a point immaterial to the question here presented.]

If the action were to be regarded as brought, and the recovery had, upon the note, it might be doubtful whether the judgment could be sustained, because the plaintiff has neither alleged nor proved enough to show to the court that the defendant was in default in paying the note, regarding it as his personal obligation. By the terms of the note, it was payable " at such time or times as the directors of said company may, agreeably to their act of incorporation, require." The act of incorporation here referred to is the charter of the company which the statute requires the original corporators to make and file in the office of the Secretary of State. (Laws of I849, ch. 308, $\$ \$ 3$, Iо, I2, I6.) There does not seem to be anything in the statute under which the company was organized to which the reference could be held applicable. Neither the pleadings nor the proofs show what the provisions of the charter of the Union Insurance Company were, and consequently it does not appear whether the maker of the note was in default or not. The allegations in the complaint of notice of assessment by publication and by mail are put in issue by the answer; and if we could assume that those allegations indicated correctly what was required by the charter to charge the parties assessed, there is an entire want of proof on the subject. 'This objection is distinctly presented by the third ground of the defendant's motion for a nonsuit; and if the plaintiff was confined to a recovery on the note, I think this objection 
would be fatal $t$, his action; but, regarding the liability as depending on the warranty, no assessment or notice was necessary.

Several objections were taken by the defendant to the introduction of testimony; but, with the exception of those relating to the action against Snow, they are so clearly untenable as not to require notice. If this action was to be regarde 1 as an action simply to charge the defendant as the maker of the note, the record in the case of Snow would not have been admissible against the defendant. Assuming that it was incumbent upon the plaintiff to show that the defendant was not authorized to make the note for Snow (ig Barb. 74), this record, to which the defendant was a stranger, was not admissible to prove that fact, or as having any tendency to prove it, though it might have been otherwise if seasonable notice had been giren to the defendant that his authority to make the note for Snow was denied in that suit, and requiring him to maintain his authority on the trial. (2 Cow. \& Hill's Notes, $8_{17}$.) If the record was inadmissible, the parol evidence of the grounds on which the decision proceeded was equally so. Nor was the record necessary to authorize the introduction of proof of what the defendant testified to on that trial, showing his want of authority. What he said in the witnessbox was admissible against him, as declarations made at any ot'her time would be, without reference to his oath or to the issues in the record. But, resting the plaintiff's right of recovery, as I do, upon the warranty, the record was admissible to show that the plaintiff had been subjected to the expenses of an action in attempting to enforce the contract against the principal, whom the defendant undertook to bind. These expenses - the action being brought in good faith - were a legitimate item of damages in the present action. (Randell v. Trimen, 37 L. \& E., 275; s. C., 86 Eng. C. L. 786; Collen v. Wright, to L. \& E. I 82 ); and the parol evidence was admissible to rebut a possible inference that the nonsuit was granted on account of some formal defect in the prosecution of the action. It is always competent to show by parol the grounds on which a verdict or judgment was rendered, when the grounds become material, and do not appear in the record. (Wroodv. Jackson, S Wend. Io-45; Doty v. Broz'n, + Comst. 7 I-75.) The judgment should be affirmed.

Denio, Ch. J, Davies, Wright and Gould, JJ., concurred. Allen, J., dissented.

Judgment affirmed. ${ }^{1}$

1 Accord: Bultzen v. Nicolay, 53 N. Y. 467; Taylor v. Nostrand, 134 N. Y. Io8; Bartlett v. Tueker, 104 Mass. 336, ante, p. 306; Taylor v. Shelton, 30 Conn. 122; Kroeger v. Pitcairn, Ior Pa. St. $3 \mathrm{II}$; Huffcut on Agency, $\$ \mathrm{I} 8_{3}$.

It will be observed that the language of the Neg. Inst. Law (S 39 [2o]), seems 
in Massicincesetts, is9. - I875.

Contract against the defendants as drawers of three drafts indorsed in blank by the payees, of which the following is a copy:-

Foster \& Cole, General Agents for the

New England

States.

I5 Devonshire

Street,

Boston.

No. 176 .

$\$ 5,000$

New Exglant Agexcy of the Pexsyluarid Fire lastraxce Compair, Philadelphia.

Bostor, August IS, I573.

Pay to the order of Haley, Morse \& Company, five thousand dollars, being in full of all claims and demands against said company for loss and damage by fire on the thirlieth day of May, IS73, to property insured under policy No. 824, of Boston, Mass., agency.

Foster \& Cole.

To the Pennsylvania Fire Insurance Company, Philadelphia.

Defendants were general agents of the Pennsylvania Fire Insurance Company of Philadelphia, and drew the drafts in question in payment of three policies issued by that company. The company refused to honor the drafts, and they were duly protested.

GRAY, C. J., - Each of these drafts, upon its face, purports to be issued by the New England agency of the Pennsylvania Fire Insurance Company, and shows that Foster \& Cole are the general agents of that corporation $f \circ r$ the New Fngland States, as well as that the draft is drawn in payment of a claim against the corporation. It thus appears that Foster \& Cole, in drawing it, acted only as agents of the corporation, as clearly as if they had repeated words expressing their agency after the signatu:e; and they cannot be held personally liable as drawers thereof. (Carpenter r. Farnsworth, ro6 Mass. 56r), and cases cited.

Judgment for the defendants."

139 NEW YoRK, $307 .-$ I 893.

ACtion against defendants as makers of a promissory note. Judgment for plaintiff. The opinion states the facts.

to imply that if the agent is not duly authorized he will be liable on the instrument; bat it is open to question whether the courts would change a well-established rule of law upon a negative implication.

A few courts hold an agent liable upon the instrument when he signs in the capacity of an agent, but without authority. Dale v. Donaldson, 48 Ark. I88; Weare v. Gove, 44 N. II. I96. - En.

${ }^{1}$ Accord: Mechanics' Bank v. Bank of Columtia, 5 Wheat. (U. S.) 326; Hitch. cock v. Buchanan, 105 U. S. 4 I6. - En. 
GRAY, J. - The action is upon a promissory note, in the following form, viz. :

Brooklyx, N. Y., August 2, ISgo. $\$ 7,500$. Three months after date, we promise to pay to the order of Clark it Chaplin Ice Company, seventy-five hundred dollars at Mechanics' Bank: value received.

E H. Close, Treas.

JohN Clakk, Presi.

Ic was delivered in payment for ice sold by the payee company to the Ridgewood Ice Company, under a contract between those companies, and was discounted by the plaintiff for the payee, before its maturity. The appellants, Clark and Close, appearing as makers upon the note, the one describing himself as " Prest." and the other as "Treas.," were made individually defendants. They defended on the ground that they had made the note as officers of the Ridgewood Ice Company, and did not become personally liable thereby for the debt represented.

Where a negotiable promissory note has been given for the payment of a debt contracted by a corporation, and the language of the promise does not disclose the corporate obligation, and the signatures to the paper are in the names of individuals, a holder, taking bona fidc, and without notice of the circumstances of its making, is entitled to hold the note as the personal undertaking of its signers, notwithstanding they affix to their names the title of an office. Such an affix will be regarded as descriptive of the persons and not of the character of the liability. Unless the promise purports to be by the corporation, it is that of the persons who subscribe to it; and the fact of adding to their names an abbreviation of some official title has no legal signification as qualifying their obligation, and imposes no obligation upon the corporation whose officers they may be. This must be regarded as the long and well-settled rule. (Byles on Bills, ss 36, 37, 71; Pentz v. Stanton, ro Wend. 27 1; Taft v. Breaister, 9 John. 334; Hills v. Bannister, 8 Cow. $3 \mathrm{r}$; Moss v. Licingston, 4 N. Y. 208; Dellitt v. Walton, 9 Id. $57 \mathrm{I}$; Bottomley v. Fisher, I Hurlst. \& Colt. 2II.) It is founded in the general principle that in a contract every material thing must be definitely expressed, and not left to conjecture. Unless the language creates, or fairly implies, the undertaking of the corporation, if the purpose is equirocal, the obligation is that of its apparent makers.

It was said in Briggss v. Partridge $(64$ N. Y. 357,363$)$, that persons taking negotiable instruments are presumed to take them on the credit of the parties whose names appear upon them, and a person 
not a party cannot be charged, upon proof that the ostensible party signed, or indorsed, as his agent. It may be perfectly true, if there is proof that the holder of negotiable paper was aware, when he receired it, of the facts and circumstances connected with its making, and knew that it was intended and delivered as a corporate obligation only, that the persons signing it in this manner could not be held individually liable. Such knowledge might be imputable from the language of the paper, in connection with other circumstances, as in the case of Mottr. Hicks (I Cow. 5I3), where the note read, "the president and directors promise to pay," and was subscribed by the defendant as " president." The court held that that was sufficient to distinguish the case from Taft v. Brezister, sufra, and made it evident that no personal engagement was entered into or intended. Much stress was placed in that case upon the proof that the plaintiff was intimately acquainted with the transaction out of which arose the giving of the corporate obligation.

In the case of Bank of Genescev. Patchin Bank (r9 N. Y. 312), referred to by the appellant's counsel, the action was against the defendant to hold it as the indorser of a bill of exchange, drawn to the order of " S. B. Stokes, Cas.," and indorsed in the same words. The plaintiff bank was advised, at the time of discounting the bill, by the president of the Patchin Bank, that Stokes was its cashier, and that he had been directed to send it in for discount, and Stokes forwarded it in an official way to the plaintiff. It was held that the Patchin Rank was liable, because the agency of the cashier in the matter was communicated to the knowledge of the plaintiff as well as apparent.

Incidentally, it was said that the same strictness is not required in the execution of commercial paper as between banks, that is, in other respects, between individuals.

In the absence of competent evidence showing or charging knowledge in the holder of negotiable paper as to the character of the obligation, the established and safe rule must be regarded to be that it is the agreement of its ostensible maker and not of some other party, neither disclosed by the language, nor in the manner of execution. In this case the language is, "we promise to pay," and the signature by the defendants, Clark and Close, are perfectly consistent with an assumption by them of the company's debt.

The appearance upon the margin of the paper of the printed name " Ridgewood Ice Company" was not a fact carrying any presumption that the note was, or was intended to be, one by that company.

It was competent for its officers to obligate themselves personally, for any reason satisfactory to themselves, and, apparently 
to the world, they did so by the language of the note; which the mere use of a blank form of note, having upon its margin the name of their company, was insufficient to negative.

[The court then decides that the fact that one Winslow was a director in the payee company, and also in the plaintiff bank, did not charge the latter with notice as to the origin of the paper.]

Judgment affirmed. ${ }^{1}$

\$ 40 [2I] Stagg í. Elliott, i2 Common Bench, N. S. 373. I862. Bill accepted "per pro. William Elliott, George Elliott." George was the son of the defendant, William, and manager of his business. Brles, J. - The words "per procuration " are an express statement that the party accepting the bill has only a special and limited authority, and therefore a person who takes a bill so accepted is bound at his peril to enquire into the extent and nature of the agrent's authority. It is not enough to show that other bills similarly accepted or endorsed have been pald, although such evidence, if the acceptance were general by an agent in the name of a principal, would be eridence of a general authority to accept in the name of the principal. . . . The result of the decisions seems to be this, that the way in which this bill was accepted is the legitimate way of showing the fact that the acceptor has only a special and limited authority. Further, it is to be observed, that this rule depends upon the law-merchant, which extends over Europe and America; and this is the way in which it is understood all over the world.

S40 [2I] The Floyd Acceptances, 7 Wallace (U. S.), 666. i\$68. Mr. Justice Miller. - An individual may, instead of signin 3 , with his own hand, the notes and bills which he issues or accepts, appoint an agent to do these things for him. And this appointment may be a genera! power to draw or accept in all cases as fully as the

1 Accord: First N. B. v. Hallis, I50 N. Y. 455 ; Collins v. Buckeye, etc., Co., I Oh. St. 215. There is a clear distinction between makers, drawers, and acceptors, on the one hand, and indorsers on the other. An indorsement being necessary to transfer title a payee designated as "A. B. agent" may indorse in that form without becoming liable as indorser. Huffcut on Agency, $\$$ 194; Babcock v. Beman, I E. D. Smith (N. Y.) 593; Souhegan Vat. Bk. v. Boardman, 46 Minn. 293; Tater v. Lerits, 36 Ind. 298; First Nat. Bk. v. Hall, 44 N. Y. 395: Falk v. Mochs, I27 IJ. S. 597. See especially the statement in Collins v. Buckcye, etc., $C_{0}, \mathrm{I}_{7}$ Oh. St. 215 . The rule is especially liberal in favor of cashiers who indorse instruments drawn to their order, as, " pay to the order of A. B. cashier." Bank of Genese' v. Patihin Bank, i9 N. Y. 312; Folser v. Chase, is Pick. (Mass.) 63, post. Neg. Inst. L.. $\$ 72$ [42], fost, which extends the liberal rule to a "cashier, or other fiscal officer of a bank or corporation." - En. 
principal could; or it may be a limited authority to draw or accept under given circumstances, defined in the instrument which confers the power. But, in each case, the person dealing with the agent, knowing that he acts only by virtue of a delegated power, must, at his peril, see that the paper on which he relies comes within the power under which the agent acts. And this applies to every person who takes the paper afterwards; for it is to be kept in mind that the protection which commercial usage throws around negotiable paper, cannot be used to establish the authority by which it was originally issued. These principles are well established in regard to the transactions of individuals. They are equally applicable to those of the government. Whenever negotiable paper is found in the market purporting to bind the government, it must necessarily be by the signature of an officer of the government, and the purchaser of such paper, whether the first holder or another, must, at his peril, see that the officer had authority to bind the gorernment.

$\$ 40$ [2I] Nixon 2 . Palmer, 8 New York, 398. - i 853 . Bili accepted "Jeremiah G. Palmer, by James L. Palmer." D :fense, want of authority. MAson, J. - "The bill being on its face accepted by James L. Palmer for the defendant, was notice that he professed to act under an authority, and imposed upon the plaintiffs the duty of ascertaining that he acted within it."

4. Indorsement by INfant or Coporation.

I4 INDIANA, 382. - I860.

Worden, J. - Action by Massey against the appellants upon a promissory note made by the latter to William T. Hess, and by Hess indorsed to the plaintiff.

Answer that said William T. Hess, the payee of the note, was, at the time he indorsed it to the plaintiff, a minor under the age of twenty-one years; wherefore, etc.

To this answer a demurrer was sustained, and the plaintiff had judgment.

The ruling on the demurrer raises the only question involved in the case.

We think it clear that the demurrer was correctly sustained to the answer. The disability of an infant to make a valid, binding contract, is a personal privilege intended for the benefit of the infant NEGOT. INSTRUMENTS - 21 
himself, and none but he, or his representatives, can take advantage of such disability. (I Pars. Cont. 275.) Besides this, the defendants, by making the note to Hess, asserted to the world his competency to negotiate and assign the paper, and they cannot be permitted to gainsay the assertion so made. ${ }^{1}$ (Edw. on Bills, p. 250; Story on Prom. Notes, \$ 80, 5 th ed.)

Per Curiam. - The judgment is affirmed with 6 per cent. damages and costs.

\section{Forged Signatures.}

$\S 4 I$ LANCASTER $\%$ BALTZELL.

7 Gill \& Johnson (MD.), 468. - I836.

ACtion by indorsee against maker. Judgment for plaintiff. Defendant appeals. The facts appear in the opinion.

Buchanan, Ch. J., delivered the opinion of the court. A bill or note payable to order can only be transferred by endorsement; and as an action against the acceptor or drawer can only be sustained by one who has legal title, which cannot be derived through the medium of forgery, it is incumbent on the plaintiff in such an action to show his interest in the bill or note, which must be done by proving that it was endorsed by the person to whom, or to whose order, it is made payable.

This is an action by the second indorsee against the maker of a promissory note, payable to the payee or order, which was resisted at the trial on the ground, that the first endorsement, purporting to be by the payee was a forgery, of which proof was offered by the defendant. On the part of the plaintiffs, it was proved, that the defendant on being called on by their counsel, after the endorsement to them, to pay the note, examined it, and said it was right, and he would settle it with them. Upon which the court instructed the jury that if they believed the defenclant, when the note was presented to him by the counsel of the plaintiffs, had examined the endorsements and said it was right, the plaintiffs were entitled to recover, although they might believe the endorsement of the payee's name had been forged, and notwithstanding that acknowledgment had been made, after the transfer of the note by these endorsements to them; on an exception to which instruction the case is brought up.

\footnotetext{
${ }^{1}$ See Neg. Inst. L.,, I $10[60]$, A second indorser cannot deny the competency of the first indorser. Prescott Bank v. Caverly, 7 Gray (Mass.) 27I. - ED.
} 
Apart from the alleged conversation between the defendant and the counsel of the plaintiffs, it is very clear that the plaintiffs are not entitled to recover, if the first endorsment in the name of the payee of the note was forged; as the title was not and could not thereby be transferred,but continued in the payee, who on obtaining possession of the note, might sue upon it, and recover against the maker, notwithstanding he should hare paid it to him, into whose hands it came, through the medium of forgery; for besides that in such case the payee has not parted with his title, the paree of a note whose name is forged knows nothing of it, and the maker before he pays it to the holder as endorsee should look carefully to the endorsements. And if one is to suffer, the loss should fall on him who is most in fault, or most negligent.

The only question then, in this case is, whether, if after the endorsements had been made, the defendant, on the note being presented to him by the counsel of the plaintiffs, examined the endorsements and said it was right, that makes any difference. And we think it does not. By saring so, he gave no credit to the note; and did not thereby induce the plaintiffs to take it. That had been done before, and not on the faith of what he said. The plaintiffs might before they took the note have inquired whether the first endorsement was by the payee or not, and not having done so, they must abide by the consequence and cannot throw the loss upon the defendant, who had done nothing to mislead them or induce them to take the note; and who if made to pay the amount in this action, may be made to pay it over again by the payee, whose right remains unimpaired.

It is not like the case of a drawee of a bill, who if on being asked if the acceptance is in his handwriting, says that it is and that it will be duly paid, cannot afterwards set up as a defense the forgery of his name; because by saying so he has accredited the bill and induced another to take it, which being his own fault the loss ought to fall on him, and not on another, who has been induced to take the bill on the faith of his assurance. ${ }^{1}$

Judgment reversed. ${ }^{2}$

\footnotetext{
${ }^{1}$ Nor like the case of a drawee who accepts or pays a bill upon which the drawer's name is forged. See Vational Park Bk. v. Winth Nat. Bk., $46 \mathrm{~N}$. Y. 77 , post. - ED.

2 Money paid to a holder rleriving title through a forged indorsement may be recovered back. Chambers v. C"nion Bank, 75 Pa. St. 205; Estoy v. Cincinnati Bank, is Wall. (U. S.) bo4; Holt v. Koss, 54 N. Y. 472 ; Green v. Purcell . Y. B. (Ind. Ter.), 37 S. W. Rep. 5o. Contra: London, etc., Bank v. Bank of Livirpool, (I896), I Q. B. D. 7. - Ev.
} 
$\$ 42$ [23] Wellington $\because$ Jackson, iz I Massachusetts, I57.(IS76). GRaY, C. J. - "Although the signature of Edward H. Jackso.n was forged, yet if, knowing all the circumstances as to that signature, and intending to be bound by it, he acknowledged the signature and thus assumed the note as his own, it would bind him, just as if it had been originally signed by his authority, even if it did not amount to an estoppel in pais. (Greenfield Bank v. Crafts, + Allen, 447: Bartlett v. Tucker, rot Mass. 336, 34r.)"'

${ }^{1}$ Accord: Howard v. Duncan, 3 Lansing (N. Y.) Iit; Hifne; v. Iandolah, 62 I11. $4^{5} \hat{3}$. But non-repudiation is not conclusive eridence of ratification. Truters' N. B. v. Rogers, 167 Mass. 315. Contra: Brook v. Hook, L. R. 6 Ex. S9: Harkman v. Wrisht, 33 Oh. St. 405; Henry v. He'bl, In Ind. 275; Henry Christian, ctc., Association v. Walton, IS I Pa. St. 20I; Oäsley v. Philifs, 7 S Ky. 5 ז 7 .

While there is a sharp conflict of authority as to the possibility of ratifying a forgery, all of the cases agree that one may by his admissions or conduct estop himself from denying the genuineness of his signature as against one who has changed his legal position relying on such admissions, representations, or con-

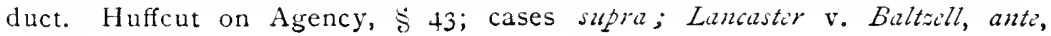
p. $322 .-\mathrm{ED}$. 


\section{ARTICLE III. \\ Consideration of Negotiable Instruments.}

\section{Presumption of consideration.}

I9 CoNecticti, 7.-IS 4 S.

Assumpsit on the following instrument:

" On demand, after my decease, I promise to pay Josiah W. Bristol, or order, eight hundred and fifty dollars, without interest."

The making of the instrument being admitted, the plaintiff intro. duced the instrument in eridence and rested his case. The court charged that the note imported on its face a valuable consideration; that it was a promissory note and not a testamentary paper. Conflicting evidence was given as to the consideration. Verdict for plaintiff.

Church, Ch. J. - I. The question first presented by this motion, is, whether the note in controversy imports, on its face, a valuable consideration? We think it does; and that the charge to the jury on this point was correct. It has now become the settled law of this state, after a time of some doubt, that a promissory note not negotiable, and not purporting on its face to be for value received, does not imply a consideration; and that a plaintiff, prosecuting such a note, is left to prove one, or fail to recover. ${ }^{\prime}$ (Edgertoll v. Edgerton, S Conn. R. 6.)

But this note is, in form, negotiable, though not yet negotiated; and no consideration is expressed in it. And therefore, it was claimed at the trial, that it should be treated as if it were not negotiable paper; - that it, being a simple contract, and as yet confined in its operation to the original parties to it, required proof of consideration. But we believe that the negotiability of the note gave it a character and a credit at its inception, then importing a consideration, as well between payer and payee, as between the maker and indorsers or subsequent holders. We suppose this court so

${ }^{1}$ Contra: Camwright vray, 127 X. Y. 92, post. But see Neg. Inst. L., 520 [184]. - En). 
regarded it in the case of Camp r. Tomplins (9 Conn. R. 445), in which it is said, that such instruments, as well as bills of exchange, from their very nature, import a consideration. Our statute making a certain description of notes negotiable, intended to give to them the same effect here, as such paper was known to have in England, and in the commercial community generally. The most respectable elementary writers upon this branch of the law, treat this as a wellestablished principle. Mr. Chitty says: "In the case of bills of exchange and promissory notes, they are presumed to have been on good consideration; and it is not necessary for the plaintiff to state any in his declaration, or prove it, in the first instance, on the trial, etc." Evans, in his learned commentary on Pothier, remarks, that "the case of bills of exchange and promissory notes affords, in some degree, an exception to the general rule, which has been under discussion, when they are indorsed over for a valuable consideration; the want of consideration, between the original parties is immaterial; as betwe'n them a consideration is presumed; but if the contrary is shown it is a sufficient defense." Chancellor Kent, in his commentaries, speaks thus: "It is usual to insert ialut reccio' ${ }^{\prime} d$ in a bill or note; but this is unnecessary, and value is implied in every bill, note, or indorsement." (Chitty on Bills, 67; 2 Pothier on Obligations, 22; 3 Kent's Com. 50; I Stephen's N. P. 766; Goshen \$ Minisink Turn. Co. v. Murtin, 9 Johns. R. 2 I 7 Manderille v. Wich, 5 Wheat. $277 ; 2$ Mciean, 2r2.) And yet, there is an essential difference between promissory notes before they are indorsed, and afterwards, in respect to their original consideration. In the former case, a consideration is implied, but may be denied in defense; while in the latter, only in special cases; it cannot be disputed if the holder be a meritorious one, receiving the paper before due.

$\$ 23[4$.$] 2. It is said that this paper is merely testamentary,$ and should have been proceeded with, as such, in the probate court. We set nothing of this character attached to it, either upon its face, or from the circumstances claimed to have been connected with its execution. To be sure, it is payable after the death of the maker; but this alone does not constitute it a will. Notwithstanding this, it is only what it purports to be - a promissory note. It is an obligation to pay; it was delivered to the payee, as an evidence of debt; and it is made payable to order, as a negotiable and irrevocabie instrument. (Burirh v. Preston, $S$ Term R. $48_{3}, 486$; Roffey v. Greentiell, ro Ad. \& El. 222; 37 E. C. L. 99; Stin et al. v. North, 3 Yeates, 324; Toner v. Hagsart, 5 Binn. 490.) 
There are a few cases, in which papers, not strictly testamentary in their object, have, however, been treated as such, when otherwise they would entirely fail of effect; and we recollect no case, nor do we know of any good reason, why an instrument intended as obligatory inter aivos should be construed or treated as a will, except for the cause suggested. (Masterman v. Mabcrly, 2 Hagg. 235 ; 4 E. Ecc. R. 103.)

[Omitting other questions.]

New trial not to be granted. ${ }^{1}$

\section{What constitutes consideration.}

I. Paynent of Pre-existing Debt.

2 Allen (Mass.), 236 - I 86 I.

[Reported herein at f. 293. $]^{2}$

\section{Collateral Security for Pre-existing Debt.} IO2 United States, I 4 . - I880.

ACTion by the bank against the railroad company on a promissory note. Defence, that the note was diverted by the defendant's

${ }^{1}$ The doctrine that a bill or note requires any consideration is of comparatively recent origin. It was unknown in the time of Blackstone $(2 \mathrm{Comm} .4+6)$, and early American cases are to be found in which it appears to be denied or doubted. (Bowers v. IIurd, Io Mass. 427; Liz'ingston v. Ilastie, 2 Cai. (N. Y.) 2.46.) But the modern cases now uniformly hold that a bill or note executed and delivered as a gift is unenforceable for want of consideration. Hill v. Buckminster, 5 Pick. (Mass.) 391; Parish v. Stone, r4 Pick. (Mass.) 198; Sihoonmaker v. Roosa, 17 Johns. (N. Y.) 301 ; Harris v. Clark, 3 N. Y. 93 . Nor will a meritorious consideration sustain a promissory note even in equity. Whitaker. Whitaker, 52 N. Y. 368 . See also Matter of Jumes, 146 N. Y. 78 (bond and mortgage), but see 37 Am. L. Reg. 337 .

The cases are uniform that a bill and a negotiable note have presumptive consideration. I Daniel on Neg. Inst., I6I-163. Whether non-negotiable notes import a consideration is a matter of the construction of the statute governing promissory notes. Ilid, S I63; Art. XVII, Div. I. 3, fost. As to burden of proof, see Neg. Inst. L., $\$ 98[59]$.

The courts do not inquire in to the adequacy of the consideration; but inade. quacy of consideration may be evidence of bad faith or fraud. Fone's v. Gordon, L. R. 2 App. Cas. 6r6; Huffcut's Anson (8th Eng. ed.), pp. 90-92. - Ev.

${ }^{2}$ Accord: Mayer v. Heidelbach, I23 N. Y. 332. - ED. 
agent, and that the bank is not a holder for value and therefore subject to the defence.

The note was made by the company payable to William $V$. Le Count, its treasurer, and indorsed by him in blank and by Palmer $\&$ Co., owners of the larger portion of the stock. The note thus indorsed was placed by the company in the hands of Hutchinson \& Ingersoll, note-brokers, for negotiation and sale in order to raise money for the company. Hutchinson \& Ingersoll pledged the note as collateral for a loan, and subsequently agreed that it should stand as collateral for a loan previously made. No agreement was made to extend the pre-exising debt, or to refrain from calling it in.

Mr. Justice Harlan, after stating the facts, delivered the opinion of the court.

The next proposition involves the right of the railroad company to show, as against the bank, that the note was executed and delivered to Hutchinson \& Ingersoll for the purpose only of raising money upon it for the company, and that, consequently, they had no authority to pledge it as collateral security for their own indebtedness to the bank. ${ }^{1}$ It will have been observed, from the statement of facts, that the note in suit was among those pledged to the bank as security for the call loan of $\$ 36,000$, made June 19, I 873 ; that Howes, Hyatt \& Co., whose notes had been pledged as security for the call loan of $\$ 10,000$ made June $19,18_{73}$, having become insolvent, Hutchinson \& Ingersoll, July 22,1873 , at the request of the bank, executed the writing, dated June $19, \mathbf{1} 8_{73}$, whereby they pledged all securities, bonds, stocks, things in action, or other property theretofore deposited with the bank, whether specifically or not, as security for the payment of any and every indebtedness, liability, or engagement held by the bank, for which they were, or should become, in any way liable. Although, therefore, the call loan of $\$_{36,000}$ was extinguished, without resorting to the note in suit, that note, under the agreement made July 22,1873 , stood pledged as collateral security, also, for the $\$ 10,000$ call loan of July i [ [June i 9 ?], I873.

The bank, we have seen, received the note, before its maturity, indorsed in blank, without any express agreement to give time, but without notice that it was other than ordinary business paper, or that there was any defence thereto, and in ignorance of the purposes for which it had been executed and delivered to Hutchinson \& Ingersoll. Did the bank, under these circumstances, become a holder for value, and as such entitled, according to the recognized

${ }^{1} \mathrm{Only}$ so much of the opinion is given as relates to this question. $-\mathrm{ED}$. 
principles of commercial law, to be protected against the equities or defences which the railroad company may have against the other parties to the note?

This question was carefully considered, though, perhaps, it was not absolutely necessary to be determined, in Sizift r. Ty'son (I6 Pet. I.)

The opinion in that case has been the subject of criticism in some courts, because it seemed to go beyond the precise point necessary to be decided, when declaring that the bona fide holder of a negotiable note, taken as collateral security for an antecedent debt, was protected against equities existing between the original or antecedent parties. The brief dissent of Mr. Justice Catron was solely upon that ground, which renders it quite certain that the whole court was aware of the extent to which the opinion carried the doctrines of the commercial law upon the subject of negotiable instruments transferred or delivered as security for antecedent indebtedness. In the judgment of this court, as then constituted (Mr. Justice Catron alone excepted), the holder of a negotiable instrument, received before maturity, and without notice of any defence thereto, is unaffected by the equities or defences of antecedent parties, equally whether the note is taken as collateral security for or in payment of previous indebtedness. And we understand the case of $M c C a r t y$ v. Roots (2 I How. 432), to affirm Szift v. Tyson, upon the point now under consideration. It was there said: "Nor does the fact that the bills were assigned to the plaintiff as collateral security for a pre-existing debt impair the plaintiffs right to recover." (p. $43^{8}$.) "The delivery of the bills to the plaintiff as collateral security for a pre-existing debt, under the decision of Suift v. Tyson, was legal." (p. 439.)

It may be remarked in this connection that the courts holding a different rule have uniformly referred to an opinion of Chancellor Kent in Bay v. Coddington (5 Johns. Ch. [N. Y.] 54), reaffirmed in Coddington v. Bay (20 Johns. [N. Y.] 637.) There is, however, some reason to believe that the views of that eminent jurist were subsequently modified. In the later editions of his Commentaries (vol. I I , p. 8I, note b.), prepared by himself, reference is made to Stalker v. McDonald (6 Hill [N. Y.] 93), in which the principles asserted in Bay v. Coddington were re-examined and maintained in an elaborate opinion by Chancellor Walworth, who took occasion to say that the opinion in Swift v. Tyson was not correct in declaring that a pre-existing debt was, of itself, and without other circumstances, a sufficient consideration to entitle the bona fude holder, without notice, to recover on the note, when it might not, as between 
ite original parties, be ralid. But Chancellor Kent adds: "Mr. Instice Story, on Promissory Totes (p. 2Ij, note $I$ ), repeats and sustains the decision in Swift r. Tysn, and I am inclined to concur in that decision as the plainer and better doctrine." Of course it did not escape his attention that the court in Su'ift v. Tyson declared the equities of prior parties to he shut out as well when the note was merely pledged as collateral security for a pre-existing debt, as when transferred in payment o extinguishment of such debt.

According to the very general concurrence of judicial authority in this country as well as elsewhere, it may be regarded as settled in commercial furisprudence - there being no statutory regulations to the contr. - that where negotizble paper is received in payment of an antecedent debr; ' or where it is transferred, by indorsement, as collateral security for a deb: created, or a purchase made, at the time of transier; " or the transier is to secure a debt, not due, under an agreement, express o: to be clearly implied from the circumstances, that the collection of the principal debt is to be postponed or delayed until the collateral matured: or where time is agreed to be given and is actually given upon a debt overdue, in consideration of the transier of negotiable paper as collateral security therefor: ${ }^{3}$ or where the transferred note takes the place ot other paper preriously pledged as collatera! security to: a debt, either at the time such debt was contracted or before it became due, - in each of these cases the holder who takes the transiered paper, beiore its maturty, and without notice, actual or otherwise, of any defence thereto. is heid to have received it in due course of business, and, in the sense oi the commercial law. becomes a holder for value, entited to entorce paymenc. without regard to any equity or defence which exists between prior parties to s'uch paper.

Upon these propositions there seems at this day to be no sibstuntial confict of authority. Put there is such conflict where the nots is transfered as collateral security merly, without other circumstances, for a debt previousiy created. One of the grounds upon which some courts of high autho-ity refuse, in such cases, to apply the rule announced in Sürit r.T.50\%, is, that tansactions of that kind are not in the usual and ordinary course of commercial dealings. But this objection is not sustained by the recognized usages of the commercial world, nor, as we think, by sound reason. The transter of negotiable paper as security for antecedent debts con-

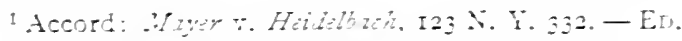

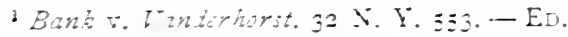

${ }^{3}$ The agrement io extension mus: de definite and binding. Attantic $\therefore . B$.

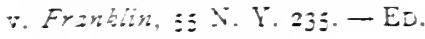




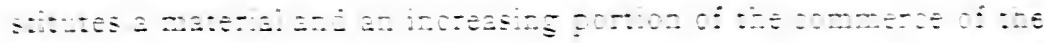

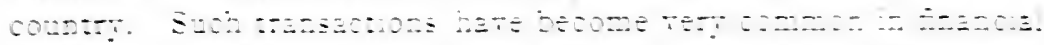

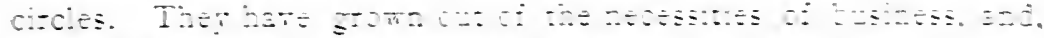

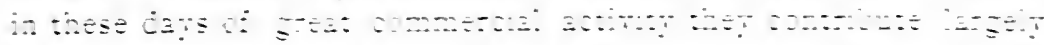

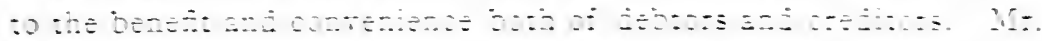

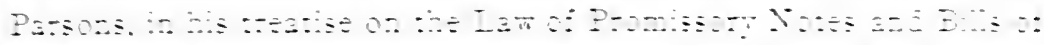

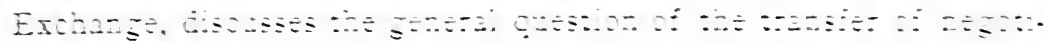

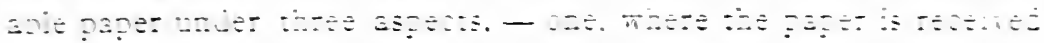

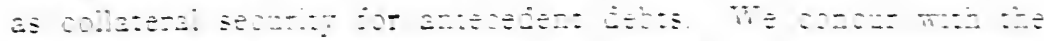

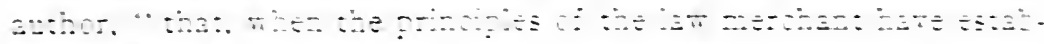

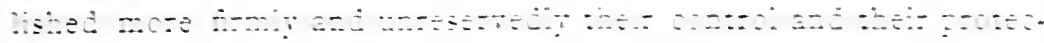

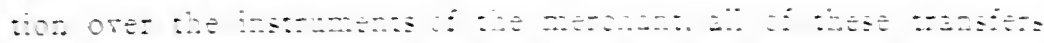

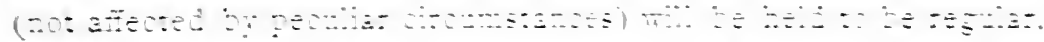
a-d o res:

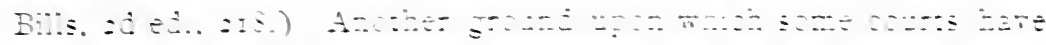

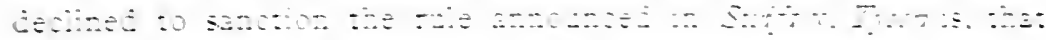

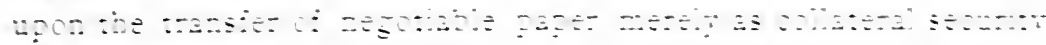
$\therefore=$ an and

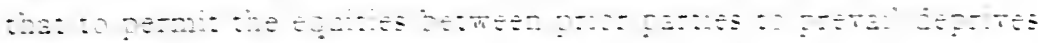

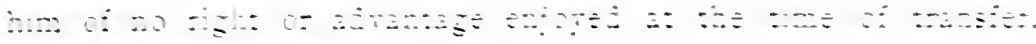

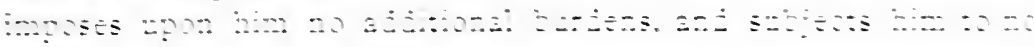

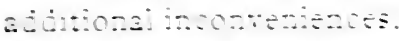

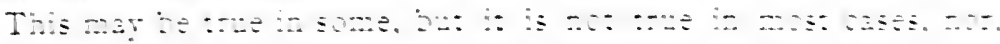

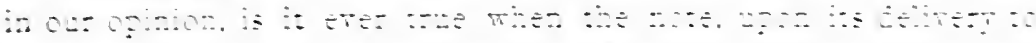

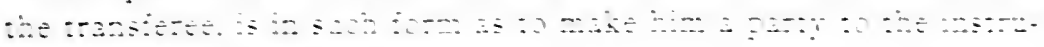

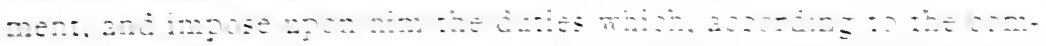

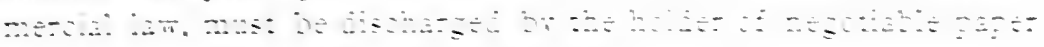
的

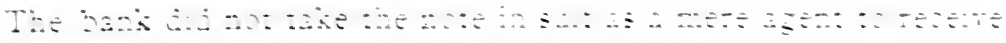

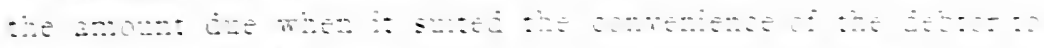

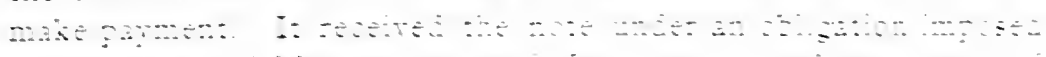

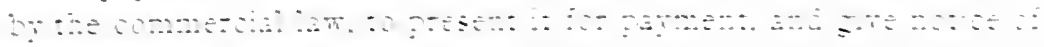

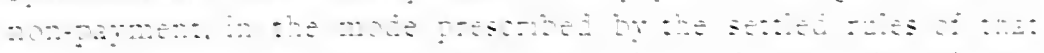
l. w. We ..A

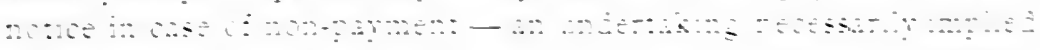
1-

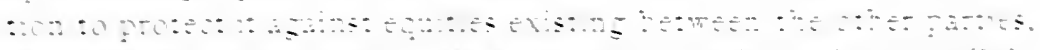

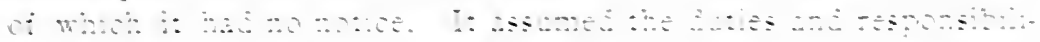

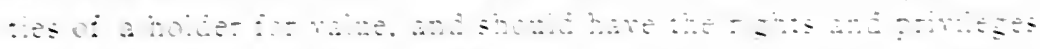

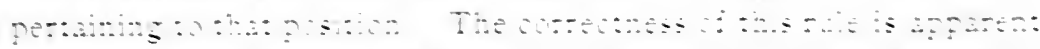

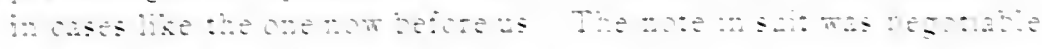
iz: 
negotiated. Had it been regurlarly discounted by the bank, at any time before maturity, and the proceeds either placed to the credit of Hutchinson \& Ingersoll, or applied directly to the discharge, pro tanto, of any one of the call loans previously made to them, it would not be doubted that the bank would be protected against the equities of prior parties. Instead of procuring its formal discount, Hutchinson \& Ingersoll used it to secure the ultimate payment of their own debt to the bank. At the time the written agreement of July 22, I 873 , was executed, by which this note, with others, was pledged as security for any debt then or thereafter held against them, the bank had the right to call in the $\$ 10,000$ loan, that is, to require immediate payment. The securities upon which that loan rested had become, in part, worthless, and it is evident that but for the deposit of additional collateral securities the bank would have called in the loan, or resorted to its rightful legal remedies for the enforcement of payment. It was, under the circumstances, the duty of the debtors to make such payment, or to secure the debt. It was important to them, and was in the usual course of commercial transactions, to furnish such security. If the bank was deceived as to the real ownership of the paper, or as to the purposes of its execution and delivery to Hutchinson \& Ingersoll, it was because the railroad company intrusted it to those parties in a form which indicated that the latter were its rightful holders and owners, with absolute power to dispose of it for any purpose they saw proper.

Our conclusion, therefore, is that the transfer, before maturity, of negotiable paper, as security for an antecedent debt merely, without other circumstances, if the paper be so endorsed that the holder becomes a party to the instrument, although the transfer is without express agreement by the creditor for indulgence, is not an improper use of such paper, and is as much in the usual course of comme:cial business as its transfer in payment of such debt. In eiticer case, the bona fide holder is unaffected by equities or defences between prior parties, of which he had no notice. This conclusion is abundantly sustained by authority. A different determination by this court would, we apprehend, greatly surprise both the legal profession and the commercial world. (See Bigelow's Bills and Notes, 502 it seq.; I Daniel, Neg. Inst., 2d ed., c. 25, $\$ \$ 820-833$; Stor: Prom. Notes, \&s I86, I95, 7 th ed. by Thorndyke; I Parsons, Notes and Bills, 2 d ed., 2 I $\&, \$$, c. 6; and Redfield and Bigelow's Leading Cases upon Bills of Exchange and Promissory Notes, where the authorities are cited by the authors.)

[The Court then holds that the Federal courts are not controlled by the decisions of State courts on questions of general commercial law.] 
[Mr. Justice Clifford concurred in an opinion of great learning, but of too great length to be reprinted here.]

Mr. Justice Brader. - I concur in the judgment rendered in this case, and in most of the reasons given in the opinion. But, in reference to the consideration of the transfer of the note as collateral security, I do not regard the obligation assumed by the indorsee (the bank), to present the note for payment and give notice of nonpayment, as the only, or the principal, consideration of such transfer. The true consideration was the debt due from the indorsers to the indorsee, and the obligation to pay or secure said debt. Had any other collateral security been given, as a mortgage, or a pledge of property, it would have been equally sustained by the consideration referred to; namely, the debt and the obligation to pay it or to secure its payment. If the indorsers had assigned a mortgage for that purpose, the title of the bank to hold the mortgage would have been indubitable. In that case prior equities of the mortgagor might have prevailed against the title of the bank; because a mortgage in not a commercial security, and its transfer for any consideration whatever does not cut off prior equities. But the bona fide transfer of commercial paper before maturity does cut off such equities; and every collateral is held by the creditor by such title and in such manner as appertain to its nature and qualities. Security for the payment of a debt actually owing is a good consideration, and sufficient to support a transfer of property. When such transfer is made for such purpose, it has due effect as a complete transfer, according to the nature and incidents of the property transferred. When it is a promissory note or bill of exchange, it has the effect of giving absolute title and of cutting off prior equities, provided the ordinary conditions exist to give it that effect. If not transferred before maturity or in due course of business, then, of course, it cannot have such effect. But I think it is well shown in the principal opinion that a transfer for the purpose of securing a debt is a transfer in due course. And that really ends the argument on the subject.

Mr. Justice Miller and Mr. Justice Field dissented.

Judgment affirmed. ${ }^{1}$

'See also Brook, O. \& Co. v. Vannest, 58 N. J. L. I62, post, p. 359. "We are of the opinion that a creditor to whom a negotiable security is given on account of a pre-existing debt holds it by an indefeasible tille, whether it be one payable at a future time or on demand." Currie v. Misa, L. R. Io Ex. I53, Lord Coleridge, C. J., dissenting.

For full collection of authorities on this vexed question, see $4 \mathrm{Eng}$. \& Am. Encyc. of Law, 2d ed., pp. 290-295.

It was probably the intent of the framers of $S 5 I[25]$ of the Neg. Inst. L. to abolish the rule established in Coddington v. Bay, 20 Johns. 637, and ever sin e 


\section{Holder for value.}

4 Exchequer Rerorts, 4 S9. - IS 49 .

This was an action by the plaintiff, as endorsee of a bill of exchange, against the defendant, as acceptor. The defendant pleaded (in substance), that the bill of cxchange was drawn by one McLean, at the request and for the accomrodation of the defendant, and without any consideration or value whatever, and that the till was endorsed by the said McLean without any consideration or value given by the plaintiff for such endorsement, to the defendant, or to the said McLean, or to any other person whomsoever. The plaintiff had signed interlocutory judgment upon this plea, the defendant being under terms of pleading issuably. A rule nisi was subsequently obtained, on the part of the defendant, to set this jurgment aside, but without any affidavit of merits.

IVilles now showed cause. - The plaintiff was clearly entitled to sign judgment, for the plea is not issuable. It is quite consistent with the plea that there was a good consideration given for the bill. It may have passed through many hands, each party having given consideration. [Rolfe, B. - It may have been endorsed to A. B., who made a present of it to the plaintiff.] Or the defendant may have owed a debt to some third party. The allegation that the bill was drawn for the accommodation of the defendant is absurd. [RoLFE, B. - The plaintiff may be the executor of a person who gave full value for it.] He was then stopped by the Court, who called upon

Barnard, in support of the rule, who contended that the plea was good upon general demurrer.

PARKE, B. - The plea is clearly not issuable, and the plaintiff was entitled to sign judgment. There is not even an allegation in the plea, that none of the previous parties to the bill had given value for the endorsement. The rule, therefore, ought to be discharged, and with costs, as the defendant is not prepared with an affidavit of merits.

Pollock, C. B., Aldersox, B., and Rolfe, B., concurred.

Rule discharged, with costs.

in force in New York; whether the language used is apt for that purpose will be a question for judicial determination.

For the New York and general rule as to transfer of accommodation paper as security for a pre-existing debt, see Grocers' Bank v. Pinfield, 69 N. Y. 502 , post, p. $339-\mathrm{En}$. 
$\$ 52$ [26] HoffuaN $i$. Baxk, I 2 Wallace (U. S.), I $S_{\text {I }}$, I 9o. (I 870 .) Mr. Justice Clifford. . . . Different rules apply between the immediate parties to a bill of exchange - as between the drawer and the acceptor, or between the payee and the drawer, ${ }^{1}$ - as the only consideration as between those parties is that which moves from the plaintiff to the defendant; and the rule is, if that consideration fails, proof of that fact is a good defence to the action. But the rule is otherwise between the remote parties to the bill, as, for example, between the payee and the acceptor, or between the indorsee and the acceptor, ${ }^{2}$ - as two distinct considerations come in question in every such case where the payee or indorsee became the holder of the bill before it was overdue and without any knowledge of the facts and circumstances which impeach the title as between the immediate parties to the instrument. Those two considerations are as follows: First, that which the defendant received for his liability, and, secondly, that which the plaintiff gave for his title, and the rule is well settled that the action between the remote parties to the bill will not be defeated unless there be an absence or failure of both these consideration. (Robinson v. Reynolds, 2 Q. B. 202; Same v. Same, in error, Ib. 210 ; Byles on Bills (5th Am. ed.), 124; Thicdcmann v. Goldschmidt, I De Gex, Fisher and Jones, Ch. App. Io.)

Unless both considerations fail in a suit by the payee against the acceptor, it is clear that the action may be maintained, and many decided cases affirm the rule, where the suit is in the name of a remote indorsee against the acceptor, that if any intermediate holder between the defendant and the plaintiff gave value for the bill, such an intervening consideration will sustain the title of the plaintiff. (Hunter v. Wilson, 4 Exchequer, $489 ;$ Boyd v. McCann, ro Maryland, i $\mathrm{S}$; Howell v. Crane, i 2 La. Annual, i 26 ; Watson v. Flanggan, it Texas, 354.)

33 IoWA, 537. - I871.

[Reported hercin at p. 4I7.]

\footnotetext{
'Or between maker and payee, or between indorser and immediate indorsee. - ED.

${ }^{2}$ Or berween indorsee and maker, or between indorsee and remote (not immediate) prior indorser. - ED.
} 
IOI NEW YORK, 63. - I 885 .

Action against acceptor. Judgment for plaintiffs; reversed at General Term. Plaintiffs appeal.

The bill was drawn upon defendant and transferred to plaintiffs for value. Defendant afterward accepted it.

RUGER, CH. J., [after disposing of another matter]. - The General Term conceded that the plaintiffs were bona fide holders for value of the bill before acceptance, but deny them that character after acceptance as against the acceptor. We think the concession is fatal to the conclusion reached by that court.

It is said that the $F$. B . M. Bank v. Empire Stone Dressing Co. (5 Bosw. 290), is authority for the position. It is true that some expressions of the learned judge writing in that case may justify the citation, yet it should be considered that those remarks were unnecessary to the decision of the case, and the same court has twice since then refused to follow it.

We conceive the rule there laid down finds no support in the doctrines of the text-writers or the reported cases. (Philbrick v. Dallett, 2 I. \& S. 370; First Nat. Bank of Portland r. Schuyler, 7 Id. 440; Parsons on Bills and Notes, 323; Daniel on Neg. Inst., $\S 534$; Edwards on Bills [zd ed.], 4ro.)

If a party becomes a bona fide holder for value of a bill before its acceptance, it is not essential to his right to enforce it against a subsequent acceptor, that an additional consideration should proceed from lim to the drawee. The bill itself implies a representation by the drawer that the drawee is already in receipt of funds to pay, and his contract is that the drawee shall accept and pay according to the terms of the draft. (Parsons on Bills, 323, 54t; Arpin v. Chapin, Mass. Sup. Ct., Oct., I 885. .) The drawee can, of course, upon presentment refuse to accept a bill, and in that event the only recourse of the holder is against the prior parties thereto; but in case the drawee does accept a bill, he becones primarily liable for its payment, not only to its indorsees but also to the drawer himself.

The delivery of a bill or check by one person to another for value implies a representation on the part of the drawer that the drawee is in funds for its payment, and the subsequent acceptance of such check or bill constitutes an admission of the truth of the representation, which the drawee is not allowed to retract. (Daniel on Neg. Inst. 534; Parsons on Bills, 323, 54+, 545.) By such acceptance the drawee admits the truth of the representation, and having obtained a suspension of the holder's remedies against the drawer, and an 
extension of credit by his admission, is not afterwards at liberty to controvert the fact as against a bona fide holder for value of the bill.

The payment to the drawer of the purchase price furnishes a good consideration for the acceptance which he then undertakes shall be made, and its subsequent performance by the drawee is only the fulfillment of the contract which the drawer represents he is authorized by the drawee to make.

The rule that it is not competent for an acceptor to allege as a defence to an action on a bill that it was done without consideration, or for accommodation, as against a bona fide holder for value of such paper, flows logically from the conclusive force given to his admission of funds, and is elementary. (Daniel on Neg. Inst., $\$ \$ 532-$ 534; Edwards on Bills, 410; Harger v. WVorrall, 69 N. Y. $37 \mathrm{I}$; Com. Bk. of Lake Erie v. Norton, I Hill, 50I ; Robinson v. Reynolds, 2 Q. B. 196, 211; Hoffmanv. Bk. of Milwaukee, I2 Wall. I81.)

Of course the cases determined upon the ground that the payee of such paper received it to apply upon an antecedent debt, or that it had been unlawfully diverted from the purpose for which it was designed, have no application to the circumstances of this case.

The judgments of the courts below should, therefore, be reversed and a new trial ordered, with costs to abide the result.

All concur. Judgment reversed.

6 Cushing (Mass.), 469. - I85o.

SHAw, C. J. . . . In the present case, it appearing that the note was negotiated to the plaintiffs before it was due, for a valuable consideration, and the jury having found that they took it without notice of the misapplication by the maker, it is clear that they have a right to recover; and the only remaining question is, for what amount they may recover. In general, the holder of an indorsed note will be entitled to recover the whole amount of the face of the note, because the presumption of fact, in the absence of counter proof, is, that he gave the full value for it, or that he took it from some other holder for value, to collect the amount, receive a certain part to his own use, and account to the party from whom he took it for the surplus. Having taken it to secure a pre-existing debt, of a less amount, he is a holder for value in his own right, only to the amount of the debt due him. If therefore it appears in proof, that the plaintiff is not accountable to any third person for any surplus, 
then there is no reason why he should recover any more than the balance of the debt, for which he is a bona fide holder for value. Here, it appears that the plaintiff received this note of the maker, for whose accommodation the defendant indorsed it. It being obvious that the plaintiff can recover nothing as trustee for the party from whom he received it, he is liable over to nobody for the surplus, and therefore can have judgment only for the amount due to himself, for his own use and in his own right, which is so much of the note as may be necessary to satisfy the balance of the debt, for the security of which he received it.

Judgment on the verdict for the plaintiff for the smaller sum.

\section{Effect of want of consideration.}

I7 FederAL RePORTER, 575.- - I883.

[Reported herein at p. 375.]

97 Massachusetts, $166 .-$ I 867.

Contract upon a promissory note. Defence, partial failure of consideration in that plaintiff, having agreed not to peddle milk in H., had continued to do so, etc. The trial court held evidence of this inadmissible. Plaintiff alleges exceptions.

Chapman, J., [after disposing of another question]. - It was competent to the defendant to prove that the note was given as well in consideration of a sale of the good will of the milk route, and an agreement not to go into business which should interfere with it, as of a sale of the articles enumerated in the bill of parcels. Agreements of this character are valid, and are often specifically enforced in equity by injunction, and at law by actions for damages. Evidence that the plaintiff has interfered with the route in the manner stated, would tend to show that he has deprived the defendant of a part of the consideration for which the note is given. It was formerly held that such damages must be recovered by a crossaction, and could not be proved and allowed in defence of an action on the note, by way of recoupment. But the doctrine of recoupment of damages was fully established in this court, in Harrington v. Stratton, 
(22 Pick. 5ro.) (See Burnettr. Smith, 4 Gray, 50.) It has since been applied in numerous cases, and was already well established in New York. It is an equitable set-off of damages which ought to be deducted from the plaintiff's demand, and for the recovery of which the defendant ought not to be turned round to a cross-action. The court are of opinion that it should be applied to a case like the present, where the plaintiff has deprived the defendant of a valuable part of the consideration of the note in suit, if the facts which were alleged shall be proved.

The first exception must be overruled; and the second sustained.'

\section{Liability of accommodation party.}

69 New YORK, 502. - IS77.

Appeal from judgment of the General Term of the Supreme Court in the first judicial department reversing a judgment in favor of defendants, entered upon the report of a referee. (Reported below, 7 Hun, 279.)

This action was upon two promissory notes, on which defendants Penfield and Stone were makers, which were made payable to defendant Truax, and by him indorsed and transferred to plaintiff.

The referee found, in substance, that the notes were executed by the makers without any consideration; were accommodation notes, and were received by plaintiff solely as collateral security for a precedent debt, without any agreement to extend the time of payment of the debt, and thereupon held that plaintiff was not a bond fide holder for value, and directed judgment dismissing the complaint as to said makers.

Rapallo, J. - We think that the order in this case must be affirmed on the ground stated by Brady, J., in his opinion delivered at General Term. Whatever confusion may have existed upon the point, we think that we may now safely say, in the language of Professor Parsons (I Parsons on Notes and Bills, 296), that it is tmiversally conceded that the holder of an accommodation note, without

${ }^{1}$ Accord: Torinus v. Buckham, 29 Minn. 12S; I Daniel on. Neg. Inst. \$S 20I-204. One who is "not a holder in due course" stands in the same relation as an immediate party. Thus a transferee of over-due paper is subject to the defence of failure of consideration. Bryan v. Primm, I Ill. 33; Diamond v. Harris, 33 Tex. 634; Sawyer v. Hoovey, 5 La. Ann. 153. - Ed. 
restriction as to the mode of using it, may transfer it either in payment or as collateral security for an antecedent debt, and the maker will have no defence. (See, also, Story on Bills, $\S$ I92, note $m$, and Story on Notes, $\S 195$, and authorities cited.) The existing debt is a sufficient consideration for the transfer, and no new consideration need be shown. It is only where the note has been diverted from the purpose for which it was entrusted to the payee, or some other equity exists in favor of the maker, that it is necessary that the holder should have parted with value on the faith of the note, in order to cut off such equity of the maker. (Cole v. Saulpaugh, 48 Barb. I04; Bank of Rutland v. Buck, 5 Wend. 66; Lathrop v. Morris, 3 Sandf. 7.) It has been held by high authority that an antecedent debt is sufficient even in the case of a note fraudulently diverted to constitute the holder a bona fide holder for value without any extension of time or surrender of securities or other new considerations. (Suilft v. Tyson, I6 Peters, I.) But in this State that doctrine does not prevail. (Stalker v. McDonald, 6 Hill, 93.) The leading authorities upon the subject are reviewed in the case of Maitland $\mathrm{v}$. Citizens' Bank (40 Maryland, 540.) Whatever difference of opinion may have existed, as to the case of a note diverted or fraudulently put in circulation, it must be regarded as settled that an indorsee of a negotiable note made for the accommodation of the indorser, but without restriction as to its use, taking the note in good faith as collateral security for an antecedent debt, and without other consideration, is entitled to the position of a holder for value, and not affected by the defence of want of consideration to the maker. We should not have deemed it necessary to discuss the point so much at length, but for the reason that it does not appear ever to have been previously expressly adjudicated in this court.

The order should be affirmed and judgment absolute, etc.
All concur. Order affirmed and judgment accordingly.

${ }^{1}$ See also Continental N. B. v. Townsend, 87 N. Y. S, post. - ED. 


\section{ARTICLE IV.}

\section{Negotiation.}

\section{What constitutes negotiation or transfer.}

\$60 [30] Crouch i'. Crédit Foxcier, L. R. S Q. B. 374. (i 873. )

BLACKBURN, J. - In the present case the plaintiff has taken upon himself the burden of establishing both that the property in the debenture passed to him by delivery, and that the right to sue in his own name was transferred to him.

The two propositions are very much connected, but not identical. The holder of an overdue bill or note may confer the right on the transferee to sue in his own name, but he conveys no better title than he had himself.

But the two questions go very much together; and, indeed, in the notes to Miller v. Race (I Smith, L. C. 9th ed., p. 49r), where all the authorities are collected, the very learned author says: "It may therefore be laid down as a safe rule that where an instrument is by the custom of trade transferable, like cash, by delivery, and is also capable of being sued upon by the person holding it protempore, then it is entitled to the name of a negotiable instrument, and the property in it passes to a bona fide transferee for value, though the transfer may not have taken place in market overt. But that if either of the above requisites be wanting, $i . e$., if it be either not accustomably transferable, or, though it be accustomably transferable, yet, if its nature be such as to render it incapable of being put in suit by the party holding it pro tempore, it is not a negotiable instrument, nor will delivery of it pass the property of it to a vendee, however bona fide, if the transferor himself have not a good title to it, and the transfer be made out of market overt."

Bills of exchange and promissory notes, whether payable to order or to bearer, are by the law merchant negotiable in both senses of the word. The person who, by a genuine indorsement, or, where it is payable to bearer, by a delivery, becomes holder, may sue in his own name on the contract, and if he is a bona fide holder for value, he has a good title notwithstanding any defect of title in the party (whether indorser or (leliverer) from whom he took it.'

'For a luminous discussion of 'negotiability.' see Willis on Negotiable Securities (I896), Lectures I and II. - ED. 
I. Transfer by Delivery.

83 Michigan, 223. - I89o.

Actron on the following promissory note:

$\$ 100.00$.

HaRT, Mich., March 20, I889.

Eight months after date I promise to pay to the order of Marget A. Bitzer (or bearer), one hundred dollars, at the Oceana County Savings Bank, value received, with interest at the rate of 6 per cent.

\section{Bert Spellaiax。 G. L. Wagar.}

Judgment for plaintiff. Defendant brings error on the ground that the court erred in admitting in evidence the note in question for the reason (a) that the note is payable to Margaret A. Bitzer, and has never been indorsed or transferred by her to plaintiff; (b) that said note is not competent evidence, for the reason that plaintiff has not shown that he owns or has property in said note.

LoNG, J., [after disposing of another matter]. - The note is plainly payable to bearer, and suit could be maintained thereon in the name of any holder.

\section{Judgment affirmed. ${ }^{1}$}

I Johnson (N. Y.), I43. - ISo6.

Frox the return to the certiorari in this cause, it appeared that an action had been brought by the defendant in error against the present plaintiff, before a justice of the peace, in which he declared on a writing or note, in the following words:

Due the bearer hereof, 31 , ISs, Iod., which I promise to pay to Abraham Thompson. or order, on demand, as witness my hand, this $22 \mathrm{~d}$, IIth month, ISo3.

[Signed] JORDAN COCK.

The note was not endorsed by 'Thompson, and the declaration stated the note as made payable to the bearer. The justice gave judgment for the plaintiff below, for the amount of the note.

${ }^{1}$ Accord: Grant v. Vaughan, 3 Burr. I516; Pierce v. Crafts, I2 Johns. (N. Y.) 90; Ellis v. Wheeler, 3 Pick. (Mass.) Is; Matthews v. Hall, x Vt. 3 I6. In Illinois promissory notes payable " to A. or bearer" require indorsement, though not if payable "to bearer." Roosa v. Crist, 17 Ill. 450; Garfield v. Berry, 5 Ill. App. 355 ; cf. Avery v. Latimer, 14 Oh. 542.

For meaning of "instruments payable to bearer," see $\$ 28$ [9], ante.

As to effect of special indorsement see Fohnson v. Mitchell, 50 Tex. 212, post. ED. 
PER CURIam. The word bearer has reference to Thompson as the payee, and as the promise is expressly to pay to him or oider, anothet person could not maintain an action on the note without his endorse. ment. The judgment below must be reversed.

Judgment reversed.

$\S 60$

CURTIS ${ }^{\prime}$. SPRAGUE.

5I Califorita, 239. - is76.

[Reported herein at p. 268.]

2. Transfer by Indorsement and Delivery.

(a) Transfer by indorsing assignment.

$\S 60$

MARKEY $v$. COREY.

$[\S 30]$

Michigan, .- I895.

[66 Northwestern Reporter, 493.]

ACTION against Corey as indorser. The indorsement read: "I hereby assign the within note to Matthew M. Markey and Catherine Sundars." The note also referred to a certain contract which provided that in case of default in any one of five notes (of which the note in suit was one), all of the notes, at the option of the payee, might be declared due and payable. ${ }^{1}$ Judgment for plaintiff.

LoNG, J., [after stating the facts]. - The usual mode of transfer of a promissory note is by simply writing the indorser's name upon the back, or by writing also over it the direction to pay the indorsee named, or order, or to him or bearer. An indorsement, however, may be made in more enlarged terms, and the indorser be held liable as such. In Sands v. Wood (I Iowa, 263), the indorsement was, "I assign the within note to Mrs. Sarah Coffin." In Sears v. Lantz (47 Iowa, 658), the indorsement on the note was, "I hereby assign all my right and title to Louis Meckley." And in each case the party so assigning was held as indorser, the court in the latter case saying of Sands v. Wood: "He used no words that, in and of themselves, indicated that he had bound or made himself liable in case the maker, after demand, failed to pay the note. But it was held the law, as a legal conclusion, attached to the words used the

${ }^{1}$ Neg. Inst. L., \$2I [2], subsec. 3. - En. 
liability that follows the indorsement of a promissory note." (See, also, Duffy's Adm'r v. O'Conner, 7 Baxt. 498; Shelby v. Judd, 24 Kan 166; Brotherton v. Street [Ind. Sup.], 24 N. E. I068.) The rule of the American cases is well stated in Daniel on Neg. Inst., ( $\$ 688 \mathrm{c}$ ), as follows: "The question arising in such cases, is a nice one, and depends upon rules of legal interpretation. The mere signature of the payee, indorsed on the paper, imports an executed contract of assignment, with its implications, and also an executory contract of conditional liability, with its implications. ${ }^{1}$ The assignment would be as complete by the mere signature as with the words of assignment written over it. The conditional liability which is executory is implied by the executed contract of assignment, and the signature under it, which carried the legal title; and the question is, does the writing over a signature an express assignment, which the law imports from the signature per se, exclude and negative the idea of conditional liability, which the law also imports if such assignment were not expressed in full? We think not. When the thing done creates an implication of another to be done, we cannot think that the mere expression of the former in full can be regarded as excluding its consequence, when that consequence would follow if the expression were omitted."

The language used in the assignment to the note in suit does not negative the implication of the legal liability of the assignor as indorser, and as the words are to be construed, as strongly as their sense will allow, against the assignor, he must be held as indorser. This rule is fully supported in Hatch v. Barrett ( $3+\mathrm{Kan}$. 230; 8 Pac. r29.) (See, also, Adams v. Blethen, $66 \mathrm{Me}$. r9.) In the case of Aniba v. Yeomans (39 Mich. 17r), the assignment read as follows: "I hereby transfer my right, title, and interest of the within note to S. A. Yeomans." Mr. Justice Marston said in that case: "The right or interest passing, therefore, under the usual and customary indorsement, is much greater than the mere right, title, and interest of the payee; and when the transfer, as made, only attempts to pass the title and interest of the payee of the note, no greater right or interest than he then held can pass." In other words, the learned justice seemed to think that the words used limited the transfer to the right and title he then held. While this holding appears to be at variance with the cases elsewhere, we think it readily distinguishable from the present, as here the words are, "I hereby assign the within note to Matthew M. Markey and Catherine Sundars," and do not purport to limit the liability of Corey as an indorser. In Stevens v. Hannan (86 Mich. $307 ; 48$ N. W.

${ }^{1}$ See Neg. Inst. L., §II6 [66], post. - ED. 
95I), the note sued upon was negotiable in form, and made payable to Batchelder, and he assigned it before maturity, as follows: "For" value received, I hereby assign all interest in and to this note to Ralph E. Watson." Defendant insisted in that case that the plaintiff could not sue in his own name, but should have sued in the name of the payee. It was said by Mr. Justice NcGrath: "I do not think the point well taken. If Batchelder's indorsement did not affect its negotiability, then Watson's indorsement entitled the plaintiff, as holder of the note, to sue in his own name." It must be held, therefore, that the memorandum on the note did not relieve Corey from his liability as indorser.

The court was not in error in admitting the contract in evidence, as its purpose was to show that the note was not in fact limited by its provisions, and those provisions of the contract cited did not destroy the negotiability of the note. (Daniel, Neg. Inst., $\$ 48$.)

The judgment must be affirmed. The other justices concurred.

$\S 60$ [30] Hall 2 . Toby, i io Pennsylvania State, 3 IS. - I $\$ 85$. Action by D. B. Toby as indorsee under the following instrument and assignment:

$\$ 551.50$.

WARREX, AuS. IS, IS79.

For value received I promise to pay $\mathrm{Wm}$. Toby, or order, five hundred and fifty-one $\frac{50}{100}$ dollars with interest.

OrRis HaLl.

[On the back of this paper was the following transfer or assignment]:

For value received $I$ hereby assign, transfer and set over to D. B. Toby all my right, title, interest and claim in the within note.

Wr. Torr, D. B. TคBY.

Tionesta, Hoo. 2I, ISSI.

Per CuRiam. - This note was negotiable. It contained an absolute and unconditional promise to pay to Wm. Toby or order the sum specified. As no time of payment was therein expressed, the law adjudges the money to be payabie immerliately. A right of action accrued at once and would be barred by the Statute of Limitations at the expiration of six years thereafter. The note had all the essential language to constitute a promissory note.

The legal right of action thereon would have passed by indorse-

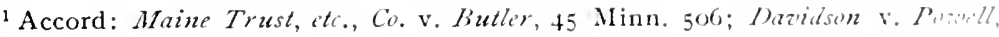
I 4 N. C. 575 ; Merrill v. Hurley, 6 So. Dak. 592.

Contra: Lyons v. Divelbis, 22 Pa. St. 185; Spencer Y. Ilalpern, 62 Ark. 595; Cf. Aniba v. Yeomans, 39 Mich. I7I. - E1). 
ment and delivery. For purpose of transfer the assignment on the back of this note passed the legal title. ${ }^{1}$

(b) Transfer by indorsing guaranty.

$\$ 60$ TRUST COMPANY $v$. NATIONAL BANK.

ioI UNited States, 68. - I879.

BiLl to compel surrender of note. The note with security was given by the Wyandotte Bank to the Cook County National Bank to obtain credit, and not to be negotiated. The latter did negotiate it to the Trust Company. At its maturity there was due on it to the Cook County National Bank $\$ 3^{2}$, which the Wyandotte Bank offers to pay.

Mr. Justice Strong [after stating the facts]. - The note was not indorsed to the Trust Company, and it was not, therefore, taken in the usual course of business by that mode of transfer in which negotiable paper is usually transferred. Had it been indorsed by the Cook County Bank, it may be that the Trust Company would hold it unaffected by any equities between the maker and the payee. But instead of an indorsement, the president of the Cook County Bank merely guaranteed its payment, and handed it over with this guaranty to the Trust Company. The note was not even assigned. There was written upon it only the following:-

For value received, we hereby guarantee the payment of the within note at maturity, or at any time thereafter, with interest at ten per cent. per annum until paid, and agree to pay all costs and expenses paid or incurred in collecting the same.

B. F. Allen, Pres't.

In no commercial sense is this an indorsement, and probably it was not intended as such. Allen had agreed that the note should not be negotiated, and for this reason perhaps it was not indorsed. That a guaranty is not a negotiation of a bill or note as understood by the law merchant, is certain. (Snevily v. Ekel, I Watts \& S. [Pa.], 203; Lamourieux v. Hcwitt, 5 Wend. [N. Y.], 307 ; Miller v. Gaston, 2 Hill [N. Y.], ISS.) In this case, the guaranty written on the note was filled up. It expressed fully the contract between the Cook County Bank and the Trust Company. Being express, it can raise

${ }^{1}$ Cf. Aniba v. Yiomans, 39 Mich. 171. While the indorsement passes title it does not make the " assignor" liable as an indorser. Lyons v. Divelbis, 22 Pa. St. I85. Contra: Henderson v. Ackelmire, 59 Ind. 540; Adams v. Blethen, 66 Me. 19. - ED. 
no application of any other contract. Expressum facit cessare tacitum. The contract cannot, therefore, be converted into an indorsement or an assignment. And if it could be treated as an assignment of the note, it would not cut off the defences of the maker. Such an effect results only from a transfer according to the law merchant; that is, from an indorsement. An assignee stands in the place of his assignor, and takes simply an assignor's rights; but an indorsement creates a new and collateral contract. (2 Parsons, Notes and Bills, 46 et seq., notes.)

At best, therefore, the defendants below can claim no more or greater rights than those of the Cook County Bank, and the complainants are entitled to a return of the note and of the collaterals on payment of the sum of $\$ 13^{2}$.

Decree affirmed. ${ }^{2}$

\section{Minesota, 487. - IS94.}

Action by indorsee against maker. The question was whether plaintiff was an indorsee, or an assignee and so subject to the defence of fraud or failure of consideration. The court directed a verdict for plaintiff. The facts appear in the opinion.

Mitchell, J. - The defendant executed his negotiable promissory note, payable to the order of one Daniel Dunham, who transferred it to the plaintiff, with the following indorsements: "Pay the Elgin City Banking Co. D. Dunham." "Payment Guaranteed. D. Dunham."

Whether these indorsements be construed as constituting a single contract, or two distinct and separate contracts, we are clear that they constitute an "indorsement," in the commercial sense, and that the transferee is an "indorsee," and entitled to protection as such, under the law merchant. The fact that Dunham enlarged his responsibility beyond that of " indorser," by guarantying payment, did not change or affect the character of his indorsement.

Order affirmed. ${ }^{2}$

'Accord: Tuttle v. Bartholonew, I2 Met. (Mass.) 452; Belche'v. Simith, 7 Cush. (Mass.) 482; Canfueld v. Viuughan, 8 Mart. (La.) 683.

Contra: Myrick v. Hasey, 27 Me. 9; Mtard v. Dubuque Bank, 8 Neb. Io; Hclmer v. Bank, 28 Neb. 474; Kéllogis v. Doutglas Co. Bank (Kan.), 48 Pac. R. $5^{87}$; Dunham v. Peterson, 5 N. Dak. 414, where the question is fully discussed and authorities collected; Elgin City Bankings Co. v. Zelch, 57 Minn. 487, infra. - ED.

"See note I, above. "A guaranty of the payment of a note does not necessarily include a contract of indorsement, but when such guaranty is written upon the back of the note in general terms and signed by the payee named 
50 TEXAS, 212. - I 878.

[Reported herein at p. 369.]

2 NEW YORK, 225. - I 849.

[Reported herein at p. 487.]

\section{Indorsement: form required.}

\section{Must be Written on Instrument or Allonge.}

29 Illinois, 92. - 1862.

Breese, J. - The first point made in this case is, that the note was not properly indorsed, the transfer being on the face of the note. Literally, indorsement means a writing, in dorse, upon the back of the bill or note. But it is well established, that though

therein, the universal custom is to treat such contract of guaranty as a transfer of the title of the payee to the person to whom the guaranty is made." National Bank of Commerce v. Galland, I4 Wash. 502, 505. Such a guaranty constitutes " an indorsement of the note with an enlarged liability." Donnerberg v. Oppinheimer, 15 Wash. 290. "I guarantee attorney's fees up to Io per cent. if this note has to be collected by law, and its prompt payment," - held an indorse ment by the payee with an enlarged liability. Pattillo v. Alexander, $96 \mathrm{Ga} .60$. For a distinction between the case where the guaranty is executed by the payee and where it is executed by a third person, see Vanzant v. Arnold, 31 Ga. 2ro; Geiser $M f_{g}$. Co. v. Fones, go Ga. 307. See title "Guarantor's Liability," post, Art. VI, Div. VII. p. 486.

DELIVERY. - "It has often been decided, that the assignment [transfer] of a note is not complete without a delivery, and that where a promissory note is found in the hands of one who has made an indorsement thereon, which, if accompanied by delivery, would have amounted to an assignment [transfer], the presumption will be that the assignment was never completed, and that he may, even after suit brought, strike out such indorsement." Wulschner $v$. Sells, 87 Ind. 71, 74. Accord: Spencer v. Carstarphen, 15 Colo. 445

NoN-Negotiable INSTRUMent. - The indorsement and delivery of a non-negotiable note does not (independent of statute) authorize the holder to bring an action in his own name, and the holder is subject to all defenses that might have been set up against his transferror. Kobinson v. Brown, 4 Blackf. (Ind.) I28; Maule v. Crawford, 14 Hun (N. Y.) I93; post, Art. XVII, Div. I. 3, p. 667. - ED. 
such is its import, it may be made on the face of the bill, ${ }^{\text {and }}$ numerous indorsements may be made on a separate paper, called an allonge. (Chit. on Bills, 227; Yarborough v. Bank of England, I6 East, I $2 ; \operatorname{Rex}$ v. Bigg, I Strange, r 8 ; Story on Prom. Notes, $\$$ I2I; Gibson v. Powell, 6 Howard [Miss.] 60.) And any form is sufficient which manifests an intention to transfer the note. (. Morris v. Bird, I I Mass. 436.) . . .

18 Pickering (Mass.), 63. $-\mathrm{IS}_{3} 6$.

Action on three promissory notes. The opinion states the facts. WILDE, J., delivered the opinion of the Court.

This was an action of assumpsit on three promissory notes of hand, on two of which the defendants are sued as executors of an indorser, and they object to the plaintiff's recovery on these notes, on the ground that no demand has been made on the makers and no diligence used to collect the debts of them. These notes, however, were made payable at the Phœnix Bank, and were the property of the bank. ${ }^{2}$ No demand was necessary except at the bank; and although there is no express proof that the notes were there, and some officer of the bank in attendance, at the times the notes fell due, yet this must be presumed, and it was for the defendants to show that the makers called at the place appointed, for the purpose of making payment. The testator, by his indorsements, guaranteed that the makers would respectively be at the bank and pay the notes according to their tenor. (Berkshire Bank v. Jones, 6 Mass. R. 525.)

[Omitting a question as to the authority of the bank to indorse.]

As to the objection, that the indorsement is not made in the name of the corporation, we think the indorsement by the cashier in his official capacity sufficiently shows, that the indorsement was made in behalf of the bank, and if that is not sufficiently certain, the plaintiffs have the right now to prefix the name of corporation. ${ }^{3}$

The last objection is, that the indorsement on one of the notes was not made on the back of the uriginal note, and therefore amounted only to an equitable transfer. The indorsement was made on a paper attached to the back of the note by a wafer, and it had

${ }^{1}$ Accord: Young v. Glover, 3 Jur. N. S. 637; Haines v. Dubis, 30 N. J. L. 259; Shain v. Sullivan, ro6 Cal. 208. See Neg. Inst. L., 36 [17], subsec. 6. - ED.

${ }^{2}$ See Neg. Inst. L., \$ $135[75]$, post. - Ev.

${ }^{3}$ See Neg. Insi. L., $52[+2]$, fost. - E1). 
been before thus attached for the purpose of entering thereon indorsements of payments, the back of the original note having been before covered with indorsements; and several payments had been indorsed on the attached paper, before the note was transferred by indorsement to the plaintiff. This paper thus attached had become a part of the note, and no good reason can be given why an indorsement made thereon should not be held a valid and legal transfer. The objection is, that such an indorsement is not sanctioned by custom; but we think it is supported by the reasons on which the custom was originally founded. Biils of exchange and promissory notes were indorsed on the back of the bills and notes, because it was a convenient mode of making the transfer, and in order that the evidence thereof might accompany the note. Such an indorsement as this will rarely happen, and no authority to support it could reasonably be expected; but there is no authority against it.

If a person write his name on a blank paper, to be used as an indorsement of a note to be written on the other side, and it be filled up as intended, the party would be held liable as indorser of the note, although such indorsements are infrequent, and are not according to the customary form of making a transfer; but they have been held to be within the reason of the custom, and are supported by principle. (Bayley on Bills, 92; Violett v. Patton, 5 Cranch, I42.) ${ }^{1}$

So in the present case, as there is no authority against the validity of the indorsement, we think we shall violate no principle in holding it to be a legal transfer of the note.

Judgment for the plaintiffs.

$\$ 6 I$

OSGOOD $\approx$. ARTT.

$[\S 3 I]$

I7 Federal, Reporter, 575.- I883.

[Reported herein at $p$. 375.]

2. Must be of Entire Instrument.

$\$ 62$ HUGHES $\%$ KIDDELL.

2 BAY (So. CAR.), 324. - I8OI.

THIS was an action against defendant as indorser on a note of hand, in which there was a verdict for defendant. The note of hand

${ }^{1}$ See Neg. Inst. L., $\$ 33$ [I4], ante. - ED. 
in question was given by David Bush, of Camden, to the defendant Kiddell, for $473^{l}$. sterling. Kiddell afterwards made the following indorsement, viz: -

"I assign over to Hudson Hughes, the sum of $\mathrm{I}, 93^{\circ}$ dollars and 50 cents, as part of this note of hand.

(Signed.)

Benjamin Kiddell."

Afterwards he made another indorsement, and assigned over the residue of said note [to Hughes.] (Signed) Benjamin Kiddell.

The court, after hearing the arguments, refused to grant a new trial, on the ground that an indorsement for part of a note or bill is bad. (Lex Mercatoria, 445, Carth. 466.) And if so, then two vitious indorsements can never constitute a good one.

Rule discharged

\section{Indorsement: kinds of.}

i. Special Indorsement.

$\$ 64$

REAMER $v$. BELL.

79 Pennsylvania State, 292. - I875.

ACTION by holder against makers of a note payable " to the order of William Dilworth, Jr.," and indorsed: “Wm. Dilworth, Jr.-Pay R. McCurdy. Cash." Defence, want of title in holder (Bell). Judgment for plaintiff.

Mr. Justice Paxson delivered the opinion of the Court.

We think the affidavit of defence filed in this case, while not as specific as it might have been, was nevertheless sufficient to prevent judgment. The copy of the note filed by the plaintiff below goes to sustain the denial of his title contained in the affidavit referred to. It is indorsed "Wm. Dilworth, Jr.; pay R. McCurdy, Cash." This is a special indorsement, and upon its face conveys no title to the plaintiff below.

The further allegation that the note in controversy was procured by false and fraudulent representations, and that the consideration thereof has failed, coupled with the denial of said plaintiff's title, was sufficient to put the latter upon proof that he is a bona fide holder."

Judgment reversed and a procedendo awarded. ${ }^{2}$

${ }^{1}$ See Neg. Inst. L., $\$ 9^{8}[59]$, post. - ED.

${ }^{2}$ See also Lawrance v. Fussell, 77 Pa. St. $460 .-$ ED. 
2. BLANK INDORSEMENT.

5i California, 239.-is.

[Reported herein at p. 265.] ${ }^{1}$

\$65 [35] Evans $v$. Gee, i I Peters (U. S.), 8o. - i 837. Bill payable "to the order of Thomas Evans" was indorsed in blank by payee (defendant). Plaintiff became a holder in due course and wrote over the indorsement, "Pay to Sterling H. Gee." Mr. JusTICE WAYNE: - As regards the right of a bona fide holder of a bill to write over a blank indorsement to whom the bill shall be paid, at any time before or after the institution of a suit against the indorser, it has long been the settled doctrine in the English and American courts; and the holder by writing such direction over a blank indorsement, ordering the money to be paid to particular persons, does not become an indorser. (Eden v. East India Co., 2 Burr. r216; Com. $3_{1 \text { I }}$; Str. 557 ; Vincent v. Halock, I Camp. 6; Smith v. Clarke, Peake, 225.)^{2}$

6I IowA, 42. - I883.

Question certified by Circuit Court: Whether a holder of a note under a blank indorsement may write above the indorsement "guarantee payment at maturity to bearer, " and proceed against the indorser upon the guaranty without presentment, demand and notice.

RothROCk, J. . . . It is well understood that the blank indorsement of a promissory note by the payee creates the liability of an indorser as understood in the law merchant. Such indorsement creates the same liability from the indorser to the indorsee, as if it were in full. (Bean v. Briggs \& Felthouser, I Iowa, 488.)

1 "I see no difference between a note indorsed in blank and one payable to bearer. They both go by delivery, and possession proves property in both cases." Lord Mansfield in Peacock v. Rhodes, 2 Doug. 633. - ED.

"Accord: Lovell v. Evertson, II Johns. (N. Y.) 52. While it is proper, it is not necessary, for a holder to fill up the indorsement before bringing an action or offering the note in evidence. Rich v. Starbuck, 5I Ind. 87; Grecnough v. Smead, 3 Oh. St. 415; Palmer v. Nassau Bank, 78 Ill. 38o. Contra: Day v. Lyon, 6 Harris \& Johns. (Md.) I 40 ; Péaslee v. Robbins, 3 Met. (Mass.) I64. - ED. 
But the contract of indorsement is very different from a contract of guaranty, and the holder of a note with a blank indorsement by the payee has no legal right to change the obligation of the indorser, by writing a contract of guaranty over the name of the payee, "without the knowledge or consent of the payee."

What the rights of the parties may be to show by parol the real contract entered into by the indorser, need not be considered here, because no such question is certified to us. We are required to determine the questions certified, and not questions of fact or law in the case which are not certified, and we cannot consider the question as to the rights of the parties upon a guaranty upon a chattel mortgage given to secure this note, as we are requested to do by counsel. Taking these questions as they are certified, we answer, unhesitatingly, as did the court below, that the guaranty written over defendant's name, without his knowledge or consent, was void.

Affirmed. ${ }^{1}$

$\S 65$

$$
\text { SCOTT }{ }^{\prime} \text {. CALKIN. }
$$

139 Massachusetts, 529.-I $88_{5}$.

ACTION against Calkin as maker and Cherrington as subsequent guarantor of a note. Cherrington's name was in blank on the back of the note and she defended on the ground that she had received no notice of dishonor. Calkin made and delivered the note, secured by mortgage, to Pierce and the latter indorsed it to plaintiff. Calkin then sold the real estate covered by the mortgage to Cherrington who assumed and agreed to pay the mortgage debt. In consideration of plaintiff's forbearance to foreclose the mortgage Cherrington agreed with him to pay the note and signed her name on it. She now pleads (I) want of notice as indorser; (2) statute of fraud as guarantor. ${ }^{2}$ Plaintiff was permitted to write above C's name, "I guarantee the payment of the within note," and had judgment.

W. Alles, J. - The indorsement of the note by the defendant Cherrington, under the circumstances proved, imported a guaranty of the payment of the note to the plaintiff, and gave him authority to write, over her name, the contract implied by law; and this, if necessary at all, could be done during the trial. (Josselyn v. Ames, 3 Mass. 274; Tenney v. Prince, 4 Pick. 385.)

${ }^{1}$ The holder cannot enlarge the liability of the indorser. Hood v. Robbins, 98 Ala. 484. - ED.

${ }^{2}$ The consideration need not be expressed in a contract of guaranty. Mass. Pub. St., c. $78, \frac{3}{3}$ 2. - ED.

NEGOT. INSTRUMENTS -23 
The finding of the court renders immaterial the question whether demand and notice were necessary.

Judgment for the plaintiff.

$\S 65$

CLARKE v. PATRICK.

6o Minnesota, 269. - 1895 .

CANTY, J. - This is an action against the defendant as indorser of a negotiable promissory note. The answer admits the making of the note to defendant, and the indorsement of it by him to plaintiff for a valuable consideration before maturity, as alleged in the complaint; but alleges that the transaction between the parties was a sale by defendant to plaintiff of the note and a mortgage securing the same, which was evidenced by a written assignment, and that said indorsement was not intended by the parties as a guaranty of payment of the note, but was made merely in aid of said assignment. Such written assignment is not inconsistent with defendant's liability as indorser, and it is well settled that the legal effect of an indorsement cannot be thus varied by parol. ${ }^{1}$ The answer states no defence, and judgment on the pleadings was properly ordered for plaintiff.

The judgment appealed from is affirmed."

3. Restrictive Indorsement.

$\S 66$

POWER $\imath^{\prime}$. FINNIE.

4 Call (VA.), 4 II. -1797.

ACtion by Power against drawer (Finnie) and payee-indorser (Tabb) upon a bill indorsed by Tabb in these words: "Pay the within contents to Jack Power only." There is a good defence (of which evidence is offered and received against plaintiff's objection), unless plaintiff is a bona fide holder for value. Judgment for defendant. Plaintiff appeals.

ROANE, JUdGE. - In the case of a negotiable bill no consideration is necessary to be proved, and the indorsee is not affected by the want

${ }^{1}$ This does not apply to "irregular indorsements." Peterson v. Russell, 62 Minn. 220. See Neg. Inst. L., SS II $3-\mathrm{II}_{4}\left[6_{3}-6_{4}\right]$. - ED.

2 Whether a blank indorsement is a written contract and so not to be varied by parol, or evidence of a contract not yet reduced to writing and so subject to establishment by parol, is open to dispute. I Daniel on Neg. Inst., $\$ \S 717-723$. See post, p. $48_{5}$, note. - ED. 
of it. But a negotiable bill may be restrained by special indorsement, as was decided in the case of Ancher v. The Bank (Dougl. 615); and, in questions upon such restrictions, the intent must be collected from the face of the indorsement only. An absolute indorsement imports, upon the face of it, a valuable consideration received, and that the payee has transferred his right; after which receipt and sale, he can have no pretense for limiting the indorsement, as it must be immaterial to him, to whom it is paid. But a limited indorsement is a presumptive evidence that the indorsee is agent only; otherwise it would be his interest not to accept of it in that form, as it would impede the future transfer of the bill.

Therefore, whenever such a prohibition appears, it may, I think, be inferred, that the indorsement was not intended to be absolute. If the transfer to Power had, in fact, been absolute, his interest would have prompted him to object to the words restricting the negotiability, when the restriction would have tended to lessen the value of the bill. The presumption, therefore, is fair, that no consideration was paid for it: but that presumption might have been repelled by proving a consideration actually paid. That, however, was not done; and, therefore, I infer that Power was an agent only, and not a purchaser. I think, therefore, that the evidence was proper.

FLEMING, JUdGE. - " On the present occasion, the endorsement is to Jack Power or his order only; which furnishes a strong presumption that he was but an agent, and paid no consideration for the bill, as there is no evidence to the contrary."

Carrington, JUdge. - " "Something must have been meant by this endorsement so out of the common way. It affords a very strong presumption that the endorsee was an agent only."

Pendleton, President. - "The word only which is not commonly used, could have been used for no other purpose than to restrict the negotiability of the bill, and make Power an agent."

\section{Judgment affirmed. ${ }^{2}$}

1 "If the words ' to A. B. only' were inserted, I should think it would not be restrictive; at least it should be left to the jury . . Where a man says 'pay to A.,' the law says it is 'to A. or order.' He then says, I intend it should not be so. What signifies what you intend. The law intends otherwise." Denison, J., in Edie v. East India Co., I Wm. BI. 295

"Whether this indorsement is only an authority to A. B. to receive the money for the use of the indorser, or for his own use, if made for value received, or whether in this last case the restriction is not void, and $A$. B. may further negotiate it, seems not to be settled. If the property of the note be vested in A. B., perhaps he will hold it with its negotiable quality, notwithstanding the restriction. But of this we give no opinion." Parsons, C. J., in Rice v. Stearns, 3 Mass. 225, post, p. 365 . - Ev. 
3 NEW YORK, 494. - I850.

Hurlbut, J. - On the $29^{\text {th }}$ day of August, i $8_{44}$, Messrs. J. W. $\&$ R. Leavitt made their note for $\$ 1,570.5^{2}$, payable to the order of T. Putnam \& Co. (the defendants), eight months after date. A few days after the maturity of the note the defendants indorsed it as fol. lows: "Pay the within to A. Thacher, value received, May 2 I, 1 845. T. Putnam \& Co." Thacher indorsed without recourse, and delivered the note for a valuable consideration to the American Exchange Bank, in whose behalf this action is brought.

On the trial the defendants urged, among other grounds of objection to the plaintiffs' recovery, that the defendants' indorsement was in effect a new draft payable to Thacher only, and not negotiable, so that no action could be maintained upon it in the name of the plaintiff. In this they were sustained by the court, and the plaintiff was nonsuited.

The other objections taken by the defendants on their motion for a nonsuit were not considered by the court below, and under the circumstances of the case cannot be noticed on this appeal; so that the only thing for us to consider is, whether the indorsement of a note made after due, differs from one made before maturity in respect to its negotiability ? 1

It was conceded on the argument that no express authority could be found sustaining the distinction upon which the decision of the superior court was based; but it was urged that the defence could be sustained upon the principle that a dishonored note loses it mercantile character, and its indorsement becomes an original contract which must be made expressly negotiable in terms, or it could not be held to possess the character of negotiability. There is unquestionably a difference between the indorsement of a note after due and one while it is running to maturity, but this relates only to a single point arising from the necessity of the case, to wit, the time of payment, which, in the latter indorsement, is fixed at a future day by the express agreement of the parties, while in the former, it is declared by law to be within a reasonable time, upon demand. But in all other respects the contract is the same as an indorsement in the usual course of trade; and it is difficult to perceive how the single difference referred to can at all affect the negotiability of the indorsement. A bill or note does not lose its negotiable character by being dishonored. If originally negotiable, it may still pass from

' See Neg. Inst. L., § 26 [7], ante, and cases. - ED. 
hand to hand ad infinitum until paid by the drawer. Moreover, the indorser after maturity writes in the same form and is bound only upon the same condition of demand upon the drawer and notice of non-payment as any other indorser. Thus the paper preserves its mercantile existence and retains the main attributes of a proper bill or note, and circulates as such in the commercial community.

Exceptions to a general rule affecting so important and numerous a class of transactions as the one under consideration must be productive of great inconvenience, and will not be indulged except for urgent reasons; and nothing has been made to appear in the argument or seems to exist in the case, which warrants the court in treating the ordinary indorsement of a dishonored bill or note as without the law merchant and not negotiable. While it was questioned whether such a note was negotiable, and whether the indorser was chargeable except upon the usual condition of demand and notice, there was perhaps reason enough to sustain the decision of the court below. But since both the note and its indorsement, by a long course of decisions, have been treated as within the law merchant in respect to their main attributes, the indorsement ought to be regarded as negotiable to the same extent as an indorsement before maturity. The latter follows the nature of the original bill and is equally negotiable. (Edie v. East India Co., 2 Burr. I216; Milford v. Walcott, I Ld. Raym. 574; Allwood v. Hazelton, 2 Bailey's S. C. R. 457 ; Bishop v. Dexter, 2 Conn. R. 4 I9; Berry v. Robikson, 9 John. I2I.)

The note in the present case was upon its face transferable, and its character in respect to negotiability could only have been changed by an indorsement containing express words of restriction. The defendant's indorsement was a full one, containing the name of the person in whose favor it was made, but omitting the words " or order," the legal effect of which was, nevertheless, to make the note payable to him or his order, and his indorsement therefore was effectual to transfer the note to the plaintiff. (Chitty on Bills, $13^{6}$; Story on Prom. Notes, \$ r 39.)

I am of opinion that the judgment of the superior court should be reversed, and a new trial awarded.

Judgment reversed.

73 GEORGIA, $383 .-1884$.

BLANDFORD, JUSTICE. - The defendant in error brought its action. 
for money had and received, against the plaintiff in error, alleging that plaintiff in error had received from one Mayer and Glauber a sum of money due on a draft of which the following is a copy:

$\$ 276.85$.

Lynchburg, VA., Feb. I7, $188 \mathrm{t}$.

Sixty days after date, pay to the order of Allen W. Tslly, Cashier, two hundred and seventy-six dollars and eighty-five cents, with current rate of exchange on New York, value rec ived, and charge the same to account of

To S. Mayer \& Glauber, Hunter \& Marshall.

Albany, Georgia.

[On the back of the draft were the following indorsements: First]:

Pay W. H. Patterson, cashier, or order, for collection for account of First National Bank, Lynchburg, Va.

[Second]:

(Signed) Allen W. Tally, Cashier.

"Pay to John A. Davis, agent, or order, for account of Citizens' Bank of Georgia, Atlanta, Ga.

(Signed) W. H. Patterson, Cashier."

The evidence showed that the plaintiff in error had collected this draft; upon demand being made on plaintiff in error for the pay. ment of the money thus collected by the attorney for defendant in error, payment was refused; the railroad claimed that the Citizens' Bank was indebted to it, and that they had given that bank credit for the amount thus collected. It was further shown that the Citizens' Bank had failed before the money had been collected by the Central Railroad and Banking Company.

The court below held that the Central Railroad and Banking Company was liable to the defendant in error, and this ruling is assigned as error.

I. The qualified indorsements on the back of this draft by the cashier of The First National Bank of Lynchburg, whereby he directs payment to be made to W. H. Patterson, cashier of the Citizens' Bank, or order, for collection for account of First National Bank, Lynchburg, Va., was nothing more nor less than a warrant of attorney auchorizing the indorsee to collect the amount due on the draft for the indorser. It conveyed no title to the paper, but was notice to all persons subsequently dealing with this paper, that defendant in error had not parted with the title or intended to transfer the ownership of the proceeds to another. The legal import and effect of the indorsement was to notify the plaintiff in error that the defendant in error was the owner of the draft, and that the Citizens' Bank was merely its agent for collection; that a qualified title for this purpose only, and no other, was in the Citizens' Bank. (Morse on Banks, 52; Swift v. Ty'son, 16 Peters, I; r Howard, 234; 3 Penn. 
Stat. 348; 22 Md. 148; I Wall. 166; 102 U. S. 658; I Bond, 389; II R. I. II9; 5 I Iowa, 15.) ${ }^{1}$

2. But it is insisted that there was no privity between these parties respecting the transaction, so as to authorize this action. When the plaintiff in error received from Mayer \& Glauber the money due on the draft, they received something which belonged to the defendants in error; it was their money, and this act put them in privity for the purpose of this action. Where one person is in possession of money which of right and in equity belongs to another, this action may be maintained for its recovery. The law implies a promise on the part of any person who has received the money of another to pay that person on demand. The reception of money by one and the demand by the other makes all the privity that is necessary to maintain this action.

And we are clear that plaintiff in error had no right to retain the proceeds of this draft as payment of or security for any balance which the Citizens' Bank might be due it.

Judgment affirmed. ${ }^{2}$

58 NEW JERSEY LAW, I62. - I895.

VAN Syckel, J. - This is an action to recover the amount due upon the following promissory note:

$\$ 4,086.25$.

Trenton, N. J., Fany. $30, \mathrm{I} 83 \mathrm{I}$.

Four months after date, we promise to pay to the order of ourselves, fortynine hundred and eighty-six $\frac{25}{100}$ dollars at the office of Wm. B. Brook \& Co., at 40 John St., New York City, value received.

[Indorsed]

Brook, Oliphant \& Co.

Brook, OliphaNt \& Co.

For discount and credit of the Central Rubber Selling Co.

John H. BRitTon, Treas.

'Accord: Commercial Bank v. Armstrong, ItS U. S. 50; Butchers', etc., Bank v. Hubbell, II7 N. Y. 384; Freman's Bank v. National Tube Works, I5 I Mass. 413. - ED.

"If a bill or note be indorsed without restriztion by the payer and deposited in bank for collection and the banker pledg: or $\mathrm{s} .11$ it, the pledgee or buyer $\mathrm{g}$ ts good title. Collins v. Martin, I Bosanquet \& Puller, 64; Ayer v. Tilden, I5 Gray (Mass.) I7S; Bank v. Vanderhorst, 32 N. Y. 553. But if the bill or note be restrictively indorsed "for collection " or " on account of A." (indorser), or B. (a third person), the pledgee or buyer gets no title other than that held by the bank as agent or trustee. Treuttel v. Barandon, 8 Taunton, Ioo; Lloyl v Sigour. wey, 5 Bingham, 525; First 1 . B. of Clarion v. Greegr, 79 Pa. St. $38+\left(\right.$ semble $\left.^{2}\right)$ - ED 
This note was executed by Brook, one of the firm of Brook, Oliphant \& Company, in favor of said firm, and passed to the Central Rubber Company, without consideration.

It was discounted in New York for the Central Rubber Company, and was taken up by that company before it was due and put in its safe at Trenton, in this State.

The manager of the Central Rubber Company, after that and before the maturity of the note, passed it to Vannest, who is the plaintiff below.

The makers of the note set up in defence in the trial court - first, that the plaintiff below acquired no legal title to the note under the special indorsement of the treasurer of the Central Rubber Company; secondly, that the plaintiff below was not a bona fide holder for value.

It is undoubtedly true that if the note had fallen into the hands of anyone before it had reached the bank which discounted it, he could not have acquired or passed to another any valid title to it.

The special indorsement would have been notice of an infirmity in the holder's title.

But after that indorsement had served its purpose, and the note came back to the Central Rubber Company, that company, by passing it to Vannest, gave him as good a title as if the indorsement had not been special but general.

The trial judge properly ruled that under the circumstances the burden was cast on Vannest to show that he was a bona fide holder for value. ${ }^{2}$

The circumstances under which he acquired the note were these: -

On the 6th of May, I891, he loaned to the Star Rubber Company, of which one Thomas A. Bell was manager, the sum of $\$ 5,000$ in cash, and took the note of that company for the amount so loaned. Within a week after that date, Bell, on behalf of the same company, applied to him for another loan of $\$ 7,000$. To induce Vannest to make this loan, Bell, who was also secretary and manager of the Central Rubber Company, gave to Vannest the note sued on, to pay the aforesaid loan of $\$ 5, \infty 00$, and thereupon, on the $\mathbf{1}^{\text {th }}$ of May, r 89 r, Vannest loaned the said sum of $\$ 7,000$ to the Star Rubber Company. This transaction was made in Trenton.

In Allaire v. Hartshorne (I Zab. 665), the court of last resort in this state settled the law to be that where one takes a negotiable note before maturity as security for a precedent debt, he is a bona fide holder, and may recover upon it. ${ }^{2}$

${ }^{1}$ Neg. Inst. L., $\leqslant 98\lceil 59\rceil$, post. - ED.

${ }^{2}$ Neg. Inst. L., $§ 51[25]$. ED. 
The law of this state must govern this controversy. ${ }^{1}$

The validity of a contract depends upon the laws of the state where the contract is made. (Armour v. MicMichacl, 7 Vroom. 92.)

But a transfer of personal property, which is valid by the law of the place where such transfer is made, is sufficient to pass a valid title to it. (Frazier v. Fredericks, 4 Zab. 162; Runyon v. Groshon, I Beas. 86.)

The consideration given by Vannest for the note being sufficient according to the rule which obtains in this state to constitute him a bona fide holder for value, it is not necessary to discuss the New York cases.

There is no error in the proceedings below, and, therefore, the judgment should be affirmed.

7S NEW YORK, 37I. - I879.

THis action was brought by plaintiff, as trustee of Charles $\mathrm{H}$. Hook, against defendants, as executors of the will of James $P$. Haskin, deceased, upon a draft signed and indorsed by said testator, of which the following is a copy:

$\$ 5, \infty 00$.

Syracuse, N. Y., September 13, I872.

OrRIN Welch, Treasurer Morris Run Coal Co. Pay to the order of myself, one year after date, five thousand dollars, for value received.

(Signed) J. P. Haskin.

[Indorsed] Pay to the order of Mrs. Mary Hook, $35 \mathrm{King}$, for the benefit of her son Charlie.

(Signed) J. P. Haskin.

Defendants waived demand upon the drawee and notice of protest.

Upon the trial defendants' counsel moved for a nonsuit, in substance, upon the ground that the indorsement was restrictive and did not import a consideration, but imported a gift. The motion was denied and said counsel excepted.

Rapallo, I. - The point mainly relied upon by the appellant is that the draft and indorsement upon which this action is brought do not on their face import a consideration. The draft was drawn by the defendants' testator upon the treasurer of an incorporated company, payable to the drawer's own order and purported to be for value received. It was indorsed by the drawer by a special indorsement "Pay to the order of Mrs. Mary Hook, for the benefit of her

${ }^{1}$ Neg. Inst. L., $\$ 76[46]$, post. - Ev. 
[ART. IV.

son Charlie." The appellant claims that this is one of those restrictive indorsements which do not purport to be made for a consideration, and do not entitle the indorsee to maintain an action on the bill, without proving a consideration.

As a general rule an indorsement of a negotiable bill which purports to pass the title to the bill to the indorsee, imports a consideration, and the burden of proving want of consideration rests upon the party alleging it. The restrictive indorsements which are held to negative the presumption of a consideration are such as indicate that they are not intended to pass the title, but merely to enable the indorsee to collect for the benefit of the indorser, such as indorsements "for collection" or others showing that the indorser is entitled to the proceeds. These create merely an agency, and negative the presumption of the transfer of the bill to the indorsee for a valuable consideration.

But where the indorsement purports to pass the title to the bill therein from the indorser, and divest him of all beneficial interest, a consideration for such transfer is presumed. All the cases cited by the counsel for the appellant rest upon these principles. The citation from 3 Kent Com., 92, states the principle to be that when the indorsement is a mere authority to receive the money for the use or according to the directions of the indorser, it is evidence that the indorsee did not give a valuable consideration for it and is not the absolute owner. This accords with the statement of the principle by Wilmot, J., in Edic v. E. India Co. (2 Burr, r 227.) So an indorsement "Pay to S. W., or order, for our use," (Sigournel' v. Lloyd, 8 B. \& C. 622 ; S. C. 3 Y. \& J. 220), was held to create a mere agency, and the addition even of the words "value received" to such an indorsement has been held not to vary its effect. (IVilson v. Holmes, 5 Mass. 543.) In Edie v. East India Co. (2 Burr. I2 2 I), the examples of restrictive indorsements put by way of illustration are, "Pay to my steward and no other person," or "pay to my servant for my use." These show that there was no intention to pass the title to the bill; and the same effect has been given to an indorsement, "Pay to P. only." It was held that these words indicated that the indorsee was agent only, and paid no consideration for the bill, as a purchaser would not have accepted such an indorsement. (Power v. Finnie, 4 Call [Va.], 4Ir.)

But an indorsement to one person for the use or benefit of another, affords no such indication. The indorser parts with his whole title to the bill, and the presumption is that he does so for a consideration. The only effect of such an indorsement, by way of restriction, is to give notice of the rights of the beneficiary named in the indorse- 
ment, and protect him against a misappropriation." When a bill is indorsed " Pay to A. or order for the use of B.," A. cannot pass the bill off for his own debt, but he can by indorsing it transfer the title, and will hold the proceeds for the benefit of B., and be accountable to him for them. (Evans v. Cramlington, Carth. 5, affirmed in the Exchequer Chamber, 2 Vent. 309.) In Treuttel v. Barandon (8 Taunt. 100), cited by the appellants, drafts payable to the drawer's own order were indorsed by him to De Roure \& Co., or order, "for the account of Treuttel \& Wurz." It appeared that De Roure \& Co. were the agents of Treuttel \& IVurz, and the latter were held entitled to maintain trover for the drafts against a party to whom De Roure $\&$ Co. had pledged them for their own debt. There is nothing in this case to sustain the proposition that a draft thus drawn and indorsed does not import a consideration, or that the indorsee could not maintain an action upon it against the drawer and indorser with out proving a consideration. The effect of the special indorsement was simply to give notice of the interest of Treuttel \& Wurz, and prevent De Roure \& Co. from appropriating the drafts to their own use. Blaine v. Bouine, (I I Rh. I. I I9), is to the same point.

In the present case the indorsement did not purport to restrain the indorsee from negotiating the draft, for it was "Pay to the order of Mrs. Mary Hook "for the benefit of her son Charlie. She was constituted trustee of her son and held the legal title. (3 Kent's Com. 89.) The indorsement gave notice of the trust, so that if she had passed it off for her own debt, or in any other manner indicating that the transfer was in violation of the trust, her transferee would take it subject to the trust, but there was nothing reserved to the drawer and indorser. He retained no interest in it. The presumption is that the draft was drawn and indorsed by him for a consideration received either from the indorsee or the beneficiary. If the youth of the beneficiary should be deemed to afford a presumption that no consideration was paid by him, the presumption would be that it enanated from his mother. The facts admitted on the trial do not establish that the consideration was illegal. They show that the boy lived with his mother and was taken care of by her. There is nothing illegal in an undertaking by a putative father to support his illegitimate child, or to pay a sum of money in consideration of such support being furnished by another, though it be the mother of the child. If such was the consideration of this obligation, and it was furnished by Mrs Hook, she was at liberty to take it, payable to herself in her own right, or for the benefit of her child. (Iticks v. Gregory, 8 C. P. 378; Smith v. Roche, 6 C. B. [N. S.] 223; Nichole

\footnotetext{
${ }^{1} \mathrm{Neg}$. Inst. L., $\$ 9 \mathrm{I}[52]$, post. - ED.
} 
v. Allen, 3 C. \& P. 36; Fennings v. Brown, 9 Mees. \& W. 496 ; Knowlman v. Bluett, 9 L. R. [Exch.] I, 307; Bunn v. Winthrop, I J. Ch. 337, 338.)

The judgment should be affirmed. ${ }^{2}$

\section{$\$ 67$ BLECKLEY, C. J., in FREEMAN v. EXCHANGE BANK.}

$$
87 \text { GEORGIA, 45. - I89I. }
$$

I. An indorsement for collection, or the like, is not a contract of indorsement, but the creation of a power, the indorsee being a mere agent to receive or enforce payment for the indorser's use. (Central Railroad v. First National Bank, 73 Ga. 383 ; Tiedeman, Com. Pap., § 268; I Daniel, Neg. Inst., § 698-698(d); 2 Randolph, Com. Pap., § 724-5-6-7, Iо09; I Morse Banks, § 21 7; 2 Id., $\$ \S 583$, 593; Bolles' Banks and Depositors, $\$ \S 220,384(\mathrm{e})$, et seq.; Benj. Chalmers' Bills, Notes and Checks, (2 Am. ed.), 132 ; Commercial National Bank v. Armstrong, 39 Fed. Rep. 684; [s. C. 148 U. S. 50]; National B. \& D. Bank v. Hubbell, iा 7 N. Y. 384.)

A suit is not maintainable by the indorsee against the indorser. (White v. National Bank, ro2 U. S. 658. And see Lee v. Chillicothe Bank, I Bond, 387.)

Tosue other parties in order to enforce payment is deemed within the delegated power of the agent; and by reason of the great favor shown by the law to commercial paper, the restricted indorsee is allowed in some jurisdictions to sue in his own name. (Wilson $\mathrm{v}$. Tolson, 79 Ga. 137; Boyd v. Corbitt, 37 Mich. 52; 2 Randolph, Com. Pap., $\$ 726$; Benj. Chalmers' Bills, Notes and Checks [2 Am. ed.], I $33, \mathrm{r} 49)^{2}$

The maker of a restricted indorsement can follow the bill or its proceeds over any number of subsequent indorsements, the terms of his indorsement being notice of his title. (Elementary Works cited supra: First Nat'l Bank v. Reno. Co. Bank, 3 Fed. Rep. 257; Bank of the Metrop. v. First Nat'l Bank, I9 Id. 301; First Nat'l Bank v. Bank of Monroe, 33 Id. 408; In Re Armstrong, Id. 405; Commercial Nat'l Bank v. Hamilton, 42 Fed. Rep. 880.) The last case is criticised from the standpoint of bankers, but only with reference to transmitting the proceeds of collection from the collecting bank to

"Whether the indorsement " pay to A. B. trustee," is restrictive see discussion of instruments payable " to A. B. trustee," post, p. 412. - ED.

${ }^{2}$ Contra: Rock County $N$. B. v. Hollister, 2 I Minn. 395 . In any event, only the special indorsee can sue. Lawrance v. Fussell, 77 Pa. St. 460. - ED. 
the intermediary through whom the bill was received. The expert opinion seems to be that transmission according to custom, by correspondence and proper entries of debit and credit founded thereon, the entries being made after collection, will serve commercially, and therefore legally, as the equivalent of paying over the money or forwarding it by mail or express; and consequently that transmission by such entries, each bank making the appropriate entry for itself, will discharge the collecting bank. (See 45 Bankers' Magazine, 24I; 4 Banking Law Journal, 3.) The learned United States circuit judge who decided the case which is thus criticised took a different view.

A deposit of paper in bank by a customer, he indorsing it "For deposit," may operate to clothe the bank with title under certain circumstances. (National Commercial Bank v. Miller, 77 Ala. i68; 2 Morse on Bank, $\S 577$.) But the general rule is, that by a restrictive indorsement the depositor retains the title. (Bolles on Banks and Depositors, §220.)

[Held: That where A. deposited a bill with B. indorsed "for deposit to the credit of A," and B. indorsed it, "Pay C. for collection account of B," and C. collected it, the funds were subject to garnishment in C's hands by the creditors of A., for as yet they had not actually been deposited in the hands of $\mathrm{B}$. The legal import of the indorsement is to make B. an agent for collection and deposit. "The proceeds would be impressed with A.'s ownership until they were actually so deposited."']'

\section{QUALIFIED INDORSEMENT.}

3 Massachusetts, $225 .-1807$.

Assumpsit by indorsee against makers, upon a note payable to Jonathan Symonds, or order, and indorsed by him in these words: "for value received I order the contents of this note to be paid to Merrick Rice at his own risk." The defendants denied their signatures, and Symonds was offered as a witness to prove the execution

"There is some conflict as to the legal effect of an indorsement "For Deposit." Some courts hold that title passes under such an indorsement. Ditch v. Western N. B., 79 Md. I92; s. C., 47 Am. St. Rep. 375 and note. Others hold that title does not pass, but that the bank is a bailee for collection until the money is actually in its hands, when it becomes a debtor as in the usuai case of monev deposits. Beal v. City of Somerville, 50 Fed. Rep. 647. - Ev. 
of the note, and was objected to as a witness on the ground that he was interested. Objection overruled. Judgment for Plaintiff. Defendants appeal.

Parsons, C. J. - The interest of Symonds must depend on the effect of his indorsement.

A security negotiable in its creation must, during its negotiation, preserve its negotiable quality; otherwise, when assigned, the assignee would hold a contract by the assignment different from the contract assigned. It is for this reason settled that a negotiable note indorsed in blank, or by a direction to pay the contents to $\mathrm{A}$. B., omitting the words, " or his order," is further negotiable by the holder under such indorsement. It is also settled that when a negotiable security is indorsed, "pay the contents to my use," or, "to the use of a third person," or, "carry this bill to the credit of a third per. son," such an indorsement is not an assignment of the security, but is only an authority to pay the money agreeably to the direction of the indorsement. There are other restricted indorsements also made; as "pay the contents to $A$. B. only." Whether this indorsement is only an authority to $A$. B. to receive the money for the use of the indorser, or for his own use, if made for value received, or whether in this last case the restriction is not void, and A. B. may further negotiate it, seems not to be settled. If the property of the note be vested in A. B., perhaps he will hold it with its negotiable quality, notwithstanding the restriction. But of this we give no opinion.

The case at bar is a restricted indorsement of another kind, and which in practice is very common. The promisee of a negotiable note indorses it to a third person, or his order, for value received, stipulating that the indorser is not to be responsible, if the maker does not pay it. If, notwithstanding this stipulation, the indorser is answerable, if the maker do not pay the note, then the witness, Symonds, is interested, and ought not to have been sworn.

Upon consideration we are of opinion that the promisee, indorsing the note under this express stipulation, is not eventually holden to pay the note, if the maker should not. As the promisee had the property of the note, he might dispose of it on what terms he pleased, with the assent of the purchaser, and the latter cannot complain of the necessary effect of his own agreement; and the indorser cannot be charged upon his own contract, directly against the express intent of it. If this opinion is correct, Symonds, after this restricted indorsement, had no interest in the event of the suit, and was a competent witness.

Another point of some importance arises, which involves the ques- 
tion, whether, by this restricted indorsement, the property of the note passed to the indorsee: so that he may sue upon it in his own name. If the restriction applied to the quality of the contract, so as to render a negotiable security no longer negotiable, there would be some difficulty in allowing, consistently with legal principles, an indorsement of this effect to operate as a transfer of the note. Lut this is not the effect of the restriction; the note remains negotiable in the hands of the indorsee, although he has no remedy against the indorser; and in whose hands soever the note may come, the maker is still liable, according to the terms of his original contract, to pay to the promisee or his order. The note, therefore, being the absolute property of the plaintiff, and Symonds being a competent witness, the verdict must stand, and judgment be entered accordingly.

$\S 68$ [38] Lomax 2 . Picot, 2 Randolph (Va.), 247, 260. - I $\$ 24$. JUDGE GREEN. - " An indorsement without recourse is not out of the due course of trade. The security continues negotiable, notwithstanding such an indorsement. Nor does such an indorsement indicate, in any case, that the parties to it are conscious of any defect in the security, or that the indorsee does not take it on the credit of the other party or parties to the note. On the contrary, he takes it solely on their credit, and the indorser only shows thereby, that he is unwilling to make himself responsible for the payment."

6o Minvesota, 269. - IS95.

[Reported herein at $p .35+$.]

5. Conditional Indorsement.

$\S 69$ JOHNSON $\approx$. BARROW.

12 Louisiana Axveal, 83. - 1857.

SPOFFORD, J. - This suit is brought against the indorser of a promissory note of the following tenor:-

Donalosonvilie, 3oth Oit., $185 \mathrm{r}$.

One year after date, I promise to pay to the order of Robert R. Barrow the sum of five hundred dollars, for value received, payable at the office of the Recorder, Donaldsonville.

[The indorsement is in these words:]

(Signed) Joux Hurnes.

Houma, Parish of Terreboniti.

I indorse the within note for the benefit of Mrs. Hutson in the purchase of a tract of land from Gov. H. Johnson.

(Signed) R. R. BARrow. 
The defendant pleaded that this restrictive indorsement does not bind him, inasmuch as the special object for which it was given was never consummated, Mrs. Hutson not having purchased a tract of land from the plaintiff Johnson.

There was judgment in the defendant's favor, and the plaintiff has appealed.

It is needless to recapitulate any other facts than that Mrs. Hutson did not buy a tract of land from Henry Johnson, nor contract to do so in any manner that could bind her.

The condition with which the defendant clogged his indorsement of the note never having been accomplished, the plaintiff has no action against him.

The judgment is, therefore, affirmed with costs. ${ }^{1}$

IV. Indorsement: Methods and effect.

I. Indorsement of Instrument Payable to Bearer.

$\$ 70$ RIDER $v$. TAINTOR.

4 Allen (Mass.), 356. - I862.

ConTRACT upon the following promissory note:

$\$ 107$.

LEE, Dec. I, I86o.

Six months from date, for value received, I promise to pay Stephen E. Avery, or bearer, one hundred and seven dollars, with use.

[The note bore the following indorsement:]

Albert J. Taintor.

Pay E. A. Bliss, cashier, or order.

\section{WarRen Newton, Cashier.}

At the trial in the superior court, it appeared that the plaintiff had purchased the note in suit before it became due for a full consideration, but the bill of exceptions stated that " there was no evidence that E. A. Bliss, to whom said note had been indorsed, had trans-

${ }^{1}$ In Robertson v. Kensington (4 Taunt. 30), the indorsement was "Pay the within sum to A., or order, upon my name appearing in the 'Gazette' as ensign in any regiment of the line, between the Ist and 64th, if within two months from this date." In this form the bill was accepted by defendants, who subsequently paid the bill to $E$., a remote indorsee of $A$. The payee's name did not appear in the 'Gazette,' and he brought an action against the acceptor. Held: plaintiff could recover. It is the rule of this case that is changed by $\$ 69$ [39], of the Neg. Inst. Law. A conditional indorsement does not affect the negotiability of the instrument. Tappan v. Ely, I5 Wend. (N. Y.) 362. The indorsee is a trustee for the conditional indorser if the condition is not fulfilled. - ED. 
ferred or indorsed said note to the plaintiff;" or " that the plaintiff had any title in said note from said Bliss, or that said note was sued with the knowledge or assent of said Bliss." Rockwell, J., ruled that the plaintiff was entitled to recover, and the jury returned a verdict accordingly; and the defendant alleged exceptions.

Bigelow, C. J. - The contract of the promisor of the note declared on is to pay the sum due on the note at its maturity to the person who shall then be the bearer. The production of the note by the plaintiff is therefore evidence of his title; and, accompanied as it was in the present case with proof that the plaintiff had become the owner of the note by purchase before it became due, established a conclusive right to recover againsi the defendant.

The indorsement of a third person, directing the payment of the note to be made to the order of another, did not change the contract of the promisor, or enable him to set up in defense that the plaintiff's title was imperfect, merely because he had not obtained the signature of the person to whom some intermediate holder had ordered the note to be paid. (IVilbour v. Turner, 5 Pick. 526; Waynam v. Bend, I Camp. r75; Story on Notes, $\$$ I 32 .)

Exceptions overruled.

50 Texas, 212. - r878.

THE facts are stated in the opinion.

Gould, Associate Justice. - This suit was brought by B. F. Mitchell against appellants, W. L. Johnson and C. R. Bedford, the makers of a promissory note, payable January I, IS73, to J. W. Crabtree, or bearer, and against Crabtree, who had indorsed the note as follows: "I hereby assign the within note to S. L. Gilbert for value received, and guarantee the solvency of the makers of said note, rith of September, r873. J. W. Crabtree."

The averments of Mitchell's petition as to his right or title to the instrument sued on were, that he was the legal holder and owner of the note; that Crabtree sold and transferred it to Gilbert, setting out the assignment as indorsed, and that, after said transfer, he (plaintiff) purchased the note from Gilbert, who transferred it to him by delivery. The only evidence of ownership introduced by Mitchell was the note and indorsement. The defendants had all filed a general denial, but produced no evidence. A jury being waived, the court gave judgment against Johnson and Bedford as principals and Crabtree as guarantee. Johnson and Bedford asked 
for a new trial, claiming that the evidence was insufficient to support the judgment; and their motion being overruled, they alone have appealed.

It is insisted, on their part, that the production of the note, transferred as it was to Gilbert, did not establish that Mitchell was the legal holder or owner.

As Crabtree does not complain, the sole question is as to the legal effect of possession of a note payable to bearer and indorsed in full by the payee, as against the makers.

Feeling that uniformity of decision, in all cases important, is not least so in questions of commercial law, and failing to find decisions directly in point, we have given the authorities bearing on the question a careful examination.

According to the elementary authorities, a bill or note payable to order and indorsed in blank, so long as the indorsement continues blank, " is in effect payable to bearer." (Chitty on Bills [I Ith ed.] $227 ; 3$ Kent [9th ed.] side p. 89; Story on Bills, $\S 60 ; 2$ Pars. on Notes and Bills, p. I9, note w; Edws. on Bills and Notes, 131, 269; I Dan'1. on Neg. Inst. $\$ 693$; Groneaux v. Whecler, 6 Tex. 522; Wethered v. Smith, 9 Tex. 625; Whithed v. McAdams, I8 Tex. 553; Ross v. Smith, 19 Tex. I72.)

Lord Mansfield said, in Pcacock v. Rhodes: "I see no difference between a note indorsed in blank and one payable to bearer; " and Chancellor Kent said, in Conroy v. Warren: "A note indorsed in blank and one payable to bearer are of the same nature. They both go by delivery, and possession passes property in both cases." (2 Doug. $6{ }_{3} 6 ; 3$ Johns. Cases, 263.) So " a note payable to the maker's order becomes, in legal effect, when indorsed in blank, a note payable to bearer." (Byles on Bills, ch. 7, p. 68; Broun v. De Winton, 6 M. G. \& S. [60 Eng. Com. Law], 336.)

From these authorities, we conclude that Mitchell's possession was at least as satisfactory evidence of his ownership as it would have been had the note been payable to Crabtree or order, indorsed in blank by Crabtree, and then indorsed in full by Gilbert and someone other than Mitchell.

The negotiability of a note payable to bearer is certainly not further restrained by an indorsement in full than would be, by the same indorsement, the negotiability of a note payable to order and indorsed in blank by the payee. But the rule is well settled, that " if a bill be once indorsed in blank, though afterwards indorsed in full, it will still, as against the drawer, the payee, the acceptor, the blank indorser, and all indorsers before him, be payable to bearer, though as against the special indorser himself title must be made through 
his indorsee." (Byles on Bills [5th ed]., Io9; cited by Pollock in 2 Exch., infra; Chitty on Bills, 228, $230 a$; 3 Kent, side p. 90; Story on Prom. Notes, $\$$ I $39 ; 2$ Pars. on Notes and Bills, 19, 26; Walker ct al. $a^{\prime}$. McDonald, 2 Exch. [Welsby, H. \& G.], 53 I ; citing Smith v Clark, I Peak. N. P. C. 295, and I Esp. iso; Hitchell v. Fuller, I5 Penn 270; Huic v. Bailey, 16 La. $2 \mathrm{r}_{3}$; Little v. O'Brien, 9 Mass. 423; Dugan v. The United States, 3 Wheat, r72; Edw's on Bills and Notes, 275; citing Dolfus v. Frosch, I Denio, 367; Saz'anah National Bank v. Haskins.)

We conclude, then, that however it might have been as against Crabtree, on which point we express no opinion, as against the makers of the note, its production by Mitchell was sufficient evidence of title.

It may be objected that the safe transmission, by mail or otherwise, of notes and bills payable to bearer requires a different rule The answer is, first, that such a consideration will not justify a departure by the courts from established principles and precedents, second, that what is known as a "restrictive" indorsement stops the currency of negotiable paper. (Chitty on Bills, 232; Story on Prom. Notes, $\$ \mathrm{I}_{42}$, et seq.; 2 Pars. on Notes and Bills, $2 \mathrm{I}$; I Dan'l. on Neg Inst. \$698.)

Whilst we have disposed of the case on the assumption that Crabtree's transfer was equivalent to an indorsement in full to Gilbert or order, it is not intended to pass upon that question. ${ }^{1}$ Looking to the original nature of the note, which was that it should pass by delivery, and following what was long since said to be the settled rule, "that the assignment follows the nature of the thing assigned," it may be questioned whether that indorsement does not receive full effect by treating it as intended to secure Crabtree's liability as guarantor to Gilbert or bearer. (See Edie v. East India Co., 2 Burr. r216; Lane v. Krekel, 22 Iowa, 400.)

The judgment is affirmed.

Affirmed.

2. Indorsement Where Payable to Two or More Persons.

3 Mcleas, 94 (s. c. 8 Fed. Cas. 186). - I842.

[U.S. Circuit Court, Dist. Wich.]

Opinion of the Court. - This action was brought upon the following promissory note:

See pp. 343-348, ante.-Ev. 
Detroit, January I, I837. Two years after date, I promise to pay to the order of Walter Chester, and Pease, Chester and Co., one thousand and five hundred dollars, for value received, at the Farmers and Mechanics' Bank of Michigan, with interest.

[Indorsed:] Pease, Chester \& Co.

(Signed) John Chester.

[and also] D. E. Jones (in blank).

The declaration contained three counts, to the first of which there was a demurrer. This count states that one John Chester, on the Ist of January, I837, made his note payable to order of Walter Chester, and Pease, Chester \& Co., and that Pease, Chester \& Co., under their partnership name, indorsed and delivered the said note to the plaintiff. John Chester, the maker, was a member of tho firm of Pease, Chester \& Co. Demand of the note when due, and notice to the defendants, was proved.

Walter Chester, one of the promisees in the note, seems not to have indorsed it, and this is fatal to the right of the plaintiff. The interest of the promisees is joint in the note, and not being in partnership, they must each transfer the note. (Chitty on Bills, 123; Tayl. 55; Carick v. Vickerv', Doug. 653; Fones v. Radforl, I Camp. $8_{3}$; 2 I Eng. C. L. Rep. 4r.)

Only one-half of the note was transferred by the indorsement of Pease, Chester \& Co., and this does not give a right to their or any subsequent assignee to sue on the note. Recourse against the maker cannot thus be divided and suits multiplied. The plaintiff seeks by this action to recover the full amount of the note against the defendants, as indorsers. But as he holds but one-half of the note under the assignment, the indorsement, at most, can only be evidence of that amount.

The declaration is defective in not averring that Walter Chester, one of the payees, did indorse the note. Demurter sustained. The plaintiff dismissed his action.

§ $7 \mathbf{I}$ ALABAMA COAL MINING CO. $v$ BRAINARD. [\$ 4I] 35 Alabaina, 476. - I860.

[Reported herein at p. 273.] 


\section{Indorsement Where Payable to Cashier, Etc}

is Pickering (Mass.) 63. -1836

[Reported herein at p. 349.] ${ }^{1}$

4. Indorscment Where Nalie Misspelled, Etc.

i Cushixg (Mass.), $320 .-1853$.

From the auditor's report, it appeared that Stearns was the holder of a note executed by Bolles payable to " John P. Reed, or orcler," and indorsed "Joseph P. Reed." There was, when the note was given, a person living in the same town whose name was "John $P$. Reed," but it was proved that the note was in fact given by Bolles to Joseph P. Reed for money lent him by the latter, and that it was indorsed by Joseph P. Reed to Stearns.

Metcalf, J. . . The court are also of opinion that the note given by the plaintiff, payable to John P. Reed, or order, and indorsed to the defendant by Joseph P. Reed, cannot be allowed to the defendant by way of set-off. That note, though given for money lent to the plaintiff by Joseph P. Reed, was made payable, not to him, but to John P. Reed, a person in esse. Now it is certain that the legal interest in that note was not transferred to the defendant by Joseph P. Reed's indorsing his name on it. He was not the payee nor the legal representative of the payee. And a transfer by indorsement can be made in the first instance only by the payee, or by some one claiming in his right, as his executor, administrator, or assignee in bankruptcy or insolvency. ( $\mathrm{Kyd}$ on Bills [ist Amer. ed.], ro6, ro7.) If there had been no such person

\footnotetext{
'See note p. 320, ante. "The usage is universal for presidents and cashiers of incorporated companies, acting as the executive officers and agents of such companies, to make, in their behalf, indorsements and transfers of negrotiable paper, by simply indorsing their names, with the additions of their titles of office. I cannot doubt that such an indorsement is sufficient to charge the corporation under whose authority the indorsement is made, and to transfer the note to the indorsee, so that the latter can maintain an action thereon in his own name." Hall, J., in State Bank v. Fox, 3 Blatch. (U. S.) +31. - Ev.
} 
as John P. Reed, perhaps the note might have been regarded as payable to bearer, and might have been passed to the defendant by delivery, as if it had in terms been made payable to bearer. Of this, however, we give no opinion. But as the note was made payable not to a fictitious person, but to a person in being, the indorsement of a third person transferrea no legal title to it.

If the indorsement and delivery of this note to the defendant by Joseph P. Reed, could be regarded as an equitable assignment of it, still the defendant would not be entitled to set it off against the plaintiff's claim on him, because it is not shown that notice of such assignment was given to the plaintiff before this action was commenced. (Rev. Sts., c. 96, $\S 5$. )

[Set-off on the note not allowed.]

5. Indorsement in Representative Capacity.

$\S 74$

SCHMITTLER $i^{\prime}$. SIMON.

$[\S 44]$

IOI NEW YORK, 554. - ISS6.

[Reported herein at p. 183.$]^{1}$

6. Presumption as to Time of Indorsement.

$\$ 75$ [45] Ranger $\%$. Cary, I Metcalf (Mass.), 369. - 1840.

Dewey, J. - The instructions of the court of common pleas, to which exceptions were taken, embraced substantially the following propositions: I. That the burden of proof was on the defendants to show that the note was transferred after it was due and when dishonored, if they would avail themselves of a defence only open to them as upon a dishonored note. . . . Upon the first point, the law is very fully settled according to the rule stated by the judge at the trial. A negotiable note being offered in evidence, duly indorsed, the legal presumption is that such indorsement was made at the date of the note, or at least antecedently to its becom. ing due; and if the defendant would avail himself of any defence that would be open to him only in case the note was negotiated after it was dishonored, it is incumbent on him to show that the indorsement was in fact made after the note was overdue.

\footnotetext{
'See note, p. 320, anti. - ED.
} 
7. Presumption as to Place of Indorsenent.

§ 76 BROOK, OLIPHANT \& CO. $v$. VANNEST.

58 New Jersey Law, 162. - 1895.

[Reported herein at p. 359.]

8. Continuation of Negotiable Character.

$\S 77$

LEAVITT $v$. PUTNAM.

[§ 47]

3 NEW YORK, 494. - 1850.

[Reported herein at p. 356.]

9. Striking Out Indorsement.

$\S 78$

CURTIS $r$ SPRAGUE.

[§ 48]

5 I California, 239. - I 876.

[Reported herein at p. 268.] ${ }^{1}$

\section{Transfer without indorsement.}

$\S 79$

OSGOOD $\tau$. ARTT.

[§ 49]

I7 Federal Reporter, 575. - I883.

[From Circuit Court, N. D. Illinois.]

ARTt gave the R. \& M. R. Co. his negotiable note for $\$ 2,500$ secured by mortgage. The R. \& M. R. Co. gave Osgood a bond for $\$ 2,500$ and in it "assigned and transferred" Artt's note and mortgage as security, and specified that "said note and mortgage are hereto appended." The bond, note and mortgage were attached firmly together with eyelets in the order named. Each had the number 1964 written on it. Osgood at this time had no notice of any defense to Artt's note. Subsequently Osgood learned of the

${ }^{1}$ If the note is indorsed by the payee and by subsequent holders, but comes again into the hands of the payce, he may strike out the indorsements. Berney v. Steiner Bros., 108 Ala. 111 ; Midlliton v. Griffith, 57 N. J. L. 442. - ED. 
defense (failure of consideration and fraud), and thereafter the R. \& $M$. R. Co. indorsed the note by writing its name upon the back.

HaRLan, J., (after stating the facts). - These facts have been especially found by a jury, and the sole question for determination is whether, upon this finding, the plaintiffs are entitled to judgment. The only issue of fact made on the third plea is whether Osgood, prior to the indorsement of the note, had notice of the alleged fraud and failure of consideration.

I. It is a settled doctrine of the law merchant that the bona fide purchaser for value of negotiable paper, payable to order, if it be indorsed by the payee, takes the legal title unaffected by any equities which the payer may have as against the payee.

2. But it is equally well settled that the purchaser, if the paper be delivered to him without indorsement, takes, by the law merchant, only the rights which the payee has, and therefore takes sub. ject to any defense the payer may rightfully assert as against the payee. The purchaser in such case becomes only the equitable owner of the claim or debt evidenced by the negotiable security, and, in the absence of defense by the payer, may demand and receive the amount due, and, if not paid, sue for its recovery, in the name of the payee, or in his own name, when so authorized by the local law.

3. As a general rule the legal title to negotiable paper, payable to order, passes, according to the law-merchant, only by the payee's indorsement on the security itself. The only established exception to this rule is where the indorsement is made on a piece of paper, so attached to the original instrument as, in effect, to become part thereof, or be incorporated into it. This addition is called, in the adjudged cases and elementary treatises, an allonge. That device had its origin in cases where the back of the instrument had been covered with indorsements, or writing, leaving no room for further indorsements thereon. But, perhaps, an indorsement upon a piece of paper, attached in the manner indicated, would now be deemed sufficient to pass the legal title, although there may have been, in fact, room for it on the original instrument.

4. But neither the general doctrines of commercial law, nor any established exception thereto, make words of mere assignment and transfer of such paper - contained in a separate instrument, executed for a wholly different and distinct purpose - equivalent to an indorsement within the rule, which admits the payor to urge, as against the holder of an unindorsed negotiable security, payable to order, any valid defense which he has against the original payee.

5. The transfer of the note in suit, by words of assignment in the 
body of the railroad company's bond, did not, in the judgment of the court, amount to an indorsement of the note, although the bond, note, and mortgage were originally fastened together by eyelets. The facts set out in the third plea, and sustained by the special finding, constitute, therefore, a complete defense to the action, unless, as contended by plaintiffs, the subsequent indorsement, in form, by the railroad company, after Osgood was informed of Artt's defense, has relation back to the time when the former, without notice of such defense, purchased the note for value then paid. If, at the time of Osgood's purchase, it had been agreed that the company should indorse the note, but the indorsement was omitted by accident or mistake or fraud upon the part of the company, a different question would have been presented. In such case, the company might, perhaps, have been compelled to make an indorsement which would have been deemed effectual as of the time when, according to the intention of the parties, it should have been made. But no such case is presented by the special finding. It is entirely consistent with the facts found that the indorsement by the company was an afterthought, induced by notice of Artt's defense, and was not within the contemplation or contract of the parties when Osgood purchased the bond. Moreover, and as a circumstance significant of an intention to restrict, in some degree, the assignability of the note and mortgage, it is expressly stipulated, in the company's bond, that they are transferable in connection with the bond, and not otherwise.

I am of opinion that the facts which came to Osgood's knowledge prior to the indorsement, and which, in substance, constitute the defense set out in the third plea, furnished notice that the company had, by reason of fraud and failure of consideration, lost its right to demand payment of the note from Artt. By the indorsement, after such notice, Osgood could not acquire any greater rights than the company possessed. He did not become the holder of the note by indorsement, as required by the law-merchant, until after he had notice that the company could not rightfully pass the legal title, so as to defeat Artt's defense.

While the adjudged cases are not in harmony upon some of these propositions, the conclusions indicated are, in the opinion of the court, consistent with sound reason, and are sustained by the great weight of authority. (Chief Justice Marshall in ITopkirk Y. Int, 2 Brock, 4I; Sturges' Sons v. Met. Nat. Bank, 49 Ill. 2.31 ; Ma! ndI v. Keen, 89 Ill. 404; Haskell v. Brou'n, 65 Ill. 37 ; Lancaster liet. Bank v. Taylor, 100 Mass. 24; Bacon v. Cohed, I 2 Smedes \& M. 5.2.; Grand Gulf Bank v. Wood, Id. 482 ; Clurk v. Whitaker, $5 \circ$ N. H. 
474; Haskell v. Mitchell, 53 Me. 468; Franklinv. Twogood, I 8 Iowa, 515; French v. Turner, 15 Ind. 59; Folger v. Chase, r8 Pick. 63; Whistler v. Forster, I4 C. B. 246 ( 108 E. C. L. 248); Harrop v. Fisher, 1० C. B. [N. S.] 1ọ6; Gibson v. Minet, r H. Bl. s. p. 606; Story, Notes, § r 20 ; Story Bills, § $20 \mathrm{r}$; Chitty, Bills [rath Amer. from 9th Lond.], 252; 2 Pars., Notes and Bills, I, 17, I8; I Daniel, Neg. Inst. [3 ed.], $\$ \$ 664 a, 689 a, 690,74 \mathrm{I}$, and 748a.) The facts specially found do not authorize a judgment for the plaintiff. ${ }^{1}$

\section{Retransfer to prior party.}

51 California, 239.- -1876.

[Reported herein at p. 268.]

\section{BROOKS, OLIPHANT \& CO. $v$. VANNEST.}

58 New Jersey LaW, I62. - I895.

[Reported herein at p. 359.] ${ }^{2}$

1" Griffith having defrauded the defendant of the bill, he could pass no right by merely handing over the bill to another. According to the law-merchant, the title to a negotiable instrument passes by indorsement and delivery. A title so acquired is good against all the world, provided the instrument is taken for value and without notice of any fraud. The plaintiff's title under the equilable assignment here, therefore, was to be rendered valid by indorsement: but, at the time he obtained the indorsement, he had notice that the bill had been fraudulently obtained by Griffiths from the defendant, and that Griffiths had no right to make the indorsement. Assuming, therefore, that there may be conflicting equities between the plaintiff and the defendant, I think the right should prevail according to the rule of law, and that the plaintiff had no title as transferee of the bill at all." Erle, C. J., in Whistler v. Forster, 14 C. B. N. S. 248. - ED.

"See post, Art. IX. p. 571, Div. I. I. See $\$ 202$ [121], post. If an indorser reissue the paper after maturity without striking out his indorsement he remains liable and is estopped to require a new presentment and demand. ITilliams v. Matthezs, 3 Cow. (N. Y.) 252; St. John v. Roberts, 31 N. Y. 44I. - ED. 


\section{ARTICLE V. \\ Rights OF Holder.}

\section{To sue and to receive payment.}

21 LAW JOURNaL, Q. B., 391. - I852.

Assumpsir. Count on a promissory note made by defendant for I,, $00 l$., payable on demand to E. Curtis (deceased). Plea, that the payee had by his will bequeathed the note to his son, Charles Curtis; that piaintiff had probated the will and assented to the bequest; that Charles Curtis had subsequently been convicted of felony by reason of which his interest was forfeited to the crown. The replication merely set out verbatim the probate of the will. Special demurrer to the replication, and joinder in demurrer.

Maxwell, in support of the demurrer. - The question is, whether the plea discloses a good defence to the action. First, by the will of E. Curtis, made since the passing of the Wills Act (I Vict. c. 26), the right of suing on this promissory note passed to $\mathrm{C}$. Curtis. That act enables any person to bequeath by will all personal estate which he is entitled to, either at law or in equity, at the time of his death, which, if not so bequeathed, would devolve upon his executor or administrator.

[Lord Campbell, C. J. - It does not make any kind of personalty bequeathable which was not so before, as it does as to realty.]

Section I defines personal estate as including debts and choses in action, which it places in the same category as chattels. A chose in action could formerly only have been assigned in equity, but now it may be passed by will. 'The right of suing on this promissory' note is a chose in action, which, if not bequeathed, would devolve on the executor or administrator, and, therefore, it passes by the will.

[CRompton, J. - According to that, it would vest in the legatee without any assent of the executor.]

The legatee would no doubt take this, as he would any chattel, subject to the paramount right of the executor to require it for the payment of debts. But the plea alleges that the executor assented, and so that point does not arise. 
[CROMPTON, J. - No; the assent would pass the property in the note, but not the right of suing upon it.]

The meaning of the Wills Act must be, that the legatee is to take all that the executor would take, that is, the right of property and the right of suing.

[COLERIDGE, J. - How would the legatee have sued on the note?]

$\mathrm{He}$ would allege that by the bequest the right of suing passed to him, and show that the executor assented.

[Lord Campbell, C. J. - The will says the note is not to be put in suit until a certain time: would the legal right vest in the legatee in the interval?]

That must be the effect of the bequest. But, secondly, even if the right of suing on the note did not pass to Charles Curtis, still he had the equitable interest in it; and the crown took it on his conviction.

[Lord Camprell, C. J. - Is there any authority for that?]

In Hawkins, P.C. b. 2, c. 49, s. 9, it is said, "all things whatsoever which are comprehended under the notion of personal estate, whether they be in action or possession, which the party has in his own right, are liable to forfeiture; and so, a bond taken in another's name, or a lease made to another in trust for a person who is afterwards convicted of treason or felony, are as much liable to be forfeited as a bond made to him in his own name, or a lease in possession." Bullock v. Dodds, 2 B. \& Ald. 25 , decides that to an action on a bill of exchange the attainder of the plaintiff may be well pleaded. The prerogative of the crown extends so as to take the right of suing on this note, in which the convict was beneficially interested.

Hoggins, who appeared for the plaintiff, was not called upon to argue.

Lord Campbell, C. J. - This plea is clearly bad. It is said that the property in and right of suing upon this promissory note passed to Charles Curtis by virtue of the I Vict. c. 26 . It is admitted that before that act such property and right of suing would not have passed to a legatee. But that act never was intended to have any operation to make anything bequeathable as personal estate which might not have been previously bequeathed. It only provides a mode for executing wills, and with respect to real estate a clause is introduced making things devisable which before were not so, such as rights of entry, which may now pass by will. But there is nothing to indicate an intention of enabling a party to bequeath a chose in action sn as to pass the right of suit. Therefore, before the con- 
viction of Charles Curtis, it seems quite clear to me that the right of suing upon this note was in the executor, and not in Charles Curtis. Then, his conviction did not take that right out of the executor and vest it in the Crown. 'The executor became a trustee for the Crown in this note, but the interest of Charles Curtis did not pass to the Crown.

Coleridge, J. - The Wills Act does not extend the power of disposing by will, so as to change an equitable into a legal interest. Therefore, Charles Curtis must have sued on this note in the name of the executor, and the right of suing did not pass to the Crown on his conviction.

ERLE, J. and Crompton, J., concurred.

Fugigment for the Plaintiff.

\$ 90 [5I] CRIST $i$. CRIST, I Ind. 570 (I $\$ 49)$. Blackford, J. This is a suit by an executor on notes given by the defendant to the testator. The defence is, that the notes and mortgage were specifically bequeathed to one William Crist, in whose name the suit should have been brought. We have shown that the notes and mortgage are part of the personal estate of the testator, and that, supposing them to have been specifically bequeathed by him, they cannot be said to be the property of the legatee until the executor shall have assented to the legacy. No such assent being shown, the defence must fail. A debtor to an estate, where the debt has been specifically bequeathed by the testator, cannot, before the executor has assented to the legacy, say to the latter, "I will not pay you." (Bank of England v. Parsons, 5 Ves. 665.) Whether, if the executor had assented to the legacy, the suit on the notes should still not be in his name, we have not examined.'

${ }^{1}$ Property in a negotiable instrument payable to a feme sole vests upon her marriage in her husband, and he alone is entitled to maintain an action upon it or to transfer it by indorsement. Mc Neilage v. Holloway, I B. \& Ald. 218; Evans v. Secrest, 3 Ind. 545; Sutton v. Warren, ro Metc. (Mass.) 45I: Mollifild v. Wilkinson, 54 Ala. 275 . Yet it is not strictly a chattel since if he fail to reduce it to possession during coverture, it survives to the wife upon his death to the exclusion of his executors. Wilder v. Aldrich, 2 R. I. 5I8; Mll'n v. Ililkins, 3 Allen (Mass.) 32I. It is also held that the husband and wife may sue jointly on the instrument. Philliskirk v. Pluckitill, 2 .1. \& Sel. 393. The courts seem, therefore, to treat the instrument in such cases neither strictly as a chattel nor yet as a chose in action. - ED. 


\section{New YORK, 486. - I878.}

ACtion on a promissory note alleged to have been made by defendants (Hathorn \& Southgate), payable to the order of one of them (Frank H. Hathorn), and by him indorsed in blank and transferred to plaintiff. Judgment for plaintiff.

HAND, J. - In their answer, the defendants denied that the note on which the action was brought was ever transferred to the plaintiff or that he was the legal owner or holder thereof. They further denied that the plaintiff was the real party in interest; alleged that the Saratoga County Bank was the real party in interest and the owner and holder and should be the plaintiff, and that the note was duly transferred to it instead of to the plaintiff. ${ }^{1}$

Upon the trial, the plaintiff having produced the note which was payable to the order of F. H. Hathorn and indorsed in blank by him, rested. The defendants then offered to prove that the note "was not the property of the plaintiff, that the same was never transferred to him, that he was not the real party in interest, that the note was the property of the Savings Bank who is the real party in interest." The evidence was objected to by the plaintiff as immaterial and was excluded. This ruling I think was erroneous and renders necessary a reversal of the judgment.

Under the answer and this offer, the defendants unquestionably proposed to show substantially that the plaintiff had no title legal or equitable to the note, and no right as owner to its possession. This might have been done by proving that he was the mere finder or the unlawful possessor, or that the right to its possession and ownership was in the bank to whom they were liable thereon, or in some other way. This they had a right to show.

It may be that, had their offer been admitted, they would have produced in fact no evidence to sustain it or prevent a recovery, but in considering the validity of their exception to the exclusion, we must assume that the evidence would have fully covered the propositions contained in the offer. And, as remarked in the dissenting opinion in the court below, "unless the defendants are to be precluded altogether from giving any evidence of a matter confessedly issuable, I do not see how this offer could be rejected."

The cases relied upon as justifying the exclusion of the evidence do not go that length. In Cummings v. Morris $(25$ N. Y. 625), it

1" Every action must be prosecuted in the name of the real party in interest." N. Y. Code Civ. Proc., $\$ 449 \cdot-E_{D}$. 
was held that the maker of a note could not defeat the plaintiff, not a payee, by proof that the consideration of the transfer to him was contingent upon his collecting the note. Such plaintiff was declared to be the real party in interest on the express ground that the transfer was complete and irrevocably vested in him the title to the note.

In City Bank v. Perkins (29 N. Y. 554), there was no question of exclusion of evidence, but all the circumstances being proved, it was held that where the cashier of a bank holding commercial paper, pledged it "duly indorsed " to the plaintiff as security for a loan by the plaintiff to his bank, and it had been actually transmitted under his direction to the plaintiff so indorsed, it was no defence to one admitting his liability upon such paper to show lack of authority in the cashier alone to contract a loan for the bank; or the fraudulent diversion by him of the funds received from the plaintiff on such loan. Some remarks in the opinion in that case, not necessary to the decision, are perhaps too broad to be entirely approved, but it is fully conceded in it that proof that the plaintiff had no right whatever to the possession but was a mere finder or had obtained it by some "positive breach of law" would be a defence.

Brown v. Penficld ( 36 N. Y. 473), holds merely that proof, by the party liable on a bill, of gross inadequacy of the consideration for the transfer of such bill to the plaintiff does not impeach the validity of such transfer as to the party so liable.

In Allen v. Bron'n ( $4+4$ N. Y. 228 ), it was decided that, as against the plaintiff holding legal title to the claim by written assignment valid upon its face, the debtor cannot raise the question as to the consideration for such assignment or the equities between the assignor and assignee.

In Eaton v. Alger ( 47 N. Y. 345 ), the note being payable to bearer and produced by the plaintiff upon the trial, it was proved that the payee had delivered it to the plaintiff upon his undertaking to collect it at his own expense and pay to such payee upon its collection a certain sum of money. This was held to show sufficiently that the plaintiff, and not the payee, was the real party in interest under the Code.

Sheridan v. The Wayor (68 N. Y. 30 ), reiterates the doctrine that, as against the debtor, the plaintiff holding a written assignment of the claim to himself valid on its face, obtained the legal title and was the real party in interest notwithstanding the fact that the assignment was without consideration and merely colorable as between him and the original claimant. Such assignment is expressly declared to protect the debtor paying the assignee against a subsequent suit by the assignor. 
In Gage v. Kendall (I5 Wend. 640), the fact that the prosecution of the note was by its owner and holder in the name of the plaintiff, a stranger to it, without his consent or knowledge, was sought to be set up as a defence, but it was ruled out on the ground that the nominal plaintiff need have no title to or interest in the paper sued upon. We apprehend the Code has changed this and that such facts would now be fatal to an action. Such a plaintiff could not in any view be the real party in interest. Indeed, he would not ever have manual possession of the paper.

From this glance at the cases, it appears that it is ordinarily no defence to the party sued upon commercial paper, to show that the transfer under which the plaintiff holds it is without consideration or subject to equities between him and his assignor, or colorable and merely for the purpose of collection, or to secure a debt contracted by an agent without sufficient authority. It is sufficient to make the plaintiff the real party in interest, if he have the legal title either by written transfer or delivery, whatever may be the equities between him and his assignor. ${ }^{1}$ But to be entitled to sue, he must now have the right of possession and ordinarily be the legal owner. Such ownership may be as equitable trustee, it may have been acquired without adequate consideration, but must be sufficient to protect the defendant upon a recovery against him from a subsequent action by the assignor.

As we understand the scope of the offer in the present case, it went to entirely disprove any ownership or interest whatever or even right to possession as owner in the plaintiff. It should therefore have been admitted. It may be true that the plaintiff, if this note had been delivered to him with the intent to transfer title, might have lawfully overwritten the blank indorsement with a transfer to himself; it is also true that the production of the paper by him was frima facie evidence that it had been delivered to him by the payee and that he had title to it, but the defendants' offer was precisely to rebut this very presumption, and for aught that we can know the eridence under it wonld have done so.

The judgment must be reversed, and a new trial ordered, costs to abide the event.

All concur, except Miller and Earl, JJ.. absent.

Judgment reversed.

${ }^{1}$ A transfer merely to enable the transferee to sue upon the instrument is valid. Law v. Parnell, 7 C. B. N. S. 282; Whecler v. Fohnson, 97 Mass. 39; Boyd v. Corbitt, 37 Mich. 52; Beattic' v. Lett, 28 Mo. 596; Bank v. Senior, II R. I. 376 ; Walker v. Wait, 50 Vt. 668. If acting by authority of the beneficiary, 
46 Weekly Reporter (Q. B. Div.) 96. - I897.

Acrion to recover the price of goods. Defendant had accepted a bill drawn by plaintiff for the price of the goods. This was transferred to one Bullock, and while in his hands was dishonored by defendant. At the commencement of this action the bill was still in Bullock's hands, but before the trial it was delivered up to plaintiff. The trial judge gave judgment for plaintiff, on condition that the bill be handed over to defendant. Defendant appeals.

WRIGHT, J. - There are no merits in the appellant's case, but on the point of law I feel bound to agree with his contention. It is settled that where a man is sued upon a debt it is a good defence to say that he has given a bill as security for the debt and that that bill is outstanding in the hands of a third party. When this action was brought the plaintiff was not the holder of the bill, and he cannot by afterwards getting it in give himself a cause of action at the date when he commenced his proceedings.' Now that the bill is in his hands it is, of course, open to him to bring a new action; ${ }^{2}$ but in the present proceedings I think he must fail. We must, therefore, allow the appeal.

KenNeDY, J. - I agree.

Appeal allowed.'

5i California, 239. - is76.

[Reported herein at $p .268$,]

such transferee is the real party in interest. The authority may be revoked. Comstock v. Hoag, 5 Wend. (N. Y.) 600; Best v. Nokomis Bank, 76 III. 608. - Ev.

'Accord: Small v. Fones, 8 Watts (Pa.) 265; Black v. Zacharie, 3 How. (U. S.) 483. - Ev.

${ }^{2}$ Oliphant v. Church, 19 Pa. St. 318; Dickinsonv. King, 28 Vt. 378. - En.

2 A bill or note given by a debtor to his creditor for a precedent debt is presumptively only conditional payment. 2 Daniel on Neg. Inst., \& I26o (citing exceptional doctrine in Mass., Me., Vt., Ind. and La.). Such is also the weight of authority in case of the giving of debtor's bill or note for a contemporaneous debt. $16 ., \$ \mathbf{2} 26 \mathrm{I}$. There is a strong conflict of authority as to the presumption in case a stranger's bill or note is transferred for a precedent or contemporaneous debt. $1 b ., S S$ I262-1265. Whatever the presumption, it is open to rebuttal by showing an actual agreement. $I h$., $\$$ I 267 . Laches on the part of the creditor in exercising diligence to charge third parties upon paper transferred as security may discharge the original debt. Ib., \$\$ 1276-1278. - Ev. 


\section{Holder in due course.}

\section{Requisites to Constitute Holder in Due Course.}

\section{(a) Instrument must be complete and regular.}

$\S 9$ [52] Davis Sewing Machine Co. v. Best, ro5 N. Y. 59. 1887. Action to recover the value of certain notes diverted by plaintiff's president. At the time defendant purchased the notes they were complete and regular and signed by the plaintiff's treasurer, except that they were not signed by the president although a blank space with a diagonally ruled line, with the title of his office printed thereunder, was left at the foot of each instrument.

RUGER, Ch. J. - It is not seriously questioned, but that the notes were unlawfully converted by W., and that the plaintiff was entitled to recover their possession, unless the defendant became the bona fide holder thereof, by virtue of their purchase from the Security Bank.

The authorities seem to be consistent and uniform to the effect that the defendant cannot be considered such a holder.

The suggestion that a party issuing negotiable paper with blank spaces therein, apparently intended to be filled up to make a complete contract, impliedly authorizes its holder to insert appropriate words in such blanks, may be dismissed as inapplicable to such a case as this.

It has sometimes been held that a party signing such paper and delivering it to a third party unfilled by implication confers such authority, but it can hardly be claimed that one drawing the form of a promissory note which is unsigned, and falls into the hands of another, thereby authorizes the holder to attach the maker's signature or to add anything which is incomplete in its execution.

The rule that a party buying commercial paper which remains in some essential particular incomplete and imperfect, does not acquire the character of a bona fide holder, rests upon sound reasons and is well established in commercial law. No stronger evidence could be afforded that such paper had been prematurely put in circulation contrary to the will and intention of its maker, than the fact that it had not been fully and completely prepared, to perform the office for which it was designed. It is apparent that such paper must have been taken from the possession of its maker before an intention to part with it had been fully formed, and that he still designed to add some provision or formality to give it vitality and effect. It was said by the late Judge Folger in Ledzcich v. McKim (53 N. Y.307, 
3r3), that " a negotiable instrument must be a complete ana perfect instrument when it is issued, or there must be authority reposed in some one, afterwards to supply anything needed to make it perfect." The rule is also laid down in Daniel on Negotiable Instruments $(\S \S 84 \mathrm{I}, 842)$.

We cannot, therefore, hold that the Trust Company [defendant] became the bona fide holder of the seven notes. ***

(b) Instrument must not be overdue, ete

$\S 9$ I

O'CALLAGHAN ‘. SAWYER.

5 Johnson (N. Y.) II 8. - rSog.

ACtion by indorsee against maker. Defendant offered to prove a set-off for goods sold the payee before the transfer to plaintiff. The court rejected the evidence although, at the time of the transfer, the note was overdue.

PER CURiam. The set-off ought to have been received. The note had long been due and dishonored, when it was indorsed; and the point has been too long settled, and too repeatedly recognized, to require any discussion now, that the indorsee took the note, subject to all the equity, and to every defence which existed against it, in the hands of the original payee. (2 Rev. Stat. 354; 2 Caines, 372 ; I Johns. Rep. 319; 3 Term Rep. So.) The judgment below must be reversed.

Judgment reversed.

\section{\$r CONTINENTAL NATIONAL BANK $\%$ TOWNSEND.}

87 NEW YORK, S. - 1881 .

Action by indorsee against accommodation maker. Defendant offers to prove off-set against payee-indorser. On the last day of grace the note was inclorsed to plaintiff as collateral security for a pre-existing debt. Evidence excluded. Judgment for plaintiff.

Finch, J. - The principal question on this appeal has been decided in this court adversely to the views of the appellant. In the Grocers' Bank v. Penficld ( 69 N. Y. 502 ), we determined. after a very full examination of the authorities, that where a promissory note is made for the accommodation of the payee, but without restriction as to its use, an indorsee taking it as collateral security for an antecedent 
debt of the indorser, without other consideration, but in good faith and before dishonor, occupies the position of a holder for value and is protected as such. ${ }^{1}$

That doctrine decides this case, unless there be something in the further point sought to be raised out of the fact that the note was transferred on the last day of grace. The court was asked to find as matter of fact that the transfer was not before maturity, and refused so to find. The refusal was correct. The rule must be deemed settled in this state that the maker has the whole of the last day of grace within which to pay, and that any earlier action against him is premature. (Osborn v. Moncure, 3 Wend. r7o; Hopping v. Quin, r2 Id. 5r7; Cavuga Co. Bank v. Hunt, 2 Hill, 635; Simith v. Aylesworth, 40 Barb. I04; Oothout v. Ballard, +1 Id. 33.) While a different rule prevails elsewhere to some extent (Story on Prom. Notes, 278, note 2; Sargent v. Southgate, 5 Pick. 312; Ayer v. Hutchins, 4 Mass. 370; Pine v. Smith, I I Gray, $3^{8}$ ), the current of authority in this State is very manifest, and we can see no just reason for doubting it, or cleparting from it. Although this note was transferred on the last day of grace, it was yet transferred before actual dishonor, and so as to bar the equities sought to be interposed.

The judgment should be affirmed, with costs.

All concur. Judgment affirmed.

Action against indorser, of eight notes, each in the following form:-

$\$ 500.00$

NoRTHField Fanuary I5th, I858.

Eight months after date, we promise to pay to the order of James A. Dorr, five hundred dollars, at No. 34 Pine street, New York City.

The Northfield Brick Company, By James A. DORR, Treasurer.

[Indorsed]: Protest waived, JAMes A. Dorr.

Dorr indorsed the notes solely for the accommodation of one Myers, a creditor of the brick company, and without consideration. Some two or three years after the maturity and dishonor of the notes Myers transferred them to plaintiff. 
Woodruff, J. - Mr. Justice Story, in his treatise on Promissory Notes (section I $_{7} 8$ ), thus states the difference between the legal effect of the transfer of a promissory note, before and after maturity:

"If the transfer is made before the maturity of the note, to a bona fide holder, for a valuable consideration, he will take it free of all equities between the antecedent parties, of which he has no notice.

If the transfer is after the maturity of the note, the holder takes it as a dishonored note, and is affected by all the equities between the original parties, whether he has any notice thereof or not. But, it is not to be understood by this expression, that all sorts of equities existing between the parties, from other independent transactions between them, are intended; but only such equities as attach to the particular note, and as between those parties, would be available to control, qualify or extinguish any rights arising thereon."

The learned author gives this as the final conclusion, from the numerous cases cited by him, an examination of which shows, that it is only after some difference of opinion that it has come to be deemed settled. Or, as Mr. Chitty says, of the opinion of Buller and Ashhurst, JJ., in Brown v. Dazis ( 3 T. R. So), expressed, when Lord Kenyon doubted its broad extent, "this latter opinion is now the law." That opinion was to the effect:

"That where a note is overdue, that alone is such a suspicious circumstance, as makes it incumbent on the party receiving it, to satisfy hinself that it is a good one, otherwise much mischief might arise." "If a note indorsed, be not due at the time, it carries no suspicion whatever on the face of it, and the party receives it on its own intrinsic credit. But if it is overdue, though I do not say that, by law, it is not negotiable, yet, certainly it is out of the common course of dealing, and does give rise to suspicion. . . Generally, when a note is due, the party receiving it, takes it on the credit of the person who gives it to him."

The foundation of the rule, which distinguishes commercial paper from ordinary common-law choses in action, is in harmony with the law thus stated; the holder of the former is protected against any inquiry into its previous history, and is warranted in giving it full faith, according to its tenor, because commercial convenience and the importance of the free and unembarrassed use of commercial credits required it; and on this, the mercantile customs, which ripened into the law merchant, were founded. These reasons, however, could have no application to paper which had been dishonored. The credit it was adopted to invite is spent, and the very fact of dishonor is inconsistent with the purposes which the rule was intended to subserve.

The rule is simple and convenient of application, is in no sense 
inconsistent with the usefulness of negotiable paper for the purposes for which it is intended, and, as it seems to me, is a just security against mischief and fraud.

In the terms in which it is above stated it includes the defence of want of consideration, whenever that renders the note invalid in the hands of him who holds it, when it becomes due. Such want of consideration is an inherent defect in the contract itself. Or, in the language of the rule, attaches to the note itself, in the hands of one for whose accommodation a note is made, and does not, like a setoff or other collateral matter apart from the note, arise out of an independent transaction.

But the same learned writer, above referred to, states that the mere fact that an accommodation note has been indorsed after it became due, does not of itself, without some other equity in the maker, defeat a recovery by the indorsee. (Story, \$ r94.) And Mr. Chitty states that it has been so decided. The cases of Charles v. Marsden (I Taunt. 224); Sturtezant v. Ford (4 Man. \& Gr. ror); 4 Scott, 6o8, and Caruthers v. West (I I Q. B. I 43), are in support of the proposition.

These are the cases upon the authority of which the present case was decided below.

I am constrained to say that I am not satisfied that such an exception to the rule is either just or called for by any principle; nor am I at all convinced by the reasons assigned for the exception.

That the maker or indorser of a note for the accommodation of another should be held to the terms of his own indorsement according to their just interpretation, I fully agree. That one who receives such paper before maturity, should not be affected by the mere fact that it was made or indorsed without consideration, I equally agree. That when a party lends his note or indorsement to another without restriction as to its use, he authorized the negotiation thereof in any manner which may serve the convenience or credit of the borrower, may be conceded.

From this latter concession it is argued, that such a lending of one's name is furnishing a continuing guarantee of the payment of the note, irrespective of its terms as to time of payment, and is therefore binding whenever it is transferred, and however long after it has become payable and been dishonored. That the absence of express restriction warrants the inference, that the making or indorsement was to enable the borrower to use it whenever thereafter it suited his pleasure, and so "enforcing its payment is in accordance with the object for which the note was, as matter of accommodation, made or indorsed;" and in the discussion in England, it has been 
suggested, that supposing an accommodation acceptance to remain in the hands of the party accommodated, it may be treated as giving authority by implication to use it thereafter, as his convenience or needs may require.

In respect to the last suggestion, two observations are pertinent; first, it begs the question, for assuming the rule to be that he who receives the note or bill, after dishonor, acquires no better title to recover thereon than he has from whom it was received, then there is no reason why the accommodation maker or indorser should not treat the note in the hands of the borrower, after maturity, as functus officio, and inere waste paper. And, second, how is the maker or indorser, in such case, to withdraw his note or indorsement? Is he to be driven into a court of equity, and to praying out an injunction, to prevent a subsequent transfer? I think not. Take the present case; the note itself was the property of the holder at its maturity (Myers), and was a valid note. in his favor against the maker. The indorsement of the defendant (the appellant's testator) was material as a transfer of title, although, being made for Myers' accommodation, it could not be enforced against such defendant as indorser. I cannot agree that it was incumbent on the defendant to go into a court of chancery to compel Myers to suffer a writing of the words, "without recourse," or an equiralent expression, as a qualification of such indorsement.

As to the other reason, it is even less satisfactory, because it proceeds, I think, upon an entire misconstruction of the act of making or indorsing a note for the accommodation of another. Its purpose and object, is to obtain credit for such other, or to enable him to do so. The very terms of the note declare the credit it is intencled to procure, that is to say, until the maturity of the note. Within that range, the making or indorsement being unrestricted as to its use, the borrower may use it as his exigencies require, and a transferee may receive it in reliance upon the undertaking which is imported by its terms.

But the very term of payment, contained in the note, imports that the accommodation party undertakes that the note shall be paid at its maturity; and that he who then holds the note, shall have recourse to him, if it be not then paid. Where the accommodation (as in the present case) is by indorsement, that is the precise contract, viz., that the note shall be paid at maturity, and not that it shall be paid at any future time. If the note be not pand at maturity, the contract is broken, and if he who then holds it can recover thereon, then his right of recovery may be transferred to another; and the recovery of the latter will be, not because the accommodation 
indorser undertook that the note should be paid to him, or should be paid at some date after it was due, but because a valid cause of action, existing in favor of the holder at maturity, has been transferred to him.

It is not according to the intent or meaning of an indorsement for another's accommodation, to say that the indorser intends to give the use of his credit for any other period than that limited in the note; or that such an indorsement imports authority to use it, when that period has elapsed.

One may be willing by indorsement, to guarantee the solvency of another for sixty days, or for six months, and yet he would wholly refuse to do so for a period of two years. And accordingly, when such accommodation is given, it is a most material circumstance that the time during which the borrower is at liberty to obtain credit on the note, is fixed by the limitation of the time of payment therein.

I deem the just view of the subject to be, that when a note has become due and is dishonored, the rights and responsibilities of the parties thereto are fixed. The note then loses the chief attribute of commercial paper. It is no longer adapted to the uses and purposes for which such paper is made, and in respect of which it is important that it should circulate freely. And thereafter, he who takes it, takes it with knowledge of its dishonor, with obvious reason to believe that there exists some reason why it was not paid to the holder; and takes it with just such right to enforce it as such holder himself has, and no other.

In thus stating my views, I am not insensible of the apparent authority for the decision macle below, but I am also aware that the judges in England have not been at all agreed upon the subject, and have expressed doubt of the correctness of the decision in Charles v. Marsden, upon which the other two cases above referred to were decided. The cases, largely collected in the notes to Chitty in the recent edition, warrant, I think, the dissatisfaction I have expressed.

No case in this State has called for a decision of the question; and yet in Brown v. Mott (7 J. R. 36I), and in Grant v. Ellicott (7 Wend. 227), the case of Charles v. Marsden is referred to without disapprobation, and the proposition to be derived therefrom is stated; but in neither case was the point now raised before the court, for in neither did it appear, that the plaintiff took the note after it became due.

And that in other States in this country, such an exception to the general rule first above stated is repudiated, see Brozen v. Hastings (36 Penn. 285); Britton v. Bishop ( I Vt. 70); Odiorne v. Howard ( $о$ N. H. 343); Cummings v. Little (45 Maine, 183 ); Vinton v. King (86 Mass. 4 Allen, 563); Kellogg v. Barton (94 Mass. 22 Allen, 527). 
And the general proposition, that he who takes a note when overdue, takes it subject to all defences inherent in the note, or arising out of any agreement with the holder, expressed or implied, and relating thereto, or in another form, that such an indorsee obtains no greater or other rights than his indorser had in it at the time of the indorsement, has been stated as law in cases almost without number. It will, perhaps, suffice to refer to two from the Supreme Court of the United States. Andrew's v. Pond (i 3 Pet. 79), says of the indorsee of a dishonored bill: "If he chooses to receive it, he takes it with all the infirmities belonging to it; and is in no better condition than the person from whom he received it." (Fowler $\mathrm{v}$. Brantley, 14 Pet. 32r.) "A note overdue or bill dishonored is a circumstance of suspicion to put those dealing for it afterward on their guard, and in whose hands it is open to the same defences it was in the hands of the holder when it fell due. After maturity, such paper cannot be negotiable 'in the due course of trade,' although still assignable." See also Folcy v. Smith (6 Wallace, 492.)

In my own opinion, the just rule, and the rule resting on the soundest principle, requires us to reverse. The supposed exception to the general rule rests on neither reason, nor as I think on authority, certainly not in this country.

It was suggested by the counsel for the respondent, that as matter of fact, the defendant's indorsement was not without consideration, and for the accommodation of Myers, who heid the note at maturity.

The finding of the referee on that subject is conclusive in this court; and that finding is, that the indorsement was made without consideration at Myers' request, and to enable Myers to use the notes. This is but a statement that the defendant indorsed the notes for the accommodation of Myers. It was so treated in the court below, and it is an unwarranted assumption to say, that possibly the defendant had some other inducement to inclorse the notes, in order that the plaintiff might accept the notes, and give credit to the maker thereof, who was his debtor.

Murray, J., also read an opinion for reversal.

Grover, Lott, James and Daniels, J J., concurred for reversal.

Mason, J., thought the law settled in this State in favor of the plaintiff, by the cases (7 Johns. $3^{61} ; 7$ Wend. 227; and 1 Hill, 513), and was for affirmance.

Hunt, Ch. J., was also for affirmance. He clid not approve of construing the defendants' contract as conditioned upon transfer before due.

Judgment reversed.'

Accord: Battle v. Wems, 44 Ala. 105 (but cf. Connerly' P'lanters', etc., Insul- 
45 Wisconsin, rro. - I 878.

Action to foreclose a mortgage. Defence, payment to plaintiff's assignor. When plaintiff purchased the note and mortgage the note was not yet due, but instalments of interest were overdue and unpaid. Judgment for defendants. Plaintiff appeals.

Cole, J. - Can the plaintiff, under the circumstances, claim the protection which the law affords a bona fide purchaser of commercial paper for value, before maturity? The learned circuit court, in obedience to the decision of this court in Hart v. Stickney (4I Wis. 630 ), decided that the plaintiff took the note and mortgage as dishonored and subject to equities, because instalments of interest were due and unpaid when they were transferred. If there is error in this ruling of the court below - as we are well satisfied there is, - it is an error for which this court, and not the circuit court, should be held responsible. When the case of Hart $\mathrm{v}$. Stickney was decided, our attention was not called by counsel, and we entirely overlooked in our examination, the previous case of Boss v. Hezitt, in the 15 Wis. 260, where a directly opposite ruling was made. The case of Boss v. Hezwitt was decided in $\mathbf{r} 862$, and the point was directly involved in the judgment. The defendant had given four negotiable notes payable respectively in one, two, three, and four years, with interest payable annually, for the price of sheep bought of the payees, and secured all the notes by a mortgage. One of the notes, and an instalment of interest on all of them, being due and unpaid, the payees transferred the notes and mortgage to the plaintiff, who brought an action to foreclose the mortgage. The defendant pleaded fraud on the part of the payees in the sale of the sheep. The court held that the fact that the first note was due and unpaid at the time of the transfer to the plaintiff, did not let in the defence as against the notes not then due. On the other point, Mr. Justice Paine, in delivering the opinion of the courl, says: "Neither do we think that the fact that the interest had not been paid makes the case equivalent to a purchase after maturity, so as to let in defences that might have been made against the original parties. The interest is a mere incident to the debt, and although it is frequently provided that it shall be paid at stated periods before the principal falls due, we know of no authorities holding that a failure to pay it dis-

ance Company, 66 Ala. 432); Bacon v. Harris, I5 R. I. 599; Cottrell v. Hatkins, 89 Va. 80I; cases cited in principal case. But see Niller v. Larned, I03 Ill. 562; Seyfort v. Edison, 45 N. J. L. 393; Sale'm Bank v. Grant, 7 I Me. 374. - ED. 
honors the note, so as to let in all defences against subsequent purchasers for value without any other notice of defects except the mere fact that such interest has not been paid. And we do not think it should have that effect. The maturity of the note, within the meaning of the commercial rule upon this subject, is the time when the principal becomes due," pp. 262-3. Boss v. Hewitt derives direct support from the decisions in National Bank of North America r. Kirby (ro8 Mass. 497), and Cromiell v. County of Sac (96 U. S. 5r). It is true, in National Bank r. Kirby, while it was held that failure to pay interest, standing alone, was not sufficient in law to throw such discredit upon the principal security upon which it is due, as to subject the holder to the full extent of the security, to antecedent equities, yet it was also held that it was a fact proper to be considered by the jury, in connection with other circumstances, on the question whether the holder is entitled to the protection of one who has taken it in good faith and without actual or constructive notice of existing defences. What is said in the opinion in Hart $\mathrm{v}$. Stickncy upon the point now in question was not necessarily involved in the decision, and must therefore be regarded as a mere dictum. The judgment in that case was reversed on the appeal of the plaintiff, the holder of the note, on the ground that the trial court refused proper, and gave erroneous, instructions as to the legal consequences resulting where a vendee abandons possession of premises held by him under an executory contract of sale, and the vendor takes the possession. That was the precise point upon which the judgment was reversed. And as the earlier case of Boss v. Heailt was entirely overlooked, which, by implication, is sustained by many decisions of this court, made in the farm mortgage cases and in actions arising upon town, county and city bonds, we deem it our duty to adhere to the rule, that a purchaser for value of unmatured commercial paper, with interest overdue, is not, from that fact alone, affected with notice of prior equities or infurmities in the title.

[The court then holds that the plaintiff was a bona fide holder; the indorsement " without recourse," is not enough to charge a purchaser with notice of a defence or to put him on inquiry; nor were the other facts alleged enough for that purpose.]

By the Court. - The judgment of the circuit court is reversed, and the cause remanded with directions to enter such a judgment [for plaintiff]. 


$$
7 \text { Johxson (N. Y.) 70. - } 1810 .
$$

In ERROR, from the Court of Common Pleas of Dutchess county.

The suit below was an action of assumpsit on a promissory note given by the defendant to David Newton, payable on demand, to Newton or bearer, for the sum of 55 dollars, with interest, and dated the r6th day of January, I805. An assignment in writing from Newton to the plaintiff, dated April 3, I805, was indorsed on the note. The declaration was in the usual form, on the note. Plea, non assumpsit.

The defendant proved, that shortly after the date of the assignment, he paid Newton 50 dollars, which he agreed to credit on the note.

The plaintiff's counsel contended, that this evidence was inadmissible, on the issue of non assumpsit; but the court ruled, that it should be admitted; and the jury found a verdict for the plaintiff for six dollars and seventy-five cents; and judgment was given for the plaintiff for that sum, and for the defendant, for the costs.

PER CURIAM. - The note was payable on demand, and negotiated upwards of two months and a half after it was given. The first question that naturally arises is, whether this is to be considered as a note negotiated after it was due, so as to let in the defence. There is no precise time at which such a note is to be deemed dishonored. In Furman v. Haskin ( 2 Caines, 369), a note payable on demand, and negotiated eighteen months after it was given, was considered as a note out of time, so as to subject the indorsee to the matter of defence existing when it was indorsed. On the other hand, in $H_{c} n$ dricks v. Judah (I Johns. Rep. 319), the note was payable on demand, and drawn in England, and was put in suit in this State by the indorsee within a year from its date, and the court said that the maker was not entitled, in that case, to a set-off of demands against the payee, without proof of a fraudulent assignment, for it was to be presumed that the note was assigned soon after its date. The demand must be in reasonable time, and that will depend upon the circumstances of the case, and the situation of the parties. There are no particulars peculiar to this case disclosed; and the court cannot say that it was erroneous to let in the defence, for the circumstances of this case might have been such as to justify the conclusion that the note was dishonored when it was assigned.

Assuming this to have been the case, there is no doubt but that the defendant might give in evidence, under the general issue, payment to the original payee before the indorsement. (Brown v. 
Dawis, 3 Term Rep. So; Brown v. Cornish, I Ld. Raym. 2ri.) If the payment was in full discharge of the note, it would go in bar of the suit; and if it was not a payment in full, it will go only in mitigation of damages.

The judgment below must, therefore, be affirmed.

Judgment affirmed.'

(c) Must be taken in good faith and for value.

$\S 9$ I

DE WITT $\%$ PERKINS.

22 WisCONSIN, 473. - IS6S.

Action on defendant's promissory note. The jury, by direction of the court, found for the plaintiff; and the defendant appealed from the judgment. The questions in dispute will sufficiently appear from the opinion.

Dixos, C. J. - The plaintiff, knowing the defendant, and that he was in fair credit and able to respond, purchased, shortly before its maturity, a promissory note against him for three hundred dollars and interest for six months, paying therefor only the sum of five dollars. As between the defendant and the payee, the note was invalid for want of consideration. Is the plaintiff a bond fide holder for value, so as to protect him against the defence of a want of consideration? We answer, no. The consideration paid by him was merely nominal. It is as if the note had been given to him, and he should claim the protection afforded a bona fide holder for value. It appears on the face of the transaction that it was not a negotiation of the note in the usual course of business, but that the sum exacted on the one side and paid on the other was to give that the semblance of a sale, which otherwise was intended as a mere gift, or, what is worse, a shift to get the note out of the hands of the payee so as to cut off the defence of the maker, for the payee's benefit. Either view is equally fatal to the action of the plaintiff, provided the defence of a want of consideration is established.

" On this question the authorities are not uniform, but no case slows that more than three months can reasonably be overlooked. Business paper would usually be adjusted within that time, if regular." Paine v. Cintral r\%. K., it Fed. Rep. 269, 27r. See the whole matter as between holder and maker and between holder and indorser (host, $S \mathrm{I} 3 \mathrm{I}[7 \mathrm{r}]$ ), and as to demand notes payable with interest and like notes payable without interest, discussed in I/cricks. Woolverton, 4I N. Y. $5^{8 \mathrm{I}}$. - EI). 
Again, the buying of a note against a solvent maker, the purchaser knowing him to be such, for a mere nominal consideration, is very strong, if not conclusive, evidence of mala fides. It is constructive notice of the invalidity of the note in the hands of the seller - such as to put the purchaser upon inquiry, which if he fails to make, he acts at his peril. (Brozin v. Taber, 5 Wend. 566 ; Matheze's v. Poythress, $4 \mathrm{Ga} .287$, 299 et seq., and cases cited; Anderson v. Nicholas, 28 N. Y. 600; Whitbread v. Jordan, I Younge \& Collyer [Exch.], 303, 328; Jones $\%$. Smith, I Hare, 68; r Parsons on Notes and Bills, $254,259-60$.) The proof offered to show a failure of consideration should have been received, and the case submitted to the jury on this ground.

[Omitting a question of evidence.]

By the Court. - Judgment reversed, and a new trial awarded. ${ }^{1}$

\section{R. 2 Appeal Cases, 616. - IS77.}

FARTHER, my Lords, I think it is right to say that I consider it to be fully and thoroughly established that if value be given for a bill of exchange, it is not enough to show that there was carelessness, negligence, or foolishness in not suspecting that the bill was wrong, when there were circumstances which might have led a man to suspect that. All these are matters which tend to show that there was dishonesty in not doing it, but they do not in themselves make a defence to an action upon a bill of exchange. I take it that in order to make such a defence, whether in the case of a party who is solvent and sui juris, or when it is sought to be proved against the estate of a bankrupt, it is necessary to show that the person who gave value for the bill, whether the value given be great or small, was affected with notice that there was something wrong about it when he took it. I do not think it is necessary that he should have notice of what the particular wrong was. If a man, knowing that a bill was in the hands of a person who had no right to it, should happen to think that perhaps the man had stolen it, when if he had known the real truth he would have found, not that the man had stolen it, but that he had obtained it by false pretences, I think that would not make any difference if he knew there was something wrong about it and took it. If he takes it in that way he takes it at his peril.

1 Accord: Smith v. Jansen. I2 Neb. 125 (\$100 for \$30); Hunt v. Sandford, 6 Yerg. (Tenn.) 387 (\$333.33 for \$125); Gould v. Stevens, 43 Vt. I25 (\$300 for \$50). - En. 
But then I think that such evidence of carelessness or blindness as I have referred to may with other evidence be good evilence upon the question which, I take it, is the real one, whether he did know that there was something wrong in it. If he was (if I may use the phrase) honestly blundering and careless, and so took a bill of exchange or a bank-note when he ought not to have taken it, still he would be entitled to recover. But if the facts and circumstances are such that the jury, or whoever has to try the question, came to the conclusion that he was not honestly blundering and careless, but that he must have had a suspicion that there was something wrong, and that he refrained from asking questions, not because he was an honest blunderer or a stupid man, but because he thought in his own secret mind - I suspect there is something wrong, and if I ask questions and make further inquiry, it will no longer be my suspecting it, but my knowing it, and then I shall not be able to recover - I think that is dishonesty. I think, my Lords, that that is established, not only by good sense and reason, but by the authority of the cases themselves.

I think, my Lords, that since the repeal of the Usury Laws we can never inquire into the question as to how much was given for a bill, and if Searby was in such a position that he could have proved against the estate it would have been no objection at all that he conveyed these bills to another for a nominal amount, that he sold bills nominally amounting to $£ \mathrm{I}, 727$ for $£ 200$. Although I think that could not have been inquired into, yet the amount given in comparison with the apparent value is an important piece of evidence guiding us to a conclusion as to whether or not it was a bona fide transaction. I am sure of this, that in criminal cases the general evidence that is given to show that the receiver of goods which were stolen knew that they were stolen is that he has given a great under value for them. That is not by any means conclusive, because it may very well be that he has given the undervalue under circumstances which do not suffice to prove that he had a felonious intention, or a felonious knowledge, which would be required to make him guilty. In like manner, $I$ think if it is shown that a considerable unclervalue was given for bills, although that alone would probably not be sufficient, it is an element, and an important element, in considering whether the man who gave that undervalue was bona fide doing it because he was in honest blundering and stupidity taking the thing without knowing that he was committing or assisting in fraud, or because he had a suspicion that he would deprive himself of a good bargain if he made too much inquiry and so had it brought home to him that there was fraud. 


\section{(d) Must be taken without notice of infirmity or defect.}

$\$ 95$ [56] Goodman $v$. Harvey, 4 Adolphus \& Ellis, 870. - I836. Lord Denman, C. J. - The question I offered to submit to the jury was whether the plaintiff had been guilty of gross negligence or not. I believe we are all of opinion that gross negligence only would not be a sufficient answer, where the party has given consideration for the bill. Gross negligence may be evidence of mala fides, but is not the same thing. We have shaken off the last remnant of the contrary doctrine. ${ }^{1}$ Where the bill has passed to the plaintiff without any proof of bad faith in him, there is no objection to his title. The evidence in this case as to the notarial marks ${ }^{2}$ could only weigh as rendering it less likely that the bill should have been taken in perfect good faith. ${ }^{3}$

34 New Jersey Law, I87. - I87o.

Beasley, Chief Justice. - We have presented to our consideration in this case but a single question, viz., whether the title of a holder of negotiable paper, acquired before it was due, for a valuable consideration, is affected by the fraud of a prior party, without proof of bad faith on the part of such holder.

At the trial of this cause, the jury was instructed that if the holder of the note sued on - the plaintiff in the action - acquired his title under circumstances which should have put a person of ordinary prudence upon his guard, the note was invalid, if its inception had been fraudulent.

The verdict was in favor of the defence, and the plaintiff now insists that the judicial instruction should have been, that suspicious circumstances attending the acquisition of his title were not sufficient to defeat his claim, unless of a character to raise a conviction of actual fraud on his part.

${ }^{1}$ The contrary doctrine was held in the earlier cases of Gill v. Cubitt, 3 B. \& C. 466 (1824) and Crook v. Jadis, 5 B. \& Ad. 909 (1834). - ED.

${ }^{2}$ Ordinarily the presence of notarial marks of dishonor on the paper is constructive notice, but the facts of this case were such as to involve only the question of actual notice, or bad faith. - ED.

${ }^{3}$ The doctrine of this case, that negligence however gross is not equivalent to notice, but is merely evidence of bad faith, is now generally followed in the application of the law of notice to the purchase of negotiable paper. See the matter fully discussed and Goodman v. Harvey approved in Goodman v. Simonds (2n How. [U. S.] 343); Scybel v. National Currency Bank (54 N. Y. 288), and Phelan v. Moss (67 Pa. St. 59). - Ed. 
Counsel who so ably argued this case in behalf of defendant, did not deny that the modern English authorities were hostile to their position, but they went upon the ground that the rule thus sanctioned was an innovation, and consequently would not be followed by this court. The ancient rule, it was maintained, is that declared in Gill v. Cubitt (3 Barn. \& Cress. 466). This decision was made in the year 1824 , and, beyond all question, it sustains the principle now claimed by the defence, for in the reported case referred to the jury were explicitly told that "there were two questions for their consideration: first, whether the plaintiff had given value for the bill, of which there could be no doubt; and, secondly, whether he took it under circumstances which ought to have excited the suspicions of a prudent and careful man." The authority is directly in point, and the only question which can arise is, whether it correctly states the ancient rule of the common law upon the subject.

My first remark in this connection is, that from the opinion of the judges in the case of Gill v. Cubitt, it appears that the doctrine adopted was intended to be an innovation upon the antecedent practice, and that it was avowedly opposed to a decision of the greatest weight. Twenty-three years before, in the year $180 \mathrm{r}$, Lord Kenyon, in Lawson v. Weston (4 Esp. 56), had expressly repudiated the idea that suspicious circumstances, in the absence of actual fraud, would avoid a note in the hands of a holder for value. But this doctrine did not harmonize with the views of the judges in the case of Gill v. Cubitt, and it was accordingly overruled. Thus, Chief Justice Abbott says, in his opinion: "I think the sooner it is known that the case of Lawson $r$. II eston is cloubted, at least by this court, the better. I wish doubts had been cast on that case at an earlier time." And he concludes: "For these reasons, notwithstanding all the unfeigned reverence I feel for everything that fell from Lord Kenyon, by whom Law'son r. II eston was lecided, I cannot think that the view taken by that learned lord was a correct one." Nor is this rejection of this antecedent decision attempted, in the slightest degree, to be put upon the foundation of pre-existing authority. Not a case is referred to for its justification, and although in Lazison $\mathrm{v}$. Weston, the authority of Lord Mansfield, in Miller $r$. Race, was mooted, no remark is made on that circumstance. I think a perusal of the opinions in Gill r. Cubitt will satisfy anyone that it was a wellunderstood intention to deviate from the legal rule upon this subject which had previously existed; or, if any doubt should remain, such doubt will certainly be dispelled by a reference to the case of Slater v. West (3 Carr \& Payne, 325), decided in the year 1828 , in which Chief Justice Abbott (then Lord Tenterden), in laying down the

NEGOT. 1NSTRUMENTS - 26 
doctrine that a person is not entitled to recover who takes a bill of exchange " under circumstances which ought to excite suspicions in the mind of a reasonable man," says: " This doctrine is of modern origin. I believe I was the first judge who decided this point at nisi prius. The court to which I belong confirmed my decision, and the other courts have, I believe, acted on the same principle." And Chief Justice Bayley, in his opinion in Gill v. Cubitt, is equally explicit. " But, it is said" - such is his language - " that the question usually submitted for the consideration of the jury in cases of this description, up to the period of time at which my Lord Chief Justice's direction was given, has been whether the bill was taken bona fidc, and whether a valuable consideration was given for it. I admit that has been generally the case."

From these citations, I think it is manifest that the judges who participated in the decision of the case of Gill v. Cubitt were aware that by the views expressed by them, they introduced a novelty, and departed from the older practice of the courts. That the principle adopted in that case was an innovation, seems to me unquestionable. I have shown that it is irreconcilable with Lar'son v. Weston. So it plainly occupies the same relation to the case of Pcacock v. Rhodes (Doug. 632), decided by Lord Mansfield in $\mathbf{z} S_{\mathbf{I}}$. The rule which it endeavors to overthrow will be found sustained in Miller v. Racc (1 Burr. 452); Price Neal (3 Burr. I355); Grantv. Vaughn (3 Burr. 1516); Anonymons ( 1 Lord Raymond, 738); Morris v. Lce (2 Lord Raymond, 1396.) There was not a case cited upon the argument, nor have my researches led me to one anterior to the decision of Gill v. Cubitt, which sustains the doctrine there propounded. I confidently conclude, therefore, that the case above criticised cannot stand on the ground of ancient authority. In my apprehension, the original rule as it existed in the time of Lords Kenyon and Mansfield was, that nothing short of mala fudes would vitiate the title of the holder of negotiable paper taking it for value, before maturity. It is entirely out of the question, therefore, for this court to regard Gill v. Cubitt as imperative authority. It is true that that case was followed for a time to a considerable extent by the English courts. But, as I have already said, in England the original rule has been reinstated. In Backhouse v. Harrison (5 B. \& Ad. Iog\$), Mr. Justice Patterson says: "I have no hesitation in saying that the doctrine first laid down in Gill v. Cubitt, and acted upon in other cases, has gone too far and ought to be restricted." And in Goodman v. Marrel' (4 Ad. \& El. 870), Lord Denman thus forcibly expresses the rule at present prevailing in the courts at Westminister: "The question I offered to submit to the 
jury was, whether the plaintiff had been guilty of gross negligence or not. I believe we are all of opinion that gross negligence only would not be a sufficient answer where the party has given consideration for the bill. Gross negligence may be eridence of mala fudes, but it is not the same thing. We have shaken off the last remnant of the contrary doctrine. Where the bill has passed to the plaintiff without any proof of bad faith in him, there is no objection to his title." The following cases recognize and enforce the same rule: (Uther $\because$. Rich, ro Ad. \& El. $7 S_{4}$; Arthouin v. Andersen, I Ad. \& E1. (N. S.) 498 ; Stcphens v. Fostcr, I Cromp., Mees. \& Ros. S94; Palmer v. Richards, I Eng. L. \& Eq. 529; Marston v. Allen, \& Mees \& Wels. 494; Raphacl v. Bank of England, i 7 C. B. r6r.)

An examination of the American reports will disclose a similar mutation of judicial opinion upon this subject. For a time, in several of the States, the rule broached in the case of Gill v. Culbitt has been acted upon; but now, in most of them, and in those of the most commercial importance, that rule has been entirely discarded. (34 New York, 247, Magee v. Badger; 7 Bosworth, 543, Bcl. Bank of Olizo v. Hoge ct al.; ro Cush. 488 , Horcester, ctc, Bank v. Dorchester, etc., Bank; 4 Geo. 287, Mathez's v. Poythess; 6 MId. 509, Ellicott $\checkmark$ Martin; $3^{6}$ New Hamp. 273, Croslyv v. Grant.)

The subject has also recently been settled, after an elaborate discussion and full consideration in the Supreme Court of the United States, in the case of Goodman w. Simonds (20 How. 343), the result being an explicit repudiation of the doctrine that suspicious circumstances will, per se, vitiate the title to commercial paper.

From this brief review of the cases, I think it may be safely said that the doctrine introduced by Lord Tenderden stands at the present moment marked with the disapproval of the highest judicial authority. Nor does such disapproval rest upon merely speculative grounds. That doctrine was put in practice for a course of years, and it was thus, from experience, found to be inconsistent with true commercial policy. Its defect - a great defect, as I think-was, that it provided nothing like a criterion on which a verdict was w be based. The rule was, that to defeat the note, circumstances must be shown of so suspicious a character that they would put a man of ordinary prudence on inquiry - and by force of such a rule it is obvious every case possessed of unusual incidents would, of necessity, pass under the uncontrolled discretion of a jury. An incident of the transaction from which any suspicion could arise was sufficient to take the case out of the control of the court. There was no judicial standard by which suspicious circumstances could be measured before committing them to the jury. And it is precisely 
this want which the modern rule supplies. When mala fides is the point of inquiry, suspicious circumstances must be of a substantial character, and if such circumstances do not appear, the court can arrest the inquiry. Under the former practice, circumstances of slight suspicion would take the case to the jury; under the present rule, the circumstances must be strong, so that bad faith can be reasonably inferred. Thus the subject has passed from the indefinite to comparatively definite; from the intangible to the comparatively tangible. From a mere matter of fact, the question, to some extent, has become one of law.

I cannot doubt, when we recollect that inquiries of this nature always attend that class of cases where judgments are sought against innocent and unfortunate parties, that the change is most beneficial. All experience has shown how hard it is to prevent juries from seizing on the slightest circumstance, to avoid giving a verdict against the maker of a note which had been obtained by fraud or theft. To preserve the negotiability of commercial paper and guard the interests of trade, it is absolutely necessary that large power should be placed in the judicial hand when the question arises as to what facts are sufficient to defeat the claim of the holder of a note or bill which has been taken before maturity, and for which value has been paid. It is only in this mode that the requisite stability in transactions of this kind can be retained.

But I do not think the difference between the two rules above discussed is as great as some persons have supposed. In my apprehension, the entire variance consists in the degree of proof which the court will require in order to submit the inquiry to the jury. Mere carelessness in taking the paper will not, of itself, impair the title so acquired; but carelessness may be so gross that bad faith may be inferred from it. Nor is it necessary, in order to defeat the title of the holder, that he have actual knowledge of the facts and circumstances constituting the particular fraud; it is sufficient if he have knowledge that the paper is tainted with any fraud, although he may be ignorant of the nature of it. In the case of May' v. Chapman (i6 Mees \& W. 355), Baron Parke says: "I agree that "notice and knowledge ' means not merely express notice, but knowledge, or the means of knowledge, to which the party wilfully shuts his eyes." Reviewed in this sense, as I have already remarked, the principle seems to me a highly salutary one, and, in the language of Professor Parsons, is well "adapted to the free circulation of negotiable paper and the true interests of trade." (I Par. B. \& N. 259.)

I think a new trial should be granted. 
$\S 95$ [56] Hotchkiss $v$. National Banks, 2 I Wallace (U. S.), 354, 359. - I874. Mr. Justice Field. - " The law is well settled that a party who takes negotiable paper before due for a valuable consideration, without knowledge of any defect of title, in good faith, can hold it against all the world. A suspicion that there is a defect of title in the holder, or a knowledge of circumstances that might excite such suspicion in the mind of a cautious person, or even gross negligence at the time, will not defeat the title of the purchaser. That result can be produced only by bad faith, which implies guilty knowledge or wilful ignorance, and the burden of proof lies on the assailant of the title. It was so expressly held by this court in Murray v. Lardner (2 Wallace, i го.) See, also, Goodman v. Simonds, (20 Howard, 343), where Mr. Justice Swayne examined the leading authorities on the subject and gave the conclusion we have stated."

56 NEW YORK, I37. - I874.

[Reported herein at p. 435.]

$\S 95$ NATIONAL BANK OF COMMONWEALTH $v$. LAW. [\$56] I27 Massachusetts, 72. - I879.

Contract, against maker and indorsers of the following instrument: -

$\$ 3000$.

New Yokк Jamuary 20, IS:7.

Four months after date I promise to pay to the order of Charles F. Parker $\&$ Co. three thousand dollars at the National Bank of Commerce, Boston, Mass. Value received.

[Indorsed]: JohN SAVERY'S SONS.

Charles F. Parker \& Co.

Law was a member of the firm of Charles F. Parker \& Co., and also of the firm of John Savery's Sons. Law indorsed the firm name of "John Savery's Sons " and one D. (a partner), indorsed the firm name of Charles F. Parker \& Co., and deposited the note as col. lateral for a loan at plaintiff bank. The note was in fact macle without authority of the firm of John Savery's Sons and in fratcl of the firm. The trial judge ruled that, from the form of the note itself, 
plaintiff was, as matter of law, affected with notice of the defence existing to the note on the part of the defendants (John Savery's Sons), other than Law, and directed a verdict for such defendants. If this ruling was incorrect, a new trial was to be ordered; otherwise, judgment on the verdict.

GRAY, C. J. [After deciding that the liability of John Savery's Sons was secondary to that of Law.]" One partner has no authority, without the assent of his copartners, to sign the name of the partnership to a note for the individual debt of himself or of a stranger; and all persons who take such a note with knowledge, either from its appearance or otherwise, that it was made for the separate accommodation of one partner or of another person, cannot recover against the other partners without proving thesr authority or assent. In the present case, the defendants' name being upon the back of the note above that of the payees, it was apparent upon the note itself, read in the light of the statute, which everyone was bound to know, that the liability of the partnership was but conditional and secondary, and therefore that, prima facie at least, their signature was affixed for the accommodation and benefit of Law; and the ruling at the trial was correct. (Angle v. Northoustern Ins. Co., 92 U. S. 330; West St. Louis Saings Bank v. Shaminee Bank, 95 U. S. 557; Chazournes v. Edadrds, 3 Pick. 5; Sa'etser v. French, 2 Cush. 309; Rollins v. Sterens, 3 I Maine, 45+; Fielden v. Lahens, 2 Abbott, N. Y. App. I I : Lemoine v. Bank of North Ameriat, 3 Dillon, 44.)

Judgment on the verdict. ${ }^{2}$

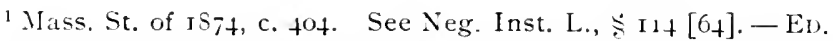

"Similar notes were made by Law and indorsed first, in the name of Charles F. Parker \& Co., and second, in the name of John Savery's Sons, and discounted for D. by plaintiff. The trial judge made the same ruling as above. Held: error. "Upon the face of the note in this case, there is nothing which indicates any irregularity or invalidity in the origin or negotiability of it." The note indicates that Charles F. Parker \& Co. had transferred it to John Savery's Sons, and the latter by blank indorsement to a new holder. There is no conclusive evidence that plaintiff knew it was discounting the note for C. F. Parker \& Co. The inference is quite as natural that D. was the owner. Freman's National Bankv. Sar'ry, 127 Mass. 75, $7 \mathrm{~S}$.

Where one of four partners signed in his individual name a note payable to his firm, and another partner indorsed the firm name, and the first partner then took the note to the plaintiff, filled in certain blanks in plaintiff's presence, and transferred the note to plaintiff to take up another similarly executed, but plaintiff testified that he had no knowledge that the loan was not for the benefit of the firm, held, that there is no conclusive proof, as matter of law, from the form of the note or other circumstance, that plaintiff had notice that the indorsement was for the maker's accommodation. It was a question of fact for the jury. Wait v. Thayer, II8 Mass. 473. 
I5O NEW YORK, 59. - I896.

ACTION by holder against maker. Judgment for defendants. Plaintiff appeals.

O'BRIEN, J. - The complaint in this action contained four separate causes of action, each upon a promissory note of the defendant. The last two causes of action were not defended, and upon these the plaintiff recovered, but was defeated upon the two notes embraced in the first and second causes of action. The defence to these two notes was that they were made by the defendant's president, one MI. S. Frost, and by him wrongfully diverted from the uses and purposes for which they were intended to his own personal or private benefit, or the benefit of a firm of which he was a member, and that the plaintiff is not a bona fide holder, but chargeable with notice of these facts.

The following are copies of the two notes in controversy, with the indorsements thereon when put in circulation by the defendant's president:

$\$ 5,000$

Greextille, PA., Feb' $y^{\prime} 2$ th h, ISSS.

Four months after date the Pittsburgh, Shenango and Lake Erie Railroad Company promises to pay to the order of John T. Bruen five thousand dollars, at the American Exchange National Bank, New York City. Value received.

Attest: E. S. Templetox, Secritary'.

The Pittsburgh, Shenaxgo \& Lake Erie Railroad Company,

By M. S. Frost, President.

D. loaned money to the firm of Stewart, Hammond $\&$ Mead, taking a note signed by Hammond and indorsed by the firm. This firm was dissolved, and the firm of Hammond \& Scripture was formed. Hammond arranged with D. to retain the money for the benefit of the firm of Hammond $\&$ Scripture, and gave D. a new note signed by Hammond and indorsed in the firm name. Scripture had no knowledge of this. Hild: Scripture not liable. "We do not think a partner can shift his private indebtedness from his own shoulclers to those of his firm by offering to his creditor to pay his debt, and then asking him to lend the amount to the firm of which he is a member, and thereupon, on the creditor's assenting, giving him without anything more a firm note for the amount, unless it is shown that the transaction is in some way brought to the knowledge of and assented to by the other member or members of the firm. It certainly would open a wide door to fraud to admit such a doctrine." Naniels v. Hammond, 154 Mass. 165.

The results of the cases on constructive notice from the form of the paper in the case of partnership signatures upon bills or notes negotiated by or for a partner for his own benefit, are fully stated in Ames' Cases on Partnership, Pp. 526, 527-529, 533-53t. See the same work (Pp. 496-521) for a discussion of the subject of the authority of a partner to execute or transfer negotiable instrumente in behalf of his firm, and the manner in which such instruments must be exezuted in order to bind the partnership. - En. 
[Indorsed]:

Pay to the order of M. S. Frost \& Son.

JOHN T. BRUEN.

M. S. Frost \& Son.

$\$ 5,000.00$.

Greenville, Pa., Feb'y 24 th, 1888 .

Three months after date the Pittsburgh, Shenango and Lake Erie Railroad Company promises to pay to the order of John T. Bruen five thousand dollars, at the American Exchange National Bank, New York city. Value received.

Attest: E. S. Templeton, Secretary.

The Pittseurgh, Shenango \& Lake Erie Railroad Company, By M. S. Frost, President.

[Indorsed]: JoHN T. BRUEN,

M. S. Frost \& Son.

The body of these notes, and every part of them except the signature of the president, was in the handwriting of Templeton, the secretary. The president was authorized by the board of directors to issue the corporate notes to the extent of $\$ 10,000$ for the purpose of purchasing flat cars. In March, I888, before the notes became due, Frost went to Boston and there negotiated a cash loan of $\$ 30,000$ from Francis A. Brooks for the benefit of M. S. Frost \& Son, giving the firm note therefor and delivering to him the two notes in question, indorsed as they now appear, with other obligations, as collateral security for the payment of this loan. Subsequent to the maturity of the notes Brooks became the absolute owner by consent of the pledgor and the proceeds applied upon the debt, and still later he transferred them to a third party, and they have come to the hands of the plaintiff for value. It is not claimed that the plaintiff occupies any other or different position than Brooks would if he had brought the action upon the notes at maturity. Bruen, the payee of the notes, was the private secretary of Frost, the president, and the notes were made payable to him by Templeton, the secretary of defendant, who drew them in that form at the suggestion of the president. There is not and cannot be any dispute with respect to the authority of Frost to make the notes. They were made with sufficient authority, the fraud upon the defendant consisting in the wrongful use of them, when made for a legitimate purpose, by the president for his own private business.

Nor is there any dispute with respect to the fact appearing on the plaintiff's case, that Brooks paid value for the notes and made present advances in cash to Frost in the sum already stated. It is equally clear upon the record that Brooks had no actual knowledge of the facts surrounding the origin of the paper or of the diversion of it by the president. He received the notes and made the advances in Boston, whereas they were made and the transactions stated with 
respect to them took place in a distant state, where the office of the company was, and is indicated on the paper as the place where made.

The learned trial judge held as matter of law that the plaintiff could not recover upon the notes for the reason that he was chargeable with knowledge of the facts and circumstances that rendered them invalid in the hands of Frost. The plaintiff is, doubtless, chargeable with such knowledge or notice as to the antecedent equities of the defendant as Brooks, his assignor, had, but with no others. If the notes were valid obligations in the hands of Brooks the plaintiff may assert every right that he could have asserted. It needs no argument to show that if Brooks had knowledge or notice or is in law chargeable with knowledge or notice of the fraud by means of which the notes were diverted from the purpose for which they were authorized to be made, that the plaintiff cannot recover. But it is not claimed that he knew anything about the origin or diversion of the paper in fact. All that is claimed is that when it was presented to him in Boston by Frost, whom he knew to be the president of the railroad, there was enough upon the face of the paper to put him upon inquiry and, therefore, to charge him with knowledge of all the facts that such inquiry would have disclosed. He knew nothing, so far as appears, outside of the paper itself, except the fact that the party presenting it was defendant's president, and that he was proposing to pledge the notes for his own debt, or rather for the debt of his firm, which for all the purposes of the question may be assumed to be the same thing. The question in the case is, therefore, reduced to a very narrow inquiry, and that is, whether Brooks, standing in all other respects in the position and sustaining the character of a bona fide purchaser of negotiable paper, is deprived of that character and the benefits of that position by reason of anything appearing upon the face of the notes themselves.

The mind, at the threshold of the inquiry, encounters two principles that point in opposite directions and lead to different conclusions, as the one or the other is allowed to preponderate in the mental process of determining the legal rights of the parties. On the one hand is the principle which protects a bone fide holder of commercial paper from existing antecedent equities between the parties, and on the other the principle which protects a corporation from the unauthorized and fraudulent acts of its own officers. There is not much difficulty in stating the rule of law defining the duties and obligations of a party to whom negotiable paper is presented for discount or sale before due. He is not bound at his peril to be on the alert for circumstances which might possibly excite the sus. 
picion of wary vigilance; he does not owe to tine party who puts the paper afloat the duty of active inquiry in order to avert the imputation of bad faith. 'The rights of the holder are to be determined by the simple test of honesty and good faith, and not by a speculative issue as to his diligence or negligence. The holder's rights cannot be defeated without proof of actual notice of the defect in title or bad faith on his part evidenced by circumstances. Though he may have been negligent in taking the paper, and omitted precautions which a prudent man would have taken, nevertheless, unless he acted mala fide, his title, according to settled doctrine, will prevail. (Magee v Badger, 34 N. Y. $249 ;$ Am. Ex. Nat. Bankv. N. Y. Belting, etc., Co., i 4 S. Y. 705 ; Knox v. Eden Musee Am. Co., I48 N. Y. 454; Canajoharie Wat. Bank v. Diefendorf, г 23 N. Y. 202 ; Voshurgh v. Diefenaorf, I 9 N. Y. 357 ; Jariis v. Manhattan Beach Co., I48 N. Y. 652.)

Applying these rules to the conceded facts of the case, it seems to me to be impossible to impute bad faith to Brooks in the transaction. He advanced a large sum of money on the faith of the paper, without any actual knowledge that the relations of the party with whom he dealt to the paper were different from what they appeared to be on the face of it. The question now is, not what the facts were, but what they appeared to be, and what he had the right, from the notes themselves, to assume. He had the right to assume that the relations to the paper of every party whose name appeared on it were precisely what they appeared to be. (Hoge v. Lansing, 35 N. Y. I36.) He had the right to believe that the notes had been issued by the defendant to Bruen for value in the regular course of business, and were by him transferred to Frost $\&$ Son in like maner. 'There was nothing to suggest to him that Frost was dealing with paper that belonged to the railroad for his own benefit. The appearances were that the defendant had put the notes in circulation by delivery to Bruen, and that they came to Frost's firm in the regular course of business for value and were then the property of the firm. It is quite true that all these appearances were deceptive and that the actual facts were otherwise. But how was a banker or business man in Boston to know or suspect that Bruen was only the nominal payee and a mere instrument in the transaction to enable the pres!dent to divert the paper to his own use. The name of the party who presented it and had it in his possession appeared on the face of the paper to have signed it as president. The name of another officer of the corporation was upon it also, attesting its regularity, and everything was in his handwriting except the signature of the president and the indorsement of the payee. So far as Brooks was concerned, the paper showed that it had been issued to a 
stranger in the regular course of business, and, through his indorsement, had come to the hands of a mercantile firm of which the president of the corporation was a member. If this were the fact, there is no doubt as to his right to use it in the business of the firm. The holder of a note who has no actual knowledge or notice of a defect in the title, or other equities between the parties, when circumstances come to his knowledge sufficient to put him upon inquiry, is chargeable with knowledge of all the facts that such inquiry would have revealed. The difficulty in this case is to find the circumstance which can be said to be sufficient to put Brooks upon the inquiry. There was absolutely nothing on the face of the paper except the signature, as president, of the party who was dealing with it, and that, we think, was not sufficient in view of the fact that the appearances were that he was a purchaser from a third party.

The principle that applies in a case where an officer of a corporation makes the corporate obligation payable to himself, and then attempts to deal with it for his own benefit, does not aid in solving the question in this case. When paper of that character is presented by the officer or agent of the corporation, it bears upon its face sufficient notice of the incapacity of the officer or agent to issue it. ${ }^{1}$ (Hanover Bank v. Am. Dock \& T. Co., I48 N. Y. 612; Bank of $V$. Y. v. Am. Dock \& T. Co., I43 N. Y. 559; Hilson v. M. E. R. Co., I 20 N. Y. I45; Gerona v. McCormick, I30 N. Y. 26r.) There are numerous cases that belong to that class cited by the learned counsel for the defendant on his brief. There is a manifest distinction between them and the case at bar. Here the officer was not dealing with the corporate notes payable to himself, but with notes that had been regularly issued, so far as appeared from their face, to a stranger and by him transferred to a firm of which the officer was a rnember, and for which he acted as agent in procuring the loan from Brooks and pledging them as security. The presence of Frost's name upon the paper, as one of the agents who issued it, was not naturally or reasonably calculated, under the circumstances, to arouse suspicion in the mind of Brooks, or to lead him to believe that the president was attempting to defraud the corporation in dis-

1 " Undoubtedly the general rule is that one who receives from an officer of a corporation the notes or securities of such corporation, in payment of, or as security for, a personal debt of such officer, does so at his own peril. Prima facie the act is unlawful, and, unless actually authorized, the purchaser will be deemed to have taken them with notice of the rights of the corporation (Garrard v. P. \& C. R. R. Co., 29 Penn. St. 154; Pendletonv. Fay, 2 Paige, 202 ; Shaw v. Spencer, 100 Mass. 388)."-Wilson v. Metropolitan El. Ry., I20 N. X. I45, I5o. C ntra: Doe v. Northwestern Coal, etc., Co., 78 Fed. Rep. 62, 68. - Ev. 
posing of the notes. None of the cases cited by the learned counsel for the defendant sustain the proposition that such a circumstance is sufficient to put the purchaser of negotiable paper upon inquiry or charge him with knowledge of the fact in case he fails to make it, and there are many cases that tend to support the contrary view. (Am. Ex. Nat. Bank v. N. Y. B. \& P. Co., ${ }_{4} 8$ N. Y. $698 ;$ Miller v. Consolidation Bank, 48 Penn. St. 5 I 4 ; Walker v. Kee, I4 S. C. I+2.)

It is said that if the plaintiff's right to recover in this case is sanctioned by this court an easy way will be opened for the perpetration of frauds upon corporations by officers intrusted with its negotiable obligations, and that the device of making the paper payable to the order of a nominal payee, interested or aiding in the fraud, will be a favorite one to accomplish the end. We must leave all such cases to be dealt with upon the peculiar facts and circumstances as they arise. It is more reasonable and just to assume that corporations will be able to protect themselves by proper vigilance from the dishonesty of their own officers, than to impute to parties who have taken the paper for value, ignorant of its origin, constructive knowledge of the facts upon such circumstances as exist in this case.

We think that there was nothing on the face of the paper or in the facts shown to warrant the court in holding, as matter of law, as it did, that the obligations were received by Brooks and the advances made on them mala fide. That is the effect of the ruling at the trial, and the conclusion was not supported by the facts.

It follows that the judgment must be reversed and a new trial granted, costs to abide the event.

BARTLETT, J., delivered a dissenting opinion.

Andrews, Ch. J., GraY and Martin, JJ., concur with O'Brien, J; Haight and VanN, JJ., concur with Bartlett, J.

Judgment reversed.

§ 95 FOX $v$. CITIZENS' BANK AND TRUST COMPANY. [\$56]

37 Southwestern Reporter (Tenn.), i to2. - i8g6.

Bill to enjoin defendants from further prosecuting suits on notes executed by complainants to J. C. Anderson, trustee, and indorsed by him to defendants. Decree for defendants. Complainants appeal.

It is conceded that there is a total failure of consideration: and that there would be a perfect defence against Anderson. 
Wilson, J. (After stating the facts and holding there was no actual notice given the bank.) - It is next insisted that the notes, being payable on their face to Anderson, trustee, carried notice of the equities of complainants. (Hilliard, Vend. $\$ 408$, 1 Story, 99, $\$ \$$ 399, 400, and Covington v. Anderson, I6 Lea, 3 10, are cited.) Beyond question, a trustee converting trust assets to his own use is liable to the beneficiaries; and equally liable is any one purchasing from him knowing of his fraudulent intention, as having knowledge of facts that would put a reasonably prudent man on inquiry as to the power and dishonest ends of the trustee, and which inquiry, if properly prosecuted, would discorer the truth. This is the extent to which the authorities cited go. But we are unable to perceive the direct connection and application of the principle cited to the facts of this case. It is well settled that the fact that the consideration for which a note is given is stated in it will not destroy its negotiability, unless the recital qualifies the promise to pay, or renders it uncertain either as to the time of payment or the sum to be paid. And if the note be received before maturity, and before a failure of consideration, it will be held free from the equities, although, from the recital, it was known to the indorser that the consideration was future and contingent. (Goodloe v. Taylor, ro N. C. $45^{8}$; Stevens v. Blunt, 7 Mass. 240; Dawis v. McCready, 7 N. Y. 230 : Bank v. Cason, 39 La. Ann. 865, 2 South. 88I: Siegelv. Bank, I3I Ill. 569, 23 N. E. 417; Daniel, Neg. Inst. \$\$ 790-796.) In other words, says the Louisiana Annual (2 South.) case and the cases in 13 I Ill. 569 , and 23 N. E. 417 , “ it cannot affect the negotiability of a note that its consideration is to be hereafter realized, or that, from contingency, it may never be enjoyed.

The argument or proposition is advanced by implication, at least, that the fact that these notes are made payable to Anderson, trustee, impaired their negotiability, or put a transferee on notice of all equities existing as between the maker and the trustee. In a contest between the beneficiaries of these notes, assuming that Anderson was not their real owner, and the transferee of Anderson, the fact that the notes appeared on their face to be payable to him as trustee would put the transferee on notice, and the claim of the beneficiaries would be superior (Cardwell v. Cheatham, 2 Head, 14; Duncan v. Jaudon, 15 Wall. 175; Shaw v. Spencer, roo Mass. 389 ; Alexander v. Alderson, 7 Baxt. 403), because the notes gave direct information that they were trust property, and the direct purpose of the transfer was to pay his individual debt. (Coington v. Anderson, i6 Lea. 3 10.)

The question as to whether a note payable to one as trustee is nego- 
tiable is a subject of dispute in the authorities or adjudged cases. In Maryland it seems to have been held that such a note is not commercial paper, and that an indorsement of it by the trustee transfers it, subject to the trust, and that, after such transfer, it is open to the equitable defences between the original parties. (Bank v. Lange, 5I Md. 139.) But it is holden in other jurisdictions that a note to and indorsed by one as trustee of a named person does not carry to an innocent purchaser any notice of a restriction upon the payee's right to transfer it. (Downer v. Read, I 7 Minn. 493 [Gil. 470]; Bush v. Peckard, 3 Har. [Del.] ${ }_{3}{ }_{5}$; citing Rand. Com. Paper, $\&{ }_{5} s$, p. 242 ; Daris v. Garr, 6 N. Y. I 24 ; s. C. 55 Am. Dec. $3^{87}$, and note; Picree v. Robie, 63 Am. Dec. 614; Conner :. Clark, 73 Am. Dec. 529.)

As a general thing, the addition of the words " trustee" and the like will be treated as descriptio persona. (Authorities supra; 2 Am. and Fng. Enc. Law, p. $35^{8}$, notes on pages $35^{8}$ and 359 .) We take it that the decided weight of authority, and, it seems to us, of sound reason, supports the position that the addition of the word "trustee" to the name of the payee of a note of itself does not destroy its negotiability. Under the rules of the common law, all conveyances by a trustee, whether to innocent purchaser or not, even if made in contravention of the trust, operated upon the legal title, and vested it in the grantee. The beneficiary had to go into equity, and there he could compel the grantee to respect the trust, as the original trustee should have done. (Gale r. Mensing, 20 Mo. 46 I ; s. C. $64 \mathrm{Am}$. Dec. I97, and notes; see, also, Tyler v. Herring, 67 Miss. I69, 6 South. 840 ; s. C., I9 Am. St. Rep. 263, and extended note where the subject with the authorities, is fully presented.) The substance or real rule, in the absence of a statute, in respect to unauthorized sales or transfers of property by trustees, is that they are voidable at the election of the parties in interest, and, until so avoided, the grantee has all rights in the property as to third parties. In this case there is no evidence that the notes did not belong to Anderson, or that he did not have the right to deal with them as he pleased. The result is that as to these complainants, the defendant bank is an innocent purchaser of the notes, for value, without notice of any equities in their favor; and, this being so, the decree of the chancellor is correct, and must be affirmed, with costs. ${ }^{1}$

1 The addition of the term " trustee," " agent," etc., to the name of the payee is restrictive in effect. It merely gives notice of the rights of the cestui or the principal; it cannot logically be held to give notice of a defence in favor of the maker. See as to restrictive indorsements, Neg. Inst. L., $\$ 66[36]$. See also $\$ 27$ [8], subsec. 6: Dazis v. Garr, 6 N. Y. I24, ante, p. $26 \mathrm{I}$.

A qualified indorsement is not notice of any infirmity in the instru- 
(e) Notice before full amount paid.

93 United States, 92. - I876.

Mr. Justice Hunt delivered the opinion of the Court.

This action is brought upon three several promissory notes made by the Missouri and Iowa Railway Construction Company, dated Nov. $x, 1872$, payable at $t w o$, three, and four months, to the order of William Irwin, for the aggregate amount of \$10,000

The defence is made that they were obtained by his fraudulent representations.

But a single point requires discussion. Conceding that the present plaintiff received the notes before maturity, and that his holding is bona fide, the question is as to the amount of lis recovery.

Under the ruling of the court he recovered $\$ 500$. His contestation is, that he is entitled to recover the face of the note, with interest.

After the evidence was concluded, the plaintiff asked the court to charge the jury, that if they believed, from the evidence, that the plaintiff purchased the notes in controversy of William Irwin for a valuable consideration, on the ist of November, 1872 , and paid $\$ 500$, part of the consideration, on $2 x$ st day of January, $\mathrm{i} S_{73}$, before any notice of any fraud in the contract, he was entitled to recover the whole amount of the notes; and the court refused this instruction. But the court charged the jury, -

"That, in the first place, the jury must find that there was fraud in the inception of the notes as alleged; and that if the defendants failed to satisfy the jury of that fact, the whole defence fails.

"'That if the fact of fraud be established, and the jury find from the evidence that the plaintiff paid $\$ 500$ upon the notes without notice of the fraud, and that after receiving notice of the frand the plaintiff paid the balance due upon the notes, he is protected only protanto; that is, to the amount paid before he received notice."

It does not appear that, upon the purchase of the notes in suit, the plaintiff gave his note or other obligation which might by its

ment. Lomax v. Picot, 2 Rand. (Va.) 247, anti, p. 367. The death of the maker, known to the buyer, does not deprive the buyer of the position of a holder in due course. Clarkv. Thayer, I05 Mass. 216.

The doctrine of notice by lis pendens has no application to negotiable paper. County of Warren v. Marey, 97 U. S. Iof. Nor should the maker, before maturity, be liable to garnishment at the suit of a creditor of the payee, for a purchaser from the payee in due course should be protected. I Daniel on Neg. Inst., $\$ 800 a$. - ED. 
transfer subject him to liability. His agreement seems to have been an oral one merely, - to pay the amount agreed upon, as should be required; and he had paid $\$ 500$, and no more, when notice of the fraud was brought home to him.

The argument of the plaintiff in error is that negotiable paper may be sold for such sum as the parties may agree upon, and that, whether such sum is large or small, the title to the entire paper passes to the purchaser. This is true; and if the plaintiff had bought the notes in suit for $\$ 500$, before maturity and without notice of any defence, and paid that sum, or given his negotiable note therefor, the authorities cited show that the whole interest in the notes would have passed to him, and he could have recovered the full amount due upon them. (Fowler v. Strickland, ro7 Mass. 552; Park Bank v. Watson, 42 N. Y. 490; Bank of Michigan v. Green, 33 Iowa, I40.) The present. case differs from the cases referred to in this respect. The notes in question were purchased upon an unexecuted contract, upon which $\$ 500$ only had been paid when notice of the fraud and a prohibition to pay was received by the purchaser. The residue of the contract on the part of the purchaser is unperformed, and honesty and fair dealing require that he should not perform it; certainly, that he should not be permitted, by performing it, to obtain from the defendants money which they ought not to pay. As to what he pays after notice, he is not a purchaser in good faith. He then pays with knowledge of the fraud, to which he becomes a consenting party. One who pays with knowledge of a fraud is in no better position than if he had not paid at all. He has no greater equity, and receives no greater protection. Such is the rule as to contracts generally. In the case of the sale of real estate for a sum payable in instalments, and circumstances occur showing the existence of fraud, or that it would be inequitable to take the title, the purchaser can recover back the sum paid before notice of the fraud, but not that paid afterwards. (Barnard v. Campbell, 53 N. Y. 73; Lewis v. Bradford, 10 Watts, S2; Jutenal v. Jackson, 2 Harris, 529; Id. 430; Youst v. Martin, 3 S. \& R. $423,43^{\circ}$.)

In Weater v. Barden (49 N. Y. 29r), the court use this language: “ To entitle a purchaser to the protection of a court of equity, as against a legal title or a prior equity, he must not only be a purchaser without notice, but he must be a purchaser for a valuable consideration; that is, for value paid. Where a man purchases an estate, pays part and gives bonds for the residue, notice of an equitable incumbrance before payment of the money, though after giving the bond, is sufficient. (Toutille v. Naish, 3 P. Wms. 306 ; 
Story $v$. Lord Windsor, 2 Atk. 630.) Mere security to pay the purchase price is not a purchase for a valuable consideration. (Hardingham v. Nicholls, 3 Atk. 304; Maundrell v. Maundrell, ı० Ves. 246, 27I; Jackson v. Cadwell, I Cowen, 622; Jewell v. Palmer, 7 J. C. 65.) The decisions are placed upon the ground, according to Lord Hardwicke, that if the money is not actually paid the purchaser is not hurt. He can be released from his bond in equity."

The plaintiff here occupies the same position as the bona fide purchaser of the first of a series of notes, of which, after notice of a fraud, he purchases the rest of the series. He is protected so far as his good faith covers the purchase, and no farther.

Upon receiving notice of the fraud, his duty was to refuse further payment; and the facts before us required such refusal by him. (Authorities supra.) Crandell v. Vickery (45 Barb. $\left.{ }^{56} 6\right)$, is in point.

To the same purport in principle, although upon facts somewhat different, are the cases of Garland $\vee$. The Salem Bank (9 Mass. 408); The Fulton Bank v. The Phonix Bank (I Hall, 562); and Ithite v. Spring ficld Bank (3 Sandf. S. C. 227).

The cases are numerous that where a bona fide holder takes a note misappropriated, fraudulently obtained, or without consideration, as collateral security, he holds for the amount advanced upon it, and for that amount only. (Williams v. Smith, 2 Hill, 30I; Allairev. Hartshorn, I Zabr. 663.)

The case before us is governed by the rule that the portion of an unperformed contract which is completed after notice of a fraud is not within the principle which protects a bona fide purchaser.

No respectable authority has been cited to us sustaining a contrary position, nor have we been able to find any. The judgment below is based upon authority, and upon the soundest principles of honesty and fair dealing. It has our concurrence, and is affirmed.

\section{Holder Deriving Title from Holder in Due Course.}

$\S 97$

SIMON $v$. MERRITT.

33 IowA, 537. - 1871 .

ACTI'N by the holder of a promissory note against the maker. There was a verdict and judgment for defendant. Plaintiff appeals.

$\mathrm{BECK}$, Ch. J. . . . Among other instructions the court gave the jury the following: "If you find from the evidence that the note in question was obtained of the makers by fraud and deception, and if you further find that the plaintiff, Simon, knew of such fraud 
and deception, or if he had reason to know or believe that said note was iraudulently obtained of the maker, and that it is void, and if, because of such knowledge or belief, he refused to receive or purchase it of Leggett until an indemnifying bond was executed to him by Leggett, then the law of the case is with the defendant, and if you so find then your verdict should be for defendant." And the instruction directed the jury that if plaintiff, "in good faith, for a valuable consideration, obtained the note in the ordinary course of business, before maturity, without notice of fraud, or without having reason to know or believe that the note was obtained by fraud of the maker," they should find for plaintiff.

These instructions are erroneous. They leave out of view the weli-settled doctrine that if Leggett, the transferer of plaintiff, was such an innocent and bona fide holder of the paper, that in his hands it could have been enforced against defendant, plaintiff, although he may have taken the note charged with notice of its infirmities, may recover in this action. If Leggett so held the note, his title and rights thereto were such that they could not have been defeated by defendant. In the transfer, the title and rights held by him passed to plaintiff. The notice which plaintiff may have had of the fraud in the original transaction does not defeat the rights he acquired by the transfer.

One reason of the rule is obvious. The maker of the note would be liable to the transferer; his condition is made no harder by the note coming into the hands of one having notice of its infirmities. We do not understand that there is any conflict in the authorities upon this point. (Hoskcll \& Gervey v. Whitmore, r9 Me. 1о2; Smith v. Hiscock, 14 Id. 449; Prentice \& Messenger v. Zane, 2 Gratt. 262 ; Boyd v. McCann, iо Md. i ss; Howell v. Crane, i 2 La. An. I26; see authorities cited in Story on Prom. Notes, § I 9 I.)

The instructions above set out, being in conflict with this doctrine, ought not to have been given. For this reason the judgment of the District Court is reversed. ${ }^{1}$

6 Cushing (Mass.), ig. - I850.

Acrion by indorsee against maker. Defendant offered to show that the first indorsee procured the note from the payee by fraud, and that plaintiff took it with notice of this fact and for an inadequate consideration. Evidence excluded. Verdict for plaintiff.

\footnotetext{
${ }^{1}$ See $\$ 52[26]$, ante, and cases. - ED.
} 
By THE COURT. - The directions we think were right; the plaintiff proved a legal title to the note, and the facts proposed to be proved by the defendant could afford him no ground of defence. It was no fraud upon the defendant; he was called upon to pay only what he had undertaken to pay; and payment to the plaintiff would be a good discharge. (Knights v. Putnam, 3 Pick. 184.)

Judgment on the verdict.

\section{Right of Holder in Due Course to Recover full Amount.}

$$
64 \text { Connecticut, 6i. - I894. }
$$

BALDwin, J. (After disposing of another matter.)-The plaintiff's appeal is based on the instruction given to the jury, that in the action against the maker of a negotiable accommodation note by an indorsee, who took it in gcod faith for value before maturity, and without notice of any infirmity, if the defendant proves that it was obtained from him by the payee and indorser by fraud, the rule of damages is the amount paid by the plaintiff. A note given for the accommodation of the payee, which he has thus negotiated to a bona fide purchaser, stands, as between the holder and maker, on the same footing as if it were business paper. ${ }^{1}$ The jury should therefore have been instructed that the rule of damages under the circumstances stated in the charge, was the face of the note, with interest from its maturity. (Beldin v. Lamb, I7 Conn. 441, 453; First Ecclesiastical Socicty v. Loomis, $4^{2}$ Conn. 570, 574; Rowland v. Fowler, 47 Conn. 347; Cromitell v. County of Sac, 96 U. S. 5 I, 60.)

${ }^{1}$ Business paper (as distinguished from accommodation paper), may be purchased for any price without involving any question of usury, for the transaction is a sale and purchase and not a loan. Cram r. Hindricks, 7 Wend. (N. Y.) 569; Cornins v. Pond, 29 Hun (N. Y.) I29. But a transfer of accommodation paper by the accommodated party to one knowing the facts, is a loan and not a purchase and sale, and if it be at a rate of discount greater than that allowed by the usury laws, is usurious. Ibid; I Daniel on Neg. Inst., $\$ \$ 750-753$. Many cases hold the same as to accommodation paper even though the buyer does not know it to be accommodation paper; but this view has been criticised. Ilid.

There has been great conflict among the authorities as to the amount a holder in due course may recover from an accommodation party or a party whose assent to the paper has been procured by fraud. I Daniel on Neg. Inst. $\$ \$ 754-75^{8}$. The Neg Inst. Law, $\$ 96[57]$, settles the law in conformity to the rule of the Supreme Court of the United States. Cromzell v. County of Sac, 96 U. S. $60 ; R$. Co. v. Schutte, 103 U. S. I18. -ED. 
There is error, and a new trial is ordered upon the plaintiff's appeal, in case one should not be granted by the City Court, on the ground that the verdict was against the evidence.

$$
33 \text { IowA, I40. - I871. }
$$

ACTION by holder against indorser. The answer set up a sale for less than the face value. Demurrer to this defence overruled. Judgment for defendant.

DAY, CH. J. - In objection to the second count ${ }^{1}$ it is claimed that the holder of negotiable paper is entitled to recover of the indorser the whole amount thereof without reference to the amount paid therefor. Upon this question the decisions are not in harmony. . . Without attempting a review of the authorities bearing upon this branch of the demurrer, we deem it sufficient to state as our opinion that the indorsee in good faith of a promissory note, is entitled to recover of the indorser the amount of the note.

This view has the unqualified indorsement of Mr. Parsons. (See 2 Parsons, Notes and Bills, 428 . Also, Durant v. Banta, 3 Dutch. 623,635 .) It follows that the demurrer to the second count should have been sustained.

Reversed. ${ }^{2}$

IO WeNDELL, II6. - IS33.

ACTION against indorser. Judgment for amount of note and notary's fees. Defendant moves for new trial.

By the Court, SAvage, C. J. - The remaining question is, whether the fees of protest were properly chargeable to the defendant. ${ }^{3}$ As to this we have not been referred to any decided case, and we understand that the practice at the circuit is not uniform, though the fees of protest are generally allowed. It is an expense to which the holder of a note is subjected by reason of the default of the

${ }^{1}$ Only so much of the opinion is given as relates to this. - ED.

2 The amount of recovery against the indorser has been a matter of great contention. I Daniel on Neg. Inst., SS 766-768. It is now settled by the Neg. Inst. Law, $\$ 96[57]$, in conformity with the view of the principal case. - ED.

${ }^{3}$ Only so much of the opinion as relates to this question is here given. - ED. 
indorser, whose duty it is to pay the note at maturity, and it is right, therefore, that the holder should recover it. It may fairly be considered as a charge incident upon the indorser's failure to perform his contract, and should be allowed to the plaintiffs in the assessment of damages.

New trial denied. ${ }^{1}$

9 JOHNSON (N. Y.) I3I. - I8I2.

IN ERROR, on certiorari from a justice's court.

Griffin sued Simpson before the justice, and declared for money had and received to his use, and for money lent. The defendant pleaded non assumpsit. The plaintiff proved, that he had been sued as indorser of a note drawn by the defendant, and had been obliged to pay, besides the amount of the note, nineteen dollars, costs of suit. The taxed bill was produced to the justice, who gave judgment for the plaintiff, for the amount.

Per Curiam. - If the indorser of a note be duly fixed, he ought to pay it, without waiting to be sued, but if he finds it more convenient to delay taking up the note, until he is prosecuted to judgment and execution, the drawer ought not to pay for that convenience. It is his own fault or misfortune that subjects him to costs, and he cannot resort to the drawer for indemnity against those costs. The mere fact of drawing the note does not imply a promise to save the payee harmless from all costs and charges that he may be subjected to, as indorser. There must be a special promise to save harmless before the payee can call upon the drawer for costs accrued by the default of the payee himself. As payee, he can only look to the drawer for the amount of the note. The judgment must, therefore, be reversed.

\section{Judgment reversed. ${ }^{2}$}

${ }^{1}$ For recovery of " re-exchange" see Bills of Exchange Act, 57, subsec, 2; 2 Daniel on Neg. Inst., SS I444-I+47; Bank of U.S. v. U. S., 2 How. (U. S.) 737. - ED.

${ }^{2}$ Accord: March v. Barnet, IIt Calit. 375. "A surety, including a drawer or indorser, may recover, in an action against his principal, . . . his reasonable costs and other expenses, incurred necessarily and in good faith, in the prosecution or defence, by the express or implied consent of the principal . . . of an action or special proceeding, relating to the demand secured." N.Y. Code Civ. Proc., \& 1916. - ED. 


\section{Burden of Proof.}

L. R. 23 Queen's Bench Div., 345. - I889.

\section{Motion for a new trial.}

The plaintiff sued upon a bill of exchange for $500 l$., drawn by the defendant Johnstone, and accepted by the defendant Haslar, payable to the order of Johnstone, and indorsed by him to the plaintiff. Judgment had been signed against Johnstone, but Haslar, having obtained leave to defend, pleaded that he had accepted the bill and handed it to one Leslie for the purpose of getting it discounted for him; that there was no consideration for his acceptance, and that Leslie fraudulently handed over the bill to Johnstone, who fraudulently indorsed it to the plaintiff, who took it without consideration and with notice of the fraud.

At the trial, before Field, J., and a jury, the defendant gave evidence of the fraudulent negotiation of the bill, which the judge held to be sufficient to throw upon the plaintiff the onus of proving that he gave value in good faith. The plaintiff gave evidence, and proved that he had given 450 l. for the bill, and also alleged that he had bought the bill honestly, without notice of the fraud.

The learned judge, in his summing-up, told the jury that the onus was on the plaintiff to satisfy them that he really gave value for the bill, but on the defendant to satisfy them that the plaintiff took the bill under such circumstances as to invalidate his title, because he had, or ought to have had, notice of the fraud. The learned judge also told the jury that the plaintiff was a bona fide holder for value, if he really and truly advanced the value alleged by him.

The jury found a verdict for the defendant, and the plaintiff mored that judgment might be entered for him, or a new trial had, on the ground that the judge misdirected the jury in telling them that there was evidence of circumstances which should have put the plaintiff upon inquiry, and that the verdict was against the weight of evidence.

DenMan. I. - The summing-up of the learned judge has been read through and fully commented upon, and I have come to the conclusion that, upon the true construction of the Bills of Exchange Act, IS82 (45 and 46 Vict. c. 6I), he put the case too favorably for the plaintiff. Inasmuch as the argument in this case has turned to a great extent upon what is the present state of the law under the Act, I think that we must express our opinion upon it. The first clause with which we must deal is s. 30 , sub-s. 2 , which provides that 
" every holder of a bill is prima facie deemed to be a holder in due course; but if in an action on a bill it is admitted or proved that the acceptance, issue, or subsequent negotiation of the bill is affected with fraud . . . the burden of proof is shifted, unless and until the holder proves that, subsequent to the alleged fraud or illegality, value has in good faith been given for the bill." Now the learned judge told the jury that, if money had really and in fact been given for the bill, value had in good faith been given. I have never so read this section of the Act; and I think that the attention of the learned judge could not have been called to the other clauses of the Act. Giving "value in good faith" must mean something more than the mere actual and real passing of money or other value, and this appears clearly when the other clauses of the Act are looked at. A " holder in due course" is, by s. 29, sub-s. I, defined to be a person who has taken a bill in good faith and for value and without notice of any defect in the title of the person who negotiated it. Then s. 30 , sub-s. 2, says, in effect, that, if fraud in the inception or negotiation of a bill is proved or admitted, the holder must prove that he is a holder in due course as defined by s.29, sub-s. I. Again, s. 90 says that " a thing is deemed to be done in good faith . . . when it is in fact done honestly, whether it is done negligently or not." This clause is obriously founded upon the distinction, which is pointed out by Lord Blackburn in Jones v. Gordon (2 App. Cas. 6i6, at p. 629), between honest blundering or carelessness and a dishonest refraining from inquiry. Applying that constrution to the words "value given in good faith" at the end of s. 30 , sub-s. 2, it appears to me that those words mean value given honestly and without any notice of the fraud, in the sense explained by Lord Blackburn, and not merely the actual giving of value.

The words of s. $3^{\circ}$, sub-s. 2, "if it is admitted or proved," mean no more than that some evidence of circumstances in the nature of fraud must be given sufficient to be left to the jury. That was the old law, as stated in Hall v. Featherstone ( 3 H. \& N. $\left.2 S_{4}\right)$, which has not, I think, been altered by this Act. When, therefore, some sufficient evidence of fraud has been given, as in this case, the onus is on the plaintiff to prove both that he gave value and that he had no notice of the fraud in the sense explained by Lord Blackburn in Jones v. Gordon, supra.

In this case there was evidence of fraud which could not have been withdrawn from the jury, and their verdict on that point cannot be set aside as against the weight of evidence. The onus of proving that he had no notice being upon the plaintiff, it was essentially a matter for the jury to say whether he had satisfied them on 
that point, and I think that even had the onus been upon the defendant there was evidence upon which the jury were entitled to find a verdict for him. The verdict, therefore, cannot be disturbed.

Charles, J. - It is impossible to say that there was not abundant evidence of the fraud, practiced upon the plaintiff, to support the verdict. Then arises the important question in the case whether there were circumstances in the transaction which ought to have led the plaintiff to make inquiries, and he wilfully abstained from inquiry.

At the time of the passing of the Bills of Exchange Act, I882, it was uncertain how much the plaintiff had to prove in cases of this kind when evidence of fraud had been given. Lord Blackburn, in Jones v. Gordon (2 App. Cas. 616, at p. 628), says, " the language of the quotation from Mr. Baron Parke would seem to show that the onus as to both is shifted, but I do not think that has ever been decided, nor do I think it is necessary to decide it in the present case." The learned judge who tried this case took the view that the onus was shifted only to the extent of making the plaintiff prove that value was in fact given, not that it was also given bona fide. Upon the construction of the Act, I respectfully differ from him. The plaintiff was bound to satisfy the jury that he gave value, and that he gave it in good faith. The Act has settled the law in accordance with the opinion expressed by Parke, B.

I agree with my brother Denman as to the meaning of the words "admitted or proved" in the earlier part of s. 30 , sub-s. 2. The latter part of that section says that the holder must prove that value was in good faith given for the bill. Referring back to s. 29, sub-s. I, a holder in due course is defined to be a person who has taken a bill in good faith and for value and without notice of any defect in the title of the person who negotiated it. Therefore a holder is by s. 30 , sub-s. 2, deemed to be a holder in due course until fraud is proved, but in that case he must prove that he is a holder in due course as defined in s. 29, sub-s. I. "Good faith" is by s. 90 , defined to be the doing of a thing honestly. When, therefore, fraud has been proved the holder must prove that he gave value honestly without notice of the fraud. The jury have found against the plaintiff, and the verdict must stand.

Motion dismissed. ${ }^{1}$

${ }^{1}$ The holder, when fraud or illegality is shown by way of defence, must assume the burden of showing " not only that he bought before maturity and paid value, but also the circumstances under which he acquired the paper, with the view of enabling the jury to determine whether he acted in good faith or not." Canajoharie Nat. B'k v. Diefendorf, I23 N. Y. I9r: also Vosburgh v. Diefendorf, Ir N. Y. 357 . But not when the defence is want or failure of con- 
$\S 98$ MARKET AND FULTON NAT. BANK $v$. SARGENT. [\$ 59]

85 MAINE, 349. - 1893 .

[Reported herein at p. 291.]

\section{Defences to negotiable instruments.}

4 I New Hampshire, 4I4. - I860.

ACtion by indorsee against maker on a promissory note. Defences: duress by imprisonment; illegality because given to compromise a crime. The defendant offered evidence to substantiate the defences.

The plaintiff excepted to this evidence, as no defence against the indorsee, without proof that he was not the bona fide holder of the note. But the court ruled that if the note was obtained by duress, it was void in the hands of an innocent indorsee, and thereupon the plaintiff, admitting for the purposes of this trial that the defendant's witnesses would testify to the facts stated, a verdict for the defendant was taken by consent, subject to the opinion of the court; and the questions thus raised were reserved, and assigned to the determination of the whole court.

SARGENT, J. - That the case presented is clearly one of duress, there can be no question. The abuse of any process, either civil or criminal, to compel a party, by imprisonment, to do any act against his will except to pay the debt for which he is arrested, is entirely illegal, and the act may be avoided on the ground of duress. (Richardson v. Duncan, 3 N. H. 508; Severance v. Kimball, 8 N. H. $3^{86}$; Shane v. Spooner, 9 N. H. 197; Burnham v. Spooner, ro N. H. 523; Beck v. Blanchard, 22 N. H. 303.) Here the arrest was without any warrant or lawful authority. Such duress is a perfect defence, upon all the authorities, to an action between the original parties.

The note in this case was not only void as between the original parties, on the ground of duress, but was given to compromise a charge of crime, and was wholly illegal upon that ground. (Plumer v. Smith, 5 N. H. 553.)

But the principal question raised here by the ruling of the court is, whether such a note is absolutely void in the hands of any holder; and if not, then another question arises upon the exception which was taken by the plaintiff, which is this: After an indorsee has

sideration. Holden v. Phanix Rattan Co., 168 Mass. 570; Galvin v. Meridian ${ }^{2}$. B., 129 Ind. 439. See Clark v. Pease, infra. - En. 
made out a prima facie case by proving the indorsement, etc., and the defendant has shown that the note was obtained from him by duress, upon whom rests the burden of proof? Must the defendant prove that the plaintiff was not the bona fide holder, and that he did not pay a valid consideration for it, as the plaintiff claimed? or, the duress being proved, does that throw the burden of proof upon the plaintiff, to prove how he came by the note, and the consideration he paid, etc., as the defendant claims? We will examine these questions in the crder in which we have stated them.

I. Is this note absolutely void in the hands of any holder, however innocent, who has paid a valid consideration for it before it was due?

[The court here discusses the grounds for avoiding contracts generally.]

Now bills and notes stand upon the same foundation as all other contracts do, in all the above respects, so long as they remain in the hands of the original payee. But bills and notes have another attribute, which other contracts ordinarily do not possess, - that is, negotiability. Where a bill or note has been negotiated, and passed into the hands of a bona fide holder before it is due, and for a valuable consideration, in such case the holder acquires rights which did not belong to the payee. He stands in a different relation to the promisor. These additional rights and privileges have been conferred upon such holder by law, for good and sufficient reasons, too well known and understood to need to be stated, but which are incident to, and dependent upon, the attribute of negotiability, which these instruments possess.

And it may be laid down as the general rule, as the general principle applying to this class of cases, that such a note, thus negotiated and in the hands of such a holder, is not liable to any defence which the maker had as against the original payee. To this general rule there are some exceptions, ${ }^{1}$ among which are -

I. When a statute not only prohibits the making of a contract, but provides that the same shall be void to all intents and purposes; or where the law provides that any contract made or securities given upon any illegal consideration shall be absolutely void, then the note which embodies such contract, or is based upon such consideration, is held void everywhere and in the hands of every holder. ${ }^{2}$ In

${ }^{1}$ These exceptions constitute what are known as real or absolute defences. See Bigelow, Bills, Notes and Checks (Students' ed.), pp. I74-205. - ED.

2 "The authorities justify the statement that a defendant may insist upon the illegality of the contract or consideration, notwithstanding the note is in the hands of an innocent holder for value, in all those cases in which he can point to an express declaration of the legislature that the illegality insisted upon shall 
England, and in most of the United States, there are or have been laws against usury, which not only, by a general prohibition of usury, made that an illegal consideration for a note, but also provided that all bills or notes founded upon such a consideration should be absolutely void. Such, however, is not the law in this State on that subject, and it is believed that we have no statutes with similar provisions. Hence, here usury may be a good defence to a note as against the original party, but not as against an innocent indorsee, for value, etc. ${ }^{1}$

2. When the note is a forgery, it is void everywhere. ${ }^{2}$

3. When the maker belongs to a class of persons who are ordinarily, and as a general rule, on grounds of public policy, held incompetent to contract at all, such as infants, ${ }^{3}$ married women, ${ }^{4}$ alien enemies, and insane persons, ${ }^{6}$ including spenthrifts and others under guardianship, ${ }^{7}$ who have been by some statute declared incompetent to contract.

make the security, whether contract, bill or note, void. But unless the legisla. ture has so declared, then, no matter how illegal or immoral the consideration may be, a commercial note in the hands of an innocent holder for value will be held valid and enforceable." Sontheim v. Gilbert, II7 Ind. 7I, 77, ISSS. See also Union Nat. Bank v. Broün, (Ky. IS97) +I S. W. Rep. 273. - ED.

${ }^{1}$ For usury laws in the United States, see Stimson, Am. St. Law, $4830-$ $4837 ; 3$ Parsons on Contracts (Sth ed.), p. " 153 . In New York, the legal rate of interest is six per cent (L. I879, c. 538). All bonds, bills, notes, etc., whereby there shall be reserved or taken, or secured, or agreed to be reserved or taken, any greater sum, or greater value for the loan or forbearance of any money, goods, or other thing in action, than is above prescribed, shall be roid; and a court of chancery may on satisfactory proof declare the same to be void, enjoin any prosecution thereon, and order the same to be surrendered and canceled. (L. 1837, c. 43 o.) But banks and bankers taking usury forfeit only the interest when payment is postponed, or twice the amount if taken in advance, whether national banks (U. S. Rev. St., 5 I9S), or State banks (L. IS92, c. 6S9, 55); and on call loans of not less than five thousand dollars secured by negotiable collateral or bills of lading, warehouse receipts, certificates of stock, etc., a bank or banker may take any sum agreed upon in writing. (L. I 892, c. $689,556$. ) No corporation shall interpose the defence of usury in any action. (L. Is 50 , c. I72.) Special rales are provided for loans by pawnbrokers. (L. I883, c. 339, s. 7 , L. IS95, c. $706, \leqslant 3$.

Many States provide that bills, notes and other securities given for gaming debts or knowingly lent for gambling purposes, shall be void. Stimson, Am. St. Law, $\$ 1132$ (c); I N. Y. Rev. St. 663, I6; Ib. 665, 24. See also N. Y. Neg. Inst. L., $\leqslant 330,331 .-$ ED.

${ }^{2}$ See Neg. Inst. L., $\leqslant 42[23]$ : ante, pp. 322-324. - ED.

${ }^{3}$ I Daniel on Neg. Inst., $\$ S 23-23 S .-E D$.

-Ibid., $\$$ 239-258. - ED.

I Ibid., \$\$ 216-222. - ED.

'Ibid., \$\$ 209-2I3; Ifosler v. Beard, 54 Oh. St. 398. - Ed.

Daniel, 5 259-260. - ED. 
4. Notes signed by agents without authority. ${ }^{1}$

In none of these case (except the first, which, as we have seen, does not apply in this State), is a note valid in the hands of anyone; and the party who discounts such paper is bound to inquire, at his peril, whether the note offered to him is signed by a party capable and competent in law to bind himself, or by an agent duly authorized to bind his principal. Besides this, he is bound to inquire whether the party from whom he receives it is competent to make such transfer in his own right, or is authorized to do it for his principal, for whom he assumes to act.

If there is a failure in either of these points of capacity or authority, it will not avail the party that he is a bona fide holder, for value, without notice. He must look to his indorser if he has one, and if he has not he must suffer loss.

5. Another case might be mentioned, which has been made an exception to the general rule above stated by express provisions of the statute, - as where a note is attached by the trustee process. There, by operation of the statute, the maker of a note may have a perfect defence against an indorsee, for value, without notice, and before due. $^{2}$ So notes discharged by operation of insolvent laws might afterwards be transferred, by possibility, so as to form another exception, where the indorsee, holding the note bona fide, etc., might be met with a perfect defence on the part of the maker. But these last cases throw no light upon the question we are considering.

These are the principal, perhaps all the exceptions to the general rule stated above, that no defence is available against an innocent indorsee, for value paid before due. ${ }^{3}$ But where the contract was illegal, being prohibited by law, or the consideration was illegal, as usury, wagers, compounding a felony, restraint of trade or of marriage, etc., or where there was a want or failure of consideration, and even where the note has been paid, - all these defences, ${ }^{4}$ and

${ }^{1}$ See Neg. Inst. L., S\$ 37-40 [I S-2I]; ante, pp. 31 I-32I. - ED.

${ }^{2}$ See I Daniel on Neg. Inst., 5 8ooa. - ED.

${ }^{3}$ To these should be added the extinguishment of the instrument by cancellation or alteration. See Neg. Inst. L., \$\$ 204-206 [123-125], post. . The case of want of delivery, or want of delivery as and for a negotiable instrument, calls for special comment and may or may not be an absolute defence according as the maker is or is not estopped to set up the defence. See I Daniel on Neg. Inst., $\$ \$ 47-853$. See post, pp. 43I-445. - ED.

"These defences are known as personal, conditional, or " equitable " defences. See Bigelow, Bills, Notes and Checks (Students' ed.), pp. I72, 206. These defences are fraud, duress, illegality, want or failure of consideration, release or payment, discharge of party primarily liable, etc. Whether a right of set-off 
many more, cannot be made against the note in the hands of such a holder. And the question here raised is, whether, in case of duress, or fraud, where there is mala fides, but it is all on one side, and the other part $y$ to the note has been induced to sign it by force or by fraud, and is in every respect ar: innocent party, such defence shall arail him as against such a holtor, for value, etc. who seeks to collect it.

And we think such a defence cannot avail the maker against such an indorsee of the note. The authorities favor this view.

Suppose an individual, thel., were about to purchase a note payable to bearer, before it was due, and pay a fair equivalent for it, with a view of collecting it of the maker, and where he is to have no ind orser to rely upon, - what would be his duty in order to proceed safely? First, he must assure himself of the genuineness of the signature, or, if it purported to be signed by an agent, he must assur: himself that the agent was duly authorized to bind his principal in that particular; secondly, he must make such inquiries, which, ordinarily, he may easily do, as to ascertain that the signer is not an infant, a married woman, an alien enemy, an insane person, etc., that he does not belong to a class of persons who are always pre. sumed by the law to be incompetent to contract; and thirdly, he might need, for his own safety, to inquire whether the signer of the note had been trusteed, or whether any other special statute could affect his claim to it. When he has satisfied himself upon these points, if he learns of no other defects, and the signer is of sufficient ability to respond, he may purchase; and there is generally very little trouble in ascertaining these facts. They are usually matters of public notoriety, about which there can be little room for mistake.

But, suppose that after being satisfied upon all these points, and having purchased the note, it, should prove that it was an illegal contract, or was for an illegal consideration, - who shall suffer? - the maker or the indorsee? This is settled on the best of authority. The original parties stood upon equal ground, both being in fault, and could neither of them enforce the contract; yet neither shall be allowed to take advantage of his own wrong as against an innocent inclorsee.

And suppose it should turn out that his note was obtained of the maker by fraud or by duress, a case in which the maker was in no fault, - what rule shall be applied here? - the long established one, that where one of two innocent persons must suffer, the loss should

exisling at the time of the transfer is an "equity" is in dispute. 2 Daniel on Neg Inst., $\$ 435^{a-1437}$. In New York it is an equity in case of the transfer of an overdue note. N. Y. Code Civ. Proc., S 502. - Ev. 
fall upon him who has suffered a negotiable security, with his name attached to it, to get into circulation, and thereby mislead the indorsee. Such rules, and such an application of them, are necessary to give security to negotiable paper.

The exception to the ruling of the court upon this point must be sustained; but we shall find that the numerous authorities which bear upon the next question to be considered have also a direct bearing upon this point.

$\S 98$ [59]. II. Next let us inquire, upon whom is the burden of proof, after duress, or fraud, or illegality of consideration is proved? Must the defendant not only prove that he had a perfect defence to the note originally, but also show that the indorsee had notice of the defect, or that he paid no consideration for it, or that he is not in some way the bona fide holder of the note? Or must the plaintiff, after such defence to the original contract is proved, assume the burden of proving that he is a bona fide holder, for a valuable consideration, without notice of any defect, and that it came seasonably into his hands?

\section{[After discussing various authorities.]}

The same doctrines very generally prevail in this country, wherever the subject has received judicial consideration. (Munroe v. Cooper, 5 Pick. 412; Woodhul v. Holmes, 10 Johns. 231; Vallett v. Parker, 6 Wend. 6r5; Small v. Smith, I Den. 583: Worcester Co. Bank v. D. \& $M$. Bank, Iо Cush. 48s; IVyer r. D. \& $M$. Bank, I I Cush. 52; Rockaell v. Charles, 2 Hill, 499; Bissell v. Morgan, I I Cush. I98; Crosby v. Grant, 36 N. H. 273.) So in Smith on Cont. (3d Am. ed. 277), in a note by Rawle, it is said that in New York it has been held that, as soon as the defendant shows there has been usury between the prior parties, he casts on the plaintiff the burden of proving that he is a holder for value, - as is the case in every instance where fraud, duress, or illegality is shown between the prior parties.

These authorities would seem conclusive, that the plaintiff's exception, - that the evidence offered would have been no defence unless it were proved that he was not the bona fide holder, - must be overruled. When the defendant had proved the duress, he had made a good defence as against the original party; and because of the legal presumption that in such cases the payee, being guilty of such illegality, would dispose of the note and place it in the hands of some other person to sue upon it (Bailey v. Bidwell, ante), he had chereby cast a suspicion on the plaintiff's title, which threw the burden upon him of showing affirmatively that he was a bond fide 
holder for value. Nor can we see that the fact that this evidence was offered under the general issue alters the position of the parties or the state of the case.

These authorities also bear directly upon the first point taken by the defendant, that duress is a defence against any holder, however innocent he may be, and however valuable a consideration he may have paid for the note; and if other authorities on this point were needed, they are not wanting. In Powers v. Ball $(27 \mathrm{Vt} .662)$, Redfield, C. J., says, "Illegality, duress, fraud, and want or failure of consideration, are no defence as against a bona fide holder for value." (See, also, St. Albans Bank v. Dillon, 30 Vt. 122; Ellicott v. Martin, 6 Md. 509; Minell 0 . Reed, 26 Ala. 730; Norris v. Langley, I9 N. H. 423; Knight v. Pugh, 4 Watts \& Serg. 445.)

The verdict must be set aside, and a new trial granted.

29 Wisconsin, I94. - IS7I.

ACtion against maker of a promissory note, by a holder who claims to have purchased it for full value, before maturity. Defence: that defendant is a German unable to read and write the English language; that the payees fraudulently induced him to sign an instrument represented to him to be a contract of agency, but which in fact was the promissory note in question. Evidence to establish this defence ruled out, and judgment given for plaintiff. Defendant appeals.

Dixon, C. J. - The defendant, having properly alleged the same facts in his answer, offered evidence and proposed to prove by himself as a witness on the stand, that at the time he signed the supposed note in suit, he was unable to read or write the English language; that when he signed the same, it was represented to him as, and he believed it was, a certain contract of an entirely different character, which contract he also offered to produce in evidence; that the contract offered to be produced was a contract appointing him, defendant, agent to sell a certain patent right, and no othe- or different contract, and not the note in question; and that the supposed note was never delivered by the defendant to any one. It was at the same time stated that the defendant did not claim to prove that the plaintiff did not purchase the supposed note before maturity and for value. To this evidence the plaintiff objected, and the objection was sustained by the court, and the evidence excluded, to which the defendant excepted; and this presents the only question. 
We think it was error to reject the testimony. The two cases cited by counsel for the defendant (Foster v. McKinnon, L. R. 4 C. P. 704 , and Whitney v. Snyder, 2 Lansing, 477) are very clear and explicit upon the point, and demonstrate, as it seems to us, beyond any rational doubt, the invalidity of such paper, even in the hands of a holder for value, before maturity, without notice. The party whose signature to such paper is obtained by fraud as to the character of the paper itself, who is ignorant of such character, and has no intention of signing it, and who is guilty of no negligence in affixing his signature, or in not ascertaining the character of the instrument, is no more bound by it than if it were a total forgery, the signature included.

The reasoning of the above cases is entirely satisfactory and conclusive upon this point. The inquiry in such cases goes back of all questions of negotiability, or of the transfer of the supposed paper to a purchaser for value, before maturity and without notice. It challenges the origin or existence of the paper itself; and the proposition is, to show that it is not in law or in fact what it purports to be, namely, the promissory note of the supposed maker. For the purpose of setting on foot or pursuing this inquiry, it is immaterial that the supposed instrument is negotiable in form, or that it may have passed to the hands of a bona fide holder for value. Negotiability in such cases presupposes the existence of the instrument as having been made by the party whose name is subscribed; for, until it has been so made and has such actual legal existence, it is absurd to talk about a negotiation, or transfer, or bona fide holder of it, within the meaning of the law merchant. That which, in contemplation of law, never existed as a negotiable instrument, cannot be held to be such; and to say that it is, and has the qualities of negotiability, because it assumes the form of that kind of paper, and thus to shut out all inquiry into its existence, or whether it is really and truly what it purports to be, is petitio principii-begging the question altogether. It is, to use a homely phrase, putting the cart before the horse, and reversing the true order of reasoning, or rather preventing all correct reasoning and investigation, by assuming the truth of the conclusion, and so precluding any inquiry into the antecedent fact or premise, which is the first point to be inquired of and ascertained. For the purposes of this first inquiry, which must be always open when the objection is raised, it is immaterial what may be the nature of the supposed instrument, whether negotiable or not, or whether transferred or negotiated, or to whom or in what manner, or for what consideration or value paid by the holder. It must always be competent for the party proposed to be charged upon any 
written instrument, to show that it is not his instrument or obligation. The principle is the same as where instruments are made by persons having no capacity to make binding contracts; as, by infants, married women, or insane persons; or where they are void for other cause, as, for usury; or where they are executed as by an agent, but without authority to bind the supposed principal. In these and all like cases, no additional validity is given to the instruments by putting them in the form of negotiable paper. (See Veeder v. Tow'n of Lima, I9 Wis. 297 to 299 , and authorities there cited. See also Thomas v. Watkins, I 6 Wis. 549.)

And identical in principle, also, are those cases under the registry laws, where the bona fide purchaser for value of land has been held not to be protected when the recorded deed under which he purchased and claims, turns out to have been procured by fraud as to the signature, or purloined or stolen, or was a forgery, and the like. (See Ei'erts v. Agnes, 4 Wis. 343 , and the remarks of this court, pp. $35 \mathrm{I}-353$, inclusive.)

In the case first above cited (Foster v. Mckimnon), the defendant was induced to put his name upon the back of a bill of exchange by the fraudulent representation of the acceptor, that he was signing a guaranty. In an action against him as indorser, at the suit of a bona fide holder for value, the Lord Chief Justice, Borille, directed the jury that, "If the defendant's signature to the document was obtained upon a fraudulent representation that it was a guaranty, and the defendant signed it without knowing that it was a bill, and under the belief that it was a guaranty, and if he was not guilty of any negligence in so signing the paper, he was entitled to the verdict;" and this direction was held proper. In delivering the judgment of the court upon a rule nisi for a new trial, Byles, J., said:-

"The case presented by the defendant is, that he never made the contract declared on; that he never saw the face of the bill; that the purport of the contract was fraudulently misdescribed to him; that when he signed one thing, he was told and believed he was signing another and an entirely different thing; and that his mind never went with his act. It seems plain on principle and on authority, that if a blind man, or a man who cannot read, or for some reason (not implying negligence), forbears to read, has a witten contract falsely read over to him, the reader misreading to such a degree that the written contract is of a nature altogether different from the contract pretended to be read from the paper, which the blind or illiterate man afterwards signs, then, at least if there be no negligence, the signature so obtained is of no force; and it is invalid, not merely on the ground of fraud, where fraud exists, but on the ground that the mind of the signer did not accompany the signature; in other words, that he never intended to sign, and therefore, in contemplation of law, never did sign the contract to which his name is appended."

NEGOT. INSTRUMENTS - 28 . 
And again, after remarking the distinction between the case under consideration and those where a party has written his rame upon a blan's piece of paper, intending that it should afterwards be filled up, and it is improperly so filled, or for a larger sum, or where he has written his name upon the back or across the back or across the face of a blank bill stamp, as indorser or acceptor, and that has been fraudulently or improperly filled, or in short, where, under any circumstances, the party has voluntarily affixed his signature to commercial paper, knowing what he was doing, and intending the same to be put in circulation as a nesotiable security, and after also showing that in all such cases the party so signing will be liable for the full amount of the note or bill, when it has once passed into the hands of an innocent indorsee or holder, for value before maturity, and that such is the limit of the protection afforded to such an indorsee or holder, the learned judge proceeded:-

"But, in the case now under consideration, the defendant, according to the evidence, if believed, and the finding of the jury, never intended to indorse a bill of exchange at all, but intended to sign a contract of an entirely different nature. It was not his design, and, if he were guilty of no negligence, it was not even his fault, that the instrument he signed turned out to be a bill of exchange. It was as if he had written his name on a sheet of paper for the purpose of franking a letter, or in a lady's album, or an order for admission to Temple Church, or on the fly-leaf of a book, and there had already been, without his knowledge, a bill of exchange or a promissory note payable to order inscribed on the other side of the paper. To make the case clearer, suppose the bill or note on the other side of the paper in each of these cases to be written at a time subsequent to the signature, then the fraudulent misapplication of that genuine signature to a different purpose would have been a counterfeit alteration of a writing with intent to defraud, and would therefore have amounted to a forgery. In that case the signer would not have been bound by his signature, for two reasons - first, that he never in fact signed the writing declared on, and, secondly, that he never intended to sign any such contract."

"In the present case, the first reason does not apply, but the second does apply. The defendant never intended to sign that contract, or any such contract. He never intended to put his name to any instrument that then was or thereafter might become negotiable. He was deceived, not merely as to the legal effect, but as to the actual contents of the instrument."

The other case first above cited (Ithitney' v. Suyder), was in all respects like the present, a suit upon a promissory note by the purchaser before maturity, for value, against the maker; and the facts offered to be proved in defence were the same as here; and it was held that the evidence should have been admitted.

In Nance v. Larey (5 Ala. 370), it was held that where one writes 
his name on a blank piece of paper, of which another takes possession without authority therefor, and writes a promissory note above the signature, which he negotiates to a third person, who is ignorant of the circumstances, the former is not liable as the maker of the note to the holder. In that case the note was written over the signature by one Langford, and by him negotiated to the plaintiff in the action, who sued the defendant as maker. Collier, C. J., said:-

" The making of the note by Langford was not a mere fraud upon the defendant; it was something more. It was quite as much a forgery as if he had found the blank, or purloined it from the defendant's possession. If a recovery were allowed upon such a state of facts, then every one who ever indulges in the idle habit of writing his name for mere pastime, or leaves sufficient space between a title and his subscription, might be made a bankrupt by having promises to pay money written over his signature. Such a decision would be alarming to the community, has no warrant in law, and cannot receive our sanction."

And in Putnam v. Sullizan (4 Mass. 54), Chief Justice Parsons said: -

" The counsel for the defendants agree that, generally, an indorsement obtained by fraud will hold the indorsers according to the terms of it, but they make a distinction between the cases where the indorser, tinrough fraudulent pretenses, has been induced to indorse the note he is called on to pay, and where he never intended to indorse a note of that description, but a different note and for a different purpose. Perhaps there may be cases in which this distinction ought to prevail. As, if a blind man had a note falscly and fraudulently rad to him, and he indorsed it, supposing it to be the note red to him. But we are satisfied that an indorser cannot avail himself of this distinction, but in cases where he is not chargeable with any laches or neglect, or misplaced confidence in others." (See also I Parsons on Notes and Bills, I 10 to I I 4 , and cases cited in notes.)

The judgment below must be reversed, and a cenire de noi'o awarded.

By the Court. - It is so ordered. ${ }^{1}$

56 NEW Yokk, I37. - IS74.

THIs action was upon a promissory note of $\$ 270$, signed by defendant, payable to E. A. Miller or bearer.

${ }^{1}$ Accord: Gibbs v. Linahul', 22 Mich. 479; De Camp v. IIamma, 29 Oh. St. 467; Puffer v. Sinith, 57 Ill. 527; Gritn v. IVilkie, (Iowa) 66 N. W. Rep. Io46. See Canlkins v. Whisler, 29 Iowa, 495, anti, p. 259 . So also the want of delivery of an incomplete instrument is a real or absolute defence. Neg. Inst. L.. $\$ 34$ [15]. See cases and notes, anti, pp. 275-283. - Ev. 
Defendant entered into a contract with Miller to act as agent for the sale of a patent hay fork and pulley. A contract was filled out by Miller and signed by both; also an order, which was signed by defendant, for one of the liay forks and two pulleys, for which, by the order, defendant agreed to pay nine dollars. These were delivered to defendant. Another paper was then presented to defendant for his signature, which Miller represented to be but a duplicate of the order. Defendant without reading or examining it, signed it and delivered it to Miller; the paper so signed was the note in suit. Plaintiff purchased in good faith before maturity, paying therefor $\$ 245$.

The court charged the jury: "If you find that this paper was never delivered as a note, plaintiff fails in his action; if you find that it was delivered but this plaintiff failed or neglected to make the proper inquiry, then he is not entitled to recover for he fails as a bona fide holder.'

Plaintiff excepted generally to the whole of the charge.

Plaintiff requested the court to charge:-

First. That if the signature upon the note is the genuine handwriting of defendant, circumstances of fraud in its inception constitute no defence to the note in the hands of an innocent purchaser.

The court refused to so charge.

Second. That if the plaintiff purchased said note in good faith and for a valuable consideration, the plaintiff is entitled to judgment for the full amount thereof.

Third. That if defendant negligently and without sufficient care and precaution put his name to the paper and delivered it to Miller, he is liable for its amount as a promissory note.

Fourth. That there are no circumstances in this case indicating a fraud in the inception, and which were calculated to put the plaintiff on his guard, and therefore he is a purchaser in good faith.

The court declined to charge either of these propositions.

Verdict and judgment for plaintiff (defendant ?)

JoHnson, J. - The judge charged the jury that if the paper sued upon was never delivered as a note, the plaintiff must fail in the action; and that even if it was delivered, and the plaintiff neglected to make proper inquiry as to its origin, he was not a bona fide holder and could not recover. The exception to the charge was general, but if both propositions were erroneous the error can be reached and corrected; especially as the attention of the judge appears to have been called, by requests to charge, to the precise grounds on which the charge is now claimed to be erroneous. 
The latter branch of the charge presents the question of notice to put a party on inquiry, as affecting his right to be regarded as a bona fide holder. It is now, however, the settled law that mere negligence, however gross, is not sufficient to deprive a party of the character of a bona fide holder. There must be proof of bad faith. That alone will deprive him of that character. (Itelch $\because$ Sage, $47 \mathrm{~N}$. Y. I 43 ; Sevbel r. Tational Curency Bank, Commission of Appeals, 54 N. Y. zSS; Murray r. Larducr, 2 Wall. r ro; Goodman v. Simonds, 20 How. 452.) This part of the charge, therefore, cannot be sustained. If, then, the appellant can maintain the position that the other branch of the charge is also erroneous, he will be entitled to the reversal of the judgment, notwithstanding the generality of the exception.

The evidence tended very strongly to show that the signature of the defendant to the note sued upon, was obtained from him through a very gross and fraudulent representation perpetrated upon him by one Miller. That when he signed it, he supposed he was signing a paper of a very different character, and not an engagement to pay money absolutely. He had, just before, signed an order for the delivery to himself of a hay fork and two grappling pulleys, amounting together in price to nine dollars, for which he engaged to pay; and this paper now in suit was presented to him as a duplicate of that order, and was signed as such without examination or reading it, upon the statement of Miller, with whom he was dealing, that such was its character. There does not appear to have been any physical obstacle to the defendant's reading the paper before he signed it. He understood that he was signing a paper by which he was about to incur an obligation of some sort, and he abstained from reading it. He had the power to know with certainty the exact obligation he was assuming, and chose to trust the integrity of the person with whom he was dealing, instead of exercising his own power to protect himself. It turns out that he signed a promissory note, and that it is now in the hands of a holder in good faith, for value. The question which arises on the branch of the charge now under consideration is, whether it is enough, as against a bona fide holder, to show that he did not know or suppose that he was signing a note, unless it also appears that he was guilty of no laches or negligence in signing the instrument. To that inquiry the attention of the judge, at the trial, was distinctly called; and the instruction which he gave and which was excepted to, did not submit, but excluded the consideration of it from the jury. It is quite plain that if the law is that no such inquiry is admissible, a serious blow will have fallen upon the negotiability of paper. It will be a premium offered 
to negligence. To insure irresponsibility only the utmost carelessness, coupled with a little friendly fraud, will be essential. Paper in abundance will be found afloat, the makers of which will have had no idea they were signing notes, and will have trusted readily to the assurance of whoever procured it that it created no obligation. To avoid such evils it is necessary, at least, to hold firmly to the doctrine that he who, by his carelessnes or undue confidence, has enabled another to obtain the money of an innocent person, shall answer the loss. If it be objected that there must be a duty of care, in order to found an allegation of negligence upon the neglect of it, it must be answered that every man is bound to know that he may be deceived in respect to the contents of a paper which he signs without reading. When he signs an obligation without ascertaining its character and extent, which he has the means to do, upon the representation of another, he puts confidence in that person; and if injury ensues to an innocent third person by reason of that confidence, his act is the means of the injury, and he ought to answer to it.

In Foster v. Mackinnon (L. R. 4 C. P. 704), the action was upon an indorsement of a bill of exchange, and the evidence was that the defendant indorsed it believing it to be a guarantee - that being represented to him as its nature by a person in whom he put confidence. The judge charged the jury that if the defendant signed it not knowing it to be a bill, but believing it to be a guarantee, in consequence of a fraudulent representation as to its character, and if he was not guilty of any negligence or laches in signing it, he was not bound. The jury found for the defendant. Upon a review of the decision, and after a very full and able discussion of the questions involved, the court held the direction at the trial to have been right; but a new trial was granted upon the ground that they were not satisfied with the finding of the jury on the question of fact, as I understand it, in respect to the question of negligence.

In Ihitney v. Snyder (2 Lans. 477), evidence had been refused that the defendant was unable to read, and that the note which he had, in fact, signed was represented to him to be an instrument of a different character, and was signed by him under such a belief. The court held that the evidence ought to have been received, principally upon the ground and authority of the case last cited - approving both branches of the rule as stated in that case, and adding that the case then in judgment was stronger for the defendant on the question of negligence than was Foster v. Mackimnon. This was clearly so; for in Whitney v. Snyder it appeared that the defendant could not read, and he was therefore compelled to put confidence in 
some one as to the contents of any paper which he might be called upon to sign. Indeed, the same exception in respect to negligence is recognized as a necessary element in the decision at General Term in this case. The difficulty is that, at the trial, the judge rejected that qualification of the rule, and held that if the party did not intend to make a promissory note he could not be held bound, even in favor of a bona fide holder for value.

The principle involved is recognized and in substance decided in Putuam v. Sullizan (3 Mass. 45). In that case the defendants had left with a clerk some signatures on blank pieces of paper, intended to be used as notes or indorsements, according to specific instructions. The clerk was induced by fraud to part with one of these blank signatures, and it was filled up as a note leaving the signature to appear as that of a payee and indorser. The action was by a holder in good faith, and the court, giving judgment by Chief Justice Parsons, say: “The counsel make a distinction between the cases where the indorser, through fraudulent pretenses, has been induced to indorse the note he is called upon to pay, and when he never intended to indorse a note of that description but a different note and for a different purpose. Perhaps there may be cases in which this distinction ought to prevail; as if a blind man had a note falsely and fraudulently read to him, and he indorsed it supposing it to be the note read to him. But we are satisfied that an indorser cannot avail himself of this distinction, but in cases where he is not chargeable with any laches or neglect or misplaced confidence in others. Here, one of two innocent parties must suffer. . . . The loss has been occasioned by the misplaced confidence of the indorsers in a clerk too young or too inexperienced to guard against the acts of the promisors." Upon these grounds the indorsers were held liable.

In Douglas $\because$. Matting (29 Iowa, 49S), the judge says: "It is better that the clefendants and others who so carelessly affix their names to papers, the contents of which are unknown to them, should suffer from the fraud their recklessness invites, than that the character of commercial paper should be impaired and the business of the country thus interfered with and unsettled."

In all these cases, the real ground of decision is nct that the party meant to make a promissory note, but that meaning to make an obligation in writing, and which was put in writing that it might of itself import both the fact and the form and the measure of the obligation, he trusterl another to fix that form and measure, without exercising that supervision which was in his power and by which perfect protection was possible. In such cases, the rule is, that he is bound 
by the act of him who has been trusted in favor of a holder in good faith.

The judgment must be reversed and a new trial granted, costs to abide the event.

All concur. Judgment reversed.

42 Solicitors' Journal (Jan. I, r898), I51, 67 L. J. Q. B. 224.

ACтIOx by payee against defendant as one of two makers of two joint and several promissory notes, for $\mathcal{E}_{3}, \mathrm{II}_{3}, \mathrm{I}_{5}$ s., and $£_{8} 8,000$, respectively. It is admitted that defendant's signatures are genuine and that his signatures to two letters authorizing plaintiff to pay the proceeds to Lord William Nevill, the other maker, are also genuine. Plaintiff gave value in good faith for the notes. Defendant's signatures to the notes and letters were procured by Lord William Nevill in this wise: The latter came to defendant and asked him to witness some documents, producing a roll of papers covered by blotting or other paper in which there were four openings; defendant asked what the documents were and was answered that they concerned private family matters, that defendant could see them if he insisted, but it was preferred that he should not; defendant did not insist and signed his name four times through the openings. Lord William Nevill also signed, and defendant believed he was signing as witness to the former's signatures. Defendant had just come of age, had known Lord William Nevill intimately for some years, and had no reason to doubt his honor.

The following questions were put to the jury, who gave the answer appended to each: - (I) Did the plaintiff take the promissory notes in good faith? [It is admitted he took them for value.] Answer.-

1" The law of the State is, that where a party is induced to sign a negotiable instrument by reason of fraud, artifice or deception practiced upon him by another as to the nature of the instrument, and the maker signs the same innocently and under the belief that it was a contract of a different character, then there can te no recovery upon the note, although the holder may be an innocent purchaser for value before maturity, unless the maker was guilty of laches or carelessness in omitting to read the same, or by some other means ascertaining the true nature and import of the instrument. (Fational Ex. Bk. v. Leneman, 43 Hun, 241, ciled with approval in Page v. Kreke', 137 N. Y. 313)."-Hutkoff v. Noje, 20 Misc. (N. Y.) 632 ( 1897.$)$ Negligence on the part of the one signing renders him liable to a holder in due course. Shirts v. Oa'rjohn, 6o Mo. 305; Citizens . Viat. Bank v. Smith, 55 N. H. 593: Killogs v. Curtis. 65 Me. 59: Nibiker v. Cutsinger, 4 Ind. 436 ; Ort v. Fowler, 3 I Kans. 478 . - ED. 
Yes. (2) Is the defendant's account of the circumstances under which he signed his name substantially true? Answer.- Yes. (3) Was the defendant, in signing his name as he did, recklessly careless, and did he thereby enable Lord William Nevill to perpetrate the fraud? Answer. - No; not under the circumstances. (t) Were the signatures to the documents given by the defendant in misplaced confidence in the statements of Lord William Nevill as to their nature? Answer. - Yes. (5) Did the defendant sign his name to be used by Lord William Nevill for any purpose he chose? Answer. - No. (6) Did the defendant attach his signature to the documents without due care? Answer. - No; not under the circumstances.

On these findings the case was reserved by the Lord Chief Justice for further consideration.

Lord Russell of Killowex, C. J.- I have now to consider in the light of these findings which of the parties is entitled to judgment. It is clear that the proof of the signature of the defendant to the promissory notes, coupled with proof of their delivery to the plaintiff under the apparent authority of the defendant, makes out a prima facie case for the plaintiff. Is it a conclusive case? Here two questions arise - (I) Is the defendant precluded or estopped from setting up the true circumstances under which his name came to appear on the documents in question? (z) If not, do those true circumstances afford an answer in point of law to the plaintiff's claim?

I. As to the first question the defendant is not, in my judgment, estopped or precluded from setting up the actual facts upon any principle of law. Apart from statute such preclision or estoppel can only arise (in circumstances like the present) where the defend. ant had so conducted himself that it wottd be contrary to natural justice to permit him to assume a position inconsistent with that which he had ostensibly occupied, or which he led others to believe he occupied, and upon which others had, nisled by his conduct, been suffered to act. In the present case the suggestion on the part of the plaintiff is that the defendant had not used due care in signing his name, and that he had signed in misplaced confidence in Lord William Nevill. The jury have found that there was, in fact, no want of due care in the circumstances in signing his name as he dicl; but it was urged that the finding as to misplaced confidence was sufficient, and the authority of a distinguished American judge in the case of Putnam v. Sullitan ( + Mass. +5) was cited. What does mis. placed confidence mean? It may mean conindence placed where you know or ought to know it is not safe, or confidence placed where you have every right to believe it is safe, but where it is afterwards 
betrayed. The former, I think, is the case the learned judge had in his mind, and the facts there may afford evidence of want of due care; but that clearly is not here the meaning attributed by the jury to misplaced confidence, for they have found that there was in the circumstances no want of due care on the part of the defendant. Taking the findings together they amount to this - that the defendant was in the circumstances guilty of no want of due care in placing confidence in the statement made by Lord William Nevill, and accordingly in signing his name as he did; and I decline to hold that the placing of confidence as here shown, which is afterwards betrayed, where it is not recklessly or negligently so placed, in any way precludes the defendant from setting up the true facts as a defence. I conclude, therefore, the defendant is not, upon any principle of law, estopped or precluded from setting up the true facts.

How, then, is the plaintiff's case put? It was argued that whatever was the law before or apart from the Bills of Exchange Act, I $8 S_{2}$, the facts here did not under that Act afford a defence as against a "holder in due course," which, it was said, the plaintiff was within section 29 , and that the question must be determined by reference to that Act alone. I think this argument involves a misconception both of the plaintiff's position and of the scope and effect of the Act of $\mathbf{r} 882$. It will be apparent from a consideration of the facts of the case that the plaintiff was not a "holder in due course" at all, but that he was, in fact, simply the named payee of two promissory notes. Further, an examination of sections $20,2 \mathrm{I}, 29,3^{\circ}$, and 38 , relating expressly to bills, and sections $\delta_{3}, s_{4}, 88$, and $\delta_{9}$, relating to promissory notes, will make it quite clear that " a holder in due course " is a person to whom, after its completion by and as between the immediate parties, the bill or note has been negotiated. In the present case the plaintiff is named as payee on the face of the promissory note, and therefore is one of the immediate parties. The promissory notes have, in fact, never been negotiated within the meaning of the Act.

I desire to say here that, even if the plaintiff were " holder in due course," it would, in my judgment, make no difference in the result.

But is the contention right that the Act of r 882 must alone be looked to? I think not. That Act was intended to be mainly a codification of the existing law, but it is not merely a codification Act, for some alterations of the law are clearly effected by it and it does not purport to be exhaustive, for, by section 97 , the rules of the Common Law (including the Law Merchant), save in so far as they are inconsistent with the express provisions of the Act, continue to apply. But I agree that in determining questions of liability on bills 
or notes it is proper to examine the Act before turning to the cases declaratory of the Common Law decided before that Act.

It is unnecessary to set out the provisions of the Act and to comment in detail upon them. It is enough to say that there is nothing in the Act which prevents the defendant from setting up the defence that he never made the promissory notes in question - which is the real defence here. It would, indeed, be strange if it did. For the purposes of the present case the question is precisely the same as if any other contract than one by promissory note had been written on the documents to which the defendant was induced to sign his name - for instance, if it had been a contract of guarantee or suretyship. Then the question would have been - Did the defendant make the contract of guarantee or suretyship? Here it is - Did he make the promissory notes sued upon?

II. The question, then, is, on the facts as they are now found to be - Did the defendant make the promissory notes in question? If he did not, then the finding of the jury that the defendant was not guilty of any want of due care establishes that he is not precluded from saying so. 'That there is a 'prima facie case on the plaintiff's evidence that he did, I have already said; but is that prima facie case rebutted and displaced by the defendant's evidence? According to that evidence it must, after the findings of the jury, be taken to be the fact that he was witnessing a deed or document; that he was so told; that he had no idea of signing, and was not asked to sign, any bill or promissory note, or to undertake any contractual obligation of any kind. A promissory note is a contract by the maker to pay the payee. Can it be said that in this case the defendant contracted to pay the plaintiff? His mind never went with such a transaction; for all that appears, he had never heard of the plaintiff, and his mind was fraudulently directed into a different channel by the statement that he was merely witnessing a deed or other document. He had no contracting mind, and his signature obtained, by untrue statements fraudulently made, to a document of the existence of which he had no knowledge, cannot bind him. It is as if he had written his name for an autograph collector, or in an album. The case diffors in no material respect from one in which a genuine signature is deftly transferred by delicate contrivance from one clocument to another, and so skillfully as to escape notice under ordinary examination. Or, again, if the body of the promissory notes liad been fraudulently written above, and after his signature had been made, it would have been forgery, and in such case it is clear no recourse could be had upon it. Can it make any difference as to resulting contractual obligation that the body of the note was, with. 
out his knowledge, filled up before he was fraudulently induced to put his name in the belief that it was something wholly different? I think not. In plain reason it must he said that the use to which the defendant's signature was applied was in substance and effect forgery, whether or not it amounted to the criminal offense of forgery.

I think it well to point out that cases like the present differ widely from those in which the party sought to be charged has agreed and intended to enter into contractual obligation by bill or note, but has been defrauded into agreeing, or been defrauded in the manner in which the bill or note has been dealt with. In such cases he is liable on principle and authority, to any one who has dealt with the bill or note in good faith and for value.

It was in argument admitted that the case of Foster v. Mackinnon (17 IT. R. I105, 4 L. R. C. P. 704), is in point, and is an authority binding on me if the Bills of Exchange Act of ISS2 has not altered the law as there declared. I find that the law has not been so altered. I see nothing in the Act to warrant the suggestion that it has been altered, and it is noteworthy that all the text-writers dealing with the Bills of Exchange Act, ISSz (including, indeed, the draftsman of the Act), treat that case as an existing authority. The facts in Foster v. Mackinnon were, that an old man of feeble sight was induced - without, as the jury found, any negligence on his part - to sign his name on the back of a bill by the fraudulent statement that it was a guarantee which, in fact, he had undertaken to sign. The Court of Common Pleas (consisting of Bovill, C. J., and Byles, Keating, and Montagu Smith, IJ.), held that he was not liable, and this in an action by what was then called a bona fide holder for value and without notice, of which " holder in due course " is now the legal equivalent.

In these islands, cases in litigation of frauds such as that here practiced are of rare occurrence, partly because of the existence and character of our stamp laws, but in the United States of America, where no such laws exist, there are many authorities dealing with points similar to that in the present case. (Douglas a'. Matting, 4 Am. Rep. $23 S$ [29 Iowa, 498]; Taylor v. Atchison, 5 Am. Rep. II [5+ Ill. 196]; Whitney v. Snyder, 2 Lans. 477; Walker v. Ebert, 9 Am. Rep. $54^{8}$ [29 Wis. 194]; Griffiths v. Kellogg, 20 Am. Rep. 48 [39 Wis. 290]). The great weight of United States authorities supports the riew of the common law expressed by the English judges.

I have thought it right to say so much, but in truth these authorities are not necessary for the purposes of this case. They are all cases where the bills or notes had been negotiated to persons now 
called " holders in due course." It follows, if such a holder cannot in a case like the present recover, a fortiori that the plaintiff - who, as named payee, is one of the immediate parties - cannot recover.

In the result, therefore, my judgment must be for the defendant, and the plaintiff must be enjoined from in any way dealing with the notes, and the same must be canceled so far as they purport to be the notes of the defendant. 


\section{ARTICLE VI. \\ Liability of Parties.}

\section{Maker: absolute, primary liability; admissions.}

\section{PResentient For PAiment tinecessary.}

See Neg. Inst. Law, $\$$ г 30 [70], fost, pp. 498-50г.

2. Libaility on Lost or Destroyed Instrunent.

$$
\text { McGREGORY } \approx \text {. MCGREGORY. }
$$

$$
\text { IO7 Massachuset'Ts, 5+3. - I87I. }
$$

Action against makers on notes alleged to be lost. Verdict for plaintiff, who filed a bond for protection of defendants from liability on the lost notes, to the approval of the judge.

GraY, J. ${ }^{1}$ - Destruction by fire is one mode by which property may be lost, and an allegation that a note has been lost is fully supported by proof that it has been destroyed by fire.

It is well settled in this commonwealth, that an action at law may be maintained on a lost promissory note, whenever a bond of indemnity will afford complete protection to the defendant; and that such an action may be maintained against the maker of such a note, upon filing a sufficient bond of indemrity. All the makers of the notes described in these three counts are defendants in this action; and they do not stand like an indorser of a promissory note, who is entitlecl, upon taking it up, to the possession thereof, in order that he may have his recourse over against the maker, or negotiate it again; or like the acceptor of a bill of exchange, who may need it as a voucher in settling his account with the drawer. (Falesv. Russell, 16 Pick. 315; Almy v. Reed, ro Cush. $42 \mathrm{I} ;$ Boston Lead Co. v. McGuirk, 15 Gray, 87; Tower v. Appleton Bank, 3 Allen, 387 ; Tuttle v. Standish, 4 Allen, 48I ; Sazannah National Bank v. Haskins, ${ }^{2}$ го Mass. 370.)

Judgment on the verdict for the plaintiff. ${ }^{3}$

\footnotetext{
${ }^{1}$ Omiluing other questions. - ED.

${ }^{2}$ Holds acceptor of lost bill liable only in equity. Accord: Pierson v. Hutchinson, 2 Camp. 2II. - ED.

${ }^{3}$ If a note or bill is shown actually to have been destroyed, most courts allow
} [446] 
3. Admission of Existence and Capacity of Payee.

II INDIANA, IOg. - ISSS.

Elliott, C. J. - The plaintiff, Maria Conklin, brought this action to recover the amount evidenced by a promissory note executed to her as payee by the appellant. The trial court sustained demurrers to several paragraphs of the answer filed by the appellant. . . . The answer is bad. It seeks to show that the payee of the note was not the real party in interest at the time the note was executed, and this the maker of a promissory note is estopped from doing. (Blacker v. Dunbar, ros Ind. 217 ; Wells v. Sutton, $8_{5}$ Ind. 70; Rogers v. Place, 29 Ind. 577; French v. Blanchard, I6 Ind. 143.)

$$
\text { Judgment affirmed, with ten per centum damages. }{ }^{1}
$$

an action at law. Des.4rtsv. Legsett, I6 N. Y. 582; Deanv. Speakman, 7 Blatchf. (Ind.) 317. But not if it is voluntarily destroyed by the holder. Blade v. Noland, I2 Wend. (N. Y.) I73. Some courts make a distinction between instruments lost before maturity and those lost after maturity, allowing an action at law on the latter. Thayer v. King, I5 Ohio, 242; Mowiry v. Mast, It Neb. 5 ro. But other courts deny the validity of this distinction. Moses $v$. Trice, 2I Gratt. (Va.) 556. See in general on lost or destroyed bills and notes, 2 Daniel on Neg. Inst., 5 I $475-1485$.

The matter is governed by statute in New York. Code Civ. Proc., $\$$ I9I7. - ED.

"Maker of a note payable to the order of "A. B. Attorney-General" cannot dispute his right to transfer it. Wolke v. Kuhn', Iog Ind. 313. Maker of a note payable at "A. B." cannot deny the existence of such a place when the statute requires negotiable instruments to be payable at a place certain. Frowen $\mathrm{v}$. First $N . B .$, I03 Ala. 123. Contra, where the statute requires it to be payable at a bank. Parkinson v. Finch, 45 Ind. 122. - Ew.

${ }^{2}$ In like manner the drawer (Grey v. Cooper, 3 Doug. 65), and acceptor (Taylor v. Croker, 4 Esp. 187; Smith v. Marsack, 6 C. B. 486 ), admit the existence of the payee and his then capacity to contract. See two following sections of Neg. Inst. Law. - ED. 


\section{Acceptor: absolute, primary liability; admissions.}

\section{Presentment for Payment Unnecessary.}

See Neg. Inst. LAw, $\$ 30$ [70]; post, pp. 498-50I.

2. Adilssions as to Drawer and Payee.

\section{$\S$ II2 NATIONAL PARK BANK $z^{\prime}$. NINTH NATIONAL [§62] $\mathrm{BANK}$.}

$46 \mathrm{NEW}$ YORK, 77. - $187 \mathrm{I}$.

THE first case is an appeal from judgment of the late General Term of the first judicial district, reversing order of Special Term sustaining demurrer to complaint, and also judgment entered upon said order.

The last is an appeal from judgment of General Term, New York Common Pleas, affirming judgment of Special Term of that court overruling demurrer to complaint.

The complaint in the first case states, in substance, that on the 25th March, 1867, the Ridgely National Bank, of Springfield, Illinois, drew its draft, or bill of exchange on plaintiff, for the sum of fourteen dollars and twenty cents, payable to the order of Ely Shirly, and delivered the same to the payee. That afterwards the amount of said draft was fraudulently changed to $\$ 6,300.00$, and the name of the payee to E. G. Fanchon, Esq. That the name of Wm. Ridgely, cashier, signed to said draft was erased, and afterward re-written by the person making the erasure. That the same was then discounted by the Lexington National Bank, and by it was indorsed to defendant. That afterward, and on or about April I 2, I867, defendant presented said draft to plaintiff, and said plaintiff paid thereon the sum of $\$ 6,300$. That plaintiff discovered the forgery May го, I867, and forthwith notified defendant thereof, and demanded re-payment of said sum, less fourteen dollars and twenty cents, which was refused. Defendant demurs, "that the complaint does not state facts sufficient to constitute a cause of action."

In the last case the facts are similar, save as to amount and names.

Allen, J. - The checks paid by the plaintiffs, the drawees, were forgeries throughout, as well the signatures as the bodies. The name of the signer, the cashier of the Ridgely Bank, was not the genuine signature of that officer, and was not written by his authority. The fact that a genuine check had been drawn, and signed by the proper party, upon the same piece of paper, does not 
affect the character of the instrument in its altered, and forged condition. The forger, by skillfully obliterating the genuine signature, together with the words and figures indicating the amount parable thereon, effectually destroyed the instrument, and it was incapable of being restored to its original condition, in the form of a check, and made available for any purpose.

It was but a blank form of a draft or bill, and the act of signing the name of the cashier as drawer, with intent to utter and pass the same as genuine, was a crime, and the signature a forgery, whether the check was for the same or a different amount from that for which the original and genuine bill had been drawn.

Whether the forger used the same paper on which the original instrument had been written and signed, and manipulated it to suit his purposes, or made and forged a check on another, and different piece of paper is not material, so long as the signature of the drawer was counterfeit.

The drafts paid by the plaintiff were not merely raised checks, that is, forged and altered by the obliteration and removal of onc sum, and the insertion of another, but were forged instruments in every sense.

The drafts signed by the cashier are not in existence in form as drafts. The genuine signature was wanting to make the instruments the checks of the nominal drawer for any amount. The money was then paid by the plaintiff upon bills drawn upon it, to which the name of its correspondent had been forged.

For more than a century it has been held and decided, without question, that it is incumbent upon the drawee of a bill to be satisfied that the signature of the drawer is genuine, that he is presumed to know the handwriting of his correspondent, and if he accepts or pays a bill to which the drawer's name has been forged, he is bound by the act, and can neither repudiate the acceptance nor recover the money paid.

The doctrine was broached by Lord Raymond in Fonss v. Fariler ( 2 Strange, 9 $f^{6}$ ), the Chief Justice strongly inclining to the opinion that even actual proof of forgery of the name of the drawer would not excuse the defendants against their acceptance. In 1762 the principle was flatly and distinctly decided by the Court of King's Bench, in the leading case of Price v. Nial (3 Burrows, r 354 ), which was an action to recover money paid by the drawee to the holder of a forged bill. Lord Mansfield stopped the counsel for the defendant, saying that it was one of those cases that never coukl be made plainer by argument; that it was incumbent on the plaintiff to be satisned that the bill drawn upon him was the drawer's hand, before 
he accepted and paid it, but it was not incumbent for the defendant to inquire into it. This case has been followed and the doctrine applied, almost without question or criticism, in an unbroken series of cases, from that time to this, and it has been distinctly approved in very many cases, which have not been within the precise range of the principle decided. (See Archer r. Bank of England, 2 Doug. 639; Smith r. Werer, 6 Taunt. 76 ; IIikinson v. Fohnson, 3 B. \& C. 428 ; Cook v. Mastcrman, 7 B. \& C. 902; Cooper v. Mever, ro B. \& C. 468: Saunderson r. Coleman, + M. \& G. 209; Smith v. Chester, I D. \& E. R. 655; Bass v. Clive, + M. \& S. I5; Bank of Commerce v. 'nion Bank, 3 Comstock, 23o; Goddard r. Merchants' Bank, 4 Comstock, r 49 ; Canal Bank v. Bank of Alban!', I Hill, 287.)

Cases have been distinguished from Price r. . Tal, and its applicability to a transfer of a forged instrument, between persons not parties to it, has not been extended to forgeries of indorsements or handwriting of parties to negotiable instruments, other than the drawer. But, as applied to the case of a bill to which the signature of the drawer is forged, accepted or paid by the drawee, its authority has been uniformly and fully sustained, and the rule extends as well to the case of a bill paid upon presentment, as to one accepted and afterward paid. (Bank of St. Albans r. Farmers' $\$ M$. Bank, ro Vermont, I4I; Le'y r. Bank of the U.S., 4 Dallas, 234; Bank of U. S. v. Bank of Georgia, ro Wheat. 333; Youngr r. Adams, 6 Mass. I82; Gloucester Bank v. Bank of Salem, I7 Mass. 4r.)

A rule so well established, and so firmly rooted and grounded in the jurisprudence of the country, ought not to be overruled or disregarded. It has become a rule of right and of action among commercial and business men, and any interference with it would be mischievous. Judge Ruggles in Goddard r. Morchants' Bank (supra), well says, "it should not be departed from or frittered away by exceptions resting on slight grounds, and cannot be overruled, without overthrowing valuable and well-settled principles of commercial law."

In the first above entitled action, the judgment of the General Term should be reversed, and that of the Special Term affirmed, and judgment absolute for the defendant with costs; and in the other, the judgment of the General and Special Term should be reversed, and judgment for the defendant with costs.

All concur; PECkHAri, I., not voting.

Judgment accordingly. ${ }^{1}$

\footnotetext{
${ }^{1}$ In the case of a bill payable to drawer's order the acceptor admits the capacity of the drawer to draw and to indorse: he admits the genuineness of the signature as drawer, but, it seems, not the genuineness of the signature as
} 
IOI New YORK, 63. - ISS5.

This action was brought upon defendant's acceptance of a bill of exchange drawn upon him at ninety days by Ran Runnels of Rivas, in the State of Nicaragua, payable to the order of Hourquet \& I'oylo and by them indorsed hefore acceptance to plaintiffs, who obtained defendant's acceptance.

Defendants offered to show that the acceptance was made without consideration and was induced by fraudutent representations on the part of the drawer; this was objected to and excluded. Judgment for plaintiff at trial. Judgment reversed at General Term (2S Hun, 77). ${ }^{1} \quad$ Plaintiff appeals.

[Reportid he'in at $\$ .336$.

indorser. Brathatati v. Gardiner, 8 Q. B. 473 ; Smith v. Marsack, 6 C. B. 4 \$6, is L. J. C. P. 65; Halifax v. Lyle, 3 Exch. +46 ; Bicman r. Duck, II M. \& W. 25I; Garland r. Jacomb, L. R. S Exch. 2i6. See Bills of Exchange Act, 54 , subsec. $2(b)$. In like manner he admits the authority of an agent to draw, but not his authority to indorse. Robinson v. Farrow, 7 Taunt. 455 .

The acceptor does not admit the genuineness of the body of the bill. Hence if it has been raised he is not bound on his acceptance, and if he has paid a raised bill or check, he may recover the money. Murine - I. B. v. Nat. City Bk., 59 N. Y. 67; Hhite v. Contincutal Bh., 64 N. Y. $3 \mathrm{I} 6$; Ridington v. Woods, +5 Cal. 4o6. But see llard v. Allen, 2 Met. (Mass.) 53. He is not under a duty to take precautions against subsequent fraudulent alterations; it is the drawer who has control over its form. Scholfieli v. Londeshorough, ISg6, A. C. 5 I4. - ED.

1."The acceptance was a new contract between the plaintiffs and the defendant, based, of course, upon the supposition that the defendant was indebted to the drawer in the amount of the bill, or had sufficient money of the drawer in his hands to meet the same. If, in point of fact, that supposition was wholly unfounded and he was induced by misrepresentations of the drawer to make the acceptance, his liability, in the absence of all consideration for accepting the bill, is no greater than that which Runnels himself could have enforced, except as between him and some bona fide holder for value. The plaintiffs did not occupy that position, they having parted with nothing of value for the acceptance itself." s. c. at General Term, 25 Hun, 77. - En. 


\section{Drawer: secondary, conditional liability.}

I. Conditions: Presentment; Notice; Protest.

[See ART. ViI, ViII, Xili, post.]

2. Admissions as to Payee.

$\S$ III

GREY $\imath^{\prime}$. COOPER.

3 Douglas (K. B.), 65. - 1782 .

Action against drawer by indorsee. Plea, that the payee-indorser at the time of his indorsement was an infant. Demurrer.

LORD MANSfield. - The ground on which the drawer is charged is that he drew a bill by which he engaged to pay according to the order of the payee, whoever that payee might be. He might give the infant an authority which the law itself does not give him. In the same manner he may give a bill to his own wife. The drawer says, "Let anybody trust the payee on my credit." The acts of an infant are void or not, accordingly as they are for his benefit. The privilege of an infant is personal, and there is no question here as between the infant and another person. The infant sets up no claim, and the drawer is liable to pay.

Judgment for the plaintiff.

IV. Seller: warranties.

I. Instrument Genuine and What it Purports to Be.

$\S$ II5

MEYER $i$. RICHARDS.

163 United States, $3 S_{5}$. - isg6.

Action to recover back the purchase price of thirteen bonds of the State of Louisiana, payable to bearer, sold by defendant to plaintiff, and afterwards discovered to have been issued without authority of law and declared by the Constitution of the State to be null and vold. The bonds were in the State treasury for cancellation and were fraudulently issued by the State treasurer, who put them on the market surreptitiously and without authority. The signatures and seal were genuine. Judgment for defendant.

Mr. Justice White, after stating the case, delivered the opinion of the court.

We will . . consider the case upon the theory that the only warranty, if any, is one to be implied from the nature of the contract. 
It is obvious from the facts just detailed that the thirteen bonds which were sold by the defendant in error to the plaintiff in error were at the time of the sale absolutely roid. The twelve which originally belonged to the two college funds were in express terms declared by the Constitution of the State to be " null and void," and the General Assembly was forbidden to make any provision "for their payment," and they were ordered to be "destroyed in such manner as the Generai Assembly may direct." This provision of the Constitution was in existence while the bonds were in the hands of the State, and before they were fraudulently and surreptitiously sold. Indeed, these bonds were never lawfully put into circulation, because, having been originally issued to represent trust funds belonging to the State, they were held by officers of the State for its account. The remaining bond was also void under the Constitution of the State, since it had been, under the express terms of that instrument, surrendered to the State treasurer for cancellation and another bond issued in its stead.

The bonds were undoubtedly sold by the defendant in error as lawful obligations of the State. Both parties to the contract of sale so considered. The pleading and the statement of facts leave no question on this subject. The controversy here presented is wholly between the vendor and vendee as to the nature and extent of the obligation of warranty resulting from the sale. We are therefore not concerned with whether the defendant at the time of the sale stood in the attitude of a third holder of negotiable paper for value before maturity. Even if he were in such a condition, and at the time of the sale there was a constitutional provision which rendered the bonds void and incapable of enforcement, it is clear that the delivery by the vendor to the vendee of bonds stricken with constitutional nullity was not the delivery of an existing obligation within the meaning of the contract if it imported a warranty of the existence of the bonds which it covered. The admission being that both parties contemplated the delivery of valid obligations, honds of that character being outstanding, if warranty of existence was implied by law, such purpose was not fulfilled by the delivery of a mere equity, which one of the parties, the seller, claims was existing in his behalf. Valid bonds, and not the mere claim lyy the seller to enforce invalid bonds, was the object of the contract. 'This is especially true in view of the fact just referred to, that at the date of the sale the Constitution of the State in express terms forbade the enforcement of twelve of the bonds, and practically stupulated to the same effect as to the other.

The sale was a Louisiana contract. We must consequently 
determine the rights and obligations of the parties by the law of that State. By the civil law, which prevails in Louisiana, warranty whilst not of the essence, is yet of the nature of the contract of sale, and is, therefore, implied in every such contract unless there be an express stipulation to the contrary. (Bayon v. Vaz'asseur, ro Martin, 61 ; Strawbridgev. Warfeld, 4 Louisiana, 20.) The following provisions on the subject of warranty are found in the Louisiana code:

"The seller is bound to two principal obligations, that of delivery and that of warranting the thing which he sells." (C. C. 24i5.) "Although at the time of the sale no stipulations have been made respecting the warranty, the seller is obliged, of course, to warrant the buyer against the eriction suffered by him from the totality or part of the thing sold and against the charges claimed on such thing which were not declared at the time of the sale." (C. C. 250r.) "Even in case of stipulation of no warranty, the seller in case of eviction is liable to a restitution of the price, unless the buyer was aware, at the time of the sale, of the danger of the eviction, and purchased at his peril and risk." (C. C. 2505.)

These articles of the Louisiana Civil Code, which do but formulate the principles of the civil law as to warranty, are not wholly in accord with the doctrines of the common law. The distinction between the two systems may be briefly summed up by saying that the one, the civil-law doctrine, finds its expression in the maxim ateat aenditor, whilst the rule of the common law is conveyed by the aphorism careat cmptor. It is unnecessary to determine the scope, under the Louisiana law, of the obligation of warranty as to property generally, since we are in this case concerned only with its limit when arising from the sale of a credit or other incorporeal right. The code of that State contains express provisions defining the extent of the obligations arising in such case:

"He who sells a credit or an incorporeal right, warrants its existence at the time of the transfer, though no warranty be mentioned in the deed." (C. C. 26.46.) "The seller does not warrant the solvency of the debtor unless he has agreed so to do." 1 (C. C. 26+7.)

These provisions, instead of causing the obligation of warranty in a sale of an incorporeal right to be broader than in the case of tangible property, on the contrary makes it narrower.

As then, under the law of Louisiana, the seller under the contract of sale was obliged to warrant the existence of the thing sold, the case of the defendant in error involves the practical contention that a bond which at the time of the sale was declared by the Constitu-

\footnotetext{
${ }^{1}$ See frown v. Hontgomery, 20 N. Y. 287, fost, p. 469. - ED.
} 
tion of the State to be non-existing, is yet for the purposes of the sale to be treated as an existing obligation. This proposition is an obvious contradiction in terms, and of course refutes itself. [Citing authorities from Louisiana and French courts.]

Of course, this warranty of existence, as established by the law of Louisiana and as found in France and other civil-law countries, does not govern a contract of sale when the object contemplated by a sale is a thing whether existing or not existing: in other words, where the parties buy, not an existing obligation, but the chance of there being one. This is illustrated by Knight v. Lanfear ( 7 Rob. [La.] 172), where the court, per Martin, J., said, in speaking of the thing sold: "Whatever may be its value, if it be not in substance what the purchaser believed he was receiving, his error must invalidate the sale, because it prevented his consent; non a'idetur, qui crrat, consentire." And, in speaking of a sale of doubtful or non-existing things, this great judge said: "This claim was a fair object of sale if its nature had been disclosed, but that was concealed and was probably unknown to them, and what was offered for sale was something quite different from this claim." The same distinction has been considered and applied by the courts of France. (Dulac $c$. Clusel et Cie., Lyons, Nor. 30 , I 849 , Journal du Palais, I, I8 $5=32$.)

The defendant in error does not dispute that the foregoing principles exist in and are controlling under the Louisiana law, under the law of France, and also under the civil law generally from which the law of Louisiana is derived. But whilst thus admitting, he denies that the contract of sale, involved in this case, was governed either by the Louisiana code or the general principles of the civil law. This proposition rests on the contention that when the Civil Code of Louisiana was compiled, its framers contemplated the simultaneous enactment of a Commercial Code which was then drafted, and therefore onitted from the former Code the necessary provisions to govern commercial contracts, under the hypothesis that the latter would also be enacted; that in consequence of the failure to adopt the Commercial Code, the courts of Louisiana have held that cases arising under the law merchant are governed by that law in the absence of an express statutory requirement to the contrary. From this premise the conclusion is drawn that as the contract in question involved the sale of negotiable bonds, the obligations resulting from the sale are commercial in their nature, and are controlled by the law merchant, by which it is asserted the vendor in such a case, when sellng in good faith, warrants only that the signatures to the paper sold are not forgeries. In a restricted sense the part of the proposition relating to the operation of the law merchant, in 
the State of Louisiana, is well founded. (Harrod v. Lafayre, I 2 Martin, 29; Wagner v. Kenncr, 2 Rob. La. I2 ; Barry r. Insurance Co., I 2 Martin, 49\$; MiDonald v. Milloudon, 5 Louisiana, 403.) Whilst this is true, the contention is yet erroneous in a twofold sense; first, in presupposing that a mere contract of sale of commercial paper, without recourse, is governed as to the obligations, between the vendor and rendee, by the law merchant; second, in assuming that in such a sale, either under the principles of the civil law or what the argument presumes to be the law merchant, the only warranty resting upon the rendor is that of the genuineness of the signatures to the paper sold. [Citing authorities from Louisiana and French courts.]

None of the authorities referred to by counsel for defendant in error sustain the proposition heretofore stated with reference to the supposed existence and applicability of the law merchant, and the results which it is claimed flow therefrom. On the contrary, both in England and in the United States the doctrine is universally recognized that where commercial paper is sold without indorsement or without express assumption of liability on the paper itself, the contract of sale and the obligations which arise from it, as between vendor and vendee, are governed by the common law, relating to the sale of goodis and chattels. So, also, the undoubted rule is that in such a sale the obligation of the vendor is not restricted to the mere question of forgery a'cl non, but depends upon whether he has delivered that which he contracted to sell, this rule being designated, in England, as a condition of the principal contract, as to the essence and substance of the thing agreed to be sold, and in this country being generally termed an implied warranty of identity of the thing sold.

Benjamin on Sales (4th Am. ed., sec. 600), says:

"When the vendor sells an article by a particular description, it is a condition precedent to his right of action " [to recover the price agreed to be paid by the vendee] "that the thing which he offers to deliver, or has delivered, should answer the description; " [and, in sec. 607 , the author says: "Under this head may also properly be included the class of cases in which it has been held that the vendor who sells bills of exchange, notes, shares, certificates and other securities, is bound, not by the collateral contract of warranty, but by the principal contract itself, to deliver as a condition precedent that which is genuine, not that which is false, counterfeit or not marketable by the name or denomination used in describing it."

It is upon this general principle of the common law, not upon any peculiar doctrine of commercial law, that the cases in the common law courts proceed. [Discussing fones v. Ryde, 5 Taunt. $488 ;$ Fcnns 
v. Harrison, 3 T. R. 757; Hilkinson v. Folnton, 3 B. \& C. 428 ; Young v. Cole, 3 Bing. N. C. 724; Lamert v. Heath, I 5 M. \& W. 486 ; Gomperts v. Bartlett, 2 E1. \&. B1. S49; Gurncy v. Womersley, 4 El. \& B1. 133.]

The cases in the American courts, whilst declaring the same rule as that recognized in England, place it upon a theoretical basis differing somewhat from that pronounced by the English courts; that is, instead of pronouncing it a condition of the principal contract that the thing suld, in its essence and substance, must be delivered, declare that there is an implied warranty of identity, or, in other worls, that the thing sold is what it purports to be. Daniel, in his treatise on Negotiable Paper $\left(\$ 733^{a}\right)$, calls attention to the different definitions given to the same obligation by the American and English courts, and indicates the view that the form of expression used by Benjamin in the passage already quoted is the more accurate one.

Aside, however, from the mere garb in which the thought is clothed, the American and English courts are in full accord. This is shown by the case of Utley v. Donaldson (94 U. S. 29, 45), where Benjamin on Sales is approvingly referred to, as also Flyn $\mathrm{x}$. Allen (57 Penn. St. 482 ), and $I V c b 6$ v. Odcll (49 N. Y. $5 s_{3}$ ), both of which cases, as also the line of American adjudications which enforce the same doctrine, are noted in the margin of this opinion.'

Many of the controversies covered by the cases referred to arose in consequence of the sale of a forged note, but the principles upon which all the authorities proceed do not confine the right of recovery to such a case, but rest upon the general doctrine to which we have already referred. In fact, no case is reported wherein the obligation, as between vendor and vendee, in the sale of negotiable paper, is claimed to be controlled other than by the general principles of the common law, though in three cases, Baxter v. Duren (29 Naine, 434); Fisher v. Ricman (I 2 Maryland, 497); and Ellis v. IVild (6

1 Thralt v. Niwith, I9 Vt. 202; Lyons v. Millir, 6 Gratt. 427; Aldrich v. Jackson, 5 R. I. 218; Barton v. Trent, 3 Head, 167; Dilatare Bank v. Jaritis, 20 N. Y. 226; Mirriam v. Wolcott, 3 Allen, 25s; Bill v. Cafferty, 2 I Ind. fIr; Sananzey v. Parker, 50 Penn. St. 4tr; Morrison v. Lozhll, + IV. Va. 346; Wibh v. Odell, 49 N. Y. 583 ; Worthington v. Cowles, II Mass. 30; Snytir v. Rino. 35 Iowa, 329; Giffert v. West, 33 Wis. 617, 37 Wis. 1I5; Itannum v. Richardson, ts Vt. 508; IIusscy v. Sibley, 66 Me. I92; Hitrst v. Chambers, I2 Bush (Ky.) r55; Allen v. Clark, 49 Vt. 390; Bankhead v. Ozenn, 60 Ala. 457 ; Smith v. Mi. Vair, I9 Kans. 330; Challiss v. McCrum, 22 Kans. 157; Pogers v. Walsh, I2 Neb. 2S; Milliken v. Chapman, 75 Me. 306 ; Daskam v. Cllman, $7+$ Wis. 47t; Palmer v. Conetney, 32 Neb. 773; Ware v. McCormack, 96 Ky. 139, 28 S. W. Rep. I57; Brown v. Ames, 59 Minn. 476,6 r N. W. 448 . 
Mass. 32I), the deduction was made from the law respecting the sale of goods that on a sale of negotiable paper there was under the principle of caieat emptor no implied warranty even that the signatures to the paper were not forged. Ellis v. IVild was, however, expressly overuled in Merriam $\mathrm{r}$. Wolcott (3 Allen, $25 \mathrm{~S}, 260$ ); and from the allusions to Baxter v. Duren, contained in the later Maine decisions previously noted in the margin, it is doubtful whether the early ruling in Maine would now be followed there. The three cases referred to, it is needless to say, are practically disregarded by the entire current of American and English authority, and stand alone. They are disavowed by the defendant in error here, since his argument admits that there is a warranty of the genuineness of the signatures to an apparent negotiable instrument, thereby conceding the subsistence of the obligation to warrant the existence or identity of the thing sold, and yet seeking to avoid its consequences by limiting it to non-existence resulting from a particular nullity.

There is an exceptional case (Littauer v. Goldman, 72 N. Y. 506, - r878), which holds that the common-law obligation, as to the implied warranty of identity in the thing sold, in the case of commercial paper, extends only to the genuineness of the instrument. The case was one involving the nullity of a usurious note, and, if correctly decided, would be authority for the proposition that there was a peculiar species of warranty in the sale of commercial paper, differing from all others; in other words, that there was a law merchant of warranty where there was no commercial contract. The opinion in this case illustrates the same contradictory position presented here by the argument of the defendant in error, to which we have just called attention, that is, that it admits the common law-rule and then denies its essential result by eliminating conditions of nonexistence which are necessarily embraced by it. It follows that this New York decision leads logically to the riew expressed in the Maine and Maryland cases just referred to, for either the principle of warranty of identity must be accepted or rejected; it cannot be accepted and its legitimate and inevitable results be denied. The rule there announced was in conflict with previous decisions in New York, and the decision is strongly criticised by the Court of Errors and Appeals of New Jersey in Wood v. Sheldon ( 42 N. J. L. 421,425 ).

In Giffert v. West (33 Wisconsin, 6I7, - IS73), where a note was sold which was void for usury, the vendee was allowed to recover the consideration paid by him, and his right to do so was based upon the general doctrine that one making a sale is bound as a condition of the principal contract to an implied warranty of the existence of the thing sold. 
In Hannum v. Richardson ( 48 Vermont, $508,-1875$ ), a very clear statement of the doctrine is found. There an indorser sold a negotiable promissory note without recourse. The note had been given for intoxicating liquors sold in Vermont in violation of law, and on that account was void at its inception. It was claimed that the defendant knew of the invalidity of the note when he transferred it. The court, however, held that knowledge on the part of the seller was not necessary to fix his liability, saying (p. 5 ro):

" $\mathrm{By}$ indorsing the note 'without recourse,' the defendant refused to assume the responsibility and liability which the law attaches to an unqualified indorsement, so that, in respect to such liability, it may perhaps be regarded as standing without an indorsement. If it be so regarded, then in what position do these parties stand in respect to the transaction? The principle is well settled, that where personal property of any kind is sold, there is on the part of the seller an implied warranty that he has title to the property, and that it is what it purports to be, and is that for which it was sold, as understood by the parties at the time, and in such case knowledge on the part of the seller is not necessary to his liability."

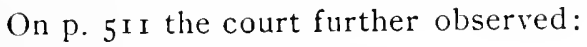

"The note in question was not a note, it was not what it purported to be, or what it was sold and purchased for; it is of no more effect than if it had been a blank piece of paper for which the plaintiff had paid his fifty dollars. In this view of the case we think the defendant is liable upon a warranty that the thing sold was a valid note of hand."

Nor is there any foundation for the assertion that Otis v. Cullum (92 U. S. 447), and the cases of Orlcans v. Platt (99 U. S. 676), and Etna Life Ins. Co. v. Middleport (12+ U. S. 5.34), both of which cite Otis v. Cullum, support the doctrine that a sale of commercial paper without recourse is not, as between the vendor and vendee, governed by the ordinary rule of the common law. On the contrary, that case expressly rested its conclusion on the decision in Lamert v. Heath, sufra, which iatter case, as we have seen, whilst enforcing the principles of the common law, considered that uncler the particular facts there presented it was a question for the jury to determine whether the scrip delivered was the kind of scrip which the defendant had ordered purchased. That case not only, as has already been stated, concerned non-negotiable paper, but its decision involved no question of the scope of the warranty, but solely what was the thing bought. Nor does the case of Otis v. Cullum justify the alssumption that this court laid down the rule that a mere sale of commercial paper, as between vendor and vendee, when the sale was matle without recourse, created some peculiar and exceptional warranty to be considered in this particular as the law merchant. It is true that in 
expressing the general doctrine Mr. Justice Swayne said: "The seller is liable $e x$ delicto for bad faith, and $e x$ contractu there is an implied warranty on his part that they belong to him and are not forgeries. Where there is no express stipulation there is no liability beyond this." But in using this language, as to the extent of the warranty, the mind was directed to that form of non-existence which more commonly obtains, and the expression is a mere illustration of the rule de co quod plerumque fit. If this were a case where a vendee claimed to recover back the price paid by him on a purchase of negotiable securities, which pass by delivery from hand to hand, on the averment that after the sale it had developed that they were not valid (although not forgeries), because the law under which they had been issued was constitutionally void or ultra ires, the claim of implied waranty of existence would be without merit, for the reason that such a state of fact would present a case of a sale of securities whether valid or invalid, hence engendering no implication of warranty of existence. Under the state of facts thus supposed, the purpose of the parties to make a contract of that nature would legally result from the fact that they were both necessarily equally chargeable with notice of want of power, and therefore would be both presumed to have acted with reference to such knowledge. This is Otis v. Cullum. But it is not the case at bar, since it is here admitted that both parties, in entering into the contract of sale, contemplated valid securities, of which there were many outstanding, and those delivered were void, not because of a want of power to enact the law under which they were issued, or because they were ultra ilres for some other legal cause, but because they were stricken with nullity by a constitutional provision adopted after the act authorizing the issue of the securities, and where nothing on the face of the bonds indicated that they were illegal. The distinction pointed out by the foregoing statement not only illustrates the correctness of the decision in Otis v. Cullum, but also demonstrates the error of attempting to extend it to the state of facts presented in the case under consideration. Indeed, in examining and applying Otis v. Cullum the fact that it does not control a case like this has been recognized. (Daniel, Neg. Inst., \$ 734a; Rogers v. Malsh, supra; Cincinnati, Nez' Orleans, ctc., Railizay v. Citizens' National Bank, 24 Week. Law Bull. [Ohio], I98, 2 i r.)

The foregoing analysis of the principles and review of the authorities governing the law of sale of negotiable paper, transferred without recourse, as between vendor and vendee, clearly demonstrates the unsoundness of the positions upon which the defendant in error relies, since it affirmatively establishes that there is no peculiar 
warranty, in a sale of commercial paper, and that the reasoning by which it is attempted to prore its existence is a mere misconception of the principles of the common law relating to the sale of goods and chattels.

In passing, however, it is worthy of note that whilst the civil law enforces in the contract of sale generally the broadest obligation of warranty, it has so narrowed it, when dealing with credits and incorporeal rights, as to confine it to the title of the seller and to the existence of the credit sold, and, econcerso, the common law, which restricts warranty within a narrow compass, virtually imposes the same duty by broadening the warranty as regards personal property so as to impose the obligation on the vendor to deliver the thing sold as a condition of the principal contract or by implication of warranty as to the identity of the thing sold. By these processes of reasoning the two great systems, whilst apparently divergent in principle practically work substantially to the same salutary conclusions.

There are many questions discussed in the brief of counsel which we do not notice, and which we content ourselves with saying are without merit. The views above stated are controlling and decisive of the case and lead necessarily to the reversal of the judgment. As the case was heard upon a stipulation waiving a jury and upon an agreed statement of facts, it is our duty, in reversing, to direct that the proper judgment be entered below. (Fort Siott v. Hickman, i I U. S. I 50 , and cases there cited.)

It follows that -

The judgment of the Circuit Court must be reversed, and the case be remanded with directions to enter judgment for plaintiffs for eight thousand three hundred and eighty-three dollars and seventy-five cents $\left(\$ S, 3 S_{3} \cdot 75\right)$, with interest from judicial demand and costs.

$\S$ II5

CHALIISS $\tau$. MCCRUM.

$[365]$ 22 KaxSAS, I57. - IS79.

Action to recover damages upon an implied warranty in the sale of certain notes. Demurrer to the petition overruled. Defendant appeals.

The opinion of the court was delivered by -

Brewer, I. - On December $4, \mathbf{I} 8_{7} \mathrm{I}$, plaintiff in error loaned one Edward A. Ege $\$ 250$, and took his note therefor in the sum of $\$ 265$, payable to Richard Probasco or bearer, and secured by mortgatge. Long after its maturity, and in 1876 , several payments having been 
made thereon in the meantime, plaintiff in error sold the note for its then face value to defendant in error. At the time of such sale he indorsed it, "Without recourse. - W. L. Challiss." McCrum sued on the note. Ege pleaded usury. The plea was sustained, and McCrum recovered $\$ 229.90$, less than the face value of the note, for which sum he brought this action. A demurrer to the petition was overruled, and this ruling is now presented for review.

Can the action be sustained? Of course no action will lie on the indorsement, for by his written contract Challis expressly declines to assume the liabilities of an indorser. If sustainable at all, it must be as against him as a vendor, and not as an indorser, and upon the doctrine of an implied warranty. The theory of the defendant in error is, that every vendor of a bill, bond or note impliedly warrants that it is what it purports on its face to be - the legal obligation of the parties whose names appear on the instrument; and that the character of the indorsement or the lack of an indorsement in no manner affects this implied warranty. On the other hand, the counsel for plaintiff in error lays down the broad proposition that "there is no such thing as implied warranty in the sale of chattels;" and that, in the absence of express warranty, the maxim carcat emptor is of universal application. It is clear that the character of the indorsement cuts no figure in the question; as stated, no action will lie on it. But further, the restriction is only as to his liability as indorser, and in no manner affects his relation to the paper as vendor. An unqualified indorsement is the assumption of a conditional liability. The indorser becomes a new drawer, and is liable on the default of the drawee. "Without recourse," does away with this conditional liability. It leaves the indorsement simply as a transfer of title, and the indorser liable only as vendor; yet it leaves him a vendor, and divests him of none of the liabilities of a vendor. It makes the transaction the equivalent of a delivery of paper payable to bearer, and transferable by delivery. (Hannum v. Richardson, 48 Vt. 508.)

Independent, therefore, of any matter of indorsement, what implied warranty is there in the transfer of a promissory note? Two things are clear under the authorities: First, that there is an implied warranty of the genuineness of the signatures; and, second, that there is no warranty of the solvency of the parties. It is unnecessary to more than refer to a few of the authorities upon these propositions: (Byles on Bills, pp. 123, 125, and cases in notes; Foncs v. Ryde, 5 Taunt. 488 ; Gurney v. Womersley, 4 El. \& Bl. r32; Gomperts : Bartlett, 24 Eng. Law and Eq. 156; Terry v. Bissell, 26 Conn. 23; Mcriam v. Wolcott, 3 Allen, 259; Aldrich v. Fackson, 5 
R. I. 2 I 8 ; Lobdcll v. Baker, 3 Metc. 469 ; I Addison on Cont., p. 152; Ellis v. Wild, 6 Mass. 321 ; Eagle Bank $\because$ Smith, 5 Conn. 71 ; Shaz'er v. Ehle, r6 Johns. zor; Dumont v. Williamson, is Ohio St. 515; 2 Parsons on Notes and Bills, ch. 2, 2.) But in the case at bar, the signature of the maker was genuine. The objection is, that it was never his legal obligation to the full amount for which it pur. ported to be. How far is there any implied warranty in this respect? A reference to some of the leading cases will throw light upon this question.

In Thrall $v$. Vitell (ig Vt. 203 ), it appeared that one of the makers of a note was insane. The vendor made a written assignment, in which was a description of the note, and the court construed this as an express warranty that the instrument was the legal obligation of the apparent makers, and one being incapable of contracting, gave judgment against the vendor on account of this breach for the amount received by him. While the judgment of the court is rested upon the fact of an express warranty, the judge who writes the opinion expresses his individual conviction that the same result would follow on a mere transfer without any express warranty, and quotes approvingly an extract from Rand's edition of Long on Sales, that "there is an implied warranty in every sale that the thing sold in that for which it was sold."

In Lobdell v. Baker (3 Hetc. 469 ), it appeared that the owner of a note procured the indorsement of a minor, and then put the paper in circulation. He was held liable to a subsequent holder. Chief Justice Shaw, delivering the opinion of the court, says:

"Whoever takes a negotiable security is understood to ascertain for himself the ability of the contracting parties, but he has a right to believe, without inquiring, that he has the legal obligation of the contracting parties appearing on the bill or note. Unexplained, the purchaser of such a note has a right to beheve, upon the faith of the security itself, that it is indorsed by one capable of binding limself by the contract which an indorsement by law imports."

In Hannum v. Richardson ( ${ }_{4} 8 \mathrm{Vt}$. 5 oS), a note was given for liquor sold in violation of law, and was by statute void. Defendant knew its invalidity, transferred it by an indorsement without recourse, and he was held liable to his rendee.

In Delaware Bank v. Faris (20 N. Y. 226), a usurious note was sold, and the vendor was adjudged liable, not merely for the money received by him, but also the costs paid by his vendee in a suit against the makers of the note. In the opinion, Mr. Justice Comstock uses this language:

" The authorities state the doctrine in general terms that the vendor of a chose in action, in the absence of express stipulation, 
impliedly warrants its legal soundness and validity. In peculiar circumstances and relations, the law may not impute to him an engagement of this sort. But if there are exceptions, they certainly do not exist where the invalidity of the debt or security sold arises out of the vendor's own dealing with or relation to it. In this case, the defendant held a promissory note which was void, because he had himself taken it in violation of the statutes of usury. When he sold the note to the plaintiffs and received the cash therefor, by that very act he affirmed in judgment of law that the instrument was unattainted so far at least as he had been connected with its origin." 1

In Young v. Cole (3 Bingham N. C. 724), certain bonds were sold as Guatemala bonds, which turned out afterward to be lacking the requisite seal, and the vendor, though ignorant of the defect and innocent of wrong, was compelled to refund the money. The thing in fact sold was not the thing supposed and intended to be sold.

In Gompertz v. Bartlett (24 Eng. Law and Eq. ${ }_{5} 6$ ), the plaintiff discounted for the defendant an unstamped bill, purporting on its face to have been a foreign bill, drawn at Sierre Leone and accepted in London, but which was in fact drawn in London. If actually a foreign bill, it required no stamp, and was valid; but being an inland bill, it required a stamp to make it a valid bill in a court of law. The acceptance was genuine, and the acceptor had previously paid similar biils. But the acceptor becoming bankrupt, the commissioner refused to allow it against his estate because not stamped. Thereupon the plaintiff, who had sold the bill and been compelled to take it up, brought his action to recover the price he had paid for it, and the action was sustained. Lord Campbell, before whom the case had been tried, and who then held adversely to the plaintiff, said:

"I then thought that the rule careat emptor applied; but after hearing the argument and the authorities cited, I think the action is maintainable, and upon this ground: That the article sold did not answer the description under which it was sold. If it had been a

1." The defendant in the case cited [Marvin v. Furris] had knowledge of the usury, which was not the fact here, and hence it differs from the case at bar, and is not decisive of the question. . . The law in regard to the transfer of negotiable bills of exchange and promissory notes, as laid down for a century $r$ more, only excepts two cases as coming within the doctrine of an implied warranty, viz.; a warranty of title, and that the instrument is genuine and not forged. There is no precedent and not a single reported case in the books in favor of the doctrine that where a promissory note is infected with usury, and that fact is unknown to the party who transferred it, that is an implied warranty of the validity of the note."-Littauer v. Gotdman, 72 N. Y. 506. See criticism of Littaur $z^{\prime}$. Goldman, in Mey v. Richards, I63 U. S. $3 S_{5}, 4 \mathrm{II}$, and Hoot v. Shetion, 42 N. J. L. 42I, 424. - ED. 
foreign bill, and there had been any secret defect, the risk would have been that of the purchaser; but here it must be taken that the bill was sold as and for that which it purported to be. On the face of the bill it purported to be drawn at Sierre Leone, and it was sold as answering the description of that which on its face it purported to be. That amounted to a warranty that it really was of that description."

In Ticonic Bank v. Smilcy (27 Me. 225), an overdue note was transferred with this indorsement, "Indorser not holden; "yet it was decided that the indorser was liable to his vendee for any payment made on the note before the transfer, or any set-off existing against it of which the note gave no indication and the rendor no information.

In Snyder v. Reno ( 38 Iowa, 329), it was held that there is an implied warranty that there has been no material alteration in the paper since its execution. The court says: "We have no doubt that there is an implied warranty of the transferer that there is 110 defect in the instrument, as well as that the signature of the maker is genuine." (See also, Blethen v. Lovering, $5 \mathrm{~S}$ Me. 437; Osdenv. Blydenburgh, I Hilton, I8z; Fake v. Smith, 2 Abb. [N. I.] App. 7ó; 2 Parsons on Notes and Bills, ch. 2, $\$ 2$, and cases in notes; Tiry v. Bissell, 26 Conn. 23; I Daniel on Neg. Inst., \$670.)

In this, the author thus states the law:

"When the indorsement is without recourse, the indorser specially declines to assume any responsibility as a party to the bill or note; but by the very act of transferring it, he engages that it is what it purports to be - the valid obligation of those whose names are upon it. He is like a drawer who draws without recourse; but who is, nevertheless, liable if he draws upon a fictitious party, or one without funds. And, therefore, the holder may recover against the indorser without recourse, (I) if any of the prior signatures were not genuine; or, (2) if the note was invalid between the original parties, because of the want, or illegality of, the consideration; or, (3) if any prior party was incompetent; or, $(4)$ the indorser was without title."

These authorities fully sustain the ruling of the district court. The note was not the legal obligation of the maker to the full amount. As to the usurious portion, it was as it were no note. This was a defect in the very inception of the note. It was known to the vendor and arose out of his own dealings in the matter. ${ }^{\prime} y^{*}$ all these authorities there is an implied warranty against such a defect, and the vendor is liable for a breach thereof.

The suggestion of counsel that the change in the usury law, by the legis!ation of 1872 , affected the right of recovery upon the

1 It will be observed that this brings the case within subs. 4 of $\$ 115$ [65]. - ED.

NEGOT. INSTRUMENTS - 30 
note, has been already decided adversely, in the case of $\mathcal{F}$ enness v. Cutler (r 2 Kas. 500).

All the justices concurring. Judgment affirmed.

$$
\text { fS VERMONT, 505. - I3:5. }
$$

Assumpsit for false warranty in sale of a promissory note. The note was made by Lincoln payable to McIntosh, for an illegal consideration rendering it void by statute; was indorsed without recourse by McIntosh to defendant and without recourse by defendant to plaintiff. Judgment for plaintiff.

The opinion of the court was delivered by

Pierpont, Ch. I. - It may be observed in the outset, that this action is not brought by the plaintiff as the indorsee of the note referred to against the defendant as the indorser, and the action is not based upon the indorsement, but is brought upon an alleged warranty by the defendant that the note was a valid and binding note, based upon a valid and lawful consideration, when in fact it was given for an illegal consideration, and was at its inception void. On trial the plaintiff introduced evidence in support of his declaration. After the evidence was in, the defendant insisted that as it appeared from the note that it was indorsed by the defendant "without recourse," the legal effect of the indorsement could not be varied or controlled by evidence outside of the indorsement itself - that the same was conclusive in that respect; but the court held that such indorsement was not of itself conclusive of its legal effect in such sense as to exclude the evidence aliunde; and submitted the case to the jury in accordance with such ruling, and it is upon this decision and the charge of the court in respect to it, that the only question that has been raised and discussed by the defendant's counsel arises.

What would have been the effect of this objection if the action had been based upon the indorsement, it is not necessary now to inquire. By indorsing the note " without recourse," the defendant refused to assume the responsibility and liability which the law attaches to an unqualified indorsement, so that in respect to such liability, it may perhaps be regarded as standing without an indorsement. If it be so regarded, then in what position do these parties stand in respect to the transaction? The principle is well settled, that where personal property of any kind is sold, there is on the part of the seller an implied warranty that he has title to the property, and that it is what it purports to be, and is that for which it was sold, as under. 
stood by the parties at the time; and in such case, knowledge on the part of the seller is not necessary to his liability. The implied warranty is, in this respect, like an express warranty, the scienter need not be allegeil or proved. Edwards, in his work on Bills and Promissory Notes (p. isS), says "One who transfers a negotiable instrument by delivery or by indorsement, impliedly guarantees that it is genuine, and that he has title to it. The rule is the same in regard to personal property. The vendor of a chattel always gives an implied warranty of the title. (is Johns. 240;6 Cow. ${ }_{4} S_{4}$; 4 Duer [N. Y.] I9I; 6 Johns. 5.) Though the indorser transfers the note upon condition that it is to be collected at the risk of the indorsee, he is, nevertheless, responsible if the note proves to be a forgery." (Edwards, 2S9.)

In this case the note in question was given for intoxicating liquor sold in this State in violation of law, and therefore wis roid at its inception; in short, it was not a note, it was not what it purported to be, or what it was sold and purchased for; it is of no more effect than if it had been a blank piece of paper for which the plaintiff had paid his fifty dollars. In this view of the case we think the defendant is liable upon a warranty that the thing sold was a valid note of hand.

The plaintiff has declared as upon an express warranty. If he could prove one, very well; if he could not, the implied warranty is just as available to him, the declaration being according to its legal effect.

This view of the case relieves it from all embarrassment growing out of the question as to the admissibility of parol testimony to vary the indorsement, as the effect of the indiorsement is really not involved in the case. And the ruling and charge of the court were really more favorable to the defendant than he had the right to ask.

The exceptions to the orerruling of the motion in arrest were waived. The exceptions to the refusal to set asicle the verdict as against the evidence, this court refuses to hear, the decision of the County Court being conclusive in such cases.

Jucloment affirmed. ${ }^{1}$

1 Where the State constitution forbids the cnforcement of any deht the consideration of which was a slave, the indorser of a nole is nevertheless liable on his indorsement, although the original consideralion between the maker and the payee was a slave. Graham r. Maguire, 39 Ga. 53I. - ED. 


\section{Titlf of Seller.}

\section{§II5 WILLIAMS $v$. TISHOMINGO SAVINGS INST'N. [\$65]}

57 Mississipi'1, 633. - I88o.

George, C. J., delivered the opinion of the court.

The appellants, having indorsed to the appellee a bill of exchange, to which they claimed title through a forged indorsement, now insist that they incurred no responsibility by their indorsement, except a guaranty that the drawee would pay it on presentation. But the rule is well settled that an indorser warrants the genuineness of the prior indorsements on the bill, and also his title to the paper. Should it be ascertained, even after payment of the bill, that any of the indorsements are forged, the drawee can recover back the amount of the bill from the person to whom he paid it; and so each preceding indorser may recover from the person who indorsed the bill to him. The drawee is bound to know the signature of the drawer, but not of the indorser. The judgment, which is in accordance with these views, is

Affirmed. ${ }^{1}$

3. Capacity of Prior Parties.

$\S$ II5

$$
\text { ERWIN }{ }^{\prime} \text {. DOWNS. }
$$

$$
\text { I5 NEw YoRk, 575. - I857. }
$$

ACTION against indorser of notes signed by a firm of married women, and indorsed by defendant for their accommodation. Plaintiff took the notes with knowledge that the makers were married women. Judgment for plaintiff.

SHANkLAND, I. - The note was void, as against the makers, because they were married women, and incapable of contracting obligations in that form. But when the defendant indorsed the note, he impliedly contracted that the makers were competent to contract, and had legally contracted, the obligation of joint nakers of the note. He also assumed the legal obligation, in most respects, of the drawers of the bill. The fact, known to the plaintiff at the time he took the note, that the makers were married women, did not deprive him of the character of a bona fide purchaser. Nor does the payee's knowledge that the drawee is a married woman, discharge the drawer in case of non-payment of the bill by the drawee.

${ }^{1}$ Accord: State Bank v. Fearins, 16 Pick. (Mass.) 533. - ED. 
Nor is the indorser discharged, though the name of the maker is forged. (I Comst. Ir3.) The fact is not found that the plaintiff was aware the note was accommodation paper. The plaintiff was a bond fule purchaser within the law merchant. Neither the complaint, nor the finding of the referee, tell us who transferred the notes to the plaintiff. The legal presumption is, that he received them from some legal holder in clue course of business.

The judgment should be affirmed.

BRows, J., delivered an opinion to the same effect.

All the other judges concurring.

Judgment affirmed.

4. Knowledge of Intalidity or Valuelessness.

$\S$ II5

$$
\text { BROWN } \because \text { MONTGOMERY. }
$$

20 NeW YORK, 287. - IS59.

Action on a note. Defence, fraud. Plaintiffs sold defendants a post-dated check drawn by Farnham \& Co. to the order of $L$. R. Farnham, one of the firm, and by him indorsed. On the day of the sale plaintiffs employed Cutting, a bill broker, to sell the check. Cutting offered it to one Chard, who declined it on the ground that he held one drawn and indorsed by the same parties which had just been protested for non-payment. Cutting then sold it to defendants without disclosing the conversation with Chard. The drawers were, unknown to defendants, insolrent. The note in suit was given for the purchase price of the check.

The court charged the jury that the non-payment and protest of the check, on the IIth April, was evidence tending to show insolvency in the drawers; that it was the duty of Cutting to communicate to the defendants what he had heard Chard say about the protest of that check, without regard to what he may have thought about the solvency of the drawers; and if he did not do so, and they were really insolvent, the plaintiifs could not recover on the note. The plaintiffs' counsel excepted to both branches of the charge. There was a verdict and julgment for the defendants, which was affirmed at a general term. The plaintiff appealed.

Denio, J. - I think there was no error in the charge to the jury in the Superior Court. The law unquestionably is, as it was assumed on the argument, that notice to the plaintiffs' agrent, Cutting, while he was actually engaged in attempting to sell the check, of the failure of the drawers, was equivalent, so far as the present action is concerned, to notice to the plaintiffs themselves. 
What Chard informed him, was not precisely that Farnham \& Co. had failed, but that their check on the bank at which they kept their account was that day protested for non-payment. This, prima facie, was notice that they had suspended payment; for when a business man in a commercial town fails to meet his paper, payable at a bank, and especially his checks upon the bank at which he keeps his account, the natural inference which every one draws is, that he is no longer able to pay his debts. Such a circumstance may occur from oversight or accident, but those are exceptional cases. The failure to meet the paper is itself a suspension of payment, and notice of such a fact, unaccompanied with any explanation which would give it a different character, is notice of the commercial failure of the party. That it was so understood by Cutting and Chard is evident from the fact that they speculated upon the question, whether the members of the firm drawing the check would ultimately be able to pay. Upon that question, Chard, as a creditor is apt to do, took the most favorable view It is apparent that neither of them expected the check to be paid on presentation when it should mature, fi:e days afterwards. The Superior Court considered that the confidence which Chard expressed in the ultimate solvency of the members of the firm, did not relieve Cutting from the duty of communicating to the defendants the fact that its check had not been met. I am of the same opinion. Up to that time the drawers were in good credit, and their paper of this kind, we are to presume, was promptly met. Thereafter, the holders of such paper were to be put upon their legal diligence in the courts, with a fair expectation, perhaps, that they might ultimately be able to obtain payment. The difference between a bank check having five days to run, and which is then to be paid, and a suspended debt against parties who have failed, is sufficiently obvious. The defendants purchased this check as one of the former class, whlle the plaintiffs' agent well knew that it belonged to the latter, and withheld that knowledge from the defendants. The plaintiffs' conduct is less censurable, morally, than it would be had it been proved that they personally knew of the failure of the drawers; but in point of law, the case is the same as though, after hearing that Farnham $\&$ Co. had failed, they took the paper which they held against them into the street, and sold it to parties who had not heard of that event. Such an act could not be justified at law any more than in the forum of conscience.

The judge was therefore perfectly correct in instructing the jury that it was the duty of Cutting to communicate to the defendants what he had heard Chard say as to the protest of the other 
check. He was also correct in advising them that the consequences of omitting to do so was that the plaintiffs could not recover on the note. Where a party negotiates commercial paper, payable to bearer, or under the blank indorsement of another person, he cannot be sued on the paper because he is not a party to it; but he nevertheless warrants that he has no knowledge of any facts which prove the paper to be worthless, on account of the failure of the makers, or by its being already paid, or otherwise to hare become void or defunct; for, says Judge Story, any concealment of this nature would be a manifest fraud. (Story on Prom. Note's, I I8.)

The plaintiffs' counsel argued that, according to the case of Vichols v. Pinner (IS N. Y. 295), the plaintiffs and their agent were warranted in maintaining silence as to the failure of Farnham \& Co., though they knew it and the defendants did not. But the cases are essentially different. There we decided, that where a merchant, knowing himself to be insolvent, purchases goods without disclosing the fact, there being no inquiry made, he is not necessarily guilty of fraud, as he may honestly believe that he can go on and retrieve his affairs. Where so much of the trade of the country is conducted without invested capital, or on borrowed capital, it must often happen that a merchant who is ultimately successful has known periods of commercial disaster when his property would not pay his debts. It would be too strict to hold, that under such circumstances he must in all cases go into liquidation, or expose himself to probable bankruptcy by disclosing his condition. But the case does not countenance the position, that a dealer who has been of known standing, but who has suddenly failed in business, can go to those who were acquainted with his former character, but who have not heard of his failure, and innocently purchase their property on credit. Judge Selden, in his opinion, puts that case as one not covered by the judgment.

The judge was also right in stating to the jury, that the non-payment of the check, spoken of by Chard, was evidence upon the question of the insolvency of the drawers. I have already stated what I consider the necessary inference from such a circumstance among business men. The judgnent must be affirmed.

Johnson, Ch. J., Constock, Gray, and Grover, J J., concurring. Judgment affirmeel. ${ }^{1}$

${ }^{1}$ Cited with approval in Rothmiller v. Stin, I +3 N. Y. p. 592. But the seller is not bound to disclose that the instrument is accommodation paper (Irawn by a clerk and accepted by the accommodated party. P'ople's Bank v. Bogart, 8r N. Y, IOI. - ED. 
5. Indorser: Instrument Valid and Subsisting.

I 57 Massachusetts, 54 S. - I $\$ 93$.

ACTION against indorser. Judgment for plaintiff.

Knowlton, J. - The defendant contends that the plaintiff cannot recover; first, because it has no title to the note; and secondly, because the note was made on the Lord's day, in violation of the statute. It is argued that, under the statutes of the United States, national banks cannot buy or sell promissory notes, and that, inasmuch as the plaintiff obtained the note by purchase, it has no right to hold or collect it. [The court holds on this that even if the purchase is ultra zires the public alone can complain, and that in any erent the bank may maintain a suit as "holder."] "

Of the second ground of defence it may be said that the contract relied on in this suit is the contract between the defendant as indorser and the plaintiff. That was not made on the Lord's day. . . Whether the note could be enforced by the payee agrinst the maker is immaterial in this suit, for an indorser of a promissory note " always warrants the existence and legality of the contract which he undertakes to assign." (Burrill v. Smith, 7 Pick. 291, 294; Teasic v. IVillis, 6 Gray, 90; Prescott Bank v. Carerly, 7 Gray, 2 I 7 ; Kenworthy v. Sazyer, I25 Mass. 28; Binney v. Globe Nat. Bank, I 50 Mass. 574, 578; Hammum v. Richardson, 48 Vt. 508 ; Henderson v. Lemly, 79 N. C. I69.) The defendant by his indorsement is estopped to deny that the note is a valid contract, and as against him it must be assumed that it was made and delivered at a time when such business could lawfully be done. The presiding justice rightly refused to rule that the plaintiff was not entitled to recover.

Exceptions overruled.²

\footnotetext{
'See Neg. Inst. L., So [5I]. - ED.

"Indorsement admits the signature and capacity of every prior party. Prescott Bank $v$. Caverlt, 7 Gray, 2I7. This includes the existence and capacity of a firm, Dalmyple v. Hillentrand, 62 N. Y. 5 ; or of a corporation, Gliddenv. Chamberlin, I67 Mass. 456 , 494 ; or of a married woman, Edmunds v. Rose, 5I N. J. L. 547. See Hannum v. Richardson, tS Vi. 50S, ante, p. 460. - ED.
} 
6. Liability of Agent as Seller.

\&I9

WORTHINGTON $\imath$. COWLES.

II MASSACHUSETTS, 3O. - IS73.

Action to recover back money paid by plaintiff to defendants for a promissory note signed by one Hanson, the indorsement upon which was forged. Defendants were note-brokers, who sold the note for Hanson, and paid him the purchase money, less commissions, before the forgery was discovered. Judgment for plaintiff. Defendants allege exceptions.

Morton, J. - This is an action of contract upon the implied warranty of the genuineness of the signature to a note sold by the defendants to the plaintiff. The plaintiff claimed that in the purchase of the note he dealt solely with the defendants, and upon their credit. The defendants claimed that they were acting as agents of Hanson in the transaction, and that their principal was disclosed to the plaintiff. Upon these points the evidence was conflicting. The defendants asked the court to rule " that if the defendants were in fact agents for Hanson, and disclosed their agency to the plaintiff, or the plaintiff knew it, or had reasonable cause to know it, the defendants would not be liable."

Considered as an abstract proposition of law, this is too broad. It omits the necessary element that, in the dealing or transaction in question, they were acting as such agents. It may be true that the defendants were agents of Hanson, and known to be such by the plaintiff, and yet if, in the purchase of this note, it was understood by the parties that the plaintiff was dealing with and upon the credit of the defendants, they would be liable. An agent may deal so as to bind himself personally; it is always a question of the intention and understanding of the parties. The presiding judge properly refused to give the instructions in the form requested by the defendants. Instead thereof, he ruled in substance that the question was, from whom did the plaintiff understand that he was buying the note - from the brokers or from Hanson? and that if such a state of facts occurred, that the plaintiff understood, or ought to have understood as a man of reasonable intelligence, that he was dealing with Hanson, the defendants would not be liable.

These instructions were correct, as applied to the facts of the case. The plaintiff dealt with the defendants. His evidence tended to show that he contracted with them as principals. To meet this prima facic case, the defendants undertook to show that in this transaction they were dealing as agents of a disclosed principal. 
Unless from their disclosures or other solirces the plaintiff understood, or ought as a reasonable man to have understood, that he was dealing with Hanson, he had a right to assume that he was dealing with the defendants as principals. The instructions given were to this effect, and were as favorable to the defendants as the instructions requested, with the addition of the necessary qualification that the defendants were in this transaction dealing as the agents of Hanson. (Wilder v. Cowles, roo Mass. 487 ; Merriam v. IVolcott, 3 Allen, 258.)

Exceptions overruled.'

\section{Indorser: secondary, conditional liability.}

\section{INdorser's Contract as Seller.}

[See preceding subdivision IV, pp. 452-472.]

2. Indorser's Contract as Assurer of Payment.

$\S$ II6 LONG $\because$. STEPHENSON.

72 North Carolina, 569. - IS75.

Action against indorser. Plaintiff alleged that the drawee refused to accept or pay, and that defendant on demand also refused to pay. Defendant alleged non-presentment to drawee and want of notice of dishonor. Judgment for defendant.

Settle, J. - The authorities cited by the defendant's counsel establish beyond controversy:

I. That the draft should have been presented for payment. ${ }^{2}$

2. That notice of non-payment should have been given in reasonable time to the defendant. ${ }^{3}$

As both of these essential requisites to the maintenance of this action are wanting, we concur with his Honor that the plaintiff is not entitled to recover.

Judgment affirmed.

${ }^{1}$ Accord: Meriden Vational Bank v. Gallaudet, 20 N. Y. 295; Brown v. Ames, 59 Minn. 476; Huffcus on Agency, § IS6. - ED.

2 Post, Art. VII. - ED.

${ }^{3}$ Post, Art. VIII. As to protest as a third requisite, see Art. XIII, post. - ED.

4 "The liability of the indorser is strictly conditional, dependent both upon due demand of payment upon the maker or acceplor, and also due and legal notice of the non-payment. The purpose and object of such demand and notice is to enable the indorser to look to his own interest, and take immediate measures for his indemnity. The demand and notice being conditions precedent to the 
3 Johnson (N. Y.), 439.-TSOS.

ThE plaintiff declared on a promissory note, given by one Spring to Reeves, the intestate, and payable to him or bearer. The note was indorsed over by Reeves, and the present suit was brought by the indorsee against his administrators. There was a general demurrer to the declaration, which was in the usual form against the indorser.

Per Curialr. - The note was negotiable under the statute, and transferable without indorsement; but if the payee chose to put his name on the back, he became as much bound as an indorser, as if the note had been made payable to him or order.

It was ruled by Chief Justice Holt, in the case of The Bank of England v. Neziman (I Lord Raym. 442), that if a person indorses a bill payable to bearer, he becomes a new security, and is liable on the indorsement. The declaration at least is good on a special demurrer. But the defendant may withdraw the demurrer, on payment of costs, and pleading forthwith.

Judgment for the plaintiff. ${ }^{2}$

4I Barbour (N. Y.), 33. - I864.

Action against indorsers on note due Nov. 29 (Saturday). Notice of dishonor received about 6 P. 1 . of that day. Service of summons and complaint in this action soon after on the same day. Judgment for plaintiff.

By the Court, Mason, J. - The only question presented in this case is whether a suit can be maintained against the indorsers of a note payable at a bank, and which has been duly protested, where

indorser's liability, it is incumbent on the holder to make clear and satisfactory proof of them before he can recover." Lawson v. Farmirs' Bank. I Oh. St. 206

"The indorser of a bill of exchange, whether payable after date or after sight, undertakes that the drawee will pay it, if the holder present it to him at maturity and demand payment; and if he refuse to pay it, and the holder cause it to be protested, and due notice to be given to the indorser, then he promises to pay it. All these conditions enter into and make part of the contract between these parties to a foreign bill of exchange; and the law imposes the performance of them upon the holder, as conditions precedent to the liability of the indorser of the bill." Musson v. Lake, + How. (U. S.) $262 .-$ ED.

${ }^{1}$ See p. 480 , note (2), post. 
the suit is commenced on the day of the protest, or the third day of grace. The rule in England, as understood by Chitty, is that the suit on the third day of grace is premature. (See Chitty on Bills, $406,407,409$, Sth Lond. ed.) And such I understand to be the rule held in Westminster Hall. (Castrique v. Brrabo, 6 Queen's B. R. ${ }_{49}$ S; Liffirty $\because$ Mills, + T. R. I70.) The rule is s, understood by Byles. (See his late work on Bills, p. I8r.) In this country there is certainly considerable conflict of authority over the question, in the courts of the different States. The courts of Maine, New Hampshire, Massachusetts, South Carolina, and some others, have held that the suit could be commenced on the third day of grace, at any time after the close of banking hours and proper protesting of the note. (r Pick. $40 \mathrm{I} ; 2$ i id. $310 ; 8$ id. $4 \mathrm{I} 4$; I Metcalf, $43,4^{\mathrm{S}} ;$ + Greenl. Rep. 479; 7 X. Hamp. Rep. 199: S Foster, 302; 4 Humph. 24r; 5 Shep.

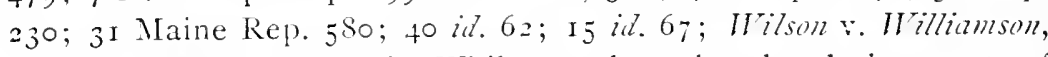
$I$ Nott \& McCord. 440.) While on the other hand the courts of Pennsytrania, Ohio, Illinois, Mississippi, Alabama and some others have held the suit prematurely brought if commenced on the third day of grace. (Thomas r. Shoemaker, 6 Watts \& Serg. I79; Walter v. Kirk, I Illinois Rep. 55; Wiggle v. Thomason, I Smedes \& Marsh. 452; Beacan v. Eldridise, 2 Miles, 353; Randolphr. Cook, 2 Porter, S65; 5 Serg. \& R. $3^{\text {I }} 8$.)

The rule in this State has long been regarded as settled that the suit commenced on the third day of grace was prematurely brought. The question came before the Supreme Court in Hogan v. Cuyler (\& Cowen's Rep. 203), when it was held to be premature to commence the suit on the third day of grace. The question was distinctly presented again in Osborn v. Moncure (3 Wend. 170), when it was distinctly held the suit could not be maintained, when commenced on the third day of grace. Chief Justice Sarage regarded the rule so well settled with us, in this State, that he held in Hopping v. Cuin ( 12 Wend. 517), that where an attorney commenced a suit upon a note on the third day of grace and was beaten and then brought suit against his client to recover for his services, he was not entitled to recover; and in speaking upon this question he says: "It was the duty of the plaintiff to have known that a suit could not be brought on the last day of grace; and his bringing such a suit must be imputed either to negligence or ignorance. In either case it lays no foundation for an action against his client, who has been the sufferer." There is no case in the courts of this State to the contrary of these cases, while all the elementary books have treated nur law in this State as settled in conformity to these cases. Judge Cowen so regarded it when he wrote his treatise. (I Cowen's 
Tr. 220 , ed. I 844 ), where he lays down the doctrine distinctly, that the suit cannot be maintained if commenced on the last day of grace. And so Edwards regards it in his treatise on Bills and Notes (see pages 525, 526,527); and the rule in this State is so regarded by Parsons in his treatise. (See Vol. I, page +40 , and also note i.) Chief Justice Shaw regards our rule in this State as different from theirs. (I Metcalf, 54.)

The rule in England seems to have conformed to a general practice - the practice to postpone notice of the dishonor and other proceedings, till the day following - so that it has been regarded amongst merchants as a right to have all of the last day of grace in which to pay. In Hartley's case (i Carr. \& P. 555), Abbott, Ch. J., on a motion to show cause, said, "I think the notice of dishonor given on the day on which the bill is payable, will be good or bad as the acceptor may or not afterwards pay the bill. If he does not afterwards pay, on that day the notice is good, and if he does it of course comes to nothing." And Byles, in his late valuable treatise on B:lls, page ${ }_{13} \mathrm{I}$, says: "The acceptor of a bill, whether inland or foreign, or the maker of a note, should pay it on demand made at any time within business hours on the day it falls lue, and if it be not paid on such demand the holder may instantly treat it as dishonored. But," he adds, " the acceptor has the whole of that day within which to make payment, and though he should in the course of the day refuse payment, which entitles the holder to give notice of dishonor, yet if he subsequently on the same day makes payment it is good, and the notice of dishonor becomes of no avail." This is precisely as I understand the rule with us. Now if we admit that the courts of Massachusetts, Maine, New Hampshire, etc., have the better reason for their decisions, there is no such great principle involved in the case as would justify us in overruling our own cases and following theirs; especially so where we are supported by equal weight of authority on our side; and Parsons, who is an earnest advocate on the other side, admits that " there is strong reason for holding that a party bound to pay has the whole of the day of maturity." (Parsons on Notes and Bills, vol. 2, p. 460.) And our rule has certainly one advantage; it tends to uniformity in the law by conforming to the general rule with reference to all other contracts, which holds that when a day is appointed for the payment of money the payer has the whole of the day, down to the last moment, in which to tender the money.

It is proper to remark that none of the cases make any difference or distinction between the case of the maker or indorser. None can be made. As regards this question of the right to bring the 
suit, there is not and ought not to be any distinction between a note payable at bank and one payable at large, or at the counting house of the merchant; and none seems to have been recognized in this State. (2 Cowen, 766.) . .

New trial granted.

3. Irregular Indorser.

$\S \mathrm{II} 4$

COULTER $\approx$. RICHMOND.

[ร 64]

$59 \mathrm{NEW}$ YORK, $+78 .-\mathrm{IS} 75$.

Actiox on promissory note, made by Anson, and indorsed by George (defendant's intestate), payable to the order of plaintiff. Judgment for plaintiff.

The note was indorsed at the request of the maker, before delivery to the payee, to enable the maker to purchase bonds of the payee.

$\mathrm{CHURCH}, \mathrm{CH} . \mathrm{J} .-$ There is considerable diversity of sentiment among the courts of the different States as to the nature of the contract implied by a blank indorsement of a negotiable note before delivery to the payee. In some of the States such an indorser is prima facie regarded as a guarantor, in others an indorser, and in others a joint promisor. (Parsons on Notes, irg, and notes e, f, $g$, and cases there cited; $40 \mathrm{~N}$. Y. $49^{2}$, reporter's note.) In this State, it has been repeatedly held, and is too strongly settled by authority to be disturbed, that a person making such an indorsement is presumed to have intended to become liable as second indorser, and that on the face of the paper without explanation, he is to be regarded as second indorser, and, of course, not liable upon the note to the payee, who is supposed to be the first indorser. (I $2 \mathrm{~J}$. R. I59; I 7 Id. $326 ; 37$ N. Y. 6I $4 ; 50$ Id. 69.) As the paper itself furnishes only frima facic evidence of this intention, it is competent to rebut the presumption, by parol proof that the indorsement was made to give the maker credit with the payee. (Id.) Such, among others, was the case of More v. Cross (19 X. Y. 227), where the indorsement was made to enable the maker to purchase coal of the payee; and it was held that the person making it was liable as first indorser, and that the payee could maintain an action against him upon the note, or, if the payee transferred it, he might indorse it without recourse.

[The Court then holds the proof sufficient in this case to show 
that defendant intended to become surety for the maker and was therefore liable as first indorser.]

Judgment affirmed. ${ }^{2}$

1 IRREgular INDORser. There is a hopeless conflict of judicial authority as to the nature of the contract of the irregular indorser, $c . s$. where a negotiable instrument payable to $A$. is indorsed first by B., delivered to A., and then (perhaps) indorsed by $A$. and transferred to $C$. The matter is solved, first, by a presumption from the appearance of the paper, and, second, by parol evidence as to the time of B.'s indorsement or as to that and also as to the actual contract intended by the parties. The conflicting rules may be thus stated:

I. Prisumftion that $B$. is an indorser. (I) The presumption from the appearance of the paper is that $B$. is a second indorser. (a) Upon proof that the indorsement was made before delivery to the payee (A.), the irregular indorser (B.) is treated as the first unqualified indorser and is liable as such to the payee (unless he signed for the accommodation of the payee), and to subsequent parties. It is as if the payee (A.) indorses without recourse to the irregular indorser (B.), and the latter then indorses in blank to the payee. In theory, therefore, the payee (A.) is the first (qualified) indorser; the irregular indorser (B.) is the second (unqualified) indorser; and should the payee (A.) then indorse in blank he becomes the third (unqualified) indorser. It is a short cut to say that the irregular indorser is the first indorser, because he is the first unqualified indorser. Hoore v. Cross, I9 N. Y. 227; Hade v. Creishton, 25 Ore. 455 ; Blakslec v. Hewett, 76 Wis. $3+1$. (b) Upon parol proof as above the same rule follows, but parol proof is further admissible to show the actual contract, as that the irregular indorser signed as maker or (if statute of frauds can be escaped), guarantor. De Paus v. Bank of Salim, 126 Ind. 553; Sizafir v. Farmers', etc., Bank. 59 Pa. St. I44; Central L. B. v. Drevdeffel, 13+ Pa. St. 499; Inayden v. I'ildon, 43 N. J. L. I2S; Meal v. Hilson, 79 Ga. 736. (c) But if the instrument is non-negotiable, the irregular indorser is held to be a maker or guarantor. Cromidell v. Hewitt, to N. Y. 492 ; First N. B. v. Balicock, $9+$ Cal. 96; Pool v. Andirson, ri6 Ind. S8; Gorman v. Kitchum, 33 Wis. 427.

(2) In Alabama it seems that the irregular indorser is treated as a regular first indorser. Hooks $v$. Anderson, 58 Ala. 238. See also Huin Luns r. Burki, 9 Hawaiian Rep. $1+2$.

(3) By statute in some jurisdictions the irregular indorser is treated as a regular indorser. Bills of Exchange Act (Eng.), $\$ 56$, and Chalmer's Notes, p. $188 \mathrm{ct}$ seq.; Dominion Bills of Exchange Act (Canada), 56; California Code, $\$ 3117$, and see Fessenden v. Summers, 62 Cal. 4\$4; Massachusetts St. of 1974 . c. 404. In Massachusetts the original doctrine that the irregular inclerser is liable as a co-maker (Union Bank v. Willis, S Mct. 504), seems to be modified only to the extent of requiring that the irregular indorser have notice of dishonor. The irregular indorser in Massachusetts is therefore a co-maker with a right to notice of non-payment the same as an indorser. Mulcar v. Milih, 160

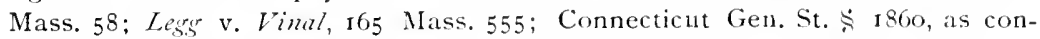
strued in Spincer v. Allerton, 60 Conn. 4 to (now governed by Neg. Inst. L..).

II. Presumption that $R$. is a comaker. (I) The presumption from the appearance of the paper is that the irregular indorser (B.) is a co-maker. Good $\mathrm{v}$. Martin, 95 U. S. go; Good v. Martin, I Colo. 165; Tabor v. Milis, 15 Colo. App. 127; McCallum v. Driggs, 35 Fla. 277; Bradfordv. Prescott, 85 Me. 4 82; Schroeder 


\section{Order of INdorsers' Liability.}

$\S \mathrm{II} 8$

MOORE $\tau^{\prime}$. CUSHING.

$[S 68]$

I62 MAssachusetts, 594. - I895.

Contract, against Louis T. Cushing and Harvey H. Pratt upon the following promissory note:-

$\$ 500$.

$247 u l v, 1893$.

Three months after date, I promise to pay to the order of William Moore five hundred dollars. Payable at any bank in Boston. Value received.

(Indorsed): Louis T. Cushing, William Moore.

Hak vey H. Pratt.

v. Tumer, 68 Md. 506 ; Gumz v. Giegling (Mich.) 66 N. W. 45 ; Peninsular Bank v. Hesie (Mich.) 70 N. W. 890; Dennis r. Jackson, 57 Minn. 286; Schultz v. Howard, 63 Minn. 196; Richardson v. Foster. 73 Miss. I2; Mastin Bank v. Hammer. slough, 72 Mo. $27+$ (cf. First Nat. Bk. v. Payne, II I Mo. 291); Salishury v. First N. B., 37 Neb. 872; Sargent v. Robbins, I9 N. H. 572; Mifetrich v. Hoodroze', (N. H.) $3^{8}$ Atl. 18; Hoffman v. Hoore, 82 N. Car. 313; Eawan v. Broots-H Itaterfield Co., 55 Oh. St. 596; Fackson Bank r. Frons, IS R. I. 7I8; Sylvester Bleckley Co. v. Alewine, (S. C.) 26 S. E. 609; Prozident, etc., Soc. v. Eamonds, 95 Tenn. 53; Barton v. American .1. B., S Tex. Civ. App. 223; Bank v. Dorset Marble Co., 6I Vt. Io6; Donohoe-Kelly Banking Co. v. Puset Sound Sav. Bank, I3 Wash. 407. (a) Most of the above jurisdictions allow parol evidence to show the real contract. I Daniel on Neg. Inst., SS 710-7I2. (b) A few States do not if in fact B. signed before delivery to the payee. Dinnis r. Fackson, 57 Minn. 286 .

(a) But if the paper is payable to the drawer's or maker's own order and indorsed by $B$. before negotiation, the irregular indorser is treated as a first indorser, the paper being put upon the same footing as paper payable to bearer. Bigilere v. Colton, 13 Gray (Mass.) 309; Clath v. Rice, 13 Gray (Mass.) 40,; Duthois v. Mason, 127 Mass. 37; First I. B. v. Paphe, I I Mo. 291; Hately'.

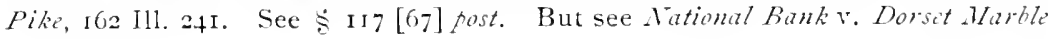
Co., 6r Vt. 106.

(3) In one or two States it seems immaterial that the payee actually indorses above the name of the irregular indorser. Bank v. Dorset. Marlle Co., 6I Vt. 106; MiFitrich v. Hodroai, (N. H.) 38 Atl. Rep. Is.

III. Presumption that $B$. is a guarantor. The presumption from the appearance of the paper is that the irregular indorser is a guarantor. Blatififord $\mathrm{v}$. Milliken, 35 Ill. 43 s; Kingslind v. Koefte, 137 Ill. 3+4; Amold v. Bryant, S Bush (Ky.) 608 (by statute); Conger v. Babbit, 67 lowa, 13 (by statute); Fullerton v. Ifill, 4 Kans. 55S. Parol evidence is admissible to show the actual contract. Malligan v. Holbrook, (Ill. IS97) $48 \mathrm{~N}$. E. Rep. I57. In some States the payee or holder may treat the irregular indorser either as a co-maker or surety as he may elect, but parol proof may show the true contract. Orrick v. Coliton, 7 Gratt. (Va). IS9; Roanoke, etc., Co. v. Hatkins, $4 \mathrm{I}$ W. Va. 757; Hiller v. Clendenin, 42 W. Va. 416 .

As to whether an irregular indorsement construed as a guaranty is within the statute of frauds, there is a conflict. That it is: Cullertson v. Smith, 52 Md. 628; Hardin v. Helden, 43 N. I. L. I28; Hater v. Pattrson, $8_{4}$ Pa. St. 274. That it is not: Bitkrith v. Angell, 6 Conn. 315; Stowell v. Raymond, $8_{3}$ Ill. 120; Piterson v. Russell, $62 \mathrm{Minn}, 220 .-\mathrm{ED}$. 
The case was submitted to the Superior Court, and, after judgment for the plaintiff, to this court, on appeal, on agreed facts, in substance as follows:

Before the delivery of the note Pratt requested the plaintiff to get it discounted, and the plaintiff refused unless there was a satisfactory indorser. Thereupon the plaintiff accompanied Pratt to the office of Cushing, whom the plaintiff told that he was going to have the note discounted for Pratt, provided Pratt obtained a satisfactory indorser. The plaintiff asked Cushing if he was good for the amount, and Cushing said that he was, and that the note would be paid when due; and that he was willing to indorse the note for the accommodation of Pratt, so that the note might be discounted for his benefit. The note was then indorsed by Cushing at the request of Pratt, and was delivered to the plaintiff, who thereafter himself indorsed it and had it discounted, and the proceeds were used for the benefit of Pratt. The plaintiff was obliged to pay the note, and Cushing alone defended, Pratt having been defaulted.

Holmes, J. - This is a suit upon a note between two persons, who both became parties on it for the accommodation of the maker. The defendant Cushing indorsed the note before delivery; the plaintiff is the payee, and indorsed after the defendant. If the plaintiff had not known that the defendant indorsed the note for accommodation, he would have been entitled to recover. (IToods v. Woods, I27 Mass. I4I.) Knowledge of that fact under the circumstances stated does not affect his rights. In the absence of agreement, successive indorsers for the accommodation of a third person are liable in the same order as indorsers for value. (Shan v. Knox, 98 Mass. 21 4 ; Danl. Neg. Inst. [3d ed.], $\$ 703$.$) 'The$ conversation which took place between the parties, so far from expressing a different agreement, gave notice to the defendant that the plaintiff required his indorsement as the condition of becoming a party. It fortifies the presumption arising from the face of the paper. The suggestion on behalf of the defendant, that he signed also for the accommodation of the plaintıff, perverts, if it does not contradict, the agreed facts. It was urged that the plaintiff took the note when overdue. But his rights and liabilities were fixed at the time of his indorsement. If the argument was sound, the judgment ought to have been for the defendant-indorser in IIouts $\mathrm{v}$. Woods.

\section{Judgment affirmed.'}

${ }^{1}$ Successive indorsements import a several, and not a joint, liability. A joint action cannot be brought against successive indorsers except by aid of statNEGOT. INSTRUMENTS - 3 I 
66 NeW YORK, 433. - I876.

ACTIOn by third indorser to recover of second indorser. The note was made by the Stevenson MIfg. Co., payable to the order of Knight, and indorsed by Knight, defendant, plaintiff, and one MacDougall. Defendant sets up that the four were stockholders in the Mfg. Co., and indorsed to give it credit, and under an agreement that they should be co-sureties and contribute equally in case the indorsers were obliged to pay. Knight and MacDougall are insolvent. The court allowed a recovery by plaintiff against defendant for one-half the sum paid by plaintiff. Plaintiff claims judgment for the whole. Defendant claims judgment should lie for one-fourth. Both parties appeal.

Miller, J. - The first question presented upon these appeals is, whether it is competent in an action by one indorser against a prior indorser for the defendant to prove by parol an agreement between all the indorsers that they were, as between themselves. co-sureties where they are accommodation indorsers. ' In Bary v. Ransom (I 2 N. Y. 462), it was held that an agreement made between parties, prior to or cotemporaneously with their executing a written obligation as sureties, by which one promises to indemnify the other from loss, does not contradict or vary the terms or legal effect of the written obligation, and it may be proved by parol evidence. It was said by Denio, J., in the opinion, that an agreement among the sureties, arranging their eventual liabilities among themselves in a manner different from what the law would prescribe, in the absence of an express agreement, would not contradict any of the terms of the bond. It was also held, that the engagement among themselves had no necessary place in the instrument between them and the other contracting parties. The case cited referred to a joint and several bond, where the obligors were equally liable upon its face. No reason exists, however, why the same principle is not applicable to notes and bills of exchange. The terms of the contract contained in instruments of this character, which are within its scope to define and regulate, cannot be changed by parol; but the understanding between the indorsers is a distinct and separate subject, an outside matter, which may be properly proved independent of and without any regard to the instrument itself. This rule is distinctly

ute. Wolf v. Hostittir, (Pa. I897) 37 Atl. R. 988. Such stalutes authorizing the joining of all parties to a negotiable instrument in one action are common in the American States. N. Y. Code Civ. Proc., $\$ 454$; Pomeroy. Remedies, $S S+02-$ 4Io: 3 Randolph, Comm. Paper. I I669. - ED. 
established in reference to joint makers of promissory notes: and although the previous decisions had been somewhat uncertain it has been recently determined by the decision of this court that where a person signed, as surety, a joint and several promissory note, and it did not appear by the instrument itself that such relation existed, he might prove such fact by parol, and that such proof did not tend to alter the terms of the contract. (Hubbard v. Gurney, 64 N. I. 457.) It is not apparent that any such difference exists between the two clisses of cases which prevents the application of the same principle to both of them.

An attempted distinction is sought to be maintained because the relation of indorsers to each other are fixed by law; while the relations and obligations of sureties and obligors are not fixed. As between the principal and the sureties they are fixed quite as much as between indorsers, and can only be settled as between sureties, where the contract does not show the fact, by parol proof of the same. In support of the same views is the case of Philits v. Preston (5 How. [U. S.] 27S, 292), where the doctrine is laid down that proof of a collateral contract, by parol, may be given to show the liability of indorsers as between themselves. (See, also, McDonald v. Magruder, 3 Peters, 470; Aiken v. Barkly, 2 Speers, 747; Edelen v. White, 6 Bush [Ky.] 4o8; Daits v. Morgan, 6+ N. C. 570.) The indorsements upon bills of exchange or promissory notes rest upon the theory that the liability of indorsers to each other is regulated by the position of their names, and that the paper is transferred from the one to the others by indorsement. But this rule has no practical application to accommodation indorsers, where neither of them has owned the paper and no such transfer has been made. It is eas to see that the application of the rule contended for, in many cases would work the most serious injustice. Suppose a person sign as accommodation maker of a promissory note, and the payce for whose benefit it is made indorses it and pays the note, and afterwards sues the maker to recover back the money, would it be seriously contended that proof could not be given to show that he was merely an accommodation maker? Clearly not; and yet such evidence would contradict the written instrument quite as much as it would to prove an agreement between indorsers in regard to their liability as between each other. Cases frecuently arise where it is competent to prove that the indorsement is made for the accommodation of the maker; and a drawee may show, after acceptance, that he has no funds $\left(3, Y ., 4^{2} 3\right)$, in his hands, and that be was merely an arcommodation acceptor. (Griffith v. Rech. 2 I Wend. 502.) The cases to which we have been referred by the plaintiff's counsel do 
not, we think, sustain the position contended for; that parol proof cannot be given to show an arrangement between accommodation indorsers different from that which appears by the legal effect of the instrument, and a particular examination of them is not required. The uniform practice in this State has been in conformity to the views expressed in reference to proof of this character, and it would be establishing a new rule at this time to hold that such testimony was incompetent. There was, therefore, no error committed by the judge in the admission of the evidence to which objection was taken.

Other questions arise upon the defendant's appeal, which should be consiclered. It is claimed that an action at law by a surety for contribution must be against each of the sureties separately for his proportion, and that no more can be recovered, even where one or more are insolvent. In the latter case, the action must be in equity against all the co-sureties for contributions, and, upon proof of the insolvency of one or more of the sureties, the payment of the amount will be adjudged among the solvent parties in due proportion. 'The principle stated is fully sustained by the authorities. It is thus stated, in Parsons on Contracts (vol. I, p. 34): “At law, a surety can recover from his co-surety an aliquot part, calculated upon the whole number, without reference to the insolvency of others of the co-sureties; but in equity it is otherwise." (See, also, Browne v. Lec, 6 Barn. \& Cress. 689; 13 Eng. C. L. 394; Cowell r. Edudards, 2 B. \& Pull. 268; Beaman r. Blanchard, 4 Wend. 432, 435; Story's Eq. Juris., 896 ; I Chitty on Con. (5th Am. ed.) 597, 598; Willard's Eq. Juris., Io\$.) There seems to be a propriety in the rule that where sureties are called upon to contribute, and some of them are insolvent, that all the parties should be brought into court and a decree made upon equitable principles in reference to the alleged insolvency. There should be a remedy decreed against the insolvent parties, which may be enforced if they become afterwards able to pay, and this can only be done in a court of equity and when they are parties to the action. The action here was not of this character: nor were all the proper parties before the court. It was clearly an action at law, and in that point of view, as we have seen, the plaintiff could only recover for one-fourth of the debt for which all the sureties were liable. The distinction between the two classes of actions is recognized by the decisions.

The remedies, the parties and course of procedure are each different. In the one, a jury trial is a matter of right; while in the other the trial is by the court. The costs are also in the discretion of the court (Code, $s \leqslant 253,306 ;$ i 3 N. Y. [supra] 498.) As the judgment 
could not require each of the parties to pay his aliquot share and furnish a remedy over against those who were insolvent and the rights of the parties be finally determined and fixed, it was under the facts proven clearly erroneous. Although in many cases under the Code the pleadings, if necessary, may be made to conform to the facts, and the case disposed of upon the merits, the defects here are so radical as to strike at the very foundation of the action, and cannot thus be remedied. Besides, the proper parties are not before us, and cannot be brought in, except on motion in the court below. As the claim was alleged in the complaint, there was no such defect of parties apparent as required the defendant to take the objection by demurrer or answer.

It follows that the judgment must be affirmed upon the plaintiff's appeal, with costs of appeal to be paid by the plaintiff upon the final termination of the action, if the defendant succeeds; and if the plaintiff succeeds, to be set off against the plaintiff's costs. And the judgment must be reversed upon the defendant's appeal, with cost of the appeal in this court, and costs in the Supreme Court to abide the event.

All concur, except Church, Ch. J., dissenting.

Ordered accordingly. ${ }^{1}$

$\S$ II8

LANE $\because$. STACY.

$[\S 68]$

8 Allen (Mass.), 4I. - I86.4.

BILL in equity to compel defendant to assign to plaintiff one-half the security given to protect plaintiff and defendant's intestate as

${ }^{1}$ An agreement for co-suretyship among accommodation indorsers may be shown by parol. Clatp v. Rice, I3 Gray (Mass.) 403; Paul v. Rider, 58 N. H.

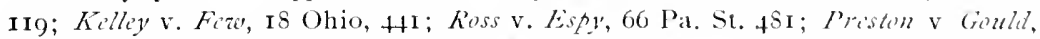
64 Iowa, 44; Rhinchart v. Schall, 69 Md. 352. Contra: Johnson v. Riamsey, 43 N. J. L. 279 .

In a few States the presumption is that successive accommodation indorsers are co-sureties. Danid v. Mikat, 2 llawks (N. Car.) s9o; Richards v. Simms, I Dev. \& B. (N. Car.) 48 ; Darason v. Pittway, \& Dev. \& B. (N. Car.) 396; Douglas v. Waddle, I Ohio, $4 \mathrm{I} 3$, as qualified in case of bill of exchange in $\mathrm{WT}$ illiams v. Bosson, Ir Oh. 67, and Barmit v. Foums, 29 Oh. St. 7; Firmanv. Cherry, to Ga. It (statutory). See also Mathado v. Formandez, 7t Calif. 362; Lecke v. Mancock, 76 Calif. 127.

Most jurisdictions refuse to hear parol evidence in qualify the nature of an indorsement, as to show that it was without recourse, or as surety, or guarantor, etc. I Daniel on Neg. Inst., \$719. A few States hold to the contrary. Ifolmes v. Lincoln F. N. Bank, 38 Neb. 326; Cake v. Pottsitlle Bank, i I6 Pa. Si. 26." Truman v. Bishop, 83 Iowa, 697. - En. 
payee-indorsers of a note. The note was made by the mortgagor to piaintiff and the intestate, and by them indorsed. The mortgage was given to the intestate without plaintiff's knowledge.

HoAR, J. - It is not denied by the defendant that a surety is entitled to share in the benefit of the security taken by his co-surety. But he contends that his intestate was not the co-surety of the plaintiff; and relies upon the well-settled rule that the liability of successive indorsers upon a note is fixed by the contract which the position of their names upon the paper establishes, and that, unless by express agreement, one is not bound to contribute to a payment of the note by the other, even if both are accommodation indorsers. The principle is sound, but has no application to the case at bar. Stacy and Lane are not successive indorsers. They are joint indorsers. The note was made payable to their joint order, and could only be transferred by their joint act. Which name is first put upon the paper is therefore immaterial, as by the indorsement they incurred a joint responsibility for the debt of the promisor. Each is therefore entitled to share in the security taken by the other.

Decree according to the prayer of the plaintiff's bill.'

\section{Acceptor for honor.}

See $\$ 284[\mathrm{I} 65]$, post., pp. $65 \mathrm{I}-657$.

VII. Guarantor.

I. (a) Does a Guaraxty-Indorsenent by the Holder TransFER TitLe?

Trest Co. $\%$ National Baxk, ioi U. S. 68, ante, p. 346.

Elgh City Baxkixg Co. $a$. Zeich, 57 Minn. 437, ante, p. 347.

Jomson $\approx$. Mitcheld, I50 Tex. 212, anti, p. 360.

I (b) MaY a Guaranty be Written Above a Blank IndorseMENT?

Beldex \%. Haxy, 6i Iowa, 42, ante, p. 352.

Scott z'. Calkis, т 39 Mass. 529, ante, p. 353.

Clakke $\approx$. PATRICK, 60 Minn. 269, ante, p. 354.

\footnotetext{
I See Neg. Inst. L., $\leq 7 \mathrm{I}[\mathrm{I}]$. This section (IIS[68]) changes the law to the extent of rendering the obligation joint and several instead of joint. - ED.
} 
2. Is a Transferee a Holder in Due Course?

Trust Co. z'. Nathosal Bask, ioi U. S. 68, ante, p. 346.

Elgix City Banking Co. 2 . Zelch, 57 Minn, 487 , ante, p. 347.

Dunham $\approx$. Petersor, 5 N. Dak. 4 I 4 .

3. What is the Contract of the Guarantor?

\section{BROWN $i$. CURTISS.}

2 NEW YORK, 225. - I 849 .

ACtion against defendant as guarantor of a promissory note. Defendant was payee of the note. He wrote upon it, " I guaranty the payment of the within; Charles Brown," and transferred it to plaintiff in payment of a debt. No demand on the maker, or notice of non-payment to defendant. Defendant offered to show that for several years after the note fell due the maker was solvent; that he then failed, and was insolvent at this time. Evidence excluded. Judgment for plaintiff.

Bronson, J. - It is said, on the one side, that the defendant is the maker of a promissory note, and liable as such; and on the other side, that he is an indorser, and has been discharged for the want of demand and notice. And strange as it may seem, there are cases in the books which go to uphold both of these positions. But they are both wrong. The defendant is neither maker nor indorser of a promissory note. On the contrary, he has in very plain terms made a contract of a different kind from either of those - one well known to the law; and by that contract he must either stand or fall. He has guarantied the payment of G. F. Brown's note; and we have no right to turn that contract into one of a different kind. This is so plain a principle that it would seem to be enough to mention it, without saying anything more. And yet there are cases which hold, that the guarantor of a promissory note may sometimes be treated as maker, and some times as indorser. This has usually been allowed for the purpose of giving effect to the supposed intention of the parties, as ascertained from extrinsic evidence; though there has not always been so fair an apology for altering the contract. But on whatever ground the courts may have acted, it is a dangerous proceeding. At the very best, it violates the salutary rule, that all prior negotiations between the parties are to be leemed merged in the firal written agreement; and allows that agreement to be overruled 
by the conversations which preceded it. If the parties have made a mistake in drawing up their contract, the instrument may be reformed in equity, by a direct proceeding for that purpose. But the courts can have no right, under color of construing the agreement, to say that it means something else from what the language of the instrument plainly imports. I have contended earnestly, though not always with success, for this doctrine. (Seabury v. Munserford, 2 Hill, So; Miller v. Gaston, Il. ISS; Manroä v. Durham, 3 Id. $5^{87}$; Legsett v. Raymond, 6 Id. 639.) But the side of truth and principle will sooner or later prevail; and the decisions of the court of errors in Hall r. Newcomb (7 Hill, 4 I6; 3 Id. 233, s. c.), and of this court in Spic's vilmore (I Comst. $32 \mathrm{I}$ ), have greatly shaken, if they have not entirely overthrown the cases in which the courts have taken the liberty to remodel the contract of the parties. Those cases have never had any ground of principle to stand on, and I trust they will never again be cited as authority in this state.

I do not mean that the very words of an agreement are always to be followed. Construction is often necessary for the purpose of ascertaining what the parties intended by the words which they used. But when the meaning of the iustrument has been ascertained, the office of construction is at an end; and the contract can only be enforced as the parties have made it. The defendant has very plainly contracted as a guarantor. If he is not liable as such, he is not liable at all; and if he is liable as such, he cannot get rid of the obligation by calling himself an indorser, or anything elsc.

The undertaking of the defendant was not conditional, like that of an indorser; nor was it upon any condition whatever. It was an absolute agreement that the note should be paid by the maker at maturity. When the maker failed to pay, the defendant's contract was broken, and the plaintiff had a complete right of action against him. It was no part of the agreement that the plaintiff should give notice of the non-payment; nor that he should sue the maker, or use any diligence to get the money from him. The cases in Massachusetts, Maine, and Pennsylvania, which hold a different doctrine, (O.vford Bank v. Haynes, S Pick. 423; Talbot v. Gay", is Id. 534; Gamage v. Hutchins, 23 Maine, 565; Gibbs v. Cannon, 9 Serg. \& R. 198; Isett y. Hoge, 2 Watts, I2\&), are not law in this State. With us, proceedings against the maker are only necessary where there is a guaranty of collection." The point was decided long ago that a guaranty of forment, like the one in question, is not conditional, but an absolnte undertaking that the maker will pay the note when due.

${ }^{1}$ Sylatstir v. Downer, is Vt. 32; Forest v. Stcwirt, It Oh. St. 246. - ED. 
(Allen v. Rightmere, 20 John. 365.) ${ }^{1}$ All of our cases go upon that ground. Some of them go so far as to hold, that the guarantor may be treated as the maker of a promissory note (Manrow $:$ Durham, 3 Hill, 5S4; Luqueer v. Prosser, 4 Hill, 420; 1 Id. 256.) That doctrine cannot be defended. Although the undertaking is absolute, it differs essentially from a promissory note. The guarantor does not promise to pay himself, but that the maker will pay. Still, such cases prove that our courts are far enough from holling the contract to be conditional. It follows from what has been said, that the evidence offered by the defendant was properly excluded. Proof that when the note became due, and for several years afterwards, the maker was abundantly able to pay, and that he had since hecome insolvent, would be no answer to this action. The defendant was under an absolute agreement to see that the maker paid the note at maturity.

If there had been an indorser on the note prior to the guaranty, and the plaintiff had allowed him to be discharged by neglecting to demand payment and give him notice, it may be that the defendant would have had a good answer to the action. But it is not necessary to consider that question; for there was no indorser, and nothing has been done or omitted to discharge the maker. If the defendant wished to have him sued, he should have taken up the note, and brought the suit himself. The plaintiff was under no obligation to institute legal proceedings.

The only remaining question is on the statute of frauds. (2 R. S. $135, \$ 2$ ) If the case is within the statute, it is impossible to get over the objection that no consideration is expressed in the guaranty. I know it was held in Manrow v. Durham (3 Hill, $5 s_{4}$ ), that a guaranty like this was a promissory note, which imports a consideration, and was therefore valid. But that case, which has heen questioned elsewhere (Story, Prom. Notes, 597), as well as at home, cannot be law. An undertaking that another man will perform his contract is not a promissory note. It is not within any definition which was ever given of a promissory note, and it cannot be held to be such, without confounding all legal distinctions in relation to the nature of contracts.

1 Accord: Bank r. Hopson, 53 Conn. 453; Hance v. Hillir, 2 I Ill. 636; Shudabaker v. Cody, 54 Ind. 556; Roberts v. Hazukins, 7o Mich. 566; Clay v. Eidserton, Ig Oh. St. $5+9$.

Contra: (Contract conditional) Crooks v. Tully, 5o Calif. 25t; Rockford N. B. v. Gaylord, 34 Iowa, 246; Vewton Wraron Co. v. Diers, io Neb. 254; Mizner v. Stier. $96 \mathrm{~Pa}$. St. 533; cases from Me., Mass., and Pa., criticised in the principal case. But the guarantor may waive the holder's laches. Sigourney v. Wetherell, 6 Met. (Mass.) 553; Pattillo v. Alexander, 96 Ga. 60. - ED. 
But I think the statute of frauds does not apply to this case. Although in form this is a promise to answer for the debt or default of another, in substance it is an engagement to pay the guarantor's own debt, in a particular way. He does not undertake as a mere surety for the maker; but on his own account, and for a consideration which has its root in a transaction entirely distinct from the liability of the maker. The defendant was a debtor to the plaintiff, and gave the note, with the guaranty, to satisfy that debt. This belongs to the third class of cases mentioned by Kent, Ch. J., in Leonard v. Vredenburgh $(8$ John. 38,39$)$. There was a new and distinct consideration, independent of the debt of the maker, and one moving between the parties to the new promise. In such cases, where the party undertakes, for his own benefit, and upon a full consideration received by himself, the promise is not within the statute. It would be good without any writing. The point was decided by the Supreme Court in Fohnson $:$ Gillert ( 4 Hill, 178 ), and I do not think it necessary to refer to other cases holding the same doctrine. ${ }^{1}$

The case of Hanroze v. Durham might have been placed upon the same ground on which I have put this, if Durham alone had signed the guaranty. He made the promise upon a new consideration,

1“ The reasoning to take this promise out of the statute is quite subtle, and I should have much difficulty in yielding it my assent, but for the authorities which I think ought now to control." - Earl, J., in Milks v. Rich, So N. Y. 269, 27r. See also Darst v. Bates, 95 111. 493; Sheldon v. Butler, 24 Minn. 513; II'man v. Goodrich, 26 Wis. 21; Hassinger v. Veriman, 83 lnd. r24; cf. Dows v. Sii'.tt, 13+ Mass. I to.

One who signs as surety with the maker is liable as an original promisor; the statute of frauds does not apply to the case. Casey r. Brahason, Io Abb. Pr. (N. Y.) 368; Frech v. Faworer, 47 N. J. L. 157; Paui v. Stackhouse, $38 \mathrm{~Pa}$. St. 302 .

Where one, not the payee or holder, signs a guaranty upon the instrument there are two cases. (I) If signed before delivery, it "requires no other consideration to support it, and need express none other, (even where the statute requires the consideration of the guaranty to be expressed in writing), than the consideration which the note upon its face implies to have passed between the original parties. (2) But a guaranty written upon a promissory note after the noze has been delivered and taken effect as a contract, requires a distinct consideration to support it; and if such a guaranty does not express any consideration, it is void, where the statute of frauds requires the consideration to be expressed in writing." - Moses v. Lawrence County' Bank, It9 U. S. 295; cf. Scott v. Calkin, I39 Nass. 529, anti, p.

An oral acceptance without consideration has been held to be within the statute. Manley v. Geagan, I05 Mass. 4+5; Walton v. Mandeville, 56 Iowa, 597. Contra: Jarvis v. Wilson, +6 Conn. 9o. An oral acceptance upon consideration is held not to be within the statute. MIcCutchenv. Rice, 56 Miss. $455 ;$ Nelson v. First Bank, 4 Ill. 36; Louisville Co. v. Caldwell, 9s Ind. 245; In re Goddard, 66 Vt. $+15 .-$ ED. 
moving between the plaintiff and himself. But Moulthrop, the other defendant, was a mere surety, and as to him the case was clearly within the statute.

Strong, J., also delivered an opinion.

Jewett, Ch. J., and Gardiner, J., were of opinion that the guaranty was within the statute of frauds, and therefore void.

Judgment affirmed.

\section{Is the Guaranty Transferable?}

(a) Is it negotiable? ${ }^{1}$

TRUE $\tau^{\prime}$. FULLER.

2i Pichering, iqo. - is 33.

Shaw, C. J., delivered the opinion of the court. The facts bearing upon this question may be thus stated. Morse made three promissory notes to Elisha Fuller, or his order, payable in two, three and five years, respectively, from date, and gave a mortgage to secure the payment of them. The notes were indorsed in blank by the payee. On the same notes was indorsed a guaranty in this form: "I guaranty the payment of semi-annual interest on this note, as well as the principal," and signed by the defendant. The notes thus indorsed were transferred, and the mortgage assigned. The mortgaged premises were entered on for breach of condition, and the mortgage foreclosed. The notes have regularly come to the hands of the plaintiff.

The Court are of opinion that the plaintiff is not entitled to recover, because the guaranty in question was not made to him, or whilst he was holder of the note; that it was not negotiable in itself, and was not made so by being written upon and intended to secure a negotiable instrument. This instrument being filled up and signed, is complete in itself, and it cannot be altered, either by striking out words so as to convert it into a general indorsement, or by filling up, as in case of a blank indorsement. In the latter case, an indorser, by leaving a blank over his name, tacitly agrees that any subsequent lawful holder may insert stitable words to render him liable in the same manner and to the same extent, implied by his indorsement and the usages of business.

1 Whether it be a guaranty-indorsement by a holder, or be written on the bill by a third party, seems immaterial when this question is involved. - En. 
This guaranty expresses no consideration, nor does it name any person as the guarantee, to whom it is made. But suppose these could be supplied by parol proof, it could only enure to the person who was the holder at the time the guaranty was given, who was not the plaintiff.

Had the defendant intended, by the credit of his name, to grive a general currency to the note, as a negotiable security, there was no reason why he should not have indorsed it generally, in which case he would have been responsible to any person who might afterwards become the holder. As it is, it is no more a negotiable promise than if it had been written on a separate paper, referring to the note, and guarantying it to the then holder. (Tyler v. Binney, 7 Miss. R. 479; Lamourieux v. Hewit, 5 Wend. 307.)

Plaintiff nonsuit. ${ }^{1}$

(b) Is it assignable?

COOPER $\because$. DEDRICK.

22 Barbour (N. Y. SUt. CT.), 5 I6. - I 556.

By the Court, Marvin, I. - The action was upon a guaranty, written upon a promissory note. The note reads thus:-

\$5.26. Due Dedrick \& Bronson, or bearer, fifty-eight and twenty-six one hundredths dollars, for value received.

[The guaranty is, that]

J. S. Stillman.

For value received, I hereby guarantee the payment of the within note. Feb. I 9, I $8+9$.

(Signed by Defendant.)

Upon the trial the plaintiffs produced the note and proved the guaranty written upon it, and rested. [Defendant asked for nonsuit: (I) That there was no evidence of the maker's signature; (2) that plaintiffs showed no title or interest in the guaranty. ${ }^{2}$ The justice gave judgment in favor of the plaintiffs.

Several objections are made to the judgment. It will not be necessary to state them particularly. It was not necessary to prove by witnesses the signature of the maker of the note. This was sufficiently proved, as against the defendant, by proving his

${ }^{1}$ Accord: M'Doal r. Jiomans, S Walts. (Pa.) $36 \mathrm{I}$; Irish v. Cutter, $3 \mathrm{I}$ Me. 536. Contra: Wibster v. Cobh, I7 Ill. 459; Donnerbers v. Oppenheimer, I5 Wash. 290. See 2 Daniel on Neg. Inst., SS I774-I $7 S_{4}$. ED.

${ }^{2}$ Other questions omitted. - ED. 
execution of the guaranty. (Cowen \& Hill's Notes, notes 168, 869, 9I 2.)

As to the evidence of their title to the guaranty, the note was payable to Dedrick \& Bronson, or bcarer, and the guaranty was written upon it. The possession and production of the note was prima facic evidence of title in the plaintiffs, and as the guaranty was upon the note, in my opinion, the possession of the note and the guaranty were prima facic evidence of right in the plaintiffs to the guaranty. Since the code, the real party in interest is to bring the action. The old question, therefore, whether the form of the contract justifies the action in the name of the plaintiffs, no longer exists; but the question is, has the plaintiff the title or right to the contract or the cause of action. If he has, he may maintain the suit, upon the contract, in his own name. In my opinion, when a guaranty is written upon a note and the note is transferred, nothing being said touching the guaranty, the contract of guaranty passes with the note. In other words, the sale and delivery of the note with the guaranty upon it furnishes prima facie evidence of a sale of the contract of guaranty. In the present case the defendant was one of the payees of the note, and the note was also payable to bearer. He transferred the note and guarantied the payment. In my opinion, any one who should become the holder of the note could maintain an action upon the guaranty, unless it should be shown that the contract of guaranty was not transferred at the time the note was transferred. (See McLaren v. Watson, 26 Wend. 425.)

The statute of limitations did not commence running in favor of the defendant until the cause of action accrued upon the contract of guaranty.

The contract of guaranty was not within the statute of frauds. The consideration, "for value received," was sufficiently expressed to satisfy the requirement of the statute. (Douglass v. Howland, 24 Wend. 35; Watson's Ex'rs v. McLaren, ig id. 557.)

The judgment should be affirmed. ${ }^{1}$

Everson $v$. Gere, 122 N. Y. 290. - I890. A. indorsed and delivered a negotiable promissory note to $C_{\text {, }}$ attached to which was an allonge containing this guaranty: "For value received of $C$., we do hereby guarantee to said $C$. the payment of the note hereto

'Accord: Harbord v.Cooper, 43 Minn. 466; Phelps v. Sargent, (Minn.) 7x N. W. Rep. 927. - ED. 
annexed, etc." (Signed by defendants.) C. indorsed the note to plaintiff " without recourse," and executed and delivered an assignment of the same and the guaranty. In an action by plaintiff against defendants on the guaranty, the trial court granted a nonsuit on the ground that the guaranty was special, personal to C., and did not pass to plaintiff, and that no cause of action had accrued on the guaranty at the time of the assignment. Held: Error. As the note and guaranty are to be construed together, and as the note is not personal and special, but general and negotiable, the guaranty is also to be regarded as general and will therefore pass by assignment. ${ }^{1}$

\section{Defences arallable to Guarantor.}

PUTNAM ${ }^{\prime}$. SCHUYLER.

$+\operatorname{Hux}($ N. Y. SuP. CT.), $166 .-1875$.

Learned, P. I.:-

Mrs. Henriques, in her lifetime, made two notes to Dr. Allen, the plaintiff's testator. After her death the defendant guaranteed them, by writing under each, as follows:

For value received I hereby guaranlee the payment of the above note.

L. W. SchuYler.

On the trial the defendant offered to prove that Dr. Allen was the medical attendant of Mrs. Henriques; was in the habit of advising her as to financial and other matters; that she reposed confidence in him in relation to her affairs; together with certain other matters tending to show that the notes were obtained by fraud, and that they were without consideration. The evidence was objected to on the ground that, by executing the guarantee, the defendant had admitted the notes, and was estopped; that the defence of fraud was personal to Mrs. Henriques and her representatives; that the defendant could not impeach the settlement between maker and payee. The evidence was excluded, and the defendant excepted.

I assume, from the manner in which the case is presented, that it was not really claimed on the trial that these matters would not have been competent in behalf of the representatives of Mrs. Henriques. Their exclusion was on the ground that they were not competent in

${ }^{1}$ For the dislinclion between special (non-assignable) and general (assignable) guaranties, see Eấlunsilli Lat. Bank̂ v. Käufmann, 93 N. Y. 273; Sawyer v. Htopgrool, I3 N. Y. Si. Rep. 7II. - ED. 
behalf of the guarantor. On this subject, of the right of a guarantor to set up defences which would undoubtedly be valid in favor of the principal, there is an apparent conflict. But a little discrimination will show that the conflict is only apparent.

First. There is a class of cases in which the owner of a note or boad has assigned it, with a guaranty. In these, it has been held that the guarantor could not show that the instrument was invalid. It would be unjust to permit him to assign an invalid instrument; to guaranty its payment or collection; to receive the value, and then, when sued on his guaranty, to assert that the original instrument was invalid. He is estopped. (Remsen v. Grâes, $4 \mathrm{I}$ N. Y. 475 ; Zabriskie v. C., C. and C.R R.Co., 23 How. [U.S.] 399.) The case of Mann v. Eckford's Excutors ( 15 Wend. 502 ), is of this character. The Life and Fire Compans, of which Eckford was president, assigned to the IVestern Insurance Company a bond and mortgage. Eckford guarantied the bond and mortgage, and the money paid for it, expressing the amount. The defendants, his executors, were not allowed to set up usury in the bond and mortgage, against the plaintiff, the receiver of the Insurance Company.

Second. The guarantor is held liable in those cases in which the debt is justly owing, although, from some defect or incapacity, the principal in not liable in an action. Thus, where the makers of a note were married women, incapable (then) of making a note, the accommodation indorser was still held liable. (Erwin v. Downs, I5 N. Y. $57^{6}$; see Kimball v. Newell, 7 Hill, i 16 .) The guarantor of a lease is liable, although only one of the two lessees executed the lease. (MiLaughlin v. MiGovern, 34 Barb. 2o8.) In that case, Judge Bacon speaks of this class of cases, mentioning, among others, the guaranty of goods sold to an infant. So the guarantor of a note purporting to be made by two, where the signature of one is unauthorized, is liable. (Sterns v. Marks, 35 Barb. 565.) In all these cases the debt is justly owing to the plaintiff; and through no fault of his, he is unable to recover against the principal, or one of the principals. ${ }^{1}$

Third A guarantor cannot set up, by way of set-off, a claim distince from that on which he is sued. The right of set-off (that is, as distinguished from a defence arising upon the clam itself) belongs only to the principal debtor, and can be used only at his option.

'A guarantor is not discharged merely because the principal has a good personal defence, as coverture, infancy or insanity. Davis v. Statts, 43 Ind. 103; Brozuning v. Carson, I63 Mass. 261; Wigrin's Afpial, 100 Pa. St. 155; Lee v. Yandell, 69 Tex. 34. But a failure of considerition in such a case, as between the principal and plaintiff, discharges the surety. Baker v. Kenneth, 54 Mo. 82. - ED. 
Such is the doctrine of Gillespie v. Torrance (25 N. Y. 306), and this is all which that case decides on this point. By indirection, however, it implies that a defence to the claim (as distinguished from a set-off), is available to the guarantor. To the same effect is Learis v. Mc Millen ( +1 I Barb. +20).

Fourth. But there are still other cases which are not embraced within either of these three preceding classes; cases where the plaintiff is the original party to the contract, and therefore has not received it by assignment from the guarantor; where the proposed defence is not the incompetency of the principal to contract; and where it arises out of the contract itself, and not by way of set-off. In these the guarantor has been permitted to make the defence.

He has thus, as to the original contract, been allowed to set up usury (Morse v. Hovey, 9 Paige, 197; Parshall v. Lamoureaux, 37 Barb. I 89 ); duress of his principal (Osborn s. Robbins, $3^{6} \mathrm{~N} . \mathrm{Y}^{6} 3_{5}$; Strong v. Grannis, 26 Barb. I22); partial failure of consideration (Sazyer r. Chambers, 43 Barb. 6z2). And I find no case which intimates that when a person has obtained an obligation from a principal by fraud, he can wipe out the fraud by obtaining a surety to the obligation. Assuming that, in justice and equity, the obligee, by reason of fraudulent acts on his part, has either no claim, or a less claim, against the principal, I see no reason why he should stand in a better position against the guarantor.

The distinction which has been pointed out, viz., that inability on the part of the principal to contract is no defence to the guarantor, while fraud in the contract is, may be found in the civil law. This says that personal defences do not pass to others, but that defences, inherent in the thing, such as, among others, fraud and duress, are available to sureties. (Dig., 44, I, de exceptionibus, c. 7, $\$$ i; Cod. 2,24 [23] de fidejuss, 2.) "If, in the principal obligation, there is any essential vice which may annul it, as if it has been contracted by force, if it is contrary to law, or to good manners, if it be founded only on a fraud, or on some error which may suffice to annul it; in all these cases the obligation of the surety is likewise annulled." (Strahan's Domat, bk. 3 , tit. $4, \S 5$, art. 2 ; id., bk. 3 , tit. 4 , $\S$ r, art. Io.)

The defendant offered to prove acts of the plaintiff's testator, tending to show that he obtained the notes improperly from the maker; that he took advantage of her confidence in him, and that she did not owe him. If these facts be true, he ought neither to recover of her representatives on the notes, nor of the defendant on her guaranties. 
The judgment should be reversed, and a new trial ordered, costs to abide the event.

Present - Learned, P. J., Boardman and James, JJ.

Judgment reversed, and new trial ordered, costs to abide the event.

${ }^{1}$ Accord: Bryant v. Crosby, 35 Mle. 562 (fraud); Suift v. Beers, 3 Denio (N. Y.) 70 (illegality); Griffith v. Sitsreaves, $90 \mathrm{~Pa}$. St. I6I (duress). For an enumeration of the circumstances which will discharge a surety, see Neg. Inst. L., $\$ 201$ [120]. - ED.

NEGOT. INSTRUMENTS - 32 . 


\section{ARTICLE VII.}

\section{Duties of Holder: Presentment for Payment.}

\section{Necessity of presentment.}

I. Not to Charge Acceptor or Maker.

7S Federal Reporter, 292. - 1897.

[Circuit Court, Dist. Washington, N. D.]

Hanford, District Judge. - This is an action to recover a balance due after deducting partial payments upon a negotiable promissory note, made payable on demand. The defendant has demurred to the complaint, his contention being that the same is insufficient, for failure to allege a demand pror to the commencement of the action. There is a rule of long standing, and supported by the weight of authority in this country, that the commencement of an action is itself a demand, ${ }^{1}$ and that failure to request payment, prior to the commencement of the action, affords no ground of defence. (Bank r. Fox, Fed. Cas. No. 2683; $5 \mathrm{Am}$. and Eng. Enc. Law, $52 S z^{46}$ [2d ed. v. 4, p. 35r.]).

It is insisted, however, that the courts and the text-books in this country have fallen into error by following early decisions, which were controlled by peculiar facts, and which are insufficient of themselves to establish a general rule upon the subject. ${ }^{2}$ It is unwise to depart from business customs and practices which have been sanctioned by repeated decisions of courts, and acquiesced in for a considerable time, and which may fairly be supposed to have been contemplated by the parties at the time of making their contract. This contract must be construed as one having been made subject to the rule above stated, and the maker of the note is, by the terms

1 "To sar that the suit is the demand is to repeat an unmeaning phrase as thus used, which no number of repetitions can make sensible. A demand note is due forthwith, and hence can be sued without demand." Wheeler v. War$n e r, 47 \mathrm{~N}$. Y. $5 \mathrm{Ig}$, holding that the statute of limitations begins to run from the date of the note. $-\mathrm{ED}$.

2 See 2 Ames' Cases on Bills and Notes, p. 6I, note 2. - ED. 
of his contract, liable without any demand, prior to the commencement of an action.

Demurrer overruled. ${ }^{1}$

$$
6 \text { Alabina, joI. - Is+4. }
$$

THIs action was commencel before a justice of the peace, by the defendant in error, on two notes, for twenty dollars each, in the following form:

The Real Estate Bank, No. 52, of Caledonia, Mississippi, promise to pay John Elliott, or bearer, twenty dollars, on demand, at their banking house, Caledonia, Mississippi. - May S, 183 S.

R. DOwdle, Cashier.

W. G. Wrigit, Prisident.

Judgment being rendered for the defendant, the plaintiff appealed to the circuit court, where judgment was rendered for the plaintiff.

The defendant mored the court to charge, that the plaintiff, to entitle himself to a recovery, must prove a demand at the banking house of the company - which the court refused, and he excepted.

The assignments of error present for revision the rejection of the testimony and the charge of the court.

Ormond, J. - The question, whether a demand was necessary before suit, is one of considerable difficulty. Upon this subject, a great contrariety of opinion formerly prevailed in England, as to the necessity of averring and proving a demand as a precedent condition to the right to recover, when the instrument was made payable on its face at a particular time and place, or where it was accepted, payable at a particular place, which was finally settled on appeal to the House of Lords, that such demand was necessary in the case of Rou'e v. Young (a Brod. \& Bing. ISo). ${ }^{2}$

\footnotetext{
${ }^{1}$ But a certificate of deposit is not due until demand is made and the certificate returned or tendered. Shuti v. Pacifi Vat. Bank, 136 Mlass. 457 ; Smiliy v. Fry, 100 N. Y. 262; 1.CGoush v. Jamison, 107 Pa. St. 336. Contra: Cuman v. Witter, 68 Wis 16: Lynch v. Gollsmith, 64 Ga. 42 ; I/unt v. Divini, 37 Ill. 137; Tript v. Curtinius, 36 . Mich. 494 . There is also a conflict as to whether bank notes must be presented for payment before suit brought. $3 \mathrm{Am}$. E Eng. Enc. Law (2d ed.) p. $778 .-$ En).

2 This was changed by Onslow's Act ( $1 \& 2$ Geo. IV., c. 78 ) which, as construed, renders presentment unnecessary to charge the acceptor of a bill, drawn
} 
In the United States a different doctrine has generally prevailed, it being considered matter of defence, and therefore, not necessary to be proved by the plaintiff. (Wallace $\mathrm{v}$. McConnell, I3 Peters, I33. See, also, Chitty on Bills [9 Am. ed.] 393, and Story on Bills, 416 ; and note, where the cases are collected.)

In this State, it has always been considered matter of defence, when the suit is against the maker or acceptor. The doctrine is so stated by Judge Saffold, in Irine r. Withers (I Stew. 234); and although it was not acquiesced in by the whole bench, it has been considered and acted on as settling the law from that time to the present. (Roberts v. Mason, I Ala. Rep. 373.)

The question in this case is, whether the same rule is to be applied where the note is payable on demand at a particular place. We are unable to perceive any substantial difference between the two cases. The same reasons which lead to the conclusion that it is a matter of defence when the note is payable at a specified time, at a particular place, apply with the same force when it is payable on demand. In either case it is impossible that the defendant can be prejudiced, as he can always defend himself by proving that he was ready at the place appointed to pay the debt, and if not ready to pay, why should the plaintiff be required to do an unnecessary act. This question is considered at some length in the case of Huxture v. Bishop ( 3 Wend. 13 ), and the law considered to be as here stated. The rule would be different where the suit is against an indorser, his contract being conditional to pay, if the maker does not on demand; a demand and notice is, therefore, necesssary by the terms of his contract to fix his liability.

It results from the view here taken, that there is no error in the judgment of the Circuit Court, and it is therefore affirmed. ${ }^{2}$

payable at a particular place and accepted generally, or drawn generally and accepted payable at a particular place; though not if accepted payable at a particular place only. Selly v. Eden, 3 Bing. 6ri. See Bills of Exchange Act, $\$ 52$, and Neg. Inst. L., $22 S$ [I 40 ]. The same rule applies to a promissory note. See Bills of Exchange Act, 87 , subsec. (I); Price r. Mitchell, 4 Camp. 200; Exon v. Russell, 4 M. \& S. 507. - ED.

1 See for a full discussion of the authorities, Montsomery. Tutt, I I Calif. 307. The American cases have almost uniformly held that presentment of a bill or note payable at a particular place is unnecessary in order to maintain an action against the acceptor or maker; an omission to do so merely stops interest and damages in case the acceptor or maker was ready at the time and place to pay. Hills v. Place, $4^{4}$ N. Y. 520; Cox v. Vational Bank, 100 U.S. 704, 713; Eldred v. Hawes, 4 Conn. 465 ; Carley v. Vance, 17 Mass. $389 .-$ ED. 
§ 30 CONTINENTAL NATIONAL BANK $v$. TOWN- [§ 70] SEND.

8; NEW YORK, S. - IS8I.

[Reforted herein at p. 387.$]^{1}$

2. Presentuent Necessary to Charge Drawer or Indorser.

$\S 130$

LONG $\because$ STEPHENSON.

$[\$ 70]$

72 Nortil Carolina, 569. - I875.

[Repatid herin at $.+47+]^{2}$

II. What eonstitutes suffieient presentment.

i. By Holder or Authorized Representative

$\S \mathbf{I 3 2}$

$$
\text { SUSSEX BANK } \because \text { BALDWIN }
$$

I 7 New Jersey Law [2 Harrison], 457 - I 4 o.

Daytor, J. - This case was tried at the Sussex Circuit of May, A. D. I $\delta_{3} \delta$, and verdict had for the plaintiff. Sundry reasons are now relied upon to set the same aside, and I will consider them in their order.

The defendants are the indorsers of a promissory note made by Conrad Teese, Oct. $24,{ }_{1} \delta_{3} 6$, for five hundred and five dollars and sixty-one cents, payable six months after date to the order of $\mathrm{Wm}$. A. Baldwin \& Co. (the defendants), and by them indorsed to the plaintiff. The first reason assigned is, that the note was not duly presented to the maker for payment. That it was presented at an improper place, to wit, the office of Teese, the maker, and by an improper person, to wit, one Dennis, who swears that he acted as the clerk and under the directions of $\mathrm{Wm}$. Tuttle, who was himself merely the agent of James Hedden, the notary public.

$'$ An action on the last day of maturity after banking hours, brought upon a note payable at bank, or after demand and refusal, is premature. Sutcliffi v.

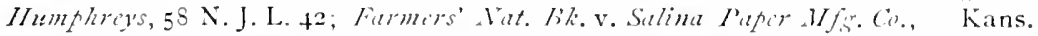
- 48 Pac. 863; Hiesinser v. Bank, 106 Mich. 29x, 64 N. W. 59; Acnncidy v. Thomas, I394, 2 Q. B. Div. 759.

Contra: Tazic Bank v. Hinn, to Me.62; Staplis v. Franklin Bank, I Met. (Mass.) +3. - E1).

:See $\$$ I $+3-1+4\left[s_{3}-s_{4}\right] .-$ En. 
As to the place of presentment, ${ }^{1}$ the objection may be disposed of very briefly. It is a point not properly arising under the evidence in the case. Dennis, the witness, swears that Teese, the maker of the note, told him, Dennis, to present his notes for payment at that place, and that he had been in the habit of doing so. This estops Teese from objecting to the place of presentment; and that which is good against the drawer, is good against the indorser. (State Bank v. Hurd, iz Mass. i72; Whitwell v. Johnson, i7 Mass. R. 449.) But it is thought advisable that this point be put at rest in this State, by an expression of opinion by this court.

It appears by the eridence that the office in question was the regular place of business of the maker; and I have no doubt where a person has an office or a known and settled place of business for the transaction of his moneyed concerns-whether he be a banker, broker, merchant, manufacturer, mechanic, or dealer in any other way, a presentment and demand at that place, (as well as a presentment and demand at his residence), is good in law. It must not, however, be a place selected and used temporarily for the transaction of some particular business, as settling up some old books or accounts merely, but his regular and known place of business for the transaction of his moneyed concerns. The counting room of a banker or merchant may be a proper place for a demand, though the manufactory or workshop would not. let if the manufacturer or mechanic have an office, or known place of business for the purpose aforesaid, a good demand may be made there. (Bank of Columbica v. Laurence, . I Peters, $5 S_{2}$; Williams v. The Bank of United States, 2 Peters, roo; Byles on Bills, ins; State Bank v. Hurd, I2 Mass. 173.)

Nor is there anything in the objection that the presentment was made by an improper person. It appears by the evidence that Tuttle did the business of Hedden, the notary public, and it must have been with the consent and knowledge of the bank that he employed and directed Dennis, who was his clerk, to present the note in question to the drawers, and put him in possession of the note for that purpose. If the note had been paid on presentment, he could and would have delivered it up to the drawers, and that would have exonerated them from further liability. An authority to make a demand, may be created by parol, and the mere possession of the paper, is evidence enough of such authority. (3 Kent. C. roS; Bank of Uticav. Smith, rs J. R. 230 ; Shea v. Brett, r Pick. $40 \mathrm{r}$; Morris v. Foreman, I Dal. 193; Froman and others v. Boynton, 7 Mass. 487 .)

There is an impression current in some degree, even with the bar, that a presentment of a note must be by a notary, or at least on his

'See $\$$ I $33[73]$. ED. 
behalf, and that he must protest it upon non-payment, before the indorser is liable. But this is not so. ${ }^{1}$ The record of a demand and notice, etc., by a notary, entered in his book, according to our statute, of zist February, i \$29, Harr. C. 249 , may serve to refresh his memory, or in case of his absence or death it may be used as evidence of the facts contained in it; but such demand and protest by a notary are not essential to a recovery against the indorser. It was not so by the common or commercial law, nor is it required by our statute. If a notary act in the premises, and make the protest, although sanctioned by general custom, it is not strictly an official act. (Nichols r. Wibl, S Wheat. 326; 3 Kent C. 93-4; r Saund. on Pl. \& Ev. 295.)

Any person may present at its maturity, a promissory note of which he is put in possession, and if paid in the ordinary course of business, and taken up, the payment is good; and if not paid, the demand is good as a ground work for notice to the indorsers, and that without any protest. ${ }^{2}$ The rule is otherwise as to foreign bills of exchange, which must be protested by a notary, and their official seal is plenary evidence in all foreign courts and countries, of the dishonor of the bill (i'ide cases above cited).

2. The next objection, is to the notice to the indorsers. ${ }^{3}$ The name of James Hedden, the notary public, was printed at the foot of the notice, not written; and this is assigned for error. There is nothing in this objection. The law prescribes no form of notice, its object is merely to appraise the party of the non-payment - to put him upon inquiry, that he may protect his rights. This is as well done by a notice with a printed as with a written name.

The signature of the notary would carry with it in a large majority of cases no higher degree of certainty thin the printed name; for it must in most cases be unknown to those to whom notices are sent. The notice in this case came from a proper source, and stated the proper facts; that is enough. It is needless to cite authorities upon this point.

[The learned judge then decides that the notice was sent in due time, and that there was no usury. Neviss, J., dissented on the lasț point.]

Rule made absolute.

ISee $\$$ I 89 [IIS]. - ED

${ }^{2}$ Baer v. Leppert, I2 Hun (N. Y.) 5 I6. - ED.

${ }^{3}$ See $\$ 166[95]$. En.

4 The drawer may provide in the instrument that it shall not be presented by a specified person. Con. Nat. Bk. v. First Nat. Bk., II8 N. C. 783. - ED. 


\section{At the Proper Time.}

$\S I 3 I$ JOHNSON $v$. HAIGHT.

I3 Johnson (N. Y.), 470. - ISI6.

Action by holder against indorsers.

SPENCER, J., delivered the opinion of the court.

On the second point, the defendants are entitled to judgment. The third day of grace fell on the $29^{\text {th }}$ day of November, and payment was not demanded of the maker until the 30 th. The law is perfectly settled, that a note must be demanded on the third day of grace, unless that falls on Sunday, and then it must be demanded on the second day of grace. (2 Caines, 3+3; 16 East, 250.) Here there is no excuse for delaying the demand on the maker, and there is a palpable want of due diligence, which discharges the indorser. Judgment for the defendant. ${ }^{2}$

$$
74 \text { Wisconsin, 355. - ISS9. }
$$

ACTION by holder against indorser of a note payable on demand with interest. The note was dated January ıo, was transferred by defendant's indorsement on February 15, was presented to maker for payment on December 16 , was dishonored and notice given to defendant. The court directed a verdict for defendant. Plaintiff appeals.

Cassoday, J. - From the undisputed evidence it appears that the demand of payment and notice of protest were made and given more

${ }^{1}$ See Hurt v. Smith, I5 Ala. So7, ante, p. 234. See $\$ \mathrm{I}_{45}\left[8_{5}\right]$, which abolishes days of grace. Paper payable without grace falling due on a legal holiday is payable on the next succeeding business day. Salter v. Burt, 20 Wend. (N. Y.) 205 .

See It6 [S6]. Days are reckoned exclusive of the day of date; exclusive of the day of sight; and, where grace is allowed, exclusive of the nominal day of payment. Ammidocan v. Hoodman, 3I IIe. 5So; Rochnir v. Knickerbocker Co., infro.

Months in bills and notes are reckoned as calendar monlhs according to the portion of the calendar covered by the instrument. Thus, a note dated January 3o, due one month from date, without grace, is due on February 28, except in leap-year, when it is due on February 29. A similar note dated February 28 is due on March 28. Wrisner v. Kinner, 2 Rob. (La.) Izo; Rochner v. Knickerbocker Co., 63 N. Y. I60. - ED. 
than ten months after the transfer and indorsement of the note. The law is well settled that a promissory note payable on demand, whether with or without interest, is due forthwith, and an action thereon against the maker is barred by the statute of limitations, if not brought within the time prescribed by statute after its date. (Whecler v. Harner, 47 N. Y. 519 ; Howland v. Edmonds, 24 N. Y. 307 ; Burnham r. Allen, I Gray, 496; Sylecester r. Crapo, I5 Pick. 92; Taylor's Adm'rs v. Witman's Adm'rs, 3 Grant's Cas. I38; Larason v. Lambert, I 2 N. J. Liw, 247; Curran v. Witter, 68 Wis. I6, 60 Am. Rep. 827; Schriber v. Richmond, 73 Wis. r2; Hitchell v. Easton, 37 Minn. 335; Hill r. Henry, I7 Ohio, 9; Caldwell r. Rodman, 5 Jones' Law, 139; Ilitks $r$ Robinson, 3 Rich. Law, IS2.) The mere fact that such note is payable at a particular place does not even make it necessary to allege or prove that it was so presented before the commencement of the action. (Dougherty v. Western Bank, ${ }_{3} 3 \mathrm{Ga} .287$.)

This being so, it necessarily follows that the note in question became due and payable immediately upon its inception, and that upon its transfer and indorsement Moore, Benjamin \& Co. might immediately have maintained an action thereon against the maker corporation, without any demand whatever.

Two questions are thus suggesed: Was it necessary for that firm to demand payment and give notice of non-payment in order to charge Henry M. Benjamin as indorser thereon? And, if so, was he discharged by the delay in making such demand and giving such notice?

It has been held in New York, and perhaps elsewhere, that an " indorsed promissory note, payable on demand with interest, is a continuing security, on which the indorser will remain liable until an actual demand, and upon whici the holder is not chargeable with neglect for omitting to make clemand within any particular time." (Merritt v. Todd, 23 N. Y. 28, So Am. Dec. 243.) But much of the reasoning in that case seems to have been disapproved by subsequent cases in the same court. (Horick v. Hoolicton, $4 \mathrm{r}$ N. Y. $5^{S_{1}}$; Whecler v. Harner, 47 N. Y. 519; Pardec v. Fish, 60 N. Y. 266; Crim v. Starkweather, 88 N. Y. 339; Parker v. Strout, 98 N. Y. 379 ; Shutts v. Fingar, 100 N. Y. 541.) The case of Merittr. Todd (23 N. Y. 28) has been expressly repudiated in Louisiana, where it is held that " a demand note must be protested and notice given within a reasonable time to hold an indorser; and the fact that the indorsement was for accommodation, and that the note bears interest, makes no difference." (Thiclman v. Gucble, 32 La. Ann. 260; 36 Am. Rep. 267.) This ruling seems to be in harmony with the current of authority in this country, as appears from the valuable notes 
by Mr. Freeman in $80 \mathrm{Am}$. Dec. 250-254. Among the cases supporting this view may be cited: Furman v. Haskin, 2 Caines, 372; Sice v. Cunningham, I Cow. 397; Field v. Nickerson, I3 Mass. 131; Seaver v. Lincoln, 2 I Pick. 267.

The ordinary contract of an indorser of a note is to pay the same, if the maker does not, on presentation at maturity, in case he is duly notified. (Charles a'. Denis, 42 Wis. 57: Sumner v. Bowen, 2 Wis. 524; Catlin v. Fones, I Pin. 130.)

The only difference between such a case and the case at bar is that here the note was due before the indorsement was made. It is substantially the same as a note payable at a fixed time, and then indorsed by the payee after maturity. The rule seems to be firmly established that, in order to charge such an indorser after maturity with liability, payment must be demanded of the maker within a reasonable time thereafter, and, in case of failure to pay, notice thereof must thereupon be given to the indorser. (Berry r. Robinson, 9 Johns. 121, 6 Am. Dec. 267 ; Poole v. Tolleson, ro Am. Dec. 663; Eefert v. Des Coudres, 12 Am. Dec. 609; Nash v. Harrington, 2 Aikens, 9, 16 Am. Dec. 672; Colt v. Barnard, 18 Pick. 260, 29 Am. Dec. 584; Kirkpatrickv. McCullough, 39 Am. Dec. I58; Gray v. Bell, 44 Am. Dec. 277 ; Leazitt v. Putnam, 3 N. Y. 494, 53 Am. Dec. 322; Mudd v. Harper, 54 Am. Dec. 644; Bassenhorst v. Willy, 45 Ohio St. 333.) This court has frequently sanctioned this doctrine. (Comith v. Morrison, I Pin. 489 ; Lindsey v. McClelland, I8 Wis. 48r ; Gunn v. Madigan, 28 Wis. $16_{4}$.)

The cases cited also firmly establish the rule that where, as here, the material facts are admitted or not in dispute, the question as to what constitutes a reasonable time for making such demand and giving such notice is one of law for the court. We are all clearly of the opinion that the delay in making the demand and giving the notice in the case at bar was unreasonable, and hence that the court properly directed a verdict in favor of the defendant, Henry $\mathbf{M}$. Benjamin.

By the Court. - The judgment of the Circuit Court is affirmed. ${ }^{1}$

${ }^{1}$ Accord: Leonard v. Olson, (Iowa, 1896) 65 N. W. Rep. 677, where although demand was excused because of the absence of the maker from the state, notice to the indorser within a reasonable time was not excused. - ED. 
65 Mississipri, 2.42. - Is87.

On Sept. 22, ISS4, $W$. I. Parker bought from Snider \& Son an instrument as follows: -

Baximg Hotse of M. C. Sxider a SoN, GrexanA.

$\$ 200.00$

GRENADA, MISs., Sift. 22, ISS t.

Pay to the order of W. I. Parker, two hundred dollars.

To Lathan, Alexayder it Co., New York, N. Y.

J. B. SNiner, Cirshier.

No. 50,665 .

On the same day Parker indorsed this instrument and forwarded it to F. M. Lamon, Brooksville, Florida. On October I, I $\& S_{4}$, Lamon indorsed it to J. M. Reddick. On Oct. 3, rS84, Reddick indorsed it to $\mathrm{A}$. $\mathrm{N}$. Chelf. On Oct. I3, I $\$ 8_{4}$, Chelf indorsed it to Hancock \& Edrington, who indorsed it to Witz, Biddle \& Co., who indorsed it to the Union Bank of Baltimore, who indorsed it to the "Republic" Bank of New York, who, on Oct. 2 I, I $\$ S_{4}$, presented the same for payment, which was refused on the gound that Snider $\&$ Son had no funds in the hands of the drawees. The instrument was duly protested, and notice was forwarded to the indorser Parker, at Grenada, Miss., and also to the other several indorsers. All the indorsers of the paper in question resided in the town of Brooksville, Florida, except Witz, Biddle \& Co., and the two banks referred to; and it was held in that town until the indorsement to Witz, Biddle \& Co., who resided in Baltimore, Md. There were daily mails from Brooksville by which a letter could reach New rork in five days.

J. M. Reddick, one of the indorsers, as well as an indorsee, after having paid the amount of the check or bill of exchange to his indorsee, brought this action against I. B. Snider, surviving partner of Snider \& Son, and W. J. Parker, to recover the value of said instrument.

On the first trial the jury found for the defendants. This rerdict was set aside by the Court. On the second trial the jury found for the plaintiff. The defendant, Parker, appealed from the judgment of the court.

ArNold, J., delivered the opinion of the court.

It is uncertain from the evidence whether the drawees of the instrument upon which appellants were sued were bankers or not; but whether the paper be called a check or bill of exchange, it expressed no time for payment, and was, therefore, payable on demand. A bill or check, payable on demand, must be presented 
for payment within a reasonable time. What constitutes reasonable time in such case, is a question of law to be determined by the court, when the facts are ascertained. (Baskerille $v$. Harris, $4 \mathrm{I}$ Miss. 535.)

No delay in making presentment of paper payable on demand, can be termed reasonable, if it is more than is fairly required, in the ordinary course of business, without special inconvenience to the holder, or by the special circumstances of the case. (Phomix Ins. Co. v. Gray, I3 Mich. I9I.) Such paper contemplates immediate payment. It cannot be said that it is intended for circulation. One who holds a bill or check payable on demand, beyond the time necessary, in the usual course of business, for its presentation for payment, does so at his peril. The general rule, derived from the authorities, but subject to modification by special circumstances, is, that if the drawee of such paper, resides in a different place from that in which it is drawn, and the instrument must be sent by mail for presentment, it must be mailed on the day next after that on which it was received by the holder. (I Danl. on Neg. Inst., \$605; 2 Id., $\$ s$ I586, I592; Byles on Bills [7th Am. ed.], 211, 212, 213 ;

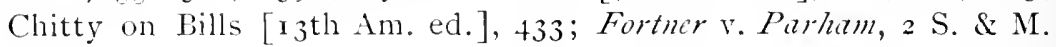
I5I.)

Paper payable on demand, while not commonly intended for that purpose, may be put into circulation; but its ultimate presentment for payment cannot be delayed beyond a reasonable time, by transfer or successive transfers, any more than it can by being locked up, or held an unreasonable time, by the first or any subsequent holder. (Chitty on Bills [ $3^{\text {th }}$ Am. ed.], +30 ; 2 Daniel on Neg. Insts., $\$$ I595; Story on Prom. Notes, $\$$ +94.)

If the paper sued on be regarded as a bill, the drawer, as well as the indorsers, would be discharged by the negligence and delay in respect to the presentment; but, if a check, indorsers would be discharged by such laches, while the drawer would not, unless he could show that he was injured by the default. He would be entitled only to such presentment and notice as would save him from loss. (2 Danrel on Neg. Insts., \& I $_{5} \delta_{7}$.)

No excuse is shown by the record for the delay which intervened in presenting the paper in question for payment, and the loss thereby occasioned cannot be imposed on the indorser, Parker. As to him, the last verdict was contrary to the law and the evidence. The court below erred in instructing the jury that the presentment was made within a reasonable time, and in refusing to instruct the jury to the contrary. The judgment is affirmed as to the drawer. Snider, who made no clefence below and assigns no error here; but it is reversed 
as to the indorser, Parker, and the last verdict as to him is set aside, and the first verdict as to him is restored, and judgment rendered thereon, here, in his faror.'

$\S$ I3I

ROBINSON $\imath^{\prime}$. AMES.

20 JOHNSON, I +6 . - I 822.

[Reported herin at p. 633.]

$\$ I 32$

FARNSWORTH $\tau^{\prime}$. ALLEN.

4 GRAY (MASS.) 453. - I 855 .

ACTION by holder against indorser. Defence, presentment and demand insufficient. Verdict for plaintiff. Defendant alleges exceptions.

The agent of the holder did not know the maker's place of residence. After inquiring it, he gave the note to a notary who went to the house of the maker and arrived there about nine o'clock in the evening. The maker and his family had retired for the night, but the maker answered the bell, and, upon the note being presented, refused payment.

Bigelow, J. - The note declared on, not being payable at a bank, or at any place where business was transacted during certain stated hours in each day, was properly presented to the maker at his place of residence. It was also the duty of the holder to present it within reasonable hours on the day of its maturity. No fixed rule can be established by which to determine the hour beyond which a presentment, in such case, will be unreasonable and insufficient to charge an indorser. Generally, however, it should be made at such hour that, having regard to the habits and usages of the community where the maker resides, he may be reasonably expected to be in a condition to attend to ordinary business. In the present case, taking

${ }^{1}$ A note indorsed when overdue must be presented within a reasonable time. Light v. Kingshury, 5o Mo. 33I, ante, p. 237.

For presentment for acceptance, see $\$ 2+1[\mathrm{I} 4 \mathrm{H}]$. For presentment of checks see $\$ 322$ [186]. The Negotiable Instruments Law has abolished the distinction between bills payable on demand and bills payable at sight. See $\$ 26[7]$.

See on reasonable and unreasonable delay, 2 Ames' Cases on Bills and Notes, 277 , note.

For effect of unreasonable delay upon the question of "holder in due course," sec $\$ 9^{2}[53]$; anti, pp. 396-397.-ED. 
into consideration the distance of the place of residence of the maker from Boston, where the note was dated, and where it was held when it became due; the means that were taken to ascertain the residence of the maker, and the season of the year at which the note fell due, we are of opinion that a presentment at nine o'clock in the evening was seasonable and sufficient. It is quite immaterial that the maker and his family had retired for the night. The question whether a presentment is within reasonable time cannot be made to depend on the private and peculiar habits of the maker of a note, not known to the holder; but it must be determined by a consideration of the circumstances which, in ordinary cases, would render it seasonable or otherwise. (Barcla1 v. Bailey, 2 Campb. 527; Triggs v. Newnham, ro Moore, 249, I Car. \& P. 631; Wilkins v. Jadis, 2 B. \& Ad. ISS; Cayuga County Bank r. Huut, 2 Hill [N. Y.], 635.)

Exceptions overruled. ${ }^{1}$

§35 NEWARK INDIA RUBBER MFG. CO. $v$. BISHOP. [§ 75]

3 E. D. Sнiтн (N. Y. СitY C. P.), 48. - IS54.

ACtron by holder against two indorsers. Judgment for plaintiff. Defendants move for a new trial, which is granted as to Griffith but denied as to Bishop. Bishop appeals.

The note was payable at the Bowery Bank. On the day of maturity Bishop left his check with the teller to take up the note. The note was not presented during banking hours and at the close of banking hours the teller left the bank having the check still in his custody. After banking hours the note was presented to a clerk who was at the bank and who examined the ledger and said there were no funds. Due notice was given.

At the trial the jury were instructed as follows:

"If funds were provided and set apart to pay the note, and if it was not paid for the reason that the note was not presented for payment in the usual business hours of the bank, the indorsers are discharged.

"A presentment of the note for payment at the bank, but not within the usual business hours, to a clerk who could not pay the note, is not a good presentment which will hold the inclorser.

"It is not enough that the clerk to whom at such a time the presentment is made, have power to bind the bank to pay the note by certifying in writing on the note that it is good.

${ }^{1}$ Compare Dana v. Sazyer, 22 Me. 24t, holding the hour unreasonable. - ED. 
" In order to make a presentment at such a time, a sufficient one, the person to whom it is made must have the power to pay the note and to take it up, by actual payment to its holder of funds that are provided in the bank for that purpose."

WoodrufF, J. - I did not feel called upon to order a new trial in this case in favor of the appellant Bishop, who had himself withdrawn the money provided to meet the note. He knew that the maker would not pay the note as early as the morning of the day it became due, for he had himself undertaken to provide funds for its payment. On learning that the note was not presented till after business hours, he himself takes the money which had been set apart for the use of the plaintiff, and appropriates it. Under such circumstances, the jury having rendered a verdict against him on the trial, I did not think, and I do not now think, that the court should set that verdict aside as against evidence for his benefit, and to enable him to keep that money, when he has not been in any manner or by any possibility injured by any defect in the presentment.

The case of the defendant Griffith is very different. It is an undisputed fact that if the note had been presented at the bank within the usual business hours it would have been paid. It is equally clear that at the time the note was presented, there was no person in the bank who could pay it. The undertaking which the note and its indorsements imported was, that there should be at the bank during the usual hours of business on that day, funds in the hands of proper persons competent to pay them over, sufficient and ready to meet that note. Not that every person who might be employed about the bank, from the president down to the porter, and who might happen to be in the bank after it was closed, should at all hours, so long as the door was unlocked, be ready to pay the note.

I do not question that there may be a grood presentment at bank after banking hours, by which I mean after the hour until which banks are open for the purpose of paying notes which may be presented. But I think that he who delays presentment till after that hour takes the risk of finding at the bank a person who can pay the note if the funds are provided, or who is authorized to refuse if they are not.

The case of Garnett v. Woodiock ( I Stark. 475), which has been referred to in support of the sufficiency of this presentment, proceeds upon the distinct ground that if a banker appoint a person to attend in order to give an answer, a presentment would be sufficient if made before 12 o'clock at night, and that in that case it did not appear but the person was stationed there for that express purpose; while the general rule that presentment must be made within the 
usual hours, is not at all repudiated but rather affirmed by that same case. (And see Parker v. Gordon, 7 East, 385; Barclay v. Bailey, 2 Camp. 527; Wilkins v. Fadis, 2 B. \& A. Is\&; Elford v. Teed, I M. \& S. S8; Bank of Utica \%. Smith, IS J. R. 230.)

In this case it does affirmatively appear that the person to whom the presentment was made was not stationed there to gire an answer. The funds were there, but he could not pay the note. Had he known that the funds were there, provided for the express purpose, still he could not pay the note, so that it was by reason of the omission to present within the usual hours, and for that cause alone, that the note was not paid at its maturity. I think that the charge was in this respect correct.

[INGRAHAM, P. J., also wrote an opinion for affirmance.]

DALY, J., concurred in affirming the order, but wrote no opinion. Order affirmed and a new trial denied. ${ }^{1}$

3. At the Proper Place.

$\S \mathbf{1 3 3}$

BROOKS $\approx$. HIGBY.

II HUN (N. Y. SUPRENE CT.) 235.- IS73.

ACTION by holder against indorsers. The bill was drawn on N. F. Mills, I 4 South Main St., St. Louis, and by him accepted. The notary's certificate stated that the bill was presented " at the place of business of N. F. Mills, St. Louis." It appeared in evidence that Milis had two places of business in St. Louis. Defendant moved for nonsuit, which was denied. Judgment for plaintiff.

${ }^{1}$ Approved in Salt Strings . V. B. v. Burton, $5^{8}$ N. Y. $430,436$.

If the bill or note is presented at a business office or a bank, it must be presented during customary business hours. Parker v. Gordon, 7 East (K. B.) 385 . But if the holder finds a person at such office or bank after business hours upon whom demand may properly be made, such demand is good. Garnett v. Woodcock, 6 Maule \& Selwyn (K. B.) 44; Salt Strings Nat. Bk. v. Burton, 58 N. Y. 430. See post, $S 35[75]$. A notary's certificate need not name the time of day when presentment was made, for it will be presumed to be a reasonable hour. Cayuga County Bk. v. Hunt, 2 Hill (N. Y.) 635. But where the notary's certificate states that he presented the instrument at the office of the maker at $5.20 \mathrm{p} . \mathrm{m}$., and found the door locked, it is error to refuse to hear evidence that this is not within the customary business hours. Clough v. Holden, II5 Mo. 336. - ED. 
SiIth, J. - As the draft was addressed to the drawee at a particular place in the city where he resided, and was thus accepted by him, the particular place thus designated was the place of payment, and a due presentment and demand of payment at that place was necessary in order to charge the indorsers. (Story on Prom. Notes, $\$ 227$ and note 3 , and cases there cited.) The certificate of the notary stated merely that the draft was presented and payment demanded "at the place of business" of the acceptor, without specifying the place. As it appeared that the acceptor had two places of business in St. Louis, the certificate furnished no evidence whatever that the presentment and demand were at the place where the draft was payable. The proof was fatally defective, and the motion for a nonsuit should have been granted.

The respondent's counsel proposed to supply the defect on the argument at banc by the production of a fresh certificate of the notary showing that the draft was presented at No. I 4 South Main street. The rule allowing evidence of a fact imperfectly proved at the trial to be exhibited at bar, in opposition to a motion for a new trial, is, in general, confined to records or documentary evidence which proves itself, and on which no question can arise in the cause, except such as is apparent on its face. (Bank of Charleston v. Emerich, 2 Sandf. 7IS; Dresser v. Brooks, 3 Barb. 429; Burtr. Place, 4 Wend. 591; Armstrong v. Percl, 5 id. 535; Ritchic r. Putnam, 13 id. 524; Hughv. Milson, 2 Johns. 46.) Under the statute of ${ }_{1} S_{33}$, a notarial certificate is but presumptive evidence, and may be explained or contradicted by the party against whom it is produced. The new certificate offered in this case cannot be received at bar to conclude the defendants; if it is to be used against them they are entitled to an opportunity to meet it at the trial.

We are also of opinion that the eridence required the submission of the question of usury to the jury.

Judgment and order should be reversed and new trial ordered, costs to abide event.

Present - Mullis, P. J., Talcott and Smith, JI.

Judgment and order reversed and new trial ordered, costs to abide erent. ${ }^{1}$

$1 \mathrm{~A}$ bill is drawn, accepted, and indorsed in Kentucky, where all the parties reside, but is addressed "To C., New York, $\mathbf{N}$. Y." The holder knows these facts. The bill is in New York on the day of maturity. Held, Presentment was sufficient. If the instrument is payable in A., and the residence of the maker is in B., presentment should be in A. Cox v. Tational Bank, Ioo U. S. jo4. - En. NEGOT, NSTRUMENTS - 33 . 
6 RHODE ISL.AND, 259. - I $\varepsilon_{59 .}$

Action by holder against indorser. At the trial before the court, to whom the case was submitted in fact and law, under the general issue, it appeared that the notes, which were not made payable at any particular place, had been left by the plaintiff at the Mount Vernon Bank, in Foster, for collection; and that the only demand of payment made upon Northup, the maker, was by the usual printed bank notice, mailed to him by the cashier of the bank, and directed to him at Providence, where he lived, in the early part of the months in which they respectively fell due, although at what time precisely, the cashier of the bank could not recollect. Due notice of non-payment by the maker was proved to have been given to the defendant.

Bosworti, J. - The defence to this suit is, that no legal and proper demand was made on the maker of the note; and that therefore the indorser, who is here sued, is discharged. The rule of the common law is, that in order to charge the indorser, demand must be made on the maker for payment on the very day on which the note becomes due. In case the note on its face is made payable at a particular place, as at a bank named, it is necessary, and only necessary, to make demand at such place; but if no place of payment is named in the note at which the note is payable, it is necessary to present the note to the maker personally, or at his place of abode or business, before the indorser cai be made chargeable. In this case, no place of payment was mentioned in the notes. The notes were left at the Mount Vernon Bank for collection; and it is agreed, that the maker had notice before the day of payment that they were there for that purpose. This notice could not avail to make the notes payable at said bank. The maker had not by the terms of his contract agreed to pay the notes at that bank; and a demand there was no demand upon him. It was necessary that demand should be made upon him personally, or at his dwelling, or place of business, on the last day of grace. No such demand was made, and the indorser, therefore, was never charged.

Judgment must, therefore, be rendered for the defendant, for his costs. ${ }^{1}$

${ }^{1}$ The anomalous custom prevails in Massachusetts and Maine of making such a demand sufficient. Michanics'Bank v. Merchants' Bank, 6 Met. 24; W'arren Bank v. Parker, S Gray, 221; Gallaghtr v. Roberts, I I Me. t59; Maine Bank v. Smith, is Me. 99. So in New England there seems to be a local custom of 
Action by holder against indorser. Note made and dated in Boston, but maker's residence and place of business then and ever since in North Carolina. This was known to holder's agent at maturity. No demand on maker in North Carolina.

Metcalf, J. [After stating the facts.] - On these facts the question is, whether the defendants are liable as indorsers. If they are, it is not because seasonable demand was made on the promisor and seasonable notice of non-payment given to them. The note fell due on Saturday, May 3 d - the last day of grace being Sunday - and no demand was made on the promisor until nine days afterwards. This delay discharged the defendants from their liability to the plaintiffs unless the fact that the promisor always resided in North Carolina excused the holders from making personal demand on him, or from using due efforts to make such demand. The plaintiffs rely on this fact to sustain their action, and cite the decision in Smith v. Philbrick (10 Gray, 252), as conclusive in their favor. That was an action by an indorser against a prior indorser of a note made in Boston by one whose only residence and place of business were in Texas, and on whom no demand was made; and it was decided that no demand on him was necessary to charge the defendant. The court said there was no evidence to show whether the plaintiff, or any of the subsequent holders of the note, knew where the promisor's residence was; that if his residence had been known to the holder, at the maturity of the note, it might perhaps have been incumbent on him to forward it to Texas for presentment, as was held in Taylor v. Sulder (3 Denio, 145).

In the case before us, the plaintiffs' agent, whom they employed to purchase and also to collect the note, knew where Moore's residence was, and the legal effect of his knowledge of that fact is the same as would have been the effect of their knowledge of it. Notice to an agent, whilst he is concerned for the principal, is notice to the principal himself. And we are of opinion, as intimated in Smith v. Philbrick, that by reason of the plaintiffs' knowledge (through their agent) of the place of Moore's residence, a demand on him there, and seasonable notice of his default, were prerequisites to the

drawing notes "payable at any bank" in a given city, and in such case it is sufficient that the instrument is at any bank in the place named on the day of maturity. Maldin Bank v. Baldwin, 13 Gray, 154; Langliy v. Palmer, 30 Me. 467; Jackson v. Parker, I3 Conn. 342. - En. 
defendants' liability as indorsers. We think this case is within the general and familiar rule which applies to the holders of indorsed notes, and not an exception to that rule.

When a resident in the State, after giving a note, removes from the State and takes up a residence out of the State, it has been repeatedly decided that it is not necessary, in order to charge an indorser of the note, to demand payment of the promisor at his new residence. ${ }^{1}$ This exception to the general rule which requires demand on the promisor, and notice to the indorser, seems to be established. But we see no sufficient reason for taking the present case out of that rule. And we hold, that where the maker of a note, when it is made and indorsed, has a known residence out of the State, which residence remains unchanged at the maturity of the note, demand must be made on him, or due diligence used for that purpose, and notice of non-payment given to the indorser before the indorser can be charged. So it was decided by the court of appeals in New York, in Taylor v. Snyder, before referred to, and in Spies v. Gilmore (I Comst. 321). In this last case, Bronson, I., said: -

"The only excuse which has been offered for not making demand is, that it would have been inconvenient to go or send to Matamoras for the purpose. It is often inconvenient to present the note for payment, when the maker and holder both reside in the same State; and yet, when the maker has a known place of residence, and there has been no change of circumstances after the giving of the note, mere trouble or inconvenience to the holder has never been held a good excuse for omitting demand. And this is so, however wide asunder the maker and holder may live. If the plaintiff wished to avoid the inconvenience of sending to Matamoras, he should have made the note payable in New York, or got an indorsement with a waiver of demand. He has no right to change the contract which the indorser made, for the purpose of promoting his own convenience."

Judgment for the defendants. ${ }^{2}$

1 W Gruder v. Bank, 9 Wheat. (U. S.) $595 .-$ ED.

${ }^{2}$ Taylor v. Snydr, 3 Denio (N. Y.) I+5-is 4 . Note dated Troy, N. Y. Maker then and afterwards resided in Florida, to the knowledge of the first holder and of the subsequent indorsee (plaintiff). Presentment (not personal or at maker's office or residence) is made in Troy. Hill, Presentment nol sufficient. "Where no change has taken place in the residence of the maker, between the making of the note and the time of its payment, the intervention of a state line does not dispense with the necessity of making due demand of payment." 
I 5 S Massachlósetts, 90. - I $s_{93}$.

Action by holder against indorser. Defence, want of demand on maker. The notes specified no place of payment. Presentment was made to the maker personally at the office of the inclorser.

FIELD, C. J. . . . Whether the defendant's office was Hart's place of business or not, if the plaintiff made a demand upon Hart personally at this office during tusiness hours of the last day of grace, and produced the notes, and Hart said that he was unable to pay them, and made no objection to the place of the demand, this would be a sufficient demand, and to this effect were the instructions given by the court. (King v. Crowell, 6I Maine, 244; I Danl. Neg. Insts., $56{ }_{3} 8$, ([4th ed. $\left.]\right)$

Exceptions overruled. ${ }^{1}$

4. To the Proper Person.

$\S \mathrm{I} 32$

STINSON $i$. LEE.

68 Mississipti, I 13. - Is9o.

Actrox by holder against indorser. Demurrer to declaration sustained. Plaintiffs appeal.

CCoper, J., delivered the opinion of the court.

The demurrers to the original and amended declarations were properly sustained. Lee was the payee in a promissory note, subscribed by the maker thereof, " A. G. Cunningham, Ag't.," nothing appearing on the face of the note indicating for whom he professed to act as agent. After the maturity of the note he inclorsed the same to the plaintiffs, who sometime thereafter presented the note to S. A. Cumningham, wife of A. G. Cunningham, and who, the declaration avers, was his principal, " and demanded payment thereof, and sued out an attachment for rent against her, in order to collect said note, of all of which said Lee had immediate notice."

The present suit is arainst $S$. A. Cunningham as maker and against Lee as indorser of the note.

The liability of Lee rested wholly upon his indorsement, and that liability was to pay the note, if seasonable presentment to the maker should be made and payment refused, and Lee notified thereof. 
A. G. Cunningham, and not S. A. Cunningham, was the maker of the note, the word "agent" following his signature being - in the absence of the name of the principal - merely descriptio persone. ( I Danl. on Neg. Inst., $\$ 303-305$.) We are not called upon to decide whether, in a proper action, Mrs. S. A. Cunningham might be made liable on the consideration for which the note was given; nor whether, as between the original parties, A. G. Cunningham was liable on the note. The sole question is whether Lee, who indorsed the note signed by “A. G. Cunningham, Ag't.," can be held on his indorsement by virtue of a presentrnent to one whose name nowhere appears on the note, and we think that he cannot, because such person was not the maker of the note, for whose default only was he bound by his indorsement.

Judgment affirmed.

ACTION against indorser. Defence, want of due presentment. Judgment for plaintiff on the authority of Hale v. Burr (I 2 Mass. 86.)

Martin, J., delivered the opinion of the court.

The defendant is sued as indorser of a promissory note, for one thousand dollars, executed by Peychaud. Judgment was rendered against him for the amount claimed. He now claims a reversal of the judgment, on the ground that he was condemned as indorser to pay the sum demanded, when payment was never demanded from the maker, nor from any person representing him, or succeeding to his rights and obligations.

The record shows that the maker died on the last day of grace, or during the night preceding it. That when the notary's clerk called at the house and late domicil of the drawer of the note sued on to demand payment, he found no person present except a mulatto woman, who informed him of the death of Peychaud, and pointed him to the corpse in the coffin. The note was then protested, without any inquiry or demand being made of any heir or representative of the deceased.

It is clear that no recourse can be had against the indorser of a note until a demand has been made on the maker, if living, or on his heir or legal representative after his death, unless the impossibility of making such a demand is made apparent. This has not been shown in the present case. The authorities on this point, and 
which support the position here laid down, are numerous, of the highest character and authority, and conclusive on this subject. (Chitty on Bills, 317, ed. isz8; Bayley, do. 128: 2 Practical Abr. of Am. Cases, 288, 292; 3 Peters, 89; 7 Id. 287; 7 Martin, 364 ; I Par. dessus, 392 ; Pothier, Contrat de Change, No. 146.)

It is therefore ordered, adjudged and decreed, that the judgment of the District Court be annulled, avoided and reversed; and that judgment be entered for the defendant, with costs in both courts.

2 HILL (N. Y.), 035.

[Reportid herein at $f .646$.

$\S 138$

BLAKE $\because$ MCMILLEN.

33 IOWA, 150.-1371.

Action against indorser of a note made by W. G. Harding and Daniel Van Patter. Presentment and demand on Harding alone. Judgment for plaintiff.

Miller, J. - On a former appeal in this case, it was held that a presentment to one only of the two joint makers was not sufficient to charge the indorser, unless some legal excuse be shown for the failure to make presentment to the other. (Fluke v. Mollilln, 22 Iowa, 358.) The agreed facts show that David Van Patter died before the maturity of the note; that Eliza Van Patter was his legal representative when the note became due and no excuse is shown for a failure to make presentment to her. Following the ruling on the former appeal the judgment is

\section{Reversed. ${ }^{2}$}

${ }^{1}$ Although the indorser be the administrator or executor of the deceased maker, demand must be made upon him as executor and notice given to him as indorser. Magruder v. Union liank, 8 Curtis Dec, 299, 3 Peters, 87; Groth v. Gyger, 31 Pa. 271. - En.

${ }^{2}$ Accord: Arnolit v. Dresser, 8 Allen (Mass.) 435; Shutts v. Fingar, Ioo N. Y. 539; Benedict v. Schmieg, 13 Wash. 476. - ED. 


\section{By Exhibiting the Instrument.}

50 NEW YORK, 474. - IS72.

ACTION by holder against indorser, after alleged presentment, demand and notice. Defendant contends there was no proper presentment or demand. Judgment for defendant

Rapallo, J. - The note upon which the defendant is sued, as indorser, contains a statement that the maker bas deposited with the payee, as collateral security, certain railroad bonds, with authority to sell them without notic 2 in case of non-payment of the note; and it is found as a fact that these collaterals came to the hands of the plaintiff when it became the holder of the note.

We think that the court below was clearly right in holding that an agreement to restore these collaterals to the maker, on payment of the note, is to be implied from the transcation as stated in the instrument itself, and that the acts should be simultaneous. The right of the maker to receive these collaterals when he should pay the note stood upon the same footing as his right to the surrender of the note itself; and, laying out of view special cases of lost notes, it is well settled that, to constitute a valid demand, the note must be produced, and ready to be surrendered on payment. ${ }^{1}$ (Story on Prom. Notes, \$\$ 445, 448, 107; Smith v. Rockicll, 2 Hill, 482 ; Edwards on Bills, $5 \circ 3,5 \circ 4$.)

It would be most unreasonable to require the maker to pay such a note in the absence of the collaterals, which frequently consist of negotiable securities, and to trust to his legal remedies against the holder to recover them.

It is found as a fact that, at the time payment of the note was demanded of the maker, he demanded of the notary presenting it, a return of the collaterals, and stated that he was ready and willing to pay the note on production of the collaterals; but that the notary did not have them, and the maker's refusal to pay was on the sole

1“No valid presentment and demand can be made by any person without having the note in his possession at the time, so that the maker may receive it in case he pays the amount due, unless special circumstances, such as the loss of the note or its destruclion, aro shown to excuse its absence." Arnold v. Dresser, 8 Allen (Mass.) 435; Musson v. Lake, 4 How. (U. S.) 262. But if the one making demand has the instrument but does not exhibit it, the presentment is good where the maker does not ask to see the instrument, but refuses payment on other grounds. Legs v. Tinal, I65 Mass. 555 . See IVaring v. Betts, go Va. 46. fost, p. 524. - ED. 
ground that the collaterals were not produced. Without any further demand, and without showing any tender or eren the production of the collaterals, ready to be surrendered, the defendant was sued as indorser.

The case contains evidence sustaining the findings, and we think the conclusion was correct that the collaterals, not being produced or in readiness to be surrendered on parment of the note, and the refusal being on that ground alone, the demand and refusal proved were insufficient to charge the indorser.

The judgment should be affirmed, with costs.'

FOLGER $\approx$. CHASE.

is Pickering (Mass.), 63. - is 36 .

[Reforted herein at $t .3+9.]^{2}$

\section{When delay in presentment excused.}

$$
67 \text { MIssolri, I63. - Is77. }
$$

Hough, J. - This was an action brought by the plaintiffs, as holders of a negotiable promissory note, against the defendants, as

1 I. presentment is made at the house or office of the maker, and it is closed, (. $n$ porson is found there authorized to act or answer, the presentment is comfl te. Miseman v. Chiappella, 23 How. (U. S.) 365; Struthers v, Kimdall, if Pa. $2 \mathrm{I}_{4}$. $-\mathrm{ED}$.

2 Where an instrument is payable at a bank it is sufficient that the instrument be in the bank on the day of maturity; the formal demand is made by the bank upon the maker's account, and if that be not sufficient to meet the note or bill, th instrument is dishonored. I Daniel on Neg. Inst., $\leqslant$ 656. But it is held th : the plysical presence of the instrument in the bank, unknown to the officers (as where the letter in which it was sent was mislaid unopened), is not a presuntment and demand. Chicopec Bank r. Philadilthia Bank, 8 Wall. (L.S.) 641 .

I 147 [87]. Whether, if a note is payable at a bank and is there presented, the bank is bound to pay it in case the maker has a sufficient deposit, has been a matter of much doubt. See Morse on Banks and Banking (3d ed.), s. 556${ }_{5}(4$. It has been held that it is authorized, but not bound, to pay. Fidford Bank v. Acoam, I25 Ind. 584. Contra: Grissom r. Commercial M. B., 87 Tenn, 350. It has been held that it is bound to pay our of the deposit if the bank itself holds the note. German .Y. L. v. Foreman, I38 Pa. St. 474. But not out of the deposit of an indorser, though he is known to be the principal debtor. First $N . R$. v. Peltz, 176 Pa. St. 513: though it may do so, Mechanics', ete.

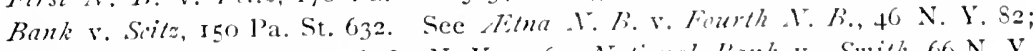
Indig v. National City Bank, so N. Y. I06; National Bank v. Smith, 66 N. Y. 271. - ED. 
indorsers thereof. The questions presented for determination are, whether the plaintiffs used due diligence in making demand of payment, and gave the requisite notice of non-payment to the defendants. The facts are as follows: The note in question matured on the $4^{\text {th }}$ day of July, IS6I, and was payable at the banking house of F. and G. Willins, in the city of St. Paul, Minnesota. Some time in April, I86I, the plaintiffs delivered the same to the bank of Cooperstown, at Cooperstown, New York, for collection. At that time a letter, in due course of mail, would reach St. Paul from Cooperstown in about six days. The cashier of the bank of Cooperstown sent the note by mail to its regular correspondent, the Bank of St. Paul, in the city of St. Paul, for collection, in ample time, as the cashier stated, for it to reach its destination by ordinary course of mail, before the maturity of the note. When the letter reached St. Paul, the Bank of St. Paul had made an assignment, and the envelope having printed on it the words " From the Bank of Cooperstown," the postmaster at once returned it to the Bank of Coopers. town, with the indorsement "bank failed." The letter was received by the Cooperstown Bank in the original envelope, unopened, on the $9^{\text {th }}$ day of July, I86I, and on the same day the note was returned by mail to St. Paul in a letter directed to F. \& G. Willins, who caused it to be presented and protested on the $5_{5}$ th day of July, is6I, the day on which it was received.

The defendants contend that there was a want of diligence in not sending the note in time to guard against such contingencies as the evidence discloses, and that the action of the postmaster in the premises is no sufficient excuse for the failure to present for payment on the day of the maturity of the note. Professor Parsons, in his treatise on Notes and Bills, says: "Ordinarily any failure to present a note at the proper time, by reason of the negligence of an agent, would discharge an indorser, but where the holder makes use of the public mail for the purpose of transmitting the note to the proper place in season to have a legal demand made, and without any negligence on his part, we should say that he would not lose his remedy on an indorser, if through any accident or disorder, or the negligence or mistake of the postoffice clerks, the note does not reach the destined place in season to make demand on the very day of maturity." (Vol. I, p. 46r.) In support of his text he cites the case of Windham Bank v. Norton (22 Conn. 213).

We have been referred by defendants' counsel to the case of Scho. fieldv. Bayard ( 3 Wend. $4 S S$ ), as being in direct conflict with the case just cited from Connecticut; but a careful examination of the facts in Schoficld v. Bayard will show that there is no conflict what- 
ever between the two cases.

It will be seen that the court places its judgment expressly upon the ground that the holder was guilty of negligence in sending the bill to Liverpool, and this fault of his produced the impossibility by virtue of which he claimed to be discharged. In the present case the letter containing the note was not misdirected; it was properly directed; it actually reached St. Paul in time, and but for its unauthorized return by the postmaster, the probabilities are that some agent or representative of the suspended bank would have received it in time to make due presentment, as the testimony tends to show that the representatives of the bank continued to receive letters addressed to it, after its suspension. The holders therefore exercised due diligence in sending the note when they did; its arrival in time demonstrates that fact; and they were not required to make provision in advance for a possible, but unanticipated suspension of the bank of St. Paul before arrival of their letter, or for an unwarrantable interference with the same by the public officer in charge of the mails, after its arrival. We are of the opinion, therefore, that under the circumstances of this case, the demand was seasonably made.

["The court then decides that a notarial certificate stating that the notices were " put into the postoffice at St. Paul directed as follows," is sufficient without a statement that the postage was prepaid.] ${ }^{1}$

Reversed. ${ }^{2}$

\section{When presentment dispensed with.}

I. When No Right to Require or Expect It.

$\$ \mathbf{I 3 9}$

CATHELL $\because$. GOODWIN.

I HARRIS \& GILL (MD.), +65.

[Reported herein at p. 560.$]^{3}$

\footnotetext{
1 See Neg. Inst. L., 176 [105]. - ED.

${ }^{2}$ See also Schofield v. Buylut, 3 Wend. (N. Y.) 4S5, post, p. 655; I Daniel, $\$ 47$ S. - ED.

${ }^{3}$ See also 5 I 85 [IIt], I86 [II5]; Cashmanv. IIarison, go Calif. 297.

Mere want of funds in drawee's hands not enough to excuse presentment

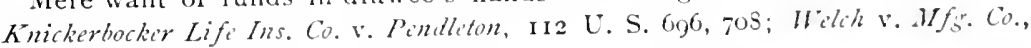
82 III. 579 .

If drawer or indorser has received funds or assets from the acceptor or maker under an agreement to pay the bill or note, he has no right to expect or require demand and notice. Mrist v. Andrews, 70 Me. S6. Query, When he has recejved security but with no agreement to pay. 2 Daniel on Neg. Inst., $\$ S$ I I $29-\mathrm{I} 1+3 ;+\mathrm{Am}$. \& Eng. Enc. Law (ad ed.), $4+7-4+5$.

An accommodaled drawer or indorser is not entitled to presentment and notice. 2 Daniel on Neg. Inst., Sิ ros5-roS9. - Ev.
} 
2. WhEN IMPOSSIBLE.

$\S 142$

MOORE $\because$. COFFIELD.

I DeveretX LAW (N. CAR.), 247. - IS27.

ACTION against indorser. Judgment for defendant.

HaLl, I. . . . It was proved that Best, the maker of the obligation, was a seafaring man, and at or about the time the obligation became payable, sailed from Washington, as master of a vessel bound to New York; and it did not appear that he had a domicil, or any establishment within the State, at which payment could be demanded. The maker being at sea, in his usual employment, and the indorsee not being bound to follow him beyond the State, it follows, that if he had no such domicil or establishment, a demand should be dispensed with.

In this view of the case, the defendant was liable upon his indorsement, without any express promise to pay, and the jury should have been so instructed - and consequently, for the judge's omission to give such instruction, there must be a new trial.

Per Curiam. - Judgment reversed and a new trial awarded. ${ }^{1}$

$\S \mathrm{r} 42$

WARING $\because$ BETTS.

[? 82]

$$
9 \text { O Virginia, +6. - IS93. }
$$

Action against indorsers of a note payable at the Business Men's Bank, Richmond. At maturity the bank was defunct. Demand (without presentment) was first made on $\mathbf{W}$., a former officer of that bank (and also one of the indorsers), who replied that the funds had been distributed and there were no assets. Later in the day, at $5: 3^{\circ}$ P. M., the notary with the note in his possession went again to the office of $W$, but it was closed; he then went to the residence of W., but he was not there. He then protested the note and gave due notice to the indorsers. The maker lived at Danville, Va., at which place the note was dated.

LACr, J. (after stating the case), delivered the opinion of the court.

The first question arising here is that raised by the demurrer. The declaration states a good case, and sets forth that on its due day it was duly presented for payment of the sum of money therein

${ }^{1}$ But if the maker have a residence, presentment must be made there. Dimite r. Hilkir, 7 N. H. Ig9.

Demand is not excused because the maker is an infant. Wy'manv. Adams, I2 Cush. (Mass.) 210. - ED. 
specified, required, payment refused, and that it was duly protested, etc.

And the defendants' demurrer to the plaintiff's declaration was properly overuled.

The claim of the defendants is that there was no presentment of the note, becaus: when payment was demanded of the indorser, $W$. L. Waring, Jr., manager of the late Business Men's Bank, Mr. Glenn did not have the note in his possession, and could not have presented it, but as has been seen from the facts found by the jury, payment was refused by Waring, and the note not asked for, but parment refused, and the statement made that he was not authorized to represent the bank, which hat ceased to do busmess and had distributed its assets.

Presentment of the bill or note and demand of payment should be made by an actual exhibition of the instrument itself; ${ }^{1}$ or at least the demand of payment should be accompanied by some clear indication that the instrument is at hand ready to be delivered, and such must really be the case. This is requisite in order that the drawer or acceptor may be able to judge (I) of the genuineness of the instrument: (2) of the right of the holder to receive payment: and (3) that he may immediately reclaim possession of, upon paying the amount. If, on demand of payment the exhibition of the instrument is not asked for, and the party of whom demand is made decline on other grounds, a formal presentment by actual exhibition of the paper is consiclered as waived. (Daniel on Neg. Inst., p. $q_{5}$, $\$ 654$, citing Lockarod $r$. Crawford, IS Conn. 36r, and Fall Riarer Union Bank v. Willard, 5 Metcalf, 2r6.)

All the parties subsequent to the principal payer are bound only as his guarantors, and promise to pay only on condition that a proper demand of payment be made, and due notice be given to them in case the note or bill is dishonored. And we repeat this as one of the fundamental principles of the law of negotiable paper; and the infrequency and the character of the circumstances which will excuse the holder from making this demand, and still preserve to him all his rights as effectually as if it were made, will illustrate the stringency of the rule itself. (Parsons on Notes and Bills, rol. I, 442.) The question of excuse, then, will depend upon whether due diligence has been used, and presents the ordinary inquiry as to negligence. The principal excuses resolve themselves into two classes -

First. 'The impossibility of demand. 
Second. The acts, words, or position of a party, proving that he had not right, or waived all right, to the demand, of the waiver of which he would avail himself.

That impossibllity snould excuse non-demand is obvious, for the law compels no one to do what he cannot perform. But it must be actual and not merely hypothetical; and though it need not be absolute, no slight difficulty will have this effect. (Id.)

The circumstances which will excuse a demand are such generally as apply to a failure to present and demand payment within the required time, not absolutely. (Parsons, 444, 445.)

In this case the presentment of the note was not made at bank within the usual bank hours, with the note in possession, but as we have seen, this was excused in this case (I) by the fact that there was no bank to present it at, and ( 2 ) because payment was refused upon the ground that the bank had ceased to do business, and its assets distributed, and the note was not asked for, nor required, payment being refused on other grounds; the right to have it produced must be considered as waived.

The note, however, was carried, during the day, to the place of business of the late manager of the bank, and the indorser sought to be charged, and this being closed, it was carried to his residence, and that being also closed, it could not be presented to him, and although it was not in banking hours, it was during the daytime and before the hours of rest.

When the note is payable at a bank, it is to be presented during banking hours; and the payer is allowed until the expiration of banking hours for payment. But when not to be made at bank, but to an individual, presentment may be made at any reasonable time during the day during what are termed business hours, which, it is held, range through the whole day to the hours of rest in the evening. (Parson, 447, citing Cayuga County Bank v. Hunt, 2 Hill, 635; Aclsonv. Fotterall, 7 Leigh, i94.)

And in the case of Farnstiorth v. Allen (4 Gray, 453), a presentment made at $9 \mathrm{P}$. $M$. at the maker's residence, ten miles from Boston, when he and his family had retired, was held sufficient.

And in Barlay'v. Bailey (z Campb. 527) Lord Ellenborough sustained a presentment made as late as $S$ P. M. at the house of a trader.

It is only where presentment is at the residence that the time is extended into the hours of rest. If it is at the place of business, it must be during such hours when such places are customarily open, or, at least, while some one is there competent to give an answer. (Parsons, +48 .)

In this case there was no presentment to the maker, who could 
not be found, which, however, was unnecessary under section $2 S_{4} 2$ of the Code of Virginia. The protest was in due form, and duly protested, which was authorized by section $2 S_{49}$ of the Code, although the said note was payable at a bank in this State. And under section $285^{\circ}$ is prima faci proof of the facts stated therein, and is substantially in accordance with the finding of the jury. It therefore appears that such presentment as was requisite was made to the indorser and late manager of the bank, and that it was impossible to present the same at the bank named therein, as it had ceased to exist. We must, therefore, conclude that there has been sufficient diligence on the part of the plaintiff, and that the judgment cf the court below in his favor was right, and should be affirmed.

Judgment affirmed.

3. BY WaIVR.

See Gove v. Vining, 7 Met. (Mass.) 2 2 2, post, p. 564 .

Curtis v. Sprague, 5 I Calif. 239, ante, p. 208.

8ฐ I $80-182$ [109-III].

\section{Payment in due course.}

See ARTIClE IX. "Discharge of Instruments." 


\title{
ARTICLE VIII.
}

\section{Duties of Holder: Notice of Dishoror.}

\section{Notice necessary to charge drawer or indorser.}

$\$ 160$

\author{
LONG $\because$ STEPHENSON. \\ 72 North Carolina, $569 .-$ Is75. \\ [Reported herein at f. 474.] $]^{1}$
}

\section{What constitutes sufficient notice.}

i. Br Whon Notice Mest be Given.

$\S$ I6I

CHANOINE ‘. FOWLER.

3 Wexpell (N. Y.), 173. - iS29.

ACtios against drawer of a bill. Judgment for plaintiffs.

By the Court, MARCr, J. [After deciding that there was no sufficient proof that the protest in France, which did not conform to the rules of the law merchant, did conform to the rules of the French Commercial Code.]

${ }^{1}$ Notice of non-acreptance, whether presentment for acceptance be necessary or not $(\$ 240[1+3])$ must be given in case presentment for acceptance is in fact made, ( $247[150])$. Blisard v. Hirst, 5 Burr. 26\%0; Thompson v. Cumming, 2 Leigh (Va.) $32 \mathrm{I}$; Watson $x$. Tarpliy, is How. (U.S.) $5 \mathrm{I} 7$. The neglect is not cured by a subsequent presentment for payment followed by notice of dishonor. Smith V. Roach, Z B. Mon. (Ky.) I7. But if the bill pass into the hands of a holder in due course after a dishonor by non-acceptance he may charge a drawer or indorser by a subsequent notice of dishonor for non-acceptance or non-payment. Dumn v. O'K'iffí, 5 M. \& S. $2 S 2$. See S ISS[II7]. If after a note is overdue it is indorsed and transferred, the indorser is entitled to notice the same as the indorser of a note payable on demand. Beer v. Clifton, $9 \mathrm{~s}$ Cal. 323. See Liavitt v. Putnam, 3 N. Y. 494, anti, p. 356.

The indorser of a non-negotiable note is not absolutely entitled to notice of dishonor, as his contract is that of guarantor. Cromivell $\mathrm{v}$. Hewitt, to N. Y. 49I: (cf. Viuman v. Frost. 52 N. Y. 422); unless in jurisdictions where a guarantor is absolutely entitled to notice. Sutton v. O'i'n, 65 N. Car. 123. See ante, PP. $346-34$ S. - ED. 
To determine whether the defendant had legal notice of the nonacceptance of the bill, it will be necessary to see when it was given, and from whom it came. Messrs. Sewalls had transmitted the bill to France, and received information of its non-acceptance on the fourth or fifth of April. H. D. Sewall says he did not himself give rotice thereof to the defendant, nor does he know that notice was given by his house; although it was their custom to give notice in such cases, and he has no doubt the defendant received it. He learned, from a conversation with the defendant between the time of receiving notice and the $\mathbf{r}$ th of April, that he had knowledge that the bill was dishonored. The judge, at the trial, ruled that if the defendant had notice in due time of the non-acceptance of the bill, it was no matter whence it came, it was available to the plaintiffs. The rule of law in relation to the notice was, I apprehend, laid down in a manner too broad and unqualified. The rule has heretofore fluctuated; but it never has been authoritatively stated, as I can find, to be as the judge laid it down on the trial, except in the case of Shau'r. Coates, at the sittings before Lord Kenyon, mentioned in Selwyn's N. P. 320, n. 25. Repeated decisions since, both in term and at nisi prius, have qualified and restricted the broad proposition of the judge in this case, and of Lord Kenyon in the case of Shaw v. Coates. In some instances, it has been decided that the holders or their agents are the only persons to give notice of the dishonor of bills; but it seems to be now settled that it is not absolutely necessary that the notice should come from the holder of a bill, but may be given by any person who is a party to it, and who would, on the same being returned to him, have a right of action on it. (Chitty on Bills, 229; 2 Campb. 373; I Stark. R. 29; Bayley on Bills, I6r.) A notice from a mere stranger is not sufficient; and the charge of the judge was broad enough to sanction such a notice. For the insufficiency of the proof of the French Commercial Code and of the protest of the bill, and the misdirection of the judge as to the notice, a new trial ought to be granted.

New trial granted. ${ }^{1}$

${ }^{1}$ Notice by the maker is not sufficient. Jasger. Vitional German-Am. Bank, 53 Minn. 386 . Nor by the drawee. Stanton r. Blossom, It Mass. Ir6. Nor by the acceptor. Harrison v. Ruscoe, I5 M. \& W. 23I. The contrary doctrine has no foundation in principle, and may now be regarded as ended by the Neg. Inst. Law, wherever that is in force. See, however, 2 Daniel on Neg. Inst., S 990. - ED.

NEGOT. INSTRUMENTS - 34 . 


\section{Common Bench (C. P.), 46. - I850.}

ACTION by holder against drawer. Defendant drew the bill to his own order and indorsed it to L. \& S. who indorsed it to plaintiff, but $L$. continued to hold it as plaintiff's agent. The bill was presented by $\mathrm{L}$. and dishonored, whereupon L. \& S. gave defendant notice in their firm name. Verdict for plaintiff. Defendant moves for a rule nisi to enter the verdict for the defendant.

MAULE, J. - I am of opinion that the notice of dishonor that was given in this case, was sufficient. Lysaght, the younger, appears to have acted as the agent of his father, the plaintiff. In that character, he received the bill from Lysaght $\&$ Smithett, by whom it was sworn to have been indorsed before it became due; and Lysaght the younger proved that it had ever since been kept by him amongst the documents which were held by him for his father. It was undoubtedly his duty to see that his father should have all proper remedies upon the bill. The bill, it seems, was presented on the day it became due, and was dishonored; and due notice of dishonor was given by Lysaght \& Smithett to the defendant, as drawer. Lysaght, the younger, having due notice of the dishonor, which operated as a notice to Lysaght $\&$ Smithett, it was clearly competent to the latter, according to the decided cases, to give notice to all prior parties to the bill, and a notice so given would enure as a notice by the party who had given notice to them. I therefore think the defendant has had a sufficient notice of dishonor.

Cresswell, J.

It seems, from the cases, that the holder of a bill may avail himself of a notice of dishonor given in due time by a prior indorsee, provided he himself is in a condition to sue the party by whom the notice was given. Here, Lysaght the younger, holding the bill as his father's agent, duly presented it, and had it returned to him dishonored. Notice of that fact to him, therefore, operating as notice to the firm, the present plaintiff was entitled to sue them, and, consequently, is in a condition to avail himself of the notice of dishonor given by them to the defendant.

I find the rule thus laid down in Byles on Bills (5th ed., p. 214): " The object of notice is twofold; first, to apprise the party to whom it is addressed, of the dishonor; and, secondly, to inform him that the holder, or party giving the notice, looks to him for payment. (Tindal v. Brozen, I T. R. I67.) Hence, it follows that notice can only be given by some party to the instrument, though he need not be the actual holder of the bill at the time (Chapman v. Keane, 3 Ad. \& E. r93, 4 N. \& M. 607 ; Harrisonv. Ruscoe, r5 M. \& W. 231 ; Miers 
v. Brou'n, I I M. \& W. 372); but that a stranger is incompetent to give it. (Steatart r. Keinett, 2 Campb. I77. Iide tamen Abel v. Potts, 3 Esp. N. P. C. 243.) And it has been held by Lord Eldon. that notice $b_{y}$ the first indorsee, who had not himself recerved notice from the second indorsee, and who was not, therefore, obliged to take back the bill, was insufficient as between the second indorsee and the drawer. (Ex Parte Barclay, 7 Ves. 597; but quare, since the case of Chapmanv. Keane, supra.) And it seems clear, that even a party to the bill, who has been already discharged by lacks, or who could not in any event sue, is incompetent to grive notice. (Harrison r. Ruscor, 15 M. \& W. 231 ; Wiers v. Bronin, I I M.\& W. 372.) But a prior indorsee, who has himself received due notice, may transmit it. (Fameson v. Suinton, 2 Campb. 373, 2 Taunt. 22.; IVilsonv. Säabey, I Stark. N. P. C. 34.) And notice by the holder, or by a party who is liable to be sued, and may be entitled to sue, will enure to the benefit of all antecedent or subsequent parties. So that a notice by the last indorsee to the drawer, will operate as a notice from each indorsee to the drawer; and, if the payee, or first indorsee, has duly received notice, a notice by him to the drawer will be equivalent to a notice from each indorser, and from the holder to the drawer. (Bayley on Bills, 209.) And a notice from an intermediate party may, in pleading, be described as a notice from the plaintiff. (Neaten v. Gill, 8 C. \& P. $3^{67 .)}$ "'

Rule refused. ${ }^{1}$

1 i6I-i64 [90-93]. In Chapmax $\checkmark$ KeANe (3 Ad. \& E. 193-1S35), A indorsed the bill to $\mathrm{B}$, who left it with A's clerk. The clerk presented it, and on dishonor notified the drawer in the name of A. A afterwards took up the bill from $B$, and brought action against the drawer. It was objected that the notice should have been in the name of $B$ the holder. II'll: That the notice was sufficient. The court employed the sweeping language, which has since given rise to some misapprehension, that "It is universally considered that the party entitled as holder to sue upon the bill may avail himself of notice given in due time by any party to it." This is properly qualified in the Neg. Inst. I.., s. $16 \mathrm{I}[90]$.

In Harrison v. Ruscoe, (I5 M. \& W. $231-r 8+6$ ), $A$ indorsed the bill to $B$ who left it with $C$. C gave notice of dishonor to the drawer, but by mistake and without authority, in the name of $A$. Action by l'a against drawer. Ilild: Notice by A would be good under doctrine of Chatman v. Katanc, (not, however, if $A$ had been discharged by lackes or had no right of action on the bill if he had taken it up); notice by $C$ in A's name is good since, though unatuthorized, the drawer is not injured.

In JeNisgs v. Roberts, (+ E. \& B. 615-IS55), A indorsed the bill to defentant and defendant to plaintiff. Plaintiff knew the acceptor had stopped payment, and probably would not pay. On the day after maturity, without knowing whether the bill (which was payable at a distance) had actually been dishonored, plaintiff told defendant it had been dishonored, and he should look 
Is JoHnson (N. Y., 327.) - I820.

ACTION by second indorser against first indorser. Defence, want of notice. Judgment for plaintiff.

The note was indorsed for the accommodation of the maker. It was discounted at bank, and on dishonor at maturity due notice was given by the agent of the bank to both indorsers. No notice was given by plaintiff to defendant. Plaintiff took up the note.

PER CUR1AM. - We see no ground to doubt the correctness of the decision at the circuit. Upon authority, as well as sound reason, it is sufficient that the first indorser had notice from any stibsequent holder of the note, of the default of the maker, and that he would be looked to for payment; provided such notice were given immediately after such default. The only object in requiring notice is, that such indorser may have recourse to the maker, to indemnify himself. And whether, after such notice, the first indorser be sued by the second, or third indorser, is immaterial; and notice of non-payment, etc., from either of them, enures to the benefit of all who stand behind him on the note.

Judgment for the plaintiff.

\section{§65 OHIO LIFE INSURANCE AND TRUS'T CO. $\tau^{\prime}$. MCCAGUE.}

IS Oillo, 54. - Is.9.

ACtion against drawer of a bill payable to his own order and indorsed by him to plaintiff and by plaintiff to its agent in New York. Judgment for plaintiff.

Spalding, J. - There are really but two questions presented in this case for our consideration: First. Was the notice of protest for non-payment transmitted with sufficient diligence and directness to the defendant?

The bill matured and went to protest on the I9th of June, 1846 . It was then in the hands of an agent of the plaintiff in the city of New York. Admit that agent to have been the actual cashier of the "Trust Company." He was then attending to an agency in

to defendant. Ileld: Notice sufficient. "If a bill is dishonored in fact, and a party to the bill unequivocally asserts that fact in a notice of dishonor, I think you cannot inquire into the state of the party's mind, or his means of knowledge." - ED. 
the city of New York, and, so far as it concerned the bill in question, which was discounted at the bank in Cincinnati and sent to him in New York for collection, he may as well be called an agent as any indifferent person. This agent, on the very next day after the protest in New York, sent the notice by mail to his principal in Cincinnati, where it arrived on the $25^{\text {th }}$ of June, and on the same day was again placed in the mail, directed to the defendant at Ripley. The most stringent rules of the law merchant will require no more than this. The whole objection of counsel is based upon the fanciful idea that the Ohio Life Insurance and Trust Company at Cincinnati, was embodied in the person of its cashier, Wm. M. Vermilye, in the city of New York; and that it was sending the notice of protest from itself in New York to itself in Cincinnati. We are not inclined to indulge in subtleties of this sort, and hold that Mr. Vermilye in New York, whether he be called agent or cashier, was employed by the holder of the bill in Cincinnati to present the same for payment; and, on payment being refused, to return it in due time, with the ordinary notice of protest, to his employer in Cincinnati, whose duty it would be to communicate with the other parties to the bill.

[Omitting a question of statutory construction.]

Judgment affirmed.

\section{Forit OF Notice.}

$\S$ I66

KING $\because$ HURLEY.

$[\$ 95]$

85 MAINE, 525. - I893.

EMERY, J. - This was an action by an indorsee against the indorser of a promissory note. At the maturity of the note, payment was duly demanded of the maker, and was refused, and notice thereof was seasonably sent to the defendant indorser. The defendant makes but two objections to the notice. First, that it did not state who were the other indorsers of the note. Second, that it misstated the amount of the note.

${ }^{1}$ Accord: Howard v. Ives, I Hill (N. Y.) 263; Church v. Barlow, 9 Pick. (Mass.) 547; Renshawe v. Triplitt, 23 Mo. 2 г3.

It has recently been held by the English Court of Appeal (Collins, L. J., dissenting), that where a bill is forwarded by the $\Lambda$. Branch of the $X$ Bank, due notice to the $B$. Branch of the same bank is sufficient to satisfy sec. 49 subsec. (12) and (13) of the Bills of Exchange Act, since the X Bank is the principal, and not a particular branch of that bank. Ficlding $\&$ Co. v. Corry, $46 \mathrm{~W}$. R. 97. These provisions are substantially the same as $\leqslant 165$ [94], and 175 [104] of the Neg. Insi. L. - EI). 
The defendant, however, does not show that he was in the least misled or confused by the omission, or by the mistake. On the contrary it clearly appears that he understood the notice to refer to the note in suit. He was, therefore, fully informed of the dishonor of this note and that the holder looked to him for payment. This was sufficient to fix his liability. (Cayuga Co. Bank r. Warden, I N. Y. $413 ; 6$ N. Y. I9.)

Exceptions overruled. ${ }^{1}$

\section{I67 MILLS $\because$ BANK OF UNITED STATES.}

II WhEATON (U. S.), 43I. - IS26.

Action against indorser on a note dated $20 \mathrm{July,} \mathrm{I} 8 \mathrm{Ig}$, payable 60 days after date at the office of discount and deposit of the Bank of the United States, at Chilicothe. The following notice of dishonor was sent to the indorser: -

Chilicothe, and September, isig.

Sir, You will hereby take notice, that a nole drawn by Wood \& Ebert, dated soth day of September, ISI9, for 3,600 dollars, payable to you, or order, in sixty days, at the office of discount and deposit of the Bank of the United States at Chilicothe, and on which you are indorser, has been protested for non-payment, and the holders thereof look to you.

Yours respectfully,

LEITN BELT,

Peter Mills, Esq. Mayor of Chilicolhe.

Mr. Justice Story, (after stating the facts), delivered the opinion of the court.

The first point is, whether the notice sent to the defendant at Chilicothe, was sufficient to charge him as indorser. The Court was of opinion, that it was sufficient, if there was no other note payable in the office at Chilicothe, drawn by Wond \& Ebert, and indorsed by the defendant.

It is contended, that this opinion is erroneous, because the notice was fatally defective by reason of its not stating who was the holder, by reason of its misdescription of the date of the note, and by reason of its not stating that a demand had been made at the bank when the note was due. The first objection proceeds upon a doctrine which is not admitted to be correct; and no authority is produced to support it. No form of notice to an indorser has been prescribed by law. The whole object of it is to inform the party to whom it is sent, that payment has been refused by the maker; that he is con-

${ }^{1}$ See also Susscx Bank v. Balduin, I; X. J. L. 48 ; ante, p. 50r. - ED. 
sidered liable; and that payment is expected of him. It is of no consequence to the indorser who is the holder, as he is equally bound by the notice, whomsoever he may be; and it is time enough for him to ascertain the true title of the holder, when he is called upon for payment.

The objection of misdescription may be disposed of in a few words. It cannot be for a moment maintained, that every variance, however immaterial, is fatal to the notice. It must be such a variance as conveys no sufficient knowledge to the party of the particular note which has been dishonored. If it does not mislead him, if it conreys to him the real fact without any doubt, the variance cannot be material, either to guard his rights or avoid his responsibility. In the present case, the misdescription was merely in the date. The sum, the parties, the time and place of payment, and the indorsement, were truly and accurately described. The error, too, was apparent on the face of the notice. The party was informed, that on the $22 \mathrm{~d}$ of September, a note inclorsed by him, payable in sixty days, was protested for non-payment; and yet the note itself was stated to be dated on the 20 th of the same month, and, of course, onl; two days before. Under these cicumstances, the Court laid down a rule most farorable to the defendant. It directed the jury to find the notice good, if there was no other note payable at the office at Chilicothe, drawn by Wood \& Ebert, and indorsed by the defendant. If there was no other note, how could the mistake of date possibly mislead the defendant? If he had indorsed but one note for Wood \& Ebert, how could the notice fail to be full and unexceptional in fact?

The last objection to the notice is, that it does not state that payment was demanded at the bank when the note became due. It is certainly not necessary that the notice should contain such a formal allegation. It is sufficient that it states the fact of non-payment of the note, and that the holder looks to the indorser for indemnity. Whether the demand was duly and regularly made, is matter of evidence to be established at the trial. If it be not legally made, no averment, however accurate, will help the case; and a statement of non-payment and notice, is, by necessary implication, an assertion of right by the holder, founded upon his having complied with the requisitions of law against the indorser. In point of fact, in commercial cities, the general, if not universal, practice is, not to state in the notice the mode or place of demand, but the mere naked nonpayment.

Upon the point, then, of notice, we think there is 110 error in the opinion of the Circuit Court. 
[The Court then decides that a usage to demand payment on the fourth day of grace, is good, and some other points immaterial here.]

Judgment affirmed. ${ }^{1}$

\section{§67 SALOMAN $\because$. PFEISTER \& VOGEL LEATHER CO. [\$ 96]}

3 I Atlantic Reporter (N. J.), 602. - IS95.

ACtion against indorser. Judgment for plaintiff.

VAN SrCKel, J. - The only question which it is deemed necessary to discuss in this case is whether a notice of protest must contain an express statement that the holder of the protested note will look to the indorser for payment. This question was before our Supreme Court in Burgess v. Treeland (2+ N. J. Law, $7 \mathrm{I})$, in which case there was a failure to state in the notice that the holder looked to the indorser for payment. The chief justice in deciding the case said: "The object of the notice is to apprise the indorser that the note is dishonored, and that he is looked to for payment. It is not necessary to state, in terms, that the holder looks to the indorser for indemnity. It is enough if that fact appears by just and natural implication. The modern cases agree that the fact of giving notice to the indorser that the note is dishonored for non-payment is in itself a sufficient notice that the indorser is looked to for payment." Many authorities supporting this rule are cited in the opinion. In the later case of Howland v. Adrain ( $30 \mathrm{~N}$. J. Law, 4I) the rule recognized was that the notice must be sufficient to inform the party, either in express terms or by necessary implication, that the bill or note had been dishonored, and that he was looked to for payment. In the case in hand the notice mailed to the indorser stated that payment of the note had been duly demanded of the maker, that payment was refused, and that the note was protested for non-payment. The only inference which the indorser could reasonably have drawn from such a notice was that the holder of the note intended to look to him for payment. The liability of the maker to the holder was

${ }^{1}$ An omission or misdescription of the maker's name may render the notice ineffectual. Home Ins. Co. v. Green, ig N. Y. 5 IS; McGeorge v. Chapman, 45 N. I. L. 395. But not, it seems, if the indorser is not misled thereby. Foniland v. Adrain, 30 N. J. L. 4I; Hodges v. Shuler, 22 N. Y. II4.

Where the notice may apply to any one of 1 wo or more notes indorsed by the defendant, the notice may be ineffectual. Cookv. Litchfield, 9 N. Y. 279. But not, it seems, if the indorser is not misled thereby. s. c., (on retrial), 2 Bosw. (N. Y.) 137 .

It is unnecessary that the notice should include a copy of the protest. Den• nistoun v. Stewart, I7 How. (U. S.) 606, post. - ED. 
fixed without presentment and protest, and therefore the only purpose which the holder could have had in sending such notice was to charge the indorser. The notice in this case was, in my opinion, sufficient, and the judgment below should be affirmed. ${ }^{1}$

3. Mode of Notice.

(a) Personal delizery.

$\S 167$

HOBBS $\because$. STRAINE.

$[\S 96]$

I 49 MASSACHLSETTS, 2 I2. - ISS9.

ACTION against indorser. Verdict for plaintiff.

Morton, C. J. - Notice of the dishonor of a note is sufficient to charge an indorser if it is delivered to him personally, or is left at his place of residence or of business, or is deposited in the mail addressed to him at his place of residence or of business, the postage being prepaid. (Pub. Sts., c. 77, s 16; Bank of America v. Shat', It2 Mass. 290; Importers \&o Traders National Bank v. Shaw', Itt Mass. 421.) The underlying principle of all the decisions upon the subject is, that reasonable diligence must be used by the holder in getting notice of the dishonor to the indorser.

In the case at bar, the evidence tended to show that the plaintiffs, in due time, took a written notice of the dishonor, addressed to the defendant, to his office, which was his place of business, and, finding no one in, left it there. The precise place in the office where it was left was not fixed with certainty, and the court instructed the jury, that, if they found that it was left in a conspicuous place in the office, it was a sufficient notice. This ruling was correct. The jury might well find that the notice was left in good faith in the defendant's office, in such way that he would be likely to see it when he came in. Such a mode of giving the notice would ordinarily be as effectual as if it were sent by mail through a letter carrier. We think the evidence shows a compliance with the rule of law requiring the holder to exercise reasonable diligence, and that the notice was sufficient to charge the defendant as indorser.

[Omitting question as to waiver.]

Exceptions overruled. ${ }^{2}$

\footnotetext{
${ }^{1}$ An indication of dishonor: " 11 as not been paid and 1 request (or demand) payment." Arnoldv. Kinloch, 50 Barb. (N. Y.) 44; Pars v. Giltert, 60 Me. 455 ; Armstrongv. Thurston, it Md. It ; Pinkham v. Macy, 9 Met. (Mass.) 174.- ED.

${ }^{2}$ Notice at a place of business may be left with any person in charge. Bank v. Mudgett, 4 N. Y. 514; Merz Y. Kaiser, 20 La. Ann. 37\%. So, also, as to
} 
(b) Mail delizery.

4 Hill (N. Y.), 129. - Is $_{+3}$.

Action against indorser. Note payable in Geneva. Holder and indorser reside in Penn Yan. Note dishonored in Geneva; notices sent by mail from Geneva to holder in Penn Yan; holder deposits notice for indorser in Penn Yan postoffice. Indorser asks nonsuit on the ground that leaving the notice in the postoffice at Penn Yan, there being no evidence that the defendant received it, was insuffcient. Motion for nonsuit denied. Verdict for plaintiff.

By the Court, Broxson, J. - It seems to have been assumed on the trial that Babcock owned the note, and sent it to the bank, where it was made payable, for collection. Notice was sent to Babcock, the last indorser, with notices for the other inclorsers; and if he was not mistaken as to the proper mode of service, he gave notice to the defendant Benham on the same day or the day after he received advices from the bank. Either day was sufficient. (How'ard v. Ii'ts, r Hill, 263; Bank v. Daz'is, 2 id. 45r.) But as Babcock and the defendant Benham both lived in the same village, I think the service should have been personal, or by leaving the notice at the dwelling house or place of business of the indorser, and that service through the postoffice was not sufficient. The postoffice is not a place of deposit for notices to indorsers, except where the notice is to be transmitted by mail to another office. (Ransom v. Mack, 2 Hill, $58_{7}$.) None of our cases have gone further than that.

New trial granted.

notice at the residence of the indorser. $U . S . B a n k$ v. Hatch, 6 Pet. (U. S.) 250; Blakely v. Grant, 6 Mass. 356; Bradley v. Dazis, 26 Me. 45 ; Howe v. Bradl' $y^{\prime}$, I9 Me. 3 I. Notice by telephone to be effective must be shown to have actually reached the indorser. Usually it would be necessary to show that the person responding was the indorser himself. Thompson, etc., Co. v. Appléty" (Kan. App.) 48 Pac. Rep. 933. See also Stewart v. Eden, 2 Caines (N. Y.) I2 I, post, p. 5to; Adams v. Wright, It Wis. 40 , post,- ED

${ }^{1}$ Notice BY MAIL. In the absence of statute the mail cannot be used as a place of deposit but only as a means of transmission. I an lechten v. Pruyn, I3 N. Y. 549. This rule was changed by statute in New York by L. I 857 , c. $4 \mathrm{~T} 6$; but the statute does not abridge the right of the indorser to designate the particular address to which the notice shall be sent. Bartlett v. Rooinson, 39 N. Y. IS7 (IS6S). Independent of statute it has been held that where the indorser resides outside the corporate limits of the town where the instrument is dishonored and is in the habit of receiving his mail there, the post-office may be used as a place of deposit in order to relieve the holder of the burden and 
ior Pexistivania State, 507.- IsSz.

Action against indorser. Holder handed notice duly addressed and stamped to a United States mail carrier who was then in the bank to deliver mail. Judgment for plaintiff.

Mr. Justice Grees delivered the opinion of the court, December 30 th, I 882 .

We think the delivery of a letter to an official letter carrier is the full equivalent for depositing it in a receiving box or at the postoffice. When left in the former it is for the purpose of being taken therefrom by the carrier, and if left at the post-office it must be taken from the receptacle there provided for its deposit, either by the postmaster or by some one of his agents, to be placed in the mail. $I_{14}$ either case the letter must come into the personal custody of some one lawfully authorized for the purpose, whose function it is to participate in the transmission of it from the sender to the mail.

It certainly can make no difference whether the letter is handed directly to the carrier, or is first deposited in a receiving box and taken from thence, by the same carrier. In the case of Skilbeck r. Garbett (7 Ad. \& El. N. S., p. 846 ), in which the very point was decided. Lord Denman, C. J., said: "If a pablic servant belonging to the post-office, takes charge of the letter in the exercise of lis public duty, it is the same as if it were carried to the office." The postal regulations of the United States require that carriers while on their rounds shall receive all letters prepaid that may be handed to them for mailing. It follows that when such a carrier receires a prepaid letter from a citizen for the purpose of being mailed, he is in the strict performance of his official duty.

[Omitting other questions.]

Judgment affirmed. ${ }^{1}$

expense of sending a messenger. Bank of Columbia v. Lazurna, I Pet. (U. S.) 573 (IS28): Barret v. Fozans, $2 S$ Mo. 331; Bellv. Stati Bank, 7 Blackf. (Ind.) 456: but the contrary has also been maintained. Forbes $r$ Omaha liat. Bi., ro Neb. 33 (I880); Browin v. Bank of Alingrdon, 85 Va. 95 (IS58). If such notice is actually received in duc time it is unquestionably good. Phelps v. Stockins", 2I Neb. 43 (I857). Where there is a letter carrier delivery at oflices and residences the mail may be used though the indorser reside in the place where the instrument is dishonored, for in such case the mail is used for transmission and not for deposit. Shoimaker v. Wechanics' Bank, 59 P'a. St. 83 (is68); Walters v. Brown, 15 Md. 285 (1559); but in such case a deposit of a notice not adldressed to a street and number has been held not within the rulc. Bendict $\mathrm{v}$. Shlmier, I3 Wash. $476(1896)$. By the statute above, notice by deposit is now sufficient. See $57 .+$ [ro3], subscc. 3, post. - Ev.

1 “' The deposit of the notice in a postoffice box on the strect was just the 


\section{To Whom Notice May Be Given.}

2 Caines (N. Y.), I2I. - ISOH.

Action against executor of indorser. Shortly after the note was indorsed the indorser removed to his country residence and there died. His will was not proved until after the maturity of the note. At its maturity the holder, upon dishonor, sent a messenger with a notice of dishonor, directed to the indorser, to the town house of the indorser, but, as it was closed, the notice was rolled up and put into the keyhole of the door.

Livingston, J., delivered the opinion of the court.

Ought notice of the maker's default to have been sent to the indorser's country house? The note being dated in New York, the maker and indorser are presumed to have resided, and contemplated payment, there. It is admitted, indeed, that the indorser did reside in the city at the time of its date, for it is stated that shortly thereafter he went to his country seat, shutting up his house in town. We must take care that, while proper diligence be imposed on the holder of negotiable paper, we do not exact from him every possible exertion that might have been made to affect an indorser with knowledge of its being dishonored. If he has done all that a diligent and prudent man could naturally and fairly do under like circumstances; if the law has prescribed no certain way of sending a notice in the given case; if the indorser's own conduct has rendered it somewhat difficult to determine in what way the notice ought to be given; and especially, if from what lias been done, it may reasonably be presumed that notice has reached the parties concerned, we should be satisned, and not ask for more. Indorsers, therefore, cannot complain, if notices of this nature are permitted to be left at their houses in town notwithstanding their removal into the country during the hot months. It is more reasonable that they leave a person in town to attend to their business, than that the holders of

same, in legal effect, as if it had been deposited in a box at the postoffice. (Skilbeck v. Garbett, 7 Q. B. S+6; Pcarce v. Langfit, ror Penn. St. 507)."-Fohnson v. Brown, 15t Mass. io5 (1891). Accord: Casco Nat. Bk. v. Shari, 79 Me. 376 ; Hood v. Callaghan, 61 Mich. fo2.

The notarial certificate need not state that the address to which the notice is sent is the correct residence or address. In the absence of evidence to the contrary, the presumption is that the notary, who is a public officer, has correctly stated the address. Lcggv. I Final, 165 Mass. 555, citing contrary holdings. As to sufficiency of notarial certificate as evidence of notice, see post, pp. 568-570. - ED. 
their paper be put to the trouble of finding out to what part of the country they have removed and sending after them. It is also probable, especially when the distance between the two houses is only four miles, as it was here, that some communication will be kept up between them, and that a letter left at the dwelling in town will not be long in finding its way to the country. I speak now of a temporary residence in the country; for a permanent removal from the city might render a different course necessary. Nor was it fatal to direct the notice to the indorser himself; for as it was not known whether he had made a will, nor who his executors were, until long after, it was full as probable that it would reach the parties interested by this address as by any other; some one of the deceased's family would either open it, or see it safely delivered to an executor. The notice, therefore, was well served, and its address proper.'

[Reversed on a point of pleading.]

$$
12 \text { Mississiprt, } 7+9 .- \text { IS } 40 .
$$

ACTION against administrator of indorser. Indorsement by Thomas \& Dabney, partners. Notice to Thomas, surviving partner. Holder knew of Dabney's death and that the partnership was thereby dissolved. Judgment for plaintiff.

Mr. Justice Turner, delivered the opinion of the court.

The only question raised in this case is whether the executor or administrator of a deceased partner is entitled to notice of the nonpayment of a note indorsed by the partners as such.

The authorities are clear, and are believed to be uniform, tinat notice to one is notice to all. (Bayley on Bills, $285 ;$ I Conl R. 368 ; + Cow. 126; 6 Louisiana, 684; 3 Litt. 25r.) ${ }^{2}$ lisut it must appeatr that

1 "When the indorser is dead and there are no personal representatives, $o r$ none can be discovered by reasonable diligence, then notice of dishonor should be addressed to the indorser at his last place of abode. (Stititrt vidin, 2 Cai, 121; Werchants' Banie v. Birch, 17 Johns. 25; Linderman's Exicutors v. Guldin, $3+$ Pa. St. 54; Edw. Bills \& N. 631; Dan. Neg. Inst., Ioor.) l3ut when there are personal representatives and they are known or discoverable by due diligence, then notice must be given to them. (Orintul Bunk $v$. likht, 22 Pick. 206; Smalley v. Wrisht, i Vroom. 471; Story, Prom. N., 310 ; Edw. Bills \& N. 63I; Dan. Neg. Inst., \& 1000; Chit. Bills, 295)."-Dedson v. Tayler, 56 N. J. L. II, I9.-EI).

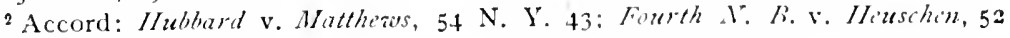
I). $207 .-\mathrm{ED}$. 
they are partners. In this case it so appears. Persons being joint payees of a note, who severally indorse it, are entitled each to notice of non-payment. ${ }^{1}$ They being joint, does not necessarily constitute them partners. The act of assembly relied on by the appellant, found in Statute Laws of Mississippi, H. \& H., 595, merely affects the remedy and not the right, and was passed to facilitate creditors in obtaining judgment for their just demands against one or all of several partners. ${ }^{2}$

\section{Time Within Which Notice Must Be Given.}

(a) Where partics reside in the same place.

$\S 174$

$$
\text { SIMPSON } \% \text {. TURNEY. }
$$

$$
5 \text { Humirey (TeNN.), } 4 \text { I } 9 .-\mathrm{I} 844 \text {. }
$$

ReEse, J., delivered the opinion of the court.

The Branch Bank of the State of Tennessee was the holder of a promissory note, payable at said bank, made by James H. Jenkins, to Anthony Dibrell, and indorsed in the following order: A. Dibrell, S. Turney, and Jno. W. Simpson. Turney's residence is within one mile of the bank, at Sparta, so known to be to the bank, and to all the other parties to the note. The note was legally due on the ist day of February, $18_{43}$, that being the third day of grace. It was on that day protested. On the second day of February no notice of the protest for the non-payment of the note was either served on Turney personally or left at his residence. He had notice from the bank, the holder, on the 3 d day of February. John W. Simpson, the plaintiff, the immediate indorsee of Turney, gave him no notice whatever.

These facts being specially found by the jury in the case, the Circuit Court gave judgment for Turney, and the plaintiff has appealed in error to this court.

It is not insisted for the plaintiff here that the notice of the bank to Turney, the only notice he received, was in time. But it is urged, that if Simpson had given him notice on the day he received

${ }^{1}$ Accord: Hillis v. Grech, 5 Hill (N. Y.) 232; Shepard v. Hawly', I Conn. $367 .-\mathrm{ED}$.

2 If notice is given to a bankrupt before a trustee or assignee is appointed it must, of course, be given to him personally. Exparte Moline, I9 Ves. 216 . If given after the appointment of the trustee it may be given to the bankrupt or to the trustee. In re Rellman, L. R. + Ch. D. 795; Callahan v. Kentucky Bank, Sa Ky. 231; American N. B. v. Funk Bros., ot Ky. 624, post, p. 563. - ED. 
notice from the bank, such notice would have been good; and that is certainly so; and the plaintiff further insists that the notice given by the bank shall inure to his benefit. If the notice had been in time and valid, it would by law have inured to his benefit, he being an intermediate party. But a notice of no benefit to the bank, because not fixing the liability of the party notified cannot inure to the benefit of another. So to hold would be to introduce a new principle into the law merchant. Suppose there were ten indorsers upon a note; if the holder, ten days after the protest, gave notice to the first indorser, this, according to the argument, would fix all the indorsers, for it would be just the time necessary to them to have given notice to each other successively.

It is perhaps a universal principle, where substitution exists at all, that the matter or thing to be substituted to must be valid and effective in behalf of the principal; if it be ineffectual in his behalf, it is difficult to see how it can inure to the benefit of others.

Upon the direct question raised in this case, Bayley on Bills expressly says: "Nor is it any excuse that there are several intervening parties between him who gives the notice and the defendant to whom it is given; and if the notice had been communicated through those intervening parties, and each had taken the time the law allows, the defendant would not have had the notice the sooner." The same principle is also decided in the case of Turner v. Leech (4 Barnwall \& Alderson, 454.)

We have been referred by the plaintiff, to what has been said by this court in the case of $M / C V_{\text {eil }}$ v. $W_{y}$ att (3 Humphreys, r 28 ). The bank at Lagrange in that case gave notice to one Glover on the 14 th to be served on Wyatt \& IIcNeil. Wyatt was served on the $I_{f}$ th,

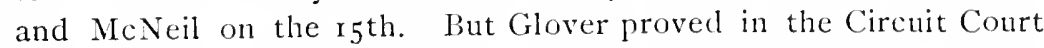
that he was the greneral agent of Wyatt to serve notices for him when his name was on paper. And the Circuit Court left it to the jury to say whether Glover, who served the notice, was not Wyatt's agent as well as the agent of the bank; and if he was, then the notice to McNeil on the 55 tin, one day after Wyatt received notice, was sufficient.

This court held that there was not any error in this part of the charge; and placing the validity of the notice, as this court clid, upon that special ground, is a distinct recognition of the greneral principle maintained by us in this case.

Upon the whole, we affirm the juclgment. ${ }^{1}$

${ }^{1}$ Accord: Rowe v. Tipper. 13 C. P. 249.

Hours of SERvice. - "It is very generally said in the books, and the doctrine is laid down without any apparent limit or qualification, that the scrvice by 


\section{(b) Where parties reside in different places}

6 Wheaton (U. S.), iO4. - I82I.

Action against indorser. Evidence that on last day of grace the notice to the inclorser was put in to the post-office properly addressed, etc. The court held the proof of notice insufficient. Plaintiff brings error.

The court were unanimously of opinion, that after the demand of the maker on the third day of grace, notice to the indorser on the same day was sufficient, by the general law merchant; ${ }^{1}$ and that evidence of the letter containing notice having been put into the postoffice, directed to the defendant, at his place of residence, was sufficient proof of the notice to be left to the jury, and that it was unnecessary to give notice to the defendant to produce the letter before such evidence could be admitted.

Judgment reversed.

leaving the notice at the dwelling-house or place of business, is equivalent to a personal delivery to the party to be notified. . . . Service at the place of business must be during business hours, but service at the residence is not so regulated. It will be sufficient if made during any of the hours when members of households are attending to their ordinary affairs. But these particulars of service need not be stated in the certificate. It will be sufficient if it shows service at the residence or place of business, which constitutes legal diligence, and the special circumstances will be presumed unless the contrary is shown." Adams v. Wright, It Wis. 403 (IS6I). But if the notice is in fact personal, it seems that it need not be during business hours although delivered at a place of business. Bonner v. New Orleans, 2 Woods (U. S. C. C.) I35 (1875); s. C., 3 Fed. Cas. 853 .

USE of Post. - Prior to the statute it was held that where there are successive indorsers and the holder sends notice to the last indorser by mail inclosing therewith notices to prior indorsers, the last indorser may use the post-office as a place of deposit for the notices to the prior indorsers who live in the same Lown as he. (But see Shidon v. Binham, + llill, I29, anti, p. 538.) Under this rule, it is held that such redeposit must be in time to reach the prior indorser in the usual course on the day following the day of receipt. Thus, if the last indorser receives the notices on the Ioth, they must be redeposited in season to reach the prior indorsers in the usual course on the IIth. If deposited on the IIth too late to reach the prior indorsers on that day, the indorsers are discharged. Shelburne Falls Nat. Bk. v. Townslev, 102 Mass. 177: S. C., Io7 Mass. 44. It is this rule, established for the exceptional case where drop letters were permitted independent of statute, that is now extended to the use of drop letters generally under the statute. -ED.

${ }^{1}$ Accord: Ex parte Moline, I9 Ves. $216 ; 2$ Daniel on Neg. Inst., S ro36. - ED. 
S7 NEW YORK, 590.-ISS2.

Action against indorser. The holder notified the third indorser by mail and inclosed notices for the second and first indorsers. The third indorser notified the second indorser and inclosed notice for the first. The second indorser received notice on the 6 th and mailed notice to the first indorsers on the 7 th, in time for the second mail of the day closing at $\mathrm{r}: 3 \circ \mathrm{P}$. M. The first mail of the day closed at 9:30 A. M. The first indorsers (defendants) contend that they were not notified with due diligence. Judgment for plaintiff.

EARL, J. [After deciding that the presentment and prior notices were sufficient.]

Smith was an aged man, upward of eighty years old. On the morning of March 7 he took the notices for the defendants and drove to Thomaston, for the purpose of consulting his counsel, and there, under the advice of his counsel, he wrote a letter addressed to the defendants, and inclosed it with the notice for the defendants in an envelope addressed to them, and caused it to be mailed at Thomaston, in time for the mail which left there for New York, the residence of the defendants, at i : 70 P. x. That mail passed through Warren, on its way to New Xork, at 2 P. x. There were two mails each day from Warren, one closing at about 9:30 A. x., and the other at about $\mathrm{I}: 30 \mathrm{P}$. M., and that letter went in the same mail that closed at Warren at $r: 30$. The contention on the part of the defendants is, that the law required that that notice should have been mailed by the first convenient, practical mail on the 7 th, and hence that it should have been mailed by the first mail on that day; and, to sustain their contention, our attention is called to various authorities. (Smedes v. Utica Bank, 20 Johns. 372 ; Miad v. Engs, 5 Cow. $3 \circ 3$; Sewall v. Russcll, 3 Wend. 276 ; Howardv. Iz'es, I Hill, 263; Haskell v. Boardman, 8 Allen, 38 ; Sussex Bank v. Baldain, 2 Harrison (N. J.), 487 ; Burgess v. Vreeland, $2+$ N. J. L. $7 \mathrm{I}$; Lan'son r. Farmers' Bk., i Ohio St. 206 ; Freemans' Bank v. P'erkins, is Me. 292.) These authorities, while not entirely harmonious, undoubtedly tend to sustain the rule that the notice must be sent on the next day by the first practical and convenient post.

The counsel for the plaintiff, however, contends that the rule is, that notice of dishonor in such cases may be sent to the prior party by any post of the next day, and he calls our attention to several authorities which tend to sustain his contention. (Chick r. Pillslury, 24 Me. 458; Whitwell v. Johnson, 17 Mass. 449; 2 Daniels on Neg. NEGOT. INSTRUMENTS -35 . 
Inst. 87 ; Story on Bills, $\S 288$; Story on Prom. Notes, $\S 324 ; 3$ Kent's Com. ro6.)

From a careful examination of all these authorities and many others it is clear that the law is not precisely settled. It appears that at first it was supposed to be necessary that notice of dishonor should be given by the next post after dishonor, on the same day, if there was one. That rule was found inconveniently stringent, and then it was held that when the parties lived in different places, between which there was a mail, the notice could be posted the next day after the dishonor or notice of dishonor. Some of the authorities hold that the party required to give the notice may have the whole of the next day. Some of them hold that when there are several mails on the next day, it is sufficient to send the notice by any post of that day. Other authorities lay down the rule, in general terms, that the notice must be posted by the first practical and convenient mail of the next day; and that rule seems to be supported by the most authority in this State. What is a convenient and practical mail depends upon circumstances. It may be controlled by the usages of business and the customs of the people at the place of mailing, and the condition, situation and business engagements of the person required to give the notice. The rule should have a reasonable application in every case, and whether sufficient diligence has been used to mail the notice, the facts being undisputed, is a question of law.

In Mead v. Enss ( 5 Cow. 303), notices of dishonor of a bill reached the post-office at the residence of the last indorser at 5 P. M., and actually came to his hands the next morning. The first mail thereafter for the residence of the prior party left at $x$ P. x., but the notices for that party were not mailed until after that hour. Sutherland, J., said: "' The cashier was not bound in the exercise of due diligence to have prepared and forwarded notices by the one o'clock mail; it is not reasonable to demand from him the neglect of his other official duties to prepare his letters and notices during the usual banking hours; " and further, that " the law does not require the holder of a bill or note to give the earliest possible notice of its dishonor; it requires of him only an ordinary and reasonable diligence; nor is he bound, the moment he receives notice of the dishonor of a bill, to lay side all other business and dispatch notice to the prior parties to the bill; if reasonable diligence is used it is sufficient." In Darbishire v. Parker (6 East, 3), Lord Ellenborough observes: "There must be some reasonable time allowed for giving notice, and that, too, accommodating itself to other business and affairs of life; otherwise it is saying that a man who has bill transactions pass- 
ing through his hands must te nailed to the post-office, and can attend to no other business, however urgent, till this is dis atched."

It does not appear here how far Mir. Smith lived from the postoffice at Warren; he was an aged man and wanted some advice about the matter. Early on the day after he received the notices, he went to Thomaston to see his counsel, and thus he missed the mail, which closed at $9: 30$. We think it cannot be said that the delay was unreasonable, or that there was the absence of that proper diligence which the law requires. There was, therefore, no error in holding as matter of law that due diligence was used by Smith in posting the notice to the defendants.

The judgment should be affirmed, with costs.

All concur. Judgment affirmed. ${ }^{1}$

il Grattan (VA.), 260. - 1854 .

Action against indorser of bill drawn on a drawee in London and protested for non-acceptance on April 5 th. ${ }^{2}$ Notice was sent in a mail leaving Liverpool on April igth by a Cunard steamship, that being the first steamship leaving England for the United States after the dishonor of the bill. But between the $5^{\text {th }}$ and the igth several sailing packets carrying mails left England for the United States. It was the usage of the London post-office to forward all mail by the Cunard line unless specially directed to be forwarded by other vessels. Judgment for plaintiff.

Samuels, J. . . . The law requires notice of dishonor of commercial paper to be transmitted to the parties thereto for the pur-

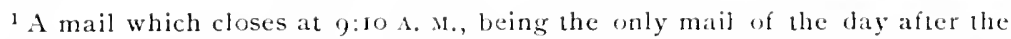
day of dishonor, is not at an unreasonabje or inconvenient hour. Lanisons. Farmers' Bank, I Oh. St. 200 (1853). Six A. M. is an inconvenient hour. (7hick v. Pillsbury, 24 Me. $45 S(1 S+4)$. "The next day is early enough; and if there should be two mails a day, whelher the notice goes by the first or the second of those mails, we think is immaterial, provided it was put into the post-oflice early enough to go by a mail of that day." - Whitiv'll $x$ Johlnsin, I7 Mass. 4t) (I82r). The second day after dishonor is ton late unless the mail of the first day after closes before business hours. Bank v. Bradliy, 117 N. C. 526 . If the day after dishonor is a holiday or Sunday, it is excluded fom the computation. See Neg. Inst. L., 5 [General Provisions]. It has been held that a notice given on Sunday is ineffective. Khem v. Carlisle tiposil bank, if Pa. St. 132. But not one given on a holiday. Detlicux v. Siullart, i Rob. (lat.) 66. - En.

${ }^{2}$ See Neg. Inst. L., $260[152] .-$ E1). 
pose of enabling them to do what is needful to protect their interests; to this end it may be important to have early notice, and the law requires it to be given. In the case before us the notice was sent in a mode which would bring it to the hands of the plaintiff in error at the earliest practicable day. Yet it is alleged that it should have been sent by another mode, which, although it might have commenced the transmission at an earlier day, yet would not have delivered it so soon as the mode adopted. If we could yield to the arguments of the plaintiff's counsel, we should sacrifice the object of the law. The notice was transmitted in the mail by an ocean steamer belonging to the Cunard line, which line carried the mail from Great Britain to the United States. It was sent by the first steamer which started after the bill was dishonored. This brings the case within the stringent rule of requiring that the notice be sent by the first mail. It appears, however, that there are regular lines of sailing packets from London (the place of the drawee's residence) to the United States; that these packets carried letter bags made up at the London post-office; and that the times for their sailing from Great Britain occurred between the day of the dishonor of this bill and the day of the steamer's learing. It further appears, that although a sailing packet should leave on the regular day for her departure, and thereafter a steamer should leave on her regular day of departure, the steamer would probably arrive first in the United States. It further appears, that the line of mail steamers is used by a very large majority of business men for the transmission of letters from Great Britain to the United States. There can be no question, that of these two modes of transmission, the proper one was adopted. This one has in its favor the facts that it carries the mail, that it is the ordinary mode of transmission, and that it may be expected to deliver a letter at an earlier day than the other; that other having in its favor the facts that it starts at an earlier day, and carries a letter bag. There is nothing to counterbalance the fact that the other line will deliver the letter at the earliest day. I think the notice of dishonor was duly transmitted.

I am of opinion to affirm the judgment.

The other judges concurred. Judgment affirmed.

${ }^{1}$ Notice must be sent by the first usual mail ship whether it sail direct to the port of the drawer or indorser or to some other port of the United Stales. Fleming v. McClure, I Brevard (S. Car.) 42S, (1504); Lenox v. Levirett, Io Mass. I $\left(\mathrm{I}_{\mathrm{I}} \mathrm{I}_{3}\right.$. $-\mathrm{ED}$. 
23 MAINE, $2 S \%$. IS 43.

Assumpsit against the defendants as drawers of a bill of exchange, dated Aug. I0, I839, on N. Dewey of the city of New York, payable in 60 days after sight, accepted by Dewey on Aug. 26,1839 , and indorsed by the defendants, and by the plaintiffs.

The plaintiffs resided at St. John, New Brunswick; the place of business of the defendants was at Calais in this State; and the acceptor resided in the city of New York.

The bill was protested in the city of New York, for non-payment by the acceptor, on Oct. 28,1839 , and a notice, addressed to the defendants, informing them of the dishonor and protest, was, at the request of the plaintiffs, placed in the post-office at Eastport on the eleventh day of November, I839. It was agreed, that the mail was at that time five days in passing from New York to Eastport; that the mail between St. Andrews and St. John passed three times each weck, leaving the former place on Monday, Wednesday, and Friday, and returning on 'Tuesday, Thursday, and Saturday, leaving each place early in the morning and arriving late in the evening; that the mail between Eastport and Calais then passed on alternate days, and on said eleventh day of November passed from Eastport to Calais, leaving before the notice was put into the office; that letters to and from the Province of New Brunswick meet through that mail; and that letters from St. John for Calais would not go by the way of Eastport, but directly from St. Andrews to Robbinston and from thence to Calais. The Court, upon this evidence, were authorized to draw any inferences which a jury would be authorized to do, and to order a nonsuit or default, as justice might require.

The opinion of the Court was by

Whitмan, C. J. - Notice of the non-payment of the draft in this case could not have reached the defendants before the 16 th or 17 th day after its dishonor. Instead of sending it directly from St. John to Calais, by due course of mail, the plaintiffs seem to have preferred sending it to Eastport; and there to have mailed it for the defendants at Calais. This was on the i 6 th day after its dishonor in New York. The mail was five days in reaching Eastport from New York. This accounts for five days of the time. How it should happen that eleven days more were necessary to forward it from thence to St. John and back to Eastport does not appear. It loes not seem, by the course of the mails between Eastport and St. John, that more than four or five days need be occupied in the tranmission of a letter and the return of an answer. It is true that the plain- 
tiffs had a right to adopt a private conveyance for the receipt and transmission of notice. But it is clearly incumbent on them to show that due diligence was used. The evidence in the case is entirely silent as to how it should hare happened that so much greater delay took place than we can see, from the evidence, to have been necessary. It was incumbent on the plaintiffs to have remored any reasonable doubts upon this point; and, not having done so, we think a nonsuit must be entered.

\section{(c) Successiz'e notices.}

17 Wiscoxsix, I51. - IS63.

ACrion against irregular indorser ${ }^{1}$ by payee. The note was payable in Janesville, Wis. Plaintiffs were merchants in New York. Plaintiffs indorsed for collection to K., in New York. K. indorsed for collection to Central Bank in Janesville. The latter, on dishonor on Nov. 22, mailed notices to $\mathrm{K}$., who received them on Nor. ${ }_{27}$, and delivered them to plaintiffs on that day. On the same day plaintiffs mailed notice to defendant at Janesville, but it was never received by him. Judgment for defendant.

By the Court, Dixon, C. J. - It is an established principle of mercantile law, that if the holder of a bill or note chooses to rely upon the responsibility of his immediate indorser, there is no necessity for his giving notice to any previous party; and if such notice be properly given, in due time, by the other parties, it will inure to the benefit of the holder, and he may recover thereon against any of them. Thus, if the holder notifies the sixth indorser, and ne the fifth, and so on to the first, the latter will be liable to all the parties. ( 1 Parsons on Bills and Notes, 503, 504; and Edwards on Bills and Notes, 473,474 , and the cases cited.) And it is no objection to such notice that it is not in fact received so soon by the first or any prior indorser, as if it had been transmitted directly by the holder or notary, provided it has been seasonably sent by each indorser as he receives it. (Colt v. Noble, 5 Mass. I67; Mead v. Engs, 5 Cow. 3०3; Howard v. Izes, I Hill, 263.) And the same degree of diligence must be exercised on the part of the indorser in forwarding notice as is required of the holder. Ordinary diligence must be used in both cases. He is not bound to forward notice on the very day upon 
which he receives it, but may wait until the next. (How'ardv. It'es, and the authorities cited.)

For the purpose of receiving and transmitting notices, those who hold at the time of protest, and those who indorse as mere agents to collect, are regarded as real parties to the bill or note; the former as holders in fact, and the latter as actual indorsers for value. (Meadv. Engs; Hou'ard v. Iies, supra.)'

It follows from these principles, that the proper steps were taken to charge the defendant Horton as indorser. Notice for him was forwarded by mail, postpaid, on the day of the protest, to the agents and last indorsers in New York, and delivered by them, on the day it was received, to the plaintiffs, their immediate indorsers, who, on the same day, deposited it, inclosed in an envelope, postpaid, in the post-office at New York, directed to the defendant at Janesville, Wisconsin, his proper post-office.

Under these circumstances, the only question which can possibly arise is, whether the defendant ought to be discharged by reason of the notice not having been in fact received by him. He testifies that it was not. Professor Parsons observes, that in all the cases of constructive notices, where notice given by a subsequent to a prior indorser has been held to inure to the benefit of the immediate indorser, it has appeared that the notice was actually received; and he raises a question whether this would be so if the notice was sent to the wrong place. (I Parsons on Bills and Notes, 504, note, and 627. $)^{2}$ But here the notice was sent to the right place. Besides, the plaintiffs, who seek to avail themselves of the notice, are the indorsers who sent it to the defendant as the indorser next immediately preceding them. We have already seen that the rule of diligence as to them is the same as in the case of the holder.

Let the judgment be reversed, and the cause remanded with directions to enter judgment in favor of the plaintiffs according to the demand of the complaint.

\section{\$78 FIRST NATIONAL BANK $i '$ FARNEMAN.}

[S 107] 93 IOWA. I6I. - I894.

ACrion against indorser. Defendant indorsed to plaintiff. Plaintiff indorsed for collection to Valley Bank. The latter indorsed for collection to German Bank, at Carroll, which place, unknown to

'See also Farmers' Bank v. Tail, 2 I N. Y. 485 ; Kosson v. Carroll, go Tenn. 9o. - ED.

${ }^{2}$ See Beale v. Parrish, 20 N. Y. 407.-ED. 
German Bank, was the residence of defendant. The German Bank, on dishonor on Nov. 1o, mailed notices to Valley Bank, which forwarded them to plaintiff, who received them on Nov. 12, and on that day gave personal notice to defendant. Of the indorsements on the bill all except that by the defendant are erased. Judgment for defendant.

Granger, C. J. . . Appellant relies, mainly, in argument, on a rule that the holder need only notify his immediate indorser, and this indorser the next, and so on, and then claims that the German Bank did notify the Valley Bank. How such a rule might affect the rights of parties were the German Bank seeking to recover, it is not for us to say. Defendant is the immediate indorser of the plaintiff bank, and, because of the erasures, there are no other indorsers; and the rule cited, if a correct one, is without force. It is to be kept in mind that, as to the indorsers other than the defendant, they were such for collection only, and the indorsements were erased. We treat the case on the theory of but a single indorser, and that one the defendant.

The judgment is affirmed.

\section{Place at Which Notice Must Be Given.}

$\S$ I79 [108] Morris $\%$ Husson, 4 Sandford (N. Y. City Superior C'rt.), 93. - r850. MAson, J.- "The addition by the defendant of the words, ' 13 Chambers Street,' beneath his indorsement, could have no other meaning than a direction as to the place where notice should be sent in case of the dishonor of the note, and the notice put in the post-office addressed to him, as was the notice in this case, to No. $1_{3}$ Chambers street, was given strictly in compliance with his directions."

\$ I79 [I08] Bartlett $a$ Robinson, 39 New York, 187.- - I868. WoodrufF, J. - “ As well when the parties do not reside in the same city or town as when (according to our statute) they do, or in short whenever notice is sent by mail or deposited in the post-office, the hotice must be directed to the indorser, not only at the city or town, but to the specific place designated by the underwriting. . . . I think . . that the words 'directed to the indorser at such city or town' includes as a part of such 'directon' conformity to the prescription which the special indorsement imports." [Hence, a notice addressed to "A. B., city of New York," is not sufficient where the indorsement is "A. B., 214 E. I8th st."]. 
4 Wendell (N. Y.), 32S. - is3o.

ACtion against indorser. Verdict for defendant.

By the Court, SutherLaxd, J. - The verdict is clearly against the weight of evidence. Charles $A$. Cook, the cashier and notary of the bank, testified that he regularly protested the note on the day it became due, and sent notice thereof on the same day to the defendant, directed to him at Geddesburgh, and put the notice in the postoffice at Geneva. He did not recollect whether he put the county on the notice of protest, but it was his custom to do so.

It was shown, on the part of the defendant, that the legal name of the post-office near which the defendant resided was Geddes, not Geddesburgh; but all the witnesses concurred in stating that it was known as well by the one name as the other, and that at least half the people called it Geddesburgh; and Mr. Earle, the postmaster at Onondaga Hill, within a few miles of Geddes, testified that until lately he supposed the name of the post-office was Geddesburgh, and if a letter was put in his office directed to Geddesburgh, he should forward it to Geddes. He further stated that there was no postoffice, either in this State or in the United States, of the name of Geddesburgh. John Wilkinson, the postmaster at Syracuse, testified that packages in the mails were as frequently directed to Geddesburgh as Geddes, except from the large offices. Upon this testimony there can be no question, if the notice was directed to Geddesburgh without the name of the county, that it was sent to Geddes. But the fair intendment from the testimony of the notary is, that the name of the county was also part of the superscription. It was his general custom so to direct his notices, and no circumstance is stated to induce the belief that he departed from it in this instance. The verdict, therefore, under the charge should have been for the plaintiff.

The judge decided, as a question of law, that the notice was good, if it was sent to the Geddes or Geddesburgh post-office. It was properly assumed as a question of law, and the opinion of the judge was correct.

The evidence shows that although the defendant resicled a mile and a half or two miles nearer to the post-office at Onondaga IIill than to Geddes, still that Geddes was his place of business, where he carried on the manufacturing of salt and the slaughtering and packing of beef; that he received letters at both offices. Nore letters for him individually were received through the office at Onondaga C. H. than at Cieddes; hut all the company letters were 
directed to the latter office. The defendant or his sons were in the habit of calling for letters at the Geddes office, and he kept a postage account there.

Under such circumstances, notice directed to either office would be good. It is not indispensable that the notice should be sent to the office nearest to the residence of the party, nor even to the town in which he resides. It is sufficient if it be sent to the office to which he usually resorts for his letters, and where he would probably receive it as soon as at the office nearer to him. (Reid v. Payne, i6 Johns. R. 2is; I Peters, 578; I0 Johns. R. 4II; I I Id. 490.) When a party has a dwelling house and counting room, or other place of business in the same place or town, notice sent to either is sufficient. (Bank of Columbia r. Lawernce, I Peters, $5^{82}, 5^{8} 3$ ); and it cannot be material whether the residence of the party and his place of business be in the same town or not, if it appears that he is in the daily or constant habit of receiving letters at both places. The notice, therefore, was sufficient, and the defendant was legally charged.

It has been decided by this court that deducting interest by way of discount at the rate of seven per cent., upon commercial or business paper, is not usurious. (Manhattan Company v. Osgrood, i5 Johns. R. I68; Bank of Utica v. Wager, 2 Cowen, 766, 767; Bank of Utica $\because$ Phillits, 3 Wendell, 408 . See, also, Fleckner v. The Bank of the U. S, S Wheaton, 838; 4 Yeates' Rep. 220, 223; 9 Mass. R. 49; 3 Bos. \& Pul. I54.)

A new trial must be granted, on the ground that the verdict is against evidence. ${ }^{1}$

It Missourl Appeals, I52.- - ISS3.

ACTION against maker and indorser. Indorser sets up want of notice. The indorser (Frost) had a general residence or domicil in St. Louis and a general place of business in St. Louis, but his family were sojourning at Selma, Mo., a place without a post-office, while he was sojourning in Washington, as a member of Congress.

${ }^{1}$ Accord: Montsomery Co. Bank v. Marsh, 7 N. Y. 48I; Mercer v. Lancaster, 5 Pa. St. I6o; Shellurne Bank v. Townsley, 102 Mass. 177.

Where the indorser lives in a town having two or more post-offices a notice addressed to him at the town generally is sufficient unless the holder knows or might reasonably know his particular post-office address. Saco Nat. $B k$. v. Santorn, 63 Me. 340; Remer v. Downe'r, 23 'Wend. (N. Y.) 620; Morton v. Westcott, 5 Cush. (Mass.) 425 ; Roberts v. Taft, I20 Mass. 16́.-ED. 
Notices were mailed to him, addressed to St. Louis, Washington and Selma, respectively. Judgment for plaintiff.

Thompson, J. [After deciding that the notices mailed to St. Louis were insufficient because holder and indorser both resided in St. Louis.]

We are of opinion that the general notice sent by mail and addressed "Hon. R. Graham Frost, Washington, D. C.," might properly have been regarded by the trier of facts as a good notice. There is evidence tending to show that, before the notary sent this notice, he went to the post-office and there inquired for Mr. Frost's address, and was told it was Washington, D. C., whereupon he maled the notice to him as stated.

This was on the $23 \mathrm{~d}$ of December, I8So. The Congress was then in regular session, but it had, on the day previous, taken the usual holiday recess, as was shown by a copy of the Congressional Record put in evidence. This recess was taken from the $22 \mathrm{~d}$ of December until the $5^{\text {th }}$ day of January following. That a notice of protest sent by mail to a member of Congress while engaged in discharging his public duties as such at Washington, is a good notice, has been held both in Massachusetts and Mississippi. (Choutcau v. Wibster, 6 Metc. 1 ; Tunstall v. Walker. 2 Smed. \& M. $6_{3} 8$.) In the former of these cases, Daniel Webster, a senator from Massachusetts, was, when the notice of protest was sent to him by mail, at Washington, D. C., attending a special session of Congress at Washington, and he had at Boston, just as Mr. Frost had at St. Louis, a place of business and an agent to attend to his business; and yet the court, Chief Justice Shaw delivering the opinion, held that the notice thus mailed to him was a good notice.

The fact that Congress had taken this temporary recess may not have been known to the notary, and, if known, it would not necessarily indicate to him that Mr. Frost would be absent from the capital during such recess. If it should indicate this it would not impair the legal sufficiency of the notice; because the controlling rule is that where the indorser has different residences and different places of business, the notice must be sent to the place where, upon diligent incuiry, it seems most likely to reach him with certainty and promptness. (Cabot Bank v. Russell, + Gray, 169 , 470, per Shaw, C. J.)

Nor can the circumstance that the inclorser was in the habit of receiving his mail, not at the general post-office in Washington, but at a special post-office in the capitol building, impair the legal suffciency of this notice, unless this fact were known to the notiry or would have been disclosed to him upon reasonable inquiry. That 
he did not know this appears from the evidence, and that it was not disclosed to him upon the inquiry which he made at the post-office in St. Louis also sufficiently appears. It seems that this post-office was the most proper place at which to make such an inquiry, for it must be supposed from the nature of Mr. Frost's public duties at the time that numerous letters were constantly received at the St. Louis post-office for transmission to him at his official residence at Washington. At all events, it cannot be said that this testimony was not sufficient to take the case to the trier of the fact upon the question of diligence. It has been held several times, that where there are two or more post-offices in the town where the indorser resides, a notice sent by mail to the town generally will be a good notice, unless a reasonable inquiry would have disclosed to the holder or the notary the actual post-office at which the indorser commonly received his mail. (Burlingame v. Foster, i2 8 Mass. I25; Morton v. Westcott, S Cush. 425; Cabot Bank v. Russell, 4 Gray, 167.)

The "towns" here spoken of are not cities or villages, but New England towns, which correspond to townships in Missouri and Iilinois, each of which frequently contains several villages and several post-offices.

[The learned judge then holds that notice addressed to Selma was good, in view of the evidence that mail addressed to Selma was regularly sent to Crystal City, the post-office nearest Selma.] ${ }^{1}$

Judgment affirmed."

\section{When delay in giving notice excused.}

$\S 184$

JAMES $\because$. WADE.

2 I Louisiana Annual, 548. - I869.

Howe, J. - The defendant is sued as the inclorser of a bill of exchange drawn by W. R. Hughes on Moore and Browder, of New Orleans, and by the latter accepted, payable on the fifteenth February, i $\mathrm{S}_{3}$.

On the day of its maturity the bill was protested by a notary in New Orleans, and a notice deposited in the post-office in that city addressed to the defendant, at IVinnfield, parish of Winn, Louisiana.

The record shows that in February, I $86_{3}$, all postal and com mercial intercourse was suspended between New Orleans and Winnfield.

1 See Bank v. Howlctt, + Wend. 328, ante, p. 553. - ED.

2 Accord: Graham v. Sangston, I Md. 59. But if the indorser simply visits a place for a purpose clearly temporary and special, he is not "sojourning" within the rule of the above cases. Walker v. Stitson, It Oh. St. S9.-En. 
The war was then raging, and the deposit of the notice in the postoffice in New Orleans had no effect in converting the conditional obligation of the indorser into an absolute liability. (19 A. 43,63 , $64,72,90 ; 20$ A. 399.)

If the holders of this bill desired to bind the indorser, it was their duty to have given him notice of dishonor within a reasonable time after the close of the war, and the resumption of commercial intercourse. There being no eridence that any notice except the one described above was ever given, the indorser must be held to have been discharged.

Judgment affirmed.

\section{$\$$ I84 UNION NATIONAL BANK $\imath^{\prime}$. MARR'S ADMLIN- [\$ II3]} ISTRATOR.

$6 \mathrm{Btsh}(\mathrm{Kr}),. 6 \mathrm{I}_{4}-\mathrm{IS6g}$.

ACTIOx against drawer of a bill drawn in Missouri upon a drawee in New Orleans and presented July i 7, IS6 I, and dishonored. Judgment for defendant.

JUDGE HARDin delivered the opinion of the Court.

This was an ordinary action by the appellant, as the holder of a bill of exchange for $\$ 1,262.5 \circ$, dated at Charleston, Missouri, the Ioth day of June, IS6I, drawn by P. N. Marr upon Samuel I. Thomas, New Orleans, Louisiana, payable to the order of Thomas Allen, and indorsed by him and Shelby Sheeks.

It appears that the bill was presented for acceptance in New Orleans on the $\mathbf{1} 7$ th of July, I $86 \mathbf{I}$, and thereupon protested for nonacceptance, of which notices addressed to the parties were mailed by the notary to the agents of the plaintiff, but it does not appear they were legally forwarded to the defendants, who in their defence denied that due notice of said protest was given, and claimed exoneration on that ground.

The principle is well settled, that although the holder of a bill of exchange, payable at a given time, is not bound to present it to the drawee for acceptance until it becomes due; yet if he does so, and the bill is dishonored, he is bound to give due notice of the fact to the parties whom he intends to hold bound. (idtullum v. Trowibridge, 2 Met. $28 \mathrm{I}$; Story on Bills, $\$ \$ \$ 227,22 S, 2 S_{4}$.) But the appellant questions the correctness of the judgment dismissing the

${ }^{1}$ Accord: Norris v. Despard, 38 Md. 457 ; Dunhar r. Tyler, $4+$ Mliss. I; Harden v. Boyce, 59 Barb. (N. Y.) 425. So, also, delay occasioned by presence of malignant disease. Tunno v. Lasu, 2 Johns. Cas. (N. Y.) I. - Ev, 
petition, on a trial of the case by the court, mainly on the ground that at the time of said protest the civil war had become flagrant, and so suspended commercial intercourse between the hostile sections of the country as to dispense with the necessity of notice of protest to bind the drawer and indorsers of said bill; and especially so as the bill was not protested till after the passage of the act of Congress of the $\mathrm{I}^{\text {th }}$ of July, I86I, authorizing the President to issue his proclamation interdicting commercial intercourse between the citizens of certain belligerent States, although the proclamation was not issued till the r6th of August, IS6r, near one month after the bill was protested.

But this case must be ruled by the case of Leathers r. The Commercial Insurance Co. (2 Bush. 296), in which, upon a careful consideration of the subject, this court, referring to the proclamation of the 16 th of August, 1861 , as public notice of the congressional recognition of a state of war, held that " before that time contracts and other acts of commercial intercourse were not made illegal by the war."

Notwithstanding the disturbed condition of the country, which we know judicially to have existed when the bill was protested, it does not appear that there was at that time such obstruction of intercommunication between the Southern and border States as to prevent the transmission and delivery of notice of the dishonor of said bill.

Wherefore, it not apearing to have been either illegal or morally or physically impossible to give notice of said protest, the judgment is affirmed. ${ }^{1}$

\section{When notice may be dispensed with.}

I. When Notice Need Not Be Given to Drawer.

$\S \mathrm{I} 85$

GOWAN $\because$ JACKSON.

$[\S \mathbf{I I} 4]$

20 Johnson (N. Y.), I76. - IS22.

ACtion against drawer of bill drawn on Jackson and Brothers. There was no notice of dishonor, but to excuse this plaintiff offered to prove that defendant was a member of the firm on which the bill was drawn, and was allowed to do so. Judgment for plaintiff.

Spencer, Ch. J. . . . Considering it, then, as established, that the partnership existed when the bill was drawn and presented,

${ }^{1}$ See criticism of this doctrine in 2 Daniel on Neg. Inst., S Io62. - Ev. 
the question arises, whether notice of non-acceptance was required to be given to the defendant. It was proved that the bill was presented for payment on the icth of January, is $\mathrm{I} S$, and was then protested for non-acceptance; and it was presented on the I6th of April, ISI8, for payment, and protested. In the absence of all other proof, the bill must be considered as drawn by one partner of the firm, on the firm itself, in relation to the partnership business; and if so, then a knowledge by one of the firm of the dishonor of the bill, is, in point of law, knowledge by the whole firm. Daniel Jackson, the partner in London, had notice that the bill was refused acceptance and payment, for he was the person who thus refused. In Porthouse v. Parker and others ( 1 Camp. N. P. 8z), Lord Ellenborough held, that where a bill had been accepted by one of the defendants, this was sufficient evidence of its having been regularly drawn; and that, the acceptor being likewise a drawer, there would be no occasion for the plaintiff to prove, that the defendants had received express notice of the dishonor of the bill, as this must necessarily have been known to one of them, and the knowledge of one was the knowledge of all. This is a very just and reasonable principle; for although Joseph Jackson is alone sued on the bill, yet, as has been already observed, it must be deemed a partnership transaction; and a knowledge by one of the firm of the dishonor of the bill, was all that ought to be required.

Judgment for the plaintiffs.'

'Accord: Rhettv. Poe, 2 How. (U. S.) 457; Fuller v. Hooper, 3 Gray (Mass.) 334 .

Fictitious DraWee. - Excuse of presentment (anti, S If2 [S2]), and notice in the case of a fictitious drawee seems to be based upon the reason that the drawer must know that the drawee is fictitious and, therefore, that the bill cannot be presented or paid. He is, therefore, from the outset the origrinal promisor. Smithv. Billamy, 2 Starkie, 223; Lithk v. Hewitt, 4 Taunt. 731 .

DraWeE Wituol"T CAl'ACITY TO CoNTR.ACT. - The reason in this case is not so clear. Presentment does not seem to be dispensed with (anti, $\$$ I +2 [s2], but see $539[79]$ ). Then why notice, since it may be that the drawee (say an

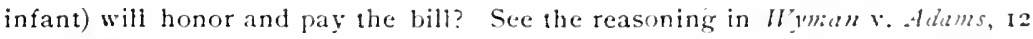
Cush. (Mass.) 210 , which, however, was a case of indorsement. See fost, $\leq 106$ [II5].

Presfintalent to Drawer. - This clause seems to cover the case where the drawer is, before the presentment, appointed the executor or trustee of the drawee's estate, and presentment is, therefore, mate to bin in his representative capacity. Actual knowledge here is, therefore, equivalent to notice. Ciunt: Thompson, 7 C. B. foo. But presentment must, to insure this result, be made to him in his representative capacity. Magruder v. Simk, 3 l'et. (U. S.) 87. And, it seems, to him personally. Groth v. Gy'rer, 31 Pat. St. 271 . Sce fost. \$ I 86 [IIE]. - EI. 
I HARRIS \& GiLl (MD.), 46S. - I\$27.

ACtion by payee against drawer of bill of exchange. No notice of dishonor. Judgment for defendant.

Dorser, J. . . . The third position was that most obstinately contended for, which was conceived to be impregnably fortified by that part of the rule established in Eichelberger v. Finley and Van Lear (7 Harr. \& Johns. $3 S_{1}$ ), which dispenses with notice only where the drawer had no reasonable grounds to expect that his bill would be honored. The reasonableness of such expectation is matter for the court, and not for the jury, to decide. If the facts, upon which the question arises, be admitted or be undeniable, then the question becomes exclusively a matter of law to be pronounced by the court; but if the facts be controverted, or the proof be equivocal or contradictory, then it becomes a mixed question both of law and fact, in which case, the court hypothetically instruct the jury as to the law, to be by them pronounced accordingly as they may find the facts. What are the facts to be found in this case justifying the drawer's expectation that his draft would have been paid? So far from having funds in the drawee's hands, he was his debtor - no proof of such a commercial intercourse between them as would imply a mutual credit - no previous promise by the drawee to accept this or any other draft for the drawer's accommodation - no consignment of goods to the drawee, which the drawer had any reason to expect would be received in time to meet his bill, but the only proof is, that the drawee informed the payee that he expected funds of the drawer would shortly come to his hands, with which, when received, he would pay. That funds afterwards did arrive, but whether in one month, or five years after, does not appear. What may have been the expectations of the drawee, as to the receipt of funds from the drawer, is immacerial; they are not even admissible evidence in this cause. But if they were, they can have no influence on those of the drawer - into whose expectations only is the inquiry to be made. The facts in the case of Legre $v$. Thorpe (1 2 East, $\mathbf{1}_{7} \mathrm{O}$ ), and Claridge $r$ Dalton (4 Maule \& Selw. 226), afford much stronger evidence of a reasonable expectation in the drawers that their bills would be honored, than those in the present case; yet there they were adjudged insufficient. The "reasonable grounds" required by law are not such as would excite an idle hope, a wild expectation, or a remote probability, that the bill right be honored, but such as create a full expectation, a strong probability of its payment; such indeed as would induce a merchant of common prudence and 
crdinary regard for his commercial credit, to draw a like bill. The facts in this case constitute no such reasonable grounds. We therefore think that the county court erred in instructing the jury that the plaintiff was not entitled to recover, and consequently reverse their judgment.

Judgment reversed, and procedendo awarded. ${ }^{1}$

2. When Notice Need Not be. Given to Indorser.

Action by one indorser against a joint indorser for contribution. Defence, want of notice and protest.

Notes were made by the Augusta Athletic Association and indorsed by plaintiff, defendant, and others, being a majority of the directors of the Association. At maturity, the Association was insolvent.

Bleckley, Chief Justicf. - Good sense, good morality, and good law are one and the same so long as they are not sundered violently by legislation or ignorantly by judicial error. Their unity and identity, so far as one of the questions in this case is concerned, we find still intact. There is no statute to drive, neither is there any precedent to lead, decision into absurdity or injustice. We can and do hold that accommodation indorsers who represent their insolvent principal in procuring a loan of money for the principal's use, upon a promissory note which they caluse to be made in his name and which they indorse in their own names, they having at the time full control of his business and all his assets, and their relation to him being such as to make it their duty to see that the note is provided for and paid at maturity, are not entitled to notice of its dis. honor. May be they do not stand in his shoes; if they do not, it is because they are his shoemakers and have sulfered him to become and remain barefooted. Though the debt is his and not their own, primarily, yet, having all his assets and full power over them, and over all his business, they are bound to know all that he would be bound to know were his business and assets in his own hands and under his own management. In this instance the principal being a corporation, and the indorsers the corporate directors, the latter

'See also Robinson v. Ame's, 20 Johns. (N. Y.) 146, fost, p. 633. Accommodation drawers, who unite with the accommodated party in drawing the bill, are entitled to notice if they had reason to believe that the latter would provide funds to meet the bill. Miser v. Trovinger's Fixicutors, 7 Ol. St. 28r. - Ev.

NEGOT. INSTRUMENTS - 36 . 
could have no right or reason to expect that funds would be provided for liquidating the debt unless it was done by their procurement or through their agency. The charter of the "Augusta Athletic Association " is not before us, and in its absence we must take it for granted that the directors of that corporation had the powers and were under the duties which appertain to corporate directors according to the general rules of law. Special provisions in the charter might vary these powers and duties in the given instance, but such provisions would, in order to gain recognition, have to be brought to the attention of the court. The usual rule is that all the assets and operations of a corporate business are under the government and control of the directors. A single director, or even a minority of the directors, indorsing a note for the corporation, might be entitled to notice of dishonor; for one only, or a small number, might have a right to suppose that the note would be attended to at maturity; but when the whole board, or a majority of its members, unite in the indorsement, each and all so indorsing should be charged with the duty and responsibility of protecting the paper, since the power to control the conduct of the corporation in respect to paying or not paying woulı be in their own hands. On the question of notice, the present case is fairly and fully within the principle of Corncy v. Da Costa (I Espinasse, 302), in which it was held that where the indorser of the notes of an insolvent person took effects of the insolvent to the full amount of his indorsement, he could not avail himself of the want of notice of non-payment of the notes at maturity. The facts of that case are meagerly stated in the report, but they indicate that the indorser took the maker's effects, not merely to hold them for his protection, but for use in raising funds with which to discharge the indorsed paper. He was treated as if he were primarily liable and the debt were his own. Following the reason and spirit of that decision, these directors ought to be treated in the same way. ${ }^{1}$

With respect to the want of protest, it is true that the letter of the Code, $\$ 278 \mathrm{I}$, makes protest necessary in order to bind indorsers upon any bill or promissory note payable at a bank, thus, in effect, putting all such paper on the footing of foreign bills of exchange as to this commercial solemnity. But the requirement as to protest was not, we think, intended to be more comprehensive than the requirement as to notice. ${ }^{2}$

[The Court then holds that the action is barred by the statute of

${ }^{1}$ Contra: Phiphs v. Harding, 7o Fed. Rep. 46S. - ED.

${ }^{2}$ Prolest not necessary where notice dispensed with. Legge v. Thorpe 12 East. I7I. - ED. 
limitations, being for money paid to the defendant's use and not founded directly on the notes.]

\section{$\S$ I86 AMERICAN NATIONAL BANK $i . J U N K$ BROS. [\$ II5] 94 Texiesee, 624. - IS94.}

BEARD, J. - This suit was instituted against the Junk Bros. Lumber and Manufacturing Co., a corporation with its situs in Nashville, as the indorser for value of certain domestic negotiable notes. The defendant resisted recovery on the ground that notice of dishonor of the paper was not given as the law requires. A decree having been pronounced against the corporation, it has filed the record in this Court, and the action of the Court below in overruling this defence is assigned as error.

Before coming to the general question raised by the assignments, it is proper to dispose of frve of these notes, which are shown by the proof to have been made for the accommodation of this corporation and afterwards indorsed by it to the complainant. As to these nozes, their makers stood in the situation of sureties to the indorser, and it was the latter's duty to provide funds to meet them at maturity, and it was, therefore, bound to the holder without presentment, protest, or notice. ( 2 Am. \& Eng. Ency. of Law, 399; 2 Daniel on Neg. Inst., \$ ro85; 3 Randolph on Com. Paper, s r 205 ; Black v. Fizer, ro Heis. ${ }_{4} 8$.) Thus disposing of those five notes, the question recurs as to the liability of the defendant as indorser of the remaining thirty-five.

[The Court then holds that as to these, notice addressed to the company and received by its assignee for the benefit of creditors is sufficient, and that notice addressed to the assignee is equally suffcient. $]^{2}$

Judgment affirmed. ${ }^{2}$

3. When Notice TO DRAWER OR INHORSER JISHANSLD With.

(a) Due dilisence.

$\S$ I83 [II2] Ransom $a^{\prime}$. Mack, 2 Hill (N. Y.), $5^{8} 7,592 .-\left(18_{42}\right)$. By the Court, Bronson, I. - The next inquiry is, whether the defendant was discharged in consequence of the misclirection of the notice. It was sent to North Adams, when it should have been sent

'See $\$ 172$ [IOI], anti. - E1'.

${ }^{2}$ Accord: Blenderman v. Price, 50 N. J. L. $29^{6}$; khot v. Poc, 2 How. (U. S.) 457. - Ev. 
to the Appling office. The defendant's place of residence not being known, the notary made inquiry of Robbins, the second indorser, who professed to be able to give the necessary information, and was interested to speak truly. The answer of Robbins was, that the notice should be sent to North Adams - that being the office where the defendant got his letters and papers. Although Robbins was mistaken, the nota:y was well warranted in acting upon information thus obtained, without pushing his inquiries further. There was due diligence, and that is enough. (Bank of Utica v. Bender, 21 Wend. 643.) That case was affirmed on error brought in June, I84I. Drawers and indorsers can easily prevent mistakes of this kind, by writing under their names their places of residence or the place where they desire notice should be sent in case the bill or note is protested. ${ }^{1}$

(b) Haià'

$\$ 180$

GOVE $i$. VINING.

$[\S 109]$

7 Metcalf (Mass.), $212 .-$ Is+3.

ACtion against indorser. Defence, want of chemand and notice. The indorser, shortly before maturity, requested the holder not to sue the note until the maker saw the holder.

SHaw, C. J. . . . The court are of opinion that when the indorser, at or shortly before the time when the note becomes due, says to the holder, that an arrangement for its payment is about being made, and in direct terms, or by reasonable implication, requests the holder to wait or give time, it amounts to an assurance that the note will be paid - that the promisor or indorser will pay it - and is a waiver of demand and notice. It tends to put the holder off his guard, and induces him to forego making a demand at the proper time and place; and it would be contrary to good faith, to set up such want of demand and notice - caused perhaps by such forbearance - as a ground of defence. (Leffingretl v. White, I Johns. Cas. 99; Mechanics' Bank v. Gristold, 7 Wend. 165; Leonard v. Gary, 10 Wencl. 504; Taunton Bank v. Richardson, 5 Pick. 436; Thornton v. Wy'm, I2 Wheat. $18_{3}$; Wood v. Brozen, I Stark. R. 217.)

Judgment for the plaintiffs. ${ }^{2}$

${ }^{1}$ Accord: Lambert v. Ghiselin, 9 How. (U. S.) 552 ; Cintral N. B. v. Adams, II S. Car. 452. Merely consulting a directory is not due diligence. Bacon v. Hanna, I 37 N. Y. 379. Nor casual inquiries. Spencer v. Bank, 3 Hill (N. Y.) 520. See 2 Daniel on Neg. Inst., SS. IIIt-I I23. - En.

${ }^{2} \mathrm{~A}$ waiver in the instrument itself binds all subsequent indorsers. Phillips v. 
5I Califoria, 239. - I8;6.

[Riported hirein at A. 268.]'

Dippo, 93 Iowa 35 (IS94). It is not therefore a material alteration in such a case to write above the indorser's name, "Payment guarantied." Ion't I'alley State Bank v. Sigstad, 96 Iowa 49I; 65 N. W. 407 (IS95).

Parol Waiver at The of Ixdorsemext. - It some jurisdictions it is held that a parol waiver made at the time of the indorsement may be shown on the theory that such evidence does not vary the terms of the written contract but establishes the waiver of a condition otherwise imported into the contract by the rules of the law merchant. Silmicd v. Frank, S6 Ind. 250; Lane v. Stiaidrd, 20 Me. 99; Dye v. Scott, 35 Oh. St. 194; Annville Nat. Bk. v. Kittering, 106 Pa. St. 53I. In other jurisdictions it is held that such evidence does vary the terms of the written contract, and is therefore inadmissible. Goldman v. Daris, 23 Cal. 256; Faratell v. St. Paul Trust Co., 45 Minn. 495; Rulncy r. Hilson, 67 Mo. I23; Bicler v. Frost, 7o Mo. I85; Bank v. Smith, +7 Barb. (N. Y.) 4 S9. Some jurisdictions now provide by statute that all waivers must be in writing. Maine R. S., c. 32, $\leq$ Io.

A parol waiver, subsequent to the time of the indorsement is (independent of statute) good. Markland v. MiDaniel, 5 I Kans. 350; Rodnc'y. Hilsen, 67 110. I23; 2 Daniel on Neg. Inst., \& IogS. - Ev.

${ }^{1}$ A promise to pay the instrument, made by an indorser after maturity and after he is discharged for want of demand or notice, is, in analogy with the promise to pay a debt barred by the statute of limitations, held to be binding. Ross v. Hurd, 7I N. Y. It; Rindse v. Kimball, 124 Mass. 209; Bred r. Hillhouse, 7 Conn. 523; Oxnard v. Famum, II I Pa. St. 193; Smith v. Curlie, 59 I11. 22I; Parsons v. Dickinson, 23 Mich. 56. Contra: Sibice Diposit Bank v. Moseland, $9^{5} \mathrm{Ky} . \mathrm{I} 50$, where it is held that such a promise is presumptive evidence ihat demand and notice were had, but that the presumption may be rebutted.

In order that the indorser may be bound by such subsequent promise he must have knowledge of the laches, and all the material facts constituting such laches. Purks v. Smith, I55 Mass. 26; Bankv. Bink, t9 Oh. St. 35 I; Sihiel v. Baumel, 75 Wis. 69. But it is not necessary that he should understand the legal effect of such laches. Cheshire v. Tuythr, 20 Iowa, ty2; Gians a. liunk, S5 Ill. 4t4; Mattherits v. Allin, i6 Gray (Nass.) 594.

Waiver, at or before maturity, of presentment and notice upon an instrument indorsed by a partnership may be by one of the partners as agent of the others, and this even though the partnership is dissolved, since it docs not create a new

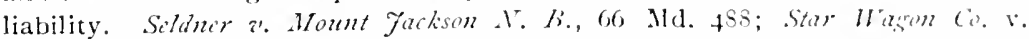
Sive ze'y, 52 Iowa, 39I. But it seems that waiver after maturity, the firm being discharged for want of presentment or notice, would not revive the olligration. 2 Daniel on Neg. Inst., I I Ioga, citing Hart v. Loms, I Rob. (Lat.) 83; Mauncy, Coit, 80 N. C. 300 ; Bair v. Lifpert, I2 Hun (N. Y.) 5 IG. - En. 
95 North Carolina, 535. - I886.

ACtion against indorser of inland bill of exchange for $\$ 90$ upon the margin of which were the words "No protest." There was no notice of dishonor. After dishonor defendant offered to pay $\$ 60$ for the draft. Judgment for plaintiff.

Ashe, J. . . His Honor charged the jury that they might consider the words "No protest," on the draft, and the language and conduct of defendant when he was informed by the plaintiff of the non-payment, and the offer to pay $\$ 50.00$; and that if the defendant had offered to pay $\$ 60.00$, as alleged by Shaw, it amounts to a waiver.

We find no such error in the charge as entitles the defendant to a new trial. There is some fluctuation in the decisions of the courts upon the question, how far a promise to pay a part of a draft is a waiver of demand and notice of non-payment. For instance, it has been held by some of the authorities, that when the promise is only as to part of the stim, it is only a waiver fro tanto, and the plaintiff could only recover that amount. (Flitcher v. Froggart, 2 Car \& P. 569 , I 2 E. C. L. R.) On the other hand, it has been held, that " a promise to pay generally, or a promise to pay a part, or a part payment made with a full knowledge that he has been fully released from liability on the bill by the neglect of the holder, will operate as a waiver, and bind the party who makes it for the payment of the whole bill." (Dixon v. Elliot, 5 Car. \& P. 437 ; Margetson V. Aitkin, 3 Car. \& P. 3 SS; Harey v. Troupe, 23 Miss. 53S.) So it would seem, that the weight of the authorities, supported the charge of the judge in this particular.

But aside from this, his Honor, in his charge to the jury, told them they might consider the words " No protest," written on the margin of the draft, as evidence of a waiver of notice of presentment and non-payment. The words "No protest," written on the margin of this draft, must have been put there with an object, and we can conceive of noze other than to dispense with the notice of presentment and refusal to pay, otherwise it is unmeaning.

It is well settled that protest, being a part of the custom of merchants which is essential in foreign bills to fix the drawee and indorsers with liability, is not necessary for such a purpose in inland bills. (Hubbardv. Troy, 2 Ired. I34; I Parsons on Notes and Bills, 643.) But even in foreign bills the protest may be waived. There the words, "I waive protest," or " Waiving protest," or any similar words, infer that the protest is waived, and when applied to foreign 
bills, was universally regarded as expressly waiving presentment and notice, the protest being, according to the law merchant, the formal and necessary evidence of the dishonor of such an instrument. In waiving " protest," the party is considered not only as dispensing with a formality, but as dispensing with the necessity of the steps which must precede it, and of which it is merely the formal, though necessary, proof of what the law required. (2 Daniel on Neg. Inst., $\$$ ro95.) But when the waiver of protest is applied to inland bills, the protest having no application to such instruments, there is a diversity of opinion in the Courts and text-books, whether such a watver would have the effect of dispensing with notice in an action upon an inland bill. But the better opinion is, that as the word "protest" has by" general usage a well-known signification, and wherever it is used, it is supposed to mean something more than the formal declarations of a notary. Hence, Mr. Daniel, who is a very high authority on the subject, says, "The weight, as well as the number of authorities, predominates in favor of construing a waiver of " protest " to signify as much when applied to inland bills and notes, as when used in respect to a foreign bill.",

"Inland bills and promissory notes may be protested, by statutory enactments, in many States, and the protest is accorded the same effect as to them, when it is made, though it is not necessary to make it, and the weight, as well as the number of authorities, )rdominate in favor of construing a waiver of protest to signify as much when applied to inland bills and notes, as when used in respect to a foreign bill." (\$ ro95a, and the cases cited in note 2. )

The doctrine there laid down, must then apply to this bill, for we have a statute which provides that when it may be necessary to prove a demand upon, or notice to the drawer or indorser of a bill of exchange, or a promissory note, or other negotiable security, the protest taken before a proper officer shall be prima facic evidence that such demand was made, or notice given, in the manner set forth in the protest. (The Code, $\S 49$.)

Our conclusion is, there was no error. The judgment of the Superior Court is therefore affirmed.

No error.

Affirmed. ${ }^{2}$

1 Waiver of protest is waiver of presentment and notice. There seems to be no decision on this point as far as concerns a foreign bill of exchange, although the text writers lay down the rule in positive terms. 2 Daniel on Neg. Inst.. $\$$ ro95; Broun v. Hull, 33 Gratt. (Va.) 23, 31 (dictum). In the case of inland bills and promissory notes, the conclusion is gencral that "waiving protest" waives presentment for pavment and notice of dishonor. Iancaster First $\Lambda$. B. v. Hartman, i 10 Pa. St. Ig6; Johnson r. Parsons, I fo Mass. 173: Jaccard v. 
(c) Prior notice for non-acceptance.

$\S I 87$

DE LA TORRE $\because$. BARCLAY.

I STARKIE (K. B.) 7. - I8I4.

ACtion against drawer of a bill. Defence, want of protest and notice.

“ But on further inquiry, it turned out that the defendants' objection did not relate to the want of protest upon the first dishonor of the bill, but to the want of protest on the bill being refused payment on a subsequent presentment at the defendants' request.

Upon this explanation, Lord Ellenborough was of opinion that the answer amounted to an admission of liability, since a second protest was perfectly gratuitous and unnecessary ",

\section{Duties of holder : protest.}

$\S 189$

SUSSEX BANK $\because$ BALDIVIN.

$[\S$ II8]

I 7 NeW Jersey LaW, 487. - I840.

[Reforted herein at f. 50I.] ${ }^{1}$

$\S 189$

BANK OF ROCHESTER $\approx$. GRAY.

$[\$$ II8]

$2 \operatorname{H1LL}(\mathrm{N} . \mathrm{Y}$.), $227 .-\mathrm{I} 8+2$.

Action against indorser. Defence, want of notice. The bill was drawn in Rochester, N. I., payable in Boston, Mass. It was presented by a notary in Boston and on dishonor a certificate of protest was drawn up in due form stating, among other things, that the notary transmitted notice of dishonor to the drawer and indorsers,

Anderson, 37 Mo. 91; Carpenter v. Reynolds, t2 Miss. So7; Hood v. Hallenbeck. 7 Hun (N. Y.) 364; Porter v. Kemball, 53 Barb. (N. Y.) 467; Coddington v. Daris, 1 N. Y. IS6. - ED.

1 When protesi is necessary, the protest fees may be recovered as damages. Worsan v. Rintzel, 7 Cranch. (U. S.) 273; Ticknor v. Branch Bank, 3 Ala. ${ }_{35}$.

Where protest is useless, protest fees cannot be recovered. German v. Ritchie. 9 Kans. Io6; Woolley'v. Tan Volkenburgh, I6 Kans. 20; Waddell's Succession, it La. Ann. 36I. Where protest is proper, but not necessary, as where it is authorized by statute in case of dishonor of an inland bill or a promissory note, protest fees mav be recovered. Legr v. ITinal, I65 Mass. 555; Merritt v. Benton, so Wend. (N. Y.) II7; 2 Daniel on Neg. Inst., \$ 933. Contra: Johnson v. Bank, 29 Ga. 260; I Parsons N. \& B. 646. - ED. 
etc. This certificate was the only proof of notice of dishonor offered by plaintiff.

By the Court, Cowen, J. [After deciding that a notarial seal stamped directly upon the paper, without the use of a wafer, is not a good common-law seal.] Suppose the protest had been duly authenticated, was the addition of a certificate stating notice of protest to the defendant admissible? It was said to be eridence by Johnson, J. in Cape Fear Bank v. Stinemetz ( I Hill's Law. Rep. S. Car. 45); and what I said in Halliday v. McDougall (20 Wend. $8_{5}$ ), is now relied upon, and perhaps rightly, as intimating an impression that he was right. The point decided in the last case was, however, that the giving of notice being the usual, not official duty of the foreign notary, and he being dead, the entry in his official record of notice being sent might be received by way of memorandum as secondary evidence. I admitted that it might not be his official business; and instituted no particular examination whether it was or not. The learned counsel for the plaintiffs has not been able to furnish anything more than what I there mentioned, going to support the notary's certificate as evidence of notice. I have been equally unsuccessful after considerable search. On the contrary, I find it expressly asserted in Brooke's Office of Notary (pp. 79 and 139), that the giving of notice is no part of his province or duty as notary. In the late case of Fitler v. Morris (6 Whart. 406, 415, March T. I $S_{41}$ ), this very question was a good deal considerd by the supreme court of Pennsyvania; and they held, that though by the local law of that State, the giving of notice is a notarial act, and on that ground proveable by his certificate, yet this is an exception to the common law. They therefore refused to receive a notarial certificate made in Alabama, as evidence of notice, or anything beyond the presentment and nonacceptance. I am entirely satisfied that such is the law of England and this State.

It is scarcely necessary to observe, that our statute (Sess. $5^{6}, \mathrm{p}$. $395),{ }^{1}$ relative to proof of notice by certificate, applies to none other than notaries of this State. ${ }^{2}$

There must be a new trial; the costs to abide the event. New trial granted. ${ }^{3}$

${ }^{1}$ L. I833, c. $271, \$ 8$. Re-enacted in substance in N. Y. Code Civ. I'roc. \$ 923. - Ed.

2 It is now provided (Code Civ. Proc. $\$ 925$ ), that froof of dishonor, and notice of dishonor, of an instrument payable in another State or country, may be mate in any manner authorized by the law of the State or country where it is payble. McAndrew v. Radzoy, 34 N. Y. 5 II; Lawsen $\because$ Pinckney, to N. Y. Super. Ct. I87. - ED.

${ }^{3}$ A notarial certificate is not competent proof of service of notice in the 
absence of statute. Real Estate Bankv. Bizzell, 4 Ark. I89; Rives v. Parmley, I8 Ala. 256; Schneider v. Cochrane, 9 La. Ann. 235; Schorr v. Woodlief, 23 La. Ann. 473; Swayze v. Britton, 17 Kans. 625.

Statutes now generally make a notarial certificate prima facie evidence of the giving of notice. As to these statutes and their construction, see 4 Ain. \& Eng. Encyc. Law (and ed.), pp. 389-393. Where a notary's certificate may include a certificate of notice of dishonor, such certificate of notice may be written below the body of the certificate and even below the seal. Olcott v. Tioga $R$ Co., 27 N. Y. 546; Jordan v. Lons, Iog Ala. 4I4. - ED. 


\section{ARTICLE IX.}

\section{Discharge of Negotiable Instruments.}

\section{Discharge of the instrument.}

\section{Parifint and Re-transher.}

$\S 200$

$$
\text { STODDARD } \tau \text {. BURTON. }
$$

4 I IOWA, 5S2. - I575.

Action against the maker on a lost or stolen promissory note payable to A, or bearer, on or before Jan. 6, r $\$ 6 \$$. Defence, payment to the holder (Thompson) on Oct. II, I866. Judgment for plaintiff.

DAY, J. . . The defendant asked the court to instruct the jury as follows:

“I2. The note in controversy was payable on or before a certain date. This made the note payable at a fixed time absolutely, and sooner if defendant saw fit to pay it sooner. Such were the express terms of the contract, and, therefore, no presumption of bad faith can arise from the simple fact that defendant paid it when lie did, though by its terms payment could not have been demanded or enforced at the time. Defenclant had the right to pay whenever he chose to do so."

The court refused this instruction, and gave the following:

“ 8. A promissory note, payable on or before two years after date, is due at the end of two years and not before; the rule of law being that the note becomes due at the time when the payee or legal holder or owner of the same has the right to demand payment, and this is true, although the note provides that the payor may at his option pay the same before the time fixed when it shall absolutely becomes due."

"9. The payment of a note by the payor before it becomes due, to a stranger who may have possession of the note, will not protect and discharge the maker, if said note has been stolen, or otherwise surreptitiously come into the hands of the party presenting the same."

Other instructions given embrace the sime doctrinc.

There was error in giving these instructions, and in refusing that asked. The note was payable to the bearer, and there is a presumption that the person in possession of it, and who presented it for payment, was the owner. It has been declared in general terms, 
that the payment of a note which has been lost or stolen, before it is due, does not discharge the maker from liability to the real owner, because the payment is out of the ordinary course of business. (2 Parsons on Notes and Bills, 255, and cases cited.) ${ }^{1}$

But the note in question, by its express provisions, at the option of the maker, is payable at any time within two years from its date. Whilst the holder could not enforce payment before January 6, I868, yet the maker might claim the right to make payment before that time. It cannot be said to be out of the ordinary course of business for the maker to insist upon a provision which was incorporated for his benefit. No presumption against the bona fides of the defendant can arise from the time of making payment.

The defendant asked the court to instruct in substance that, if Burton paid the note to Thompson in good faith, Thompson being in possession of it, and believing him to be the owner, without actual notice or knowledge that it was stolen, then Burton was protected by such payment, and that mere suspicion on Burton's part as to Thompsons's right to demand payment or negligence in making inquiries was not enough to invalidate payment; but to do so, it must appear that Burton had acted in bad faith. The court refused this instruction, and in substance directed that a payment made under circumstances that would put a reasonably prudent man upon inquiry as to Thompson's right to receive payment would not protect nor discharge defendant.

This action was erroneous. Mere suspicion that a person in possession of a note payable to bearer may not be the owner, will not exonerate the maker from payment; but there must be circumstances amounting to clear proof that he is a fraudulent holder. ${ }^{2}$ (Story on Prom. Notes, $\$$ 6i 3 , and cases cited; Gage v. Sharp, 24 Iowa, I5; Lake r. Reed, 29 Id. 258; Goodman r. Simonds, 20 How. 343; I Parsons on Notes and Bills, 238; 2 Id. 2 I 2, 279.)

For the errors discussed, the judgment is

Reversed. ${ }^{3}$

\footnotetext{
${ }^{1}$ Disapproved in Bainbridte v. City' of Louiszille, $8_{3} \mathrm{Ky} \cdot 28_{5}$ - ED.

${ }^{2}$ See $\$ 95[56] .-$ ED.

${ }^{3}$ See ItS [SS]. cf. Buhler v. McCormick, (II1.) tS N. E. Rep. 287. If an inserument is paid before maturity and a cancellation legend stamped upon it, and it is afterwards stolen, the cancellation mark effaced, and the instrument put into circulation, a purchaser for value without notice cannot recover on it against the maker. District of Columbia v. Cornell, I30 U. S. 655.

If a negotiable instrument is lost or stolen and the true owner duly notifies the maker, the latter must, at his peril, make sure that a subsequent payment is to a holder in due course. Bainbridge v. City of Louisville, $\mathrm{s}_{3} \mathrm{Ky} .28_{5}$; Chapfelear v. Martin, 45 Oh. St. I26.
}

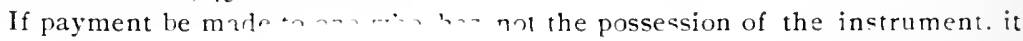


47 Northeastern Rep. (Mass.), 1016. - 1897.

ACtion against Edward $B$. Downing as maker of a note. After the note matured, plaintıff took a new note for $\$+50$ from the indorser, William B. Downing, which included the amount of the note in suit and another note of \$200 given by $\mathrm{X}$. Plaintiff retained possession of the note in suit and said note of $\$ 200$.

Mortor, J. - The defendant is the maker of the note in suit. As between him and William B. Downing, the indorser, it was an accommodation note. But there is nothing to show that this was known to the plaintiff, or that it took the note otherwise than in good faith and for value. Whether the $\$+50$ note operated as payment of it was a question of fact depending on the intention of the parties, and the other circumstances surrounding the transaction. (Brigham r. Lally, I30 Mass. 485 ; Dolge r. Emerson, I 3 I Mass. 467 ; Green r. Russell, I32 Mass. 536; Eume's v. Cushman, I35 Mass. 5i3; Woods a. Woods, 127 Mass. I 4 i Cotton r. Bank, I +5 Mass. 45, I 2 N. E. 850.) The court must have found that it did not, and its finding is conclusive. (Brigham v. Lally, supra.) There was nothing, we think, in the arrangement between the plaintiff and William B. Downing that operated to release the defendant. His liability to the plaintiff was an absolute one. Delay on its part to enforce payment, from whatever motive, or however long continued, if not for six years, would not release him. We do not see that the case is altered because the delay was at the request of the indorser, and accompanied by an agreement between the plaintiff and him that the defendant's orerdue note should be regarded as security for the new note given by William B. Downirg.

Exceptions overruled.'

is at the peril of the payor. Whecler v. Guild, 20 Pick. (Mlass.) 545. So also. it seems, if the one to whom payment is made does not actually produce the instrument. Murphy v. Barmard, i62 Mass. 72. See also Miliox r. Aultman $64 \mathrm{Ga}$. 54t; University Bankv. Tuck,96 Ga. 465. If the instrument is indorsed $\mathrm{i}_{\mathrm{n}}$ full, payment to any one except the indorsee (even to one in possession of the instrument) is at the peril of the payor. Doubleddy $\mathrm{v}$. Kiss, $50 \mathrm{~N}$. I. 410. - ED.

2 Whether a renewal note is taken in payment of the former note, or merely in extension of the obligation of the former note, is a question of the intention of the parties. Matter of Utica National Brewing Co., 154 N. Y. 265. - Ev. 
I37 New YoRK, 444. - I893.

Action on a promissory note. Defence, part payment by indorser. Judgment for plaintiff.

Finch, J. - We have a novel and interesting question before us on this appeal, although its apparent importance will lessen as we pass from first impressions to some slower reflection. It arises upon facts which are very brief and simple and may at once be stated. The defendant, Pierce, made his promissory note payable to his own order and indorsed it to the Bates Co., Limited, which indorsed it to the plaintiff bank; the latter discounting it and paying the proceeds over to the inmediate indorser. Thereafter the Bates Co. became insolvent and passed into the hands of a receiver, who paid to the bank upon the liability of the indorser seventy-three and one quarter per cent. of the amount secured by the note. Later, the bank sued Pierce, the maker, and recovered judgment for the full amount of the note in spite of the proof showing the payment made by the receiver, and in disregard of the claim asserted by the defendant that he should only be held liable for the balance remaining unpaid. That judgment has been affirmed by the General Term, Judges Daniels and Barrett each writing very strong and valuable opinions in support of their doctrine, and relying upon the authority of Foncs v. Broudhurst (9 M. G. \& S. 177; 67 Eng. Com. L. 175), which fully warrants their conclusion. The question does not seem ever before to have arisen in this country, and we are left at liberty to examine the English rule and to follow it or not as we approve or disapprove its logic and its consequences.

We are not to regard the note as being accommodation paper, but must assume its transfer for value. The form of the transaction is equivalent to what it would have been if the Bates Co. had been named as payee, and loses none of its force by the intervention of the maker as first indorser. That indorsement, in the form adopted, was needed for the regular transfer of title, but does not change or affect the nature and character of the maker's liability. He remains the ultimate debtor, the person who ought to pay the debt, in preference to and in exoneration of all the other parties to the paper, who in some form or other are entitled to have final recourse to him.

And it is to the case of such a maker of the note or such an acceptor of the bill of exchange that the English rule alone applies: and it is explicitly declared inapplicable where the indorser or drawer is the real debtor, although in form only secondarily liable.

Pierce, therefore, was the ultimate debtor, and the party who ought 
to pay the note, both in discharge of the obligation to the holder and in exoneration of the indorser. When the bank sued on the note, it was the legal holder and the legal party in interest. Upon production of the paper and the usual proof, judgment against the maker for the full amount was inevitable, unless some defence should be interposed. The only possible one for Pierce was part payment, and he was compelled to assert, and his counsel are compelled to argue, that the money paid by the indorser to the holder inured to the benefit of the maker as a payment on his debt. But that doctrine cannot prevail for very obvious reasons. The indorser's payment did not in the least lessen or satisfy the maker's debt. He owed it all exactly as before. What had happened possibly changed somewhat the real creditor, but left the whole debt due and unpaid. To whom he should pay might become a new question, but how much he should pay in discharge of the note was not made doubtful in any degree. What the receiver adranced to the holder is familiarly described as a payment; but it was such relatively to the indorser's liability alone; while relatively to the obligation of the maker, it was an equitable purchase instead of a payment. That view of it was taken in a very early case, the decision of which depended necessarily upon it. In Callow r. Lawence (3 Mau. \& Sel. 95), it appeared that one Pywell drew a bill upon Lawrence to his own order, which Lawrence accepted. The drawer indorsed the bill to Taylor, who discounted it and thereafter indorsed it to Parnett. It was protested for non-payment. The drawer paid Barnett the full amount and took the bill, and, striking off the indorsements of Taylor and Barnett, transferred the bill to Callow, who sued the acceptor upon it. The latter claimed that the bill was paid and extinguished, which the court denied, saying that the drawer "became the purchaser of the bill " when he paid and took it up out of Baruett's hands; that it was not paid by the drawer, animo soliendi, in order to extinguish it, but only to redeem hinseif from the situation in which he stood. That must always be true of payment by indorser to holder, where the maker is the ultimate debtor. To the extent of the money paid, the indorser becomes equitally entitled to be substituted to the rights and remedies of the holder, and becomes, fro tanto, the beneficial owner of the debt; so that the maker's olligiltion to pay the note in full, at first due to the holder solely in his own right, becomes, after the part payment loy the inclurser, still wholly due to the holder, but partly in his own right and partly as trustee for the indorser. A court of law cannot split the note into parts, and must act upon the legal interest and owner:ship.

In the present case there was no privity between maker and 
indorser as it respects the action of the latter. He paid not as the agent of the maker, not at his request, not for his benefit, and under no duty to relieve him, but independently, upon his own obligation, to lessen his own responsibility, and not at all to discharge the ultimate debt which it was the maker's duty to pay. It seems very clear, therefore, that the maker cannot utilize for his own benefit a payment which, as to him, is not a payment upon the debt. It becomes, as I have said, merely a question to whom he shall pay and who may sue for and collect the whole unpaid sum. In that question the maker has no concern beyond the inquiry whether he may become liable to different persons for the same debt and encounter the danger of paying it twice. I can discover no such peril. The judgment in favor of the holder is a bar to any other suit on the same note, and payment to the holder discharges the note utterly. Ordinarily, the indorser cannot recover except upon the note and as holder and in accordance with the law merchant. If he ever has any other right of action against the maker, it is either in equity or by force of some facts beyond the bare relation established by the paper. And where the note is merged in the holder's judgment or paid in full to him by the maker, the indorser's only right is through the judgment or against the proceeds, if he has made a partial payment to the holder. That does the indorser no wrong. If he is not content that the holder shall collect to some extent as his trustee, he may prevent it by payment in full to the holder and so entitle himself to the possession of the note on which to sue, or if judgment has been obtained, to be subrogated to all of the rights of the plaintiff therein.

I think this result is clearly indicated by our own decisions. In Mechanics Bank v. Hazari (13 John. 353), the maker of the note had been arrested in an action upon it and his bail sought to relieve themselves by force of a payment made by the indorser to the holder, but such effect was denied to it; the court saying that it was not a payment by or on behalf of the maker, or of which he or his bail could arail themselves. And in Guernsey. Burns (25 Wend. fII), where the suit was by the holder, representing the legal title and interest, it was said to be no defence to the maker and no concern of his that some property in the note was in another.

It thus becomes apparent that there is no very great importance in the question which method of securing payment from the maker is adopted since the same resuit foilows from each, and that it narrows down to the inquiry whether, as matter of correct doctrine and of convenience in practice, the holder may recover the whole debt against maker or acceptor for himself and as trustee for the indorser 
to the extent of his acquired interest; or whether he shall take judgment only for the balance, leaving the indorser to sue in some way and on some theory, which apparently could not be upon the note because already merged in the judgment, but might be for money paid for the use of the maker since he gets the benefit of it in the reduction of the judgment, as was held in Pownal r. Firrand (6 B. \& Cress. 439), where the holder deducted the indorser's payment from the levy against the maker. The former seems to me to be the logical and convenient method and so I think we should follow the English doctrine.

I have not underrated the assault made upon it by the appellant. He asserts that Fones v. Broalhurst is contrary to the earlier cases and has been criticised and shaken by the later ones. I have examined them all, with some wonder at the amount of learning and ingenuity expended upon the subject. (Pierson v. Dunlop, Cowper, 57 ; Walayn v. St. Quintin, I Bos. \& P. 652; Bacon r. Siarles, I H. B1. S8; Hemming v. Brook, I Car. \& N. 57 ; Randull v. Moom, 12 C. B. 261 ; Cook v. Lister, I3 C. B. [X. S.] 543; Solomon v. Darts, I Cahabe \& Ellis, 83; Thornton v. Maynard, ro Com. P!. L. R. 695.) The prior cases were very fully and carefully reviewed by Baron Cresswell in the opinion rendered in Fonts $\mathrm{v}$. Broalhurst, and of the subsequent cases I deem it only necessary to say, that, along with some criticism and occasional doubt, the doctrine has remained substantially unshaken, and the case last cited was declared by Lord Coleridge to be the accepted law.

It must not be forgotten, however, and I may prudently repeat, that the doctrine has no application to accommodation paper, and rests wholly upon the actual and ultimate indebtedness of maker or acceptor as the party who ought to pay. In such a case as that, which correctly describes the one now before us, and where no disturbing facts affect the relations of the parties as fixed by the paper itself, I think the holder may sue and recover the full anount, receiving so much of the proceeds as represents a part palyment by the inciorser as trustee for him.

It follows that the judgment should be affirmed, with costs.

All concur, except MAYNaRI, J., dissenting.

Judgment affirmed. ${ }^{1}$

1 Payment for honor must also be distinguished. Sice Neg. lnst. L., \$: 300$306[17$ I-I 77 ] - ED.

NEGOT. INSTRUMENTS - 37 . 
64 NeW YORK, 209. - I876.

Action by holder against maker. Judgment for plaintiff at circuit. Judgment reversed at General T'erm. Plaintiff appeals.

EARL, J. - The defendant made the note in suit for the benefit and accommodation of the firm of Lambert and Lincoln. It was discounted and the proceeds passed to their credit by the North River Bank. Each member was therefore bound, as to the maker, to pay the note, and thus save him from liability on account thereof. Before the note became due the firm was dissolved, and Lincoln was to close up its business. Plaintiff lived in Canada, and Lincoln wrote him, requesting him to take up the note and furuish the money for that purpose. Plaintiff, a few days before the maturity of the note, sent Lincoln the money, which he placed in the bank to his individual credit. On the day the note fell due he werit to the bank, and, by his indiridual check, paid the note to the discount clerk, who knew at the time that it was an accommodation note. He did not assume to act as agent for any one, and did not ask to have the note transferred to any one, and did not mention plaintiff's name in any way. It is true that he asked to have the note protested so that he could hold the indorser and maker, but he did not disclose why he wanted to hold them. After he had thus paid and taken it, he sent it to the plaintiff.

Upon such a state of facts, did plaintiff take his title from the bank or from Lincoln? If he took it from the bank, he took the place of the bank, and his title and right to enforce it were as good as those of the bank at the time he took it. But if he took it from Lincoln, it being past due, he took it subject to any defence defendant could have made if sued by Lincoln, and in such case defendant's defence would have been perfect. He could not be successfully sued by either of the persons for whose accommodation he made the note.

Plaintiff did not take title from the bank. It matters not that he furnished the money, and that Lincoln promised to use it in taking up this note for him. It matters not that the note was protested so that the indorser and maker could be held, or that the bank did not intend absolutely to discharge and cancel the note. The question is, did the bank transfer or sell the note to the plaintiff? To make a sale or transfer takes two parties, one to sell and the other to buy, and the bank could not be made a seller without its knowledge or consent. It was not bound to sell or transfer the note. All it was bound to do was to surrender it upon payment by the person liable 
to pay it. A seller in such a case incurs some obligation by the sale, although he does not indorse the paper. He impliedly warrants that the paper is genuine and all it purports to be on its face, and he cannot be drawn into this implied warranty without his consent. (Eastman v. Plumer, 32 N. H. 238 ; Delawite Bank v. Farilis, 20 N. Y. 226; Morrisonv. Currie, +Duer, 79; Aldrich v. Fackson, 5 R. I. 218; 2 Parsons on Notes and Bills, 2d ed. 37.) All the bank did in this case was to take payment of the note, and deliver it up to a party paying and liable to pay, after protesting it, so that he could make such use of it as the law and the facts would authorize. It did not transfer or intend to transfer it. The plaintiff, therefore, took no title to it from the bank, but he took it from Lincoln, and cannot, therefore, enforce it against the defendant.

The order of the General Term must, therefore, be affirmed, and judgment absolute ordered against the plaintiff, with costs. All concur.

Order affirmed and judgment accordingly.

\section{Cancellation or Renunciation}

go New YORK, 333. - issa.

ThIs action was brought to recover the amount of a promissory note executed by defendant to Isaac C. Loper, plaintiff's testator, which the complaint alleged had been lost or destroyed.

The referee found that said Loper executed to defendant a deed of certain premises, and in consideration thereof, the note in suit was executed, and delivered to the grantor, who thereafter volun-

${ }^{1}$ If an instrument is retransferred to the maker or acceptor at or after maturity, the transaction is treated as a payment, and the instrument cannot be reissued or negotiated. Harmerv. Stech, + Exch. Rep. I; Rallard v. Gremliush, 24 Me. 336 ; Ferree v. Viw York, ctc. Co. It Fed. Rep. 760. But if it be transferred to the maker or acceptor before maturity, the transaction may be shown to be a purchase and not a payment and the instrument may be re-issuet. Attentiorough v. Mackensie, 25 I. J. Ex. 24t; hogers V. Gallughler, t9 III. 182;

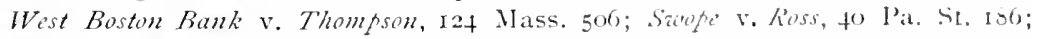
Eckert v. Cameron, +3 Pa. St. I20. Contra: Lons v. Cynthiona bank, I Litt. (Ky.) 290; Stark v. Alford, t9 Tex. 260.

If an instrument is retransferred to one of two or more joint makers, before maturity, and re-issued by him, it seems that his transferee sets only a right of contribution against the other joint makers. The case is distinguished from that of a single promisor. Sterens $v$. Hannan, S6 Mich. 305; S. C., S8 Mich. 13; Kueiland v. Mile's (Tex.) $2+$ S. W. Rep. I113. - Ev. 
tarily and intentionally canceled, destroyed, and surrendered up the same to the defendant.

Miller, J. - The note described in the complaint was given by the defendant to the plaintiff's intestate, upon the conveyance to him of certain real escate, and as a consideration therefor, on the I Ith day of October, I $\$ 70$. The referee before whom the trial was had has found that in or about the month of January, $187 \mathrm{I}$, the grantor voluntarily and intentionally canceled, destroyed, and surrendered up to the defendant said security and note, and as a conclusion of law, the intestate discharged the defendant thereon, and that no recovery could be had either on the note or on the original consideration. We think that the finding of fact by the referee is sufficiently supported by the evidence, and that the conclusion arrived at was the legal and necessary result of said finding. The rule seems to be well settled by the authorities that where an obligee delivers up the obligation which he holds against another party, with the intent and for the purpose of discharging the debt, where there is no fraud or mistake alleged or proven, that such surrender operates in law as a release and discharge of the liability thereon; nor is any consideration required to support such a transaction when it has been fully executed. (Bouv. Law Dict., title Release; Albert's Ex'rs v. Ziegler's Ex'rs, 29 Penn. St. 50; Beach v. Endress, 5 I Barb. 570 ; Doty v. Wilson, 5 Lans. ro.)

There certainly could not be higher evidence of an intention to discharge and cancel a debt than by a destruction and surrender of the instrument which created it, to a party who is liable by virtue of the same.

Judgment affirmed.

203

$$
\text { SLADE } i \text {.' MUTRIE. }
$$

$[S \quad 122]$

I56 Massachusetts, I9. - I892.

ACTION to recover the balance of a promissory note. The defendant paid the plaintiffs $\$ 125$ and received a receipt " in full settlement of all accounts to date," and the note. Charge: That if the plaintiffs surrendered the note to be canceled intending to give the defendant the balance of the debt, plaintiffs could not recover; but if the note was delivered in order that defendant might exhibit it and upon defendant's promise to pay the balance, plaintiffs could recover.

The jury returned a special finding that the plaintifis intended to receive the one hundred and twenty-five dollars " in full for the debt 
then due," and further returned a general verdict for the defendant; and the plaintiffs alleged exceptions.

Field, C. J. - The counsel for the defendant concedes that, by the law of this Commonwealth, the payment of a part of a debt after the whole debt has become payable is not a sufficient consideration to support a promise not under seal to discharge the remainder of the debt. (Brooks v. White, 2 Met. $28_{3}$; Hariman v. Hariman, I2 Gray, 3+1; Potter r. Green, 6 Allen, +t2; Grinnell r. Stink, I2S Mass. 25; Lathrop v. Page, r 29 Mass. 19; Tyler v. Odd Fillowis' Relief Association, 145 Mass. г 34 , г3i; Fodkes r. Bier, 9 App. Cas. 605$.

The jury, in returning a general verdict for the defendant, must have found on the judge's charge that the note was surrendered by the plaintiffs to the defendant that it might be canceled, and that the plaintiffs intended by delivering the note to the defendant to give him the note and discharge the remainder of the debt.

For certain purposts, a bill of exchange or a promissory note is regarded in this Commonwealth, not merely as eridence of a debt, but as the representative of a debt, or the debt itself. Each may be the subject of a gift, but to constitute a gift there must be a delivery by the owner to the donee, with the intention of passing the title. (Grozer v. Groter, 24 Pick. 26r; Sessions r. Moseley, + Cush. 87 ; Bates v. Kempton, 7 Gray, 382 ; Chase v. Reddins, I 3 Gray, 418. See Sheedy v. Roach, I2+ Mass. 472 ; Pierce v. Boston Fine Cents Sazings Bank, 129 Mass. 425; Taft v. Bowerer, 132 Mass. 277; McCann v. Randall, I.t7 Mass. Si; Cochrane V. Moore, 25 (2. B. I). 57; Gammon Theological Sem. v. Robbins, IzS Ind. $8_{5}$.)

It follows from this, that the delivery of a promissory note by the holder to the maker, with the intention of transferring to him the title to the note, is an extinguishment of the note, and a discharge of the obligation to pay it. (Hale v. Rice, 12+ Mass. 292; Steriort v. Hidden, I3 Minn. 43; Ellswiorth v. Fors. 35 Vt. 355; I'tmlerleck v. Vanderbeck, 3 Stew. $265 ; \mathcal{F}$ off ray v. Danis, $12+$ N. Y. I64, 170.)

Exceptions overruled. ${ }^{1}$

\footnotetext{
${ }^{1}$ See the provisions of $\$ 62$, subsec. I of the Bills of Exchange Act, (corresponding to $\$ 203$ [122] of the Neg. Inst. L.), construed in Filturlds v. Walters, I $896,2 \mathrm{Ch}$. 157, where it was held that a delivery to the derisee of the maker was not a delivery to the maker, though, semble, a delivery to the executor or administrator would be. - ED.
} 

FLETCHER.

68 VermoNt, Si. - I 395.

Action against a surety on a promissory note. Judgment for plaintiff.

Rowell, J. - The defendant was surety for Walter on a second renewal note to the plaintiff bank. Walter had put $\$ 20,000$ of securities into the defendant's hands, in consideration of which he agreed to and did indorse for him to that amount, of which said note was a part. The bank knew that the defendant was surety, but did not know that he had security. Said note was taken up by a note that Walter sent to the bank, signed by him and purporting to be signed by the defendant, but on which he had forged the defendant's name. There were several like forged renewals, but the defendant had no knowledge of any of them till the bank notified him of the approaching maturity of the last one and informed him that it would not be renewed; whereupon he went to the bank, saw the note, pronounced his name thereon a forgery, and refused to payit, and thereupon, at its maturity, this suit was brought thereon and on the three genuine notes and another of the forged renewals.

When the last genuine note was thus taken up, the bank stamped it "Paid," and sent it to Walter, who carried it to the defendant, who, when he saw it, was thereby induced to believe and did believe that it was paid and extinguished and he released therefrom, and thereupon, relying on that belief, he signed another note for Walter for the same amount, which otherwise he would not have done, and whereby he was damnified.

The defendant never had anything to do with the bank concerning any of the notes except as aforesaid, but the business was all done by Walter.

The defendant conceded that the bank believed the forged renewals were genuine, and acted upon that belief in taking them, and otherwise would not have taken them; but he claimed that the cashier was negligent in taking the first forged renewal and stamping and giving up as paid the last genuine renewal, for that the forgery was so manifest that, as a careful and prudent man, with both notes before him, he ought to have detected it; and he asked to go to the jury on that question, claiming that if the negligence was found, the plaintiff would be thereby estopped from recovery on the last genuine note.

The defendant also claimed that by stamping said last mentioned note "Paid" instead of "Renewed," as the fact was, the bank 
made a false statement, to its knowledge, and that when it sent the note to Walter thus stamped, it ought to have known that he would show it to the defendant, and that the defendant would be thereby induced to believe it was paid and extinguished, and to act accordingly, to his prejudice, or, at least, that it ought to have known that such would naturally and probably be the fact, and that if the jury should find that the bank, in the exercise of the requisite care and prudence, ought to have so known, then what it did in this behalf amounted to a representation by it to the defendant that the note was in fact paid and extinguished; and if it was further found that the defendant acted upon that representation to his prejudice, the plaintiff would be estopped from recovery on that note.

The defendant further claimed, that if the parties are to be regarded as equally innocent in the matter, and the taking of the first forged renewal and the stamping and giving up as paid of the genuine renewal were a mere mistake on the part of the bank, then the loss must still rest upon the plaintiff, which made the mistake, and on which the chances of business have placed it.

But the court ruled against the defendant on all his claims, and directed a verdict for the plaintiff for the amount of the last genuine renewal, to which the defendant excepted; and he now makes substantially the same claim that he made below.

It was undoubtedly the duty of the bank to act in good faith towards the defendant in the matter, but it was under no further duty to him. (Bank of Vezhury. Richards, $35 \mathrm{Vt} .2 s_{1}, 2 S_{4}$ ) The presentation by Walter of the first forged renewal was a representation by him that it was genuine, and the bank, certainly with nothing to arouse its suspicion, owed the lefendant no duty to distrust Walter and to examine the two notes to see whether his representation was true or not. No case is cited nor principle suggested requiring that. A bank is bound to know the signature of its depositor, and, therefore, if it pays a forged check purporting to be lis, it must bear the loss. So the acceptor of a bill is bound to pay it although the drawer's name is forged, for the presentation of the bill is a direct appeal to him to accept it or to reject it. It is an incuiry as to its genuineness, addressed to the one who, of all others, is supposed to be best able to answer it, and whose answer is most satisfactory. He is, moreover, the person to whom the bill itself points as the legitimate source of information to others, and if he were permitted to dishonor the bill after he has once honored it, the very foundation of confidence in commercial paper would be shaken. But the drawee of a bill is not hound to know the signature of the payee, nor to examine and ascertain whether the indorsement is 
genuine; and if he pays on a forged indorsement, though to an innocent holder, he can recover the money. (Corn Exchange Bank v. Nassau Bank, 9I N. Y. 74; Insurance Co. V. Bank, 60 N. H. 442.) Nor is a bona fide indorsee, whether before or after acceptance, bound to inquire into the genuineness of a bill, in order to retain the money received by him from the drawee in payment thereof. (Price v. Neale, 3 Burr. r 354 , a case that has never been departed from.) So if a bank receives as genuine, fraudulently altered bills of its own, and passes them to the credit of a depositor who acts in good faith, it is bound by the credit thus given, for it was its duty to know its own bills. (Bank of the United States v. Bank of Georsia, Io Wheat. 333.)

But the case at bar is unlike the case of a drawee who pays or accepts a forged bill, or of a bank that receives as genuine, forged notes purported to be its own, for here the bank was not bound to know the defendant's handwriting, and it was not its duty to examine with reference to ascertaining a thing that it was not bound to know. But by this we do not mean to say that it could shut its eyes that it might not see, or turn away lest otherwise facts might be disclosed at variance with what it represented to exist, for that would be bad faith and breach of its duty. It follows, therefore, that as here was no duty to examine, there was no negligence in not examining.

Nor was the representation of payment that the bank made, false to its knowledge, as claimed, but true in its belief, in substance and effect, for had the forged note been genuine it would, in law, have paid the other note and extinguished it as affording a cause of action against the defendant; and as knowledge of the falsity of the representation is not imputable to the bank, as it was not in a position that it ought to have known, there can be no estoppel on this score.

The case comes to this, then, that said representation was a mistake on the part of the bank, arising from its non-culpable ignorance of the truth, and brought about by the fraud of Walter; and it would seem that a representation induced by fraud will not estop. (Big. Estop., 3d ed. 49r.)

But it is claimed that if a mistake, the case is one that calls for the application of the rule that when a mistake has been made from which one of two innocent parties must suffer, he must suffer who made the mistake, especially when, as here, the chances of business have placed the loss upon him; and The Gloucester Bank v. The Salem Bank ( 7 Mass. 33,) is cited in support of this proposition. That was a case in which the plaintiff had paid to the defendant, notes on which the name of its president had been forged, but which were otherwise genuine, and had neglected for fifteen days to return 
them; and the court stated the question to be, whether, as between the parties who were equally innocent and ignorant, the loss should remain on the plaintiff, where the chances of business had placed it, or be shifted back upon the defendant, which had, by good fortune, rid itself of it. It then went on to say, that in all such cases the just and sound principle of decision had been, that if the loss could be traced to the fault or neglect of either party, it should be fixed on him; but that generally, when no fault nor negligence was imputable to either party, the loss had been suffered to remain where the course of business had placed it. But the first part of that principle is not applicable here, for the loss is not traceable to the fault nor the neglect of the plaintiff. Nor is the second part any more applicable, for it can hardly be said that the chances of business have placed the loss on the plaintiff, but rather on the defendant; but if it can, the plaintıff, in legal effect, holds the defendant's note, and it has not been paid, and the plaintiff is not estopped from collecting it of him. In these circumstances, the chances of business can avail the defendant nothing.

Judgment affirmed. ${ }^{1}$

\section{Alteration.}

(a) Effect of alteration.

$\S 205$ HORN AND LONG i'. NEWTON CITY BANK. [\$ I24] 32 Kaxsas, 5I8, - r854.

Action against makers of a promissory note. Judgment for plaintiff against both defendants.

The note was given by defendants to a named payee for the purchase price of a threshing machine which defendants intended to run as partners. Horn and the payee authorized the note to be changed so as to make one Hildreth the payee. Long did not know of or afterward consent to the change.

The opinion of the Court was delivered by -

Horton, C. J.: - It is the contention of Long, one of the plaintiffs in error - a defendant below - that there had been a material alteration in the note sued on without his consent, thereby relcasing him from all liability upon it. The note was originally drawn payable to "H. A. Pitts' Sons Manufacturing Company," and after having been given to that company it was altered ly substituting the

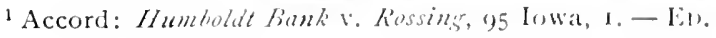


name of "O. B. Hildreth" for the original payee. This alteration was made without the knowledge or consent of Long, and he has never consented to or ratified the same. Within all the authorities, the substitution of $\mathrm{O}$. B. Hildreth in the place of the original payee was a change of the personality of one of the parties to the note, and therefore a material alteration. (Bank v. Hall, r Halst. N. J. L. 215 ; Stoddard v. Penniman, ro8 Mass. 366 ; Draper v. Wood, r 22 Id. 315; 17 Am. Rep., pp. 92, 106; 2 Daniel on Neg. Inst., $\$ \$$ г $387-1390.)^{1}$

If Horn and Long had been associated together in a trading partnership, then either member of the firm might have bound his co-partner by executing a promissory note in the name and on behalf of the firm, in any transaction pertaining to their partnership business. We suppose that under such circumstances, the material alteration of a note executed by the firm, with the knowledge and consent of one partner, would bind his co-partner, if the note had been given within the apparent scope of the business of the firm, as it is a general principle relating to trading partnerships that each partner is the lawful agent in the partnership in all matters within the scope of the business. (Deitz v. Regnier, 27 Kans. 94.)

A non-trading partnership, however, is controlled by rules differing from those controlling a commercial or trading one. (Deitz v. Regnicr, supra.) Under the findings of the court, Horn and Long were partners only in the running of a threshing machine, and such a partnership is one of occupation or employment only. It is not a commercial or trading partnership. There was joint ownership between Horn and Long in the threshing machine, and there was a co-partnership between them in the matter of operating the machine, with the intention of dividing the profits and losses equally; but yet their business did not require the execution of negotiable paper as the proper, convenient, and usual mode of conducting it. In a partnership to operate a threshing machine there does not exist the implied power in the several members to make promissory notes, and thereby hind the firm. Whoever deals with an individual jointly interested with another in the operation of a threshing machine must, at his peril, inform himself of the nature of the partnership. The note in suit was signed by the makers in their inclividual names, and not as a firm. Therefore, upon the face of the note one of the makers thereof had no right to bind the other without his consent to any material alteration. Horn had no, authority to make a promissory note in the name of the firm or to bind Long, unless the latter had been previously consulted and con- 
sented to the transaction. (Lanier v. MeCalie, 2 Fla. 3z: Prince v. Crauford, 50 Miss. 344; Crossthäait r. Ross, I Humph. [Tenn.] 23: Smith v. Sloane, 37 Wis. 285 , I 9 Am. Rep. $757 ;$ Deardorf v. Thatiher, 78 Mo. I28; I Daniel on Neg. Inst., $\$ 5355-358$.) If he had not the authority to make promissory notes and draw bills of exchange and thereby bind the firm, he had no right to authorize a change of payee in the note executed by him and Long so as to bind Long thereby. The material alteration of a note with the consent of a maker is rirtually making a new note and ante-dating it.

We therefore conclude that the material alteration of the note in question released Long. (Broughton v. Fuller, 9 Vt. 373.) 'That the bank purchased the note before maturity, for a valuable consideration, and is, therefore, a bona fide holder of the note, does not prevent Long from asserting the material alteration of the note as a defence. ${ }^{1}$ (IVait v. Pomerol', 20 Mich. 425: Bentidt r. Cou'den, 49 N. Y. 396; Bank r. Stowell, I 23 Mass. 196; 2 Daniel on Neg.

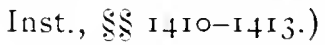

[Omitting a question of practice.]

The judgment against Long will be reversed, and the cause remanded, with direction to the court below to render judgment in his favor upon the findings of fact. ${ }^{2}$

1 "It is urged, however, that the plaintiff, being an innocent holder for value, can recover notwithstanding the alteration, because they propose to recover only the amount of the note as it was before the alteration. If such were the law forgeries by alteration would be protected by the law. The fraudulent payee would run no risk of loss because he would only have to transfer the notu to an indorsee who might recover the original amsu th the note by simply proving that he was innocent of the fraud. But the law is not so charitable to this class of persons." - Gettysburs liat. Hk. v. Chiselm, 160 1'at. St. 504, 560; Citizens Nat. Bk. v. Williams, r7t Pa. St. 6, (doubting the correceness of Kountz v. Kennedy, $63 \mathrm{~Pa}$. St. $\mathrm{I}_{7} 7$, contra).

There is some authority for the proposition that a banker after payment, las the right to hold an altered check for its correct amount as agrinst the maker. Hall v. Fuller, 5 B. \& C. 750; Susquthanna BA. V. Leomis, 85 N. Y. 207; (cf.

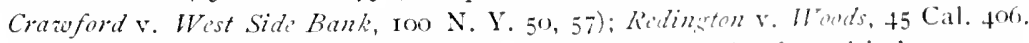
Compare Bills of Exchange Act, $\$ 60$, as to payment under forged indorscment.

Under $\$ 205$ [124] the holder in lue course of an instrument fraudulently altered is now permitted to enforce payment according to the original tenor. Prior to the statute this could not be done, thougls it seems to have been allowed in the exceptional case of Horrall v. Ghich, 39 1'a. St. 3 s. Where the alteration is by a stranger, or, if by a party to the bill, is innocent, many American courts allow a recovery upon the original consileration. Sec cases following. - ED.

${ }^{2}$ There may, of course, be a subsequent ratification of an untuthorized altera-

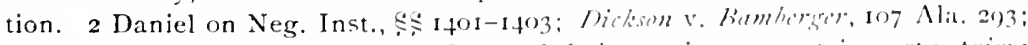
Mratlock v. Whecler, 29 Ore. 64. Blanks lefe in an instrument import a frima 
\$205 [I24] White Sewing Machine Co. $v$. Dakin, 86 Michigan, $58 \mathrm{~s} .-\mathrm{I} 89 \mathrm{I}$. Champlin, C. J. - If any alteration was made after the execution of the bond, it was done by Van Ness, and although he was the agent of the plaintiff, and received and forwarded the bond in question to the plaintiff for its approval or rejection, yet there is no testimony in this record tending to show that he was expressly or impliedly authorized to make any alteration in the bond.

The rule of law is that, when an alteration is made by a third party, it is an act of spoliation, and the alteration, although material, cannot invalidate the written instrument; and when the spoliation is done by the agent of one of the parties, it will not avoid the contract if the agent had no express or implied authority to do it. (I Am. and Eng. Encyc. Law, 505; Van Brunt r. Eoff, 35 3arb. 501; Collins v. Makepeace, I3 Ind. 488; Hunt v. Gray, 35 N. J. Law, 227; Bigelow v. Stilplen, 35 Vt. 52 i ; Hiller v. Reed, 3 Grant, Cas. 5I; S. C. 27 Penn. St. 244 ; Terry v. Hazleweod, I Duv. 104.) The declaration counts upon the bond as being in a penalty of $\$ 1,000$, and assigns breaches of the conditions. It follows that the bond would

facic authority to the holder to fill them. Neg. Inst. L., 33 [It]. But an alteration, although made in order to correct a mistake, and conform the written instrument to the actual intention of the parties, is fatal and destroys the validity of the instrument. Jialman v. King, 54 Oh. St. 273, citing cases contra; Evansv. Foriman, 60 Mo. 449.

A restoration of the instrument to its original form will not revive liability upon it. Citizens . Kat. Bank v. Richmond, I2 I Mass. I10; Locknane v. Emmersort, II Bush. (Ky.) G9; Fulmer v. Seitz, 68 Pa. St. 237 (doubting Fountz v. Kinnedy, 63 Pa. St. 187); Citizens N. B. v. Willians, I74 Pa. St. 66; Ilidunid v. Whitse't, 96 Tenn. Io.

Material Alteration. - As to what changes constitute a material alteration, see 206 [125]; 2 Daniel on Neg. Inst., $\$$ 1373-1404; 2 Am. \& Eng. Encyc. L. (2d ed.), pp. 222-2+6; Iv's v. Farmers' Bank, 2 Allen (Mass.), 236, ante, p. 293.

Burdex of Proof. - There is a hopeless conflict as to the presumption and burden of proof in the case of the apparent alteration of an instrument. One class of cases requires the one offering the paper to explain any apparent alteration. Croswill v. Labree, SI Me. 44; Simpson v. Stackhouse, 9 Pa. St. I86; Gettysburs 1. B. v. Chisolm, i69 Pa. St. 564: Elgin v. Hall, 82 Va. 65o; Cole v. Hills, 4 N. H. 227; Goradiy v. Robbins, 3 App. Div. (N. Y.) 353; Evans v. Diming, 20 Wkly. Dig. (N. Y.) 7 I.

Another and perhaps weightier class of cases raises no presumption against the paper but casts the burden upon the defendant to prove any alleged alterations. Wilson v. Hayes, to Minn. 531; Wolfirmanv. Bell, 6 Wash. S4; Yakima N. B. v. Knipe, 6 Wash. 34 ; Hagan v. Mirchants, etc. Ins. Co., Si Iowa, 32 I; Neil v. Case, 25 Kans. 5 Io; Franklin v. Baker, $4^{S}$ Oh. St. 296; Nezoman v. King, 54 Oh. St. 273. See 2 Daniel on Neg. Inst. SS I4I7-I+2I; 2 Am. \& Eng. Encyc. L. (and ed.), pp. 272-279. - ED. 
be a valid instrument in the hands of the plaintiff for what it was before the alteration was made.

63 IOWA, 15s. - Iss4.

Action on a note, and upon original indebtedness. After the note was given by defendant, with Fuller as surets, the plaintiff innocently procured W. A. R. to sign also as surets. The court held the note void, but allowed a recorery against defendant upon the original consideration. Action dismissed as to Fuller.

BECk, J. - This court has held that the signing of a promissory note by one as a joint maker, after the execution by the original maker, without his knowiedge and consent, is a material alteration, which will defeat the instrument. (Hamilton r. Hooper). it al., t6 Iowa, 5r5; Dickerman v. Miner, 43 Id. 508; Halls Admx. .. McHenry, ig Id. 52 г.)

It has also been ruled by this court that, when a promissory note has been innocently altered, without any fraudulent purpose, the payee may recover in an action brought upon the original consicleration. (Krause r. Meyer, 32 Iowa, 566; Clough r. Searl, t9 Id. 1 II; Morrison Bros. $\vee$ Huggins, ct al., 53 Id. 76 ; Eikert iv IVilliams v. Pickel, 59 Id. 545.)

Upon the facts found by the referee, which are not brought in question, and under the petition which sought to recover upon the original consideration, the circuit court rightly rendered judgment for plaintiff. ${ }^{2}$

${ }^{1}$ Contra: Mersman v. Wrases, I 2 U. S. I39; Royse r. Stati Rank (Neb.), 69 N. W. zor; Babcock v. Murray, 55 Minn. 355 . See, however, Neg. Inst. L., s $206[125]$, subsec. 4. - ED.

${ }^{2}$ Accord (where alteration innocent): Togle v. Riffer, 3t Ill. Ioo; Oarn v. Ilall, 70 Md. 97; Boot/z v. Powers, 56 N. Y. 22; York v. Jant's, 43 N. J. L. 332 ; Miller v. Sturk, I 45 Pa. St. I64; Gorden v. Rohertson, th Wis. t93; Kiche'v. Weeks, (R. I.) 33 Atl. +46. A subsequent indorsee must be trealed also as an assignee of this right of action upon the original considcration in orter io main-

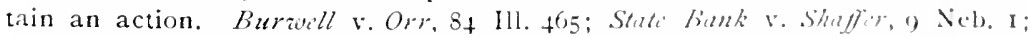
Port IIuron First N. B. v. Carson, 6o Nich. 432. If the instrument constiutes the only obligation, all remedies are lost by a material, though innocent, allerat tion. Crawford v. West Side Bank, 100 N. Y. 50; Titt V. Flikher, it Ind. 102.

A fraudulent alteration extinguishes all remedies. Smith 1 Mact, $4.4 \mathrm{~N}$. IH. 553; Green v. Sneed, Ior Ala. 205. Except, under Neg. Inst. L.. \$ 205[124], as to subsequent holders indue course of negrotiable instruments. Sec anti, p. $5^{5} 7$, note. - En. 
(b) Negligenie of maker.

I 29 Massachusetts, 596. - ISSo.

ACtion on a promissory note for $\$ 174$. Defence, an alteration by which a note drawn for $\$ 7+$ had been raised to $\$ 174$. Plaintiff contended that, as he was a holder in due course, he was entitled to recover if the jury should find that the defendant negligently signed the note in such condition that owing to blank spaces the payee was enabled to make the fraudulent alteration in such manner as to show no indication to a careful observer that any such alteration had been made. The judge ruled otherwise, and declined to submit that question to the jury. Verdict for defendant.

GraY, C. J. . . The unauthorized alteration of the note which was complete upon its face, and which had not been entrusted by the defendant to anyone for the purpose of being filled up or added to, could not make him liable to an action upon the note in its altered form. (Angle v. Northivestern Ins. Co., 92 U. S. 330; Wade v. Withington, I Allen, 561 ; Grecnfield Satings Bank v. Stowell, I 23 Mass. I96; Goodman v. Eastman, 4 N. H. 455; McGrath r. Clark, $5^{6}$ N. Y. 34 ; Holmes v. Trumper, 22 Mich. 427.)

Exceptions overruled. ${ }^{1}$

$\S 205$

NOLL $i$. SMITH.

$[\S 124]$

64 INDIANA, 5 II. - IS78.

Action against maker by indorsee. Defence, that the notes had when executed a conditicn annexed that they were not to be paid unless defendant sold machines equal to the amount of the notes, and that the notes had been altered by cutting off the portion containing the condition. Judgment for plaintiff.

Niblack, J. [After stating the facts.] - We understand the gen-

${ }^{1}$ See especially, supporting the decision that negligence of the maker is immaterial, Gricnficld Savings Bankv. Stowell, 123 Mass. 196; Scholfield v. Earl of Londesborough, IS95, I Q. B. 536, explaining Foung v. Grote, + Bing. 253; Burroais v. Klunk, zo Md. $45 \mathrm{I}$. Contra: Isnard v. Torres, ro La. Ann. ro3; Yocum v. Smith, 63 Ill. 321; Blakcy v. Johnson, I3 Bush (Ky.) 197; Garrard v. Maddan, 67 Pa. Si. S2. See Redlich v. Doll, $5+$ N. Y. 23+. The distinction must be clearly observed between an instrument issued with blanks to be filled and one issued with the blanks filled but unnecessary or negligent spaces left in the blanks. See Neg. Inst. L., $\$ 33$ [It]; Cases, ante, pp. 2SS-298; 2 Daniel on Neg. Insi., SS It05-1409: $2 \mathrm{Am}$. \& Eng. Encyc. L. (2d ed.), pp. 249.25S. - ED. 
eral rule to be that the removal or detachment of a material condition annexed to, or forming a part of, a negotiable note, without the knowledge or consent of the maker, will ordinarily be a sufficient defence to such note, even in the hands of an innocent holder, and especially when such removal or detachment is made under circumstances which put the purchaser of the note fairly upon his inquiry as to the altered condition of the note, and this we construed to be the doctrine of the case of Cochran v. Nebeker (48 Ind. 459), cited and discussed by the appellant; but that, when the note and condition are negligently so executed by the maker that the condition may easily be removed, without in any manner mutilating or defacing the note, and the note is thus, without objection, put in circulation in that form, the maker cannot be heard to deny his liability to pay the note in the hands of an innocent holder, notwithstanding the condition may have been detached from it before such innocent holder became the owner of it. Such was, in substance, the decision of this court in the case of Cornell v. Nebeker $\left(5^{8}\right.$ Ind. 425). See, also, Woollen v. Ulrich (6+ Ind. I 20$)$, approving and following that case.

Upon the authority of these last named cases, the judgment in this case will have to be affirmed.

The judgment is affirmed, with costs. ${ }^{2}$

$\S 205$ [I24] Brown i'. Reed, 79 Pa. St. 370. - I 875 . The original instrument was as follows:-

North EAst Afril, 3d, 1872 .

Six month after date I promise to pay to J. B. Smith or bearer fifty dollars when I sell by order Two HundRed AND FIFT: DOLlaks worth of Hay and Harvest Girinders, for value received, with legal interest, without appeal, and also without defalcation or stay of execution

T. H. Bhown. Agent for Ilay and llarvest Grinders.

The instrument offered in evidence was the left hand portion of the above, which bore the indorsement "J. B. Smitu." The paper had been cut in two without Brown's knowledge. Plaintiff was a holder in due course of the negotiable portion. l)efendant offered to prove the alteration, and the offer was rejected.

Hcld: "Whether there was negligence in the maker was clearly a question of fact for the jury. The line of demarcation between the two parts might have been so clear and distinct and griven the

'Such an alteration is material and will prevent recovery by bon filc holders.

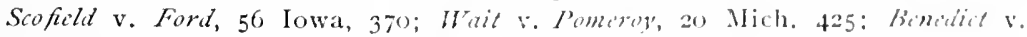
Cowden, 49 N. Y. 396; Gerrish v. Glines, 56 N. 11. 9; Stiphens v. Dazis, 85 Tenn. 27I. Negligence of the maker may, however, estop him from selling up the

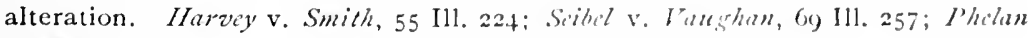
v. Moss, 67 Pa. St. 59; Zimmerman v. Roti, 75 Pa. Si. is8.- Lis. 
instrument so unusual an appearance as ought to have arrested the attention of any prudent man. But it may have been otherwise. If there was no negligence in the maker, the good faith and absence of negligence on the part of the holder cannot avai! him. The alteration was a forgery, and there was nothing to estop the maker from alleging and proving it. . . We think then that the evidence offered by the defendant below should have been received."

\section{Diseharge of party seeondarily liable.}

$\S 201$ JENKINS $\approx$ '. MACKENZIE.

$[\S 120]$

6 Upier Canada, Q. B., 54t. - I849.

Janes McKenzie made a note payable to Joseph Pierson or order, which Pierson indorsed; and after him, John James McKenzle (defenclant), indorsed to Proby, who has since died leaving said Joseph Pierson one of his executors.

Pierson is now, as Proby's executor, plaintiff in an action against defendant McKenzie. Plea, that Pierson is liable over to defendants in case defendant should be obliged to pay. Demurrer to plea.

Robinson, C. J., delivered the judgment of the court.

The plea does not take the exception, that Pierson is discharged by being made executor by Proby. It would seem to be quite clear, that if Pierson were the maker, the debt would be discharged, for it would, as to the creditors, be regarded as assets in his hands, as executor, and so there could be no remedy against this indorser. ${ }^{1}$

Discharge by Operation of LaW. - A transfer to acceptor or maker as executor of holder extinguishes the paper. Freakly v. Fox, 9 B. \& C. 130. To the wife of the acceptor or maker at common law. Abbott v. Winchester, ro5 Mass. II5. Or, after the marriage of a woman who has previously, while single, issued negotiable paper, a transfer to the husband. Chapman v. Kellogs, Io2 Mass. 246.

It seems that negotiable paper is not extinguished by a discharge in bank. ruptcy or the running of the statute of limitations, but is revived by a new promise so that a subsequent transferee is entitled to enforce it. Way v. Sferry, 6 Cush. (Mass.) 23S, citing cases contra.

So a debt barred by law is a : :ufficient consideration for a subsequent bill or note given for its payment. Wislizenus v. O'Fallon, 91 Mo. 184; Gidlings v. Giddings, 5I Vt. 227; Stafford v. Bacon, 25 Wend. (N. Y.) 354; Mull v. Van Trees, 5o Cal. 547; In re Mirriman, $4+$ Conn. 587.

A statutory bar to the enforcement of the consideration is not a bar to the enforcement of the bill or note, $c . g$., the statute of frauds. Jones v. Jones, 6 M. \& W. 84; Edgerton v. Edgerton, 8 Conn. 6; Paul v. Stackhouse, 38 Pa. St. 302. Contra: Hooker v. Knal, 26 Wis. 5 II; Combs v. Bateman, ro Barb. (N. Y.) 573 (semble). Cf. Raubitschek v. Blank, so N. Y. 479. - ED. 
We cannot hold the effect to be different, because Pierson, instead of being maker of the note, is an indorser, but prior to this defendant's indorsement. The effect is the same as if Pierson had paid the debt to the executors, or had been released without payment, after which there could be no remedy against any subsequent indorser.

As we see this to be the state of facts on the record, we must give judgment on demurrer for the defendant; for the objection is of that nature, that it goes to the very right of action and cannot be overlooked by us. (4 Scott's X. R. 287; 3 Esp., c. 46;2 B. \& P. 62; 9 B. \& C. I30; 4 M. \& Ry. 22 ; Co. Lit. 264 (b) note 209 ; I Wil. $46 ; 2$ Bl. Rep. 1 $236 ;+$ T. R. $825 ; 2$ Showers, 481 ; Story, Prom. Notes.)

Per Curiam. - Judgment for defendant on demurrer.'

\section{$\$ 201$}

JOSLIN $\approx$. EASTMAN.

$$
46 \text { VERMONT, 258. - IS73. }
$$

ACTion on a note of which Hall was maker and defendant surety. Ha!l's administrator had tendered payment to plaintiff, w! sich had been refused. Judgment for defendant.

The opinion of the Court was delivered by -

Royce, J. . . The important question is, whether the defendant can avail himself of the benefit of the tender which the jury have found was made to the plaintiff. The obligation of the surety being accessory to that of the principal, the surety could not be called upon as long as the principal had done all that could be legally required of him in the performance of the contract. The tender which the jury have found was made, was legally sufficient,

\footnotetext{
'Any voluntary act, or perhaps omission, of the holder which discharges a prior party (principal) will discharge a subsequent party (surety). Allowing statute of limitations to run in favor of principal or prior party. Awhumfursh v. Schmidt, 7o Iowa, 642; Bridges r. Blake, iof Intl. 332; Shutts n. Fingur, I(x) N. Y. 539. Contra: Villars v. Palmer, 67 Ill. 204; Rull $v$, (ive, 77 Call. 54; Banks v. State, 62 Md. 85; Hoore v. Cruy, 26, ()h. St. 525. Pringing an action against prior party resulting in juderment for, and consequent discharge of, such prior party. Ame's v. Haclay, It lowa, $28 \mathrm{I}$; Baker v. Hirriam, ot Iml. 539; State v. Coste, 36 Mo. 437. But a discharge of a prior party by mere operation of law will not discharge the surety. Discharge in bankruptey.

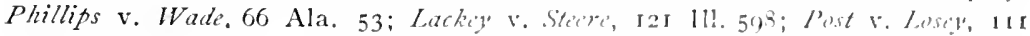
Ind. 74; Cochrane v. Cushing, 12t Mass. 219 ; Limn v. IJamiltun, $3+$ V. J. L. 305; Mall v. Fowler, 6 Hill (N. Y.) 630. Discharge by war. Beath v. Chapman, 62 Ala. 58. - ED.
} 
and would have been available as a defence in any suit the plaintiff might have instituted seeking a recovery out of the estate of Hall, and we think it is equally available to the defendant. When a debtor tenders payment of the debt for which the surety is obligated, and the creditor declines to receive it, he thereby discharges the surety. The judgment of the county court is affirmed. ${ }^{2}$

5 S Convecticut, 526. - isgo.

ACTION against the defendant as indorser of sundry notes and bills of exchange; brought to the Superior Court in Tolland county, and tried to the court before Torrance, J. Facts found and judgment rendered for the plaintiff, and appeal by the defendant. The case is fully stated in the opinion.

Andrews, C. J. - The L. B. Smith Rubber Company, a corporation doing business at Setauket, New York, being indebted to the defendant gave him three promissory notes, and accepted three bills of exchange, representing such inclebtedness and aggregating in the whole something more than five thousand dollars All of the notes and bills were payable to the order of the defendant, were by him indorsed, and at his request were discounted for his benefit by the plaintiff. Shortly thereafter the Rubber Company failed. That failure compelled the defendant to go into insolvency. The plaintiff presented its claim against his insolvent estate and received a dividend thereon. The defendant having since that time acquired other property, the plaintiff brought this suit and attached such other property Since the bringing of this suit the plaintiff, in common with nearly all the creditors of the L. B. Smith Rubber Company, including the defendant, signed an agreement which is fully set out in the finding, but which it is not necessary here to repeat. For the purposes of the present discussion it is sufficient to say that that agreement provided, among various other things, that the creditors of the Rubber Company should assign their ciaims to certain persons called a reorganizing committee, and that this committee should proceed to reorganize the company and should issue to each of the several creditors in payment for their respective claims the stock of the reorganized company, which the creditors agreed to accept. When the plaintiff signed the agreement it added to its signature:" reserving all rights against R. G. Holt, or against his estate, or

${ }^{1}$ Accord: Sears v. Itan Dusen, 25 Mich. $35 \mathrm{I}$; Spurgeon v. Smitha, II4 Ind. 453. Contra: Clark v. Sickler, o+ N. Y. 231. - ED. 
assignee for the benefit of his creditors." 'lhese words did not appear in the body of the instrument.

The defendant insists that by signing the agreement the plaintiff assigned all its claims against the L. B. Smith Rubber Company to the reorganizing committee, and that as he is liable to the plaintiff only as a surety for that company the assignment of the claim against the principal debtor discharges him.

That an unqualified release of a principal debtor will be a discharge also of the surety is admittedly good law. The plaintiff, however, claims that by the reservation appended to its signature it is not affected by that rule. The defendant cites two cases, either of which by its terms fully supports his contention. But the authority of each of these cases is greatly weakened, if not entirely overturned, by later decisions in the same jurisdiction. It ib $\mathrm{v}$. Hewitt ( 3 Kay \& Johnson, 438), is substantially overruled by Green v. II ym (L. R. 7 Eq. Cas. 3 r, and L. R. 4 Ch. Appeals, 20.4), and Farmers' Bank v. Blair (4+ Barbour, 641), by Morgan v. Smith (7o N. Y. 545); Colio v. Datit's (73 N. Y. 21 I); Nat. Bank v. Bigler $(83$ N. Y. $5 \mathrm{I})$, and Shutts v. Fingar (100 N. Y. 539.)

It is stated in De Colyar on Principal and Surety $(4 \mathbf{r})$, that such a reservation as was made by the plaintiff prevents there being any discharge of the surety, and gives as authority: (Kiarsley r. Cole,

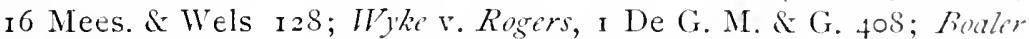
v. Major, 9 C. B. N. S. 76, 8.4; Owe'n v. Moman, + H. L. Cases, 997 ; and Close v. Close, 4 De G. M. \& G. I76. See, also, Tobru v. Ellis,

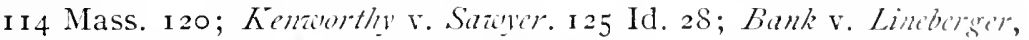
83 N. Car. 454; Morse v. Huntington, to Vt. 493 ; Hase' v. Mill, 75 Penn. St. Ios; Mucller v. Dobschueta, S9 Ill. I76.) The weight of authority seems to us to be strongly adverse to the defendant's claim.

There is another view of the case which makes it clear that the defendant is not entitled to a discharge by reason of the plaintuff's signing the agreement. Whenever a creditor gives time to, or makes a new contract with, the principal debtor, of which new contract the surety has knowledge and to which he assents, he is not thereby discharged. (Adams v. II'ay, 32 Conn. I6o; Corlie's r. Estes, $3^{1}$ Vt. 653; Smith v. Winter, \& Mees. \& Wels. 45+) The composition agreement was heneficial to all the creditors of the I. li. Smith Rubber Company, provided all entered into it. The defendant and his trustee in insolvency signed it hefore the plaintiff did. It was obviously for the advantage of each that the other should sign. Without some such arrangement neither could ever hope for any payment from that company. With such an arrangement lhere was 
a chance that they might both be paid in full. 'The plaintiff signed with the knowledge that the defendant and his trustee had previously signed. A composition deed implies not only an agreement of the debtor with each of his creditors, but also an arrangement by each creditor with each of the others. The signing of such a deed by any creditor is in some measure a request to all the others to sign also. The circumstances of this case show pretty clearly that the defendant knew of and assented to the act of the plaintiff in signing the agreement.

There is no error in the judgment complained of.

In this opinion the other judges concurred. ${ }^{1}$ BARBER.

$[\S$ I20] 50 CoNeCticut, 567.- Is83.

CARPENTER, J. - This is an action against the executors of the estate of the late Gardner P. Barber, deceased, who, when in life, indorsed a note for $\$ 8, \infty 00$. The Superior Court found the facts and rendered judgment for the plaintiff.' The defendants appealed. The record presents three questions.

I. Was the indorser discharged by the act of the plaintiff? The note fell due July $20 t h, 18_{74}$. On the $22 \mathrm{~d}$ of October, I $87+$, the maker paid $\$ 4,000$, which was duly indorsed on the note. In December, following, being urged to pay the balance, and not being able to do so, he executed another note for the sum of $\$ 4, \infty 00$, payable to the order of the plaintiff, on demand, with interest semi-annually, and executed a mortgage of certain real estate to secure the payment thereof; and, having caused the same to be recorded, delivered it

'One who takes a bill as a holder in due course, and afterwards learns that the drawer is the principal and the accommodation acceptor the surety, may nevertheless release the drawer without thereby discharging the acceptor. Fentum v. Pocock, 5 Taunt. I92; Farmers', etc., Bl. r. Kiathbone, 26 Vt. I9; Hoüturd Co. v. Helchman, 6 Bosw. (N. Y.) 280; Stephens v. Honongahela Bank, SS Pa. St. 157; Diz'rsy v. Hoor, 22 I11. 330. Contra: Ewin v. Lancaster, 6 B. \& S. 571; Lacy v. Lofton, 26 Ind. 324: Canadian Bank v. Coumbe, 47 Mich. 358; Hall v. Capital Bank, 7I Ga. 715; Shelton r. Hurd, 7 R. I. 403; Hestericlt v. Frich, 33 N. J. Eq. +5I.

But if there are two joint and several makers of a note. and, after learning that one is surety for the olher, the holder releases or gives time to the principal, the surety is discharged. Hubbard v. Gume' 64 N. Y. 457 ; Haris v. Brooks, 2 I Pick. I95: IThitihuse v. Ihunsom, f2 N. H. 9; Flynn v. Mudd, 27 I11. 323. See 2 Daniel on Neg. Inst., S 1322-133S. - ED. 
with the note to the plaintiff, without the knowledge of Barber. The plaintiff accepted the note and mortgage as additional security, but not in payment or satisfaction of the original note or any part thereof.

The claim is that the legal effect of accepting the note and mortgage was to give time to the maker of the note for $\$ \$, \infty, 0$, and so discharge the indorser.

The law is well settled, hardly requiring repetition, much less the citation of authorities, that in order to discharge the indorser by giving time to the maker there nust be a contract to that effect, express or implied; that is, the holder must have put it out of his power for the time being to proceed against the maker. The indorser cannot be deprived of the right, even for a short time, to pay the holder and proceed forthwith against the maker for his indemnity. The holder may not, during the time for which he has agreed to extend credit, bring a suit, for that would be a breach of his contract. He may not accept payment from the indorser and thereby subject the maker to an immediate suit by the indorser, for that would violate, if not the letter, certainly the spirit of his contract. Hence such a contract operates to discharge the indorser.

But here is no express contract, and we think none can be implied. It is expressly found that the second note was taken as additional security for the balance due on the original note and not in satisfaction of it nor as a substitute for it. Both notes were liable to be sued at any time, the one being overdue and the other on demand. Of course the indorser could have paid the first note and could at once have brought a suit against the maker. He was also entitled to the additional security, and could at once have brought a suit on that note, and could also have proceeded to foreclose the mortgage. Instead of being prejudiced by the transaction it was, in theory at least, a benefit to him.

The only features of the transaction which give any color to the defendant's claim are the facts that the collateral note, although on demand, was on interest payable semi-annually, and was secured by a mortgage; and it is urged with considerable force that these circumstances indicate an understanding between the partics that that note was to run at least for six months. They certainly indicate that the parties contemplated that it might run six months, but that possibility does not change the character of the note and convert it from a note payable on demand to a note payable on time. It was still a note due presently, and might be sued at once by the payee, and the indorser of the prior note might at any moment have placed himself in a position to sue it. 
The supposed analogy to notes ordinarily taken by savings banks, insurance companies, etc., does not hold good. The object in those cases is to loan money, to make investments; the object here was to grive additional security to a loan previously made and long since overdue, and which, we may add, was of a doubtful character. In the former cases the payee contemplates a present loan of money to continue for an indefinite time in the future; in the latter he is endeavoring to collect a loan previously made. It may be a breach of fair dealing to attempt to collect a note of the former description at once, but it by no means follows that it would be such a breach to attempt to collect one of the latter description. Moreover, the very object of making a note payable on demand is that the holder may collect it at any time if ine sees good reason for doing so; and, legally speaking, he is the sole judge of the sufficiency of the reason; and that applies to the notes referred to as well as to the note in this case; so that the analogy, even if it exists, or so far as it does exist, does not avail the defendants.

There is no error in the julgment of the court below.'

$\$ 201$ BRICK $\%$ FREEHOLD NATIONAL BANK.

$[\S 120]$

37 NeW Jersey LaW, 307. - I875.

The opinion of the court was delivered by

DALRIMPLE, J. - The defendant in this case is sued as indorser of a promissory note. The defence is, that the plaintiffs, the holders of the note, received from the maker a conveyance of certain property as collateral security for the payment of the note, and that because of their failure to sell the collaterals and appropriate the proceeds of the sale to the liquidation of the debt, coupled with the fact that the property held as collateral, had somewhat depreciated

1 The agreement for delay must be binding upon the holder in order troperate as a discharge of the indorser. HcLimori $v$. Powill, I 2 Wheat. (U. S.) 554 ; Smith v. Erain, 77 N. Y. $466 ;$ Cary' r. White, 52 N. Y. 13s. The taking of a new note or bond payable at a future day is construed as sufficient evidence of a binding agreement to suspend the enforcement of the original obligation until the maturity of the new obligation. English v. Darley, 2 Bosaug. \& P. 6I; Hubbard v. Gurney, 64 N. Y. 457; Siebeneck v. Anchor Bank, II Pa. St. IS7; Hamilton v. Proutv, 50 Wis. 592. But a reservation of rights against the surety is effective. Toh'y' v. Ellis, II 4 Mass. r2o; Hagey v. Hill, 75 Pa. St. IoS; Dupee v. Blake, ItS Ill. +65; Sohier v. Lorins, 6 Cush. (Mass.) 537 ; National Bank v. Bigler, 83 N. Y. 5I. Extension to the maker of time to answer in an action brought by the holder, is not an extension of time of payment. German-American Bank v. Niagara, atc. Co., 13 App. Div. (N. Y.) 450. - ED. 
in value, between the time of the maturity of the note and the commencement of the suit, the right of action as against the defendant, who is an accommodation indorser, is lost. This proposition cannot be maintained. It is well settled that mere delay by the creditor to sue the principal debtor will not discharge the surety, for the obvious reason that the surety may at any time discharge his obligation to the creditor, and thus make the principal his debtor. The same rule holds when collaterals are pledged by the principal debtor. The surety may at any time after the dcbt becomes due and owing, discharge it and take the collaterals. The law implies no contract on the part of the creditor to proceed on the collaterals before he can sue the surety. Nor are the rights of the parties affected by the fact that the collaterals have depreciated between the time of the maturity of the debt, for payment of which they were pledged, and the commencement of suit against the surety. These principles are recognized as sound law by the Court of Appeals of New York, in the well-considered case of Schroeppell v. Shaw, reported in 3 Comstock, 4t6, 5 Barb. 580 .

Rule to show cause should be discharged. ${ }^{1}$

\section{Payment by party secondarily liable. ${ }^{2}$}

$\S 202$

GARDNER $\tau^{\prime}$. MAYNARD.

[§ I2I]

7 Allex (MASs.), 456. - 1863.

Contract against the acceptor of a draft for $\$ 1,000$, drawn by Sandford C. Gardner, in favor of J. \& C. Lery \& Co., upon the defendant. The draft was duly indorsed and accepted.

At the trial in the superior court, before Allen, C. J., it appeared that the draft was protested for non-payment, ancl returned to leevy $\&$ Co., and was afterwards returned to the drawer, who assigned it by bill of sale to the plaintiff, with the indorsement of Levy \& Co. remaining uncancelled. A witness testified that he saw the draft

IIf a secured creditor part with the securities, the surety is discharged. 2 Daniel on Neg. Inst., \$ 1311.

In New York the doctrine prevails that a surety may call on the creditor in proceed promptly against the principal, and failure to th sn will discharge the surety to the extent of the loss suffered by the delay Pain v. Packarl, 13 Johns. 174; Newcomb v. Male, 9o N. Y. 326, 329. But the dectrinc dres not extend to indorsers for value. Trimble v. Thome, 16 Johns. 152; Nericomb v. Male. supra. - ED.

${ }^{2}$ See $\$ 80[50]$, ante; see p. 378 , anti, - E1). 
indorsed by one of the firm of Levy $\&$ Co, and did not see any money paid at that time.

Upon these facts, the chief justice directed a verdict for the defendant, which was accordingly rendered; and the plaintiff alleged exceptions.

Metcalf, J. - These exceptions must be overruled and judgment rendered on the verdict for the defendant, upon the authority of Beck r. Robley, r H. B1. S9, n. That case and this are alike in all particulars. In both, the bill was made payable, not to the drawer's own order, but to a third party who indorsed it, was accepted by the drawee, but afterwards was dishonored by his refusing to pay it, and was taken up from the indorser by the drawer, with the indorser's name remaining uncancelled. In that case it was decided that the bill was not negotiable, and that the drawer could not reissue it. And that decision has never been overruled or denied, but is cited as established law in all the books that treat of bills of exchange. (See, I Steph. N. P. 863; Story on Bills, \$ 223; Gitild v. Eager, 17 Mass. 615; Opinion of Patteson, J., in Williams v. Fames, 15 Ad. \& El. N. S. 505.) The doctrine of that decision is, that a bill of exchange cannot be indorsed or negotiated, after it has once been paid, if such indorsement or negotiation would make any of the parties liable, who would otherwise be discharged. (Bayley on Bills, 6th ed. I66, 167; Chit., Bills, 12th Am. ed. 254, 255.) As the first indorser of a bill is liable to every subsequent bona fide holder, although the bill be fraudulently circulated, it follows that if he leaves his name thereon, after he is entitled to a discharge, he exposes himself to liability to such holder. Therefore the bill is held not to be negotiable, in such case.

This rule of law applies only to cases in which the negotiation of a bill by the drawer, after he has taken it up on its being returned to him dishonored, would expose a discharged party to a new liability. (See Callowi v. Lazurence, 3 M. \& S. 95; Hubbard v. Fackson, 4 Bing. 390; Bayley, Chit., and i 7 Mass. ubi supra; Mead v. Small, 2 Greenl. 207.)

Exceptions overruled. ${ }^{2}$

202

BLENN $\because$ LYFORD.

$[\S \mathrm{I} 2 \mathrm{I}]$

$$
70 \text { MaINe, I49. - I879. }
$$

Appleton, C. J. - This is an action of assumpsit on the following note: -

${ }^{1}$ Accord: Price v, Sharp, 2 Ired. Law (N. C.) 4I7. - ED. 
St. Almaxs, ME., Dic. 2, Is; 1 .

Seven months from date, value received, I promisc to pay M. E. Rice, or order, three hundred dollars, at any bank in Bangor.

[The note was indorsed in blank] M. E. RICE.

11. H. LYFORD.

[The following words were also on the back of the nole, crased with ink but legible]: Holden without demand or notice. M. E. Rick.

Granting the presumption that the plaintif is a bond fide holder for value of the note before maturity, that presumption may be overcome by proof.

It appears from the testimony that the note was indorsed to one Richardson, for value, in the April following its date; that it was not paid at maturity, and that about three months after its dishonor he delivered it to Rice, the payee.

The plaintiff then received the note in suit, when overdue. The note remaining unpaid after maturity was dishonored, and it was the duty of the indorsee to make inquiries concerning it. If he takis it, though he gave a full consideration for it, he does so on the credit of the indorser. He holds the note subject to all equities with which it may be incumbered. As the plaintiff is the indorsee of a dishonored note, it was competent for the defendant to show that it was an accommodation note, and that it had been paid by the party for whose accommodation it was given.

That the note was for the accommodation of the payee is alsundantly shown by his receipt of the date of February 22, IS72, as well as by the testimony offered and excluded.

The note being for the accommodation of Rice, it was his duty to pay it. The note being found after dishonor in the hands of the one bound to pay it, the presumption is that he paid it. (2 Par. N. \& B. 220 ) It was competent to show that in fact he paid it, but the answer to an inquiry whether the note was paicl by Rice was excluded. This was erroneous.

Assuming the note to have been paid by Rice, it was the same as if paid by the maker. It was paid by he party whose duty it was to pay it. The purpose for which it was griven has been accomplished. The negotiability of a note ceases after its payment by the party who should rightfully pay it. "Now it cannot be deniced," says Denman, C. J., in Lazarus v. Comie (+3 E. C. I. Sig), " that if a bill be paid when due by the person ultimately liable on it, it has done its work, and is no longer a negotial)]e instrument.

But the drawer of an accommodation bill is in the same situation as the acceptor of a bill for value; he is the person ultimately liable, and his payment discharges the bill altogether."

Rice, when he took up the note in suit, lad no right of action 
against the maker, and could not transfer to the plaintiff any better right after maturity than he had. (Edwd. B. \& N. 564; Fish v. French, I5 Gray, 520; Tucker v. Smith, + Maine, 415.)

In the cases cited by the plaintiff there are most important differences from the one under consideration. In Bank r. Crow $(60 \mathrm{~N}$. Y. 85 ), the plaintiffs were the indorsees of the note for value and before maturity, and were consequently to be protected. In Thompsons. Shepard (I 2 Met. $3 \mathrm{II}$ ), it was held that the indorsee of a note, who receives it for value from the second indorser, after it has been dishonored by the maker, can recover thereon against the maker, although he knew when he received it that as between the maker and first indorser it was an accommodation note. But this is upon the principle affirmed by the court in IFoodman v. Churchill (52 Maine, 58), that where the first indorsee of a promissory note acquires a right of action against the maker, by being a bona fide purchaser, without notice and before maturity, he can transfer a good title as well after as before the note becomes due.

Exceptions sustained.

Action to stand for trial.

\section{Payment for honor.}

SEE ART. XV, post, pp. 658-66o.

Accord: Merrillv. First L. B., 9+ Cal. 59; Cottrell $v$. Watkins, 89 Va. Sor.-ED. 


\section{ARTICLE X.}

Bills of Exchange: Form and Interpretation.

\section{Form.}

I. Formal Requisites Generally.

\$210 See Article II. Aute, pp. i6i-285.

[S I26]

2. The Drawee or Drawees.

(a) Miust be certain.

$\$ 20$

See Article II. Ante, pp. 270-275.

$[\S I]$

(b) May be joint, but not alternatizer or successize.

$\$ 2 I 2$ TOMBECKBEE BANK $\because$ DUMELL \& LYMAN. [\$ I28]

5 Mason (U. S. C. C.) $56 .-1823$.

[Reported hirein at p. 6.6.9. $]^{1}$

$\S 212$

$$
\begin{aligned}
& \text { JACKSON } \because \text { HUDSON. } \\
& \text { 2 CaMpheli, 447. - ISIo. }
\end{aligned}
$$

THIs was an action against the defendint as acceptor of a bill of exchange, which was drawn and accepted in the following form:

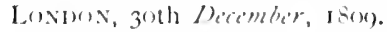

Two months after date, pay to my order $157 \%$, for vilue received.

To Mr. I. IRving

F. Jacksox.

Accepted, I. IRving

Accepted, Jos. Hunson, payable at Mr. Iludson's, I32 Oxford street.

The first count of the declaration stated, that the bill was directed to Irving; the second took no notice of there being any drawee; and

'An acceptance by some one or more of several drawees, bu now ball, is a qualified acceptance. See Negr. Inst. L., \$229[1+1], subsec. 5. - ED. 
both averred that the defendant accepted it, "according to the usage and custom of merchants."

Garrow for the plaintiff stated, and undertook to prove, that the plaintiff having dealings with Irving concerning the sale of goods, refused to sell him any more, unless the defendant would become his surety; that the defendant agreed to this; that goods to the value of ${ }_{5} 5 \%$. were in consequence sold by the plaintiff to Irving; that the bill in question was drawn for the price of them, and that the defendant with a knowledge of all these facts, had put his name upon the bill as acceptor. He must, therefore, be considered as having accepted the bill jointly with Irving; and as he had not pleaded in abatement, he was separately liable in the present action.

Lord Ellenborovgh. - If you had declared, that in consideration of the plaintiff selling the goods to Irving, the defendant undertook that the bill should be paid, you might have fixed him by this evidence. But I know of no custom or usage of merchants, according to which, if a bill be drawn upon one man, it may be accepted by two. The acceptance of the defendant is contrary to the usage and custom of merchants. A bill must be accepted by the drawee, or failing him, by some one for the honor of the drawer. There cannot be a series of acceptors.'

The defendant's undertaking is clearly collateral, and ought to have been declared upon as such.

Plaintiff nonsuited.

\$212 [128] Axox. I2 Mod. 447. (I701). A bill of exchange was directed to A. or, in his absence, to B., and began thus: "Gentlemen, Pray pay." The bill was tendered to A., who promised to pay it as soon as he should sell such goods; and in an action against him for non-payment, the declaration was of a bill directed to him without any notice of B., and Hol held it well. ${ }^{2}$

${ }^{1}$ There seems to be no direct authority upon this proposition of the Neg. Inst. L., $\$ 212$ [I2S]. In the case above but one drawee is named and the conclusion is that no other person can accept. Of course successive "drawees in case of need" may be named in the bill. Neg. Inst. L., S215 [13I]. - ED.

"In this case B. may have been a "drawee in case of need;" if not, it is contrary to the statutory rule. A note cannot be made payable by two makers in the alternative. Ferris v. Bond, 4 B. \& Ald. 679. - ED. 
3. Referee ix Case of Neen.

\section{S2I5 Chittr ox Bills of Exchange, Etre, p. iss. [S I3I]}

Whes the drawer has any apprehension that the drawee will either not accept, or not pay the bill, he may, as a matter of precaution, to prevent the expenses and inconveniences resulting from a return of the bill, require the holder in such an event, to apply to a third person, named in the bill for that purpose. This requisition is intimated by writng in the corner of the bill, under the drawee's address, these words, "Alt besoin chiz Messrs. - _, at - , " or, in other words, "In case of need apply to Messrs. _- at - - ." This, in effect, points out one or more persons whom the drawer is desirous, in case of refusal or failure by the drawee, to become parties to the bill, in the nature of an acceptor or payer for honor: and is valid and usual on the Continent, though we have jist seen that there cannot be a series of acceptors. (I Pardess. 351, 394, 437-S; Fackson v. Hudson, 2 Campb. 4+7.) The holder is bound to apply to the parties so addressed, ${ }^{1}$ ( 1 Pardess. +38 ), and who may accept and pay without previous protest, in which respect he differs from an acceptor supra protest (I Pardess. $43 \mathrm{~S}$ ); and the party so paying has a right to sue the drawer for the amount. (I Pardess. 4j8.) It should seem, however, that the introduction of these worls rather imports an apprehension that the bill will not be regularly accepted or paid, and therefore tends to diminish the credit which might otherwise be attached to the bill without such clesire being expressed."

\section{Interpretation.}

I. Bill Not an Assignimat of funds.

$\$ 2$ II HOLBROOK $i$. PAYNE.

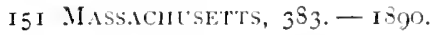

Plantiff by " trustee process" attached funds in the hands of the town of Winchester belonging to defendant. Alexis Cutting intervened as claimant of the funds.

1 This seems to have been so before the enatement of the Bills of Bxchange Act, $\$$ I5, and the Neg. Inst. L., $\leqslant 215$ [131]. See Chalmers, Bills of lixchange Act (5th ed.) pp. 39-39. - E.t.

${ }^{2}$ There is little English or American authority upon the " referee in case of

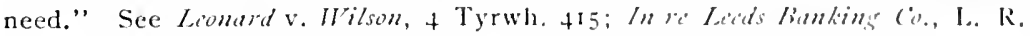
I Eq. I. - E1). 
The town owed defendant $\$ 217.27$ on an account stated. Defendant gave Cutting this order: "Winchester, July $\mathrm{r} 2 \mathrm{th}$, ' 88 . Town of Winchester. Pay to the order of A. Cutting ninety and thirty-two hundredths dollars, value received, and charge the same to account of H. B. Payne." He gave similar orders amounting to $\$ 65.27$ to four other persons, who also appear as claimants. The orders were all left with the selectmen of the town, where they continued to remain, but were never formally accepted.

Holmes, J. - The defendant in this action has been defaulted, and the question before us is whether the plaintiff or the claimant Cutting is entitled to a certain part of the debt due from the trustee to the defendant.

There is no doubt that an order for a specific fund, identified by the order itself, may be a good assignment. (Kingman v. Perkins, I 5 Mass. I I .) We assume in favor of the claimant that an equitable assignment to him of a part of the debt would be good as between him and the plaintiff upon trustee process. (Dana v. Third National Bank, I Allen, 445, $4+7$; Fames v. Newton, I+2 Mass. 366, 374.) Our difficulty is to discover any ground for saying that the instrument relied upon constituted such an assignment.

On its face, the order given to the claimant by the defendant does not refer to a particular fund or debt, but is an ordinary negotiable draft, or unaccepted bill of exchange, drawn upon the town on the general credit of the drawer. An indorsement of the instrument by the claimant would have given the indorsee a right of action in his own name against the drawer, if the draft should be dishonored. But the fact that the order is a negotiable instrument on its face shows that it is not drawn against a particular fund. If it were drawn against a particular fund, it would not be negotiable. ${ }^{1}$ (IVhecler v. Sonther, 4 Cush. 606, 607; Marriman v. Sanborn, 43 N. H. I28.)

The case is stronger for holding a check upon a bank to be an assignment, than it is for holding an ordinary draft to be so. A check is supposed to be drawn against a fund deposited, for which, to be sure, the bank is no more than a debtor; but a debtor on the implied term that the creditor has a right to split up the debt at will, and to require part payments in such amounts, at such times, and to such persons as he chooses. In general, the creditor has no right to draw above the amount of his deposit, and would be guilty of a fraud if he obtained money or goods for a check knowingly so drawn. Yet the weight of authority is that a check is not an assignment either at law or in equity. ${ }^{2}$ (Bullard v. Randall, I Gray, 605;

\footnotetext{
${ }^{1}$ See Neg. Inst. L., $\$ 2 \mathbf{2}[3]$. - ED.

${ }^{2}$ See Neg. Inst. L., $\$ 325[189]$. ED.
} 
Dana v. Third National Bank, I3 Allen, 445, 447; Attorney-Gcneral v. Continental Life Ins. Co., 7 I N. Y. 325; First National Bank of Mount Foy v. Gish, 72 Penn. St. 13; Hopkinson v. Forster, L. R. I9 Eq. 74; Schrocder v. Central Bank of London, 24 W. R. 710. See Laclede Bank v. Schuler, izo U. S. 5 II, 5 I 4 .)

A fortiori, the same rule must hold good of an ordinary draft unaccepted, which does not import the existence of a debt from the drawee to the drawer, but leaves the mode of the drawee's reimbursement to such private arrangements as may exist between the drawer and himself. And so are the decisions: (IVhitney v. Eliot Nat. Bank, 137 Mass. 35I, 355, 356; Nitional Exchange Bank v. McLoon, 73 Maine, 498, 5 I ; Bank of Commere v. Bogry', $4+$ Mo. I3. See First Nat. Bank of Canton v. Dubuque Southutestern Railu'dy', $5=$ Iowa, 378 .)

There is no extrinsic fact in the present case which gives the document a different effect from that which results from its tenor, if it be possible that its effect should be varied by parol. (See Whitney v. Eliot Nat. Bank, supra; Griffin v. Whatherby, L. R. 3 Q. B. 753, 759; First Nat. Bank of Cantoil $\therefore$. Dubuque Southiiestirn Railu'ay', 52 Iowa, 378.) The defendant had done work for the town, and his only right to draw was in respect of the price of his work. If we assume this fact to have been known to all parties concerned, still it only shows that the town was known to have means of indemnifying itself if it saw fit to pay. It does not enlarge the meaning of the draft beyond that which it bears on its face, of a general request to the town to pay. Even a reference to a fund out of which a drawee may indemnify himself will not take away the negotiable character of the draft. ${ }^{1}$ We may remark that the concluding words of the draft in question are "charge to account of." In some of the others, they are "charge to the account of," which is slightly more specific. But we do not see any sound distinction in favor of the latter. If the town had accepted the order, having power to do so, it would have become liable on a direct and absolute contract to the claimant, very likely having a right to withhold an equal amount of its debt to the defendant. Jint mere retention of the draft was not acceptance. ${ }^{2}$ (Overman r. Hobokin City Fank, 2 Vroom, 563.)

\section{Trustee charged. Judgment for plaintilf."}

\footnotetext{
${ }^{1}$ Neg. Inst. L., \$ $22[3]$; anti, pp. I83-189. - Ev.

${ }^{2}$ See $\$ 225[137]$. - ED.

${ }^{3}$ As to whether a bill is an assignment shere has been a conflict of authority, especially where the bill is drawn for the whole of the fund. See 1 Danicl on Neg. Inst., S5 15-23; 2 Am. \& Eng. Encyc. L. (2nd cdl.), 11). 1062-1064. That a
} 


\section{Inland and Foreign Bills.}

30 TEXas, $17 .-1867$.

THE bill on which suit was brought was in these words, with the indorsement of "Henderson, Terry $\&$ Co.," across the face of the note: -

$\$ 307.7$ s.

New ORLEANs, 2d May, is6r.

On the I2th day of December, after date, pay to the order of C. Yale, Jr. \& Co., $\$ 307.7 \mathrm{~S}$, value received, and charge the same to account of

MatT. Ward.

To Messrs. Hexdersox, Terry \& Co.

To it was attached the usual formal protest, dated " United States of America, State of Louisiana," by a " notary of the parish of New Orleans, State of Louisiana," I 4 th December, I86r.

Willie, J. . . There being no allegation to the contrary, we must treat the draft upon which this suit is founded as a domestic bill of exchange. Neither the place where the draft was drawn, nor where it was accepted, is stated in the petition. The instrument itself, made part of the petition, purports to have been drawn at New Orleans; but there is no averment that this place is beyond the limits of Texas. This court has held, that it will not take judicial notice of the division of other States into towns, cities, etc., and that knowledge of the fact that any place is within a different State of the Union must be derived from the allegations of the parties or the evidence contained in the record. (Andrez's v. Hoxie, 5 Tex. I $85 ; 4$ Tex. 420.)

The rights of the parties to this contract, therefore, must be ascertained, and their liabilities fixed according to the law of our own State. ${ }^{1}$

bill drawn for the whole of a fund is not anassignment, see Shand $\mathrm{v}$. Du Buisson, Is Eq. Cas. $28_{3}$; First M. B. v. Dubuque S. R. R., 52 Iowa, 378 ; Bush v. Foote, 58 Miss. 5 ; $B a n k$ v. $B 0_{5} y, 4+$ Mo. I5. But an order for a payment of a particular, specified debt in full, is an assignment. Lewis v. Bank, 3o Minn. I35; Brady v. Chadbourne (Minn ), 7o N. W. Rep. 951; Moore v. Davis, 57 Mich. 255. - Ed.

1 Accord: Kiarncy v. King, 2 B. \& Ald. 301; Rigsin v. Collier, 6 Mo. 568. $A$ bill drawn and dated in Philadelphia, payable in London, but actually delivered by the drawers in London, is to be treated as a foreign bill in the hands of a bona fate holder. Leminis v. Ralston, $23 \mathrm{~Pa}$. St. 137. A bill drawn and delivered in Wisconsin, but dated and payable in Illinois, is an inland bill, as between the parties. Strawbridge v. Robinson, Io Ill. (5 Gilman) $470 .-$ ED. 
II.]

\& 214
INTERPRETATION.

3. Bill Treated as Promissory Note.

FUNK $\because$ BABBITT.

I56 ILLINOIS, ŁOS. - IS 95.

[Reported herein at f. 272.] ${ }^{1}$

1." Where a party frames his instrument in such a way that it is ambiguous whether it be a bill of exchange or a promissory note, the party holding it is entitled to treat it either as one or the other, and the plaintiff ought not to be defeated by the party who framed the instrument being allowed to say that it is a bill of exchange" [where such party has had no notice of dishonor]. Lilts $\mathrm{r}$. Bury, 6 B. \& C. 433. See also Lloyd v. Oliver, IS Q. B. 471 ; Hits v. Bumfuss, 40 Ark. 545; + Am. \& Eng. Encyc. Law (ad ed.), pp. 119-I23.

See cases, ante, pp. 270-272. .-ED.

NEGOT. INSTRUMENTS - 39 . 


\section{ARTICLE XI.}

\section{Acceptance of Bills of Exchange.}

\section{Form and effect.}

I. Acceptance Must Be in Writing and Signed By Drawee.

(a) Writing and signature.

$\$ 220$

SPEAR $\%$. PRATT.

$\left[\begin{array}{ll}\S & 132\end{array}\right]$

2 HILL (N. Y.) $582 .-18+2$.

Action against Pratt as acceptor. Judgment for plaintiff. The defendart's name was written across the face of the bill; and the question was whether this was such an acceptance as is required by statute.

By' the Court, Cowen, J. - Any words written by the drawee on a bill, not putting a direct negative upon its request, as " accepted," "presented," "seen," the day of the month, or a direction to a third person to pay it, is prima facie a complete acceptance, by the law merchant. (Bayley on Bills, $16_{3}$, Am. ed. of $18_{3} 6$, and the cases there cited.) Writing his name across the bill, as in this case, is a still clearer indication of intent, and a very common mode of acceptance. This is treated by the law merchant as a written acceptance - a signing by the drawee. "It may be," says Chitty, " merely by writing the name at the bottom or across the bill;" and he mentions this as among the more usual modes of acceptance. (Chitty on Bills, 320, Am. ed. of i 839 .)

It is supposed that the rule has been altered by x R. S. 757 (2d ed.) $\$ 6$. This requires the acceptance to be in writing, and signed by the acceptor or his agent. The acceptance in question was, as we have seen, declared by the law merchant to be both a writing and a signing. The statute contains no declaration that it should be considered less. An indorsement must be in writing and signed; yet the name alone is constantly holden to satisfy the requisition. No particular form of expression is necessary in any contract. The customary import of a word, by reason of its appearing in a particular place, and standing in a certain relation, is considered a written 
expression of intent quite as full and effectuas as if pains had been taken to throw it into the most labored periphrase. It is said tine revisers, in their note, refer to the French law as the basis of the legislation which they recommend; and that the French law requires more than the drawee's name - the word accepted, at least. That may be so; but it is enough for us to see that both the terms and the spirit of the act may be satisfied short of that word, and more in accordance with the settled forms of commercial instruments in analogous cases. The whole purpose was probably to obviate the inconveniences of the old law, which gave effect to a parol acceptance.

New trial denied. ${ }^{1}$

(b) Only the dratiec can acect.

$\$ 220$

WALTON $i$. WILLIAMS.

[S I32]

$4+$ Alabaia, 347. - is;o.

Action against James $W^{\circ}$. Walton as acceptor of a bill addressed to James J. Walton. Defendant offered to prove that he signed as indorser, but the court excluded the evidence. Judgment for plaintiff.

SAFFOLD, J. - The only evidence that the defendant accepted the bill, is his signature across its face. It is where the acceptor's signature is usually found, and in the absence of proper rebutting testimony this would be sufficient proof of the fact, if it was directed to him, or without direction to anyone. But the name of James I. Walton is also found in the position on the bill usually occupied by the drawee, and he must be considered the drawee as well as the drawer.

${ }^{1}$ By the English and American decisions parol acceptance of an existing bill is sufficient. I Danicl on Neg. Inst., S50 it sig.; Siadder v. Lank, $9 \mathrm{I}$ U. S. 406, 413 . In England, since 19 and 20 Vict., c. 97, the acceptance must be written on the bill. Bill of Exchange Act, S I7, subsec. (2). In the U. S. where there are statutory provisions they generally provide for an acceptance in writing; but this need not be upon the bill. An acceptance by telegraph has becel held good. North Atchison Binti v. Garretson, 5 I Fed. Rep. I6,s, note p. 162, ante. See also Spaulding v. Androws, t5 Pa. St. tIr. 13ut, by 522 [133], of the Neg. Inst. L., the holder is entitled to require the acceptance (1) be written upon the bill; and by 522 [134] an extrinsic acceptance is bincling only in fator of one to whom it is shown and who takes the bill on the faith thereof. This latter provision is a departure from the jurlicial decisions upon this print. Sprollding v. Andrews, 48 Pa. St. 411 : Jones v. Conncil filuffs bank, 34 I11. 313. - En. 
Where a bill is directed to a particular person, no one but the person to whom it is directed can accept it, except for honor. (May v. Kelly \& Frasicr, 27 Ala. 497.) If the defendant was an acceptor, he was one supra protest, and his obligation was, that if the bill was not paid by the drawee upon due presentment at its maturity, then upon protest for non-payment, and lue notice thereof to him, he would pay it. (Story on Bills of Ex., $123 ; 3$ Wend. 491.)

There was no proof, in this case, of protest and notice, and for this reason the charge of the court was erroneous.

The plaintiff was the payee. It was, therefore, clearly competent to show by parol the intention of the parties, at the time the contract was entered into, with regard to their several liabilities among themselves, and the relation which they were to bear to the bill. (Branch Bank at Mobile v. Coleman, 20 Ala. 140.)

The evidence of the defendant, who was a competent witness under section 2704 of the Revised Code, ought to have been admitted.

The judgment is reversed and the cause remanded. ${ }^{1}$

$\$ 220$

JACKSON i' HUDSON.

$[\S \mathbf{1 3 2}]$

2 C.MMPBell, 477. - ISIO.

[Reporte! herein at f. 6003.]

(c) Delizery necessary.

Dunavan v. Flyin, il 8 Mass. 537. - I875. Gray, C. J. It was rightly held that the mere writing of the acceptance upon the bill, not communicated to the drawer or holder, and the detention of

${ }^{1}$ Accord: Dazis v. Clarke, 6 Q. B. R. I6; Smith v. Lackridge, S Bush. (Ky.) 423. In Markham v. Hazen, is Ga. 570, the stranger-acceptor was held as guarantor.

If a bill is directed to an agent (A.) and accepted by him in the name of his principal (X. Co., by A.), no one is bound; not the agent, for he has not accepted; not the principal, for it is not the drawee. Walker v. Bank, 9 N. Y. (5 Seld.) 5 s2.

If a bill is directed to a partnership (A. B. \& Co.) and is accepted by one partner in his own name, it has been held that no one is bound; not the partnership, for it has not accepted; not the partner, for he is not the drawee. Ileenan $\mathrm{v}$. Nash, S Minn. fo7. Contra: Oaten v. Tan Uster, 2o L. J. C. P. 61. See note p. 306 , ante. This is to be distinguished from the case of a bill directed to two or more drawees and accepted by one. See $\$ 212$ [I $2 S$ ], $\$ 229$ [I4I], subsec. 5. - ED. 
the bill in the defendant's custody, did not bind him, or operate as a payment of his debt to the drawer. (Clatey r. Dollin, Cas. temp. Hardw. 278; Feune r. Mard, 2 Stark. 326; s. c., I B. \& Ald. 653; Mason 5 Barff, 2 B. \& Ald. 26 ; Cox v. Troy, 5 B. \& Ald. 474, s. c., I Dowl. \& Ryl. $3^{8}$; Oèrman צ. Hoboken City Bank, I Troom, 61, and 2 Troom, $56_{3}$.)

2. Promise to Accept Must Be in Writing, etc.

$\$ 223$

$$
\text { BANK OF MICHIGAN }{ }^{\prime} \text {. ELY. }
$$

I7 Wexnell (N. Y.), 50S. - IS37.

Action of assumpsit against defendant as acceptor. Defendant wrote his agents: "If you want more funds, you can make drafts on me payable at the office of A. S. Marvin \& Co., N. York, due in August next. . . . I have authorized Mr. D. D. Hatch to accept these drafts for me." The agents wrote plaintiff communicating the contents of defendant's letter, and subsequently transmitted bills drawn on defendant, which plaintiff discounted and passed to the drawer's credit. There was no evidence that defendant's letter was ever shown to plaintiff. Referees' report for defendant.

By the Court, Nelsox, Ch. J. - It is objected that the acceptance of the defendant, under the circumstances of the case, is not within the provisions of the Revised Statutes, however obligatory it may be upon the principles of the commercial law. The provisions of the statute, I R. S. 768 , are as follows:

$\$ 6$. No person within this State, shall be charged, ats an acceptor on a bill of exchange, unless his acceptance shall be in writing signed by himself or his lawful agent.

$\$ 7$. If such acceptance be written on a paper other than the bill, it shall not bind the acceptor except in favor of a person to whom such acceptance shall have been shown, and who, on the faith thereof, shall have received the bill for a valuable consideration. ${ }^{2}$

$\$ 8$. An unconditional promise, in writing, to accept a bill before it is drawn, shall be deemed an actual acceptance in favor of every person who, upon the faith thereof, shall have received the hill for a valuable consideration. ${ }^{3}$

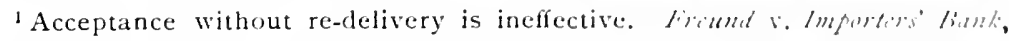
$3 \mathrm{Hun}$ (N. Y.) 659. Except as provided in 525 , post. 13u1 sece 2 Anses' Cases on Bills and Notes, p. 790 . An acceptance once complesel ly delivery is, in the absence of fraud on the part of the holder in precuring the accepranec, irrevocable. Trent Tile Co. v. Fort Deartorn X. 1S., 5+ N. J. 1. 33, 599; Firt Diarborn N. B. v. Carter, 152 Mass. 34. - E11.

${ }^{2}$ Re-enacted in substance in Neg. Inst. I., $522[13+1$ - EN.

${ }^{3}$ Re-enacted in substance in Negr. Inst. L., $\leqslant 223$ [135]. - En). 
A brief recurrence to the law as it stood in this State before the adoption of these provisions, will aid in comprebending their object ard effect. It was settled, ( 1 ) that a parol promise to accept a bill already drawn, was valid and binding, and amounted to an actual acceptance; and (2) that a parol promise to accept a future bill, or one not in existence, was not binding, unless the bill was taken by the holder upon the faith and credit of such promise. If it was so taken, then it was binding and amuunted to an actual acceptance according to some of the cases. (I Holt, I $8_{1}$; 2 Kent's Comm. 85; I 2 Wendell, 598.) There are other authorities which require the promise to be in writing. Now by the Revised Statutes, no person, within this State, can be charged as an acceptor of a bill, unless the acceptance be in writing, signed by himself or his agent; and if such acceptance be in writing, but not on the bill, still the party is not charged, unless the fact be disclosed to the person taking it, and he on the faith of such acceptance, pay a valuable consideration for the same. The acceptance here referred to relates to a bill already drawn.

By $\$ 8$, an unqualified promise in writing to accept a bill to be thereafter drawn, is deemed an actual acceptance in favor of any one who upon the faith of such promise takes it for a valuable consideration. There is some difference in the phraseology of $\$ 7$ and $\$ 8$, in respect to the circumstances under which the credit is to be given to the promise to accept. The language of the former, is " in favor of a person to whom such acceptance shall have been shown, and who on the faith thereof," etc., whereas, the Sth section contains only the latter branch of the sentence; the other was in the section as reported by the revisers, but was subsequently stricken out. No reason can be perceived for a distinction in this respect between the two cases, and we do not believe any was intended by the legislature; and that the difference in the phraseology is altogether accidental. It can be of no possible consequence to the acceptors in what mode the holder comes to the knowledge of the acceptance, whether by inspection or by oral communication; it is a matter that can only concern the latter. If he acts upon the representation of a third person, he incurs the risk of being imposed upon, as he must, as to the genuineness of the writing upon an inspection. The language, " shall have been shown," means nothing more than to express the idea that the holder must know of the acceptance; this is, indeed, the only effect of it. All this is undoubtedly implied in the next sentence, and the clause, therefore, might as well have been omitted altogether, as it is in the next section. 
In Piersonv. Dunlop (Cowper, 571), the first case in which this doctrine is stated, Lord Mansfield remarked: "It has been truly said, as a general rule, that the mere answer of a merchant to the drawer of a bill, saying he will duly honor it, is no acceptance, unless accompanied with circumstances which may induce a third person to take the bill by indorsement; but if there are any such circumstances it may amount to an acceptance," etc. In Mason r. Hunt (Doug. 299), Lord Mansfield used language from which, probably, the phraseology of the statute was taken; but it is manifest he intended to do no more than repeat the principle he had before stated in Pierson v. Dunlop. In Clarke v. Cock ( 4 East, 5i), this very objection was taken by Gibbs, (p. 67), namely, that the letter, itself, ought to have been shown, and not merely the purport of it given; but it was disregarded by all the judges. The communication of the fact of the promise, was deemed the material circumstance.

Now it must be conceded in this case, that the promise to accept is in writing, and, in my judgment, it is an unqualified promise. "If you want more funds, you can make draft on me, cotc., to the amount of \$ro,000." Who was to determine whether more funds were wanted? Undoubtedly, Beach \& Hudson. The question was referred to their sole discretion; and when decided and the drafts drawn, the obligation to accept became imperative. As the discretion to draw was thus left solely with them, the terms of the letter are equivalent to an absolute promise to accept whenever they lrew upon him in the manner specified. It is not for him to set up an abuse of this discretion to aroid the obligation, unless it be brought home to the plaintiffs, of which there is no pretence.

Did the plaintiffs receive the bills upon the faith of the defendint's promise to accept them, and for a valuable consideration? It must be conceded, that most, if not all the money now relied on as the consideration for these bills, was actually received by the agents, and therefore paid to them by the bank, before the written authority to draw, and promise to accept was given: and hence, it cannot be said, strictly speakingr, that it was advanced upon the faith of this promise. So much must be admitted. But ats we have already shown, the agents possessed authority to raise funds for the purchase of the wheat upon the defendant's paper, and in this case, no doubt could be entertained of his liability as drawer, if he ball bech so charged. It is true, that regularly, the drafts should have been drawn in the name of the principal, but IJudson's practice wats uniformly otherwise, and was sanctioned by the defendiat. Ha cammet be permitted to avail himself of that objection. It may then be con- 
fidently said, that the money when taken from the packages by Hudson operated as a loan to, or charge upon, Ely, the principal; that the debt was his, and if no drafts had been given he would have been holden to discharge it, upon the plainest law applicable to the relation of principal and agent. Now, assuming the advance to have stood on this footing on the 18 th January, when the written authority to draw the bill was given, and the drafts in question were subsequently drawn; is not the taking of them by the plaintiffs for this debt, a taking upon the faith of the promise to accept and for a valuable consideration? A man's own debt or account owing by him is certainly a good consideration for the draft of his authorized agent, and there can be no doubt of the fact that the paper was received on the credit of the engagement of Ely to accept, or which is the same thing, in judgment of law, upon the authority to draw upon him. Here, then, are the three ingredients required by the statute: I. A written promise to accept; 2. Taking the drafts upon the faith of it; and 3. A valuable consideration, to wit, the debt existing against the defendant, created by an agent with full authority.

It is to be regretted the attorney had not inserted the common counts in his declaration, and then the question upon the statute might have been avoided; the defendant would have been charged as drawer of the drafts in question.

Prudence would, perhaps, require that the pleadings should be amended in this particular.

Motion to set aside the report of referees granted; costs to abide the event.'

${ }^{1}$ See also Exchanse Bank v. Hubbard, 62 Fed. Rep. II2.

Virtual Acceptaxces. - An unconditional written promise to accept a bill to be thereafter drawn is binding in favor of holders in due course who take the bill upon the faith of the promise. Coolidge v. Payson, 2 Wheat. (U. S.) 66; I Daniel on Neg. Inst., $\$ 55$ I, 560; + Am. \& Eng. Encyc. L. (2nd ed.), pp. 233-245. But the promise must be unconditional. Merchants' Bank v. Gristold, $22 \mathrm{~N}$. Y. +72; Germania . 1. B. v. Taaks, IOI N. Y. H2; Bank v. Recknagel, IO9 N. Y. 482. The promise must be in writing. Fohnson v. Clark, 39 N. Y. 216 (telegraphic promise sufficient); I Daniel, $\$ 556$. The promise must describe the bill in unequivocal terms. Foyce v. Edatards, + Peters (U. S.) II ; Franklin Bank v. Lynch, 52 I1d. 270 (cf. Flora First 1. B. r. Clark, 6I IId. 400); Ulster Co. Bank v. MICFarlan, 5 Hill (N. Y.) 432 ; 3 Den. 553; I Daniel, 5560,561 . The bill must follow the terms of the promise. Lindliy v. First . I. B., 76 Iowa, 629; Brinkman $r$. IIunter, 73 Mo. 172: + Am. \& Eng. Encyc. L. (and ed.), p. 243 . The bill must be drawn within a reasonable time after the giving of the promise. First $A$. $B$. v. Bensliy, 2 Fed. R. 6o9; I Daniel, s560. Cf. Fohnsonv. Clark, 39 N. Y. 216 . The bill must be taken by the holder upon the faith of the promise. M'Evrs v. .Mason, ro Johns. (N. Y.) 207; Exchange Bank v. Rice, 98 Mass. 2SS. - ED. 
3. Acceptance by Refusal to Return the Bill.

II Hux (N. Y.), $268 .-1877.1$

Action against defendant as acceptor. Judgment for plaintiff.

TAlcotT, J. - This is a motion for a new trial on a verdict directed by the court at the Cattaraugus Circuit. Exceptions sent to the General Term in the first instance.

The action was upon an inland bill of exchange, drawn by one McDonald on the defendant for $\$ 526.76$. The bill was never accepted by the defendant in writing, as required by the statute, which provides that no person within this State shall be charged as an acceptor on a bill of exchange unless his acceptance shall be in writing, signed by himself or his lawful agent. (r R. S., $2(1$ edl., 757,56 ); and unless he is made iiable as an acceptor under the subsequent eleventh section, he is not liable upon the bill. 'The said section I I is as follows:

" Every person upon whom a bill of exchange is drawn, and to whom the same is delivered for acceptance, who shall destroy such bill, or refuse within twenty-four hours after such delivery, or within such other period as the holder may allow, to return the bill accepted or non-accepted to the holder, shall be deemed to have accepted the same."

The bill was sent by a third party with directions to leave it at the office of the defendant, which was done, and, so far as appears, no demand of acceptance was ever made. The defendant did not destroy the bill, for he produced it on the trial. The defendant never refused to return the bill; in fact, he was not directly reguired to return it, and 120 direct demand of the bill was ever male upon him. Two days after the making of the bill and the delivery of it to his agent at his office, the plaintifi called at the office and ascertained that the bill had been left there, and was informed by the agent that they were hard up and would not pay that disy, but received no promise that the bill should be paid at any future diay. The plaintiff went away and left the bill unaccepted at the office of the defendant. Two or three days after this, the plaintiff met the defendant at the hotel, in the same place in which the office of the defendant, before spoken of, was located, and had a conversation with the defendant about the bill, informing the defendant that he (the plaintiff) had such a bill and that it was at defendant's office. 
The following conversation, as testified to by the plaintiff, then ensued between the parties:

"I wanted to know whether he was going to pay it or not, and if not, I wanted the order; and he (the defendant) said he could not pay it then, but as soon as he had completed five miles of the rail. road running into Jamestown he should have the money. I asked him how long that would be, and he said ten days or two weeks. I told him it was considerable of an amount, and I wanted to know whether I should get my pay on it or not. He said I would get my pay on it inside of two weeks. I told him I wanted my pay on the order, and he said I would get my pay on the order as soon as he completed five miles of the railroad. Buffalo city was going to pay him, and that he would get done inside of two weeks." This conversation occurred in June, and it does not appear that anything else took place between the parties until the sixth day of October, when they again met, and the plaintiff asked the defendant about pay on the bill, and the defendant stated that " he had been disappointed about pay." The plaintiff also stated that the defendant never returned the bill or offered to return it.

We do not think that the evidence established a refusal to return the bill, within the eleventh section of the statute above referred to. The refusal mentioned in the statute, as it seems to us, refers to something of a tortious character, implying an unauthorized conversion of the bill by the drawee. In this case it is obvious that the plaintiff willingly left the bill in the possession of the defendant, and in no way gave the defendant to understand that a redelivery of the bill was rquired, relying probably upon the expectation that it would be ultimately paid. The attempt to charge the defendant with the payment of the bill upon the ground of a promise is, as it appears to us, simply an attempt to charge the defendant with a liability on the bill upon a parol acceptance. If an action can be maintained under such circumstances, the provisions of section 6 of the statute before referred to would be rendered wholly nugatory.

Besides, as to the promise, there was no evidence to show that the five miles of railroad, on the completion of which the promise to pay the bill was conditioned, had been completed.

The defendant moved for a nonsuit on the ground: First. That there was no acceptance of the bill in writing. Second. That there was no demand of the bill before suit Third. That there was no refusal to deliver the bill. Fourth. That the plaintiff had failed to make out a cause of action. The court held that the defendant was liable because he was indebted to McDonald, the drawer, because he had received and retained, and declined to return the bill, and 
had promised to pay it; to which ruling and to the refusal of a nonsuit the defendant excepted. We think the nonsuit should have been granted for the reasons stated by the defendant.

The verdict is set aside and a new trial ordered, costs to abide the event. ${ }^{3}$

\section{Acceptance of Incomplete or Dishonored Bill.}

69 Mariland, 513. - ISS3.

Action against defendant as acceptor. Defendant accepted the draft before the drawer (Waddy) signed it. The draft, payable " to order of myself," was then indorsed to plaintiff by Waddy. Plaintiff presented it to defendant who refused to accept or pay it and pointed out that Waddy had not signed it as drawer. Plaintiff then procured Waddy's signature as drawer. Judgment for plaintiff.

Miller, J. [after stating the facts] delivered the opinion of the Court. . . . The material facts are undisputed. Hopps wrote the draft himself, accepted it, and then gave it to Wadkly for the express purpose of enabling him to raise money upon it. It is true it was delivered to him before Waddy had signed it as drawer, but there can be no doubt as to the fact that Hopps intended Waddy should sign and negotiate it. In such case the law implies an authority from Hopps to Wadly to sign his name as drawer. Four days after its date, and long before its maturity, Waddy indorsed the draft to Savage, and received from the latter its full face value. That Savage thereby became a bona fide holder for value is undeniable. Even if he had then known that, as between Hopps and Wadcly, it was without consideration and merely an accommodation bill, his position as such holder would not have been affected by such knowledge. (Maitland :. Citizens' Nat. Bank of Balte., to Mrd. 540.)

It is also true that Waddy's signature was not put to the draft until after Savage had become the holder. In other words, the draft, when indorsed to Savage, was in blank in respect to the drawer's name, but this blank was afterwards filled up in accordance

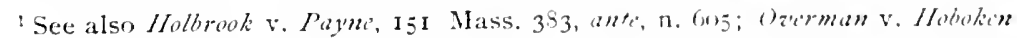

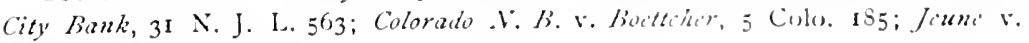
Wiard, I B. B. Ald. 653 .

The drawer has twenty-four hours in which to decide whether to accept or not, if presentment is made before the day of maturity. IIontsomery Ciunty Bank v. Albany City Bank, 8 Barb. (N. Y.) 306; I Daniel, $492 .-$ Ev1. 
with the intention of the parties when the bill was written and accepted. We are clearly of opinion the law authorized this to be done. In fact the authorities go to the extent of holding that Savage would have been authorized to fill the blank by inserting his own name as drawer. Such was the decision of the Common Pleas Division in Harey v. Cane (34 Law Times, N. S. 64); and in Scard and IIfe $v$. Fackson, reported in a note to the same case, it was held that the name of the holder could be thus inserted after the maturity of the bill. (See, also, Schultz v. Astley, 2 Bing. N. C. 544.) In the case before us the suit is by a bona fide holder for value before maturity, against the acceptor, and the drawer's name was signed in strict accordance with the intention of the parties. We hold that in such a case it makes no difference whether the blank was filled before or after the maturity of the draft.

From these views it follows there was no error of which the appellant is entitled to complain in the rulings of the court upon the instructions, and the judgment must be affirmed.

Judgment affirmed.

$\$ 226$

STOCKWELL $i$. BRAMBLE.

[S I38]

3 INDIANA, 129. - I852.

ACTION against defendant as acceptor of a bill. Judgment for defendant.

Plaintiff offered to prove that defendant stated that he would accept the bill, but did not want it generally known that he was accepting the drawer's bills, and would therefore write " protested" across the face, which he did and signed his name; that afterward on the same day defendant again promised to pay the bill. This evidence was excluded.

BLACKFori, I. [after stating the facts]. We think that the parol evidence offered by the plaintiff was admissible, on the ground that it showed a valid acceptance of the bill by the defendant, after he had written on it the word "Protested."

Suppose the word "Protested," as written on the bill, 10 mean that the defendant refused to accept the bill, and the holder so understood that word: and suppose, also, that evidence of what the defendant said, at the time of such refusal, was objectionable as contradicting the word "Protested," still the subsequent parol acceptance would be good. We know of no reason why the drawee of a bill, who has refused to accept the same, may not afterwards accept it. It frequently happens that a bill, after being protested for non- 
acceptance, is accepted by a third person supra protest. The following case is cited by Mr. Chitty: A foreign bill drawn on defendant was protested for non-acceptance, and returned, and afterward defendant told the plaintiff, " if the bill comes back I will pay it," and this was held a good acceptance. (Chitty on Bills, 316 , note l.) It is clear, therefore, that the fact of a bill's having been protested, does not prevent its being afterwards accepted by the drawee.

The acceptance is not objectionable merely because it was by parol. By the law merchant, a bill, whether foreign or inland, may be accepted by parol as well as by writing, (Chitty on Bills, 3 r6); and that is the law here.

PER Curiar. - The judgment is reversed with costs. Cause remanded.

\section{Kinds of Acceptances.}

I. General Acceptance.

$\$ 227$ MEYER \& CO. i'. DECROIX, VERLEY ET CIE. [\$ I39]

$$
\text { L. R., ISgi, Appeal Cases (H. L.), } 520 .
$$

Action by indorsees against acceptors, upon the following instrument: ${ }^{2}$

No. 501. $£ 778{ }_{4} s .2 d$.

Rovbax, Sift. izth, Issg.

On Oct. 3 Ist after date pay to - order $^{3} \mathrm{Mr}$. L. Delobbel Flipo seven hundred and seventy-eight pounds 4 . $2 d$. Value received.

To Messrs. H. MEYer \& Co., Limited,

L. Delobbel Flipo.

$$
\text { London, Eng. }
$$

[Across the face was witten and stampid:]

In favor of Mr. L. Delobbel Flipo only.

$$
\text { No. } 25 .
$$

Accepted payable at Alliance Bank, Lonclon, for II. Meyer \& Co., Limited.

B. Mannixg, Arthlr Maxisg, Directors. Arthur Maxisa, Secritary.

The word " order" in the bill was struck out, but when or by whom did not appear.

1"A promise to accept, even after a protest for non-acceptance, is binding; and a promise to accept made after the bill becomes due according to its lenor, amounts to a promise to pay immediately." (irant v. Shaw, I6 Mass. $3+1$ (I820). - ED.

${ }^{2}$ In fac-simile in 59 L. J. Q. B. 539 . - ED.

${ }^{3}$ This word was struck out by a pen mark. By the provisions of the Bills of Exchange Act $(\$ 8$, subsec. 4$)$ the words "order" or "bearer" are not necessary to render a bill negotiable. - Ev. 
Plaintiffs, bankers at Lille, in France, discounted the bill for Flipo. They did not understand English and their attention was not called to the form of the acceptance until after the dishonor of the bill by the Alliance Bank.

The Divisional Court (Cave and A. L. Smith, JJ.) held the acceptance was a qualified one, rendering the bill non-negotiable, and gave judgment for defendants. The Court of Appeal (Lord Esher, M. R., Lindley and Bowen, L. JJ.) reversed that decision and entered judgment for the plaintiffs. ${ }^{1}$ Defendants appeal.

LORd Herschell. - My Lords, the respondents in this case seek to recover from the appellants the amount of a bill of exchange accepted by them. The defence set up is that the acceptance was a qualified one, and restricted the right to require payment to the payee alone, and that the acceptors are therefore under no obligation to the respondents who took by indorsement from him.

It was not disputed at the bar that the acceptor of a bill of exchange may make his acceptance a qualified one. If he do so, the drawer may, of course, refuse to take such an acceptance, and treat the bill as dishonored: but if he takes the bill, the obligation of the acceptor is not absolute, but subject to the qualification which he has introduced. I think, further, that it is beyond dispute that if an acceptor seeks to qualify his acceptance, and thus to modify the obligations which an acceptance ordinarily imposes, he must do so on the face of the bill in clear and unequivocal terms, and in such a manner that any person taking the bill, if he acted reasonably, could not fail to understand that it was accepted subject to an expressed qualification.

About these propositions I do not think there can be any difference of opinion; the difficulty lies in applying them to the facts of the particular case. The bill in question was drawn in France by a person named Delobbel Flipo upon the appellants, and forwarded to London for their acceptance. The bill is drawn on a printed form containing the word "order" immediately preceding the name of Delobbel Flipo, which has been inserted as the payee of the bill. This word " order" has been erased, but by whom does not appear, nor do I think it material. If, as suggested, it was done by the acceptors, they were not justified in making the erasure, and in any case there would be nothing to show a person taking the bill that the word had not been struck out by the drawer at the time he inserted the name of the payee. I do not think, therefore, that the erasure of the word " order" can in any way assist the contention

${ }^{1}$ See 59 L. T. Q. B. 539 ; L. R. 25 Q. B. D. 3+3. - ED. 
that the acceptance was a qualified one. That must be determined by a consideration of the effect of the words written across the bill by the acceptors.

For the purpose of accepting the bill the appellant company impressed upon it by means of a stamp the words " accepted payable at Alliance Bank, London," underneath which the signatures of two directors and the secretary were written. The acceptors wrote across the bill above the word "accepted" the words "In favor of Mr. L. Delobbel Flipo only:" between these words and the word " accepted " was written "No. 28." In considering whether the effect of the words " In favor of Mr. L. Delobbel Flipo only" was to make the acceptance a qualified one in the manner suggested, regard must be had both to the words used and to the situation in which they are placed. It may be that if the same words had been found in the body of the acceptance following the word " accepted," they would have amounted to the qualification contended for. The presence of any words in the body of the acceptance would of itself suggest the idea that some qualification of it was intended; but where the words are not inserted in the body of the acceptance, I do not think the same impression is likely to be produced, though the words may, of course, be so clearly intended to qualify the acceptance and so incapable of any other reasonable construction that they would be as effectual for the purpose. But in the present case the words written above the acceptance are not "Payable to Delobbel Flipo only," which is the meaning sought to be attached to them, but "In favor of Delobbel Flipo only," which do not seem to me necessarily to bear the same meaning. The words " in favor of," when used in relation to a bill of exchange, do not ordinarily mean that it is payable only to the person in whose favor it is said to be drawn; the words are equally applied when the bill is made payable to his order. The words "In favor of," therefore, are properly paraphrased by " payable to, or to the order of; " but then it is said that the insertion of the word "only" after Flipo's name would show that this could not be the meaning intended. It must be remembered however that between these words and the acceptance "No. 28 " was inserted, which separates the words which it is suggested qualify the acceptance from the acceptance itself.

Under these circumstances I do not think that it is impossible that a person taking the acceptance by way of inclorsement might suppose that these words "In favor of Delobbel Flipo only" were, like the “No. 28," a mere memoranclum inserted by a party to the bill, and not intended to affect the acceptance. It might be supposed to indicate that it was the 28 th bill, or No. 28 of the bills accepted " in 
favor of Delobbel Flipo only," as distinguished from bills accepted in favor of Flipo and some other persons. I do not say that this would be the interpretation given to it by a person who carefully and critically considered it. But that is not the question. It is impossible, as I have said, to dissociate the words used from the position and collocation in which they are found, and if these be such as to suggest that the words are a mere memorandum, a person taking the bill, even if he exercised the ordinary care to be expected in such transactions, would not be likely to examine or weigh them with the same care as if they were found in the body of the acceptance.

In my opinon the qualification was not made in clear and unequivocal terms, and in such a manner that any person taking the bill, if he acted reasonably, could not fail to understand that it was accepted subject to that qualification. I think, therefore, the judgment ought to be affirmed. ${ }^{1}$

LORD Bramwell. - My Lords, I consider what was written and printed by the defendants on the face of the bill as one - one thing only - an acceptance and no more, not an acceptance and something else. That being so, I am unable to see any difference between "In favor of Flipo only, accepted payable," etc., and " Accepted in favor of Flipo only, payable," etc. I do not know where the body of the acceptance begins, unless at the beginning of what is written. It is said that "In favor of Flipo only" does not necessarily mean the same as " accepted in favor of Flipo only." I think it does; but if not necessarily, what does it naturally mean? Especially when it is remembered that the word "order" was erased. That was no doubt unauthorized, if done by the drawees, but it clearly shows the intention of the drawees if done by them, and the knowledge by the drawer of that intention if done by him. The striking out of "order" was not a memorandum for the use of the drawees. I cannot find that any other cause for what was done can be suggested.

As to the thing Deng clear and unequivocal, I begin to doubt if there is such a thing, but it is enough if words are intelligible. Can there be a doubt that this bill might have been protested for nonacceptance according to its tenor? I suppose from the form of the acceptance that the appellants thought they had, or might have, some cross-claim against Flipo. Flipo, probably, was glad to get anything from them, and so put up with the acceptance, and perhaps

\footnotetext{
1 Opinions for affirmance were also delivered by Lord Halsbury, L. C., and Lord Watson. - ED.
} 
indorsed it in satisfaction of a bad debt to those glad to get anything from him. ${ }^{1}$

Order appealed from affirmed, and appeal dismissed with costs.

$\$ 228$

$$
\text { TROY CITY BANK } \because \text {. LAUMAN. }
$$

I9 NEW YORK, 4iT. - I859.

Action against indorsers of bills addressed to the payee at New York, and accepted by the payee "payable at Continental Bank, New York." Presentment at the Continental Bank; payment refused; due notice. Judgment for plaintiff.

S. B. Strong, J., [after disposing of other questions]. The two drafts were respectively addressed to the drawee in New York, and were accepted by him, payable at the Continentai Bank in that city, where the demand of payment was made. The defendants' counsel contended on the trial that the drafts were not duly accepted or demand of payment properly made, and they cited the case of $\| T^{\circ}$ iolworth v. The Bank of America (ig Johns. 39I), to show that such practices were irregular and did not attach any responsibility to them. In that case, however, the note was in fact payable in Albany, and there was a marginal memorandum, signed by the maker, that it was payable in New York. 'That memorandum was made after the note had been indorsed by Judge Woodworth, and without his knowledge. It was held, and perhaps properly, that the memorandum was an alteration of the note, and discharged the inclorser. The alteration consisted in making it payable in a different city, and that rendered it material. It is not of conrse an alteration of a draft to accept it as payable at a designated place in the same city, and if it could be deemed a change at all, it is not made by the payee or indorsee, nor is it at all material.

So, too, in the case of Walker $r$. Bank of the State of Now York (r 3 Barb. 636), the draft was directed to the drawee in New lork and accepted by him, payable at Clayville Mills, in ()neida county. It was properly held that the change was material and rendered the acceptance roid, and that as no notice of such acceptance was given to the indorsees, they were discharged.

If, in the case under consideration, the drafts had been made payable at a particular store, counting house, or office in New Vork, it would have been a change, although I do not thimk that it would even then have been a material one, to have accepted it as payable

1 Opinion for reversal was also delivered by Lord Morris. - E1,. NEGOT. INSTRUMENTS - 4 . 
at another place in the same city. No possible injury can result to the drawer or indorser by making a bill of exchange, directed to the drawee in a city generally, payable at some particular place in the same city. It becomes fro hac aice the place of business of such drawee. The cases differ as to whether the holder may not, nevertheless, present the bill for payment at the ordinary place of business, or if he has none, the residence of the drawee; ${ }^{1}$ but I have seen none which decides that he is bound to do so. I am confident that the practice pursued in this instance corresponds with commercial usage, and think that it should be sustained.

[The Court then holds the notices sufficient.]

$$
\text { Judgment affirmed. }{ }^{2}
$$

2. Qualified Acceptance.

(a) Conditional accoptance.

62 MALAF, $+93 .-1374$.

Appleton, C. J. - This is an action of assumpsit against the defendants, as acceptors of the following order, drawn on them by James Hibbard:

1 If a particular place is specified in the acceptance, the presentment for payment must be made at that place or the drawer and indorsers are discharged. Brown v. Fone's, II 3 Ind. +6. Contra: Miagara District Bank v. Fairman, etc., Co., 3 I Barb. (N. Y.) 407 , where it is held that if the bill is addressed to the drawee in Town A., and he accepts it payable in Town B., it is improper to make presentment in B., but it should be presented to the acceptor in A. Otherwise if he accepts it payable at a particular place in Town A. - ED.

2 "Before the I $\&$ Geo. 4 , c. 7 (Sergeant Onslow's Act), it was a point much disputed whether, if a bill payable generally was accepted payable at a particular place, such an acceptance was a qualified one. That statute, however, has now setıled that an acceptance payable at a banker's or other particular place is, as against the acceptor, a general acceptance unless the acceptor express in his acceptance that the bill is payable there only, and not otherwise or elsewhere." Byles on Bills, p. I97. Row'r. Y'oung, (2 Brod. \& Bing. 165), held such an acceptance to be qualified. In the United States such acceptances have generally been held to be unqualified. Hallaci V. Miconncll, i3 Peters (C. S.) 136: I Daniel, $\$ \$ 520,641-643$. The Neg. Inst. L., $\$ 22 S$ [I 40 ], enacts substantially the provisions of Sergeant Onslow's Act, now found in Bills of Exchange Act, S I9. - ED. 
Androscoggin Water Power Co.,

Shelderie, Fit. $25,1573$.

EDWARn Pltimer, tyint.

Please pay to James A. Stevens, for cutting and hauling lumber, the sum of one hundred and thirty-four dollars, and charge the same 10 my account.

JMUES HIIBIRD.

In answer to a letter from the plaintiff, the defendants on March I 8, I 873 , wrote the following letter to him:

Mr. James A. Stevens:

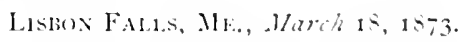

Dear Sir: Yours of the thirteenth inst., is received. We shall not pay any orders of Mr. Hibbard until we settle with him. If there is anything over, I will keep it back for the purpose.

Yours iruly.

E. lilmus, - lisht.

The order of February 25 was retained by the defendants in their possession. On March 25, I $\delta_{73}$, the defendants were summoned as trustees of James Hibbard, in a suit in which one Bean was plaintiff, returnable at the September term of the Supreme Judicial Court for the county of Androscoggin, and for the sum of $\$ 356.70$. On April 28,1873 , the plaintiff's attorneys were notified that this action would be entered at the September term, and that the trustee would make a full statement as to all orders drawn, and leave the question of liability to the decision of the court. Prior, however, to the September term, Hibbard settled the suit of Bean, and directed the defendants to pay the amount due, without notifying the plaintiff in this suit. At the time of this settiement there were due Itibbard from the defendants, four hundred and four dollars and forty-seven cents, out of which sum they paid Bean three hundred and sixtynine dollars and fifteen cents, and the balance of thirty-five dollars and thirty-two cents they paid Hibbard. This payment was on August 2, I 873 .

An acceptance may be absolute or conditional. A conditional acceptance at once becomes absolute upon the performance or happening of the condition.

In the present case the defendants" promise is to pity if in sottlement " there is anything over." When the acceptance is condutional, the holder may accept or refuse the offer.' The plaintiff acreded to the proposition of the defendants - permited the order to remain with them, and did not sue out a trustee writ, by which his whole debt would have been secured. There was a settlement and the amount due exceded the amount of Hiblard's order. The defendants then became lable, and this Jiability, conditional in the 
first instance, accrued long before the trustee suit of Bean. The payment to Bean by the defendants was in their own wrong, and canot defeat the prior right of the plaintiff.

Defendants defaulted. ${ }^{1}$

(b) Partial acceptance.

$\$ 229$

$$
\text { PETIT i'. BENSON. }
$$

$[\S \mathrm{I} 4 \mathrm{I}]$

Comberbacil, 452. - I697.

A BILl was drawn upon the defendant, who accepts it by indorsement in this manner: "I do accept this bill to be paid, half in money and half in bills." And the question was, whether there could be a qualification of an acceptance; for it was alleged that his writing upon the bill was sufficient to charge him with the whole sum. But 'twas proved by divers merchants, that the custom among them was quite otherwise, and that there might be a qualification of an acceptance: for he that may refuse the bill totally, may accept it in part. But he to whom the bill is due may refuse such acceptance, and protest it so as to charge the first drawer; and tho' there be an acceptance, ret after that he hath the same liberty of charging the first drawer as he before had. ${ }^{2}$

(c) Local acceptance.

19 NeW YORK, 47\% - IS59.

[Reported herein at P. 625.]

\footnotetext{
${ }^{1}$ Any condition clearly varying the tenor of the bill renders the acceptance conditional. I Daniel on Neg. Inst. S 509-5I5; + Am. \& Ens. Encyc. L. (2nd ed.), pp. 227-232. The conditional acceptance becomes absolute upon the happening of the condition. Ibid. An acceptance "when in funds" is conditional. The bill is payable when the acceptor has in his hands funds which the drawer has a present right to demand and receive. Irintimute r. Post, 24 N. J. L. 420 ; Hallace v. Douglas, in6 N. Car. 659. An acceptance of a sixty-day bill " payable on giving up bill of lading, etc.," is a qualified acceptance; but the acceptor is bound even though the bill of lading is not tendered until after the maturity of the bill. Smithr. Iirtue, 30 L. I. C. P. 56. - ED.

2 "In Volloy and the other books there is a whole paragraph about the partial acceptance of a bill of exchange, and they allow it to be good." Wigersloffir. Kiene, I Strange, 214, 225. - Ev.
} 
Halstead $v$. Skelton, 5 Q. B. $86\left(\right.$ I $\left.S_{43}\right)$. Tindal, C. J. - A bill of exchange drawn generally on a party may be accepted in three different forms: Either generally, or payable at a particular banker's, or payable at a particular banker's and not elsewherc. If the drawee accepts generally, he undertakes to pay the bill at maturity when presented to him for payment. If he accepts payable at a banker's, he undertakes (since the statute) to pay the bill at maturity when presented for payment either to himself or at the banker's. If he accepts payable at a banker's and not elsewere, he contracts to pay the bill at maturity provided it is presented at the banker's, but not otherwise.

Here the bill was accepted according to the second of these three forms; $i . c$., payable at a banker's, without any restrictive words; so that presentment at the banker's (though if male it would have been a good presentment) was yet not, as against the acceptor, necessary

\section{(d) Aiciptance qualificd as to time.}

\section{$\S 229$}

\section{HATCHER $i$. STALWORTH.}

25 MISSISSIPPI, $376 .-1853$.

$[\S \mathrm{I} 4 \mathrm{I}]$

Action by payee against acceptor on a bill payable at sight. Plaintiff presented the bill to defendant, who wrote to plaintiff that he (defendant) would pay the order, but coukl not say when. Julgment for plaintiff.

Mr. Justice Yerger delivered the opinion of the court.

We see no error in this record. Where a party, on whom a bill is drawn at sight, offers or promises to pay at a future day, that amounts to an acceptance, if acceded to by the holder. (7 P'ick. R. 34 ; Story on Bills, $5.52+3,24+$ )

The proof in this case shows this to have been the state of facts; and we, therefore, must affirm the judgment.'

${ }^{1}$ If the bill is drawn payable on a given dare it may be acepted payable at a

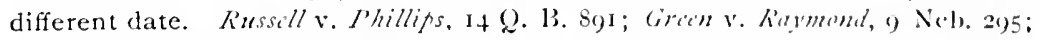
Vanstrum $v$. Liljengrem, 37 Minn. I9I.

If a bill is drawn payable two months after sight, and is presented on sept. It. and accepted "payable Nov. It," this is nol a qualification whelher mere be days of grace or not. So, if there be days of grated and is is alecepted "payable Nov. I7," this is also treated as an acceptance accorling wo the Icnor of the bill. But an acceptance payable on any other day laan the nominal or peremptory day of payment is a qualified acceptance. Ainner v. Crititurs. 7 Martin N. S. (La.) 540. - Ev. 
(c) Accoptance by one or more drawecs, but not by all.

5 Mason (U. S. C. C.), 56. - IS2S.

[Reported herein at p. 639.]

\section{EfFfit of Qualified Acceptance.}

(a) Holder may refuse qualified accotance.

I CAMPBell, 425, noti. - Isos.

Action on a bill drawn on Lisbon, "payable in effectize, and not in rals reals." The defendant was the drawer of the bill; and the question was, whether it had been dishonored for non-acceptance? The drawees offered to accept it, payable in a'als denaros, another sort of currency, which was refused. The defendant now proposed to show, that ials denaros was sufficient to answer what was meant by " effectic't."

LORD Ellenborough. - The plaintiff had a right to refuse this acceptance. The drawee of a bill has no right to vary the acceptance from the terms of the bill, unless they be unambiguously and unequivocally the same. Therefore, without considering whether a payment in denaros might not have satisfied the term "effectic'c," an acceptance to pay in denaros was not a sufficient acceptance of a bill drawn payable in "effectiô,." The drawees ought to have accepted generaily, and an action being brought against them on the general acceptance, the question would properly have arisen as to the meaning of the term.

\$230 [I42] Wintermute $z^{\prime}$. Post, 24 N. J. L. 420,423 (I 854 ). Haines. J. - The remaining and principal point arises from the tenor of the acceptance, "when in funds." This is a conditional acceptance, and the plaintiff was not bound to take it. If lie were not satisfied with it, he might have protested the note for non-acceptance, and looked to the drawer for its payment. But having taken it without objection, he must submit to its terms, and before he can enforce it against the acceptor he must show funds of the drawer in his hands.'

${ }^{1}$ Accord: Sterens v. Androscoggin Water Power Co., 62 Me. 495, ante, p. 626; Petit v. Bronson, Comb. 452, ante, p. 628; Hatcher v. Stalworth, 25 Miss. 376 , 
(b) Qualified acceptance discharges non-assentingr antecident fartic's.

$\$ 230$ [142] WALKER $a$ BANk, I3 Barbour (N. I.), 630 (1552)." Action against the bank, as agent, for negligence in not giving notice of dishonor of certain bills. The bills were drawn upon E. C. Hanilton and were accepted in this form: "Accepted, payalle at the Am. Ex. Bank: Empire Nills by E. C. Hamilton, 'Treas." HUBBaRD, J. - The only question presented is whether Hamilton, the drawee, can be charged as acceptor. If he cannot, the defend. ant's liability is undisputed, because of their neglect to to grive notice of dishonor. It is an undoubted rule that an acceptance dispensing with notice, must be absolute according to the tenor of the bill; not qualified, or varying in any material particular. (Story on Bills, $\$ 240$, and cases cited in note 2 ; Chitty on Bills, 329.) The obrious reason is, that antecedent parties, if made liable, are entitled to full recourse against the acceptor, which they cannot have if the acceptance is conditional. It is also well settled that no one but the drawee named can become an acceptor, except for honor supra protest. (Story on Bills, $\$$ r $2 \mathrm{I}, c t s e q$.) [The court then holds that no one was bound by this acceptance.] It follows therefore, that the defendant should have treated the bills as dishonored, and given notice of nonacceptance to the indorsers, who by the omission are discharged from liability. ${ }^{2}$

ante, p. 629; Green v. Raymond, 9 Neb. 295; Gibson v. Smith, 75 Ga. 33 . If an agent, as a bank, receives a qualified acceptance without authority, the agent becomes liable to the principal for any loss ensuing therefrom. Halkir $v$. Bank. 9 N. Y. $5^{82 .}-$ ED.

${ }^{1}$ Affirmed 9 N. Y. $582 .-E_{D}$.

${ }^{2}$ See also judges' answers to the 3 d question in Row' v. Y'oung, 2 Brod. $\mathbb{E}$ Bing. I65; I Daniel, 5 510-5II. - ED. 


\section{ARTICLE XII.}

Presentment of Bills of Exchange for Acceptance.

I. In what eases presentment for acceptance necessary.

$\S 240$

HART $i$. SMITH.

$[\S \mathbf{1 4 3}]$

I5 Alabima, SO7. - IS49.

[Reported herein at f. 234. $]^{1}$

$\S 240$

PLATO $i$. REYNOLDS.

[§ 143$]$

$27 \mathrm{NEW}$ YORK. $586-\mathrm{I} 863$.

ACtion against drawers of a bill. Judgment for plaintiff.

Wright, J. - The bill which was drawn, payable one day after date, was presented to the drawee for acceptance on the day it matured; acceptance was refused, and it was protested for nonacceptance. The certificate of the notary states that on the same day ( 12 th September) he forwarded written notice, by mail, to the drawers (the defendants) and indorsers, (Miles and Bartlett), informing them of the non-acceptance thereof. It was also proved that on the following day the payees (Miles and Bartlett) received the original draft, with notices of protest for themselves and the defendants, and caused such notice to be served on the latter that day. The drawee also informed one of the defendants, on the 12 th September, at the office of the payees, that he had not accepted or paid the draft. In view of this proof, I think the referee did not err in refusing to dismiss the complaint, and in deciding that the bill was duly presented and protested, and that due notice was given to the defendants to charge them as drawers.

The defendants claim that the draft being due when presented, and demand made by the notary, it was then too late to present it for acceptance; and presentment for acceptance of a bill which is due, is not sufficient to charge the drawers. But it is well settled

${ }^{1}$ Under the Neg. Inst L., days of grace are abolished $\$+15$ [85], and such a bill would not under the Law have to be presented for acceptance.-ED.

[632] 
that the holder of a bill, payable a specified length of time after date, or on a day certain, need not, for the purpose of charging the drawers and indorsers, present it for acceptance until it becomes due and payable. It may be presented before or at the time of its miturity. (Edwards on Bills, $3 \delta_{7}$; Story on Bills, $s z_{3}$; Allin 4 S.trdam, 20 Wencl. 32r: S. C.. iz Id. 368.) . . .

All the judges, except Marrin, I., agreed that a refusal to accept on the day payment is due is equivalent to a refusal to pay, and renders a demand of payment unnecessary. ${ }^{2}$ On the question of evidence, all the judges concurred.

Judgment reversed, ${ }^{2}$ and new trial ordered.

$\$ 24 I$

ROBINSON $\approx$. AMES.

[S I I44]

20 Johnson (N. Y.) I46. - Is22.

THIS was an action of assumpsit, on a bili of exchange drawn by the defendants, merchants in Augusta, in the State of Georgia, on the 6th of March, I8Ig, upon Townsend and White, merchants, in the city of New York, for five hundred dollars, payable sixty days after sight, to Starr and Ross, or order, by whom it was indorsed to the plaintiff. The cause was tried at the New York sittings, in June, I82I, before the chief justice. The bill was presented for acceptance on the 20 th of May, r8rg, and notice of non-acceptance sent, by mail, on the next day, to the drawers, by a notary, directed to them at Augusta, in Georgia. On the $22 \mathrm{~d}$ of July, rsig, the same notary presented the bill to the drawers for payment, which they refused, alleging the want of funds. Notice of non-payment was sent through the post-office, two or three days afterwards, addressed to the defendants, at Savannah, in (icorgia.

Townsend, one of the drawees, who wals a witness for the plaintiff, testified, that on the 20 th of May, i $\$ \mathbf{I}$, the drawees had no funds in their hands belonging to the defendants, and had then accepted drafts to the amount of three or four thousand dollars more than they had funds of the defendants, and that this was the last bill drawn by them. That the want of funds proceeded from a fall in the price of cotton shipped by the defendants $t 0$ ' $T$. and $W$; that by an agreement between them, the defendants were authorized to make purchases of cotton, on the joint account of themselves and 'T. and $W$, and to draw on T. and. W for the amount. That, on the 2 foth of

'Accord Philpott v. Bryant, 3 Car. \& P. 24t: Washingtum bitnk v. Triplitt, I Pet. (U. S.) 25.-ED.

${ }^{2}$ On a question of almission of evidence.-lin. 
April, ISI9, T. and W. stopped payment. That after the 6th of Narch, and before the failure of $T$. and $W$., they had received a considerable amount of cotton from the defendants, but had accepted the bills of the defendants to a larger amount than the value of the cotton so shipped, and the difference was owing to a loss on the cotton shipped; that, if the defendants were to pay all the bills, $\mathrm{T}$. and $W$. would owe them five or six thousand dollars; but if $T$. and W. were to take up all the bills, the drawees would owe them three or four thousand dollars.

It was proved, that the mail which left Augusta about the roth of Narch, was lost; and that the mail goes from that place to New York, in ten days, and leaves the former place three times a week. That where bills are remitted by merchants, it is the usual course to send the bill by one mail, and to arlvise by the next.

A verdict was taken for the plaintiff, for five hundred and seventytwo dollars, subject to the opinion of the court on a case, as above stated.

Spencer, Ch. J., delivered the opinion of the court.

The questions in this case are: (I) Whether the bill was transmitted in due time; and (2) Whether the want of funds in the hands of the drawees, will excuse the delay in presenting the bill, or the irregularity in the notice of the non-payment of it.

I. I am entirely satisfied that there is no foundation for saying the defendants are precluded from setting up laches, because they had no right to draw the bill. The case of Bickerdike v. Bollmar ( Term. Rep. 405), is considered the first case deciding that notice to the drawer of the dishonor of the bill was unnecessary; and in that case the drawer had no funds, and knew he had none, in the hands of the drawee. The drawing the bill was considered a fraud, and it was held that he was not entitled to notice, and cou.d not be injured by the want of it. It has, however, since that case, repeatedly been decided, that where there are any funds in the hands of the drawee, so that the drawer has a right to expect the bill will be paid, or where there are not any funds, yet if the bill was drawn under such circumstances as induced the drawer to entertain a reasonable expectation that the bill would be accepted and paid, the person so drawing it is entitled to notice; and, a fortiori, he is entitled to have the bill duly presented. The rule is correctly laid down in Claridge v. Dalton (4 Maule \& Selw. 229), by Lord Ellenborough. The principle which has been stated is very ably supported by Chief Justice Marshall, in French v. The Bank of Columbia (4 Cranch's Rep. 153), where the principal authorities are reviewed. There is nothing more important, than that, in questions of a general mercan- 
tile nature, there should be a uniformity of decision; and, aithough the justice and equity of this rule may not, in some cases, be perceived, where the payee has purchased a bill, and it is lrawn in good faith, and no conceivable loss has happened by the want of notice: yet, as there may be cases where, though there were no funds in the hands of the drawee, the drawer may be injured by the want of notice, it is better that the rule on the subject should be general and uniform throughout the mercantile work. ${ }^{1}$

In the case of Hiller. Hackley (5 Johns. Rep. 375); Hildon and Furniss r. Buck and another (t Johns. Rep. I+t); and .lason and Smede r. Franklin (3 Johns. Rep. 202), it was decided that if a bill was presented for acceptance, and the drawce refused to accept it, and notice thereof was duly given, a demand of payment, and notice of a refusal to pay, was unnecessary, because the drawer was fixed already. ${ }^{2}$

2. The only remaining question, then, is, whether there was laches in presenting the bill for acceptance; for there is no doubt that regular notice was given of the refusal to accept the bill, the day subsequent to the demand. I do not find, that where a bill of exchange has been drawn payable at sight, or any specified number of days after sight, that there is any definite or fixed rule when the bill shall be presented for acceptance, other than this, that due diligence must be used. And it is certain, that with respect to such bills, and particularly where they are negotiated by the payee, there is much more latitude, as to the time of presentment, than where the bill has a fixed period of payment. In the case of Muilman r. D' Firmino ( 2 H. Bl. Rep. $5^{6} 5$ ), which is a very leading case on this subject, the judges felt the difficulty of saving at what time such a bill should be presented for payment. Ch. J. Eyre observed, that the courts had been very cautious in fixing any time for an inland bill, payalse at a certain period after sight, to be presented for acceptance. He said, that if, instead of drawing their foreign bills payable as ustacts, in the old way, merchants chose, for their own convenience, to draw them in this manner, and to make the time commence when the holder pleases, he did not see how the courts could liy down any precise rule on the subject. But he thought the holder was hound to present the bill in a reasonable time, in order that the period might commence from which the payment was to take place: and that what was reasonable time must depend on the particular cir. cumstances of the case. Buller, J., said, that he thourht at rule

1 See Neg. Inst. Law, $185[114]$, and $\$ 245[1+5]$. E1).

See $248[$ I 51$]$. ED. 
might, thus far, be laid down as to laches, with regard to bills payable at sight, or a certain time after sight, namely, that tiney ought to be put in circulation. If they are circulated, he said, the parties are known to the world, and their credit is looked to; and if a bill, drawn at three days sight, was kept out in that way for a year, he could not say there would be laches; but further than that, no rule could be laid down. Heath, J., observed that no rule could be laid down as to the time for presenting bills, payable at sight, or a given time after; that in the French ordinance of 1673 , (Postlethwaite's Dict. tit. Bills of Exchange), it is said, that a bill, payable at sight, or at will, is the same thing, and that this agreed with Marius.

Now, here, the bill was put in circulation by Ross and Starr; and, although it is probable, that the first of exchange was lost, by the loss of the mail, we are not authorized to consider that as a fact in the case; but I cannot say, that upon such a bill there has been laches. We perceive how extremely cautious the judges were, in the case cited, in laying down any rule. The evident inclination of their minds was, that when the payee put the bill in circulation, the subsequent holder was not bound to any strict presentment. The drawers of the bill evidently did not mean to limit the time of presentment, by making the bill payable at sixty days after sight. They meant to give a latitude, as to time, to the holder; and my conclusion is, that there is not such laches as will discharge the drawers.

Judgment for the plaintiff. ${ }^{2}$

1 Accord: Wallace v. Asry, 4 Mason, (U. S. C. C.) 336 ; s. C., 5 Mason, IIs, in which a "sixty days after sight" bill drawn June is at Havana, Cuba, on W. in London, and there presented Oct. 3I, having been locked up in the holder's hands in Boston, from July 6 to Sept. 29, was, on the second trial, found by the jury to have been presented within a reasonable time; Aymar v. Beers, 7 Cowen, (N. Y.) 705 , in which case a "three days after sight" bill drawn Dec. I 2 in New York, presented Jan. Io in Richmond, Va., having been in the payee's hands during that time, was held by the court to have been presented within a reasonable time, under the circumstances of the case; Bolton v. Harrod, g Mart. (La.) 326; Goteran v. Fackson, 20 Johns. (N. Y.) 176; Montelius v. Charles, 76 Ill. 305.

In the following cases the delay was deemed to be unreasonable: Mullick v. Reudakissen, 9 Moore P. C. 66; Fernandez v. Lewis, I McCord, (S. C.) 322 ; Dumont v. Poti. 7 Blackf. (Ind.) 367 ; Phanix Ins. Co.v. Allen, I I Mich. 50I; Chamliors v. Hill, 26 Tex. 472 .

Whether what is a reasonable time is a question for the jury or for the court has occasioned some conflict. The question was left to the jury in Wallace v. $A g^{\prime}{ }^{\prime}$, supra; it was decided by the court in Aymar v. Biers, supra; it was held to be " a mixed question of law and fact" in Prescott Bank v. Caverly, 7 Gray, (Mass.) 217. See I Daniel, $\$ 466$; note, 17 Am. Dec. 544-549.-ED. 


\section{What constitutes sufficient presentment.}

STUART, I. - Suit on a bill of exchange by Drew, indorsee, against Sharpe, the indorser. The action was instituted before the mayor of the city of Evansville, where the plaintiff had judgment for the bill and interest. Sharpe appealed to the Circuit Court, where it was tried with the like result. Sharpe excepted to the rulings of that court, and now appeals to this.

Two points are made and argued - $\mathrm{I}$. The evidence of presentment to the drawee for acceptance. 2. The evidence of notice of protest to Sharpe.

I. It is correctly contended that the presentment for acceptance should be to the drawee himself, if he can be found. (Chitty on Bills, 278 .) If to an agent or other person authorized to accept, the fact should appear.

In the present case the only evidence of presentment is the certificate of protest. The notary certifies " that on, etc., I did present the annexed draft of T. C. Wetmore on W. W. Peters, at the store of Silliman and Gardiner, and demanded acceptance of the same, which was refused," etc. It is contended that this is not evidence of a presentment to Peters for acceptance.

The statute makes notarial certificates eviclence of the facts therein stated. ( 2 R. S., p. 9r.) The notarial certificate is clear as to the fact of presentment, the place of presentment, the demand of acceptance, and the refusa:. To whom was it presented? Who refused to accept? It cannot admit of doubt that Peters himself Wats the person. The plain English of the protest is that the notary found Peters at the store of Silliman and Gardiner, Troy, N. Y., and there demanded of him acceptance, which leters refused. 'The form here used seems to be the common anc prescribed by the books. (Chity on Bills, 333; Byles on Bills, ror.)

The language is not eren olscure. The presentment, the demand, the refusil, all clearly mean, that it was the drawee who wats the object and actor. We are not at liberty to doubt the sufficiency of the evidence that the bill was duly presented for areptance.

[The Court then holds the notice of dishonor sufficient.]

Per Curan. - The julgment is affrmed, with 5 per cent. damages and costs. ${ }^{2}$

${ }^{1}$ It would seem that presenzment for acceptance must he mate to the drawee or his authorized agent in person and that diligent incuiry should be mate for 
5 MetCalF (Mass.) $216 .-18+2$.

Actiox against indorser of bill. The jury were instructed that if the drawees were informed by the bank that it held such a bill drawn on them by -1. (and indorsed by defendant), and they thereupon informed plaintiff that they should not accept nor pay it, and if 110 notice thereof was given to the indorser (defendant), he was discharged. Verdict for defendant.

HLBAARD, I. - It is a well established principle of the law regulating bills of exchange, that the holker of a bill, payable at a certain time after date, need not present it for acceptance prior to the day of payment. And though it is usual and siffe so to do, as he thereby strengthens his security, or, in case of non-acceptance, acquires an immediate right to call on the other parties to the bill, yet he is under no legal obligation to do it, nor can the omission be taken advantage of by the drawer or indorsers. (Goodall v. Dollel, I T. R. 7 I 2 ; Chit. on Bills, Part I., c. $5 ; 3$ Kent, Com. [4th ed.] S2; O' Keefe' v. Dunn, 6 Taunt. 305: S. C., I Marsh. 613.)

[The court then decides that an agreement by the holder made with the drawer not to present the bill for acceptance, but only for payment at maturity, will not discharge the accommodation indorser, although such agreement was not known or assented to by the indorser. ]

The evidence which was introkuced tended to show that the cashier of the Fall River Union Bank (the plaintiffs in this suit) met Chace, one of the house upon which the bill was drawn, and informed him

the drawee if no person is found at his office or resilence having a lutherify to accept for him. Banks. Triflitt, I Pet. (U. S.) 25, 3t; IIiscman r. Chiaffilla, 23 How. (U.S.) 365,377 ; Cher v. Ropir, 5 Esp. I75. It has, howerer, been held that it will be presumed that a clerk in the drawee's counting house has authority to accept or refuse to accept. Vitson v. Fotterall, TLeigh, (Va.) Iso: Staintuack v. State Rank, I I Gratt. (Va.) 260. 'Comparing presentment for acceptance with presentment for payment, it is clear that the two cases are governed by somewhat different considerations. Speaking generally, presentment for acceptance should be personal, while presentment for payment should be local. A bill should be presented for payment where the money is. Any one can then hand over the money. A bill should be presented for acceptance to the drawee himself, for he has to write the acceptance; but the place where it is presented th him is comparatively immaterial, for all he has to do is to take the bill. A rain (except in the case of demand drafts), the day for payment is a fixol day; but the drawee cannot tell on what day it mav suil the holder to present a bill for acceptance. These considerations are matcrial as bearing on the question whet ier the holder has used reasonable diligence to effect presentment." Chalmers, Bills of Exchange Act (5th ed.), pp. I37-I3S.-ED. 
that the bank had the draft (now in suit), upon which Chace told the cashier that they should not accept or pay it. And the instruction to the jury was, that if no notice thereof was given to the indorser, he was discharged. Waiving the question whether the cashier was agent for the plaintiffs for the purpose of presenting the draft for acceptance, or not, we are of opinion that this was not a due presentment of the bill for acceptance. The term presentment imports, not a mere notice of the existence of a draft which the party has in his possession, but the exhibiting of it to the person on whom it is drawn; that he may see the same, and examine his accounts or correspondence, and judge what he shall do; whether he shall accept the draft, or not. Here there appears to have been nothing more than a casual meeting of the parties, and the conversation on the subject of the draft ensued. If this had been communicated, it would have created no obligation on the part of the indorser to make present payment, and consequently such conversation imposed no present duty on the holders, as to the other parties to the bill. With this view of the case we are not satisfied with the instruction given to the jury. To confirm it, would tend to introduce a looseness of practice on the subject of presenting bills for acceptance, which will lead to disputes and difficulties greater than now exist.

Verdict set aside, and a new trial granted. ${ }^{2}$

\$242 TOMBECKBEE BANK ${ }^{\prime}$. DUMELL \& LYMAN. [S I45] 5 M.SON (U. S. C. C.) $56 .-$ I $\$ 28 . ?$

Assuxipsit on a bill of exchange drawn on izth of March, is $S_{7}$, in Alabaina, by Stone, Ellis \& Co., at sixty lays' sight, on the lefentants, for $\$ 3,000$, payable to Moses Sewall or order, and hy him indorsed to the plaintiffs. The declaration averred a presentment for acceptance, and an acceptance and a subsequent nen-payment. There were other counts on other similar bills. Pleat, the general issue.

At the trial, the sole defence relied on was, that the acreptance was made by Jacob Dumell after the dissolution of the partucrabip

${ }^{1}$ But it seems that the actual exhibition of the bill is not necessary 11 the drawee is enabled, without seeing it, to give an intelligent response. I 11.4niel.

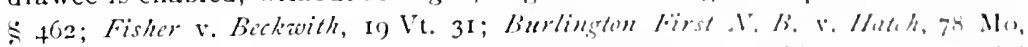
i3. Otherwise an extrinsic acceptance, as by telegram, would serve no necolful purpose. See Neg. Inst. L., S222 [134]. - E1).

${ }^{2}$ S. C., 24 Fed Cas. 18. 
between him and his co-defendant, John Lyman. It appeared in evidence, that the firm was dissolved on the Ist of January, 1827 ; but it was not advertised in the newspapers until the 5 th of April, 1827, when it was published at Providence, where the firm carried on business. The acceptances of all the bills were after the dissolution was so advertised.

Story, J. - Upon this statement of facts, which is not controverted, I am of opinion, that the plaintiffs are not entitled to recover. No partner has any authority after a dissolution of the partnership to bind his copartners by any new contract. 'The acceptance of these bills is altogether a new contract. It is true, that if the partnership is still ostensibly carried on in the name of the firm, and no public notice is given of the dissolution of the partnership, though it is secretly dissolved, third persons, dealing with the firm upon the faith of the partnership and joint responsibility, are entitled to hold all the partners. But it is otherwise, where the dissolution is made public. Here, before the acceptance, the dissolution was publicly announced. The partners had not held out to the payee, or the present holders, that they would accept the bill. Every non-accepted bill is necessarily taken upon the faith and credit of the drawer; and no person can bind the drawee by his acceptance, except a person having an express or implied authority for that purpose. After the dissolution of the partnership, and a public notice of it, there was a withdrawal of all such authority; and consequently the acceptance, as to John Lyman, is roid. Upon principle then, the action, being joint upon a joint acceptance, fails as to both.

$M \mathrm{~cm}$. By consent of the parties, the plaintiff discontinued as to Lyman, amended his declaration, and took a judgment against Dumel alone. ${ }^{1}$

$\S 242$

SCHMITTLER $i$. SIMON.

$[\S$ I45]

IOI NEW YORk. 554. - ISS6.

[Reported herein at $\mathrm{f}$. I $\left.\delta_{3}.\right]^{2}$

\footnotetext{
${ }^{1}$ Such an acceptance is a qualified acceptance (Neg. Inst. L., \& $229[\mathrm{I}+\mathrm{I}]$, subsec. 5), and binds the one accepting (Smith $v$. Milton, I33 Mass. 369), but if received by the holder discharges prior non-assenting parties, ante, p. 63r. If one of the drawees refuses to accept it would seem unnecessary to make a further presentment upon the others; but the language of $\$ 2+2$ [I45], subsec. I, provides for presentment to all.-ED.

${ }^{2}$ See $\$ 245[1+8]$, subsec. I.-ED.
} 


\section{When presentment for acceptance excused.}

\section{$\$ 245$ Chitty on Bills of Exchange, p. 307.}

IF THE drawee of a bill cannot be found at the place where the bill states him to reside, and it appear that he never lived there, or has absconded, the bill is to be considered as dishonored (. $1 \mathrm{~m})$. Ld. Raym. 743); but if he has only removed, it is incumbent on the holder to endeavor to find out to what place he has removed, and to make the presentment there (Collins v. Butle, 2 Stra. IoS 7 ); and he should in all cases make every possible inquiry after the drawee, and if it be in his power present the bill to him; though it will be unnecessary to attempt to make such a presentment if the drawee has left the kingdom, in which case it will be sufficient to present the bill at his house (Cromacll y. Hy'nson, 2 Esp. 2 I I), unless he have a known agent, when it should be presented to him. (Ibid; Phillifs $r$ Astling, 2 Taunt. 206.) If on presentment it appears that the drawee is dead, the holder should inquire after his personal representative, and, if he live within a reasonable distance, should present the bill to him. ${ }^{1}$ (Molloy, b. 2, c. 10, $\S 34$; Poth. pl. I +6.$)^{2}$

\section{Effect of dishonor of bill presented for aceptance.}

$\$ 248$ UNION NAT. BANK $\imath^{\prime}$. MARR'S ADM'R.

$[\$ 15 I]$

$6 \mathrm{Bush}(\mathrm{Ky}) .6 \mathrm{r} . \mathrm{-I} 560$.

[Reportid herein at p. 557.]

$\$ 248$

WINTHROP $i^{\prime}$. PEPOON.

[\$ I5I]

I BAY (So. Car.) 465. - I795.

[ACTION against drawer of bill, brought before time for payment had expired. The bill was presented for acceptance, dishonorcd, and duly protested.]

Upon the first ground, The CoUrt were clearly of opinion, that the action lay upon the protest for non-acceptance, although the time for payment of the bill was not expired. Every man, by the law of merchants, who draws a bill, undertakes by the very act of drawing that the bill shall be accepted and paicl, when at maturity,

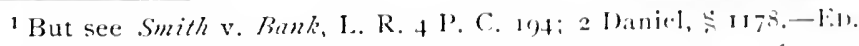

${ }^{2}$ Excuse for delay is to be distinguisherl from excuse from presentment altogether. U. S. v. Barker, I Paine, (U. S. C. C.) 156,$163 ; A$ ymar v. Air's, 7 Cow. (N. Y.) 705; I Daniel, $\$ 479 .-$ Es.

NEGOT. INSTRMMENTS - $4 \mathrm{I}$. 
agreeable to the terms of the bill. And the very end and design of a protest, is to give notice of non-acceptance; or, if accepted, of non-payment; in either event, the drawer becomes liable. And the holder, in case of a protest for non-acceptance, is under no obligation to wait till the time for payment expires; because the drawer has broke part of his original contract, that is, that the bill should be accepted; and because also (if the bill should even be paid when due), the holder would lose the benefit of the credit in trade, which the acceptance of a bill would give him, as well as the use of the money, which he might obtain at a small discount. The obligation in every such case would be on the part of the defendant to show that the bill was afterwards paid, which might be given in evidence by way of mitigation of lamages. But in this case, no payment, even at this day, is alleged; therefore, the plaintiff is entitled to a recovery. (Doug. 55; 3 Will. I7; Kyd, I7.)

${ }^{1}$ If a right of action arises on presentment for acceptance, no new right arises on presentment for payment. Whitheat V. Halker, 9 M. \& W. 506. See Robinson v. Ames, 20 Johns. 146, ante, p. 633; Stemy v. Rohinson, I Day, (Conn.) II. But if there is an acceptance for honor or a reference in case of need, there must be a presentment for payment, and protest for non-payment, before presentment to the acceptor for honor or referee in case of need. Neg. Inst. L., 5256 [I67].-ED. 


\title{
ARTICLE XIII. \\ Protest of Bills of Exchange.
}

\section{What instruments must be protested.}

$\S 260$

\author{
SUSSEX BANK $\because$ BALDWIN. \\ I7 New Jersey LaW, $457 .-$ Is 40. \\ [Rifortal herin at $f .50 \mathrm{I}.]^{1}$
}

$\left[\S I^{2}\right]$

\section{What constitutes sufficient protest.}

\section{$\S 26 \mathrm{I}$}

\author{
DENNISTOUN $\because$ STEWART.
}

I7 Howard (U. S.) 6o6. - I854.

Mr. Justice Grier delivered the opinion of the court.

The plaintiffs declared against the defendant, as drawer of a bill of exchange, by the name and style of James Reid and Co., of which the following is a copy:-

No. -. E4,4I7 I4s. II $d$. st'g.

Miniti, Sift. 9, 1550.

Sixty days after sight of this first of exchange, (second and third unpaid), pay' to the order of ourselves, in London, forty-four hundred and seventeen pounds, I4s. II $d$. st'g, value received, and charge the same to the account of 1,058 bales of cotton per 'Windsor Castle.'

Your obedient servants,

Pr. pro Janks Rlaw ans, Cr., WM. Mnst, Jk.

To Hy. Gore BooTh, Esq., Liverpool.

[Acceptance across the face of the bill:]

Seventh October, is5o. Accepted for two thousand five hundred and seventy

${ }^{1}$ As to protest of inland bills and promissory notes, sec Negr. Inst. L... In 1 sin

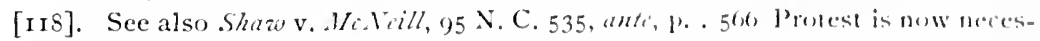
sary in three cases: (I) foreign bills: (2) bilis accepted for honor; and (3) bills containing a reference in case of necd, if the holder desires to resort to the referee. Neg. Inst. L., $\$ 286[16,7]$. Protest is proper, but not necessary, in two cases: (I) inland bills and promissory notes; (2) for better securisy : $20,[15.5 \mid$. The protest for non-payment after protest for non-icceplance is anomithus: it may be necessary to meet the requirements of foreign law. 
one pounds eighteen shillings and seven pence, being balance unaccepted for acpt. I, $05^{8}$ b. cotton, pr. Windsor Castle, payable at Glyn and Co.

Pr. pro. HeNry Gore BoOTh.

And. E. Brrne.

Lue 9 Decem.

[Indorsed:]

Pay Messes. A. Dexistolx axn Co., or order.

Pr. pro. Janes Reid aNi Co.

Wr. Molut, JR.

After reading this bill, with its indorsements, the plaintiff offered in evidence a regular protest, intlorsed on a copy of a bill agreeing in every particular with the above, except that for "And. E. Byrne", was written "Chas. Byrne."

The defendant objected to the reading of the protest in evidence, because it did not describe the bill of exchange produced by the plaintiffs, but a different bill. The court sustained this objection, and excluded the protest from the jury, which is the subject of the first bill of exceptions.

A protest is necessary by the custom of merchants in case of a foreign bill, in order to charge the drawer. It is defined to be in form " a solemn declaration written by the notary under a fair copy of the bill, stating that the payment or acceptance has been demanded and refused, the reason, if any, assigned, and that the bill is, therefore, protested.'

A copy of the bill, it is said, should he prefixed to all protests, with the indorsements transcribed a'rbatim. (I Pardess. +4t; Chitty on Bills, +5 .)

However stringent the law concerning mercantile paper, with regard to protest, demand, and notice, may appear, it is nevertheless founded on reason and the necessities of trade. It exacts nothing harsh, unjust, or unreasonable. A protest, though necessary, need only be noted on the day on which payment was refused. It may be drawn and completed at any time before the commencement of the suit, or even before the trial, and consequently may be amended accorling to the truth, if any mistake las been marle. ${ }^{1}$

The copy of the bill is connected with the instrument certifying the formal demand by the public officer, as the easiest and best mode of identifying it with the original. Mercantile paper is generally brief, and without the verbiage which extends and enlarges more formal legal instruments. Hence, it is much easier to give a literal copy of such bills, than to attempt to identify them by any abbreviation or description. The amount, the date, the parties, and the conditions of the bill, form the substance of every such instrument. 
Slight mistakes, or variances of letters, or even words, when the substance is retained, cannot and ought not to vitiate the protest. A lost bill may be protested, when the notary has been furnished with a sufficient description, as to date, amount, parties, etc., to identify it.

In indictments for forgery, it is not sufficient to state the "substance and effect" of the instrument; it must be laid according to the "tenor," or exact letter; but the law merchant demands no such stringency of construction. The sharp criticism indulged when the life of a prisoner is in jeoparly cannot be allowed for the purpose of eluding the payment of just lebts.

It is unnecessary that a copy of the protest should be included in the notice to the drawer and indorsers." 'The object of notice is to inform the party to whom it is sent that payment has been refused by the maker, and that he is held liable. Hence, such a description of the note as will give sufficient information to identify it, is all that is necessary. What was said by Mr. Justice Story, in delivering the opinion of this court, in . Wills v. The Bank of the Lintid States, with regard to variances and mistakes in notices, will ecpually apply to protests: "It cannot be for a moment mantained that every variance, however immaterial, is fatal. It must be such a variance as conveys no sufficient knowledge to the party of the particular note which has been dishomored. If it does not mislead him, if it conveys to him the real fact, without any doubt, the variance cannot be material, either to guard his rights or avoid his responsibility. "

In the case before us, the protest had an accurate copy of crery material fact which could identify the bill-the date, the plate where drawn, the amount, the merchandise on which it was drawn, the ship by which it was sent, the balance on the cotton for which it was accepted, the names of drawers, acceptor, indorsirs; in fine, every thing necessary to identify the bill. The only variance is a mistake in copying or deciphering the abbreviations and flourishes with which the christian nance of the acceptor's agent is enveloped. The abbreviation of "And." has heen mistaken for ('has., and the midale letter F. omitted. The omission of the midelle letter would not vitiate a declaration or indictment. Nor comlet the mistiske mislead any person as to the identity of the instrument descrilued.

We are of opinion, therefore, that the oljection male to this protest, " that it does not describe the hill of exchanere probucul,

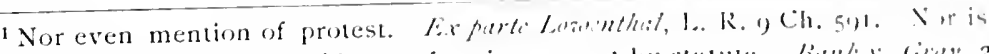
the certificate of protest evidence of notice, except by statule. Limnk 1 . firm, 2 Hill (N. Y.) 227 , ante, p. 568. - E1s.

2Anle, p. 56. - Ev. 
but a different bill," is not true in fact, and should have been overruled by the court.

This renders it unnecessary for us to notice the offer of testimony to prove the identity, which was also overruled by the court.

The judgment of the Circuit Court is reversed, and venire de no'o awarded.

$\S 261$

CAYUGA COUNTY BANK $\%$ HUNT.

$[\S \mathbf{5} 53$

$2 \operatorname{HILL}\left(\right.$ X. Y.) $635 .-1 S_{42}$.

Assumpsit. . . . The action was by the plaintiffs as indorsees against the clefendant as indorser of a bill of exchange drawn by James Treat on Stephen Sicard \& Co., New York, and accepted by them.

The bill, which bore date January 16 th, I $\delta_{39}$, was payable to the order of the defendant at ninety days; and no place of payment was mentioned therein. On the trial, after proving the signature of the defendant as inclorser, the plaintiffs gave in evidence a notarial certificate of protest, stating that on the Igth day of April, I $8_{39}$, the notary presented the bill in question at No. 4 Wall street, the office of the acceptors, but found the same closed and no person there of whom payment could be demanded; that he then presented the same to the widow of Stephen Sicard, for payment, which she refused, saying that the partner of her late husband was at the South, and she knew nothing of it. The plaintiffs also read in evidence a notarial certificate, stating that notice of protest of the bill in question had been duly given to the defendant. This certificate was dated February 9 th, I $S_{4}$ I, nearly two years after presentment and protest. No further evidence was offered by the plaintiffs. The defendant's counsel moved for a nonsuit, on the ground, I. That the presentment of the bill in question to the widow of Stephen Sicard, deceased, was insufficient to charge the indorser; 2 . That it did not appear from the certificate of protest that the bill was presented for payment to any person at the office of S. Sicard $\&$ Co., or that the notary called for that purpose during office hours; and 3 . That the certificate of notice of protest was not given till nearly two years after protest was made. The judge denied the motion, and th? defendant excepted.

By the Court, Cowen, J. - The bill of exchange was payable generally, mentioning no place. The drawees were Stephen Sicard $\&$ Co., who accepted the bill as a firm, thus becoming joint debtors. On the death of Sicard, he was discharged at law, the liability developing on the surviving partner (Story on Partn., $\$ 3^{6} \mathrm{I}, 3^{62}$ ), to 
whom alone the plaintiffs were bound to have the bill presented for payment. The mode, therefore, in which the bill was presented to the widow and supposed personal representative of Sicard, or whether she were in fact his representative, becomes entirely unimportant.

No objection was made at the trial that the presentment, which was at No. 4 Wall street, where the survivor transacted business, should have been at his residence or any other place. Therefore the question on the place of presentment does not arise. It must be taken to have been proper. Nor was the manner of presentment denied to be proper; nor the day.

But it is objected that the time of day should have been mentioned in the notary's certificate; for perhaps it might have been after the hours of rest. The certificate states that it was presented on the third day of grace. This, coming from a witness on the stand, would be deemed prima facie evidence of presentment at a proper time in the day; and if an improper hour were in truth selected, it would lie with the adverse party to show the fact by cross-examination or otherwise. It would not be intended that a late hour was resorted to. We think, therefore, that the certificate, in fair construction, imports a presentment during the proper hours of business. These, except where the paper is due from a bank, generally range through the whole day down to bed-time in the evening. (Chitty on Bills, 42 I [r.], Am. ed. I839, and cases there cited.) It woukl be quite a forced presumption on the words of an officer saying he presented on such a day, to fix the hour either before or after that when business is usually transacted. It would be to suppose the notary, at the expense of his own convenience, going at an improper hour for the mere sake of loing wrong.

It is no objection that the certificate of notice was drawn up by the notary two years, or any other length of time, after notice was given. The statute gives it as a substitute for his personal testimony at the trial. It is properly called for and may be drawn up when it happens to be wanted as evidence. The notary camot le expected always to prepare it as a matter of course; for non constat it may ever be wanted. It was said on the argument, that ordinarily it is drawn up and transmitted to the holder at or about the time when the business is done. That is the better practice; but it is not essential.

[Omitting a question of usury.]

New trial denied.

1"Went with the draft os the bank and demamed payment," is sullicicut. Bank v.Cameron, 7 Barb. (N. Y.) 143. "Went with the note and mate demand 


\section{By whom protest should be made.}

7 Humphrey (Texis.), 543. - IS 47.

Greex, J., delivered the opinion of the court.

This is an action against the plaintiff in error, as the indorser of a bill of exchange drawn in Memphis, Tennessee, by Arthur Bowen on Fort and Wilcox, New Orleans, in favor of plaintiff in error, for $\$ 2,500$, and by him indorsed. The bill was presented at maturity, payment demanded and was protested for non-payment by A. B. Cends, a notary public of New Orleans. The instrument of protest states, that the notary " by his deputy, McDime, Jr., presented said draft to Mr. Fort, one of the members of the firm of Fort and Wilcox, the acceptors, at their office, and demanded payment thereof, and was answered that the same would not be paid." The protest was made the inth June, $1 s_{45}$.

By an act of the General Assembly of Louisiana, passed the $\mathrm{r}_{4}$ th of March, IS 44 , it is made lawful, for each and every notary public in New Orleans, to appoint one or more deputies, to assist him in making of protests and delivery of notices of protests of bills of exchange and promissory notes: Provided, that each notary shall be responsible for the acts of each deputy employed by him; and provided, that each deputy shall take an oath, faithfully to peiform his duties as such, before the judge of the parish in which he may be appointed; and provided, the certificate of notice of protest shall state by whom made or served.

The defendant, at the trial below, objected to the protest which was offered as evidence, which objection was overruled by the court, and the evidence was admitted. The jury found a verdict for the plaintiff, and the defendant appealed to this court.

It is now insisted, that this protest is not evidence of the presentment and demand of the bill, because it states that the demand was made by the deputy of the notary.

It is certainly true, as the general rule, that a foreign bill must be presented by the notary in person, and demand of payment made by

at maker's office and person in charge answered, 'No funds,' "' is sufficient. The maker is entilled to have the note exhibited, yet if he does not ask to see it, and refuses payment on other grounds, the presentment is sufficient. Lerst v. Iinal, 165 Mass. 555 .

A cerificale that the notary presented the draft to " one of the firm of Warren, Clark \& Co.," is insufficient for not stating the name of the person on whom demand was made. Otsego Co. Bank v. Warren, is Barb. (N. Y.) 29o. - ED. 
him, and that the demand by his deputy is not sufficient. But it is seen, that the law of Louisiana, where this bill was payable, authorizes the employment of a deputy in this service, and that the protest must certify by whom the demand was made.

In Story on Bills $(\$ 2 ; 6)$, treating of protest of foreign bills, it is laid down, that the protest "should be made out and (lrawn up in the form required by the law or usage of the place where it is male, and that so essential is the production of the protest, that it cannot be supplied by mere proof of noting for non-acceptance, and a subsequent protest for non-payment." And Mr. Chitty observes (Chitty of Bills, 333), " whenever notice of non-acceptance of a foreign bill is necessary, a protest must also be made, which, though mere matter of form, is by the custom of merchants indispensably necessary, and cannot be supplied by witnesses or oath of the party, or in any other way, and, as it is said, is a part of the constitution of a foreign bill of exchange." The mere production of this protest, in the case of a bill payable and protested out of the country, will be evidence of its dishonor, " and to it all foreign courts give credit." And at page 456 , he says: "With respect to the protest, it should always be made according to the law of the place where the parment ought to have been made, though, with regard to notice of dishonor, it must be given to the drawer within the time, and according to the law of the place where the bill was drawn, and to the indorsers according to the law of the place where the indorsements were made."

These authorities settle the question, and establish the following propositions:-

I. That a protest is indispensable to the dishonor of a foreign bill of exchange.

2. That the protest is to be made according to the law of the place where the bill is payable.

3. That the protest properly authenticated, is evidence by its mere production, of the presentment and demand, in all forcign courts, where the dishonor of the bill is required to be prosed.

4. That no other evidence of the facts stited in the protest is competent.

The protest in the present case was made accorling to the law of Louisiana, where the bill was payable, and, therefore, is evidence here of the dishonor of the bill.

It is objected, that there is no evidence that Memplis was the defendant's place of residence.

It appears, that annexed to the name of the defendant on the bill is added "Memphis, Tennessee." This we regard as part of his 
indorsement, and as sufficient authority to authorize the holder to senci the notice to Memphis.

Affirm the judgment. ${ }^{1}$

1" In many cases, even with regard to foreign bills of exchange, the protest "may, in the absence of a notary, be made by other functionaries, and even by merchants. But where, as in Mississippi, a justice of the peace is authorized by positive law to perform the functions and duties of a notary, there is no ground to say that his act of protest is not equally valid with that of a notarv. Cuoad hoc he acts as a notary." - Mr. Justice Story in Burke v. McKay, 2 How. (U. S.) 66, 72 (rs+4). Conf. Toddv. Neal's Adm'r, 49 Ala. 273; Read v. Bank, I T. B. Mon. (Ky.) 92 . Costs for protest cannot be allowed where the protest is by a private individual not authorized to charge fees. Read v. Bank, supra.-ED. 


\title{
ARTICLE XIV.
}

\author{
Acceptance for Ho:or.a $(a)$
}

\section{BYLES, BILLS OF EXCHANGE, ErTC. (1 $3^{\mathrm{TH}}$ ED.), is 79.}

\author{
[Chapter X.]
}

WHEN acceptance is refused, and the bill is protested for nonacceptance, or where it is protested for better security, any person may accept it supra protest, (b) for the honor of the drawer or of any one of the indorsers The method of accepting sufra frotest is said to be as follows, viz.: The acceptor supra frotest must personally appear before a notary public, with witnesses, and declare that he accepts such protested bill in honor of the drawer or indorser, as the case may be, and that he will satisfy the same at the appointed time; and then he must subscribe the bill with his own hand, thus - "Accepted supra protest in honor of A. B.," ete., (c) or, as it is more usual, "Accepts S. P." And a general acceptance suppr protest which does not express for whose honor it is made is considered as made for the honor of the drawer. $(d)$

Any person may accept a bill supra protest; and the drawee himseli

(a) Called in French, "Acceptation par Intervention," Code de Commesce, I26. Byles, Ch. XX.

(b) I am not aware of any authority to show that there may be an acceptance for honor without a protest, and the statute $6 \times 7$ Will. 4 . c. 5., seems to assume

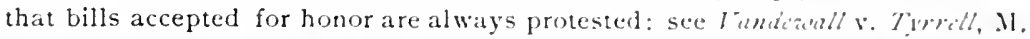
\& M. 87; Geratoputo v. Wiiler, so C. B. 6go); Bayley (toth ed.), 181; Nouguier, Lettres de Change, $\$ 554-591$. Unless, indeed. there be a tirection w another person in case of need: Chitty 165,236 . Where the direction, in case of need, is appended, it is said to be necessary un present a foreign bill to that other person. But then he is more properly an original alternative Irawee than an accepur for honor. As to a direction "in case of need" on an indorsement, sece liomurd s". Hilson. 2 C. \& M. 589 . There seems from that case no obligation u presunt an inland bill (where the direction in case of need is griven by an indurser) (1) the party to whom, in case of need, it may be presented. The referee, in case of need, appointed by the indorser, though agent to pay the bill, is not agrent $t_{1}$ receive notice of dishonor: In re Lats bunking Compung, Law Rep, I liduity $76 ; 35$ L. I. Ch. 33 .

(c) Beawes, pl. 3 \%.

(d) Chitty (9th ed.), 34t; Beawes 39 . 
though he may refuse to accept the bill generally, may yet accept it supra protest, for the honor of the drawer or of an indorser.(e) And though we have seen that, after one general acceptance, there cannot be another acceptance, $(f)$ yet, when a bill has been accepted susra protest, for the honor of one party, it may, by another individual, be accepted sufra protest, for the honor of another. $(g)$ In no' one case is the holder obliged to take an acceptance for honor.(h)

The holder of a dishonored bill, who is offered an acceptance for the honor of some one of the preceding parties to the bill, sliould first cause the bill to be protested, and then to be accepted supra. protest, in the manner above described. At maturity he should again present it to the drawee for payment, who may, in the meantime, have been put in funds by the drawer for that purpose. If payment by the drawee be refused, the bill should be protested a second time for non-payment, $(i)$ and then presented for payment to the acceptor for honor. $(k)$ Doubts haring arisen as to the day when the bill should be again presented to the acceptor for honor, or referee, in case of need, for payment, the 6 and 7 Will. 4, c. 58 , enacts that it shall not be necessary to present, or in case the acceptor for honor or referee live at a distance, to forward for presentment, till the day following that on which the bill becomes due. (l)

In a case which attracted much attention, it was proved that where a foreign bill, drawn upon a merchant residling in Liverpool, payable in London, is ref used acceptance, the usage is to protest it for nor-payment in London. The bill is put into the hands of a notary, and he formerly used to make protest at the Royal Exchange, but that custom is obsolete: the notary now is merely desired by the holder to seek payment of the bill, and on a declaration by the holder that the drawee has not remitted any funds, or sent to say where the bill will be paid, the notary at once marks it as protested for non-payment. The court (with the exception perhaps of Mr. J. Bayley), seemed to think this might, if the bill were payable in Lon-

(e) Beawes 33. And it has been held in America that it is no objection that the accepior sufra protest takes the guarantee of the drawee. Byles on Bills (6!h American edition), 403.

( $f$ ) Jackson v. IIudson, 2 Camp. $4+7$.

(s) Beawes, pl. 42.

(h) Vutford v. Halcott, I2 Mod. +IO; I Ld. Raym. 575, s. C.; Beawes, 37; Grescry v. Walcut, Comb. 76; Pillans v. Tan Mierop, 3 Burr, r663.

(i) Hoare v. Cazenove, I6 East, $39 \mathrm{I}$.

(k) Williams v. Germaine, 7 B. \& C. 477, I M. \& R. 394, s. C.

(l) According to the French law the acceptor for honor is bound to give notice to the person for whose honor he accepts. Code de Commerce, I27, r2S. 
don, be, in ordinary cases, sufficient. But they were all agreed that it would not have been sufficient in the principal ease to charge the acceptor supra protest, because the acceptance was in these words, "If regularly protested and pard when due," and they said the drawees could not be said to refuse unless they were asked. The court also appear to have been clear that, though there might be cases in which an exhibition of the bill to a notary in London is suffi. cient, yet that in all cases a bill may be sent to the drawee, and indeed that such is the more regular course. $(\mathrm{m})$

By the 2 and 3 Will. 4 , c. 98 , it is enaeted that all bills made payable by the drawee in any place other than his residence are, on nonacceptance, to be without further presentment protested for non-payment in the place where they are made payable.

The undertaking of the acceptor supra protest is not an absolute engagement to pay at all events, but only a collateral conditional engagement to pay if the drawee do not. "It is," says Lord Ellenborough, " an undertaking to pay, if the original drawee, upon a presentment to him for payment, should persist in dishonoring the bill, and such dishonor by him be notified by protest to the person who has accepted for honor." (") The learned judge proceeds to lay down the doctrine that a second protest is necessary; observing: The use and convenience, and, indeed, the necessity of a protest upon foreign bills of exchange in order to prove, in many cases, the regularity of the proceedings thereupon, is too obvious to warrant us in dispensing with such an irstrument in any case where the custom of merchants, as reported in the authorities of law, appears to have been required. $(o)$ And a second protest, for non-payment by the drawee, is, after acceptance sufra protest, equally necessary, in order that either the holders may charge the acceptor sufrof frotest, or the acceptor supra protest may charge the party for whose honor the acceptance was given. The object of an acceptance for honor is to save to the holder all those rights which he would have enjoyed had the bill been accepted in a regular manner. If the bill

(m) Witchell v. Barins, ro B. \& C. +; . I. \& M. 3r1: + C. A I. 35 .

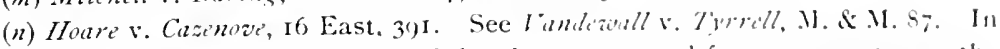
America it is held that where a drafe has been profested for nom-iteceptince, the holder is not bound to present it at maturity for payment: lixtir limk $x$ Gordon, $8 \mathrm{New}$ Hamp. 66. But this is not so when there has been an aceeptance supra protest. An acceptor for the honor of the drawer cannd recoser against him without proof of presentment for acceptance or payment and refusil, and

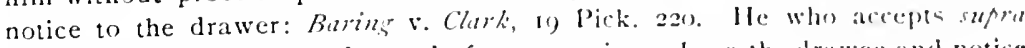
protest is not liable unless demand of payment is matle on the drawee and notice of the refusal given: Schofield v. Bayard, 3 Wendell, tyl.

(o) Ibid. 
be drawn payable at a certain period after sight, and accepted supra protest, a second presentment for payment, and a protest and notice, is still essential for the purpose of enabling the hulder to sue either drawer or acceptor supra protest, or enabling the latter to sue the party for whose honor he has accepted. And the time which the bill has to run is computed, not from the date of the exhibition to the drawee, but from the date of the acceptance supraprotest. $(p)$ Presentment to the drawee, and protest, must be averred in the declaration.(q) The acceptor supra protest becomes liable to all parties on the bill subsequent to him for whose honor the acceptance was made. $(r)$

The acceptor supraprotest admits the genuineness of the signa-. ture, and is bound ty any estoppel binding on the party for whose honor he accepts. Thus, where a bill was drawn in favor of a nonexisting person or order, but the name of the drawer and the name of the payee and first indorser were both forged and the defendant accepted for the honor of the drawer, it was held that the defendant was estopped from disputing that the drawer's signature was genuine, and that the bill was drawn in faror of a non-existing person, was negotiable, and had become payable to bearer.(s)

By acceptance supra protest, the party for whose honor it was made, and all parties antecedent to him, become liable to the acceptor supra protest for all damages which he may incur by reason of his acceptance. $(t)$ The acceptor supra protest, where the bill has been protested for better security, has his remedy also against the acceptor. $(u)$ It was once held ( $\left.i^{\prime}\right)$ that a party paying for the honor of the drawer had no claim on the assignees of the accommodation acceptor, because the drawer himself had none; but in a recent case it was decided that he could recover against the acceptor whether the acceptance were given for value or not.( $(i)$

(p) Hilliams v. Germaine, 7 B. \& C. 468 ; I Man. \& R. 394, 403, s. c.

(q) Ibid.

(r) Hoare v. Caztnow, I6 East, 391; Bayley (6th ed.), I7s; Beawes, 33; Marius, 21; E.rparte Wackerlath, 5 Ves. 574.

(s) Phillips v. Im Thurm, L. R., I C. P. $22 \mathrm{C}$

(t) Beawes, 47.

(u) Exparte Wackerbath, 5 Ves. 574 .

(v) Exparte Lambert, I3 Ves. I79.

(w) Ex parte Swan, L. R., 6 Eq. 344. In America it is held that if a third party takes up a bill at its maturity for the honor of the drawer, and at his request, he thereby releases the accommodation acceptor of such bill, whether he intended it or not. See Byles on Bills (6th American ed.), 406. 


\section{SCHOFIELD $\because$ BAYARD AND OTHERS.}

\section{Wexdell (N. Y.) 4 SS. -1830.}

THis was an action of assumpsit, tried at the New lork circuit in January, 1828 , before the Hon. Ogden Edwards, one of the circuit judges.

The defendants drew a bill of exchange in the name of Le Roy,

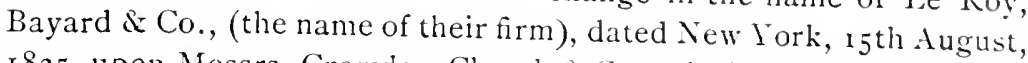
1825, upon Messrs. Crowder, Clough \& Co., of Liverpool, for $£_{1}, 000$ sterling, payable in London, at 60 days after sight, to Mr. E. Peterson, or order, and by him indorsed to the plaintiffs, merchants of Birmingham. The bill was protested for non-acceptance on the roth September, and notice given to the defendants on the r 7 th October, after which Baring Brothers \& Co., of London, accepted it supra protest in these words: "Accepted under protest and account for honor of the drawers, and will be paid for their account if needful, and regularly presented when due." The bill was subsequently sent to Liverpool to be presented to the drawees for payment. The correspondents of the plaintiffs at Liverpool, on the roth November, enclosed the bill to the plaintiffs in a letter, with advice that the presentation should be made in London, and the letter was put in the post-office on the same day, in season for the mail for Birmingham on that day, but by some oversight of the clerks in the postoffice it was not sent until the next day, and consequently did not reach the latter place until the rath November, which was Saturday. The bill could not be forwarded to be presented in season on that day, and Monday after was too late. Had the letter been forwarded from Liverpool on the roth by the mail which left there on the evening of that day, it would have reached Birmingham about I I o'clock A. 1. of the next day, and might have been forwarded from thence to London by mail on the afternoon of the same day at $f$ r. $x$., and would have reached London in sufficient time for the general delivery of letters, between 9 and ro o'clock on the following morning, which would have been in season. The bill reached London on the ifth November, and payment was demanded of Messrs. Baring Beothers $\&$ Co., who gave the following answer in writing: "liaring Brothers \& Co., accepted this bill conditionally, viz., to pay it if needful and regularly presented when due. The bill is expresily made payable in London. where payment should have been sought on the $\mathrm{r} 2 \mathrm{th}$ inst.; that has not been done, and therefore they consider their friends, Messrs. Le Roy, Bayard \& Co., as well as themselves, are acquitted from all liability by such irregularity." The bill was protested for non-payment, and notice given to the defend- 
ants on the Ioth January, I826. Messrs. Crowder, Clough \& Co. were bankrupts when the bill was drawn, the drawers had no funds in their hands, and the bill would not have been paid by them had it been presented to them for payment when due. A verdict was taken for the plaintiffs for the principal, damages, exchange, and interest, subject to the opinion of this court on a case made.

By the Court, $\mathrm{SAVAgE}, \mathrm{CH}$. J. - Where a bill is accepted supraprotest, the holder must demand payment, and if refused, notice of such refusal must be given. Such acceptance is a conditional engagement; and to render such acceptor absolutely liable, the bill must be duly presented for payment to the drawee, and protested in case of refusal. (Chitty on Bills, 242; 16 East, 391.) The above authorities say the payment must be demanded of the drawees; but if the bill is payable at a particular place, payment must be demanded at that place.

In this case the only real question is, whether the holder is excused by reason of the mistake in the post-office at Liverpool, from not making demand in season. ${ }^{1}$ It is proved in this case that the drawees were bankrupt when the bill was drawn, and had no funds of the drawers at that time or since, and that at no time would they have accepted or paid the bill. It does not appear, however, that the bill would not have been paid by the acceptors had it been regularly demanded. In the case of Patience v. Tozinley (2 Smith, 223), a bill drawn on Leghorn, due the roth September, I80o, was not demanded till the 3 rst Iecember; Leghorn being then occupied by the enemy, or in some such critical situation, it was impossible to present it in season. The plaintiff had a verdict, which the court refused to set aside, Lord Ellenborough saying: " Duly presented, is presented according to the custom of merchants, which necessarily implies an exception in favor of those unavoidable accidents which must prevent the party from doing it within the regular time; " and it was left to the jury to say whether, from the situation of the country, it was impossible for the plaintiff to present it in due time. That cause presented a case of impossibility; but this case presents no impossibility, if due diligence had been used. The plaintiff should not have sent the bill to Liverpool at all. It is true, that after the letter containing it had been left at Liverpool on the roth November, it could not have reached London in season; but it was the fault of the plaintiffs to have parted with the bill in the manner they did. Instead of sending it to Liverpool, they should have sent it to 
London, and then it would have been in season, and probably would have been paid.

I am of opinion, that, by the law merchant, payment should have been demanded in London on the I 2 th of November; and that not having been done, and there being no impossibility to prevent it but what is attributable to the want of due diligence on the part of the holders, the defendants are legally discharged, and are entitled to judgment.

NEGOT, INSTRUMENTS - +2. 


\section{ARTICLE XV. \\ PAYMeNT For HoNor.}

BYLES, BILLS OF EXCHANGE, Etc. (Ізтh ED.) I879.

[CHAPTER XXI.]

PAruext supra protest is where a bill of exchange, having been protested for non-payment, is paid by another person for the honor of some one of the parties. Any party to a bill of exchange, whether drawer, drawee, payee or indorser, may pay for honor. So may a mere stranger, without any previous request or authority from the party for whose honor he pays. This right is not founded on the English common law, but is a provision of the general law merchant, introduced to aid the credit and circulation of bills of exchange. It extends to no other instrument. Such payment should be preceded, on the part of the payer, in the presence of a notary public, by a declaration for whose honor the bill is paid, which should be recorded by the notary, either in the protest or in a separate instrument.(a) It is clear that there can be no payment for honor till the bill is dishonored by non-payment:(b) and a protest is essential, $(c)$ though it may be drawn out in due form afterward.( $d$ )

A party paying a bill of exchange supra protest has his action against the party for whom the payment was made, and against all other parties to whom the party could have resorted for reimbursement.(c) But he thereby discharges all the subsequent parties, although that discharge does not prevent his relying on any title they may have. $(f)$

(a) Beawes, pl. 53; Marius, I28; Code de Commerce, art. I5S.

(b) Diacon v. Stodhart, 2 Man. \& Gr. 317.

(c) In Findeatall s. Tyrrill, I M. \& M. S7, so held by Lord Tenterden; and in Exparte $H^{\prime} y l d e$, 30 L. J. Bky. Io. by Lord Campbell. As it is by the French Law, Code de Commerce, arı. 158, and by the law of Scotland, Bell's Comm. b. 3, pt. I, c..$+ \leqslant 367$.

(d) Geralopulo r. IViclir, ro C. B. 690.

(e) Bayley (6th ed.) $31 \mathrm{~s}$.

( $f$ ) Code de Commerce, art. I59. In America it is held that an acceptor supra protest, for the honor of the first indorser, may require as a condition of payment that the holder shall indorse the bill to him. See Byles on Bills (6th American ed.), fos. 
A man paying for honor of an indorser may, if he choose, grive immediate notice to the prior indorsers, but he 1 s not bound so to do. He may, if he please, send the protest or the bill or notice to the indorser for whose honor he pays, and any subsequent regular notice given by that party $(s)$ will suffice.

It is conceived that a man cannot, by paying supra pretest, revive the liability of an indorser already discharged by laches.

And where a party pays generally for honor, without a protest, a bill already indorsed in blank, he, as an indorsee, may, it seems, sue any party on the bill. (h)

The most obrious and advantageous conrse to be pursued by a man desiring to protect the credit of any party to a dishonored bill is simply to pay the amount to the holder and take the bill as an ordinary transferee.

But the holder may possibly object; for example, the bill may not have been indorsed in blank, and the holder may refuse to indorse even salls rourse. In such an event a payment sufra frotost becomes essential.

The party paying sufra frotest has also his remedy against the acceptor, and that whether the acceptance was given for value or not, unless there be an equity attached to tise hill amounting to a discharge.(i)

It is necessary that the protest should be made before paynent.( $k$ )

The law merchant as to payment supra frotest does not extcud to promissory notes, which are not, like bills of exchange, instruments calculated or intended for circulation all over the slobe. Whoever, therefore, pays a note for another person without authority, express or implied, does so at his peril.(/)

In ordinary cases, however, $i^{\prime}$ : $:$ the note is indorsed in lolank, he of course becomes a transferce of the note.'

(s) Goodall v. Polhill, It L. J., C. 1'. 14 f : 1 C. B. 233.

(h) Motens v. Hinnington, 1 Esp. 113. But see the observalons on this case by Lord Camplell in Ex farte H'ylde, $30 \mathrm{~L}$. J. Bky. 10.

(i) Exparte Wackerbath, 5 Ves. 574 ; Ex parte Sheth, L. R., 6 Eq. 34t, explaining and overruling Ex farte Lambert, 13 Ves. 17y. A parly laking up a bill for the honor of any party to it suceceds to the title of the farty from whom he fook $i$, and is in effect an indorsec by the law merchant, though lec cannot himself indorse: Pothier, vol. 4, pt. I, $\$ 5$ I13, 114; Nouguier, lectues de Change, S5S4-59r.

(k) Fandeatall v. Tyrrell, 1 M. \& M. 87. Although it necel not be drawn oul

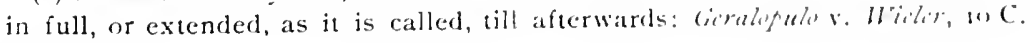
B. 6 o.

(l) Story on Promissory Notes, +53 .

1 Payment sufra protest is a peculiarity of the law merehan. The payer for honor is practically in the position of an indorsec, except that he discharges all 
parties subsequent to the one for whose honor he pays. It has been held that one who pays for the honor of the drawer cannot recover against an accommodation acceptor. HiDowell $'$ '. Cook, It Miss. 420; Gazzam v. Armstrong, 3 Dana (Ky.), 554; 2 Daniel, 5 I 255. But this doctrine was founded upon a misapprehension of the facts of Exparte Lambert (I3 Ves. I79), and the doctrine is distinctly repudiated in Exparte Säan L. R., 6 Eq. 344. By Neg. Inst. L., S 304 [175] the payer for honor succeeds to the rights of the holder, both as to the party for whose honor he pays, "and all parties liable to that party." The clause quoted seems to leave the question of the liability of the accommodation acceptor still in doubt. - ED. 


\title{
ARTICLE XVI.
}

\author{
Bills in a Set.
}

\section{BYLES, BILLS OF EXCHANGE, ETc. (І3тн ED.) I879.}

\section{[CHAPTER XXX.]}

FOREIGN bills $(a)$ are of ten drawn in parts, all the parts together making what is called a set.

Exemplars or parts of the bill are made on separate picces of paper, each part being numbered, and referring to the other parts. Each part contains a condition that it shall continue payable only so long as the others remain unpaid. These parts should circulate together: or one may be forwarded for acceptance while the other is delivered to the indorsee, thus relieving him from the necessity of forwarding his part for acceptance, but giving him the indorser's security immediately, and diminishing the chances of losing the bill.(b) Every transferor is bound to hand over to his transferee all the parts of the bill in his possession, and he may even be liable to hand them over to a subsequent transferee, if he have them still in his possession. (c)

The whole set, of how many parts soever it be composed, constitutes but one bill, and the regular payment and cancellation of any one of the parts extinguishes all.(d)

A firm, who were both payees and acceptors of a foreign bill in three parts, indorsed one part to a creditor to remain in his hands until some other security were given for it, and then indorsed another part of the same bill for value to a third person. They afterwards gave the first indorsee the proposed security, and took back the first part of the bill from him. Held, that the holder of the second part

(a) Nouguier des Lettres de Change, I, Iof.

(b) The facility which drawing a bill in sets affords for its presentment has been held to accelerate the time within which a bill, payalle after sight, ought to be presented for acceptance. Strakir v. Graham, + NI. \& W. 721.

(c) Pinard v. Klockman, 32 L. J. Q. 13. S2; 3 Best \& Smirh, 3 ss.

(d) Byles on Bills (6th American edition), 578. A contrace to delirer up a bill drawn in parts is a contract to deliver up every part. Kiamey. Wist (imanda Minings Company, r H. \& N. 412. 
was not precluded from recovering against the firm: first, because the substitution of the security for the first part was not a payment; and secondly, because the firm were, as between themselves and the second indorsee, estopped from disputing the regularity of their acceptance and indorsement of the second part.(e)

But as between bona fide holders for value of different parts of the same bill, he who first obtains a title to his part is entitled to the other parts, $(f)$ and might, it has been said, maintain trover for them, even against a subsequent bona fide holder. $(g)$

If a man be under an obligation to deliver a foreign bill, it seems he is bound to deliver as many parts as may be applied for. (h)

An omission on one part to express the reference to the others, and the condition relating to them, may have the effect of obliging the drawer to pay more than one part. (i)

The drawee should accept only one part. For if two accepted parts should come into the hands of different holders, and the acceptor should pay one, it is possible that he may be obliged to pay the other part also. $(j)$

And he should not pay without taking back the part which he has accepted, $(k)$ for, having paid the unaccepted part, he may be obliged afterwards to pay the accepted part also.

And if the indorser improperly circulate two parts to distinct holders, he may be liable on each.(l) The forgery of the payee's indorsement on one of the parts will of course pass no interest even to a bona fide holder. ( $m$ )

It is conceived that an indorser is not bound to pay any one part unless every part bearing his indorsements be delivered up to him.( $n)$

(e) Holdsworth v. Huntir, to B. \& C. 449.

(f) Ibid; Perrira v. Joft, Io B. \& C. $450 \mathrm{n}$.

(g) For it is the duty of a person taking one of the several parts to inquire after the others. Lang v. Smyth, 7 Bing. 284, 294, 5 M. \& P. 78 ; and he is advertised by the part which he does take that he takes it without the others at his peril.

(h) I Pard. 334. But since each part is now subject to a stamp, if issued or negotiated apart ( $33 \& 34$ Vict., c. 97,55 ), it may be doubtful whether he is so bound, unless the party applying will furnish the extra stamps.

(i) Dazison v. Robirtson, 3 Dow, 21S, 228; Beawes, 430; Poth. 111; 2 Pard. 367. But not an inaccurate reference or an omission to name one part obviously by mistake. Bayley (6th ed.), 30.

( $j$ ) See Holdsworth v. IIunter, to B. \& C. 449.

(k) Code de Commerce, art. ItS.

(l) See Itoldsworth v. IIunter, supra.

(m) Chap v. Harley, 3 T. R. 127. See Smith v. Mercer, 6 Taunt. 8o; I Marsh. 453, s. C.; Fuller v. Smith, I C. \& P. I97: Ry. \& M. 49, s. C.

(n) Cour de Cassation, 4 Avril, 1S32; Sirey, t. 32, 1. 29. 
Copies of bills are not, it is believed, much used in this country. A protest may be made on the copy of a bill in some cases.(0) But abroad, when a bill is not drawn in sets, it is sometimes the practice to negotiate a copy, while the original is forwarded to a distance for acceptance.

In such a case the person who circulates the copy should transcribe the body of the bill, and all the indorsements, including his own literally, and, after all, he should write "Copy: - the original being with such a person." If he should omit to state that the bill is a copy, or to write his own indorsement after the word copt, he may become liable on the copy as on an original. $(f)$

It is a common but not a safe practice for a drawer, to whom a negotiated part has come back with many indorsements on it, to substitute a new part without such indorsements. The holder of such a substituted part may be deprived of his remedy against the acceptor by the intermediate act of the drawer. $(q)$

$$
6 \text { Wiscossix, }+22 .-1853 \text {. }
$$

THE plaintiff declared in trespass on the case upon promises, for money lent; money laid out and expended; moner paid and received by the defendants for the use of the plaintifi, etc.; and gave notice of the cause of action, the indorsement by defendants upon the bill of exchange, copied, and served with the declaration as follows:

Adais \& Co.

Exchange for \$250.

No. 9,917 .

At sight of this second of exchange-first and third unoaid - pay to the order of Phobe Blatchley, two hundred and fifty doltars value receiverl, ant place to account of exchange.

To Messrs. Anams \& Co., New York.

ExlRES Exchantir ()FFIC:

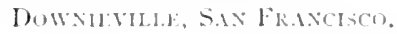

$$
(0, t, 6,1,5.4 .
$$

Allus \& Co.

(Countersigned),

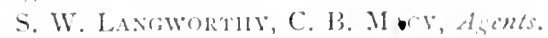

Indorsed by Phobe Blatchley w Henry Dart or orler, and by J. Henry flart to P. O. Strang or order, and by Surang to l'. Wilsh or order.

The defendants plead the general issuc; and ly mutual agreement of counsel the cause was tried hefore the circuit judge, without the intervention of a jury, who found, and reported in writing with his

(o) Dehers v. Harwiot, I Show. Io3.

(p) Cour Royale de Paris, It Janvier, 1830; Sirey, l. 30, 1. 172.

(q) Ralli v. Dennistum, 6 Exch. 483. 
decision, the facts and conclusions, and recited in full in the opinion of the court therein.

By the Court, Cole, J. - This case was tried by the court without the intervention of a jury, and the judge found the following facts:

First. That the action is brought upon the bill of exchange introduced in evidence, and described in the plaintiff's declaration. That this bill, which is the second of the set, was indorsed by the defendants on a Sunday.

Second. That the first of the set was sold by defendants to plaintiff about the ist of January, i855. That the plaintiff, without delay, sent the same by mail to his correspondent in New York city, the residence of the drawee, for presentation for payment. That by some delay in the mail the letter did not reach New York until the $9^{\text {th }}$ of April following, at which time the letter, with inclosure, was duly received by the said correspondent. That the bill was not presented for payment.

Third. That in the last of March, the plaintiff, fearing the said first bill was lost, procured the defendants to indorse and deliver to him the second of the set, and had it presented on the third day of April following for payment, to the drawee, and payment was refused. The bill was duly protested, and proper notice given to the defendants, who were indorsers.

The conclusions of law which the court drew from these facts, were, "ist. That the liability in this action, if any at all, is upon the second bill of the set, and not on the first; 2 d. That because the said hill was indorsed on Sunday, that therefore such indorsement was absolutely voil."

We have examined with considerable care the authorities, and hare not been able to find a case precisely like the present, although it would seem as if the point must frequently have arisen in the courts in this country, and in England. The case of Percirav. Jeth ctal. (cited in a note on page $4+9$, I I B. and C.), would seem to have a strong bearing upon the case at bar. It was there held that he to whom any part of the set is first transferred, acquires a property in all the other parts, and may maintain trover even against a bonc fiac holder, who subsequentiy, by transfer, or otherwise, gets possession of another part of the set. That is, deciding that the first indorsement of one of the set rests in the indorsee the absolute right to the possession of the whole set. And we suppose it would follow, from this doctrine, that the indorsement of the second in this case was entirely unnecessary. The liability of the indorser arose from indorsing the first of the set for value. We think her liability was not increased one jot or tittle by indorsing the second of the set. Suppose she had indorsed all of them in January, at the time she indorsed the first, is it not obvious that her liability would not have been different from what it is? It is conceded that the indorsement 
of the first was good, and this indorsement was entirely adequate to carry with it the second and third. (See Edwards on Bills, 304 and

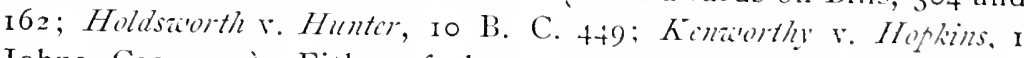
Johns. Cas. 107.) Either of the set may be presented for acceptance, and, if not accepted, a right of action arises upon dtue notice, against the indorser. (Downes and Co. r. Church, is Peters, 205.) The bill upon which the protest was made was declared on and produced, and it also appeared that the first had not been presented for payment. The court says, and we think properly and correctly, that if the first had been presented for payment and protested, even as late as April gth, that upon proper notice the indorser would have been held, for the delay in the mail would have been a sufficient excuse for the apparent neglect in not presenting it for accentance before. The case might have been relieved from all doubt or lifficulty, had the indorsee declared upon the first of the set, and produced on the trial the second, which had been presented for acceptance and dishonored. (Wells v. Whitchad, 15 Wend. 527.) This he did not see fit to do, but we think he was entitled to recover even as the facts appeared before the court.

The judgment is reversed, and a new trial ordered. ${ }^{1}$

\footnotetext{
'It seems that an indorsee has no right to demand the other parts except from his immediate indorser. Thus, the fourth indorsce cannot maintain an action against the second indorser for outstanding parts of the set. Pinard v. Klockmann, 3 B. \& S. $38 s$; s. c., 32 L. J., Q. B. S2.

In an action against the acceptor on one part of the set, the holder need nut file the other part or parts. Fohnson v. Offutt, + Met. (Ky.) I9. In an action against the indorser on the second part, after dishonor by non-acceptance, the holder need not account for the first part; it is a matter of defence " w show either that some other bill of the set has been presented and accepted, or paid: or that it has been presented at an earlier time and dishonored, and due notice has not been given; or that another person is the proper bolder, and has griven notice of his tille to the party sued; or that some other ground of defence cxists, which displaces the frima facte title mate out by the platintiff," Downes v. Church, 13 Pet. (U. S.) 205; Miller v. Palmer, 58 Mld. 452. Hut where lhe second of the set is protested for non-acceptance, the holder must produce thit mumber of the set, because otherwise it may have been accepted supre protest for the honor of the defendant, and he be liable upon it. Wills $\mathrm{v}$. Whithend, $15 \mathrm{Weml}$. (N. Y.) 527. If the drawee accepts more than one part, he is liable on each to holders in clue course. I/oldsworth v. I/untir, Io B. \& C. H9) Bank v. Iial, 22 How. (U. S.) 96 . If the drawee dishonors one part, but subseguenty honors amd pays the other part, the drawer is discharged. Page $v$ Harner, 4 Calif. 395. - ED.
} 


\section{ARTICLE XVII.}

\section{Promissory Notes and Checks.}

\section{Promissory notes.}

\section{ORIgin and History.}

L. R. Io Exchequer, 337. - I875.

[Reported herein at p. I5 $1,154-155.]^{1}$

\section{See also ante, pp. I+5-I +6 .}

The statute of $3 \& 4$ Anne, c. 9, I ( I 704), proviced that, "Whereas it hath been held, that notes in writing, signed by the party who makes the same, whereby such party promises to pay unto any other person, or his order, any sum of money therein mentioned, are not assignable or indorsable over, within the custom of merchants, to any other person; and that such person to whom the sum of money mentioned in such note is payable cannot maintain an action, by the custom of merchants, against the person who first made and signed the same; and that any person to whom such note should be assigned, indorsed, or made payable, could not, within the said custom of merchants, maintain any action upon such note against the person who first drew and signed the same: Therefore, to the intent to encourage trade and commerce, which will be much advanced if such notes shall have the same effect as inland bills of exchange, and shall be negotiable in like manner, be it enaitid, itc., (I) That all notes in writing that, after [May Ist, I 705$]$, shall be made and signed by any person. . . whereby such person . . . doth or shall promise to pay to any other person or persons, . . . his, her or their order, or unto bearer, any sum of money mentioned in such note, shall be taken and construed to be, by virtue thereof, due and payable to any such person or persons . . . to whom the same is made payable; (2) and also every such note payable to any person or persons, . . . his, her, or their order, shall be assignable or indorsable over in the same manner as inland bills of exchange are or may be, according to the custom of merchants; (3) and that the person or persons . . . to whom such sum of money is or shall be by such note made payable, shall and may maintain an action for the same, in such manner as he, she, or they might do upon any inland bill of exchange, made or drawn according to the custom of merchants, against the person or persons . . . who signed the same; (4) and that any person or persons... to whom such note . . . is indorsed or assigned, or the money therein mentioned ordered to be paid by indorsement thereon, shall and may maintain his, her, or their action for such sum of money, either against the person or persons . . . who 


\section{Form and Interpretation.}

See Article II, pp. I6I-324, ante.

\section{Non-Negotiable Notes.}

6 TERM RePORTS, I23. - I794.

Assumpsit on the following instrument, given by defendant's testator: -

Three months after date I promise to pay to Mr. Smith, currier, 40\%, value received in trust for Mrs. E. Thompson, as witness my hand.

25 Fune, 1787.

L. Asklil.

The action was commenced September 26, I793. Defendant objected that the instrument was not a promissory note within the statute ( 3 and 4 Anne, c. 9), and, if not, the cause of action accrued Sept. 25,1787 , three months after the date of the note, and consequently that six years had elapsed before the suing out of the writ, and that the cause of action was barred by the statute of limitations.

Verdict for defendant, with leave to plaintiff to move to sct that verdict aside, and to enter a verdict for him, if this Court thought he was entitled to recover. Motion accordingly.

LORD Kenyon, C. J., said, If this were res integra, and there were no decisions upon the subject, there wouk be at sreat deal of weight in the defendant's objection; but it was decided in a case in Lord Raymond (2 Lord Raym. 1545), on demurrer, that a note payable to B., without adding or to his order, or to bearer, was a legal note within the act of Parliament. It is also said in Marius that a note may be made payable either to $\Lambda$. or bearer, $\Lambda$. or orler, or to $\Lambda$. only. In addition to these authorities I have made inquiries among different merchants respecting the practice in allowing the three days' grace, the result of which is that the lank of Engrand and the merchants in London allow the three days' grace on notes like the present. The opinion of merchants indecd would not govern this

signed such note, or agranst any of the persons that indorsed the same, in like manner as in cases of inland bills of exchange."

The statute was held to apply to foreign, as well as domestic, noles. Vhlur v. Graham, i Barn. \& Cress. Ig2. Statutes of like tenor have been passed in the American States. I Daniel, S. Independent of stalute, some Slates have held promissory notes to be negoliable by force of common law. /lumn v.

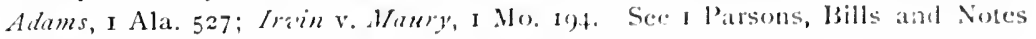
(2d ed.), pp. 9-13; Story on Prom. Noles, S̈ 6. Es. 
Court in a question at law, but I am glad to find that the practice of the commercial world coincides with the decision of a court of law. Therefore, I think that it would be dangerous now to shake that practice, which is warranted by a solemn decision of this Court, by any speculative reasoning upon the subject; and consequently this rule must be made absolute to enter a verdict for the plaintiff.

Rule absolute. ${ }^{1}$ I 27 NeW Yokk, 92. - ISgr.

Action on the following instrument, executed by defendant's testator: -

Qtarkyville, Siptember 2, isjit.

Thirty days after death, I promise to pay to Cornelius Carnwright fifteen hundred dollars, with interest.

Samuel P. Freligh.

Plaintiff gave noevidence of consideration, but proved the genuineness of the signature, put the note in evidence, and rested his case. Judgment for plaintiff. Defendant appeals.

Brows, J. - When the plaintiff rested his case and again at the close of the testimony the defendant moved to dismiss the complaint upon the ground that no proof had been give. that the instrument sued upon had any consideration. These motions were denied and the court instructed the jury that the instrument was a promissory note and imported a consideration, and that the burden rested upon the defendant to show that it was without a consideration.

The exceptions to these rulings present the principal question argued upon this appeal.

The statute of this state in reference to promissory notes provides as follows (r R. S. 768 ):

S I. All notes in writing, made and signed by any person, whereby he shall promise to pay to any other person or his order, or to the order of any other person, or unto the bearer, any sum of money therein mentioned, shall be due and payable as therein expressed; and shall have the same effect and be negotiable in like manner as inland bills of exchange, according to the custom of merchants.

$\$$ 4. The payees and indorsees of every such note payable to them or their order and the holders of every such note payable to bearer,

${ }^{1}$ Grace is allowed on non-negotiable notes. Duncan v. Maryland Savings Inst., ro Gill \& J. (Md.) 299; Dubuy's v. Farmer, 22 La. Ann. 478; Cox v. Reinhardt, $4 \mathrm{I}$ Tex. 59I. Contra: Luce v. Shoff, 7o Ind. 152. The matter is now unimportant where days of grace are abolished. Neg. Inst. L., S 145 [85]. - ED 
may maintain actions for the sums of money therein mentioned, against the makers and indorsers of the same respectively, in like manner as in cases of inland bills of exchange, and not otherwise. ${ }^{1}$

Our statute is a substantial reenactment of the statute of Anne (3 and + Anne, c. 9), which provided that: "All notes signed by a person promising to pay to another his, her or their order or to bearer " should be construed to be by virtue thereof due and payable to any such person to whom the same is made payable, etc., etc.

This statute was held by the courts of England to include within its terms a non-negotiable note. (Smith $\times$. Kindall, 6 I). \& E. I23; Burchell v. Slocock, 2 Ld. Raym. 15+5; 3 Kent's Com. 77.) It the case first cited Lord Kenyon said: "A note may be made payable to 'A.' or bearer, 'A.' or order, or to 'A. 'only." Similar decisions were made by the courts of this State under our own statute. (Dow'ning $\because$ Backenstocs, 3 Caines, 137; President r. Murtin, 9 Johns. 217; Kimball v. Huntington, 1o Wend. 675; Hall v. Farmer, 5 Denio, +84.)

In Doaning $v$. Backenstocs a non-negotiable note was declared on as within the statute and the defendant demurred on the ground that the declaration did not allege the transaction and consideration upon which the note was given. The court gave judgment for the plaintiff, saying: "The very point was settled in Green v. Lons (April Term, 1798 ), in conformity to the adjudications in Westminster Hall."

In President v. Hurtin it was said: "The note set forth is a good promissory note within the statute, though it has no words bearer $G$ order. This is the established English law, and the same rule is recognized by this court."

In Kimball v. Huntington the action was upon a due bill in this form: "Due Kimball \& Kenston three hundred and twenty-five dollars payable on demand." Judge Nelson said: "The instrument is a promissory note within the statute. Neither the ackuowledgment of value received or negotiable words are essential to bring it within the statute." (See also Carrer v. Mayes, 47 Me. 257; Franklin v. March, 6 N. H. $3^{6} 4$.)

No authority is cited in the courts of this State or of England holding that a non-negotiable note is not within the terms of the laws cited, and we are of the opinion that the language of our statute includes a note payable to a person without words of negotiability.

The instrument sued upon being, therefore, a promissory note within the statute of this State, it follows that it imports a consideration. By the express terms of the statute the sum of moncy thercin mentioned is declared to be "due and payable as therein expressed."

${ }^{1}$ This statute is now repealed by N. Y. Neg. Inst. L., 340 , and is replaced by $320[184] .-E 1$. 
That it is "due and payable" according to its terms is the legal conclusion which the court must draw from the instrument itself. A valid contract is thus declared to exist, and of course a consideration must be implied. Hence "value received" need not appear on the face of the note, as those words express only what the law implies. (Hatchv. Trayes, in Ad. \& E1. 702; Hall v. Farmer, 5 Denio, 484.)

The effect of laws which make promissory notes negotiable, or which authorize actions of debt upon them, though non-negotiable, is to take them out of the common-law rule which requires that every contract must be shown by the party who sues upon it, to be supported by a consideration, and enables the holder to maintain an action thereon without alleging or proving a consideration. In other words, a consideration is implied from the character of the instrument. (Peasley v. Boaturight, z Leigh, 195; Hatch v. Trayes, supra.)

The English statute was enacted to settle the controversy that prevailed, whether under the customs of merchants promissory notes were negotiable. They were thereby declared to be assignable or indorsable over in the same manner as inland bills of exchange were according to the customs of merchants, and holders were empowered to maintain actions thereon in the same manner as they might do upon any inland bill of exchange made or drawn according to the custom of merchants.

Our statute contains similar provisions. Promissory notes and inland bills of exchange were, by virtue of these laws, put upon an equality. They were made negotiable if they contained words of negotiability, but whether negotiable or not, and whether they expressed value received or not, it was no longer necessary in actions thereon to aver and prove consideration.

Such was and is the rule as to inland bills of exchange. (I Daniel on Negotiable Inst., \& $16 \mathbf{1}$; Raubitschek v. Blank, 80 N. Y. 479; Aierett's Adm'rs v. Booker, ${ }_{5}$ Gratt. ${ }^{6} 63$; Wells v. Brigham, 6 Cush. 6.)

And the same rule under the statute was made applicable to promissory notes. (Tomensend v. Derby', 3 Metcalf, $36_{3}$; Dean v. Carruth, Ios Mass. 242; Bank of Troy $\because$. Topping, 9 Wend. 277; r3

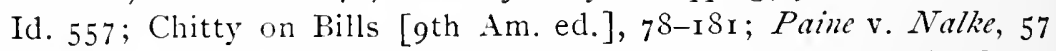
How. Pr. 273; Story on Promissory Notes, $\$ 5$ I; 3 Kent's Com. 77,78 ; I Parsons on Conts. [6th ed.], 249; I Parsons on Bills, 193.)

The statute does not require a note to express value received upon its face, and no definition of such an instrument requires the expression of that fact.

The note sued upon, although by its terms payable after the death of the maker, was a valid instrument. 
A promissory note is defined to be a written engagement by one person to pay absolutely and unconditionaliy to another person therein named, or to the bearer, a certain sum of money at a specified time or on demand. (Story on Prom. Notes, $s$; Coolidise v. Ruggles, I5 Mass. $3 S_{7}$.) It must contain the positive engagement of the maker to pay at a certain definite time and the agreement to pay must not depend on any contingency, but be absolute and at all events. Tried by this standard the instrument set out in the complaint was a valid promissory note. The fact that it was payable after the death of the maker did not affect its character. (3 Kent's Com. $; 6$.)

It follows from these views that the motion to dismiss the complaint was properiy denied, and there was no error in the charge of the court.

The point made by the appellant that the court erred in its charge as to the burden of proof on the question of consideration, assuming that evidence pro and con upon that question was given, was not raised at the trial. The proposition made by the defendant at the close of the judge's charge, and the only one to which an exception appears in the record, was as follows: "In order that there may be no doubt about our position we ask the court to charge the jury that there has been no evidence given of consideration, and to direct a verdict for the defendant upon that ground." The defendant having thus squarely planted himself on the ground that there was no evidence of consideration, and asked the court to direct a verdict in his favor, cannot now claim that there was evidence for the jury and that he was entitled to a different instruction from that given.

The defendant's claim all through the trial was that the note did not import a consideration, and that the plaintiff could not recover without proof of that fact, and his motion to dismiss the complaint and to direct a verdict in his favor, and his exceptions to the charge, all sharply present that question; but he nowhere claimed that he had given evidence which, if believed by the jury, overcame the presumption arising in favor of the note. This clearly appears from the statement I have quoted.

The exceptions to the admission of evidence present no error, and the judgment should be affirmed.

All concur, except Foldetr, Ch. J., and Vaxs, I., dissenting, and PARKER, J., not voting.

Judgment affirmed.'

${ }^{1}$ Accord: Hegeman v. Hoon, I3I N. Y. $4^{62}$. Contra: Fristol r. H'drner, 19 Conn. 7, ante, p. 325; Currie, v. Lerkinoll, fo Conn. 349, anti, p. 17o. The question as to whether a non-negotiable promissory note imports a considerat- 
40 NEW York, 49I. - I869.

ACtion against payee-indorser of two instruments as follows:-

$\$ 75$.

New York, March 22d, IS6I.

Sixty days after date I promise to pay to Richard Hewitt seventy-five dollars, value received.

[Indorsed]:

William Ryan.

JAMES R. HewitT,

RichaRd HewitT.

Another of like tenor for four months was made and indorsed as above.

James Hewitt was orginally made a defendant, but the action as to him was discontinued, and this action is against Richard Hewitt, the payee-indorser.

The plaintiff testified that the defendant was owing the plaintiff, and that it was understood between them that when these notes were passed over by him in payment, that they were taken solely upon his responsibility, and that he assured plaintiff that they should be paid.

The action was to charge defendant as guarantor. No presentation to the maker for payment or notice of non-payment to Hewitt was shown. The court below held the suit could not be maintained, and dismissed the complaint. Plaintiff appeals.

Mason, J. - This action was brought to recover of the defendant the amount of two non-negotiable notes of seventy-five dollars each, upon the following facts: One William Ryan made the notes payable to defendant by name, and the defendant transferred the notes to the plaintiff for value, and indorsed them over by writing his name upon the back. The notes were not presented for payment when they fell due, nor was any notice of non-payment given to the defendant, and the only question in the case is whether the plaintiffs are entitled upon these facts to recover of the defendant the amount of the notes. The case of Richards' Ex'r v. Warring ${ }^{1}$ (I Keyes R. 575), is an authority in point, and decides the very question in favor of the plaintiff. The case holds that the holder may overwrite the indorser's name with a contract of guaranty, or as maker of the note.

tion must turn upon a construction of the statute governing promissory notes. Apparently the Neg. Inst. L., $\$ 320$ [I84] has changed the law in New York, as the section referred to includes only negotiable promissory notes. - ED.

1 This was a case of "irregular indorsement."- ED. 
That case must be regarded as controlling, even should we think the reasons assigned for the decision unsatisfactory.

The judgment of the Supreme Court must be reversed and a new trial granted, with costs, to abide the event. ${ }^{1}$

\section{Cheeks.}

I. Check Distinguished fron Bill of Exchange.

\section{$\S 321$}

$$
\text { HARRISON } \because \text {. NICOLLET NAT. BANK. }
$$

$$
\text { 4i Minvesota, 488. - i889. }
$$

Appeal by plaintiff from an order of the District Court for Hennepin county, Rea, J., presiding, sustaining a demurrer to the com. plaint. The action was to recover $\$ 20,000$ damages for that the defendant, on April I4, I888, and before the maturity thereof, did "falsely, wrongfully, and maliciously" cause to be protested the following instrument, which had been indorsed and forwarded to defendant for collection, thereby injuring plaintiff's credit, etc.:

$\$ 199.92$ 45 Washington Ave., South, HARRISON, the TAILOR.

Minneapolis, Minn., M/. 27, 1888. 92-100 dollars.

To Citizens' Bank.

J. T. HARRISON.

Minneapolis, Minn.

No. 2,854 .

1 Accord: Swetser v. French, I3 Met. (Mass.) 262; I'rentiss r. Idinilson, 5 Conn. 175; Castle v. Candee, I6 Conn. 223: Ford v. Mitchell, 15 Wis. 304.

A payee-indorser in blank of a non-negotiable note becomes liable, not as indorser, but if at all as guarantor. In some States no presumption arises that any liability is undertaken, the indorsement being treated simply as a transfer or assignment of a common-law contract. Shaffstall 4 . McDliniel, $152 \mathrm{~Pa}$. St. 595; Story v. Lamb, 52 Mich. 525. But evidence of the true contract is admissible. (Itid.) An indorsement of a non-negotiable note "waiving protest" is an indication of an intention to assumcothe liability of guarantor. First $\mathrm{A}, \mathrm{l}$. v. Falkenhan, 94 Calif. I4r.

The indorser becomes liable only to his immediate indorsec, and not to a remote indorsce. Kendall v. Parker, ro3 Calif. 319. Contra: Warehum Liank v. Lincoln, 3 Allen (Mass.), 192 (simble).

An irregular indorser of a non-negotiable note is a guarantor. Richrards Ex'rv. Warring, I Keyes (N. Y.). $576 ;$ Mc.Mullen v. Kaffirty, 89 N. Y. 456; Fïrt N. B. v. Babcock, 94 Calif. 96 ; Orrick v. Colston, 7 Gratt. (Va.) 189 . Sec on nonnegotiable notes, Story on Prom. Notes, 128-129; 2 Randolph on Comm. Paper, \$\$ 655-661. - En. 
Mrtchell, J. - This appeal presents the question whether a written order on a bank or banker to pay a sum of money at a day subsequent to its date, and subsequent to the date of its issue, is a "check," or a "bill of exchange," and hence entitled to grace. The question is one which has given rise to considerable discussion and some conflict of opinion.

About all the law there is on it, as well as all the arguments on each side, will be found in Morse, Bank ( $3 \mathrm{~d}$ ed.), $\$ 38 \mathrm{I}$ et seq. The two principal authorities holding such an instrument a check are $I n$ re Brou'n (2 Story, 502), and Champion v. Gordon (7० Pa. St. 474). Both of these are entitled to great weight, but they stand almost alone; the Supreme Courts of Rhode Island (Westminster Bank v. Wheaton, 4 R. I. $3^{\circ}$ ), and perhaps of Tennessee, being, so far as we know, the only ones which have adopted the same views. ${ }^{1}$ All other courts which have passed upon the question, as well as the text-writers, have almost uniformly laid it down that such an instrument is a bill of exchange, and that an essential characteristic of a check is that it is payable on demand. This was finally settled, after some conflict of opinion, in New York, - the leading commercial State of the Union, in the case of Bowen v. Nezwell, several times before the courts, 5 Sandf. 326; 2 Duer. 584; 8 N. Y. 190, and I3 N. Y. 290, 64 Am. Dec. 550. (See, also, Morrison v. Bailey, 5 Ohio St. ${ }_{3} 3,64$ Am. Dec. 632; Woodruff v. Merchants' Bank, 25 Wend. 673 ; Minturn v. Fisher, ${ }_{4}$ Cal. 35 ; Bradley v. Delaplaine, 5 Har. [Del.] 305; Georgia National Bank v. Henderson, 46 Ga. ${ }_{4} 87$; It'ory v. Bank of State of Mo., 36 Mo. 475, 88 Am. Dec. 150; Work v. Tatman, 2 Houst. 304; Hawley v. Jette, Iо Or. 3 ; 2 Daniel Neg. Inst., $\$ \$$ I573-1575; Morse, Bank., supra.)

Nearly every definition of a check given in the books is to the effect not only that it must be drawn on a bank or banker, but that it must be payable on demand. (I Rand. Com. Paper, $\S 8$; Byles, Bills, I3; 2 Daniel, Neg. Inst., \$ 1566; I Edw. Bills, § 19; Bigelow, Bills and N. Ir6; Chalm. Dig. Bills and N., art. 254; Shaw, Ch. J., in Bullard v. Randall, I Gray, 605; Bouv. Law Dict.; Burrill, Law Dict.) Occasionally the expression is used "payable on presentation," but evidently - except perhaps in Story on Bills - as synonymous with " payable on demand."

As the question is a new one in this State, we would not feel compelled to follow the majority if the better reasons were with the minority. Perhaps the weightiest argument in favor of holding such an instrument a check is the practical one advanced by Shars wood, J.,

${ }^{1}$ See also $W_{a j}$ 'v. Towul', I55 Mass. 374. - ED. 
in Champion v. Gordon, supra, viz., that if held to be a bill of exchange the holder might immediately present it for acceptance, and if not accepted he could sue the drawer, or if accepted it would tie up the drawer's funds in the hands of the bank, and thus, in either case, frustrate the very object of making it payable at a future day. In answer to this, it may be said that the drawer, if he wished, could very easily aroid such consequences by inserting appropriate provisions in the instrument. On the other hand, if we hold that an instrument not payable on clemand may be a check, we are left without any definite or precise rule by which to determine when the paper is a check, and when a bill of exchange. The fact that it is drawn on a bank is not alone enough to distinguish a check from a bill of exchange, for nothing is better settled than that a bill of exchange may be drawn on a banker. Neither wili the fact that the maker writes it on a "blank check" be any test, for the kind of paper it is written on cannot control the import and legal effect of its words. Neither can the question whether it is drawn against a previous deposit of funds by the drawer with the drawee furnish any criterion, for nothing is clearer than that a bill of exchange, as well as a check, can be drawn against such a deposit, and that an instrument may be a check although the drawer has no funds in the hands of the drawee. Neither will it do to say that if it is entitled to grace it is a bill, but if not entitled to grace it is a check, because the legal character of the instrument has first to be determined before it can be known whether or not it is entitled to grace. In short, if we omit from the definition of a check the element of its being payable on demand, bankers and business men are left without any defmite rule by which to govern their action in at matter where simplicity and precision of rule are especially desirable. It might be expedient to enact, as has been done in New York and some other States, that all checks, bills of exchange, or drafts, appearing on their face to be drawn on a bank or banker, whether payable on al specified lay or any number of days after date or sight, shall be payable on the day named in the instrument without grace; or, what might be better still, to abolish days of grace altogether ats a usage which has already long outlived the condition of things out of which it hat its origin. But this is a matter for legislatures and not for courts. We are therefore of opinion that the better rule is to hold that such an instrument is a bill of exchange, and hence entitled to gralce. We may add that it is always desirable that the decisions of the conrts should be in accord with the business usages and customs of the country. Such usages are entitled to special weight on a question like this, for the whole matter of grace on bills and notes hatd its 
origin in the usage of bankers. And, so far as we are advised, the general practice of bankers in this State has been to treat instruments like this as bills of exchange and not checks.

Counsel for respondent suggests that, even if we hold that payment of this paper was demanded and protest made prematurely, yet the action of the court below in sustaining the demurrer to the complaint should be affirmed on other grounds, viz., that the act of protesting, etc., was the act of the notary and not of the bank; that the protest could not have damaged the financial standing of the plaintiff because the certificate of the notary shows on its face that it was done before maturity; also, that the instrument, being of doubtful classification, involving a legal question on which courts differed, the defendant would not be liable for an honest mistake of law. Whatever force there might be in these suggestions, either by way of defence or in mitigation, we think they are unavailing in support of a demurrer to a complaint which alleges that the defendant "falsely, wrongfully and maliciously caused " the paper to be protested for non-payment, and notices of protest sent out, and which also shows that such notices - which were presumably what, if anything, injured plaintiff's standing and credit - contained nothing indicating that payment was prematurely demanded.

Order reversed. ${ }^{1}$

2. Presentment: Effect of Delay Upon Drawer's Liability.

93 WiscoNs1x, 552. - I896.

ACtion against the drawers of a check. Defendants, after banking hours on July 20 , drew and delivered to plaintiff in Milwaukee, where plaintiff resided, a check for \$I,2 I I upon the South Side Savings Bank, located in Milwaukee. The check was not presented on July $2 \mathrm{I}$, during all of which day the bank was open and would have paid the check had it been presented. The bank did not open after July 21, by reason of which the check was not paid. Judgment for defendants.

Marshall, J. - The settled law applicable to the facts of this case is that, if a person receives a check on a bank, he must present

${ }^{1}$ A post-dated check is to be distinguished (outside of Mass., Pa., and R. I.), from a check payable by its terms after the date of issue. 2 Daniels, $\$ S$ I5771578; Crawford v. West Side Bank, Ioo N. Y. 56. A post-dated check is to be treated as if issued on the day of its date. Frazierv. Trow's, Printing, Esc., Co., 24 Hun, 28I, 90 N. Y. 678. - ED. 
it for payment within a reasonable time, in order to preserve his right of recourse on the drawer in case of non-payment by the drawee; and that, when such person resides and receives the check at the same place where such bank is located, a reasonable time for such presentation reaches, at the latest, only to the close of banking hours on the succeeding day, excluding Sundays and holiclays. (Tiedeman, Com. Paper, $\$ 443 ; 2$ Daniel, Neg. Inst., $\$ \$$ I 590,1591 , and cases cited; Lloyd r. Osbornc, 92 Wis. 93.) Plaintiff failed to comply with the law in this respect; hence defendants were discharged from all liability to answer for the default of the bank. Such was the decision of the trial court, and it must be affirmed.

By the Court. - Judgment affirmed."

69 Vermont, 22. - 1895 .

General assumpsit by the firm of Gregg \& Co., against J. H. Beane. Defendant pleaded the general issue, payment, and notice of special matter. There was a trial by the court. Plaintiffs had judgment, and defendant excepts. Reversed.

Muxsox, J. - The plaintiffs claim to recover the amount of a check drawn in their favor by the defendant on S. M. Dorr's Sons, privite bankers at Bristol, Vt., and mailed them in payment of an indebtedness. The check was received by the plaintiffs at their place of business in Trumansburg, $\mathrm{N}$. Y., on the gth of August, and was for-

${ }^{1}$ But delay which occasions no loss to the drawer will not discharge the drawer; in this respect a check differs materially from a bill of exchange. Syracuse, te., R. R. V. Collins, 57 N. Y. 641; Woolin v. Frazid, 35 N. Y. Super. Ct. 190; Cogsaicll v. Sarings Bank, 59 N. H. 43 ; Bull v. Bank, i23 U. S. Io5; 2 Morse on Banks, $\$ 21 ; 2$ Daniel on Neg. Inst., 5157.

A banker's draft, that is a check or draft by one bank upon another, need not be presented with the same promptitude as the check of an individual; it is intended to circulate for a limited period. Bull s. Bank, 123 U. S. I05; 2 Daniel, I $595 a$.

The rule of diligence as to notice of dishonor and the rules as wexcuses for delay, etc., are the same as in the case of bills and notes. 2 Danicl, $15 y^{6-}$ $1596 ; 2$ Morse, $\$ 42 S$.

An indorser of a check is entitled to due presentment and notice, and the guestion as to whether he is injured by the delay scems immaterial. ." "ry" v. Jutah, 6 Cow. (N. Y.) $48+$; Wohuwh Sunk v. Broderite, 10 Wrent. (N. Y.) 304: Girkpatrick v. Puryear, 93 Tenn. for); 2 Morse on Banks, $\$$ 422. The same ruies of diligence apply as in the case of the drawer. Cifford r. Mtarlill, 88 Wis. 538; Smith v. Fanes, 20 Wend. (N. Y.) 192; Cimmll v. Sirete, $12 \mathrm{~s}$ N. Y. I0. - En. 
warded on the same day to the First National Bank of Ithaca, N. Y., for collection. On the roth of August the Bank at Ithaca mailed the check for collection to its reserve agent, the Fourth National Bank of New York city. This bank received it on the IIth of August, and on the $\mathrm{s} 2 \mathrm{th}$ mailed it for collection to the Merchants' National Bank of Burlington, one of the banks through which it made its collections in Vermont. The $13^{\text {th }}$ was Sunday. The Burlington bank received the check on the morning of the $i_{4}$ th, at an hour which did not permit of its being sent to Bristol by the morning mail of that day. The banking house of S. M. Dorr's Sons closed its doors on the Itth, at ro o'clock in the forenoon.

It is found that 24 hours is required for the transmission of mail between Trumansburg and Bristol; and, in the absence of any statement as to the hours of departure and arrival, it must be assumed from this general finding that a letter mailed in Trumansburg to a corrrespondent in Bristol would be received on the following day. There is no special finding in regard to mails from Ithaca, but it is evident from its location and connections that it is within the facts found in regard to Trumansburg. It appears then that, if the Ithaca bank had mailed the check directly to some one in Bristol, it would have been received on the ith, and would have been presented by the I 2 th, and paid. No claim inconsistent with this view is made in argument.

It is found that, in collecting a check in the usual way, the payee deposits it in a local bank, and that the local bank sends it to its reserve bank in Boston, New York, Albany, or 'Troy, and that the reserve bank sends it to its correspondent bank nearest the bank on which the check is drawn, and that the correspondent bank sends it to the drawee. It is found, however, that in some cases a reserve bank receiving a check for collection sends it directly to the bank on which it is drawn; but it is also found that, if this course had been pursued in the present instance, the check would not have reached Bristol in due course of mail until after the suspension. It is further found that, in collecting this check, the plaintiffs pursued the usual and ordinary course, and that there was not in that course any unusual or unnecessary delay.

The plaintiffs claim that the finding of the court below that this check was forwarded for collection in the usual way is conclusive upon the question of diligence. But this cannot be so, unless it be considered that any change of method which grows into a settled practice of itself works a modification of the law. It can hardly be claimed that custom is so exclusively the test of diligence that the adoption of a particular practice by any class of business men leaves 
nothing for the determination of the court. When the custom of one period has resulted in the adoption of a definite legal rule, the development of a new custom will not effect a modification of the rule in advance of judicial sanction. The case shows the manner in which this check was forwarded for presentment, and, when the facts are found, due diligence is a question of law.

The rale, in its most general statement, requires the payce of a check to present it for payment with reasonable diligence. But the law goes further than this general statement, and determines what reasonable diligence is under ordinary circumstances. When the case presents only the simple facts of time, location, and stated means of communication, the question of liablity is to be determined by an application of the more definite rule. It is only when the case presents special circumstances which are claimed to warrant further delay that the court is left without other guidance than the general requirement. This case discloses nothing in the nature of an excuse for delay.

It is well settled that a check must be presented to the bank on which it is drawn if the bank be in the same place with the holder, or forwarded by mail if the bank be in another place, by the next secular day after it is received, and that the depositing of the check in a local bank for collection does not give the holder the benefit of an additional day. So this check was forwarded neither earlier nor later than the law required; and the controversy is confined to the question whether it was forwarded in the proper manner.

As presented by the findings, the question is whether the local bank was justified in forwarding the check through its New York correspondent. The defendant sustained no harm from the course taken by the New York bank in sending it to Burlington. It is said in Daniel on Negotiable Instruments ( $\left.\$ 59^{2}\right)$ that, when the payee receives a check from the drawer in a place distant from the place where the bank on which it is drawn is located, it will be sufficient if he forward it by post to some person in the latter place on the next secular day after it is received, and if the person to whom it is thus forwarded present it for payment on the day after it has reached him by due course of mail. If this be accepted as a correct statement of the rule, it would seem not to permit the collection through a correspondent so remote as to delay the presentment a day beyond the time so allowed. It is true that the rule is sometimes stated to be that the check should be forwarded for presenta. tion on the day after it is received, and that the agent to whom it is forwarded must in like manner present it, or forward it, on the day after he receives it. This phrascology might seem to con. 
template the collection of a check by means of several agents. But statements regarding the forwarding of a check by successive holders will ordinarily be found to refer to checks drawn for the purpose of being put in circulation, or to questions arising between indorser and indorsee where a check given in payment has been diverted from its proper use. Statements applicable to such cases must not be taken to indicate that the requirement of diligence, as between payee and drawer, will be satisfied by a regular transmission upon successive days, if an improper number of agents be employed.

The rule is ordinarily stated to be that the payee or the local bank receiving it for collection must forward it directly to the place of payment. It is said in Byles on Bills that the bank receiving it for collection cannot postpone the time of presentment by circulating it through agents or branches of the bank. In Moule v. Brown (4 Bing. N. C. 266), the right of a branch office of the plaintiff bank to send through the home office, in accordance with the custom of the bank, was considered and denied.

We do not find that any modification of the rule as before stated has been recognized in recent cases. In Bank v. Miller (37 Neb. 500,40 Am. St. R. 499,55 N. W. Io64), ${ }^{1}$ the question was as to the liability of the payee on his indorsement to the bank. The check was deposited on Saturday, the 3 Ist day of May, and was drawn on a bank located at Courtland, 27 miles distant from the bank of deposit, and accessible by two daily mails. On receiving the check, the Bank of Wymore mailed it to a bank in St. Joseph, Mo., for collection, and this bank mailed it to a bank in Omaha for collection, and the latter bank mailed it to the bank on which it was drawn. The court said the evidence did not show that this method of presentment was in accordance with any custom of bankers, but said, further, that, if such a custom had been shown, it would not have relieved the bank from liability. Without undertaking to lay down any general rule, the court said that, in this case, Tuesday, June $3 \mathrm{~d}$, would have been a reasonable tıme within which to make presentment. This was in accordance with the rule as stated by Daniel.

In Gifford v. Hardell ( 88 Wis. 538,43 Am. St. R. 925,60 N. W. 1064), a check indorsed by the defendant was delivered to the plaintiff's agent at Dousman on July $\mathrm{i} 7 \mathrm{th}$, and was at once mailed to the plaintiff at New Richmond, who received it on the $\mathrm{I} 8 \mathrm{th}$, and at once delivered it to a local bank for collection. This bank had no correspondent in Nilwaukee, and immediately mailed the check to its correspondent in Chicago. From Chicago it was forwarded to Milwaukee, and presented on the 2 Ist. If the check had been sent directly to Milwaukee

\footnotetext{
${ }^{1}$ Affirmed on rehearing, 43 Neb. 79I. - ED.
} 
from New Richmond, it would have arrived in time for presentation on the zoth, and would have been paid. The trial court held that sending the check for collection by way of Chicago was not reasonably diligent, and directed a verdict for defendant. On appeal the judgment was sustained, the court saying that, when the defendant delivered the check at Dousman, he had a right to expect that the plaintiff or his agent would present it for payment within a reasonable time, instead of which it was sent to New Richmond, several hundred miles northwest of Milwaukee, and then sent back through Milwaukee to Chicago, and from there returned to Milwaukee. The court then stated how a check should be forwarded and presented in such cases, its rule corresponding to that given by Daniel. The rule is similarly stated in Holmes v. Roe (62 Mich. 199, 28 N. W. S64.)

In First National Bank of Grafton v. Buckhannon Bank (So MId. 475, 31 Atl. 302), the plaintiff bank, located at Grafton, W. Va., received on the 12 th of January, in payment of a balance due it, a check on J. J. Nicholson \& Sons, of Baltimore, and on the same day forwarded it for collection to its correspondent bank in Philadelphia. The Philadelphia bank received it on the $13^{\text {th }}$, and at once mailed it to its correspondent bank in Baltimore. This bank received it on the I $4^{\text {th }}$, and presented it to the drawee on the same day. The court sustained this presentment, on the ground that the Grafton bank, having sent out the check one day sooner than was necessary, had it in Baltimore for presentment on the day required, notwithstanding its transmission through Philadelphia.

We think that if this rule of commercial law, stated in the various text-books, and affirmed by these recent cases, is to be modified in derogation of the rights of drawers of checks, it should be done by legislative enactment. ${ }^{1}$

\section{Judgment reversed, and judgment for defendant. ${ }^{2}$}

\footnotetext{
'Laws of Vt., Is96, No. 38 : "In order to hold the maker, endorser, gruarantor, or surety of any check or draft deposited with or forwarded to any indlividual or bank for collection, or owned by any individual or bank, it shall be sufficient for said individual or bank (o) forward the same in the usual comnercial way now in use, according to the regular course of business, and the same shall be considered due diligence in the collection of such check or draft." - Lin.

${ }^{2}$ There is some authority for the proposition that the usual or customary method of forwarding may be safely used. cven thrugh it is circuitous. Wallace v. Agry, 4 Mason (U. S.) 336; 5 Ib. 118; Smith v. Fisnes, 20 Wend. (N. Y.) 193; Taylor v. Sip, 30 N. J. L. 2S, 291. - Ev.
} 
3. Certification: Effect upon Drawer's Liability.

\section{HEAD $\approx$. HORNBLOWER.}

I56 Massachusetts, 45S. - ISg2.

FIELD, C. J. - The first case is an appeal from a judgment rendered by the Superior Court for the defendant, on his demurrer to the declaration. The defendant, on October 29, IS9I, drew a check on the Maverick National Bank, payable to the order of the plaintiff, and, being informed by the plaintiff that the check must be certified by the bank before it would be received, the defendant on the same day presented the check to the bank for certification, and the bank certified it by writing on the face of the check the following: "Naverick National Bank. Pay only through Clearing-House. J. W. Work, Cashier. A. C. J., Paying Teller." After it was certified, the check was, on Saturday, Oct. $3^{\mathrm{I}}$, IS9I, delivered by defendant to the plaintiffs, for a valuable consideration. The declaration alleges that the bank stopped payment on Monday morning, November 2, I $S_{91} \mathbf{1}$, " before the commencement of business hours on that day," and that on that day payment was duly demanded of the bank, and notice of non-payment was duly given to the defendant.

The second case is an appeal from a judgment rendered for the defendants by the Superior Court, on an agreed statement of facts. On Saturday, October $3 \mathrm{I},{ }_{1} S_{9}$, the defendants drew their check on the Maverick National Bank, payable to the order of the plaintiffs, and delivered it to them in payment of stocks bought by the defendants of the plaintiffs. The check was received too late to be deposited by the plaintiffs for collection in season to be carried to the clearing-house on that day, but during banking hours on that day the plaintiffs presented the check to the Maverick National Bank for certification, and the bank certified it by writing or stamping on its face the following: "Naverick National Bank. Certified. Pay only through Clearing-House. C. C. Domett, A. Cashier. Paying Teller."

At that time the defendants had on deposit sufficient funds to pay the check, and the bank on certification charged to the defendants' account the amount of the check, and credited it to a ledger account called certified checks, in accordance with their uniform custom. After certification, the plaintiffs, on the same day, deposited the check in the Hamilton National Bank for collection. It is agreed that if the check had been presented for payment on Saturday, in banking hours, it would have been paid; but the Maverick National 
Bank transacted no business after Saturday, and on Sunday the Comptroller of the Currency placed a national bank examiner in charge, and the bank was put into the hands of a receiver. The clearing-house on November 2 refused to receive checks on the Maverick National Bank, and the check was on that day duly presented for payment, and due notice of non-payment was given to the defendants.

Each of the checks was in the ordinary form of check on a bank, and was payable on demand, and no presentment for acceptance or certification was necessary. In a sense, undoubtedly, a check is a species of bill of exchange, and in a sense also it is a distinct commercial instrument; but according to the general understanding of merchants, and according to our statutes, these instruments were checks, and not bill of exchange. "A check is an order to pay the holder a sum of money at the bank, on presentment of the check and demand of the money; no previous notice is necessary, no acceptance is required or expected, it has no days of grace. It is payable on presentment and not before." (Bullard r. Randall. I Gray, 605, 606.) The duty of the bank was to pay these checks when they were presented for payment, if the drawers had sufficient funds on deposit. The bank owed no duty to the drawers to certify the checks, although it could certify them if it saw fit, at the request of either the drawers or the holders, and if it certified them it became bound directly to the holders, or to the persons who should become the holders. In either case, the bank would charge to the account of the drawer the amount of the check, because by certification it had become absolutely liable to pay the check when presented. When a check payable to another person than the drawer is presented by the drawer to the bank for certification, the bank knows that it has not been negotiated, and that it is not presented for payment, but that the drawer wishes the obligation of the bank to pay it to the holder when it is negotiated, in addition to his own obligation. But when the payee or holder of a check presents it for certification, the bank knows that this is done for the convenience or security of the holder. The holder could demand payment if he chose, and it is only because, instead of payment, the holder desires certification, that the bank certifies the check instean of payng it. In one case the bank certifies the check for the use or convenience of the drawer, and in the other for the use or convenience of the holder. In the present cases the checks were scasonably presented to the bank for payment, and on the facts stilted the defendants would be liable unless the certification discharged them from liability. 
It is argued that the certification of a check, whereby the bank becomes absolutely liable to pay it at any time on demand, discharges the drawer, because it is said that the check then becomes in effect a certificate of deposit; and it is also argued that the certification is in effect only an acceptance of a bill of exchange, and that if payment is duly demanded of the bank and refused, and notice of nonpayment duly given, the drawer is held. So far as the question has been considered, it has been decided that the certification of a bank check is not, in all respects, like the making of a certificate of deposit, or the acceptance of a bill of exchange, but that it is a thing suigeneris, and that the effect of it depends upon the person who, in his own behalf, or for his own benefit, induces the bank to certify the check. The weight of authority is, that if the drawer in his own behalf, or for his own benefit, gets his check certified, and then delivers it to the payee, the drawer is not discharged; but that if the payee or holder, in his own behalf or for his own benefit, gets it certified instead of getting it paid, then the drawer is discharged. (Born v. First National Bank, 123 Ind. 78 ; Rounds v. Smith, 42 Ill. 245; Brow'n v. Leckie, 43 Ill. 497 ; Andrea's v. German National Bank, 9 Heisk. 2I ; First National Bank v. Leach, 52 N. Y. 350; Bold v. Nasmith, 7 Ont. 40; Essex County Bank v. Bank of Montreal, 7 Biss. 193; First National Bank v. Whitman, 94 U. S. 343, 345; Metropolitan National Bank v. Jones, 27 N. E. Rep. 533; Contincntal National Bank v. Cornhauser, 37 Ill. App. 475 ; National Commercial Bank v. Miller, 77 Ala. i68; Larsenv. Breene, Iz Col. $480 ;$ Mutual National Bank v. Rotge, 28 La. An. 933; Morse on Banking, \$s. 414, 415.) We are of opinion that this view of the law rests on sound reasons. If it be true that the existing methods of doing business make the use of certified checks necessary, the persons who receive them can always require them to be certified before delivery. If they receive them uncertified and then present them to the bank for certification instead of payment, the certification should be considered as discharging the drawer.

It may also be said, that in the second case the certification amounted to an extension of the time of payment at the request of the payees, without the consent of the drawers. Before the certification the drawers could have requested the payees to present the check for payment on Saturday, or could themselves have drawn out the money and paid the check. After certification the amount of the check no longer stood to the credit of the drawers, and the payees had accepted an obligation of the bank to pay only through the clearing-house, which could not happen before the following Monday. 
The result is that in the first case the judgment is reversed, and the demurrer overruled, and in the second case the judgment is affirmed.

So ordered. ${ }^{1}$

4. Drawee not Liable to Holder: a Check is not an AssignMENT OF FUNDS.

Io Wallace (U. S.) I52. - I869.

IN ERRor to the Supreme Court of the District of Columbia, the case being this: -

Millard, a captain in the military service of the United States, was, in 1865 , on leaving the service, a creditor of the government for $\$ 859$, arrears of pay as captain. In settlement of this account the proper paymaster of the army drew and issued a check for that sum upon the National Bank of the Republic, a depositary of public money and financial agent of the United States, for the custody, transfer, and disbursement of the government funds, having funds for the payment of the check.

The bank, as testimony tended to show, had once paid the check on a forged indorsement of Millard's name. Ascertaining and exposing the forgery, and recovering possession of the check, Miillard now presented the same, demanding payment to himself. This payment the bank refused to make. Thereupon he sued it, declaring on a special count on the transaction, and also on a general count for money had and received by the bank to his use.

On the trial the bank requested the court to charge, "that unless the jury were satisfied from the evidence that it accepted the check in favor of the plaintiff, or his assignees, or promised to pay the same to the plaintiff, or his assignees, he was not entitled to recover." But the court refused so to charge, and verdict and judgment having gone against the bank, it brought the case here on error; the questions here argued and considered being: ist. The general one, whether the holder of a bank check could sue the bank for refusing payment in the absence of proof that it was accepted by the bank or charged against the drawer. 2d. If not, whether the fact existing in this particular case, that the check was on a national bank (a public depositary of the government funds) by an officer of the government, in favor of a public creditor, varied the general rule. 
Mr. Justice Davis delivered the opinion of the court.

The only question presented by the record which it is material to notice is this: Can the holder of a bank check sue the bank for refusing payment, in the absence of proof that it was accepted by the bank, or charged against the drawer?

It is no longer an open question in this court, since the decision in the cases of The Marine Bank v. The Fulton Bank (2 Wallace, 252), and of Thompson v. Riggs (5 Id. 663), that the relation of banker and customer, in their pecuniary dealings, is that of debtor and creditor. It is an important part of the business of banking to receive deposits, but when they are received, unless there are stipulations to the contrary, they belong to the bank, become part of its general funds, and can be loaned by it as other money. The banker is accountable for the deposits which he receives as a debtor, and he agrees to discharge these debts by honoring the checks which the depositors shall from time to time draw on him. The contract between the parties is purely a legal one, and has nothing of the nature of a trust in it. This subject was fully discussed by Lords Cottenham, Brougham, Lyndhurst, and Campbell, in the House of Lords, in the case of Foley v. Hill (2 Clark and Finnelly, 28), and they all concurred in the opinion that the relation between a banker and customer, who pays money into the bank, or to whose credit money is placed there, is the ordinary relation of debtor and creditor, and does not partake of a filuciary character, and the great weight of American authority is to the same effect.

As checks on bankers are in constant use, and have been adopted by the commercial world generally as a substitute for other modes of payment, it is important, for the security of all parties concerned, that there should be no mistake about the status, which the hoider of a check sustains towards the bank on which it is drawn. It is very clear that he can sue the drawer if payment is refused, but can he also, in such a state of case, sue the bank? It is conceded that the depositor can bring assumpsit for the breach of the contract to honor his checks, and if the holder has a similar right, then the anomaly is presented of a right of action upon one promise, for the same thing, existing in two distinct persons, at the same time. On principle, there can be no foundation for an action on the part of the holder, unless there is a privity of contract between him and the bank. How can there be such a privity when the bank owes no duty and is under no obligation to the holder? The holder takes the check on the credit of the drawer in the belief that he has funds to meet it, but in no sense can the bank be said to be connected with the transaction. If it were true that there was a privity of contract 
between the banker and holder when the check was given, the bank would be obliged to pay the check, although the drawer, before it was presented, had countermanded it, and although other checks, drawn after it was issued, but before payment of it was demanded, had exhausted the funds of the depositor. If such a result should follow the giving of checks, it is easy to see that bankers would be compelled to abandon altogether the business of keeping deposit accounts for their customers. If, then, the bank did not contract with the holder of the cleck to pay it at the time it was given, how can it be said that it owes any duty to the holder until the check is presented and accepted? The right of the depositor, as was said by an eminent judge, (Gardiner, J., Chapmanv. White, 2 Selden, 477 ), is a chose in action, and his check does not transfer the debt, or give a lien upon it to a third person without the assent of the depositary. This is a well established principle of law, and is sustained by the English and American decisions. (Chapman v. White, z Selden, 4I2; Butterworth v. Peck, 5 Bosworth, 34I; Ballard v. Randall, I Gray, 605; Harker v. Anderson, 21 Wendell, 373; Dy'kers v. Leather Wamufacturing Co., I I Paige, 616; National Bank v. Eizot Bank, 5 American Law Register, 7II; Parsons on Bills and Notes, edition of $186_{3}$, pp. $59,60,61$, and notes; Parke, Baron, in argument in Bellamy v. Majoribanks, 8 English Law and Equity, 522, 523; Wharton v. Walker, 4 Barnwell \& Cresswell, I63; Wartick v. Rogers, 5 Manning \& Granger, 374; Byles on Bills, chapter "Check on a Banker;" Grant on Banking, London edition, $1856,9^{6 .}$.)

The few cases which assert a contrary doctrine, it would serve no useful purpose to review.

Testing the case at bar by these legal rules, it is apparent that the court below, after the plaintiff closed his case, should have instructed the jury, as requested by the defendant, that the plaintiff, on the evidence submitted by him, was not entitled to recover. The defendant did not accept the check for the plantiff, nor promise him to pay it, but, on the contrary, refused to do so. If it were true, as the evidence tended to show, that the bank, before the check came to the plaintiff's hands, paid it on a forged indorsement of his signature, to a person not authorized to receive the money, it does not follow that the bank promised the plaintiff to pay the moncy again to him, on the presentation of the check by him for payment.

It may be, if it could be shown that the bank hatd clarged the check on its books against the drawer, and settled with him on that basis, that the plaintiff could recover on the count for money had and received, on the ground that the rule $e x$ (at)u ct binu would be applicable, as the bank, having assented to the order and communi- 
cated its assent to the paymaster, would be considered as holding the money thus appropriated for the plaintiff's use, and therefore, under an implied promise to him to pay it on demand.

It is hardly necessary to say, that the check in question having been drawn on a public depositary, by an officer of the government, in favor of a public creditor, cannot change the rights of the parties to this suit. The check was commercial paper, and subject to the laws which govern such paper, and it can make no difference whether the parties to it are private persons or public agents. (The United States v. Bank of Metropolis, ${ }_{5}$ Peters, 377.)

As soon as the deposit was made to the credit of Lawler as paymaster, the bank was authorized to deal with it as its own, and became answerable to Lawler for the debt in the same manner that it would have been had the deposit been placed to his personal credit. Judgment reversed and a venire de novo awarded. ${ }^{1}$

5. Liability of Drawee to Drawer for Wrongful Dishonor.

\section{ATLANTIC NATIONAL BANK $v$. DAVIS.}

96 GEORGIA, 334. - I 895 .

ACtion for damages for dishonoring plaintiff's check. The check was for $\$ 12.48$. Plaintiff had on deposit in defendant bank over $\$ 300$. By a mistake of a clerk payment was refused. Defendant on discovering the mistake wrote plaintiff explaining the matter and also wrote the holder or holder's forwarding bank explaining the error and stating that plaintiff was one of defendant's best customers and had never drawn against his account without funds to his credit. Verdict for plaintiff for $\$ 200$. Defendant appeals.

LUMPKIN, JUSTICE. - I. The plaintiff's check came by due course of mail to the defendant bank, upon which it was drawn, and in

${ }^{1}$ Accord: Northern Trust Co. v. Rogers, 60 Minn. 208; First N. B. v. Clark, 134 N. Y. 368 ; Covert v. Rhodes, 48 Ohio St. 66; Northumberland Bank v. Mc Michael, ro6 Pa. St. 460; 5 Am. \& Eng. Encyc. L. (2nd ed.), p. I06r. Contra: Munnv. Burch, 25 Ill. 35; Fonner v. Smith, 3I Neb. I07; Simmons v. Bank, 4I So. Car. 177; Gordon v. Muchler, 34 La. Ann. 604; 2 Morse on Banks, \$\$ 490538. While the presumption is that no assignment arises from the giving of a check, yet this is controlled by the actual intention of the parties. If it is a greed that the payee shall have an assignment of a fund or any portion of a fund, he is in the ordinary position of an assignee and may enforce his rights by appropriate action in law or equity. Fourth Street Bank v. Yardley, 165 U. S. 634; Risley v. Phanix Bank, 83 N. Y. 3I5; Coates v. First N. B., 9I N. Y. 26; First N. B. v. Clark, I34 N. Y. 368. - ED. 
which he had on deposit at the time sufficient funds with which to pay it. The check was returned unpaid. It seems clear from the evidence that this was done, not deliberately or maliciously, but in consequence of a mistake made by one of the employees of the bank. The paper was not protested nor wilfully dishonored. Still, so far as the plaintiff is concerned, we think what occurred amounted to a refusal to pay his check. The consequences to him resulting from the inadvertence of the bank official were exactly the same as if there had been an express refusal to pay. We do not think a bank should be allowed to send out a paper with a badge of dishonor upon it, and then protect itself by saying, in effect, that this was caused simply by its own carelessness.

2. It was not denied that if the conduct of the bank amounted to a refusal to pay, it was liable in damages to the plaintiff; but the serious question was, as to what should be the measure of such damages.

There was no proof of any actual or special damage, and the defendant therefore insisted that, at most, the damages awarded should be only nominal. We have given the subject some investigation, and as a result, we find ourselves unable to accept this as a correct proposition of law. The following authorities are pertinent, and throw much light upon the question:-

In 2 Addison on Contract, $\S \delta_{20}$, the author, after stating the general rule that a banker is bound to honor the checks of his customers, if presented within banking hours and provided he has in hand sufficient funds for the purpose belonging to the customers, adds: "And if he refuses, he is liable to an action by the customer for substantial damages, without proof of actual damage; for it is a discredit to the customer to have his cheque refused payment." Again, in 2 Morse on Banks, $\S 45^{8}$, after a statement of the general rule relating the bank's duty in the premises, we find the following: "This duty and this right are so far substantial, that if the bank refuses, without sufficient justification, to pay the check of the customer, the customer has his action for damages against the bank. It has been said that if in such action the customer does not show that he has suffered a tangible or measurable loss or injury from the refusal, he shall recover only nominal damages. But the better authority secms to be, that even if such actual loss or injury is not shown, yet more than nominal damages shall be given. It can hardly be possible that a customer's check can be wrongfully refused payment without some impeachment of his credit, which must in fact be an actual injury, though he cannot from the nature of the case furnish independent distinct proof thereof."

NEGOT. INSTRUMENTS - 44 . 
Accordingly, it would seem that the plaintiff's recovery is not to be limited to merely nominal damages. We find authority for saying that in such a case he should be awarded "temperate" damages. Thus, in Birchall v. Third National Bank (I9 Cen. Law J. 390), it was ruled that a bank is liable in temperate damages to a customer for a wrongful dishonor of his check, without proof of special damages. In the notes appended to an article on " Damages for Wrongful Dishonor of Checks," following the report of the above cited case, will be found a large collection of authorities, which may be of help to any one desiring to further pursue an investigation into this question. Another authority for the allowance of " temperate" damages to a customer for wrongful dishonor of his check, although special damage is not shown, is Newmark on Special Bank Deposits, $\S 215$; and the same rule is stated in $3 \mathrm{Am}$. and Eng. Enc. of Law, p. 226, under the title "Checks" (2d ed., vol. 5, pp. 1059-1060). In a note to the text, Birchall's case, supra, is cited.

3. In view of all the evidence disclosed by the record, we think the verdict for $\$ 200$ rendered in the present case was " temperate," and therefore sustainable.

Judgment affirmed. ${ }^{1}$

${ }^{1}$ Accord: Schaffnerv. Ehrman, I39 Ill, I09, where a judgment for $\$ 450$ for dishonoring a check for $\$ 249$ was upheld as reasonable; Patterson v. Marine $N$. $B$. I $130 \mathrm{~Pa}$. St. $4 \mathrm{I} 9$, verdict for $\$ 300$ held reasonable. See also Bank of Commerce v. Goos, $39 \mathrm{Neb} .437$. Where the depositor proceeds as for a breach of contract and not in tort it seems that in the absence of allegation and proof of special damages, he can recover only nominal damages. Marzetti v. Williams, I B. \& Ad. 4I5; Brooke v. Tradesmen's N. B., 69 Hun (N. Y.) 202; Burroughs v. Tradesmen's $N . B ., 87$ Hun (N. Y.) 6; Citizens' N. B. v. Importers and Traders' Bank, II9 N. Y. I95. - ED. 


\section{NDEX.}

The References are to the Pages.

Acceptance: (See Non-ACCEPtancr.)

definition and effect, 6, 3I, 448-45I.

form and effect, $61-62$, 610-621.

writing and signature, $6 \mathbf{r}, 6 \mathbf{r} 0-6 \mathbf{r}$.

parol, $611 n, 621$.

only by drawee, $6 \mathrm{~s}, 611-6 \pm 2$.

delivery necessary, $6 \mathbf{r}_{2}-6 \mathbf{1}_{3}$.

promise to accept, $62,613-616$.

by refusal to return bill, $62,607,612-613$, 617-619.

of incomplete or dishonored bill, $62,6 \mathbf{9}-62 \mathbf{1}$. time allowed for, $62,619 n$.

kinds of, $63-64,621-631$.

general accoptance, $63,621-626$.

qualified acceptance, $\sigma_{4}, 626-\sigma_{3} 1$.

conditional, $64,626-628$.

partial, 64,628 .

local, $64,499,628$.

qualified as to time, $6_{4}, 629$.

by part of drawees, $64,630,640 n$

effect of qualified acceptance, $6_{4}, 6_{30}-6_{3}$.

of bills in a set, 78,661662 .

\section{Acceptance for Honor:}

when allowed, 73,65 r.

parties to, $73,65 \mathrm{r}$.

for what amount, 73

formal requisites, $73,65 \mathrm{x}$.

protest for ncn-acceptance, 73,65 .

writing and signature, 73 .

interpretation,

for whose honor, 73.

effect on maturity of bill, 74 .

contract of acceptor for honor.

terms of, $74,611-612,653,656$.

in whose favor, 74 .

admissions by, 654 .

proceedings subsequent to

presentment to drawee and protest, 74,652 , 656.

presentment to acceptor for honor, 74,653 , $65^{6}$.

excuse for delay, 75, 655-657.

protest for non-payment by acceptor for honor, 75 .

\section{Acceptor:}

consideration, 336-337.

liability of, $3 \mathrm{I}, 448,45 \mathrm{I}$.

admissions of, $3 \mathrm{I}, 44^{8-450}$

only drawee can be, $61,603-604,61 \mathrm{r}-612$.

presentment not necessary to chargc, 498-500.

Acceptor for Honor:

liability of, 74, 612, 653,656 .

admissions of, 654 .

who may be, 73

\section{Accommodatlon Paper:}

accommodation party,

defined, 20.

liability to holder, $20,339-340$.

notice when maker is, 53,563

order of liability of, $480-485$.

accommodated party,

not entitled to presentment, $4^{\circ}$.

not entitled to notice, $53,56_{3}$.

payment by, 54, 55, 578-579, 6,00-602.

transfer by, after maturity, $3^{88-393}$
Accommodatlon Paper-contiused.

release of, $595 n$.

consideration for, 339-340.

anount recoverable on, 419 .

payment of supra protest, $659,660 \mathrm{n}$.

\section{Action on Negutiable Faper:}

detined, 6 .

upon last day of maturity premature, 388,478 . $50 \mathrm{n} n$.

transfer for purpose of, $384 \%$.

bringing, is a demand, 498 .

by restrictive indorsee, 23,364 .

by executor of holder, $379-38$.

by husband of holder, $38 \mathrm{~s} n$.

between indorsers, $480-487$.

upon instrument patyable to bearer, 342.

after dishonor for non-acceptance, $68,641-642$.

on bills in a set, $66_{5} n$.

against agent signing without authority, 31:316.

upon warranties in sale, $45^{2-474}$.

upon guaranty, 491-494.

upon original consideration, $3^{8} 5,5^{8} 7 n, 5^{89}$.

to recover money paid on forged paper, $44^{8-450}$.

\section{Additional $\mathbf{A} \cdot \mathbf{t}$ :}

provision for, renders instrument non-negotiable, $10,228-220$

cxceptions to rule, 10, 229-234.

\section{Adminlstrutor: (Sec ExECUTOR.)}

\section{Admissions:}

by maker, 31,447

by acceptor, 31, 448-451

by drawer, $3 \mathrm{i}, 452$

by indorser, se? W ARKANTV.

\section{Awent :}

signature by, $16-17,304,311,317-321,517,612 n$.

liability of, $16,3^{6}, 308,3^{11}, 473$

presentment by, 37, 501 .

presentment $t o, 5^{17}$.

acceptance by, $612 n$.

notice of elislunur by $45,528-533$.

notice r.f lishonor $t 0,47$.

indorsement for collection to, 23, 357-361, 364 .

drawing on principal, 613616.

\section{Al Dore:}

nature and use, $21,34^{8-350,376 . ~}$

\section{Alaratioin:}

c.ffect of, $57,428 n, 44^{8-450,} 5^{85-592 .}$

through neggligence of mitker, $590-59^{2}$

material, $57,588 n$.

burden of prous, $5^{88 n}$

innocent, $59^{2}-593$

by form of atcecistance, 621-626.

\section{Alicrnature bartles:}

pilyeces, whether allowed, $258-259$. dritwees, whether allowed, 6x/3 604. makers, whether allowed, Guth.

\section{A molienlig}

of lingualge in instruments, 15 16, 298304 .

of signatures to instruments, $5,3^{\circ 4-322 .}$

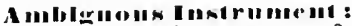

construction of, 1.1. $27,272,208-314$

may be treated as bill or note, 15,3 
The References are to Pages.

\section{Amount:}

must be certain, $8,9, \mathbf{r} 80-190, \mathbf{1} 85-218$.

recoverable, 19, 29, 337-338, 419-421, 575 .

\section{Antecedent Debt.}

is valuable consideration, $18,327-339,360$ accommodation paper, $339-340,387-3^{88}$.

Assignee: (See Bankrupt.)

\section{Assignment :}

indorsement by, $343-346$

qualified indorsement is, 23,365

transfer without indorsement, $375-378$.

of guaranties, $49 \mathrm{I}-494$.

of funds, bill is not, $59,605-607$.

check is not, $81,685-688$.

for benefit of creditors, protest for better security, $7 \mathrm{r}$.

Attorney's Fees :

provision for, does not render sum uncertain, 9. $215^{-217}$.

\section{Bad Faitl :}

equivalent to knowledge, 29,397-399, 400-4I7. undervalue as evidence of, 397-399.

Bank : (See Checks.)

definition of, 6 .

cashier as payee or indorsee, 25, 306n, 320n, $349,373^{n}$.

bill or note payable at,

presentment of, $39,349,510,521 \mathrm{~m}, 524-527$.

is an order on, $42,521 n$.

not by mere notice, 514

notice of dishonor, $532-533,550-552$.

certificate of deposit by, 17r-172.

savings bank order by, 177-179.

draft by, $677 n$.

purchase of paper by national, $\mathbf{4 7 2}$.

Bank Book :

condition of return of, $177^{-1} 79$.

Bank Notes:

history of, 140 .

whether current money, 232, 223.

whether demand necessary, $499 n$.

\section{Fankrupt :}

notice of dishonor to, $48,5 t^{2} n, 563$.

presentment for acceptance to, 66 .

protest for better security against, $7 \mathbf{1}$.

discharge of, does not discharge instrument $592 \pi$.

\section{Bearer:}

detined, 6,263 .

bill or note payable to, $8,12,263-270,342$.

instrument indorsed in blank payable to, 22 .

indorsement of instrument payable to, 24,368 .

\section{Better seeurity:}

protest for, $7 \mathbf{r}$.

Bills of Exchangre:

history, $x+2-I+9$.

form, $59,283,603$.

general requisites, se $e$ Form of Negotiable INSTRLMENTS.

drawee, $8,270-275,59,603-604$.

referee in case of need, 60,605 .

interpretation, see INTERPRETATION.

bill not an assignment of funds, 59, 605-607.

inland and foreign bills, 6o, 608 .

distincruished from check, $79,673-676$.

\section{Bills of Exeluange Aet:}

text of, $87-114$.

origin of, $117-122$.

const ruction of, $119,127,442$.

\section{Bllls in a Set}

when treated as one bill, 77, 66r, 663-665. negotiation of parts to different persons, 77, 661,662 .

rights of holder, 77

liability of indorsers, 78 .

acceptance of, $78,661,662$.
Bills in a Set-continued.

payment of, 78.662 .

discharge of, 78 .

copies distinguished, $66_{3}$

Blank Indorsement: ( $S_{i e}$ Indorsenent.)

instrument payable to bearer, 12, 268.

definition and effect, 22, 352 .

converted into special, 22,352-354.

\section{Blanks:}

when blanks may be filled, $13-14,248 n, 288-298$, $3^{86}$.

distinguished from spaces, $590 n$.

as notice of defects, 27,386 .

\section{Bona-fide Holder: (Sée Holder in Die} Colrse.)

\section{Bonds:}

when negotiable, $149-160,452-468$.

how made non-negotiable, 82 .

public or corporate, 34 .

\section{Broker: (See Agent.)}

\section{Hurden of Proof:}

when on holder to prove he is holder in due course, $30,351,422-425,430-431$.

to show mistake in cancellation, 56 .

to show alteration, $588 n$.

to show that instrument was transferred when overdue, 374.

\section{Cancellation:}

intentional, $54,56,428 n, 44^{8-450}, 579-581$.

unintentional, $56,5^{82}-5^{85}$.

burden of proof, 56 .

\section{Capacity of Parties:}

to indorse, $17,321-322$.

admissions of, 3 r, 447,448 .

warranty of, 34,468

drawee, $60,67,559 \%$.

incapacity as a defense, 427, 495.

\section{Caslier}

indorsement, when payable to, 25, 320n, 349 $373^{n}$.

signature by, $306 n$.

\section{Certainty:}

of sum payable, $8,9,180-190,195-218$.

of promise, $8,9,176-195$

of time, 9 -IO, $234-248$.

of parties.

drawee, 8,270

payee, $12,248-253$.

\section{Certificate of Deposit :}

negotiability of, $171^{-1} 7^{2}$.

demand necessary, $499^{n}$.

distinguished from deposit slip, $172 n$

distinguished from savings bank order, 177.

\section{Certitieate of Protest :}

form and contents, $69-70,643-647$.

correction of, $5 \mathbf{3} 3$

as to presentment for acceptance, $637,646,647$. as evidence of notice of dishonor, $540 \mathrm{n}, 568-570$.

\section{Certifieation of Check:}

effect upon bank's liability, 80

effect upon drawer's liability, $80,682-685$.

\section{Cliecks:}

defined, 79

distinguished from bills, 673-676.

presentinent for payment,

effect of delay upon drawer's liability, 80, $676-681$.

effect of delay upon indorser's liability, $677 n$. due diligence in, 676-68r.

certification by bank

effect upon bank's liability, 80 .

effect upon drawer's liability, $80,682-685$.

liability of drawee,

to holder, 8I, 685-688.

to drawer for wrongful dishonor, 688-69o 
The References are to Pages.

Codes:

American, 5-83, 122-125.

Continental, 125- 127 .

English, 87-114, 117-122.

construction of. $119,127-131,442$.

Collateral security :

authorizing sale of, does not render instrument non-negotiable, 10, 229-230.

instrument issued as, is contingent, 245.

instrument transferred as, for antecedent debt, I $8,327-333,339-340$.

must be tendered upon presentment for payment, 520-521.

failure to sell, 598-599.

\section{Collection :}

bill or note payable with costs of, $9,215-217$.

indorsement for, $23,357-361,364,532-533$.

of check, time allowed, 676-68t.

Conditional: (Sec Unconditional.)

orders or promises, $8,9,176-195,590-59 \mathbf{r}$.

delivery, $14-15,275-283$.

indorsement. 24,367 .

acceptance, $64,626-628$

\section{Consideration :}

necessity of, $327 n$.

presumption of, $18,325-327,354-355,668-67 x$.

adequacy of, 327n, 397-399.

what constitutes, is

payment of pre-existing debt, 18,327 .

collateral security for pre-existing debt, r8, 327-333.

in accommodation paper, 20, 339-340.

effect of want or failure of, $19,338-339$.

need not be specified, 11,283 .

for acceptor's promise, 336

by preceding holder, 19. 334-338.

action upon original, $3^{8} 5,5^{8} 7^{n}, 5^{8}$.

statement of, does not render conditional, 9 , $190-195$.

in restrictive indorsement, $36 \mathbf{6}-362$.

in transfer in trust, 362 .

patent right as, $8 \mathbf{r}$.

speculative, 82 .

\section{Comstruction:}

of ambiguous instruments, $33,15-16,285-324$. of codifying statutes, $119,127^{-13} 1,44^{2}$.

Comstructive Notice:

from form of paper, $405^{-4} 4$.

Continerency :

instrument payable on, not negotiable, 9,20 , $176-183,241-247$

what is not, 9, $183-195$.

\section{Contribution:}

among sureties, $482-485,561-562$.

\section{Copy of Hill}

use in protest, $69,7,643-646$.

negotiating copy, $66_{3}$

\section{Corporation :}

indorsement by, 17,340 .

payee a tiscal officer of, 25.

seal of, on corporate paper, $28+n$.

paper of, diverted by officer, $407 \rightarrow+12$.

signature by officers of, $3 \mathbf{I} 7-320$.

paper of, indorsed by directors, $5^{6 \mathbf{r}-563}$.

Costa: :

provision for costs of collection does not render some uncertain, $9,215$.

of wior suit, whether rccoverable by surety, $+2 \pi$.

\section{Coverture:}

as a defense, 427 .

transfer by, $3^{81} n$.

transfer after, $592 n$.

note signed by married women, $4,8-459$.

Currency :

whether treated as money, $221 n$.
Current Funds :

whether treated as money, $250-22 \mathrm{I}$.

\section{Curront Money :}

particular kind may be specified, is.

what constitute, $219-227$.

\section{Custom :}

as origin of law merchant, $140-141,147-149$, $151-100$.

\section{Date :}

non-essential, $1 \rho_{2} 283,301$.

presumption as to, $13,15,301$.

mistake in, $28,286$.

ante-dated and post-dated instruments, 13, $285-287$.

when date may be inserted, $13,288-289$.

change of, a material alteration, 57.

on or before fixed, 209 .

alteration of, 57 .

of acceptance, $62-63$.

post-dated check, $676 \mathrm{n}$.

Day : (See TIME.)

Deatll : (Sie ExectTor.)

of party primarily liable, 39, $415 n, 518-519$ $559 n, 6+6-6+7$.

of drawer or indorser, $47540-542$.

of drawee bcfore acceptance, 66, 67 .

instrument payable at or after, 240-24r, 277$279,325,670-671$

transfer by, $379^{-} 3^{81}$.

\section{Default :}

in payment of installment, 9, 208-211.

\section{Defenses:}

absolute, $426 n, 426-428$

conditional or personal, $19,28,29,423 n, 428-$ $43^{\circ}$

burden of proof, $30,4 \geq 2-425,430-43^{1}$

defenses to negotiable instruments,

alteration. $57,428 n, 448-450,585-592$.

cancellation, $54,55,428 n, 579-585$.

discharge in bankruptey, 428 .

diversion by agent, $327^{-3} 33,407^{-4}+12$.

duress, $425-430$.

failure of consideration, $3: 8,351,375,412$, $+52$.

fortrery: $14,18,280,281,322,443,473$.

fraud, $+28 \pi, 336,337,+15,417,422,452,+2 \%$.

fraudas to niture of contrict, 4 I $-4+5$.

garnishment, $\{28$.

infancy, 3-1 322

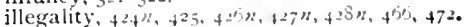
non-demand or notice, $t$ is $5(x)$

parol atgreement, 35 .

payment, 2, $54,428 n, 344,34,57 \mathrm{I}, 572$

set $-1, f f, 23 n, 3(2,3,7,493$

unauthorizel act of afrent, 1; 14, $21-298$, $304,320,429$.

want of comsideration, $+28 n, 327,333,388$, $377,45 \mathrm{I}$

want if delivery, $4: 8 \pi, 27 y-293,42-z^{\prime}$

want of delivery is at newotialibe instrument, 43 I +45 :

want of title in leslder, $38: 38$

defenses to guaranty, 4 't +7.7.

Dolaty : (Site Jullogevers.)

in miking prescntmest, f1, $\therefore 57,5: 1,80,076-$ $1,8 \mathrm{t}$.

in givitur notice, $52,55^{\prime}, 55^{8}$

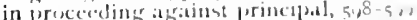

in making prescntment for acceptance, we i), $33,3 \%$.

in making protest, 72

\section{Dollivery:}

detinecl, 1 .

when presumed, 15.

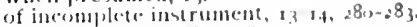

essential, $11,275,28,3.48$

conditionit, $275: 27$,

what of, is defecture, $270,280,425+15$.

negretiation by, 21,342 
The References are to Pages.

Delivery-continued.

warranty in negotiation by, $34,452-47 \mathbf{I}$.

after acceptance, $6 \mathbf{1} 2$.

indursement of paper negotiable by, 35,475 .

upon payment, 38,76 .

of notice of dishonor, $46,537-54$.

obtained by trick, $+3 \mathbf{I}-4+45$.

Demand : (See Presenthent for Pament.)

Demand Bill ỡ Note:

when payable on demand, $8, \mathrm{II}, 234-237$.

when overdue, $28,396-397,635-636$.

when presentment for payment must be made,

$$
7,504-509 \text {. }
$$

Depomit :

indotiement for, 365 .

Dryonit Slip :

distinguished from certificate of deposit, $172 n$.

Dilinence :

in making presentment, $40-41,501-512,655$.

in giving notice, $52-53,542-552,563-56$, .

deliy excused when, $521-523$

when dispensed with, 72,523-527,558-568.

in making presentment for acceptance, 67,641 . in presenting check, 8, 676-68I.

in mzking protest, 72

\section{Discharee of Instrument:}

parment and retransfer, 26, 54. 57 $5-579$

payment in due course, $25,54,571-572$.

what is payment, 573 .

payment by indorser, 574-577.

payment by partyaccommodated, $55,600-602$.

payment or purchase, $57^{8-57}$

retransfer, $579 n, 579-585,592 n, 509-600$.

cancellation or renunciation, $54,56,579-5^{8} 5$.

intentional, $5-9-581$.

mistaken, $582-585$.

alteration, $57,585-592$

effect of, $-5,58-589$.

through neglisence of maker, $590-592$.

material, $57,5^{88 n}$.

burden of proof, $588 n$.

innocent, $5 \mathrm{So}$

by operation of law, 542-593.

of bills in a set, 78 .

Dis:-harae of indety :

what effects, $43-+4,55,592-599,5^{82-53} 5,494-497$ reservation of rights against, $55,594-598$.

by qualified acceptance, $6_{4}, 6_{3}$.

by payment for honor, $76,65^{8}$.

by non-presentment for acceptance, 66, 633 .

by failure of holder to take necessary steps, 68 .

by nun-prutest, 60 .

by parment for honor, 76 .

by non-presentment of check, 8o, 676 .

Dishonor : (S S ${ }^{\prime}$ Presentaent; Notice; ProTEST.)

by non-payment, 41,75.

by non-acceptance, 61,63

notice after, 43 .

protest after, 54,60

acceptance after, 62, 620-621.

action for wrongful, 688-69g.

Drawee : (Sie ACCeptance.)

must be certain, $8,270-275$.

in case of need, 60,605 .

liability of, $59,65-607,8 \mathrm{I}, 685-690$.

joint drawees, $5,6,3-604$

alternative of successive, $53,60_{3}-60_{4}$

only drawee can accept, 6r, $6 \mathbf{I r}$.

fictitious, excuse of steps, $4 \mathrm{I}, 52,53,559 n$.

mity be also payee, $12,25 t^{-255}$

may be also drawer, $2 ; 3-274$.

Drawee in case of Need: (See Referee in CASE OF NEEd.)

Drawer : (Si' Form; Presentment; Notice; PEOTEST.)

contract of, 3 T, 452

atmissions of, $3 \mathbf{I}, 452$.
Drawer - continued.

when not entitled to presentment, 40,523.

when not entitled to notice, 52, 558-561, 563568

of check, 8o, 676-681, 682-685, 688-69o.

discharge of, $43-44,64,66,69,80$.

payment by, 55,599

may be payee, 12 .

may" be drawee, $273-274$.

\section{Due Bill :}

whether a negotiable instrument, $16{ }_{7}-\mathbf{1} 7 \mathbf{1}$.

\section{Duress:}

as a defense, 28,425 .

\section{Election :}

of holder to require something in lieu of money, 10, $233^{-234}$.

\section{Eserotx :}

delivery in, $276 n$.

Eslate: (Sec Executor.)

instrument payable to an, 252-253.

\section{Exchanue:}

provision for, does not render sum uncertain, 9. 212255 .

note payable in, not negotiable, 218-2rg.

recovery of re-exchange, $421 n$.

Exchse of Steps: (See Diligence.)

\section{Exeriltor:}

acceptance by, $183-185$.

of holder may enforce payment, $379-38 \mathbf{r}$.

presentment for payment to, 39, 518-519, 539n, $6+5-6+7$.

notice of dishonor to, $47,54 \mathrm{I}$.

transfer of instrument to maker as, $592 n$.

presentment for acceptance to, 66.

instrument payable to, $251-253$.

\section{Exenptions:}

waiver of, does not render instrument nonnegotiable, I $123^{1-23^{2}}$

Extinguishment : ( $S_{e} e^{\prime}$ Discharge.)

Failure of Consideration: (See CoNSIDERATION.)

effect of, 19,338 .

as a defense, 338,351,375, 412,452

\section{Fietitious Parties :}

payee, instrument payable to bearer, $12,253 n$, $263^{-2}-8$.

signature fictitious, $16,306-3 \mathbf{I}$.

drawee, notice excuscd, 52, 53, 5591 .

bill may be treated as note, 60

presentment excused, $+1,67,552 n$

Fionures:

discrepancy between words and, I5, 298-301.

Finder:

of instrument, right of action, $3^{82}$.

Foreign b3ills:

defined, 60,608 .

require protest, $54,69,501,566,643$.

Foreigh Money :

whether treated as money, 225-227.

\section{Formery :}

of signatures generally, 18, 322-324. of drawer's signature, $44^{8-450}$.

by filling blanks, $289-293,590$.

of indorsement, 468 .

of renewal note, $5^{82-585}$

ratification of, 324 .

money paid on, $3^{2} 3 n, 448,473$.

as a defense, $I_{4}, 18,280,289,322,448,473$. warranty against, 34 .

\section{Form of Nexotiable Instruments:} writing and signature, $8,161-164$.

promise or order, $8,164^{-175}$

unconditionial, 9 i $70^{6}-\mathbf{1} 95$.

certainty,

of sum, $9,195^{-218}$ 
The References are to Pages.

Forn of Negotiable Instruments continued.

of time. 9. I I, 23t-247

of payee, $12,248-253$.

of drawee, 8, 270-275

payable in money, $8,218-227$.

no additional act, $10,228-234$.

payable to order or bearer, 1 I, 12, 248-270

delivery, $\mathbf{4}, 275-283$

non-essentials, Io, I $1,28_{3}-28_{5}$.

Fraud:

as a defense, $28,+28 n, 336,337,415,417,422$, 451,496 .

as to nature of instrument, $431-4+5$.

by seller, $34,469-471$.

\section{Fund:}

particular fund designated for reimbursement, 9,183 .

bill is not assignment of, 59. 605 .

check is not assignment of, 81,685 .

current funds, whether money, 219-221.

acceptance " when in funds, " $628 n$.

want of funds in hands of drawee, effect, 40 , $52,67,560-56 r, 633-635$

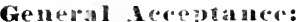

form and effect of, $63,621-626$.

to pay at a particular place, $63,625-626$.

Glft:

of donee's obligation, 56, 579-581.

Good Faitll: (Sece Notice; Holder in Due CoLRSE.)

what constitutes, 27, 397, 572 .

Grace, Dass of:

abolisned, 42.

when last day of, a holiday, 504 .

non-negotiable notes have, 667-668.

sight bill entitled to, 234-236.

Guaranty : ( Sé $^{3}$ Warrantr:)

transfer by indorsing, $346-34^{8}$.

writing above blank indorsement, $352-353$.

contract of guarantor, 487-49I.

whether iransferable, $491-494$.

derenses to, 494-497.

indorser of non-negotiable note undertakes, $672-673$.

whether accommodation contract is a continuing. $383-393$.

whether irregular indorsement a, $480 n, 673 n$.

whether acceptance by stranger a, $6 \mathbf{r} 2 n$.

\section{Ho Hare : \\ define $1,6$.}

when decmed holder for value, 19, 27. 33.4-338, $3^{86-419}$.

may convert blank indorsement into special, 22, 352 .

under ipecial indorsement of instrument pityableto bearet. 24

of instrument trimsterred without indorsement, 25,375 .

may sinc out indorsement, $26,55,375$.

may sue in his own nitme, $27,379-385$.

title wf, in action, $382 \cdot 3^{84}$.

when nit deemed loblder in due course, 28 , $395-397$.

entitle 1 to bencfit of warrinty, 34.

princijal debtoras, 54, $57^{8}$.

discharge of instrument by, 54, $57 \mathbf{I}$.

discharese of party by, $55,592$.

reaunciation of richts by, $5^{\prime}, 579-5^{81}$.

mat ruse oral acceptanee, 6 i.

mayefuse qualified acceptance, 64, 630 .

ontion tesort to referce in case of need, 6 .

consent to acceptance for lumor, 73.

refusal tor receive patyment for honor, 76 .

precurigertitication of eheck, 80,682 .

dutien 68.

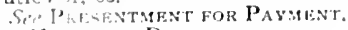

Notice of Dismonuk.
Holder - contingert.

PRESENTMENT IOK ACCEPTANCE. PRoTEST.

rights of, upon dishonor, 69

duty to receive paynent for honor, 76.

securing certitication, of check, 80, 082

no action against bunk on check, 8s, 685 .

Holder in Due Coumate (Se'e Defenses) requisites to constitute.

instrument complete and regular, 27,386 ,

instrumeut not overdue, $27,357-397$.

taken in roud taith and fur value, 27, 327$333,397399$.

laken without notice of intirmity, 29,29 , $400+17$

who tuot deemed a, 28, 396, 142.

holder deriving title from, 29, 4 in 4 ig.

may recover full amount, 29, $419-421$.

burden of proot, $30,422-425$.

notice to, before consideratiun jrati, 28,415 .

of instrument wrongfully tilled up, I $4,280-283$.

of instrument transferred without indorsement, 26.

of altered instrument, 57,587 .

of instrument transferred after dishonor for non-acceptance, 53 .

of part of billi in a set, 77.

entitled (1) warrantics, 34,452-474.

\section{ITohder tor Value:}

what constitutes, $19,334338,397-320$.

may enforce against accommodation party, 20 , 33 .

amount recoverable by, $19,337-33^{8}$.

\section{Holiday:}

what is, $7,83-8$,

bill or note due on, $42,504 n$,

presentment for acceptance on, 67

\section{IOM :}

whether reasonable for presentment, 509-512.

of service of notice of dishonor, $48,543 \%$.

of closing of mails, $12,545-5+7$.

for presentment ior acceptance, 66.

\section{Hunbad and Wife: (Se'e Conerteke.)}

\section{Ilerarality:}

as a defence, $28,2^{27} 127,456,472$

warranty acainst, $34^{t 0 t}-407$,

\section{Imponability:}

as excuse for steps, $5>4-527,557-558$.

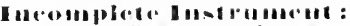

want of le.livery ot, a detense, $11,230-283$.

as notice of defects, 27,3 th

atceptituce of, $1,2,61,620$.

\section{Iandersere:}

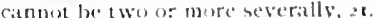

special, must indorse to transifer, $22,351$.

under restrictive intorsemint, 23, 354-355.

under conditional indorsement, 24, 367.

if two or more, all must indorse, 24,37 .

cashier, palyable to bank, 25, 373.

natune miscife.lle.t. 3,373 .

in trust, $23, \cdot 3^{\prime} 13^{\prime} 14$.

\section{Inderentement :}

delinecl, of

form reepuired, $: 1,348-351,161-162,164$

must be of whole instrument, "s, 35\%.

kinds of, 22, $3513^{\prime \prime 8}$.

special, 22, 351

blank, $12 \therefore, 35,354$, of 2870 .

restrietive, $3,3543^{1 / 4}$

qualitient, $23,3^{2}+5,307$.

comblitional, 4. $3+7,3,8$

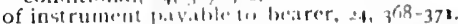

of instrument probible to two or more persons, 2.1. 371372

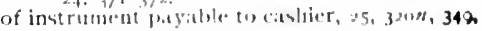
$37.3 n$.

where name inisisellenl, 25, 374, 37

in representative capucity, $25,17 \%$. 
The References are to Pages.

Indorsement - continued.

presumption as to time of, 25,374 .

presumption as to place of, 26,375

striking out, 26,375 .

transfer by, $21,3+3$.

transfer without, $26,375-378$

by infant or corporation, 17, 321-322, 452 .

of overdue instrument, 237,356 .

warranty from, $34,452-47^{2}$

forged, 322-323.

filling up blank, 352 .

Indormer:

who is, $32,348-349$.

liabilicy of general, $34,474-478$.

warranties of, $34,452-472$.

for what amount liable, 29, 420

irregular, 32, 478-480.

order of liability, $35,{ }_{4} 8 \mathrm{o}-486$.

when not entitled to notice of dishonor, 53, $5^{61-568 .}$

payment by, 574-577.

of instrument payable to bearer, 24,368 .

of parts of bills in set, $78,66 \mathrm{x}$.

of a check, $678 n$.

discharge of

by striking out indorsement, 26,375 .

by failure to take steps, $36.43,66,6$.

by taking qualified indorsement, 64 .

by certification of check, 80

action against on day of maturity, 475-478.

Indorser without Recourse : (See Without ReCOURSE.)

\section{Infant :}

indorsement by, 17, 321-322, 452 .

defense of infancy, 427 .

Inland Bill :

defined, 60,608 .

protest of, $54,5 \circ 1,566,643^{n}$.

Installments:

do not render sum uncertain, 9, 202-208.

nor provision that upon default in one, all shall be due, 9, 208-21 I.

\section{Interest :}

does not render sum payable uncertain, 9, 199202.

runs from what time, $15,166 n$, 30r

overdue does not dishonor paper, 394-395.

alteration in, 57 .

demand note payable with, 504-506.

taking in advance is not usury, 554

\section{Interpretation :}

date, $13,285-288$.

blanks, 13, 288-298.

ambiguous language, $15,298-304$.

ambiguous signatures, $16,304-324$

codifying statutes, II9, I $27^{-1} 3 \mathrm{I}, 442$.

\section{Inwrement :}

doctrine of, as to notice, $530-532$.

I. O. U. :

Whether a negotiable instrument, $164-166$

Irregular Indorser :

liability of, $32,47^{8-480}, 673^{n}$.

\section{Joint Parties:}

acceptors or makers,

presumption, $16,302-304$

presentment to, 39, 5 I 9 .

payees,

in instrument, $27,255^{-258}$.

indorsement by, 24, 35, 371 .

drawers, notice to, 47

indorsers,

presumption, $35,480-487$.

contribution among, $482-485$.

right to securities, $485-486$.

notice to, 47

drawees,

bill addressed to, 59, 603-605.

presentment to, 66, 639-640.
Joint Parties - continued.

retransfer to one of the, $579 n$.

discharge of one, $596 n$.

Judoment :

authorizing confession of, does not render instrument non-negotiable, 10, 230-23r.

in favor of principal debtor, discharges surety, $593^{\prime \prime}$.

Laeles: (See Delay.)

Law IIerchant :

when governs, $7,455-457$

history of, 132-16o.

\section{Liability of Parties: (See Parties.)}

\section{Lien:}

on instrument constitutes holder for value, ro, $337-338$.

\section{Lost Inst rument :}

liability on, $446,572 n$.

protest of, 72 .

right of finder, 382

Mails: (See Post-Offrce.)

Iaker:

liability of, $3 \mathrm{I}, 446$.

admissions by, 31,447 .

note to maker's own order, 79, 254.

signature of, $I 6_{3}$,

negligence in signing, $435-445$.

joint and several, 302-304

presentment not necessary to charge, 498-500.

Marriage : (See Coverture.)

transfer by, $38 \mathrm{~s} n$.

Iaturity : (See Grace; Holiday.)

day of, $42,3^{8} 7-338,504$.

time of, for demand notes, 504-500.

action on day of, premature,

against maker, $388,501 n$.

against indorser, $475^{-478}$

protest before day of, when proper, $7 \mathbf{I}$.

\section{Money :}

instrument must be payable in, $8,6 \mathrm{r}, 2 \mathrm{I} 8-227$.

what constitutes current, 219-227.

election in lieu of, ro, 233.

promise in addition to payment of, 10, 228-234.

foreign, 225-227.

specifying current, does not affect negotiability, II.

alteration in kind of, 57 .

\section{Negligenee :}

is not bad faith but only evidence of it, $400-405$.

in signing instrument, $435^{-445}$.

in leaving spaces, etc., $59^{\circ}-59^{2}$.

\section{Negotiable I notruments:}

history of, $1+2-160$.

codification of, I 1 7-1 $3^{2}$.

kinds of, $\mathrm{I}_{42-\mathrm{I}} \mathrm{O}$

See Bills of Exchange.

Prumissory Notes.

CheCKS.

Bonds.

form of ( MENTS).

continuation of negotiable character, 26,325 .

defenses to (sce Defenses).

paper payable in trust is, $4 \mathrm{I}_{2}-4 \mathrm{I} 4$

\section{Negotiable Iustruments Law :}

text of, $5-83$.

origin of, $122-\mathrm{r} 25$.

when takes effect, 83 .

laws repealed by, $8_{3}$.

Negotiation: (See Indorsement; Delivery.)

defined, $2 \mathrm{I}, \mathrm{I} 42,3+\mathrm{I}$.

by delivery, $2 \mathrm{I}, 342$

by indorsement and delivery, 21, 343-348.

may delay presentment, 37 .

of overdue instrument, $356,387-397$.

of gruaranties, $49 \mathrm{I}^{-494}$ 
The References are to Pages.

Non-Aceptance : (See Acceptance.) effect of, $68,641-642$.

notice of, necessary, $43,53,528$

effect of subsequent presentment for payment, $5 \div 8$.

Non-Negotiable Notes:

what are, $79,2 s_{3} n, 666$

have grace, $667-668$.

have presumptive consideration, $668-67$ I.

liability of indorser of, $247 n, 348 n, 528 n, 672-$ 673 .

any instrument in hands of holder not in due course is like, 29 .

\section{Nom-Payment}

notice of, when necessary, 43,528 .

Notarial Act of Honor : necessary to payment for honor, 76,658 .

Notary : (See Protest.)

when presentment by, necessary, 502-503.

protest by, 69-70, 643-647.

whether he must act in person, 502,648 .

signature and seal, 69,503.

fees of, $420-421,568 n$.

Notice : (Sec Holder in Due Course.)

of defect or defense, 29, 400-414.

from face of paper, 405-4I4.

before full amount paid, 28, 415 .

of accommodation, 20, 339-340.

not from indorsement without recourse, 367 .

overdue paper, $387-397$.

overdue interest not, 394-395.

not because payable in trust, $4{ }^{12-4} \mathbf{1}_{4}$.

Notice of Dishonor:

necessary to charge drawer or indorser, 43 , 528 .

what constitutes sufficient notice.

by whom given, 44, 528-533.

form of, $45-46,533-537,645 n$.

mode of service, $46,537-539$

to whom given, $47,540-54^{2}$.

within what time, $48-49,542-552$.

at what place, 50, 552-556.

when delay excused, 52, 556-558.

when notice dispensed with.

as to drawer, 52, 558-561.

as to indorser, $53,561-563$.

due diligence, 52, 563-564.

waiver, 50, 564-568.

prior notice for non-acceptance, 53, 568 .

proof of notice, 568-570.

successive notices, 50, 550-552.

\section{Noting:}

delay excused, 72

subsequent extension of protest, 70

in acceptanee for honor, 74 .

Ofince :

holder of, as payec, I2, 261-262.

Order:

bill must contain, $8,173^{-175}$.

unconditional, $8,9,17^{6-195}$

no additional act, 10, 228.

bill must be payable to, or bearer, $8,11-12,248-$ 27 .

66 Order or Banter:

not nccessary by law merchant, 283 .

not necessary by bills of exchange act, $12 n$, $621 n$.

necessary by negotiable instruments law, II, I2, $24^{8-270}$.

Dverdue Bill or Note:

is payable on demand, $11,236,356$.

continues negotiable, 356 .

indorsement of, $237,356$.

transferee not holder in due course, 27, 387397.

overdue interest, $394-395$.

when demand note is overdue, $28,396,504-$ 509 .
Orerdue Bill or Noto-contirued

acceptance of, $6 \mathbf{2}$.

presentment for acceptance before, 66,632

accommodation paper, $3^{88-393}$.

Parol: (Sic Writing.)

acceptance by, $6 \mathbf{1} \%$.

varying indorsement by, 354n.

\section{Particular Fund:}

indication of, $9,183-188$.

order or promise to pay out of, $9,180-183$.

\section{Parties:}

primarily liable, $7,36,49^{8}$.

maker, $3 \mathrm{r}, 446$.

acceptor, $31,44^{8}$

discharge of, $34,57 \mathrm{I}$.

secondarily liable, $7,36,4 \pi, 50$.

drawer, 31,452 .

indorser, 34,474

irregular indorser, 32,478 .

discharge of, 55,592 ,

guarantor, 486 .

acceptor for honor, 73-75, 65t-657.

drawee, 8,270 .

payee, II, I2, 248-262.

joint and several (sie Joint Partigs).

accommodation (see Acconmodation Partr).

alteration in, 57,585 .

to action must appear on bill, 16,304 .

\section{Partmers:}

signatures by, $306 n, 6 \mathbf{2} n$.

accommodation paper by, 405-406.

presentment for payment to, $39646-647$.

notice of dishonor to, $47,541,55^{8-559}$.

authority to make alterations, 585-587.

authority to accept, $639-64 \%$.

form of acceptance, $612 n$.

indorsement by, 24, 274-275.

\section{Patent ringints:}

negotiable instrument given for, $8 \mathbf{r}$.

\section{Payce :}

wlio may be, 11-12, 254-260,

must be certain, 12, 248-254

fictitious, 12, 263 268 .

two or more, 12, 24, 255. 37 r

one or some of several, 12,258 .

cashier as, 25, 373.

name misspellecl, 25,372

admissions as to, 31, 447,448, 452 .

whether holder in due course, $\mathbf{4 4 2}$

\section{Paymant :}

to conditional indorsec, 24, 367 .

discharges instrument, 26, 54, 57 1-579.

holder mily coforce, $27,379 \cdot 385$.

bill or notc as, $385 n$.

of forged bill, $448-45 \mathrm{I}$.

in due course, $42,571-572$.

by indorser dies not disclutrge maker, 574-577

by party seconclarily liable, 55. 599-602.

by accommodated party, 55, ewo-6or.

of bills in a set, $7^{8}$.

after notice of defect, 28,415

of bill under forged indorsement, 468,473

rencwal note :ts. 573.

\section{Payment fis Dingur:}

when proper, 75, 658.

by whom, 75,658

for wlum, 75, 658 .

formati recuisites,

prior dishonor and protest, 75,658 .

notitial act of lumor, 76,658 .

declaration of intention, 76.

effect of.

disclarge af parties subsequent, $76,657 n$.

liability of priour partices, $77^{\circ}, 658$

effect of refusil to receive, 76 .

doces not alljoly to notes, 659 .

Paymant mapra protent: (Sec Panket Iok lining.) 
The References are to Pages.

Pencil:

necessary writing may be in, $16 \mathrm{r}$.

\section{Persomal Representative: (See Exec- UTOR.)}

Place :

of drawing or payment need not be specified, II, 283 .

of indorsement, presumption, 26 .

of presentment

for payment, 38,512

for acceptance, $637 n$.

to acceptor for honor, 74 .

of acceptance, $6_{3}, 65,499 n, 628$.

of serving notice, 50,552 .

of protest, 72.

of payment, 65 .

alteration in, 57

\section{Postoftice :}

notice of dishonor through, $46,48,49,50,53^{8}$ $559,544^{12}, 544^{-5} 50,55^{2}, 553-55^{6}$.

delays caused by, 49, $521-523$.

interruption of mails by war, $55^{6-55}$.

Premexisting Debt: (See Antecedent DEET.)

Presentment for Acceptance: (See ACCEPTANCE.)

When necessary, $65,6_{32}-6_{3} 6$.

within what time, $65,632-636$.

what is sufficient, $66,637-640$

to whom. $66,637,639-640$.

at what place, $637 n$.

exhibition of bill, $63^{8}-639$.

by whom, 66 .

on what day and hour, 66, 67 .

when delay excused, 67 .

when presentment excused, 67,641 .

effect of dishonor, $68,641-6+2$.

\section{Presentment for Payment:}

necessity of

not to charge acceptor or maker, 36,498 . not after dishonor for non-acceptance, 68 .

to charce drawer or indorser. 36,50 .

to charge acceptor for honor, $74-75,653,656$.

what constitutes sufficient, $37-39,50 \mathbf{I}-521$.

by whom, 37, 501-503.

at what time. $37,38,504-512$.

at what place, $38,512-517$.

to whom, 37, 517-51\%.

when maker dead, $39,518$.

when makers joint. 39, 5 ro.

by exhibiting instrument, $38,520-521,525$.

to acceptor for honor, 74 .

when delay excused, $40.52 \mathrm{I}$.

when presentment excused.

no right to expect it, 40,523 .

when impossible, 4 I, $524-527$

when waived 41,527 .

of checks, 8, 676-681.

Presunptions: (Seg Berden of Proof.) of consideration in negotiable instrument, 18 , 325.

of consideration in non-negotiable instrument, $668-671$

of value for every signature, 18

of time of indorsement, 25,374 .

of place of indorsement, 26,375 .

that holder is holder in due course, $30,422,57 \mathrm{r}$. of order of indorsers' liability, 35, 480-486.

that parties indorse jointly and severally, 35 .

from deposit of notice of dishonor in mail, 49 . $53^{8}$.

Primary Party : (See Parties.)

Prineipal : (See Agent.)

Proeuration :

signature by, 17,320 .

Promise : (See Form.)

note must contain a, $18,164-172$

must be unconditional, $8,9,176-195$.
Promise - continued.

must not be of act additional to payment of money, 10, 228-234,

to pay out of particular fund, $9,180-188$.

to accept, when an acceptance, $62,613-616$.

\section{Promissory Note :}

origin and history, $145-146,154-155,666$.

definition of, 79 .

form (see Form of Negotiable INstrunents). interpretation (seE INTERPRETATION).

non-negotiable (se'e NoN-Negotiable Notes). protest of, $5+, 501-503$.

given for patent-right, $8 \mathrm{r}$.

given for speculative consideration, 82 .

ambiguous instrument may be treated as, 15. $27 \bigcirc-272$.

\section{Protest :}

when proper, 54.

notes and inland bills, 34

for better security, $7 \mathbf{I}$

when necessary, 54 .

foreign bills, 69,64 ;

bills accepted for honor, 74. 75, 651.

reference in case of need, 74

before payment for honor, 73,658 .

what constitutes sufficient.

form and contents, $69-70,643-647$.

by whom, $70.648-650$.

on what day, 70 .

at what place, $7 \mathbf{I}$

mode of making.

noting, 70 .

certificate, $70,643-647$.

lost bill, 72 .

when excused, 72,562

as proof of notice or dishonor, 568-570.

fees reasonable for, $420-42 \mathrm{I}, 568 n$.

waiver of, 5 I, 565-567.

Purchase for Value Without Notice: (Sei Holder 12 Die Colrse.)

Purchase of Instrument: (See Trans FER.)

distinguished from loan, $419 n$.

distinguished from payment, $578-579$.

Qualitied Aceeptance :

definition and effect. $64,626-63$ I, $640 \mathrm{n}$.

Qualified Indormement:

definition and effect, $12,3^{6} 5$.

Katitication:

of forgery, 324 .

of unauthorized alteration, $587 n$.

Reasonable Timo: ( $S_{E} T^{T}$ Tine.) how determined, 7, 239. 504-509, 636 $n$.

Referee in Case of Need : defined, 60,605 ,

protest before presentment to, 74 .

excuse for delay in presentment to, 75 .

Re-issue: (See Retransfer.) by prior party, 26, 359-361,378, 599-600.

Release : ( $S^{\circ} e^{\circ}$ DI $\backsim$ ChaRge.)

of principal, $54.57 \mathrm{I}-592$.

of surety ( see $^{2}$ DischaRge OF SURETY)

\section{Removal from state:}

effect upon presentment, $515-516$.

effect upon notice, $554-556$.

\section{Henewal Note:}

whether payment of former note, 573, 582-585. forgery of, $5^{82-585}$.

promise to make, renders instrument contingent, $246-247$.

\section{Renunciation:}

discharge by, 56, 579-58r.

writing or delivery necessary, 56 .

Restrietive Indorsement :

definition and effect, 22-23, 354-365. 
The References are to Pages.

Tetransfer :

to prior party, effect of, $26,359-361,373,579 n$, $579-585,592 \pi, 599-600$.

Sale of Negotiable Instrument : (See Negotiation: TRANSFER: Warranty.)

Saturday :

a half holiday, $s_{4}$.

maturity of instrument on, 42.

presentment for acceptance on, 87 .

\section{Sea I :}

effect upon negotiability, $\mathbf{1 1}, \mathbf{2 8 3}-\mathbf{2 8 4}$.

of notary, 6 . secoudary Party: (See Parties; Dis-

Securit y : (See Collateral Securities.) protest for better, 7 .

seller of yegotiable Instrument: warranties by, $34,45^{2-474}$.

agent's liability as, 36,473 .

payment distinguished from sale, 578-579.

Set, Hills in a : (See Bills in a Set.)

\section{set-ofr:}

as a defense, $428 n, 302,387,495$.

\section{Siglit Bills:}

presentment for acceptance, $9,65,234-236$, 632,633 .

have grace, $234-236$.

Signature :

only those whose signatures appear are liable, 16, $183-185,304-306,517$.

by maker or drawer, $8,162-163,289-29 x$.

by acceptor, 6 I, 6 Io.

by indorser, $21,348,164$.

by agent, If, 311, 3201, 517.

fictitious, $16,164,306-311$

irregular, $15,302,32,478$.

ambiguous, $15,16-17,304-311$.

forged, $18,322-324$.

presumption as to value for, 18.

joint, 16.302 .

distinguished from subscription, r6 63 .

on blank paper, $1+, 239-29$.

on incomplete instrument, not delivered, If, $280-283$. delivered, $13,291-298$.

lacking on instrument, 386 .

obtained by trick, $43^{1-445}$.

spaces:

unauthorized filling of, 590.

distinguished from blanks, $590 n$.

Special Indorsentent :

definition and effect, 22, 35r.

written above blank indorsement, 22, 352-35. of instrument payable to bcarer, $24,368-37 x$.

statement ot Tramsactlon:

does not render bili or note conditional, $9,19^{\circ}$.

statute of Fralds:

irregular indorsement, $480 \mathrm{n}$.

guaranties, $48 r-49 \mathrm{I}$.

defense to instrument, $592 n$.

\section{Stolen Inatrument : (See Lost Instru-} Mist.)

sum certaln: (Sec Certaintr.)

Sunday : (See Holidav.)

surely : (See Discharge of Surety; GuarAnT(K.)

as co-maker. $302 \cdot 304$.

contribution amons suretics, $4^{82-485}$.

right to securities, $485-486$

defenses a vailable to, $494-497$.

reservation of rights against, $55,594-596$.

\section{Tender of Payment :}

by principal discharges surety, 55, 593 .

what amounts to, $36,490-500$.
Tilue:

how computed, $7,42,504 n$.

reasonable, how determined, 7, 239, 504-509, $636 n$.

certaint $y^{*}$ of, 9-10, $234-248$

of indorsement, presumption, 25.

for making presentment, $37,39,504$

of maturity, $42,23 t^{-23}$.

for giving notice of dishonor, $48-50,542$.

allowed drawee to accept, 62, 619\%.

acceptance qualified as $t 0,64,629$.

for presentment for acceptance, $66_{3}, 66_{32}-6_{3} 6$.

for making protest, 7 .

for presenting check, 8o, 676-68r.

given to principal, dischirges surety, 55, 5و6598.

when indorsement subscquent to transfer takes effect, 26,373

when insulficient, 67

Title: (Se' HOLDER in DEe Course.)

when defective, 26, 28, 29.

warrant $5,34, \$ 08$

of indorsec under restrictive indorsement, 23. 353,364 .

of indorsee under infant's indorsement, 17, 321. of transferee without indorsement, 26,375 .

of holder of instrument payable to bearer and restrictively" indorsed, 368-37 3 .

of holder in action, $382-384$

of holder to guaranty, $\$ 9^{1-494}$.

Trade Nane:

sigrning in, $16,306$.

Trannfer: (Sé Negotiation; Holder in Due Course.)

what constitutes, 341 .

by delivery, 2I, $3+2$.

by indorsement, $21,343$.

without indorsement, $26,375-378$.

retransfer, $26,37^{8}$.

by death, $379-38$.

by marriage, $38 \mathrm{r} n$.

for purposes of suit, $384 n$.

in trust, $361 \cdot 364$

warranties, 34,452474 .

when overduc, $27,387-397$

on last day of maturity $3^{8} 7-3^{88}$.

of overdue accommodation paper, $3^{88-393}$

\section{rient :}

indorsement in, $23,351-364$

under conditional indorsement, 24, 367

instrument payable in, +12-\$14.

holker may recover in trust for indorser, 574 577 .

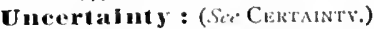

Uncenditunal n'romixe or ordor: (Sie links).

necessiry to negotiability, $8, \mathbf{3} 76$.

when order or pronsice is unconditional, 9 $17^{15} 11,5$.

Unwy :

purchase of business paper is not, $4 \mathbf{m} \boldsymbol{n}$.

taking interest in adrance is not, 554 .

as a deferse, $4.7 n$.

warranty agalust, $4^{\prime 31-466 .}$

Valma : (Sit JOLnEk Fok VALUE.)

defined, $7,18$.

need not ire specitied, $11,283$.

holder for, Jis, 334-338, 327-379.

antecedent debt as, $18,327-333$.

Virtual Inentumes:

form of, $t 2,1,13-616$

effect. $616 \%$

WaI ver :

of benetit of liww, so, $23 \mathrm{t}$.

of presentment for pisyment, 41,527

of notice of dishonor, 50-51, 564-5/,7.

of prutest, $51,72,566-567$. 
INDEX.

The References are to Pages.

\section{Warranty of Seller :}

where transfer by delivery, 34, 452-47x.

where transfers by indorsement, $34,472$. by agent who transfers, 36,473 .

by agent whosigns for principal, 31 1-316.

\section{Without Recourse :}

indorsement qualified by, $23,356,365-367$. warranties where so transfefred, $34,452-474$
Writing:

defined, 7 .

necessity of, in negotiable instrument, $8,16 \mathbf{L}$ necessity of, in case of renunciation, 56 .

holder may require acceptance in, $6 r, 6 r 0-6 \mathrm{rr}$. acceptance by separate, 6 r.

necessity of, in acceptance for honor, 73 .

promise to accept must be in, $62,6 x_{3}$. conflict with print, $15,30 \pi$, 





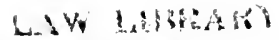

Mat'y OF CALAFORNL

WNIVERSI'Y OF CALA
LOB ANGEUTS 
UC SOUTHERN REGIONAL LIBRARY FACILITY |H |H || |.

AA 000770797 ||

AA 000770797 9 


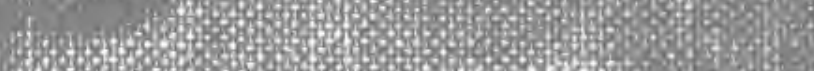

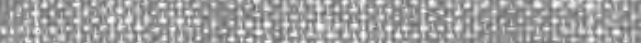

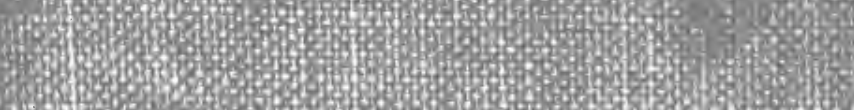

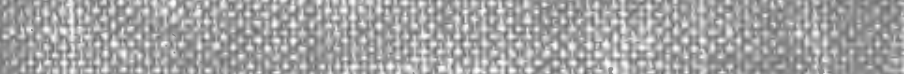

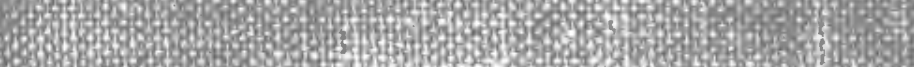

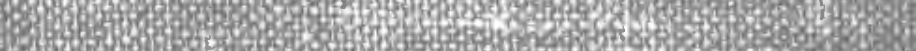

tow

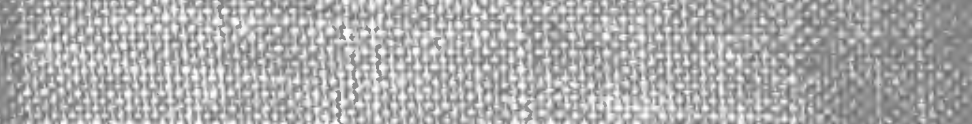

3 (1)

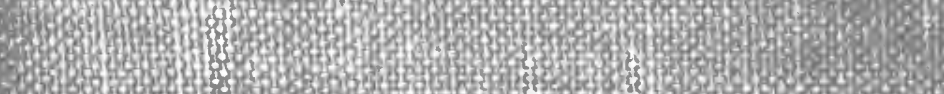

3.3

150.

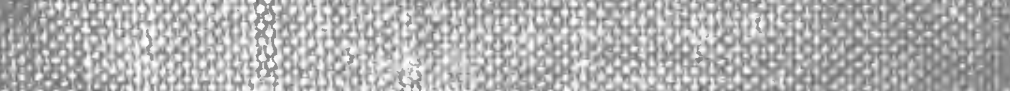

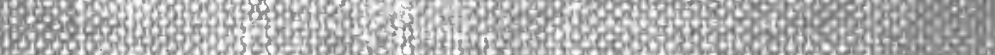

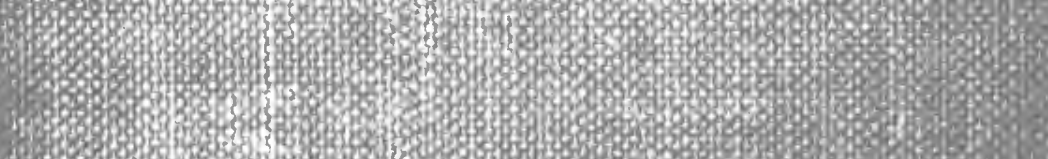

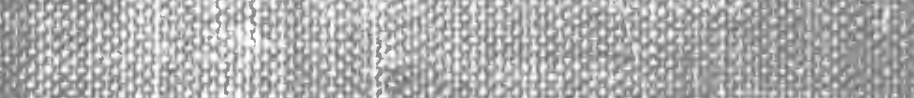

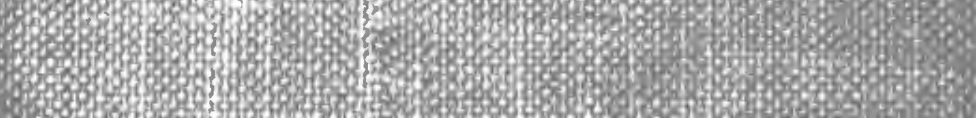

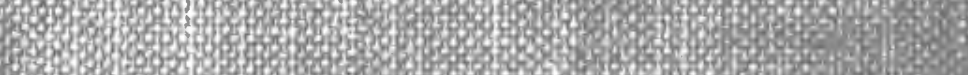

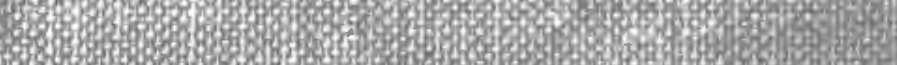

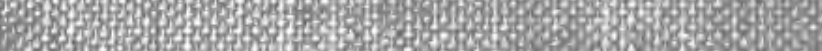

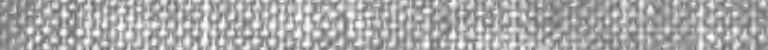

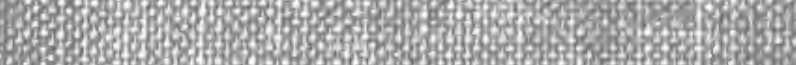

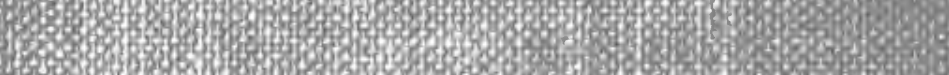

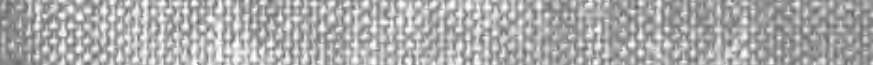

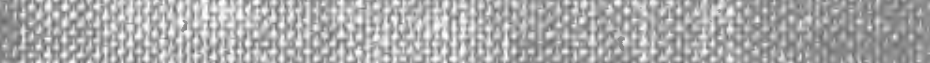

40.30 3.

for

b.

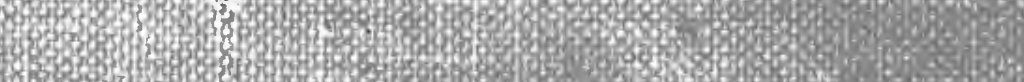

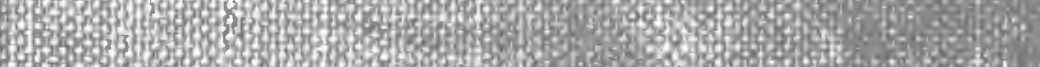

320 (3)

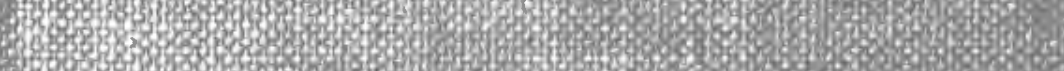

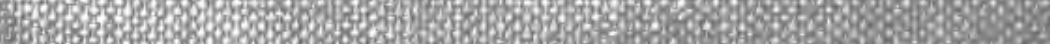

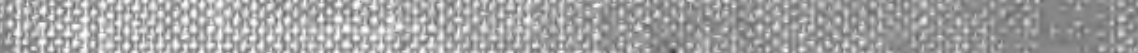

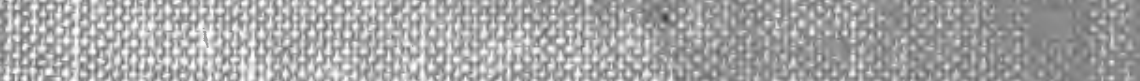

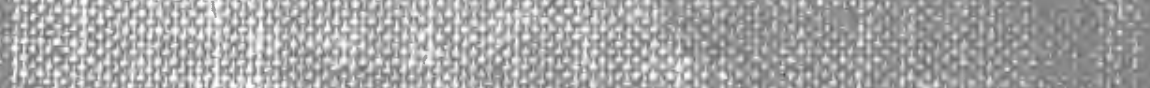

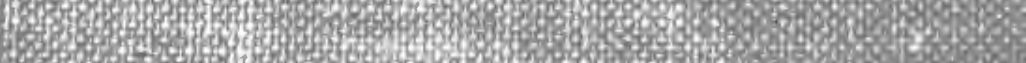

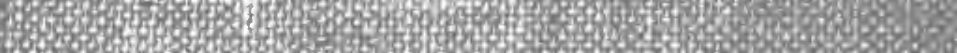

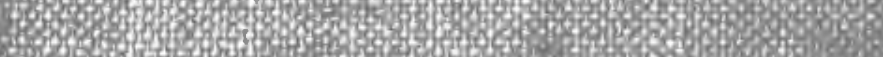

3.

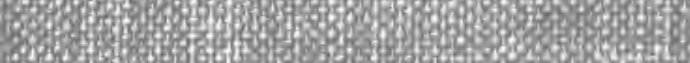

Fol 